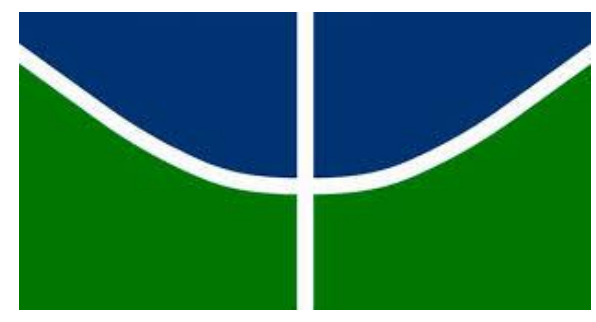

UNIVERSIDADE DE BRASÍLIA

CENTRO DE DESENVOLVIMENTO SUSTENTÁVEL

CENÁRIOS DOS ESPAÇOS VERDES URBANOS NO BRASIL

Romero Gomes Pereira da Silva

Orientador: Prof. Dr. Carlos Hiroo Saito

Tese de Doutorado

Brasília - DF

30 de Janeiro de 2018 


\author{
UNIVERSIDADE DE BRASÍLIA \\ CENTRO DE DESENVOLVIMENTO SUSTENTÁVEL
}

\title{
CENÁRIOS DOS ESPAÇOS VERDES URBANOS NO BRASIL
}

\author{
Romero Gomes Pereira da Silva
}

Tese de doutoramento submetida ao Centro de Desenvolvimento Sustentável da Universidade de Brasília, como parte dos requisitos necessários para a obtenção do Grau de Doutor em Desenvolvimento Sustentável, área de concentração em Política e Gestão da Sustentabilidade.

\section{Aprovado por:}

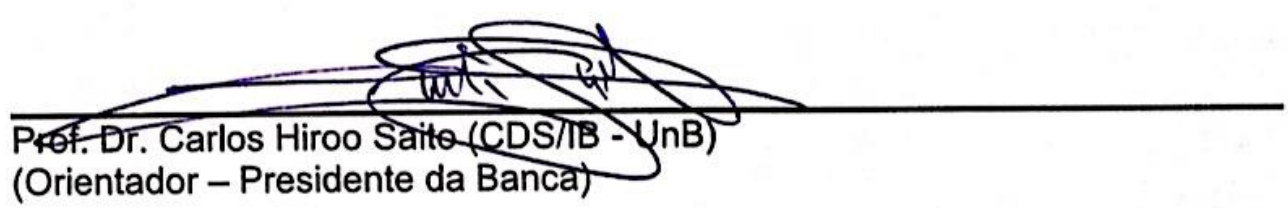

\section{Sanito}

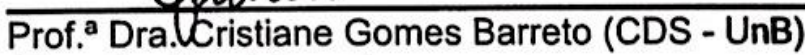

(Examinadora Interna)

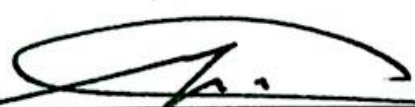

Prof. ${ }^{a}$ Dra. Marta Adriana Bustos Romero (FAU - UnB)

(Examinadgra Externa)

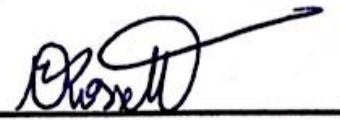

Prof. ${ }^{a}$ Dra. Onélia Carmem Rossetto (IGHD - UFMT)

(Examinadora Externa)

Prof. Dr. Saulo Rodrigues Pereira Filho (UnB - CDS)

(Examinador Suplente) 
Silva, Romero Gomes Pereira da

Cenários dos Espaços Verdes Urbanos no Brasil / Romero

Gomes Pereira da Silva.

Brasília, 2018

386 f. :il.

Tese de Doutorado. Centro de Desenvolvimento Sustentável.

Universidade de Brasília

1. Espaços Verdes Urbanos. 2. Sistema de Informação Geográfica.

3. Correlação Espacial

I. Universidade de Brasília. CDS. II.Título.

É concedida à Universidade de Brasília permissão para reproduzir cópias desta Tese e emprestar ou vender tais cópias, somente para propósitos acadêmicos e científicos. O autor reserva outros direitos de publicação e nenhuma parte desta Tese de doutorado pode ser reproduzida sem a autorização por escrito do autor. 
À Claudia Lins, pelo amor, apoio e incentivo. Aos meus pais, pelos ensinamentos e orações. Aos que lutam pelos espaços verdes na paisagem urbana. 


\section{AGRADECIMENTOS}

Agradeço à Universidade de Brasília, pelo ensino público, gratuito e de qualidade. Durante dez anos como estudante da UnB aprendi, ensinei e vivi ciência, cultivei amizades, conheci lugares no Brasil e no mundo. Se sou engenheiro florestal e pós-graduado, agradeço à ciência, aos professores e aos colegas mas, sobretudo, ao ambiente universitário que me deu liberdade de escolhas e renúncias. Das melhores escolhas cito a de integrar, ainda na graduação, as atividades do Laboratório de Ecologia Aplicada (Ecoa). Lugar onde me mantive imerso em aprendizado cientifico (onde fiz PIBIC, TCC e executei pesquisas e projetos diversos) e onde mantenho as melhores relações profissionais e pessoais. Assim, agradeço aos coordenadores do laboratório, aos professores Carlos Saito (orientador) e Carlos Henke, por todas as oportunidades dadas, aos conselhos, estímulos, puxões de orelha, auxílios e companheirismo. Agradeço a todos que passaram ou continuam no Ecoa, em especial: Lu, Ronaldo, Claudinha (meu amor), Everaldo, Raquel, Erika, Sofia, Gabis, Jô, Pri e Veni.

Ao orientador Carlos Saito, muito obrigado pelas orientações precisas e cirúrgicas, ao apoio irrestrito e incentivos, dentre eles o de continuar os passos acadêmicos no Centro de Desenvolvimento Sustentável, centro de excelência. Agradeço assim, a todos professores, alunos, técnicos e funcionários do CDS.

Obrigado também, à Cordenação de Aperfeiçoamento de Pessoal de Nível Superior (CAPES) pelo apoio financeiro.

Durante toda execução da tese, muitas pessoas passaram pelo meu caminho e de alguma forma contribuíram. Deixo aqui os meus sinceros agradecimentos a vocês.

Das renúncias feitas para executar o doutorado, cito a distância dos meus familiares em especial meus pais. Pessoas simples e batalhadoras que não se poupam em garantir o melhor aos filhos. Obrigado pais e familiares pelas orações, apoio e amor dado a mim.

E por falar amor, obrigado Cláudia, meu maior apoio sentimental e intelectual. Minha história acadêmica de UnB ganhou mais sentido ao seu lado! 
"uma vida simples e silenciosa traz mais alegria do que a busca do sucesso em um desassossego constante" (Albert Einstein).

"Toda a observação sobre a paisagem urbana depende da nossa forma de encarar o fenômeno cognitivo da percepção. A percepção é sensorial. É estética. E é uma percepção resultante do coquetel de experiências acumuladas. Mas o sensorial recupera o ambiental, assim como a estética pode ultrapassar o nível do sensorial. Assim, atingimos o ambiental, o funcional e o genético, quer dizer, o histórico. A história da implantação da cidade. A história da produção do espaço urbano" (AB'SÁBER, 2004b, p. 226). 


\section{RESUMO}

Dada a importância socioambiental dos espaços verdes no meio urbano, esta tese traz uma ampla discussão e contextualização sobre esses espaços nas cidades nos âmbitos histórico e socioeconômico. A busca do desenvolvimento urbano sustentável passa pela presença dos espaços verdes nas cidades, sobretudo nas áreas com maior vulnerabilidade social. A análise tomou como base 0 mapeamento dos espaços verdes urbanos (estabelecidos como maiores de $625 \mathrm{~m}^{2}$ ) considerando como estudo de caso as áreas urbanas de quatro Regiões Metropolitanas - RM (Manaus, Porto Alegre, Recife e São Paulo), além da RIDE-DF e Entorno. Além da ampla revisão de literatura, a análise utilizou-se dos Sistema de Informações Geográficas (SIGs) e softwares específicos como IDRISI, QGIS e GeoDa para a produção cartográfica, alicerce das análises. As principais bases de dados utilizadas foram: as imagens de satélite RapidEye (base para elaboração dos mapas dos espaços verdes urbanos), os setores censitários urbanos (IBGE, 2010) e os mapas de vulnerabilidade social segregados por Unidade de Desenvolvimento Humano - UDH (IPEA, 2015). O grande diferencial dos dados de vulnerabilidade social é que eles estão disponíveis na escala intramunicipal e reúnem em cada UDH um conjunto de setores censitários de mesmas características socioeconômicas, pontos essenciais para a análise que se propôs ir além dos ranqueamento de "cidades-verdes". Tomando 2010 como ano base, foi elaborada uma metodologia para aferir se os espaços verdes urbanos estão situados em áreas de melhores índices socioeconômicos, sendo essa a hipótese da tese. Para investigá-la, analisouse a presença dos espaços verdes urbanos e sua relação com dados demográficos, assim como a correlação espacial entre o Índice de Vulnerabilidade Social (IVS - IPEA, 2015). O método de correlação espacial utilizado foi a Autocorrelação Espacial Local pelo Índice de Moran. Destacase que a hipótese foi refutada em grande parte. Os espaços verde urbanos não estão concentradas majoritariamente em áreas com melhores índices sociais. Nas quatro RM o mais observado foi o contrário, sendo o cenário mais representativo aquele onde a vulnerabilidade social é alta, assim como a quantidade dos espaços verdes, uma vez que a periferia nas metrópoles tende ocupar espaços ainda não urbanizados em sua plenitude. A RIDE-DF e Entorno foi o único caso onde o cenário mais representativo corroborou à hipótese. O planejamento urbano da capital federal favoreceu a concentração dos espaços verdes em áreas centrais, como no Plano Piloto e regiões circunvizinhas. Retomando o cenário mais representativo, verifica-se que o problema maior não é a carência dos espaços verdes e sim a ausência de política para sua implantação como equipamentos urbanos, as quais são fundamentais para torna-los locais de interação, contemplação, lazer e cultura. Ante o exposto, quando os espaços verdes se concretizam como equipamentos urbanos tornam-se promotores do desenvolvimento sustentável nas cidades.

Palavras-chave: Espaços Verdes Urbanos; Regiões Metropolitanas; RIDE-DF e Entorno; Sistema de Informação Geográfica (SIG); Vulnerabilidade Social; Correlação Espacial; Índice de Moran 


\begin{abstract}
The socio-environmental importance of green spaces in the urban environment was considered fundamental for this thesis, reason for which it brings a wide discussion and contextualization about these spaces in the cities from the historical and socioeconomic aspects. The search for sustainable urban development involves the presence of green spaces in cities, especially in areas with high social vulnerability. The analysis was based on the mapping of urban green spaces considering as a case study the urban areas of four Metropolitan Regions - MR (Manaus, Porto Alegre, Recife and São Paulo), as well as RIDE-DF and surroundings. In addition to the extensive literature review, the analysis was based on the Geographic Information System (GIS) and specifics software's such as IDRISI, QGIs and GeoDa for cartographic production, the basis of analyze. The main databases used were: RapidEye satellite images (the base for mapping of green spaces), urban census tracts (IBGE, 2010) and social vulnerability maps segregated by Human Development Unit - HDU (IPEA, 2015). The differential of social vulnerability data is that they are available at the intra-municipal scale and bring together in each HDU a set of census tracts with the same socioeconomic characteristics, essential points for the analysis that have been proposed to go beyond the ranking of "green cities". Chosen 2010 as the base year, a broad methodology was developed to assess if the urban green spaces are located in areas with better social indexes, which is the hypothesis of the thesis. In order to investigate it, we analyzed the presence of green spaces and their relationship with demographic data, as well as the spatial correlation between the Social Vulnerability Index (SVI - IPEA, 2015). The spatial correlation method used was Local Spatial Autocorrelation by the Moran Index. It is noteworthy that the hypothesis was refuted. Urban green spaces are not concentrated mainly in areas with better social indexes. In the four MR, the opposite was observed, the most representative scenario being was the one where social vulnerability is high, as well as the number of green spaces, since the periphery in metropolis tends to occupy spaces not yet urbanized in their fullness. RIDE-DF and surroundings was the only case where the most representative scenario corroborated the hypothesis. The urban planning of the federal capital made possible the concentration of green spaces in privileged areas, such as in the Pilot Plan and nearby areas. Back to the most representative scenario, it was verified that the major problem is not the lack of green spaces, but the absence of a policy for the implantation of green spaces such as urban equipment, which are fundamental to provide spaces for interaction, contemplation, leisure and culture. Therefore, when green spaces become urban equipment they become promoters of sustainable development in cities.
\end{abstract}

Key-words: Urban Green Spaces; Metropolitan Regions; RIDE-DF and Surroundings; Geographic Information System (GIS); Social Vulnerability; Spatial Correlation; Moran Index 


\section{RESUMEN}

Dada la importancia socio-ambiental de los espacios verdes en el medio urbano, esta tesis trae una amplia discusión y contextualización sobre estos espacios en las ciudades en los ámbitos histórico y socio-económico. La búsqueda del desarrollo urbano sostenible pasa por la presencia de espacios verdes en las ciudades, especialmente en las áreas más vulnerables socialmente. El análisis tomó como base en mapeo de los espacios verdes urbanos (establecidos como los con más de $625 \mathrm{~m}^{2}$ ) considerando como estudio de caso las áreas urbanas de cuatro Regiones Metropolitanas - RM (Manaus, Porto Alegre, Recife e São Paulo), además de la "RIDE-DF y Entorno". Además de la amplia revisión de literatura, el análisis utilizó los Sistemas de Informaciones Geográficas (SIGs) y softwares específicos como IDRISI, QGIS y GeoDa para la producción cartográfica, pilares del análisis. Las principales bases de datos utilizadas fueron: imágenes de satélite RapidEye (base para elaboración de los mapas de los espacios verdes urbanos), los sectores censitarios urbanos (IBGE, 2010) y los mapas de vulnerabilidad social segregados por Unidad de Desarrollo humano - UDH (IPEA, 2015). El gran diferencial de los datos de vulnerabilidad social es que ellos están disponibles en escala intramunicipal y reúnen en cada UDH un conjunto de sectores censitarios de mismas características socio-económicas, puntos esenciales para el análisis que se propuso ir más allá de los rankings de "ciudades-verdes". Teniendo 2010 como año base, fue elaborada una metodología para evaluar si los espacios verdes urbanos están establecidos en áreas de mejores índices socio-económicos, siendo esa la hipótesis de la tesis. Para investigarla, se analizó la presencia de los espacios verdes urbanos y su relación con datos demográficos, así como la correlación espacial entre el Índice de Vulnerabilidad Social - IVS (IPEA, 2015). El método de correlación espacial utilizado fue la Auto-correlación Espacial Local por el Índice de Moran. Se pone de relieve que la hipótesis ha sido refutada en gran parte. Los espacios verdes urbanos no están concentrados mayoritariamente en áreas con mejores índices sociales. En las cuatro RM el más observado ha sido el opuesto, siendo el escenario más representativo aquél donde la vulnerabilidad social es alta, así como la cantidad de espacios verdes, una vez que la periferia en las metrópolis tiende a ocupar espacios todavía no urbanizados en su plenitud. La RIDE-DF y Entorno fue el único caso donde el escenario más representativo corroboró la hipótesis. El planeamiento urbano de la capital federal favoreció la concentración de espacios verdes en áreas centrales, como en el Plano Piloto y regiones en sus cercanías. Retomando en escenario más representativo, se observa que el problema principal no es la carencia de los espacios verdes sino la ausencia de políticas para su implementación como equipamientos urbanos, los cuales son fundamentales para hacerlos sitios de interacción, contemplación, ocio y cultura. Tras el expuesto, cuando los espacios verdes se materializan cono equipamientos urbanos se vuelven promotores del desarrollo sostenible en las ciudades.

Palabras-clave: Espacios Verdes Urbanos; Regiones Metropolitanas; RIDE-DF y Entorno; Sistema de Información Geográfica (SIG); Vulnerabilidad Social; Correlación Espacial; Índice de Moran. 


\section{LISTA DE FIGURAS}

Figura 1 - Trevo de Triagem Norte. Asa norte, Brasília-DF .............................. 28

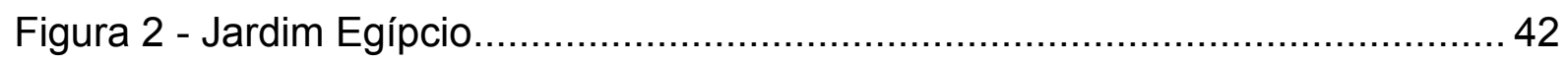

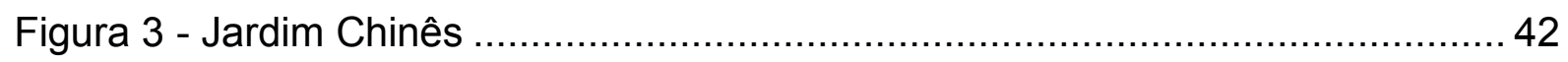

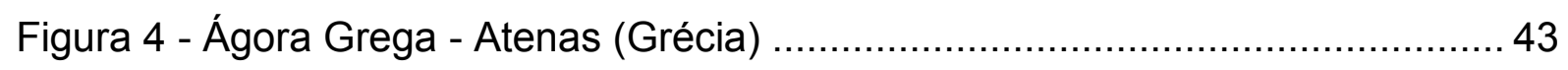

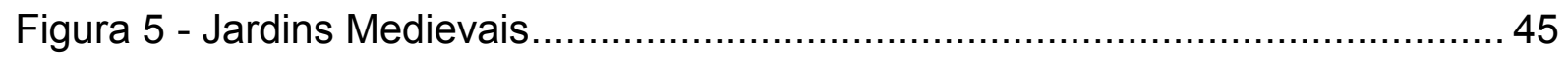

Figura 6 - Regent's Park. Londres (Inglaterra) ....................................... 46

Figura 7 - Área verde do Museu Rodín. Paris (França) ................................... 47

Figura 8 - Parque Saint James. Londres - Reino Unido ................................. 48

Figura 9 - Parque Nacional da Tijuca. Rio de Janeiro (RJ) ................................50

Figura 10 - Asa Sul. Brasília ............................................................. 51

Figura 11 - Setor Noroeste/DF. Esquerda (2005) e direita (2017) .........................60

Figura 12 - Limite entre a favela de Paraisópolis e o Morumbi. São Paulo (SP) ...... 66

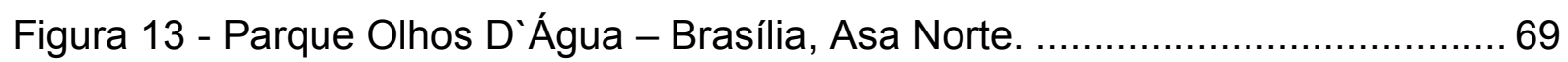

Figura 14 - Conjunto habitacional do Minha Casa Minha Vida: Brenno Garcia -

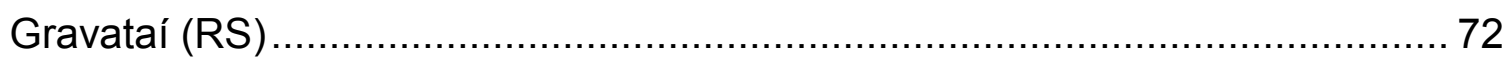

Figura 15 - Condomínio Alphaville cercado de espaços verdes - Porto Alegre...... 73

Figura 16 - Explosão do porão da mansão Matarazzo. ...................................... 76

Figura 17 - Parque Trianon. Avenida Paulista. São Paulo (SP) ........................... 77

Figura 18 - Campanha da revista Piseagrama na cidade de Lisboa (Portugal). ...... 80

Figura 19 - Mobilização contra a construção de edifícios em áreas de proteção

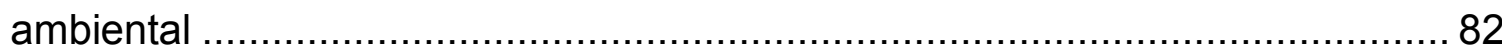

Figura 20 - Parque Olhos D`Água - em rosa o atual limite............................... 83

Figura 21 - Parque Augusta. Centro de São Paulo (SP) .................................... 84

Figura 22 - Município de Viamão (RS). Denominação de cidade e distritos conforme

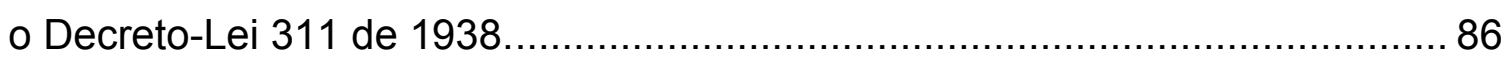

Figura 23 - Município de Viamão (RS). Setores censitários, tipo urbano e rural definidos pelo IBGE.

Figura 24 - Município de Viamão (RS). Cidade: Setores censitários tipo urbano

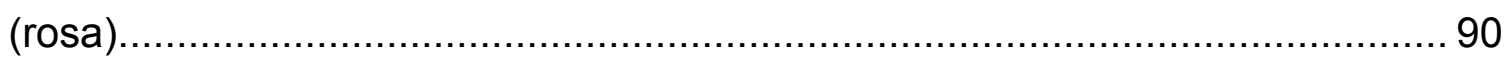

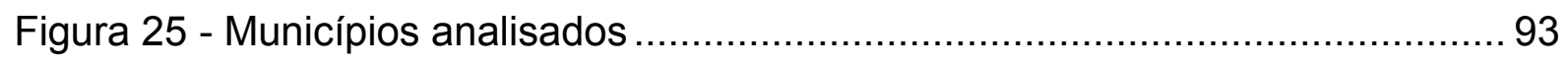

Figura 26 - Região Metropolitana de Recife. Em amarelo a cidade núcleo, Recife.. 95

Figura 27 - Conurbação urbana da Região Metropolitana de Recife.......................96

Figura 28 - Exemplo de áreas menores de $625 \mathrm{~m}^{2}$ e maiores. Porto Alegre (RS) . 105 
Figura 29 - Exemplo de área protegida dentro da área urbana analisada. 106

Figura 30 - Integração dos dados espacializados e dados alfanuméricos 109

Figura 31 - Setores censitários rurais dentro da área urbana.............................. 110

Figura 32 - Metadados dos setores censitários rurais junto à malha urbana ......... 111

Figura 33 - Inclusão dos setores rurais presentes no interior da malha urbana ..... 112 Figura 34 - Exemplo da ponderação das UDHs. Vários setores censitários da Asa Norte formam uma UDH . 114

Figura 35 - Categorização oficial do Índice de Vulnerabilidade Social (IPEA, 2015)

Figura 36 - Geração do arquivo base para a análise socioeconômica. Dados para

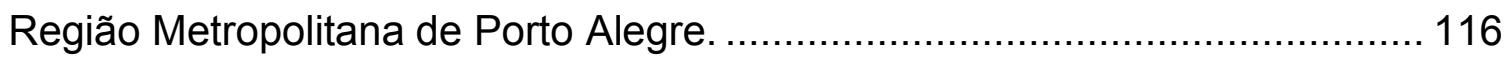

Figura 37 - Mapa dos espaços verdes urbanos para a cidade de Abadiânia ........ 120

Figura 38 - Mapa final dos espaços verdes urbanos para a cidade de Abadiânia.. 121

Figura 39 - Mapa de vulnerabilidade social e espaços verdes urbanos por unidade

de desenvolvimento humano para a Região Metropolitana de Recife. 122

Figura 40 - Regressão linear simples nas Regiões Metropolitanas analisadas na

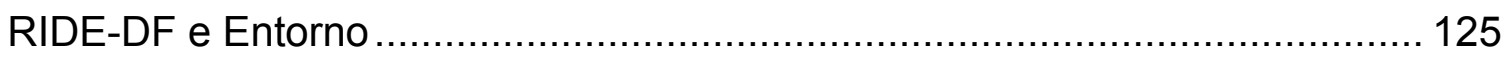

Figura 41 - Mapa LISA. Exemplo: Região Metropolitana de São Paulo ................. 127

Figura 42 - Produtos gerados na análise de autocorrelação local bivariada. Software:

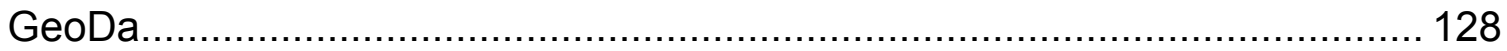

Figura 43 - Diagramação dos possíveis cenários esperados ................................ 129

Figura 44 - Seleção das unidades de desenvolvimento humano (UDH) com

significância geoestastítica ( $p>0,05$ - UDHs na tonalidade verde) .................. 130

Figura 45 - Procedimento para gerar o mapa de Espaços Verdes Urbanos (EVU)

dentro das Unidades de Conservação da Natureza (UCs) nas Unidades de

Desenvolvimento Humano (UDHs) .

Figura 46 - Cenários com significância (porcentagem da população e da área analisada)

Figura 47 - Área analisada na RIDE-DF e Entorno

Figura 48 - Densidade demográfica por unidade de desenvolvimento humano

(UDH)- na RIDE-DF e Entorno.

Figura 49 - Vulnerabilidade social por unidade de desenvolvimento humano (UDH)-

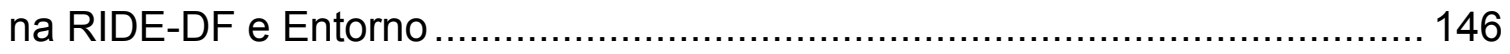

Figura 50 - Imagem aérea Lago Sul - Brasília. .............................................. 147 
Figura 51 - Imagem aérea Condomínio Sol Nascente - Ceilândia (DF) ............... 148

Figura 52 - Espaços verdes urbanos na RIDE-DF e Entorno 151

Figura 52 - Imagem áreas de Cabeceira Grande (MG). Monoculturas cercam a cidade.

Figura 54 - Espaços verdes urbanos nas Unidades de Conservação da Natureza na

RIDE-DF e Entorno 154

Figura 55 - Espaços verdes urbanos nas Áreas de Proteção de Mananciais da

RIDE-DF e Entorno 158

Figura 56 - Espaços verdes urbanos nas super-quadras do Plano-Piloto. Quadra 102 Norte. 159

Figura 57 - Porcentagem dos espaços verdes urbanos por unidade de

desenvolvimento humano (UDHs) na RIDE-DF e Entorno .......................... 160

Figura 58 - Cristalina, presença de cerrado nas bordas (cores acinzentadas)....... 163

Figura 59 - Espaços verdes urbanos $\left(\mathrm{m}^{2}\right)$ por habitantes nas unidade de

desenvolvimento humano (UDH) na RIDE-DF e Entorno. 165

Figura 60 - Categorização do tamanho dos fragmentos dos espaços verdes urbanos.

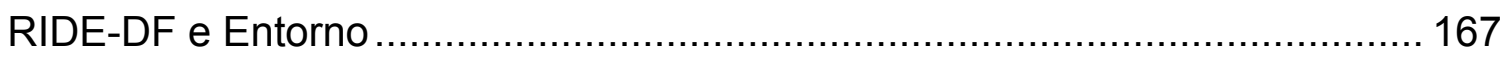

Figura 61 - Comemoração do dia da criança SQN 416 (Asa Norte)...................... 168

Figura 62 - Exemplo de fragmento alongado da classe intermediário. Local: Vicente

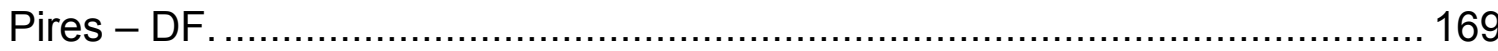

Figura 63 - Blocos de Florestas Protegidas no Distrito Federal.......................... 170

Figura 64 - Mapa de Kernel para os fragmentos pequenos. RIDE-DF e Entorno... 171

Figura 65 - Grande incidência de fragmentos pequenos em áreas de alta

vulnerabilidade social nas cidades de Valparaíso, Cidade Ocidental, Novo Gama

e Luziânia.

Figura 66 - Porcentual de área e população nas UDHs com significância. RIDE-DF e

Entorno 176

Figura 67 - Correlação espacial entre porcentagem de espaços verdes urbanos e

vulnerabilidade social por unidade de desenvolvimento humano (UDH) na RIDE-

DF e Entorno 177

Figura 68 - Área analisada na Região Metropolitana de Manaus 182

Figura 69 - Densidade demográfica por unidade de desenvolvimento humano (UDH)

na Região Metropolitana de Manaus 186 
Figura 70 - Vulnerabilidade social nas unidades de desenvolvimento humano (UDH) na Região Metropolitana de Manaus 189

Figura 71 - Careiro da Várzea (RMM). Abril de 2017 ...................................... 192

Figura 72 - Espaços verdes urbanos na Região Metropolitana de Manaus. 193

Figura 73 - Parques da cidade de Manaus sobrepostos ao mapa de vulnerabilidade social. 194

Figura 74 - Espaços verdes urbanos dentro das Unidades de Conservação da

Natureza e na Reserva Ducke. Região Metropolitana de Manaus. 197

Figura 75 - Classificação dos setores censitários de Manaus por situação. 199

Figura 76 - Porcentagem dos espaços verdes urbanos por unidades de

desenvolvimento humano (UDH) na Região Metropolitana de Manaus. 200

Figura 77 - Espaços verdes urbanos $\left(\mathrm{m}^{2}\right)$ por habitantes por unidade de

desenvolvimento humano (UDH) na Região Metropolitana de Manaus. 203

Figura 78 - Categorização por tamnho dos espaços verdes urbanos na Região

Metropolitana de Manaus 205

Figura 79 - Mapa de kernel dos fragmentos pequenos na Região Metropolitana de

Manaus. 206

Figura 80 - Bairro da Puraquequara - Manaus 207

Figura 81 - Porcentual de área e população das UDHs com significância. RMM... 211 Figura 82 - Correlação espacial entre porcentagem de espaços verdes urbanos e vulnerabilidade social por unidade de desenvolvimento humano (UDH) na Região Metropolitana de Manaus 212

Figura 83 - Área analisada na Região Metropolitana de Porto Alegre. 217

Figura 84 - Densidade demográfica por unidade de desenvolvimento humano (UDH)

na Região Metropolitana de Porto Alegre 222

Figura 85 - Vulnerabilidade social por unidade de desenvolvimento humano (UDH)

na Região Metropolitana de Recife. 224

Figura 86 - Espaços verdes urbanos na Região Metropolita de Porto Alegre 227

Figura 87 - Espaços verdes urbanos em Unidades de Conservação da Natureza nas unidades de desenvolvimento humano (UDH) analisadas da Região Metropolitana de Porto Alegre. 230

Figura 88 - Porcentagem dos espaços verdes urbanos por unidade de desenvolvimento humano (UDH) na Região Metropolitana de Recife 233

Figura 89 - Glorinha: Extensas plantações de arroz na área urbana 234 
Figura 90 - Planície inundável entre Novo Hamburgo e São Leopoldo 235

Figura 91 - "Casa dos Batistas". Cachoerinha (RMPA) ................................. 236

Figura 92 - Morro do Osso (superior); Ponta Grossa (inferior). ........................... 237

Figura 93 - Morro Santana (Campus do Vale - UFRGS) ................................. 239

Figura 94 - Parque Natural Municipal Saint Hilaire ....................................... 240

Figura 95 - Espaços verdes urbanos $\left(\mathrm{m}^{2}\right)$ por habitantes nas unidades de

desenvolvimento humano (UDH) na Região Metropolitana de Porto Alegre. .. 242

Figura 96 - Categorização por tamanho dos espaços verdes urbanos na Região

Metropolitana de Porto Alegre

Figura 97 - Mapa de Kernel para os fragmentos pequenos na Região Metropolitana

de Porto Alegre ............................................................................. 246

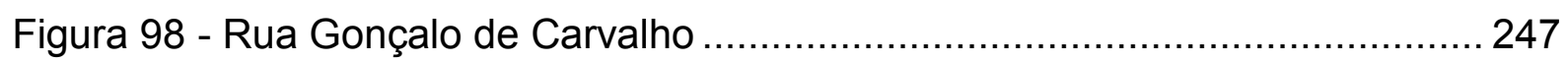

Figura 99 - Cartaz da mobilização popular contra a construção de um shopping .. 248

Figura 100 - Porcentual de área e população das UDHs com significância. RMPA252

Figura 101 - Correlação espacial entre porcentagem dos espaços verdes urbanos e

vulnerabilidade social na Região Metropolitana de Porto Alegre. ................... 253

Figura 102 - Bairro "rural” Belém Velho. RMPA......................................... 257

Figura 103 - Cidade de Igrejinha. RMPA ........................................... 258

Figura 104 - Área analisada na Região Metropolitana de Recife. .......................... 260

Figura 105 - Densidade demográfica por unidade de desenvolvimento humano

(UDH) na Região Metropolitana de Recife

Figura 106 - Vulnerabilidade social por unidade de desenvolvimento humano (UDH)

na Região Metropolitana de Recife .................................................... 267

Figura 107 - Espaços verdes urbanos na Região Metropolitana de Recife ............ 271

Figura 108 - Espaços verdes mantidos pela prefeitura sobrepostas ao mapa de

vulnerabilidade social. 273

Figura 109 - Espaços verdes urbanos em Unidades de Conservação da Natureza na

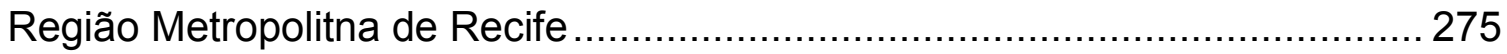

Figura 110 - Área de condomínios a oeste da RMR ...................................... 278

Figura 111 - Florestas Urbanas na Região Metropolitana de Recife estabelecidas por

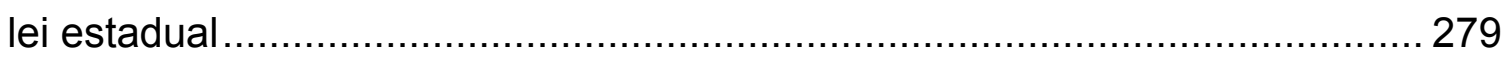

Figura 112 - Porcentagem dos espaços verdes urbanos nas unidade de desenvolvimento humano na Região Metropolitana de Recife 281 
Figura 113 - Espaços verdes urbanos (m2) por habitantes nas unidades de desenvolvimento humano na Região Metropolitana de Recife

Figura 114 - Classificação do tamanho dos espaços verdes urbanos na Região

Metropolitana de Recife

Figura 115 - Mapa de Kernel para os menores fragmentos da Região Metropolitana

de Recife 289

Figura 116 - Bairro da COHAB (Jaboatão dos Guararapes) ................................. 290

Figura 117 - Porcentual de área e população das UDHs com significância. RMR . 294

Figura 118 - Correlação entre porcentagem dos espaços verdes urbanos e

vulnerabilidade social Região Metropolitana de Recife 295

Figura 119 - Área analisada na Região Metropolitana de São Paulo 301

Figura 120 - Densidade demográfica por unidade de desenvolvimento humano

(UDH) na Região Metropolitana de São Paulo 305

Figura 121 - Vulnerabilidade social na Região Metropolitana de São Paulo 308

Figura 122 - Espaços verdes urbanos nas cidades da Região Metropolitana de São

Paulo.

Figura 123 - Espaços verdes urbanos nas Unidades de Conservação da Natureza

na Região Metropolitana de São Paulo. 316

Figura 124 - Espaços verdes urbanos nas Áreas de Proteção de Mananciais na

Região Metropolitana de São Paulo.

Figura 125 - Espaços verdes urbanos mapeados pela prefeitura de São Paulo sobrepostos ao mapa de vulnerabilidade social

Figura 126 - Porcentagem de espaços verdes urbanos por unidade de

desenvolvimento humano na Região Metropolitana de São Paulo.

Figura 127 - Espaços verdes urbanos $\left(\mathrm{m}^{2}\right)$ por habitante nas unidades de

desenvolvimento humano (UDH) na Região Metropolitana de São Paulo.

Figura 128 - Espaços verdes urbanos categorizados por tamanho na Região

Metropolitana de São Paulo

Figura 129 - Mapa de Kernel dos menores fragmentos na Região Metropolitana de

São Paulo 332

Figura 130 - Porcentual de área e população das UDHs com significância .... 336

Figura 131 - Correlação espacial entre a porcentagem dos espaços verdes urbanos

e vulnerabilidade social por unidade de desenvolvimento humano (UDH) na

Região Metropolitana de São Paulo 337 


\section{LISTA DE TABELAS}

Tabela 1 - Tipos de definição de espaços verdes 57

Tabela 2 - Descrição da área mapeada e população inserida na área. Ano Base: 2010 .94

Tabela 3 - Dados dos dos espaços verdes urbanos nas cidades a da 150

Tabela 4 - Espaços verdes urbanos nas Unidades de Conservação da Natureza na RIDE-DF e Entorno 155

Tabela 5 - Espaços verdes urbanos por tipo de Unidade de Conservação da Natureza na RIDE-DF e entorno 156

Tabela 6 - Espaços verdes urbanos nas Áreas de Proteção de Mananciails na RIDEDF e Entorno 157

Tabela 7 - Categorização do tamanho dos fragmentos dos espaços verdes urbanos 166

Tabela 8 - Resumo dos resultados da correlação aplicada na RIDE-DF e Entorno176 Tabela 9 - Espaços verdes urbanos nas cidades da Região Metropolitana de

Manaus 191

Tabela 10 - Espaços verdes urbanos nas Unidades de Conservação da Natureza196

Tabela 11 - Categorização do tamanho dos fragmentos dos espaços verdes urbanos 204

Tabela 12 - Resumo dos resultados da correlação aplicada na Região Metropolitana de Manaus 211

Tabela 13 - Espaços verdes urbanos por cidade na Região Metropolitana de Porto Alegre. 226

Tabela 14 - Espaços verdes urbanos em Unidades de Conservação da Natureza 229

Tabela 15 - Categorização do tamanho dos fragmentos dos espaços verdes urbanos

Tabela 16 - Resumo da análise geoestastítica na Região Metropolitana de Porto Alegre. 252

Tabela 17 - Espaços verdes urbanos nas cidades da Região Metropolitana de Recife 270

Tabela 18 - Espaços verdes urbanos dentro de Unidades de Conservação da Natureza 274

Tabela 19 - Classificação dos espaços verdes urbanos por tamanho 286 
Tabela 20 - Resumo dos resultados da análise geoestastítica na Região Metropolitana de Recife

Tabela 21 - Espaços verdes urbanos por cidade na Região Metropolitana de São

Paulo.

Tabela 22 - Espaços verdes urbanos por Unidades de Conservação da Natureza 315

Tabela 23 - Espaços verdes urbanos por Unidade de Conservação da Natureza . 315

Tabela 24 - Espaços verdes urbanos na Áreas de Proteção de Mananciais. 318

Tabela 25 - Classificação dos fragmentos dos espaços verdes urbanos por tamanho

Tabela 26 - Resumo da correlação espacial na Região Metropolitana de São Paulo

Tabela 27 - Áreas $\left(\mathrm{km}^{2}\right)$, população, porcentagem de espaços verdes e índice de vulnerabilidade social médio nas regiões analisadas

Tabela 28 - Espaços verdes urbanos nas Unidades de Conservação da Natureza nas áreas analisadas

Tabela 29 - Área de Proteção de Manaciais e espaços verdes urbanos nestas áreas

Tabela 30 - Porcentagem de área e população das regiões analizadas por categoria dos espaços verdes urbanos

Tabela 31 - Porcentagem de área e população nas categorias de espaços verdes urbanos (m2) por habitante

Tabela 32 - Porcentagem dos espaços verdes urbanos por tamanho nas regiões analisadas

Tabela 33 - Resultados da correlação espacial aplicada às regiões analisadas .... 349

Tabela 34 - Porcentagem de área e população residente nos cenários obtidos na correlação espacial das regiões analisadas 


\section{LISTA DE QUADROS}

Quadro 1 - Coeficiente de Gini da renda domiciliar per capita, segundo capital ......92

Quadro 2 - Síntese da formulação do IVS (IPEA, 2015) .................................. 113

Quadro 3 - Classes mapeadas na tese conforme adaptação metodologia utilizada no projeto de mapeamento cobertura vegetal de cidades brasileira (Projeto parceria entre MMA-UnB) 118

Quadro 4 - Princípios de fotointerpretação utilizados para mapeamento dos espaços verdes

Quadro 5 - Categorização do mapa de densidade demográfica 131

Quadro 6 - Categorização da \% das EVU nas UDHs 134

Quadro 7 - Categorização do mapa dos espaços verdes urbanos por habitantes . 134 


\section{LISTA DE GRÁFICOS}

Gráfico 1 - Explosão demográfica do sec. XX

Gráfico 2 - Utilização dos termos green space e greenspace em artigos científicos,

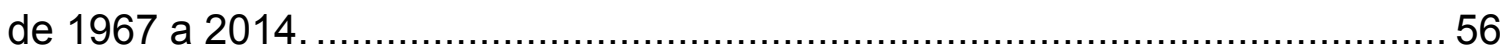

Gráfico 3 - Porcentagem dos municípios segregados por faixa da população 88

Gráfico 4 - Porcentagem de habitantes por municípios segregados por faixa da população

Gráfico 5 - Diagrama de espalhamento de Moran na RIDE-DF e Entorno..... 173

Gráfico 6 - UDHs sem significância na RIDE-DF e Entorno 174

Gráfico 7 - UDHs sem vizinhança na RIDE-DF e Entorno................................... 174

Gráfico 8 - UDHs com significância na RIDE-DF e Entorno ................................. 175

Gráfico 9 - Diagrama de espalhamento de Moran na RMM ................................. 208

Gráfico 10 - UDHs sem significância na RMM..................................................... 209

Gráfico 11 - UDHs sem vizinhança na RMM ................................................ 209

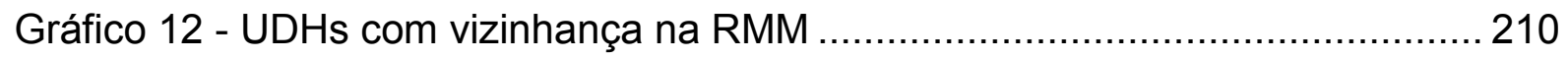

Gráfico 13 - Diagrama de Espalhamento de Moran. RMPA .................................... 249

Gráfico 14 - UDH sem significância. RMPA................................................... 249

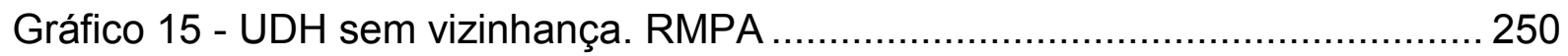

Gráfico 16 - UDH com significância. RMPA.................................................. 250

Gráfico 17 - Diagrama de Espalhamento de Moran. RMR ................................... 291

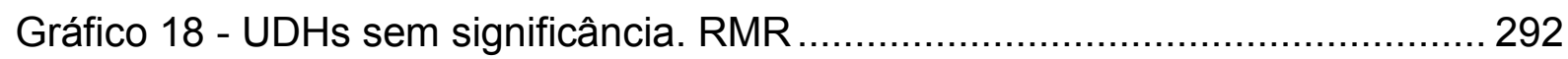

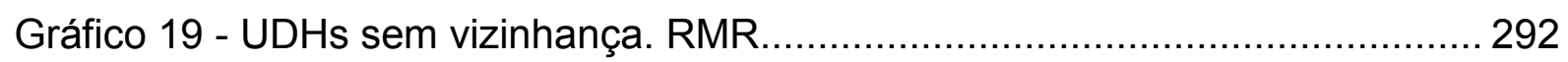

Gráfico 21 - Diagrama de Espalhamento de Moran. RMSP ...................................333

Gráfico 22 - UDHs sem significância. RMSP.................................................. 334

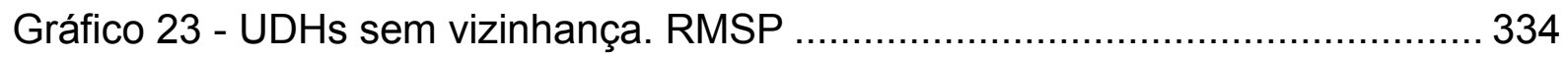

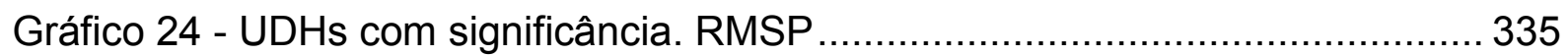




\section{LISTA DE ABREVIAÇÕES E SIGLAS}

AEDE

APA

APM

APP

ARIE

CAESB

CAR

CDS

CETESB

CF

CIGS

DF

DNOS

EE

Embrapa

EVU

Gegran

IAV

IBGE

ICMBio

INCRA

INPA

IPEA

IVS

IPVS

LISA

MCMV

MMA

MNRU

NDVI

ODS
Análise Exploratória de Dados Espaciais

Área de Proteção Ambiental

Área de Proteção de Mananciais

Área de Preservação Permanente

Área de Relevante Interesso Ecológico

Companhia de Saneamento Ambiental do Distrito Federal

Cadastro Ambiental Rural

Centro de Desenvolvimento Sustentável

Companhia Ambiental do Estado de São Paulo

Constituição Federal

Centro de Instrução de Guerra na Selva

Distrito Federal

Departamento Nacional de Obras e Saneamento

Estação Ecológica

Empresa Brasileira de Pesquisa Agropecuária

Espaços Verdes Urbanos

Grupo Empresarial da Grande São Paulo

Índice de Áreas Verdes

Instituto Brasileiro de Geografia e Estatística

Instituto Chico Mendes de Biodiversidade

Instituto Nacional de Colonização e Reforma Agrária

Instituto de Pesquisa da Amazônia

Instituto de Pesquisa Econômica e Aplicada

Índice de Vulnerabilidade Social

Índice Paulista de Vulnerabilidade Social

Indicador Local de Correlação Espacial

Minha casa, Minha Vida (programa habitacional)

Ministério do Meio Ambiente

Movimento Nacional da Reforma Urbana

Índice de Vegetação da Diferença Normalizada

Objetivos do Desenvolvimento Sustentável 


\begin{tabular}{|c|c|}
\hline ONU & Organização das Nações Unidas \\
\hline PAC & Programa de Aceleração do Crescimento planasa \\
\hline PAV & Porcentual de Áreas Verdes \\
\hline PDOT & Plano Diretor de Ordenamento Territorial \\
\hline PDUI & Plano de Desenvolvimento Urbano Integrado \\
\hline PEc & Parque Ecológico \\
\hline PIM & Polo Industrial de Manaus \\
\hline PL & Projeto de Lei \\
\hline PNDR & Política Nacional de Desenvolvimento Regional \\
\hline QGIS & Quantum GIS (software) \\
\hline RB & Reserva da Biosfera \\
\hline REc & Reserva Ecológica \\
\hline RF & Reserva Florestal \\
\hline RIDE & Região Integrada de Desenvolvimento Econômico \\
\hline RIDE-DF e Entorno & Região Integrada de Desenvolvimento Eco. do Distrito Federal e Entorno \\
\hline Rio-92 & Conf. das Nações Unidas sobre o Meio Ambiente e Desenvolvimento \\
\hline RM & Região Metropolitana \\
\hline RMM & Região Metropolitana de Manaus \\
\hline RMPA & Região Metropolitana de Porto Alegre \\
\hline RMR & Região Metropolitana de Recife \\
\hline RMSP & Região Metropolitana de São Paulo \\
\hline RPPN & Reserva Particular de Patrimônio Natural \\
\hline RU & Reino Unido \\
\hline RVS & Reserva de Vida Silvestre \\
\hline SBAU & Sociedade Brasileira de Arborização Urbana \\
\hline SDUC & Sistema Distrital de Unidades de Conservação da Natureza \\
\hline SEDUMA & Secretaria de Desenvolvimento Urbano, Habitação e Meio Ambiente \\
\hline SEUC & Sistema Estadual de Unidades de Conservação da Natureza \\
\hline SIG & Sistema de Informação Geográfica \\
\hline SMAM & Secretaria Municipal de Meio Ambiente - Porto Alegre \\
\hline SNUC & Sistema Nacional de Unidade de Conservação da Natureza \\
\hline SP & São Paulo \\
\hline SUFRAMA & Superintendência da Zona Franca de Manaus \\
\hline
\end{tabular}


UC

UDH

UFAM

UFRGS

UnB

UR

ZA

ZEIS

ZFM
Unidade de Conservação da Natureza

Unidade de Desenvolvimento Humano

Universidade Federal do Amazonas

Universidade Federal do Rio Grande do Sul

Universidade de Brasília

Unidades Residenciais

Zoneamento Ambiental

Zonas Especiais de Interesse Social

Zona Franca de Manaus 


\section{SUMÁRIO}

INTRODUÇÃO

Espaços Verdes Urbanos e Sustentabilidade ..................................................... 35

Espaços Verdes e os Objetivos do Desenvolvimento Sustentável .................36

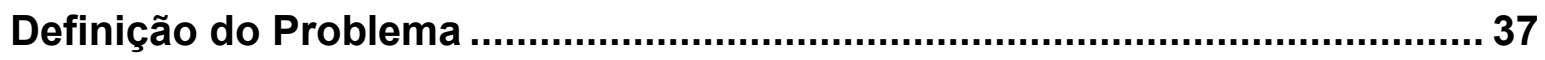

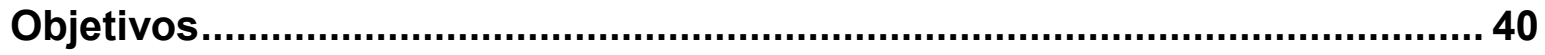

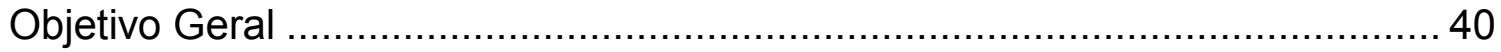

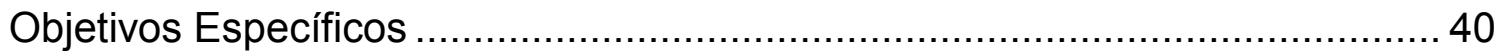

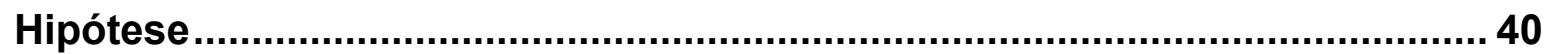

1. OS ESPAÇOS VERDES URBANOS …....................................................... 41

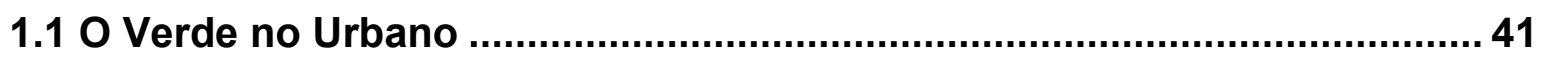

1.2. Histórico dos Espaços Verdes Urbanos no Brasil.................................. 48

1.3 Conceito: Áreas e Espaços Verdes Urbanos ........................................ 52

1.4 Gestão dos Espaços Verdes Urbanos no Brasil ........................................ 58

1.5 Espaços Verdes na História das Cidades .................................................. 59

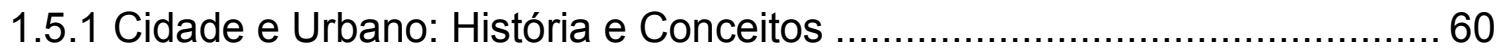

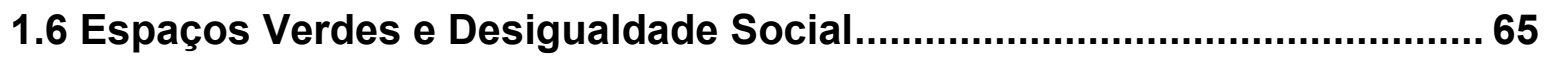

1.6.1 Espaços Verdes como Equipamentos Urbanos ..................................... 68

1.6.2 Exemplos de Resistência e Luta ao Direito da Cidade ............................ 75

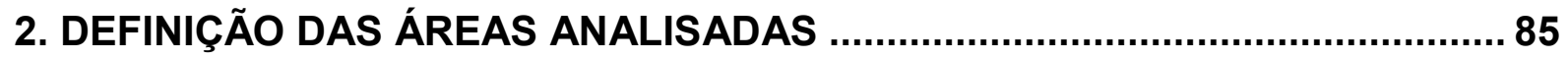

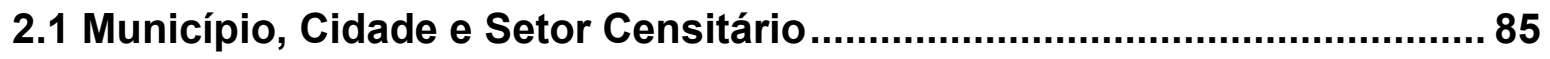

2.2 Escolha das Cidades Analisadas ........................................................ 90

2.3 Região Metropolitana - Histórico ………….............................................. 94

3. ANÁLISE DOS ESPAÇOS VERDES URBANOS ............................................ 100

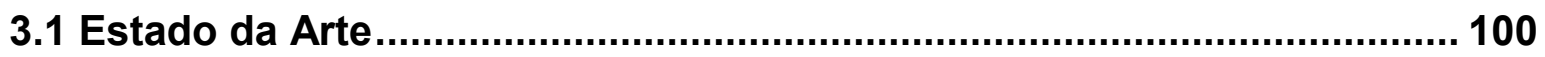

3.2 Procedimentos Básicos ................................................................... 103

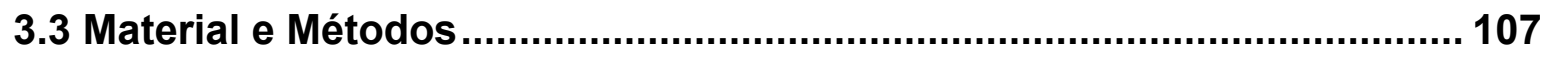

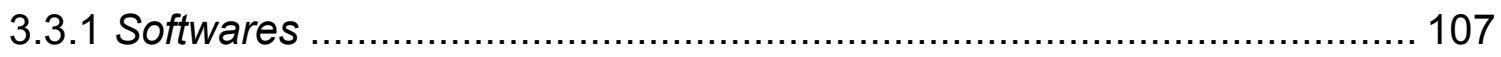

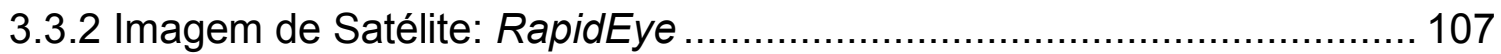

3.3.3 Setores Censitários: Delimitação Espacial ......................................... 108

3.3.4 Dados socioeconômicos: Índice de Vulnerabilidade Social (IVS)........... 112

3.3.5 Mapeamento dos Espaços Verdes Urbanos ...................................... 116 
3.3.6 Recorte dos Arquivos dos Espaços Verdes Urbanos

3.3.7 Espaços Verdes Urbanos nas Unidades de Desenvolvimento Humano 121

3.3.8 Correlação Espacial: Espaços Verdes Urbanos e Vulnerabilidade Social

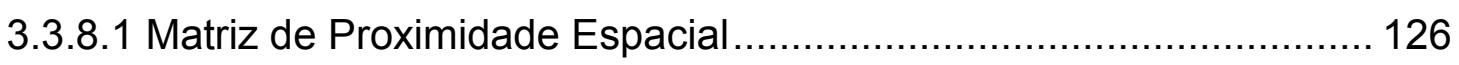

3.3.8.2 Autocorrelação Espacial Local Bivariada ....................................... 126

3.3.8.3 Diagramas de Espalhamento de Moran e Mapas de Cluster........... 128

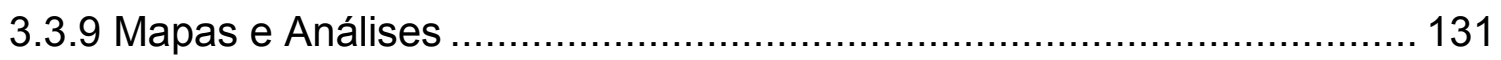

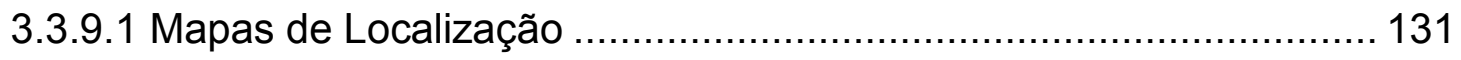

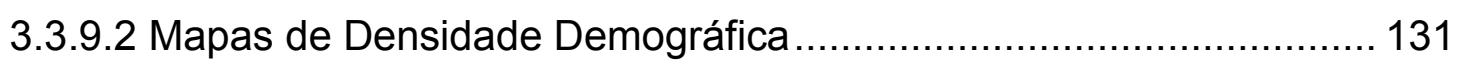

3.3.9.3 Mapas de Vulnerabilidade Social ................................................. 132

3.3.9.4 Mapas dos Espaços Verdes Urbanos .......................................... 132

3.3.9.5 Mapas dos Espaços Verdes Urbanos dm Áreas Protegidas: Unidades de Conservação da Natureza e Áreas de Proteção de Mananciais............. 132 3.3.9.6 Mapas da Porcentagem dos Espaços Verdes Urbanos por Unidade de Desenvolvimento Humano ................................................................... 133

3.3.9.7 Mapas dos Espaços Verdes Urbanos por Habitante (Análise

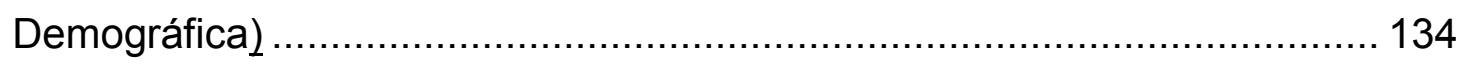

3.3.9.8 Mapas do Tamanho dos Fragmentos dos Espaços Verdes Urbanos

3.3.9.9 Mapas de Kernel dos Fragmentos Pequenos ............................... 135

3.3.9.10 Mapas de Correlação Espacial: Espaços Verdes Urbanos e

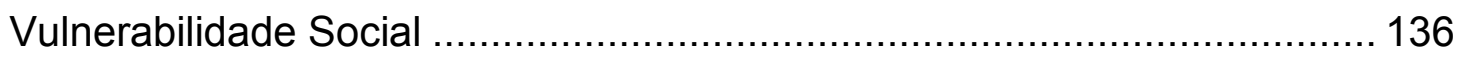

4. ESPAÇOS VERDES URBANOS NAS CIDADES ANALISADAS ....................138

4.1 Região Integrada de Desenvolvimento Econômico do Distrito Federal e

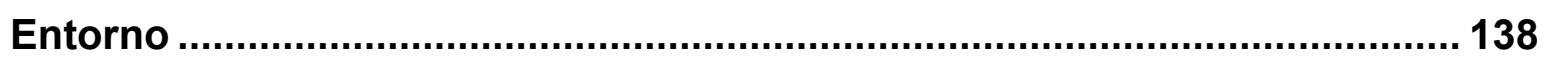

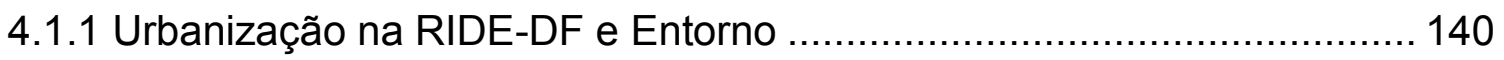

4.1.2 Espaços Verdes Urbanos na RIDE-DF e Entorno ................................ 150

4.1.3 Espaços Verdes Urbanos e Áreas Protegidas (UCs e APM) ................ 153

4.1.4 Espaços verdes urbanos nas unidades de desenvolvimento humano ... 159

4.1.5 Análise Dependente da Demografia.................................................. 164

4.1.6 Tamanho e Distribuição dos Fragmentos dos Espaços Verdes Urbanos 
4.1.7 Correlação dos Espaços Verdes Urbanos e Vulnerabilidade Social ...... 173

4.2 Região Metropolitana de Manaus ......................................................... 181

4.2.1 Urbanização na Região Metropolitana de Manaus ............................... 183

4.2.2 Espaços Verdes Urbanos na Região Metropolitana de Manaus ............ 191

4.2.3 Espaços Verdes Urbanos e Unidades de Conservação da Natureza .... 194

4.2.4 Espaços Verdes Urbanos nas Unidades de Desenvolvimento Humano 198

4.2.5 Análise Dependente da Demografia................................................ 202

4.2.6 Tamanho e Distribuição dos Fragmentos dos Espaços Verdes Urbanos

4.2.7 Correlação: Espaços Verdes Urbanos Vulnerabilidade Social ............... 208

4.3 Região Metropolitana Porto Alegre ...................................................... 216

4.3.1 Urbanização na Região Metropolitana de Porto Alegre ........................ 218

4.3.2 Espaços Verdes Urbanos da Região Metropolitana de Porto Alegre ..... 225

4.3.3 Espaços Verdes Urbanos nas Unidades de Conservação da Natureza. 228

4.3.4 Espaços Verdes Urbanos nas Unidades de Desenvolvimento Humano 232

4.3.5 Análise Demográfica 241

4.3.6 Tamanho e Distribuição dos Fragmentos dos Espaços Verdes Urbanos

4.3.7 Correlação: Espaços Verdes Urbanos e Vulnerabilidade Social ............ 249

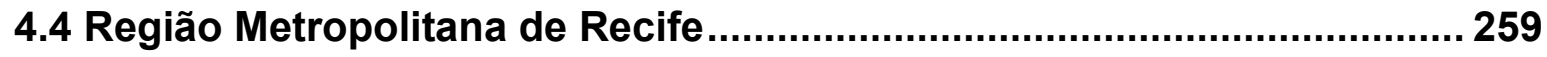

4.4.1 Urbanização da Região Metropolitana de Recife ................................ 263

4.4.2 Espaços verdes urbanos na Região Metropolitana de Recife ................ 269

4.4.3 Espaços Verdes Urbanos nas Unidades de Conservação da Natureza. 272

4.4.4 Espaços Verdes Urbanos nas Unidades de Desenvolvimento Humano 280

4.4.5 Análise Demográfica ............................................................ 284

4.4.6 Tamanho e Distribuição dos Fragmentos dos Espaços Verdes Urbanos

4.4.7 Correlação: Espaços Verdes Urbanos e Vulnerabilidade Social ............. 291

4.5 Região Metropolitana de São Paulo ................................................... 300

4.5.1 Urbanização na Região Metropolitana de São Paulo ........................... 303

4.5.2 Espaços Verdes Urbanos na Região Metropolitana de São Paulo ........ 310

4.5.3 Espaços Verdes Urbanos e Unidades de Conservação da Natureza .... 313

4.5.4 Espaços Verdes Urbanos nas Unidades de Desenvolvimento Humano 322 4.5.5 Análise Demográfica ................................................................... 326 
4.5.6 Tamanho e Distribuição dos Fragmentos dos Espaços Verdes Urbanos

4.5.7 Correlação: Espaços Verdes Urbanos e Vulnerabilidade Social 333

4.6 Síntese dos Resultados 341

4.6.1 Áreas Mapeadas: Espaços Verdes Urbanos e Vulnerabilidade Social... 341 4.6.2 Espaços Verdes Urbanos e Áreas Protegidas nas Unidade de Desenvolvimento Humano

4.6.3 Porcentagem dos Espaços Verdes Urbanos nas Unidades de Desenvolvimento Humano 345

4.6.4 Análise Demográfica: Espaços Verdes Urbanos $\left(\mathrm{m}^{2}\right)$ por Habitante...... 346

4.6.5 Tamanho dos Fragmentos dos Espaços Verdes Urbanos 347

4.6.6 Correlação Espacial: Porcentagem dos Espaços Verdes Urbanos e Vulnerabilidade social. 349

5. CONSIDERAÇÕES FINAIS E RECOMENDAÇÕES 352

Referências Bibliográficas 328 


\section{INTRODUÇÃO}

De acordo o censo demográfico de $2010,84 \%$ dos brasileiros vivem no meio urbano (IBGE, 2010). A falta de planejamento no processo de urbanização, impulsionado principalmente após a década de 1950, decorrente da industrialização e aumento exponencial da população trouxe uma série de problemas urbanos (MORO, 1976). Tais problemas se traduzem na falta de serviços básicos, como: esgotamento sanitário, abastecimento de água potável, coleta de lixo, além do surgimento dos aglomerados subnormais ${ }^{1}$ e loteamentos clandestinos que crescem de forma desordenada sem infraestrutura adequada e desrespeitando as legislações de ordenamento territorial e ambientais (SIRKIS, 2003).

A expansão industrial, após as décadas de 1950 e 1960, foi guiada pela inauguração das primeiras plantas automobilística no Brasil (RANGEL; DA SILVA, 2004). Por ser constituída por uma longa cadeia produtiva, liderada por montadoras e fornecedores de suprimentos automobilísticos, essas indústrias exercem impacto na economia nacional e na dinâmica das cidades (CONSONI; CARVALHO, 2002).

É importante ressaltar aquilo que o sociólogo André Gorz descreve de Ideologia Social do Carro (GORZ, 2004). O autor relata que existe uma política de incentivo na venda de carros para fortalecer a indústria automobilística, entendida imprescindível para a economia. Assim, o carro torna-se um bem almejado pela maioria das pessoas e que compromete a vida de todos que precisam se locomover pela cidade. A grande vantagem do carro, que seria a velocidade na locomoção, é seriamente prejudicada pelo aumento da frota e pelos congestionamentos (GORZ, 2004).

Para melhorar o tráfego dos carros, altera-se por completo a configuração urbana, o que prejudica a circulação dos habitantes em suas próprias cidades (Figura 1). A construção de novos eixos rodoviários, pistas de alta velocidade, viadutos e de condomínios em áreas distantes traz severas consequências. Como por exemplo: diminuição dos espaços com cobertura vegetal, ampliação da malha asfáltica, ocorrência de enchentes, maior poluição atmosférica.

\footnotetext{
${ }^{1}$ Normatização de nomenclatura realizada pelo IBGE às áreas conhecidas, como: favela comunidade, grotão, vila, mocambo. Assim, o IBGE definiu como aglomerado subnormal "o conjunto constituído por 51 ou mais unidades habitacionais caracterizadas por ausência de título de propriedade e pelo menos uma das características: irregularidade das vias de circulação e do tamanho e forma dos lotes e/ou carência de serviços públicos essenciais (como coleta de lixo, rede de esgoto, rede de água, energia elétrica e iluminação pública)" (IBGE, 2010a, p.18).
} 
A ampliação do transporte coletivo e a efetivação do direito à cidade para toda sociedade tem ficado de lado. A Figura 1 mostra uma das obras de infraestrutura urbana no Distrito Federal, denominada de "Trevo de Triagem Norte". É um complexo de viadutos e novas vias que priorizam o transporte individual.

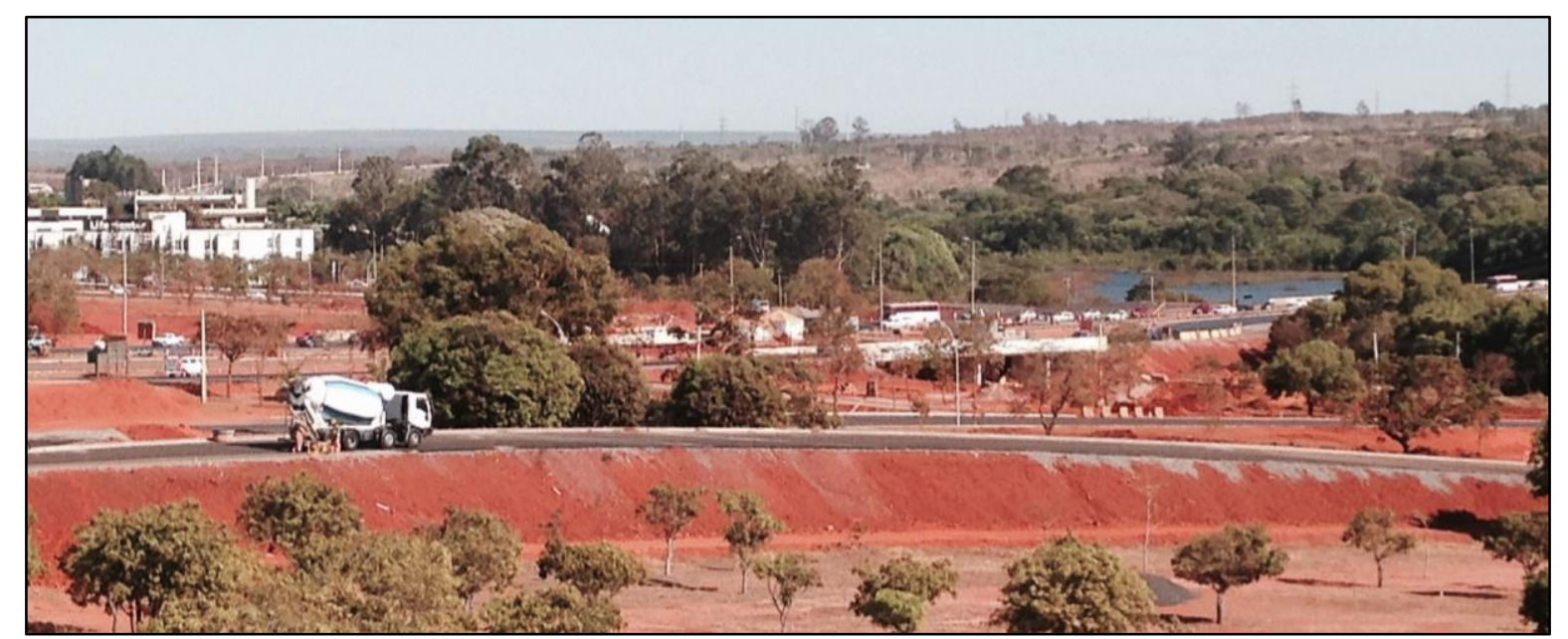

Figura 1 - Trevo de Triagem Norte. Asa norte, Brasília-DF

Fonte: Autor (2017)

Ressalta-se no entanto que o aumento de carros em si não pode ser considerado como único motivo da desordem territorial nas cidades, haja vista que mesmo após duras penas vários países atingiram números maiores de carros e souberam lidar com a eclosão de automóveis, através de massivos investimentos em transporte público. Destarte, Menezes (1996) analisa como problema maior, a falta de investimentos em infraestrutura e planejamento urbano que acompanhasse a explosão demográfica do século XX junto ao aumento de carros, ruas, vias, loteamentos e ocupações irregulares.

Afora as obras viárias que ficam expostas ao olhos dos cidadãos, a maior parte da infraestrutura urbana foi realizada sem o planejamento adequado. As obras de drenagem, abastecimento de água e esgotamento sanitário, por exemplo, não cobriram a necessidade de todos, tampouco integrou as políticas de expansão urbana (RIBEIRO, 1992).

Assim, os efeitos da degradação das condições ambientais urbanas começaram a ser visíveis ainda na segunda metade do século XX, acompanhada da explosão demográfica (Gráfico 1 ) e do desenvolvimento industrial brasileiro, não atrelados por investimentos estruturais nas cidades (PRIETO, 2006). 


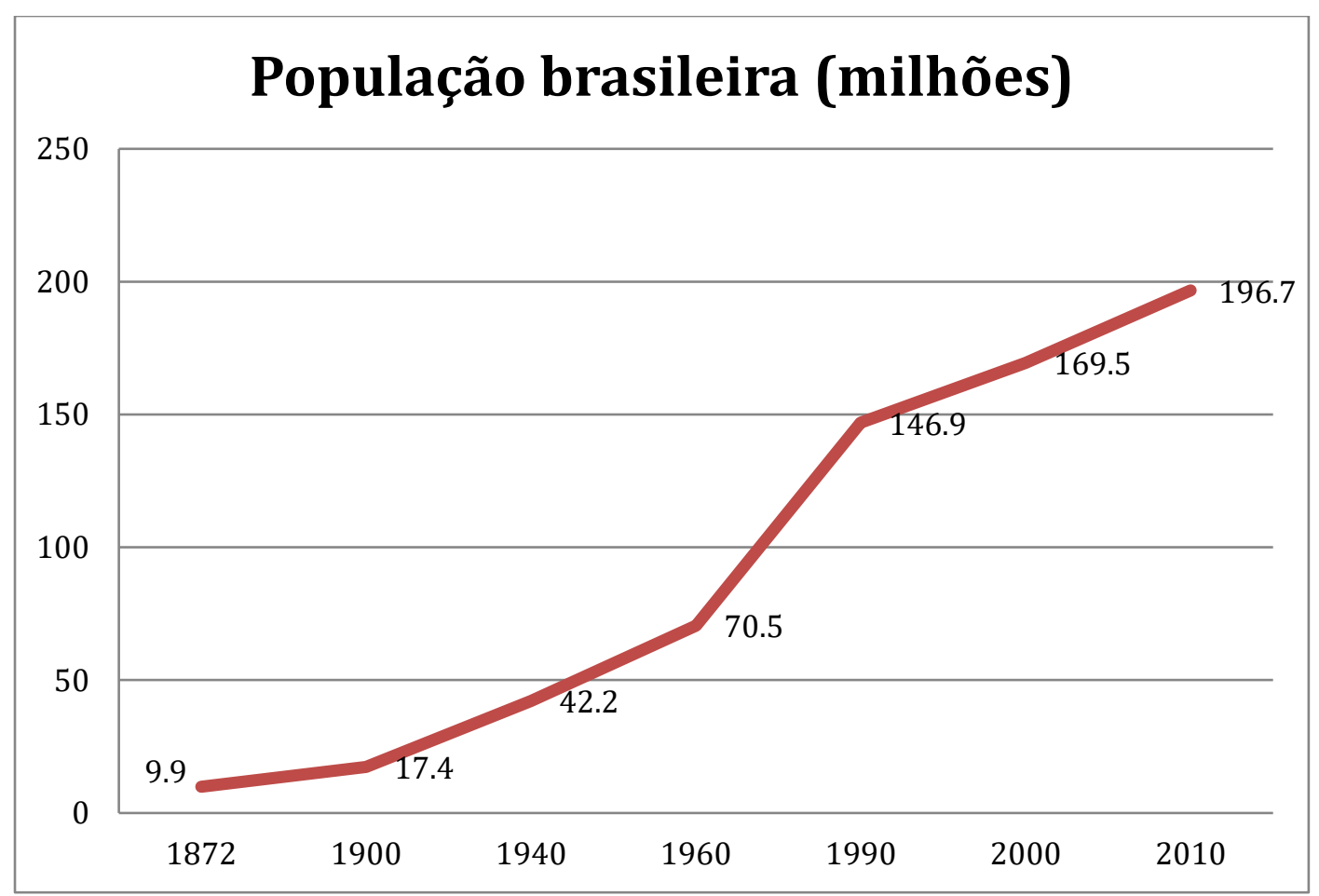

Gráfico 1 - Explosão demográfica do sec. XX

Fonte: IBGE (2010). Adaptado pelo autor

Além da poluição industrial e da falta de saneamento, Bitoun (2003) destaca como a maior problemática ambiental urbana: as ocupações irregulares. $O$ déficit habitacional, a falta de fiscalização e a falta de apoio do Estado, estimulam a ocupação de terrenos, morros, formando os bolsões de pobreza muitos deles em áreas de proteção ambiental (BITOUN, 2003).

As áreas mais frágeis do ponto de vista ambiental e que, por esse motivo não deveriam ser ocupadas, passaram a dar suporte a ocupações precárias (sem infraestrutura adequada) e predatórias (áreas de riscos de saúde, de deslizamento, erosão) (MARICATO, 1999). No início da década de 1980, os dados do Instituto Brasileiro de Geografia e Estatística (IBGE) apontaram a dimensão dessa ocupação: os índices de crescimento da ordem de $118,33 \%$ em relação à população residente em aglomerados subnormais e de $133,19 \%$ do aumento de domicílios situados nessas localidades mostram o retrato da falta do planejamento urbano.

Dada a problemática, na década de 1970, surgem ações legislativas acerca do parcelamento irregular do solo. Em 19 de dezembro de 1979 foi editada pelo Congresso Nacional a Lei do Parcelamento do Solo n. ${ }^{\circ} 6.766$ (BRASIL, 1979). Essa legislação buscou estabelecer um regramento mínimo ao empreendimento, em 
nome do bem-estar da coletividade que sofre efeitos diretos da ocupação territorial urbana desordenada.

O artigo $4^{\circ}$, da referida lei, estabelece requisitos para o fracionamento imobiliário, exigindo itens de infraestrutura mínima (BRASIL, 1979). A lei impôs regras de cunhos urbanísticos que minimizariam futuros danos ambientais quando se realizar a subdivisão da gleba original (loteamentos). Ocorre que os empreendimentos responsáveis por uma série de danos às cidades já se encontravam estruturados quando da edição da Lei do Parcelamento do Solo.

O crescimento abrupto e desordenado das cidades ainda continua gerando ocupações em situações irregulares ou clandestinas. A lei por si não gerou grandes resultados, embora seja um importante marco legal. Prevaleceu-se assim, a ineficiência e conivência dos mecanismos de controle dos órgãos públicos responsáveis pela expansão urbana e principalmente a necessidade das pessoas de se estabelecerem em algum lugar, mesmo que em zona de risco ou de vulnerabilidade socioambiental (TEIXEIRA-NETO, 2007).

Na década de 1970, durante o "milagre econômico brasileiro" até houve uma estruturação institucional para executar um plano de saneamento - Plano Nacional de Saneamento (Planasa) planejado e executado no regime militar (1967-1985). Mendes (1992) relata que nesse período verificou-se avanços nos serviços de abastecimento de água que pulou de $45 \%$ para $88 \%$ e a coleta de esgoto de $22 \%$ para $35 \%$ da população urbana brasileira.

Por outro lado, Mendes (1992) destaca que a ausência desses serviços urbanos se concentrava-se na população de baixa renda, que compunha na época mais de $50 \%$ da população urbana. Assim, cabe ressaltar que o processo de urbanização no regime militar caracterizou o que Santos (2005) denomina de "urbanização pretérita".

De acordo com o mesmo autor, a "urbanização pretérita" está vinculada à segregação socioespacial e à exclusão das camadas pobres das áreas providas de condições básicas de sobrevivência (SANTOS, 2005). Assim, sobraram para a população mais pobre as áreas não valorizadas pelo capital imobiliário, com pouca infraestrutura, ausência de serviços básicos de saneamento, saúde, educação, segurança e poucas áreas públicas de lazer, como parques ou praças (CORREA, 1994). 
Para agravar a situação estrutural urbana, durante a década de 1980, considerada como a "década perdida", devido às sucessivas crises econômicas, foram suspensos todos os planejamentos e investimentos necessários (FERREIRA, 1996). Foram extintos órgão federais que tocavam obras de infraestrutura urbana como o Ministério de Urbanismo, Habitação e Meio Ambiente (MHU), incluindo a primeira Secretaria Nacional de Saneamento e Departamento de Obras Sanitárias (DNOS) (MENDES, 1992).

Assim, na década de 1980, com o afloramento dos problemas socioambientais e de novos movimentos sociais e urbanos, surgem os primeiros questionamentos do processo de urbanização excludente, o que gerou uma luta pela reforma urbana (CARDOSO, 1983). No primeiro momento, as reivindicações dos movimentos não eram ambientais e tinham o objetivo, primário, de reverter as desigualdades sociais com base em uma nova ética social. Essa ética trazia como dimensão importante a politização da questão urbana, compreendida como elemento fundamental do processo de democratização da sociedade brasileira (JÚNIOR; UZZO, 2009).

Paralelamente ao processo da politização da reforma urbana, a questão ambiental é introduzida na pauta dos debates sobre as cidades, através de movimentos sociais. A "ecologização" da pauta urbana é fruto de um movimento internacional, que se iniciou nos anos 1960 e foi efetivado após a Conferência das Nações Unidas para o Meio Ambiente Humano, conhecida como Conferência de Estocolmo (1972). Essa foi a primeira conferência de âmbito global para tratar o meio ambiente, por isso é considerada um marco político internacional para o surgimento de políticas ambientais (BURSZTYN; BURSZTYN, 2012).

No Brasil, o meio ambiente ao ser definido à luz da Lei Federal n. 6.938 (1981) que instituiu a Política Nacional de Meio Ambiente, ainda estava à parte das questões urbanas, como descrito no artigo $3^{\circ}$, parágrafo I: "meio ambiente, 0 conjunto de condições, leis, influências e interações de ordem física, química e biológica, que permite, abriga e rege a vida em todas as suas formas" (BRASIL, 1981).

Nesse momento era difícil pensar numa integração entre gestão urbana e questões ambientais. Spósito (2003 p. 297), relata que essa cisão entre questões urbanas e ambientais é usual, uma vez que: 
sendo a cidade, uma das expressões materiais mais contundentes da capacidade social de se apropriar da natureza e transformá-lá, ela é vista como contraponto da própria cidade, ou seja, a cidade é considerada, por excelência, a não-natureza (SPÓSITO, 2003 p. 297).

Em 1988, a luta pela reforma urbana se consolidou no plano político brasileiro. Na Assembleia Nacional Constituinte, as forças populares representadas pelo Movimento Nacional da Rforma Urbana (MNRU) articularam as suas demandas e fizeram o embate com blocos políticos conservadores. Em meio à esse percurso, foram inseridos na Constituição de 1988 os artigos 182 e 183 (a partir da Emenda Popular $^{2}$ de Reforma Urbana subscrita por cerca de 200 mil assinaturas), nos quais se encontra a nova regulamentação da política urbana (JÚNIOR; UZZO, 2009).

Com a emenda popular, o direito público brasileiro passou não somente a garantir a propriedade privada e o interesse individual, mas a assegurar o interesse coletivo quanto aos usos individuais da propriedade. Os artigos 182 e 183 serviram ainda de base para a elaboração das propostas das constituições estaduais e dos planos diretores elaborados pelas administrações municipais logo após a constituinte (BRANDÃO, 2011).

A questão ambiental também recebeu atenção dos parlamentares, novamente de forma separada às questões urbanas. Pela primeira vez, a Constituição Federal dedicou um capítulo exclusivo sobre o meio ambiente. $O$ capítulo VI tem apenas um artigo, 225, que exerce o papel de principal norteador indicando a obrigação do Estado e da sociedade na garantia de um meio ambiente ecologicamente equilibrado (BRASIL, 1988):

Art. 225 - Todos têm direito ao meio ambiente ecologicamente equilibrado, bem de uso comum do povo e essencial à sadia qualidade de vida, impondo-se ao Poder Público e à coletividade o dever de defendê-lo e preservá-lo para as presentes e futuras gerações (BRASIL, 1988).

No Brasil, o alinhamento das questões ambientais no meio urbano ganhou força após a Conferência das Nações Unidas para o Meio Ambiente e Desenvolvimento (Rio 92) realizada no Rio de Janeiro. A questão foi bastante debatida especificamente no Fórum Global das Organizações não-Governamentais (ONGs) realizado paralelamente à conferência, onde foi introduzida a questão

\footnotetext{
${ }^{2}$ Mecanismo estabelecido pelo regimento interno da Constituinte que permitiu a iniciativa popular elaborar emendas.
} 
ambiental como uma temática de estudos urbanos (CAMARGO; SILVA; OLIVEIRAPRESZNHUK, 2004).

Como resultado da Rio 92, os 170 países participantes acordaram e assinaram a Agenda 21 Global, um programa de ação baseado num documento de 40 capítulos cunhados sob o tema: "Pense globalmente, haja localmente" (SEABRA, 2012). Vale lembrar que esse documento não é dotado de valor jurídico legal, como uma lei. Porém foi uma importante tentativa de se promover o "desenvolvimento sustentável" (BURSZTYN; BURSZTYN, 2012). Termo que foi amplamente divulgado em 1987, no relatório Brundtland, "Nosso Futuro Comum", e adotado no contexto da Rio-92.

O desenvolvimento que procura satisfazer as necessidades da geração atual, sem comprometer a capacidade das gerações futuras de satisfazerem as suas próprias necessidades, significa possibilitar que as pessoas, agora e no futuro, atinjam um nível satisfatório de desenvolvimento social e econômico e de realização humana e cultural, fazendo, ao mesmo tempo, um uso razoável dos recursos da terra e preservando as espécies e os habitas naturais (CMMAD, 1991, p. 10).

Cardoso (2011) afirma que a integração da questão ambiental e urbana apareceu na Agenda 21 Global quando se discutiu maneiras de melhoria na qualidade de vida nos países pobres, através do enfrentamento da pobreza e da degradação ambiental por meio de intervenções públicas. Deu-se ênfase na importância da melhoria nas condições de vida nos assentamentos populares, através do desenvolvimento sustentável. Nesse sentido, a questão ambiental-urbana é tratada no Capitulo 7, intitulado: "Promoção do Desenvolvimento Sustentável dos Assentamentos Humanos".

O fato é que após vinte anos de concepção da Agenda 21 Global, o desafio de tornar as cidades sustentáveis ainda é posto à mesa (SEABRA, 2012). O autor relata que "o planejamento das cidades esbarra nos interesses políticos, econômicos e na natureza multidisciplinar dos urbanistas, oriundos de diferentes escalas, onde, muitas vezes, as visões de mundo são conflitantes" (SEABRA, 2012, p. 25). Por esses motivos, a Agenda 21 Global não se consolidou como uma política pública, mas sim um mero documento replicado pelos países, haja visto que o desafio da sustentabilidade das cidades persiste.

Destaca-se também a morosidade política para definir regramentos ou obrigações no âmbito da gestão urbana. Um exemplo, a promulgação da lei que 
regulamenta o capítulo "Política urbana" definida na constituição brasileira de 1988 só correu treze anos após, no ano de 2001. Denominada de Estatuto da Cidade, instituída pela Lei Federal $n^{\circ} 10.257$ (BRASIL, 2001), mesmo que tardia ela é um marco no estabelecimento de normas de ordem pública de interesse social em ambiental que regula o uso da propriedade urbana.

O estatuto seguiu premissas da proteção ambiental visando a sustentabilidade urbana, por meio do planejamento territorial. Esse fato remonta a importância de se tratar de forma integrada as questões ambientais no âmbito da urbanidade (PIOLI; ROSSIN, 2005). A inserção da sustentabilidade no planejamento urbano implicou na necessidade de integrar as políticas urbanas e de meio ambiente, antes tratadas separadamente (PIOLI; ROSSIN, 2005).

Um dos pontos mais importantes do Estatuto da Cidade é a exigência de plano diretor para os municípios acima de 20 mil habitantes e a sua execução sob o norte da expansão urbana planejada de acordo com critérios sustentáveis (PIOLI; ROSSIN, 2005). Assim, o plano diretor é um importante instrumento de gestão ambiental urbana no âmbito municipal - lugar onde a população reside - sobretudo pelo fato de não haver uma tradição de política ambiental no plano municipal brasileiro (BRAGA, 2001).

Mesmo com o estatuto vigente, persistem os conflitos sociais urbanos e a luta por melhores condições de vida. As desigualdade nas condições de renda, a ausência de políticas e programas de desenvolvimento urbano com base na justiça social e a ação dos mercados imobiliários continuam varrendo os mais pobres para as periferias das cidades (ROLNIK, 1999). Esses efeitos são avaliados e discutidos sob nuances ambientais e de qualidade de vida (JACOBI, 2000).

Assim o crescimento desordenado das cidades ainda tem gerado problemas de ordem estruturais, sociais e ambientais. Os serviços públicos são insuficientes, mal distribuídos e contribuem para uma atenção diferenciada, favorecendo a desigualdade social. A questão ambiental nas cidades, passa por um processo de desmonte, degradação e ineficiência de uma política que continua gerando um número expressivo de "sem-tetos", acentuando os problemas socioambientais urbanos (SILVA, 2003a).

Para Schiffer (1999), planejar e gerir os efeitos da urbanização não exige apenas investir na infraestrutura das cidades. É preciso dar maior abertura à participação social e à questão ambiental. A gestão conjugada dos recursos 
ambientais, sociais, econômicos e dos serviços públicos é a melhor alternativa de se buscar o desenvolvimento sustentável nas cidades (SCHIFFER, 1999).

\section{Espaços Verdes Urbanos e Sustentabilidade}

Ao analisar a sustentabilidade em áreas urbanas é necessário refletir sobre os espaços verdes nas cidades. De forma representativa, o verde da vegetação vem como símbolo maior das cidades sustentáveis e de qualidade de vida. Embora as palavras verde e sustentável possuam grande correlação, destaca-se que uma cidade com grande quantidade de espaços verdes nem sempre é sustentável.

Primeiramente, a sustentabilidade urbana é um conceito amplo e inclui eficiência energética, reciclagem de resíduos sólidos, uso de energias renováveis, uso de transportes coletivos eficientes, estímulo ao uso de bicicletas, etc. A quantidade de espaço verdes é uma parte representativa e importante dentro das variáveis da sustentabilidade.

Outro aspecto a se considerar é a distribuição espacial dos espaços verdes, quando concentrados em zonas específicas das cidades, não cumprem funções sociais de maneira igualitária. Ab`Sáber (2004e); Carlos (2004); Jacobi (1999) discutem que eles estão concentradas em uma porção do espaço urbano, possivelmente em áreas mais nobres.

Outros estudos analisam que os espaços verdes urbanos não exercem uma função social, em consequência da ausência de infraestrutura e planos de uso adequados (JACOBS, 2011). Nesse caso, os espaços verdes são vistos como zonas perigosas e de risco.

Cabe aqui ressaltar algumas funções vitais dos espaços verdes para a infraestrutura urbana que refletem diretamente na qualidade de vida $e$ na sustentabilidade urbana. Ecologicamente, elas cumprem funções essenciais que vão desde o auxilio à drenagem urbana, tamponamento do microclima, à redução da erosão, alagamentos e poluição do ar (MERCADANTE, 1991). Ahern (2007); De Toledo (2007); Moro (1976); Nucci (2001) ponderam os benefícios dessas áreas na infraestrutura urbana via serviços ecossistêmicos, manutenção e/ou restabelecimento de conexões como os fluxos dos rios e da biodiversidade entre os fragmentos florestais.

De forma direta, os espaços verdes urbanos auxiliam na homeostase entre solo-clima-vegetação, na melhoria das condições atmosféricas, na redução na 
propagação de ruídos e na melhoria estética (LOBODA; DE ANGELIS, 2009). Assim, a presença da vegetação nas cidades forma espaços estruturais e funcionais fundamentais para a sustentabilidade urbana, gerando maior qualidade de vida.

Socialmente, além de proporcionar atividades de cunho esportivo, de lazer e descanso, funcionam como núcleos de convivência onde as pessoas exercerem a sociabilidade (AMATO-LOURENÇO et al., 2016). Além disso, quando utilizadas conferem uma boa referência e identidade à região do entorno (SMANIOTTO COSTA, 2008).

\section{Espaços Verdes e os Objetivos do Desenvolvimento Sustentável}

Considerando a importância socioambiental dos espaços verdes urbanos em nível global e de como correlacionam-se com outros fatores que interferem na qualidade de vida, destaca-se que a Cúpula das Nações Unidas sobre o Desenvolvimento Sustentável (Nova York - 2015) criou a Agenda 2030. Essa agenda descreve um plano de ação, assinado por 193 países, para o alcançar 17 Objetivos do Desenvolvimento Sustentável (ODS). Estabeleceu-se assim 169 metas para alcançar as ODS até 2030 (ONU, 2015a).

O objetivo $n^{\circ} 11$ que visa a sustentabilidade nas cidades e comunidades apresentou sete metas. Duas delas, relacionam com a importância de implantação dos espaços verdes como equipamentos urbanos nas cidades ou comunidades. $A$ meta 11.7 se relaciona de forma direta, ao estabelecer que "até 2030, proporcionar o acesso universal a espaços públicos seguros, inclusivos, acessíveis e verdes, em particular para as mulheres e crianças, pessoas idosas e pessoas com deficiência" (ONU, 2015b, p. 25). Essa meta, evidencia que os espaços verdes que funcionam como equipamentos urbanos promovem a inclusão social.

Assim, a meta 11.3 ao propor que se "aumente a urbanização inclusiva e sustentável, e a capacidade para o planejamento e a gestão participativa, integrada e sustentável dos assentamentos humanos" (ONU, 2015b, p. 25), observa-se que os espaços verdes estão diretamente relacionados. Ao se propor espaços verdes como equipamento urbano em comunidades carentes de infraestrutura urbana, além do espaço de convivialidade, inclusão e participação, a sociedade tende a apropriá-la. Com o sentimento de pertencimento por parte da população, os espaços verdes poderão ser mais protegidos estabelecendo sinergia dos benefícios sociais, ambientais e econômicos nas áreas onde forem implantados. 


\section{Definição do Problema}

Com a expansão urbana desordenada das últimas décadas, os espaços verdes vêm sendo suprimidos nas cidades. A substituição da cobertura vegetal por casas, prédios, arruamentos, indústrias, entre outros, é a consequência mais visível nos processos de urbanização (LOBODA; DE ANGELIS, 2009).

A supressão dos espaços verdes ocorrem em diferentes escalas geográficas e lugares, causando impactos negativos como, por exemplo: impermeabilização do solo, alagamentos, desmoronamentos, erosões, elevação da temperatura, mudanças no microclima e alterações no regime de chuva (BOVO; AMORIM, 2011).

A redução de vegetação no ambiente urbano implica na redução da qualidade de vida nas cidades (SHASHUA-BAR; HOFFMAN, 2000). Kuchelmeister (2000) enfatiza que os mais pobres são os mais vulneráveis com a perda de vegetação nas áreas urbanas, principalmente nos países em desenvolvimento.

Para agravar, o referido autor afirma que a maioria das pesquisas e projetos que visam a proteção e implantação dos espaços verdes urbanos estão, sobretudo, nos países mais ricos. Esses casos estão centrados em aspectos recreacionais e nos benefícios ambientais (MILLER; HAUER; WERNER, 2015).

O levantamento realizado por Taylor; Hochuli (2017) em importantes repositórios de artigos científicos ratifica que a ampla maioria dos estudos que envolvem o termo "green spaces" são estudos de casos de cidades do hemisfério norte (Europa, América do Norte e Ásia). Assim, Kuchelmeister (2000) chama a atenção para a necessidade de pesquisas e projetos que envolvam o planejamento e manejo dos espaços verdes principalmente nas áreas periurbanas nas cidades de países em desenvolvimento, zonas de maiores problemas socioambientais.

Daí a importância da gestão dos espaços verdes urbanos, principalmente nas áreas mais vulneráveis, sendo estes espaços "instrumentos de desenvolvimento" (KUCHELMEISTER, 2000; KUCHELMEISTER; BRAATZ, 1993). Como exemplo, Kuchelmeister (2000) cita um projeto na África do Sul, na cidade de Durban:

los parques multifuncionales son un componente de los programas de mejoramiento de los barrios de tugurios; los parques se utilizan para recoger agua de lluvia, evacuación y tratamiento de aguas residuales, actividades recreativas y jardineira (KUCHELMEISTER, 2000, p. 50). 
Organismos internacionais, como a FAO (Food and Agriculture Organization of the United Nations) têm-se empenhado no incentivo de projetos e pesquisas que incluem os espaços verdes na gestão urbana. É importante mencionar o "Guideline on urban and peri-urban forestry" como uma recente e importante publicação do referido órgão que mostra um panorama dos benefícios dos espaços verdes para tornar as cidades mais sustentáveis (SALBITANO et al., 2016). Além do panorama a publicação cita projetos executados, aportados na relação espaços verdes e ODS. Os projetos citados estão em várias cidades no mundo, inclusive em países em desenvolvimento como: Dhaka (Bangladesh), Ouarzazate (Marrocos), Manila (Filipinas), Nova Deli (Índia) e Lima (Peru) (SALBITANO et al., 2016).

No Brasil, a maioria das pesquisas que abarcam os espaços verdes são pontuais e relacionam-as com qualidade ambiental e de vida (HENKE-OLIVEIRA, 1996; MAZZEl et al., 2007). No geral são estudos de caso realizados em escala local e, geralmente, onde já existe uma política de valorização dos espaços verdes, sendo grande parte sobre cidades nas regiões Sudeste e Sul. As conclusões dos estudos caminham no sentido da valorização e regulamentação de alguns espaços (principalmente parques e praças), para que a população usufrua deles de forma sustentável.

Faltam estudos que ressaltem a importância de inserir no planejamento urbano análises sobre os espaços verdes sob a ótica distribuição e localização destes. Assim, o mapeamento de tais espaços serve como instrumento fundamental de análises que sustentem planos e gestões urbanas de cunho socioambiental que visem a sustentabilidade nas áreas urbanas.

As informações sobre os espaços verdes são básicas para qualquer diagnóstico relacionado à problemática socioambiental urbana. Por exemplo, análises de enchentes, variações do microclima, incidência de mosquitos e transmissores de doenças tornam-se mais esclarecedoras quando confrontadas com a localização e dimensão dos espaços verdes. Além da relação dos impactos negativos da expansão urbana, a maioria dos estudos que mapeiam os espaços verdes tendem a relacioná-los com a qualidade de vida, seja na promoção de parques ou espaços para o lazer ou pela a preservação ambiental no espaço urbano.

Ainda que existissem amplos recursos financeiros para efetivar 0 planejamento urbano vinculado à importância dos espaços verdes, persiste a 
dificuldade de obter mapas e dados que auxiliam na implementação e manutenção de políticas e projetos pró-espaços verdes nas cidades. Essa foi uma das constatações em âmbito do projeto denominado: "Levantamento da Cobertura Vegetal e dos Corpos D`Água Existentes em áreas Efetivamente Urbanizadas e Periurbanas de Municípios Brasileiros Selecionados"3, parceria entre Ministério do Meio Ambiente (MMA) e Universidade de Brasília (UnB).

Durante o levantamento realizado, antes da execução do projeto, constatouse que pouquíssimas prefeituras municipais dispunham de dados espacializados como: hidrografia, vegetação, uso do solo e área de preservação permanente (APP) em escala detalhada, passível de efetivar projetos, planos ou mesmo estudos ambientais, ou mesmos dados atualizados.

Além das informações e mapas dos espaços verdes urbanos, observa-se escassez de discussões sobre a relação entre a concentração desses espaços nas cidades e sua correlação com índices socioeconômicos. Ao estabelecer essa relação, é importante analisar setores com carência de espaços verdes e assim melhor direcionar ações e estratégias de política ambiental urbana.

Nesse sentido, as análises espaciais correlacionadas aos dados socioeconômicos fundamentam a discussão desta tese sobre os espaços verdes urbanos. Acredita-se que as informações levantadas e analisadas possam colaborar no planejamento territorial dos municípios, inserindo os espaço verdes urbanos como equipamentos urbanos para a promoção do desenvolvimento sustentável.

Tão importante quanto ter espaços verdes urbanos é estimular a sua apropriação e usos de forma mais igualitários. Tal importância é visível quando eles são utilizados em articulação com políticas públicas sociais através da promoção de atividades de lazer, esporte, cultura e educação permitindo uma maior sociabilidade, refletindo na melhoria de qualidade de vida.

Assim, a tese analisa a presença ou ausência dos espaços verdes urbanos como possíveis indicadores de desigualdades sociais, correlacionando dados dos

\footnotetext{
3 Iniciado em dezembro de 2010 e finalizado em janeiro de 2015, o projeto materializou em mapas e arquivos vetoriais de formato shapefile os espaços verdes, hidrografia e áreas de preservação permanente (APP) na área urbana de 732 cidades brasileiras. O projeto reuniu mais de 20 técnicos, dentre eles o autor desta tese. Em mais de quatro anos de trabalho, a equipe finalizou o mapeamento proposto em escala detalhada (1:25.000), tendo como base imagens de satélite RapidEye (resolução espacial de 5 metros) cedidas pelo próprio MMA. Informações do projeto constam no site: www.mma.gov.br/cidades-sustentaveis/areas-verdes-urbanas.
} 
espaços verdes aos socioeconômicos. Para tanto, buscou uma amostra de cidades com grandes desigualdade de renda (Regiões Metropolitanas de Manaus, Porto Alegre, Recife, São Paulo, além da RIDE do Distrito Federal e entorno) para aferir se os espaços verdes estão concentradas em zonas mais privilegiadas ou com menores índices de vulnerabilidade social.

\section{Objetivos}

\section{Objetivo Geral}

Analisar a ocorrência dos espaços verdes nas áreas urbanas a partir de padrões espaciais (tamanho, distribuição) e da correlação com dados socioeconômicos.

\section{Objetivos Específicos}

- Produzir referencial teórico sobre os espaços verdes urbanos;

- Construir amostra de cidades considerando as regiões metropolitanas de forma representativa a nível nacional;

- Elaborar metodologia de análise dos espaços verdes que possa ser replicada;

- Mapear e analisar a ocorrência e distribuição dos espaços verdes no espaço urbano;

- Correlacionar a presença dos espaços verdes urbanos com índices socioeconômicos.

\section{Hipótese}

Os espaços verdes urbanos estão mais concentrados em áreas com melhores índices socioeconômicos. 


\section{OS ESPAÇOS VERDES URBANOS}

A presença de árvores, plantas, jardins ou espaços verdes opõe-se, em primeiro instante, ao que se imagina ser urbano. A ideia de cidade e urbano quase sempre está associada ao cinza dos prédios, casas, ruas, asfalto, carros e pessoas. Esses elementos que compõem a cidade surgem na nossa percepção no plano do imediato, do visível e cognitivo (CARLOS, 1992).

Falar das florestas, do verde das árvores e de natureza remetem, numa primeira percepção, ao ambiente rural e áreas externas aos limites urbanos (CARLOS, 1992). A discussão que o verde perde espaço para o cinza nas cidades é válida e atual. Ao longo da história, os espaços das florestas, jardins e de cobertura vegetal foram relegados a segundo plano para os projetos comerciais, industriais e de consumo (CARLOS, 1992).

O fato de serem relegados não quer dizer que os espaços verdes estejem desconexos ao processo de urbanização, tampouco são apêndices da malha urbana. Ao longo da história, os espaços verdes têm mostrado funcionalidades e que sua presença em determinado lugar na cidade não é mera casualidade, conforme veremos a seguir.

\subsection{O Verde no Urbano}

Historicamente, os espaços verdes nas cidades remetem às antigas civilizações da China, Ásia Ocidental e Grécia (JELLICOE, 1985). O referido autor afirma que muitas cidades dessas civilizações tinham parques, jardins e outros espaços verdes extremamente sofisticados - o mais famoso foi na cidade de Babilônia, a "Cidade Jardim", que remonta a mais de 3000 anos.

Loboda; De Angelis (2009) narram que a jardinagem egípcia foi transmitida aos gregos, persas, romanos e árabes no século ainda no século $V$ a.C. e tinham uma tradição baseada em crenças estéticas, culturais e religiosas. Por mais que a questão estética relaciona-se ao surgimento dos jardins egípcios, o real motivo era estabelecê-lo como sistema de irrigação cuja função primordial era amenizar o calor (LOBODA; DE ANGELIS, 2009). Dessa forma, a presença dos jardins caracterizava como uma extensão das propriedades privadas dos mais nobres (GRIMAL, 1964). A figura 2 ilustra o que seria o "Jardim Egípcio". 


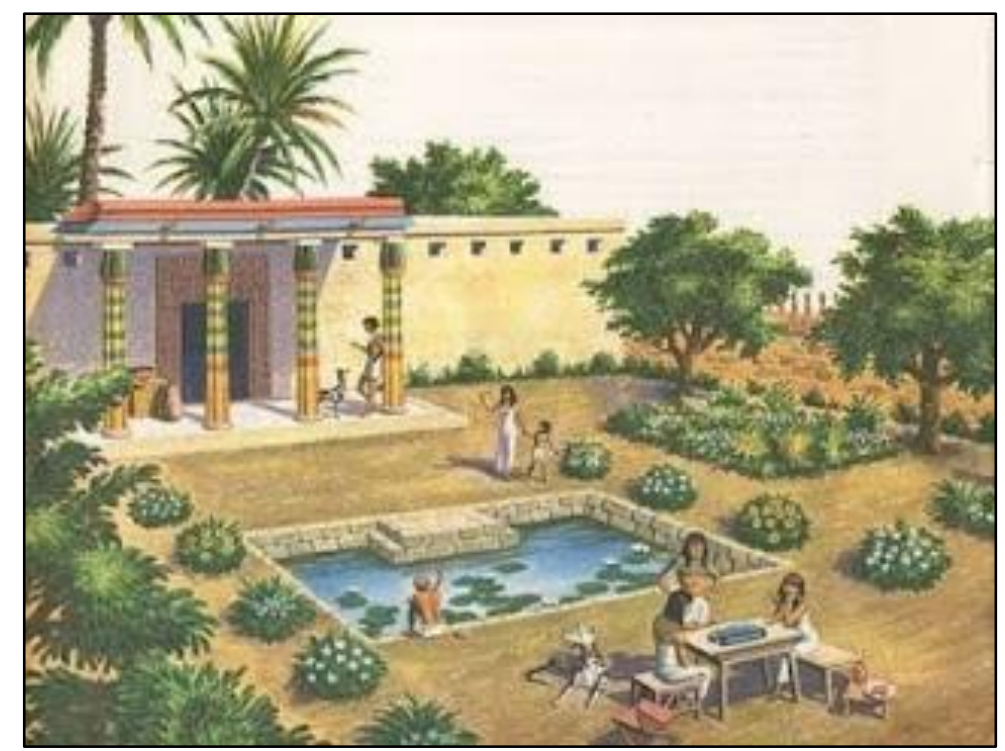

Figura 2 - Jardim Egípcio

Fonte: http://paisagismo.brasil.blogspot.br/2015_11_01_archive.html

Em outra vertente, pela tradição de jardinagem chinesa, construíram-se espaços com fins religiosos e espirituais através da inserção dos elementos da natureza (Figura 3). Os jardins chineses influenciaram os japoneses de outros países asiáticos através da significação espiritual e cultural dados aos elementos que os compõem: pedras, água, pontes, lamparinas, flores (LOBODA; DE ANGELIS, 2009).

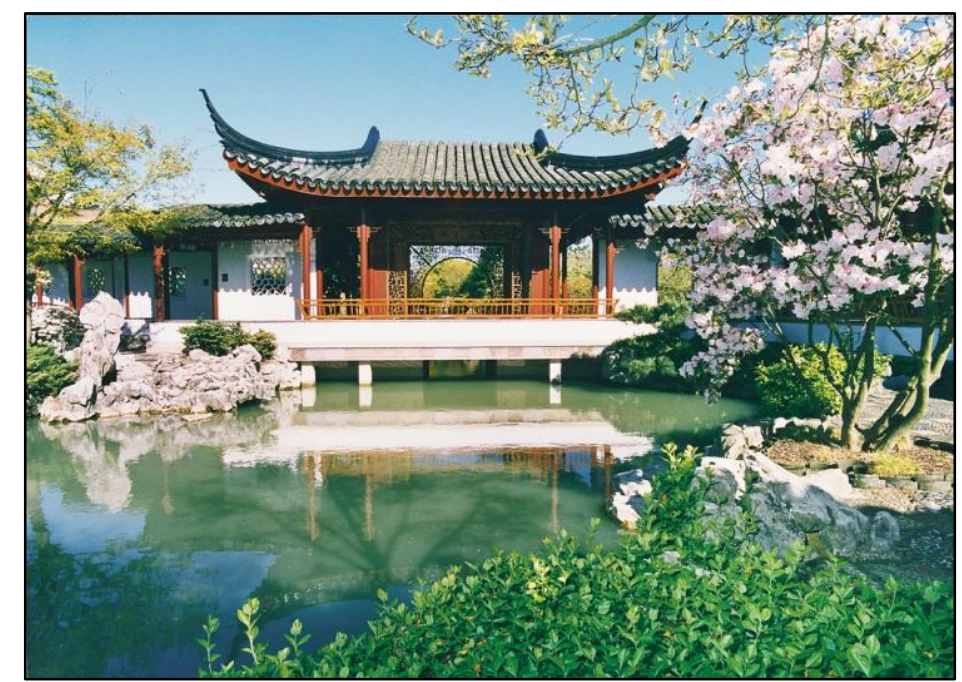

Figura 3 - Jardim Chinês

Fonte: www.gardenvisit.com/classicalchinese. Autor @ Dr. Sun Yat-Sen.

Na história ocidental, a Grécia foi pioneira na utilização dos espaços livres como espaços públicos de lazer, integração e de sociabilidade (LOBODA; DE ANGELIS, 2009). O espaço livre reservado para as relações sociais de lazer, descanso e diálogo foi denominado de ágora. Fisicamente, era um lugar adornado com templos e estátuas, e era arborizado (HARVEY, 1987). Lá havia relações comerciais onde pescadores e camponeses vendiam seus produtos (Figura 4). 


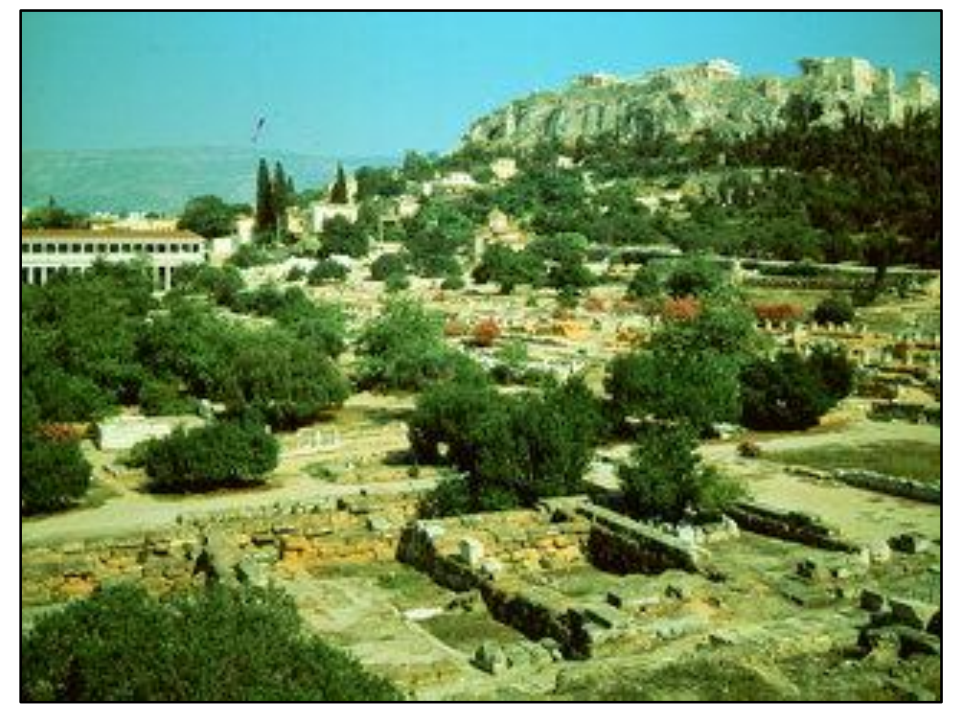

Figura 4 - Ágora Grega - Atenas (Grécia)

Fonte: http://www.greece-athens.com/

Além de fins comerciais, a ágora era o lugar para encontros e conversas. Nesse sentido, Saldanha (1983) a descreve como locus da democracia direta, visto que este era o local para discussão e debate entre os cidadãos: "A ágora situava a vida pública, com as conversas, as facções, as decisões: nela a palavra se fazia pública, como se fazia pública a condição do homem" (SALDANHA, 1983 p.9).

A batalha de Queronéia (338 a.C.) que marcou a derrota dos gregos ao Império Macedônico refletiu na perda de elementos primordiais da democracia grega como o espaço ágora (SALDANHA, 1983). Surge então o tempo de Epicuro e a busca do espaço à reflexão. No lugar da ágora surge o "jardim" como o abrigo maior da razão e da vida privada. O filósofo Epicuro tinha a ideia de que, para ser feliz, precisava de tempo e lugar para filosofar. Assim o "jardim" seria exatamente o refúgio onde encontraria a felicidade (ULLMANN, 1996).

Na prática, o tempo de Epicuro foi uma escola de pensamento proeminente por um período de sete séculos depois da sua morte (270 a.C.) (ULLMANN, 1996). Com o início da Idade Média (sec. $\mathrm{V}-\mathrm{XV}$ ) a ideia de cidades com jardins foi esquecida, assim como a maioria dos escritos deste filósofo. Ainda assim, no século XIX surge na Inglaterra um padrão de urbanismo influenciada pelas ideias de Epicuro, denominado de cidades-jardim. Modelo esse, implementado em áreas mais valorizadas do espaço urbano e refletidos atualmente em condomínios fechados de grandes cidades brasileiras (CHOAY, 1999). 
Voltando ao tempo de Epicuro, Saldanha (1983) relata que houve um confronto ao modo político do Império Romano: enquanto os gregos transitaram do público ao privado, os romanos passaram do privado ao público. Assim, nessa época, a importância das propriedades agrárias privadas do Lácio (conhecida como Lazio, região de alta fertilidade agrícola) seria reduzida pelo fortalecimento da figura da vila. A vila seria um conjunto de moradias privadas e edificações de finalidade públicas com a presença de um pátio central. Esses pátios possuíam um jardim, seriam um espaço semelhante ao que denominamos de praças ou parques urbanos (SALDANHA, 1983).

Os jardins no Império Romano faziam parte de um conjunto de artes cênicas composto de esculturas e obras arquitetônicas, como: fontes, pontes e vias. Assim, até o elemento vegetal (árvores e plantas ornamentais) era modelado por técnicas de poda, segundo uma nova arte, denominada pelos romanos de topiaria (LOBODA; DE ANGELIS, 2009). O estilo desses jardins se preservou durante séculos, refletindo o luxo do Império Romano (SALDANHA, 1983).

No processo de ruralização da Europa (Idade Média - sec. V ao XV) houve uma redução drástica não só dos espaços verdes (jardins e pátios) e áreas de lazer, como o próprio espaço das cidades. As inúmeras invasões de outros povos e grandes fluxos de migrações definharam as cidades ao par do aumento da dependência pessoal, dos avanços da servidão, da submissão do poder dos senhores feudais e da igreja $(\mathrm{BLOCH}, 1979)$.

A cidade medieval era fechada, geralmente cercada de muralhas, com 0 mínimo de trocas e atividades liberais $(\mathrm{BLOCH}, 1979)$. O que existiam de espaços verdes e jardins, durante esse período, remontam às funções especificas de consumo de pequena escala (Figura 5), tratando-se de jardins e hortas internos para produção de ervas, flores, frutas e outros alimentos (LOBODA; DE ANGELIS, 2009). 


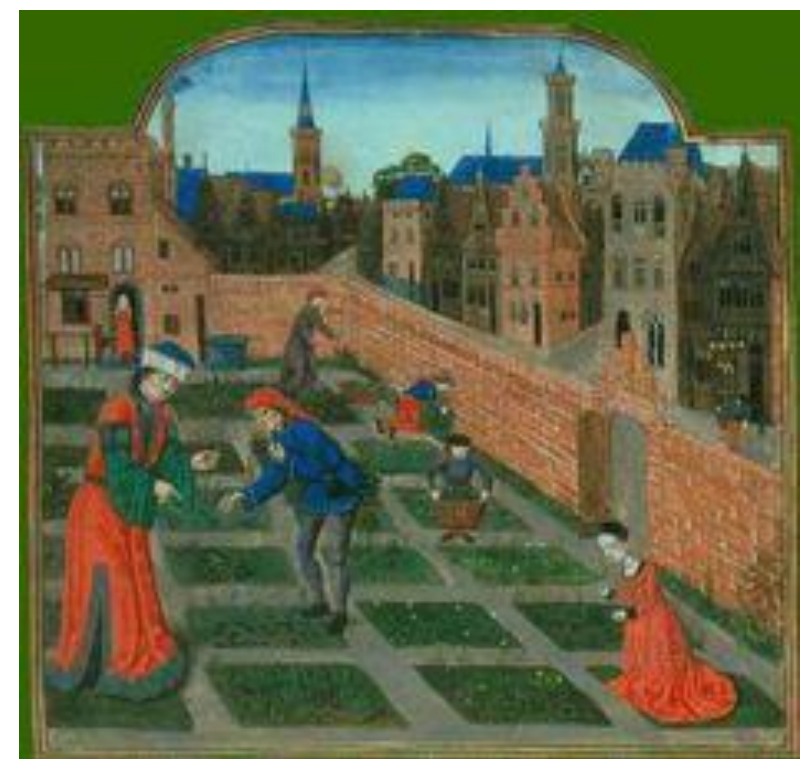

Figura 5 - Jardins Medievais

Fonte: http://paisagismo-brasil.blogspot.com.br/medievais.html

A partir do século XI as cidades renascem na Europa, e passam a ser espaço de liberdade, frente ao feudalismo (PIRENNE, 1973). Com a consolidação do Renascimento (sec. XV), os espaços verdes passaram a ser produzidos à luz dos refinamentos estéticos e artísticos, afim de dotá-los como espaços fruto da liberdade e do racionalismo humano. Observa-se assim, a presença de elementos artificiais de ornamento e de formas diversas e ricas. Como por exemplo: as fontes de Roma, esculturas de mulheres, homens, anjos e deuses nus (LOBODA; DE ANGELIS, 2009).

A arte nos jardins da Renascença ainda são vistos em parques e praças de vários países europeus, principalmente na Itália e na França (LOBODA; DE ANGELIS, 2009). No geral, foram planejados de forma que a vegetação e obras de arte pudessem unir-se em um complexo de espaços abertos à população (LOBODA; DE ANGELIS, 2009).

Kuchelmeister; Braatz (1993) relatam que na Europa, nos séculos XVII e $\mathrm{XVIII}$, as florestas municipais e reais (ligadas às monarquias) foram criadas para a caça recreativa. Posteriormente, em muitas cidades europeias incluindo Itália, França, Áustria e Inglaterra, criou os primeiros jardins e parques urbanos para fins de lazer e estéticos. 
O fato de observar a natureza e entendê-la como um espaço aberto, ilimitado a quem o homem deveria se submeter, fez dos ingleses os pioneiros na idealização e criação dos primeiros parques urbanos públicos (LOBODA; DE ANGELIS, 2009). O Saint James é o mais antigo parque inglês, inaugurado em 1603, pouco depois inaugurou-se o Hyde Park em 1637. Já no início século XIX o Regent's Park é inaugurado e junto com os anteriores e são considerados parques pioneiros em áreas urbanas no mundo (CHOAY, 1999). Até hoje esses espaços verdes estão presentes no cenário urbano, sendo exemplos de espaços de descanso, lazer, prática de esporte dentro da malha cinza, entremeada de prédios e ruas (Figura 6).

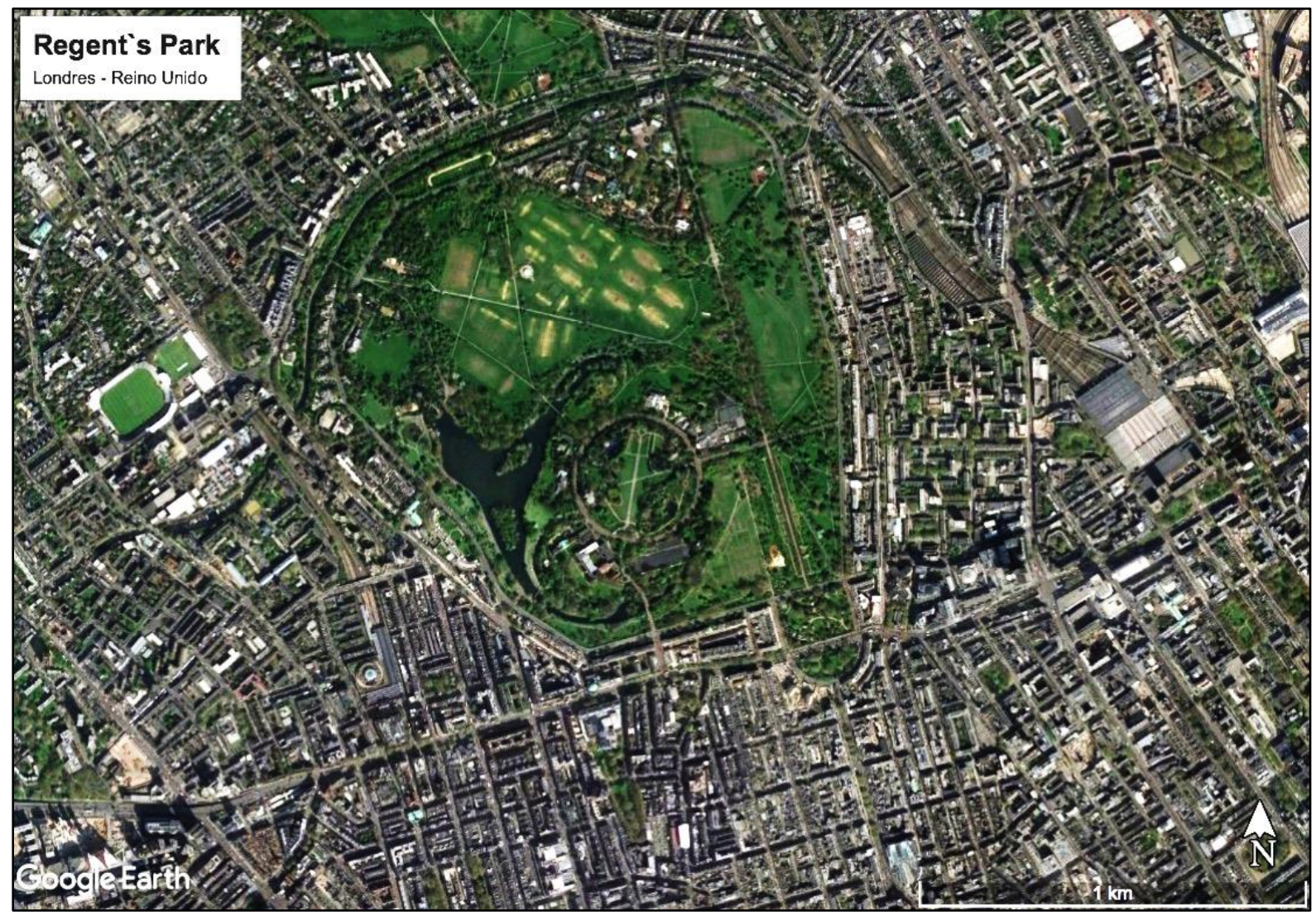

Figura 6 - Regent's Park. Londres (Inglaterra)

Fonte: Google-Earth (2017)

Choay (1999) relata que após a segunda metade do século XIX os parques e os jardins públicos afloraram nas cidades europeias, como consequência direta da Revolução Industrial (1760 - 1840). Ao mesmo tempo, o referido autor relata como enorme efeito da urbanização as mudanças repentinas do fluxo demográfico, fruto do crescimento exponencial da população nas cidades (CHOAY, 1999).

Assim, Choay (1999) aponta que a manutenção dos espaços verdes públicos atendia, em primeiro lugar, as demandas sanitárias e higienistas, uma vez que as 
cidades industriais apresentavam altos níveis de insalubridade refletindo graves problemas de saúde pública. A partir de técnicas de drenagem urbana, as águas paradas sujas e fétidas foram escoadas para os rios e mares (CHOAY, 1999).

Concomitantemente, a natureza foi domesticada por padrões estéticos através de cortes, técnicas de podas com delimitações em linhas retas e geométricas (CHOAY, 1999). Assim, as áreas insalubres compostas de água parada e vegetação nativa foram transformadas em jardins e parques, remontando as tendências renascentistas ou naturalistas (CHOAY, 1999). Uma vez implantados, tais espaços passaram a ser considerados um refúgio para a vida contemplativa, de descanso, lazer e atividades, em meio ao caos urbano (HENRIQUE, 2009).

Os espaços verdes contribuíram ao mesmo tempo para as mudanças repentinas da forma das cidades e para o surgimento de uma nova urbanidade. Choay (1999) destaca que os modelos de parques urbanos elaborados pela Inglaterra e França serviram como modelos para os outros parques na Europa e América.

O modelo francês (Figura 7), criou uma visão mais urbana, com planejamento de ruas, vias, sistemas de escoamento de água, lagos, coretos para música, restaurantes e cafés, locais para venda de jornais, revistas e livros (CHOAY, 1999). Para Jones (2018) o exemplo francês mais marcante é o jardim de Versalhes. "Its radiated display of power over nature and nation, with hydraulic fountains and transplanted trees, designed by Andre Le Notre from 1661" (JONES, 2018, p. 40).

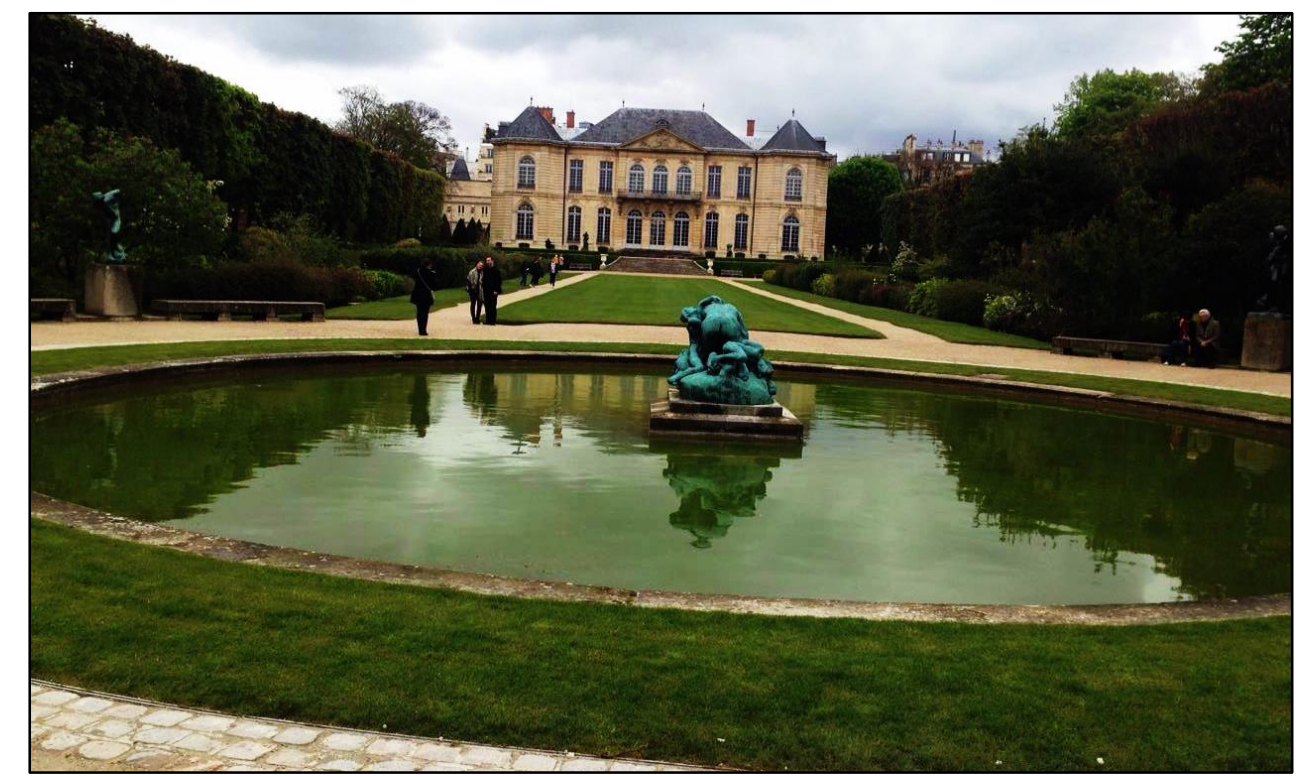

Figura 7 - Espaço verde do Museu Rodín. Paris (França)

Fonte: Lins; Cláudia (2016) 
O modelo inglês criou um cenário de campo incorporados à cidade (Figura 8). É comum a presença de animais, como os cisnes brancos (historicamente propriedades do rei ou rainha do Reino Unido - RU), além de extensas áreas imitando a vida rural, com muitas árvores, chão sem ladrilhos ou asfaltamento (CHOAY, 1999).

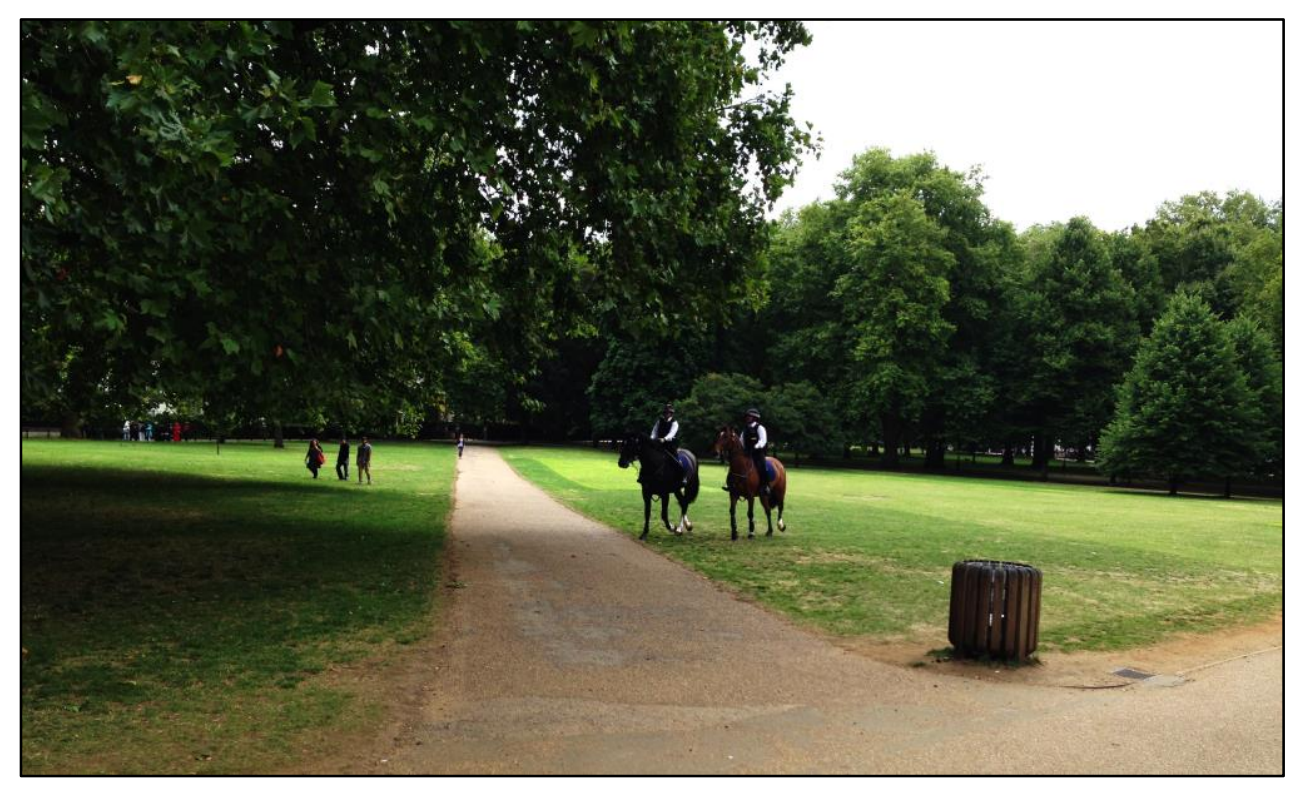

Figura 8 - Parque Saint James. Londres - Reino Unido Fonte: Autor (2015)

Nota-se que a inclusão dos espaços verdes nos assentamentos humanos e a integração dos mesmos nas cidades não é uma atividade recente. Ao longo da história a introdução desses espaços refletem valores estéticos, espirituais e seus benefícios funcionais que refletem na melhoria da qualidade de vida.

\subsection{Histórico dos Espaços Verdes Urbanos no Brasil}

Além da influência anglo-francesa, destacou-se no Brasil a presença de espaços verdes nas áreas urbanas na metade do século XVII em Pernambuco (Recife e Olinda), por obra de Maurício de Nassau. A gestão holandesa primou por plantar nas áreas urbanas, uma enorme quantidade frutíferas: laranjeiras, tangerinas, limoeiros. Mesmo após a expulsão dos holandeses do Brasil, Recife ficou conhecida pela diversidade de frutíferas pelas ruas (LOBODA; DE ANGELIS, 2009). 
No Brasil, a presença dos espaços verdes nas áreas urbanas não foi impulsionada diretamente pela Revolução Industrial, como na Europa no século XIX, uma vez que no período o país ainda não possuía uma rede urbana expressiva (SCOCUGLIA, 2009). Existiam casos pontuais da presença dos espaços verdes nas principais cidades, sobretudo nas capitais, onde os parques funcionavam como uma extensão do cenário das elites e repetiam os modelos ingleses e/ou franceses (SCOCUGLIA, 2009).

No início do século XIX, o Brasil passou por uma organização urbanística, reflexo da vinda da família real portuguesa em 1808. Assim, as principais mudanças ocorreram na nova sede da coroa: Rio de Janeiro. A capital precisou ser reorganizada e passar por inúmeras intervenções urbanísticas para desempenhar novas funções politico-administrativas (SCHIFFER, 1999).

Nesse período, destacam-se a construção dos três primeiros parques urbanos públicos no Rio de Janeiro. O primeiro foi denominado Passeio Público do Rio de Janeiro, construído por ordem do vice-rei Dom Luís de Vasconcelos e suas obras iniciaram em 1779. Já o segundo, Campo de Santana (projetado em 1873) foi considerado uma réplica dos parques e jardins mais modernos de Paris. Já o Jardim Botânico do Rio de janeiro é o terceiro mais antigo e foi uma determinação de Dom João VI para abrigar coleções botânicas (MACEDO; SAKATA, 2002).

Em meados do século XIX, após longo período de devastação de áreas de vegetação para uso da madeira e lavouras de cana-de-açúcar e café, o Rio de Janeiro começou a sofrer com a falta de água. Assim, em 1862, Dom Pedro II ordenou o reflorestamento do local de maior devastação florestal dentro da cidade do Rio de Janeiro, hoje conhecida como Floresta da Tijuca (DRUMMOND, 1998).

A missão foi confiada ao major da polícia militar Archer, que iniciou o trabalho com seis escravos. Foram plantadas 100 mil mudas em treze anos, principalmente espécies nativas da Mata Atlântica. O tenente-coronel D'Escragnolle, executou o paisagismo, transformando a floresta em um espaço para uso público, com áreas de lazer, trilhas, mirantes e lagos (DRUMMOND, 1998). Hoje ela é considerada a maior floresta urbana do mundo (Figura 9), além de ser a unidade de conservação da natureza mais visitada do país e uma importante área de lazer com trilhas e espaços privilegiados para prática de turismo ecológico dentro do espaço urbano (ICMBIO, 2017). 


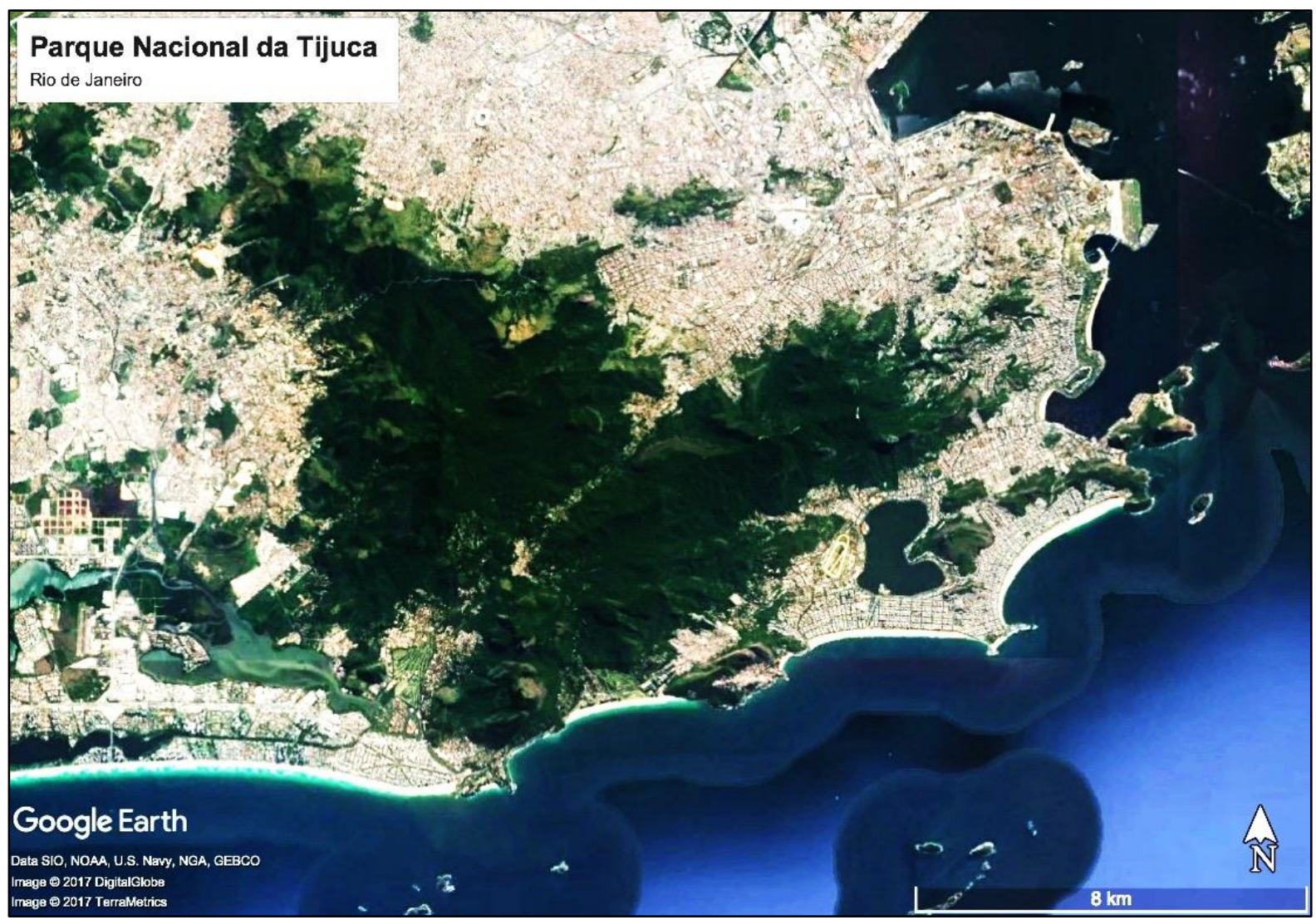

Figura 9 - Parque Nacional da Tijuca. Rio de Janeiro (RJ)

Fonte: Google-Earth (2017)

A disseminação urbanística de bulevares, ajardinamentos em avenidas e praças e a criação de parques urbanos foram iniciativas marcantes das primeiras décadas da República, no final do século XIX (SEGAWA, 1996). O autor relata também que nesse período, surgem os primeiros parques privados do país. Para exemplificar, o autor cita o Jardim da Saúde (bairro nos padrões cidade-jardim, planejado para a alta sociedade paulistana) e o Parque Antártica (parque criado pela Companhia Antarctica Paulista - para fins de lazer dos seus funcionários). (SEGAWA, 1996).

Apenas no século $X X$, os parques e espaços verdes urbanos no Brasil passam a ser um elemento comum presente nas principais capitais e cidades de médio porte. Exemplos disso são os parques criados em estâncias hídricas nas cidades de Araxá e Poços de Caldas, ambos em Minas Gerais; assim como os inúmeros passeios públicos em Curitiba, Recife, Belo Horizonte, Porto Alegre, São Paulo e Fortaleza (MACEDO; SAKATA, 2002).

Segawa (1996) destaca que no início do século XX, São Paulo tornou-se a principal cidade sul-americana, dado o elevado número de habitantes e pela potência econômica. Assim, foram adotadas inúmeras obras urbanísticas para 
suportar o crescimento demográfico e econômico da capital. Na parte ambiental destaca-se o aterro e saneamento da área da várzea do Carmo, atualmente conhecido como Parque Dom Pedro II e o Parque do Anhangabaú, ambos criados nos anos 1910/1920. Além de caráter ambiental, esses parques são considerados importantes obras urbanísticas com fins de valorização cultural da cidade (SEGAWA, 1996).

Macedo (1999) acrescenta que após o início da República, somente a partir dos anos 1970 e 1980 que o número de parques cresceram e consolidaram nos centros urbanos. Destacam-se parques nas cidades do Rio de Janeiro e Brasília, onde novos parques foram construídos. $O$ autor afirma que o exemplo mais significativo dessa nova fase é Brasília (Figura 10) que inaugurada em 1961 foi idealizada como cidade parque, onde todos os edifícios foram projetados para serem envolvidos por extensos espaços verdes (MACEDO, 1999, p.84).

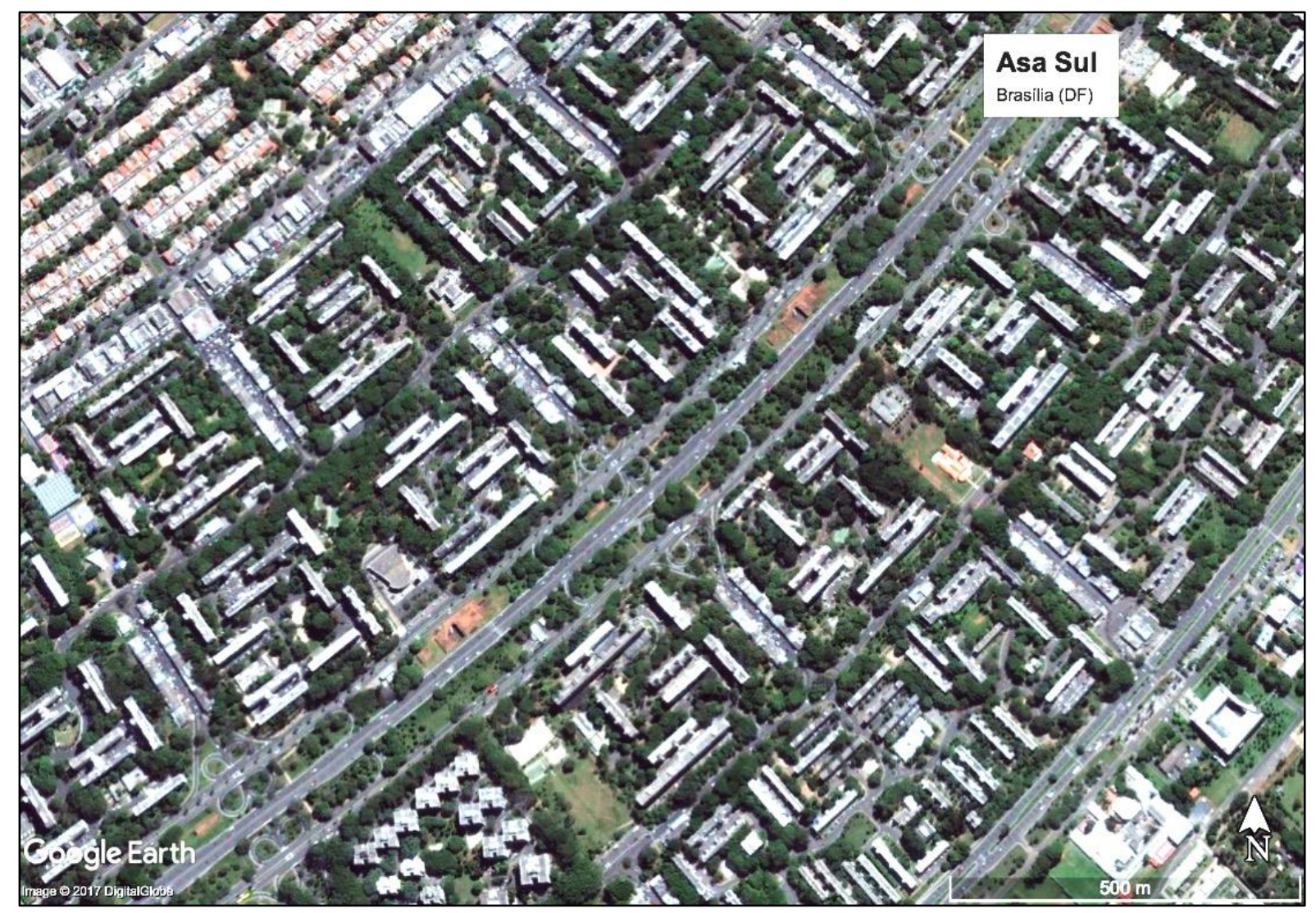

Figura 10 - Espaços verdes urbanos em meio ao prédios e arruamentos. Asa Sul. Brasília Fonte: Google-Earth (2017)

O papel desempenhado pelos espaços verdes nas cidades tem sido uma consequência das necessidades experimentadas de cada momento, ao mesmo 
tempo em que é um reflexo das preferências e costumes da sociedade. Públicos ou privados, os espaços verdes vem ganhado maior importância no planejamento das cidades, dados os benefícios: paisagísticos, sociais, ambientais e econômicos. Ainda assim, é importante relatar que eles continuam sendo relegados, sobretudo pelos projetos empresariais.

\title{
1.3 Conceito: Áreas e Espaços Verdes Urbanos
}

A legislação federal brasileira definiu as áreas verdes urbanas, recentemente, pelo Novo Código Florestal (BRASIL, 2012). De acordo com o art. 30, inciso $\mathrm{XX}$, entende-se por área verde urbana, como:

\begin{abstract}
espaços, públicos ou privados, com predomínio de vegetação, preferencialmente nativa, natural ou recuperada, previstos no Plano Diretor, nas Leis de Zoneamento Urbano e Uso do Solo do Município, indisponíveis para construção de moradias, destinados aos propósitos de recreação, lazer, melhoria da qualidade ambiental urbana, proteção dos recursos hídricos, manutenção ou melhoria paisagística, proteção de bens e manifestações culturais" (BRASIL, 2012, grifo do autor).
\end{abstract}

O conceito legal converge com os conceitos técnicos de áreas verdes urbanas usados por vários autores (HARDT, 1994; LIMA et al., 1994; MACEDO, 1995; NUCCI, 2001) nas seguintes características: são áreas com predomínio de vegetação, sem levar em conta o seu porte, apresentam alta percentagem de solos não impermeabilizados e cobertos por vegetação.

Macedo (1995 p. 16) reitera a amplitude conceitual de áreas verdes, ao afirmar que o conceito "designa toda e qualquer área plantada, tendo um significado social expressivo ou não". Da mesma forma Loboda; De Angelis (2009) relatam que as áreas verdes urbanas apresentam uma grande variedade de tipos, estruturas, formas e funções. Podem ser espaços construídos como jardins, parques, praças, cemitérios arborizados ou áreas como florestas urbanas e áreas protegidas para a conservação da natureza e/ou da paisagem (LOBODA; DE ANGELIS, 2009).

Apesar da amplitude conceitual, Macedo (1995) não considera apropriado designar todas praças, parques, hortos e bosques urbanos como áreas verdes, uma vez que nestes casos nem sempre necessitam de vegetação para desempenhar função social no espaço. Nestes casos, "a utilização do termo sistema de espaços livres públicos de lazer e/ou conservação é precisa e objetiva e evita o uso irresponsável do conceito para os mais diversos fins" (MACEDO, 1995, p. 17). 
Frente a amplitude conceitual das áreas verdes urbanas, Silva (2012) salienta que nelas admite-se certos tipos de construção, só que em proporção reduzida. Para o autor, o que caracteriza as áreas verdes urbanas é a existência de vegetação continua (independente do porte), amplamente livre de edificações, ainda que recortada de caminhos, vielas, brinquedos infantis e equipamentos de atividades esportivas, quando tais áreas se destinem ao uso público.

Na definição de Nucci (2001) há destaque para as funções essenciais dessas áreas: estética (paisagística), ecológica e lazer (social). Diferentes autores investigaram e forneceram evidências dos benefícios gerados pelas áreas verdes, seja em nível ecológico (TOLEDO, 2007; MAZZEl et al., 2007), social (AMATOLOURENÇO et al., 2016) e econômico (SMANIOTTO COSTA, 2008). A multifuncionalidade das áreas verdes se reflete em benefícios diversos aos usuários de diferentes perfis (crianças, idosos, jovens) e ao meio ambiente urbano.

Dando enfoque à questão social, Lima et al. (1994) enfatizam a importância do uso das áreas verdes para a recreação da população. No mesmo sentido, Cavalheiro e Del Picchia (1992) incluem as áreas verdes como parte de equipamentos urbanos que, materializadas em parques, jardins, "playgrounds" ou 'campings", exercem a função de agregar, sociabilizar e melhorar a qualidade de vida das pessoas. Quando se possibilitam atividades sociais, as áreas verdes são mais utilizadas e apropriadas, sendo associadas à imagem de um bairro ou cidade, ajudando a formação da identidade de uma comunidade (SMANIOTTO COSTA, 2008).

Posto o conceito legal, técnico e as funções das áreas verdes, Abreu; Oliveira (2004) relatam que não podem ser consideradas áreas verdes aqueles lugares que integram os espaços livres previstos no inciso I, do art. $4^{\circ}$, da Lei 6776/79 Parcelamento do Solo Urbano (BRASIL, 1979). Tais áreas são denominadas de faixas "non edificandi" determinadas pelo inciso III do mesmo artigo, quais sejam: lotes sem construções ou quintais de casas.

O artigo 22 da referida Lei do Parcelamento do Solo Urbano estabelece que para o registro de loteamento é preciso a constituição e integração ao domínio público das vias de comunicação, praças e dos espaços livres (BRASIL, 1979). Assim, ao tratar de área verde urbana é importante destacar que ela está dentro das classificações de espaço livre, conforme relata Macedo (1995). 
Tem-se como espaços livres todas as ruas, praças, largos, pátios, quintais, parques, jardins, terrenos baldios corredores externos, vilas, vielas e outros por onde as pessoas fluem no seu dia-a-dia em direção ao trabalho, ao lazer ou à moradia ou ainda exercem atividades específicas tanto de trabalho, como lavar roupas (no quintal ou no pátio), consertar carros, etc., como de lazer (na praça, no play-ground, etc.) (MACEDO, 1995, p. 16).

A seguir outras classificações de espaços livres, descritas por Lima et al. (1994):

- Parque urbano: são áreas verdes, maiores que as praças e jardins, com forte apego às funções ecológicas, no entanto permite-se atividades esportivas, de descanso ou cultural.

- Praça: não pode ser considerada uma área verde caso não haja vegetação e seja impermeabilizada. Considera-se quando apresentar vegetação e jardins e sua função principal é de lazer, além da estética.

- Arborização urbana: São os elementos vegetais de porte arbóreo tais como árvores e arbustos no ambiente urbano, geralmente plantados ao longo das ruas, avenidas e calçamentos.

Assim, o artigo $4^{\circ}$ da Lei 6776/79, ao explicitar critérios imprescindíveis à implantação de um loteamento urbano mostra que as definições descritas anteriormente são complementares quanto à importância, como os que consta em seu inciso I:

as áreas destinadas a sistemas de circulação (vias públicas que podem ter arborização urbana), a implantação de equipamentos urbanos e comunitários bem como a espaços livres de uso público, serão proporcionais à densidade de ocupação prevista pelo plano diretor ou aprovada por lei municipal para a zona em que se situem (BRASIL, 1979).

Macedo (1995) reitera que é comum a confusão conceitual entre área verde e de espaço livre. Isso devido às ideias consagradas no imaginário popular de que as áreas verdes precisam ter fins de lazer, assim como os espaço livres. "Este ideário associa na existência simples de áreas vegetadas ou ajardinadas dentro do urbano, a possibilidade de seu uso exclusivo e imediato para o lazer" (MACEDO, 1995, p. 16).

O fato é que as áreas verdes urbanas, independente da denominação, precisam fazer parte do domínio público do munícipio e em alguns deles as leis de parcelamento do solo determinam que nos projetos de loteamentos sejam 
destinados percentuais dessas áreas para o cumprimento deste fim. Isso pela importância sócio-ecológica dessas áreas (ABREU; OLIVEIRA, 2004).

Ante todo o exposto, considerando que a conceituação legal de áreas verdes urbanas (BRASIL, 2012 - Novo Código Florestal) exclui as áreas disponíveis para construção de moradias, significa que esse conceito não se adequa às áreas analisadas nessa pesquisa. Isso, pois, dada a amplitude da amostra, não é possível uma análise minuciosa sobre a possibilidade e a disponibilidade de cada área para construção de moradias.

Assim, optou-se por denominar de espaços verdes urbanos (EVU) o objeto de estudo desta pesquisa. Este conceito está amparado na descrição de espaços verdes de Macedo (1995, p. 16):

Toda área urbana ou porção do território ocupada por qualquer tipo de vegetação e que tenham um valor social ... O valor social atribuído pode ser vinculado ao seu utilitarismo em termos de área de produção de alimentos, ao interesse para a conservação ou preservacão de conjuntos de ecossistemas ou mesmo de um único ecossistema, ao seu valor estético/cultural e mesmo a sua destinação para o lazer ativo ou passiva (MACEDO, 1995, p. 16).

Para o referido autor, a diferença conceitual de espaços verdes e áreas verdes reside no fato das áreas verdes contemplar toda e qualquer área onde exista vegetação. No caso do mapeamento a partir de imagens de satélite, áreas pequenas com vegetação são excluídas da análise devido a impossibilidade técnica de mapeamento, o que ratifica mais uma vez a pertinência do uso do termo espaço verde.

Desta feita, Taylor; Hochuli (2017) destacam que a denominação espaço verde (green space, no inglês) é a mais usual na literatura científica internacional, sobretudo para pesquisas de âmbito multidisciplinar e interdisciplinar. Os autores realizaram um levantamento em importantes repositórios de artigos científicos (CABI, BioSIS Previews e Medline) que buscou 367 publicações entre 1975 e 2014 que utilizaram o termo green spaces ou grenspaces (TAYLOR; HOCHULI, 2017).

Como mostra o Gráfico 2, a maioria são artigos do século XXI, isto mostra a emergência e atualidade do uso do termo espaços verdes. Ademais, Taylor; Hochuli (2017) relatam que o contexto urbano é o mais analisado embora haja outros (áreas naturais, não-urbanas), o que mostra a necessidade do adjetivo urbanos na nomenclatura utilizada nesta pesquisa (EVU). 


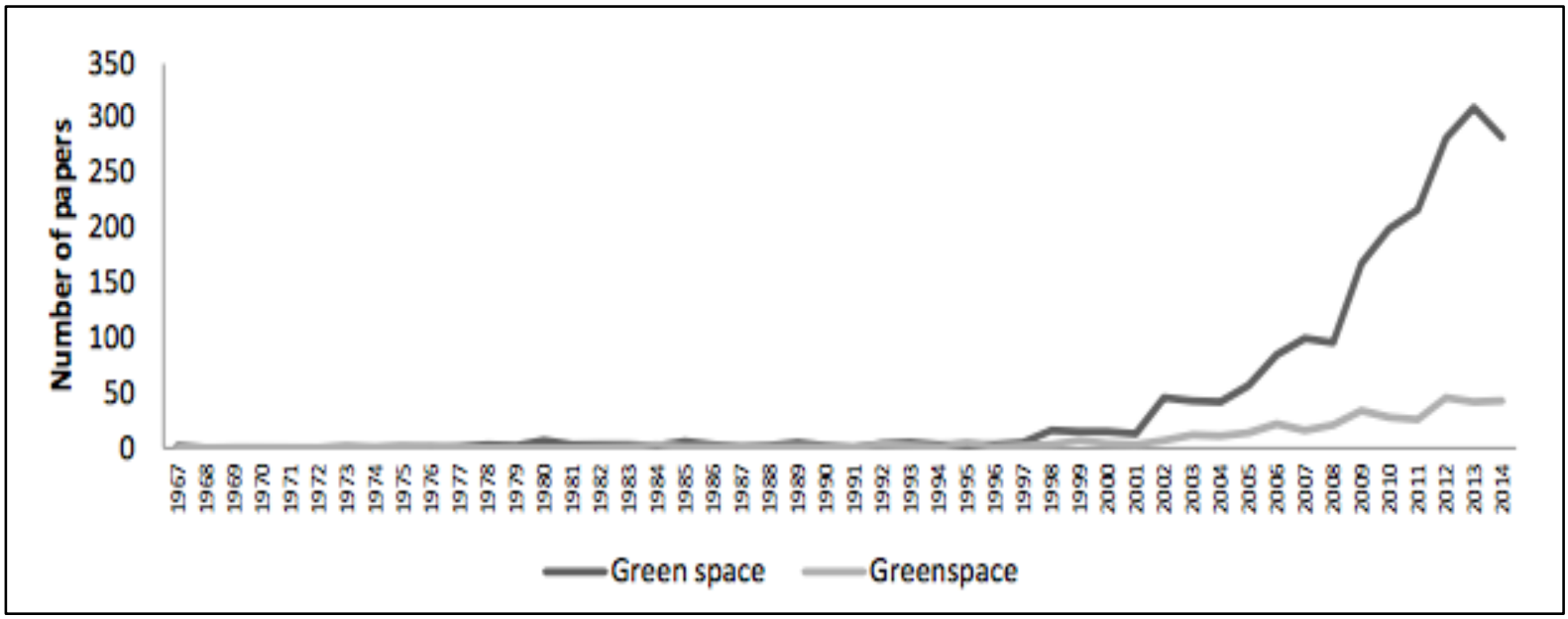

Gráfico 2 - Utilização dos termos green space e greenspace em artigos científicos, de 1967 a 2014. Fonte: Taylor; Hochuli (2017, p. 28).

Quanto a definição dos espaços verdes Taylor; Hochuli (2017) relatam a amplitude conceitual do termo. Os autores conseguiram estabelecer seis tipos de definição diferentes (Tabela 1). Isso sugere que os pesquisadores não têm a mesma compreensão de espaço verde devido aos seus múltiplos contextos e áreas de análises (TAYLOR; HOCHULI, 2017). 
Tabela 1 - Tipos de definição de espaços verdes (TAYLOR; HOCHULI, 2017)

\begin{tabular}{|c|c|c|}
\hline Tipo de definição & Descrição & Exemplo \\
\hline Intervalos de vegetação & $\begin{array}{l}\text { Definição que } \\
\text { reconhece um intervalo } \\
\text { daquilo que se } \\
\text { considera espaço } \\
\text { verde. }\end{array}$ & $\begin{array}{l}\text { O espaço verde é descrito pelo } \\
\text { nível de vegetação, que vai de } \\
\text { ruas paisagísticas, caminhos } \\
\text { arborizados para campos de } \\
\text { recreação e parques cobertos de } \\
\text { floresta (ALMANZA et al., 2012). }\end{array}$ \\
\hline Por exemplos & $\begin{array}{l}\text { Exemplos que ilustram } \\
\text { os espaço verde. }\end{array}$ & $\begin{array}{l}\text { Espaços que combinam: áreas } \\
\text { abertas, plantadas, urbanas } \\
\text { abertas, pastagens, florestas e } \\
\text { plantas perenes (TAVERNIA; } \\
\text { REED, 2009). }\end{array}$ \\
\hline Serviços ecossistêmicos & $\begin{array}{l}\text { Exemplos que } \\
\text { incorporam serviços } \\
\text { ecossistêmicos, como } \\
\text { a agricultura urbana } \\
\text { e/ou uma referência } \\
\text { relacionada às } \\
\text { necessidades } \\
\text { humanas. }\end{array}$ & $\begin{array}{l}\text { Um tipo de uso da terra que } \\
\text { apresenta contribuições aos } \\
\text { ambientes urbanos em termos } \\
\text { ecológicos, estéticos, de saúde } \\
\text { pública e que também atende as } \\
\text { necessidades básicas humanas } \\
\text { (AYDIN; ÇUKUR, 2012). }\end{array}$ \\
\hline Áreas verdes & $\begin{array}{l}\text { Uma referência às } \\
\text { áreas verdes e/ou } \\
\text { naturais sem maiores } \\
\text { detalhamentos. }\end{array}$ & $\begin{array}{l}\text { A área investigada inclui } \\
\text { subtanciais elementos verdes } \\
\text { (GENTIN, 2011). }\end{array}$ \\
\hline Uso da terra & $\begin{array}{l}\text { O uso da terra } \\
\text { descreve espaço verde }\end{array}$ & $\begin{array}{l}\text { Espaço de recreação ou } \\
\text { inutilizado (BOONE-HEINONEN et } \\
\text { al., 2010). }\end{array}$ \\
\hline Áreas com vegetação & $\begin{array}{l}\text { Áreas que contenham } \\
\text { vegetação. }\end{array}$ & $\begin{array}{l}\text { Espaço verde no sentido de ser } \\
\text { predominantemente coberto de } \\
\text { vegetação (HECKERT, 2013). }\end{array}$ \\
\hline
\end{tabular}

Fonte: Taylor; Hochuli (2017, p. 27).

Dada a amplitude conceitual, Taylor; Hochuli (2017) remetem a importância da definição clara de cada pesquisa que inclua os espaços verdes no seu escopo. Ademais, recomendam que a definição abarque elementos quantitativos e qualitativos de modo a torná-lo mais aplicável.

Assim, a presente pesquisa considera os espaços verdes urbanos como áreas predominantemente coberta de vegetação, seguindo a definição de Heckert (2013), conforme mostra o último item da Tabela 2. Dado o interesse de investigar várias cidades e regiões metropolitanas, foram excluídas quaisquer restrições conceituais e funcionais de espaços verdes, como: parques, praças, jardins. Além 
disso, em termos quantitativos, cabe esclarecer que a área mínima de análise foi determinada considerando as espeficações técnicas de mapeamento, as quais são tratadas no capitulo 3.

Por fim, Taylor; Hochuli (2017) ratificam a necessidade das pesquisas utilizarem o termo espaços verdes, independentemente do contexto e disciplinas. A normatização do termo no âmbito científico, agregada a uma definição clara, permite e facilita a realização de meta-análises, estudos comparativos ou mesmo parametrização de referências.

\subsection{Gestão dos Espaços Verdes Urbanos no Brasil}

No Brasil, a gestão dos espaços verdes urbanos ficou a cargo dos municípios, uma vez que a Constituição Federal (BRASIL, 1988) determinou que os temas de interesse local são competência exclusiva dos municípios. Antes disso, a própria Lei do Parcelamento do Solo Urbano (Lei nº 9785/79) deu competência aos municípios para definir os usos permitidos e dos índices urbanísticos de parcelamento e ocupação do solo, dentre os quais o quanto que será destinado aos espaços verdes para preservação, espaços para lazer e uso público, podendo o critério ser definido pelo plano diretor ou por legislação municipal (BRASIL, 1979). Assim, as gestões municipais ficaram encarregadas de gerir diretamente esses espaços.

O poder legislativo federal vem pautando algumas discussões e projetos de lei que envolvem os espaços verdes. Atualmente existe um Projeto de Lei (PL) específico sobre áreas verdes urbanas em destaque no senado federal pelo $\mathrm{PL} \mathrm{n}^{\circ}$ 396 (BRASIL, 2014). O projeto obriga a delimitação desses espaços pelos planos diretores municipais. O texto proposto modifica o Estatuto da Cidade (BRASIL, 2001) e obriga os municípios a incluírem nos seus planos diretores o planejamento e delimitação de todas as áreas verdes urbanas, além das zonas urbanas passíveis de reflorestamento.

Quanto aos espaços verdes que formam as Áreas de Preservação Permanente (APP), elas estão amparadas de acordo com o Novo Código Florestal Lei Federal no 12.651 (BRASIL, 2012). Porém há uma discussão se aquelas dentro das áreas urbanas deveriam ser estabelecidas por legislações municipais. Os que advogam à favor, citam a insegurança jurídica daquelas cidades que historicamente 
instalaram-se próximo aos cursos d`água justamente para usufruir do fundamental abastecimento.

Nesse sentido, destacam-se aqui dois PLs, um na câmara federal ( $n^{\circ} 6830$ 2013) e outro no senado federal ( $n^{\circ} 368$ - 2012), propondo que os municípios passem a legislar sobre as APP urbanas. Apesar da pertinência de se observar características locais para a definição da largura das faixas marginais das APP, Hulsmeyer; Macedo (2015) citam a fragilidade técnica e financeira da maioria dos municípios como motivo de preocupação se esses PL forem levados à frente.

Aprovar as referidas legislações sem diretrizes que incorporem as diferentes características e padrões morfológicos das APP urbanas, podem servir de instrumento para a legalizar a redução das faixas marginais das APP, ampliando as áreas sem cobertura vegetal e com edificações (HULSMEYER; MACEDO, 2015). Entretanto, considerando que as APP urbanas estão localizadas em áreas geograficamente frágeis: alta declividade, geralmente com pouca vegetação nativa e presença de corpos d’água, quaisquer medidas que visem a redução da vegetação poderão aumentar as áreas de riscos e ocasionar desastres ambientais, além dos prejuízos socioeconômicos.

Mesmo que os referidos PLs tenham boa intenção, deve-se ponderar que a obrigatoriedade de execução da lei recai apenas aos municípios. Estabelecer mais uma obrigação ao ente federativo que menos tem recurso técnico e financeiro para executá-la talvez não dê resultados efetivos. Tão importante quanto as obrigações é criar mecanismos de incentivos técnico e financeiro para efetivar estudos que garantam a permanência dos espaços verdes urbanos.

\subsection{Espaços Verdes na História das Cidades}

Ao analisar a relação dos espaços verdes e cidades, é comum fazer usos de parâmetros quantitativos a fim de analisar a cobertura vegetal de uma cidade e vislumbrar potencialidades ou vulnerabilidades. Assim, pode-se citar como análise quantitativa estudos que evidenciam a redução dos espaços verdes como consequência do processo de expansão urbana, como afirma Copque et al. (2011).

Um exemplo bastante recente e emblemático foi a construção do Setor Noroeste em Brasília (Figura 11). Penhavel (2013) relata que a atuação do mercado imobiliário, do poder público e da mídia auxiliaram a transformar uma importante área remanescente de vegetação nativa de cerrado (zona de amortecimento do 
Parque Nacional de Brasília), onde habitavam índios de diversas etnias, em um bairro "ecológico e sustentável" de alto padrão.

Esse exemplo mostra o quão os espaços verdes podem estar pautados na lógica do capital e do mercado. Para Haase et. al (2017), é comum o uso de estratégias ecológicas como ingredientes para promoção de novos empreendimentos imobiliários ou para revitalização urbana orientados para o mercado, direcionados aos grupos mais privilegiados quanto ao nível de renda em detrimento àqueles menos privilegiados.

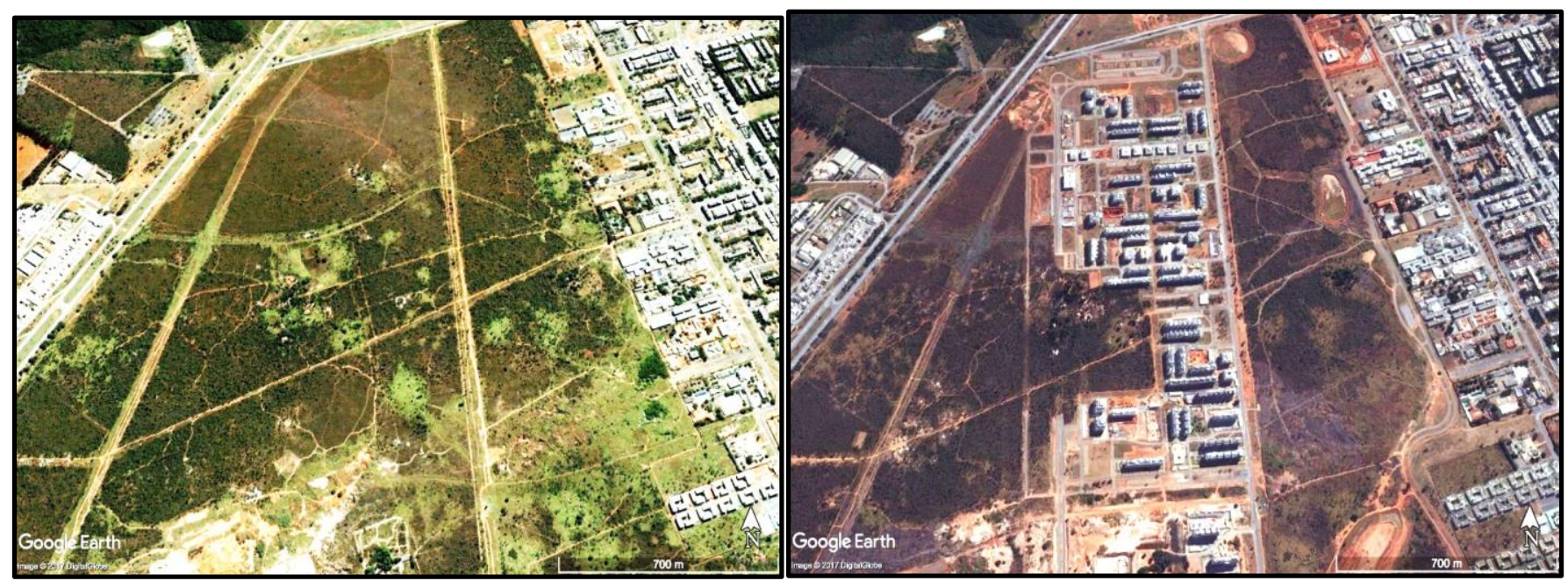

Figura 11 - Setor Noroeste/DF. Esquerda (2005) e direita (2017)

Fonte: Google-Earth.

Ao longo da história, os projetos empresariais tomaram vantagem frente aos benefícios socioambientais dos espaços verdes. Por isso, antes de discorrer sobre tais benefícios, é importante retomar a cronologia das cidades, estabelecendo como pano de fundo as mudanças nos sistemas político-econômicos e a relação com os espaços verdes.

\subsubsection{Cidade e Urbano: História e Conceitos}

Analisar uma cidade é um tanto complexo, uma vez que não é um sistema isolado. Dos menores distritos até as grandes sedes municipais, em todos as cidades há trocas de informação, bens, produtos, serviços e fluxo de pessoas. A cidade é, portanto, resultado da materialização do trabalho, do movimento e circulação de mercadorias, pessoas, ideias e informações (CARLOS, 1992). 
O dinamismo da cidade só é possível de ser analisado a partir de relações socioespaciais que são realizadas de formas diferenciadas no tempo e no espaço (CARLOS, 2004). Tais relações diferenciadas criam uma hierarquia de espaços, de poder e domínios entre as cidades e dentro da própria cidade (DEAECTO, 2008). Esse fato indica que a presença ou ausência dos espaços verdes estão inseridos no dinamismo do processo de produção de espaço e fruto das relações socioespaciais.

Nesse contexto, a presente discussão transcende à ideia da cidade enquanto núcleo da aglomeração de capital e nos permite pensar o espaço como "produto de lutas, fruto das ações contraditórias, criadas e aprofundadas pelo desenvolvimento do capital" (CARLOS, 1992, p. 71). Assim, o espaço urbano se produz por ação e interesses do homem, modificando a estrutura e funcionalidade dos espaços da cidade (CARLOS, 1992).

A partir dessa visão geográfica de produção de espaço (CARLOS, 1994; LEFEBVRE, 1991) há de considerar que a presença dos espaços verdes em partes específicas das cidades vai além de casualidades ou necessidades individuais, mas fruto de ações, intencionalidades, vontades e interesses político-econômicas, além dos acontecimentos históricos. Por isso, as implicações da presença de espaços verdes urbanos vão além das abordagens ecológicas ou urbanísticas e podem ser analisadas sob a ótica da prática socioespacial, ao longo da história.

$\mathrm{Na}$ história ocidental, por muito tempo (século $\mathrm{V}$ até o século $\mathrm{XVI}$ ) a cidade foi de fato um organismo fechado, fruto da organização feudal que fazia uso da servidão e do poder religioso (BLOCH, 1979). Com o fim da Idade Média as cidades feudais perderam suas muralhas, possibilitando um maior contato entre elas e também do homem com a natureza (HENRIQUE, 2009).

Foi por meio das novas rotas comerciais atreladas às técnicas de transporte como as caravelas que o horizonte da ação humana foi ampliado. A cidade, assumiu assim a vocação comercial, frente aquela cidade política, das hierarquias medievais e dos poderes personificados (DEAECTO, 2008).

Assim, Max Weber na obra "Economia e Sociedade" ao definir cidade discriminou dois pontos (WEBER, 1979). Primeiro, a cidade é o lugar onde se instala a sede política-administrativa, denominada na obra como "sede senhorial-territorial ou principesca" - ainda resquícios da Idade Média. Nesse ponto, cabe destacar que esse primeiro conceito de Weber condiz com aquilo que o sociólogo francês Henri Lefebvre intitulou posteriormente de cidade política (LEFEBVRE, 1972). 
Já no segundo ponto, a cidade é o lugar onde há relações diretas com as atividades econômicas, ou seja, permite "a realização de troca de bens como componente essencial das atividades aquisitivas e da satisfação das necessidades dos moradores: a essência de um mercado". Com isso, surge então o que Lefebvre intitulou de cidade comercial (LEFEBVRE, 1972).

Com o surgimento das rotas comerciais e de trocas de produtos, a riqueza foi deixando de ser imobiliária (ligada a terra) para ser também mobiliária (dinheiro). Essas rotas criaram um fluxo de mercado entre cidades. Esse fluxo favoreceu que as cidades permanecessem ligadas em rede em uma composição hierárquica, ou seja, algumas cidades tornaram-se mais importantes (economicamente e politicamente) e outras mais dependentes (DEAECTO, 2008).

A organização hierárquica das cidades reflete na "divisão do espaço e do tempo" (LEFEBVRE, 1972). Ou seja, em um modelo espacial de desenvolvimento e de subdesenvolvimento traduzido por: riqueza e pobreza. Essa separação espacial é tão cruel quanto aquela que separava burguesia do proletariado. Assim, a antiga oposição campo-cidade assumiu assim novas formas: centro-periferia, inclusãoexclusão, integração-segregação (LEFEBVRE, 1972).

O comércio conduziu ao acúmulo de dinheiro e, nesse processo, foram criados os primeiros bancos. Consolidou-se então o Estado Moderno, bastante organizado, com envolvimento das antigas ordens locais, os velhos burgueses e suas casas comerciais (SALDANHA, 2010). Para o referido autor, o Estado Moderno, foi o primórdio das nações, que foram organizadas em um espaço regido por leis e regras comuns, sistema financeiro unificado e hierarquia governamental.

O cenário de organização dos Estados e o acúmulo de riquezas da burguesia, propiciou um novo processo social: a industrialização. A indústria nos seus primórdios não fez uso da cidade porque seu foco estava nas fontes de energia e de matérias-primas localizadas nas áreas rurais (ARAÚJO, 2012). Com o passar do tempo, a indústria se aproximou das cidades por conta da necessidade de mão de obra, capital e do mercado. O movimento da indústria em direção à cidade produziu profundas transformações (LEFEBVRE, 2004).

Para Lefebvre (2004), ao preterir a cidade no primeiro momento, a industrialização negou a centralidade na cidade, gerando um fenômeno identificado como implosão, que centralizou conteúdo politico e comercial nas mãos da burguesia comercial. Depois, ao fazer uso da cidade, ocorre a sua explosão, ou 
seja, projeção de fragmentos da malha urbana por uma vasta região formando o que hoje entendemos por periferia (LEFEBVRE, 2004).

Os processos que Lefebvre (2004) denominou de implosão e explosão gerou uma cidade caracterizada na generalização das relações sociais pautadas no valor de troca, dando ênfase ao valor de uso do espaço (ARAÚJO, 2012). Assim, é o uso que faz com que o espaço seja produtivo e valorizado (PENNA, 2016).

Mesmo os espaços ditos "vazios", como os espaços verdes dentro das cidades, têm intencionalidades de usos, subordinados aos interesses de valor e do mercado. "Os valores de uso são criados de acordo com as possibilidades do mundo da mercadoria e são, ao mesmo tempo, valores de troca, que estão na base do processo de fragmentação do espaço" (PENNA, 2016, p. 2).

Assim, no início da Revolução Industrial, as florestas e remanescentes de vegetação nas cidades não passavam de matéria-prima, transformadas em larga escala em combustíveis (lenha) para mover máquinas, moradias, embarcações e ferramentas. Era muito comum espalhar queimadas, que ao gerar produtos derivados da madeira fertilizava a terra que aumentava a produção agrícola ou abria espaço para as edificações urbanas (HENRIQUE, 2009). Não havia, assim, a ideia da importância da natureza junto ao ambiente urbano.

Ante essa contextualização histórica sobre as cidades, nota-se que os espaços naturais como as florestas foram preteridos em grande parte para dar lugar à áreas que agregassem valor mobiliário. O espaço urbano acabou sendo a reprodução do sistema dominante, gerando: um sistema de classes sociais, um sistema político que permite o funcionamento do conjunto social e o domínio de uma classe, um sistema institucional e de um sistema de troca (comércio) (CASTELLS, 1983).

Assim sendo, considerando que essa tese analisa a possibilidade dos espaços verdes urbanos indicarem desigualdade social, é preciso aprofundar a teoria sobre o urbano e seus processos. Nesse sentido, para Lefebvre os problemas da urbanização devem ser postos e entendidos no âmbito do processo de (re)produção do espaço (CARLOS, 2004). Assim, a incidência dos espaços verdes nas cidades não sendo uma casualidade é lógico pensar que elas aparecem e desaparecem, consonantes ao processo de implosão e explosão do espaço.

Para Carlos (2004), a produção e reprodução do espaço são articulados e dependentes. Enquanto a produção é intimamente ligada à historicidade da cidade 
(acontecimento pontual gerando uma formação socioeconômica) a reprodução é o reflexo da dinâmica do acúmulo do capital e desenvolvimento da vida humana em todas as dimensões e significados, gerando um modo de vida (CARLOS, 1992). Assim, a ideia de reprodução é cheia de contradições: funde-se os interesses do capital, a ação do Estado e a luta de resistência dos moradores contra a segregação e ao direito à cidade (CARLOS, 1992).

Desse modo, ao trabalhar com os efeitos da (re)produção do espaço urbano, Lefebvre (2004) buscou, em primeiro momento, distinguir a cidade do urbano, dada a complexidade conceitual dos termos. Enquanto a cidade "é um objeto espacial que ocupa um lugar e uma situação" (LEFEBVRE, 2008a p. 65) o "urbano é a simultaneidade, a reunião, é uma forma social que se afirma" (LEFEBVRE, 1991, p. 159).

A cidade seria a ordem próxima que permite pensar o plano do lugar revelando o vivido. Por outro lado, o urbano seria a ordem distante revelado pelo processo de generalização e formação de uma sociedade urbana (LEFEBVRE, 1991). Em outras palavras, o urbano seria um processo extensivo e fragmentário, que redefine novos espaços, fluxo, centralidades e temporalidades para além da tradicional circunscrição da cidade (LEFEBVRE, 2004).

Assim, Lefebvre (2008) destaca que a urbanização pode ir além dos limites das cidades. Apesar de o considerar como o resultado da industrialização que penetra na cidade por meio de unidades fabris, esse fenômeno ultrapassa o espaço urbano. O fenômeno chega ao espaço rural, ditando o ritmo de produção agrícola a extração de recursos naturais e produção de energia.

Ademais, pode-se considerar o urbano como um fenômeno dinâmico, que vai além dos limites políticos da cidade, onde ocorre produção e reprodução do espaço e cria-se a possibilidade de entendê-lo como locus da "manifestação da vida, condição, meio e produto da realização humana (CARLOS, 2004, p. 11). Isso ratifica que a sociedade é responsável pela construção de um mundo objetivo, através do espaço materializado no território. Porém, esse espaço não é neutro. Segundo Carlos (2004), o espaço foi modelado a partir de elemento históricos, naturais e principalmente de forças políticas.

Assim, a prática socioespacial revela contradições no espaço, fruto do conflito das forças homogeneizadoras do capital (representadas pelas leis do mercado financeiro, especulações imobiliárias e ações do Estado) e as forças diferenciais 
(representadas pelos movimentos sociais) (LEFEBVRE, 1991). Portanto, ao discorrer sobre o histórico socioeconômico das cidades, parece claro que as forças homogeneizantes foram dominantes na incidência dos espaços verdes em lugares específicos das cidades.

Nesse sentido, Chung; Zhang; Wu (2018) ratificam que os espaços verdes urbanos não existem em formas e locais particulares simplesmente à mercê da natureza, conforme mostra a seguir:

They are politicised spaces impinged by various strategies of, regulations on and resistance to capital accumulation. Any attempt to intervene in existing patterns and characteristics of a city's green space would have to negotiate with, and thus evince, the intricate political economic dynamics reproducing it (CHUNG; ZHANG; WU, 2018, p. 4).

Assim os referidos autores afirmam que, sendo o espaço verde uma forma de uso da terra, a propriedade e a gestão da terra inevitavelmente carregam impressões na sua produção no espaço. Essas questões afetam a forma, área e localização dos espaços verdes disponível na cidades (CHUNG; ZHANG; WU, 2018).

\subsection{Espaços Verdes e Desigualdade Social}

A presença dos espaços verdes em áreas mais valorizadas é reflexo do uso diferenciado das mesmas. Nesse sentido, o "uso diferenciado da cidade demonstra que esse espaço se constrói e se reproduz de forma desigual e contraditória. A desigualdade espacial é produto da desigualdade social" (CARLOS, 1992, p. 23). Logo, o retrato das desigualdades sociais em uma cidade pode ser simbolizado pela presença ou ausência dos espaços verdes?

A Figura 12 ilustra a afirmação anterior. A fotografia é amplamente divulgada nas redes sociais e na internet em discussões sobre desigualdade social. Ela destaca-se como um exemplo da conjugação entre desigualdade social e a presença/ausência dos espaços verdes na cidade de São Paulo, especificamente na fronteira do bairro do Morumbi (classe-média alta) e a favela de Paraisópolis. 


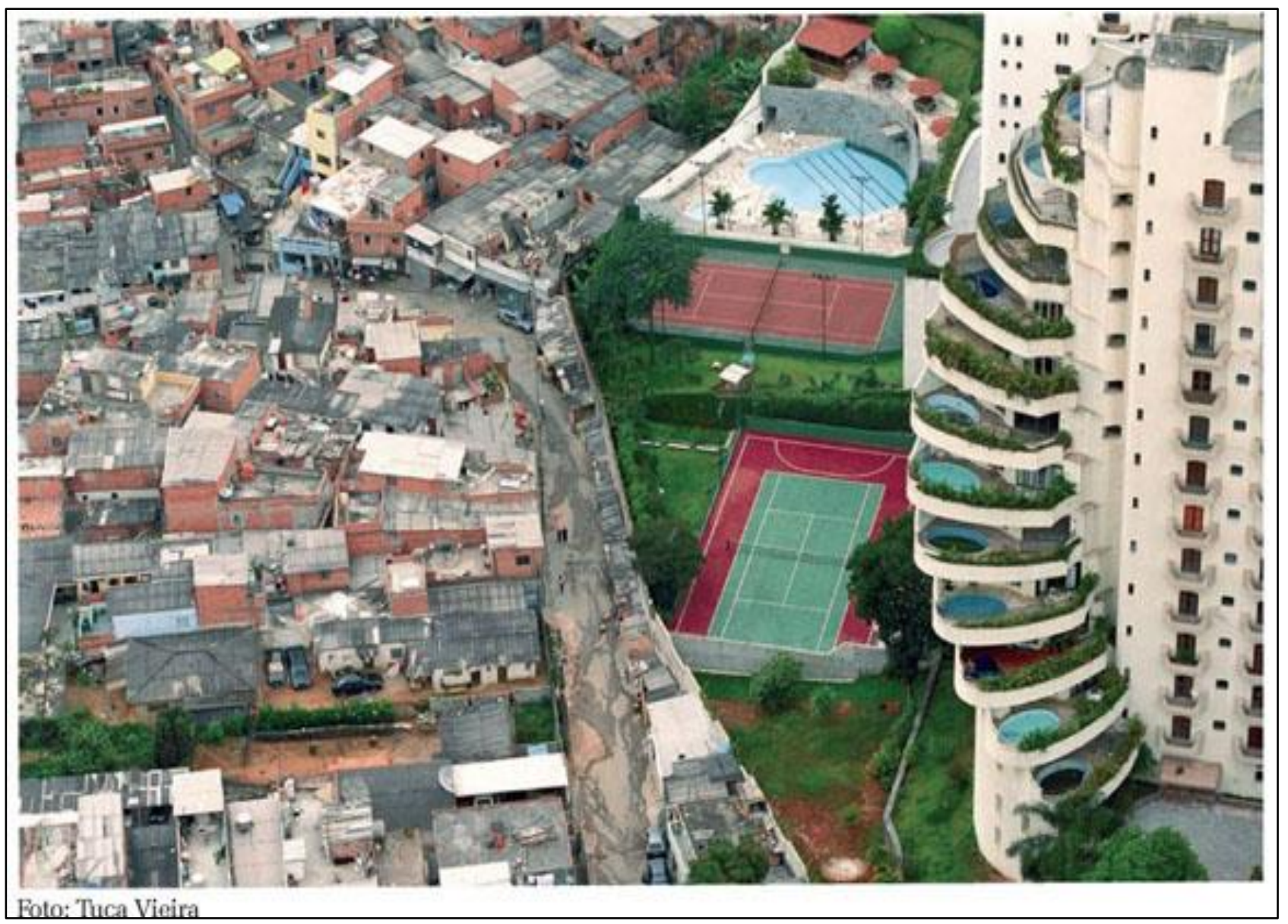

Figura 12 - Limite entre a favela de Paraisópolis e o Morumbi. São Paulo (SP)

Fonte: Folha de São Paulo. Autor: Tuca Vieira (2007)

Ademais, nota-se que os bairros de classes média e alta são bem mais arborizados do que os de periferia (JACOBI, 2000). Porém, no Brasil essa afirmação difundiu-se em observações empíricas e não foi aprofundada de maneira a correlacionar dados socioeconômicos e a distribuição dos espaços verdes nas áreas urbanas de um número expressivo de municípios. Não se conhece a dimensão dessa relação e se ou como os espaços verdes podem se concretizar como indicadores de desigualdade social.

Uma das formas mais visíveis de desigualdade social é a segregação socioespacial. Assim, cabe entender que o conceito de segregação possui diversas adjetivações tais como residencial, urbana, social, espacial ou socioespacial (ROMA, 2008). Spósito (2005) ratifica o conceito de segregação socioespacial quando afirma que ela é social e espacial. É social no sentido amplo do termo, nele se incluindo o econômico, o politico, o ideológico. Porém, Spósito (2005, p. 102) explica ainda que é também espacial "na medida em que o espaço não é apenas 
reflexo, mas é também determinação dos processos e dinâmicas que orientam o movimento da sociedade".

Para Villaça $(1998$, p.142) a segregação socioespacial pode ser compreendida "quando diferentes classes sociais se concentram em diferentes regiões ou bairros da cidade, promovendo o afastamento ou isolamento $\mathrm{e}$ dificultando o contato entre essas classes ou camadas sociais". Ela é perceptível na implantação dos loteamentos e condomínios fechados, no aparecimento das invasões, nas lógicas que orientam a localização dos conjuntos habitacionais, entre outros. Assim, tal segregação resulta no aprofundamento das desigualdades sociais expressas no espaço urbano pela forma como ele se estrutura e como nele se distribuem os diferentes usos do solo (HARVEY; SOBRAL, 2000).

Valendo-se de exemplos, Haase et. al (2017) discutem a relação entre segregação socioespacial e inclusão social a partir da implantação de espaços verdes. Os autores utilizaram de três estudos de caso - Lene Voigt Park (Lípsia, Alemanha), High Line Park (Nova York, EUA) e o Sienkiewicz Park (Lodz, Polônia) que provam que a implantação dos referidos parques resultaram no aumento dos preços dos imóveis próximos, gerando uma segregação socioespacial e exclusão social.

we observe an increasing use of greening strategies as ingredients of urban renewal, upgrading and urban revitalization as primarily market-driven endeavours targeting middle class and higher income groups sometimes at the expense of less privileged residentes (HAASE et al., 2017, p. 41).

O Estado intervém no processo de (re)produção do espaço ao reforçar a hierarquia de lugares, criando novas centralidades, expulsando para periferia os moradores mais vulneráveis ao sistema socioeconômico e criando um espaço de dominação (CARLOS, 1992). Para a autora, o Estado age para a criação do espaço fragmentado, homogêneo e hierarquizado. Assim, o espaço geográfico reflete inúmeras contradições e se relaciona com a realidade cada vez mais desigual (econômica e socialmente) (CARLOS, 1992).

O espaço geográfico é, por fim, produto da sociedade, através do trabalho materializado. A terra, enquanto matéria, não pode ser reproduzida, mas o espaço sim e assim se vai mudando de significados a medida que os processos históricos avançam (CARLOS, 1992). Dessa forma, a cidade, enquanto mercadoria, tem um 
valor dependente da localidade e da disponibilidade de equipamentos urbanos, que inclui a presença de serviços básicos: saúde, educação, cultura, segurança.

Nesse sentido, Santos (2005, p.10) aponta que "a cidade torna-se criadora de pobreza e que a pobreza não é apenas o fato do modelo socioeconômico vigente, mas, também, do modelo espacial". Por isso, Roma (2008) afirma que a análise socioespacial é capaz de englobar os processos que levam à segregação.

Os efeitos da segregação socioespacial são discutidos por Jacobi (1990). Para ele, o mais marcante é a ausência ou precariedade na disponibilização de serviços básicos à periferia, frente à garantia dos mesmos serviços aos moradores das regiões mais ricas, o que reflete na diferença da qualidade de vida: "Como reflexo, verifica-se um processo de regionalização das carências, ou seja, uma diminuição expressiva no nível de apropriação dos benefícios urbanos orientados do centro para a periferia" (Jacobi,1990, p.122).

Ao discorrer sobre esses efeitos, Saito (1996) discute o conceito de sobrediscriminação social, em referência ao conceito de regionalização de carências de Jacobi (1990). Para Saito (1996), a regionalização de carências é fruto de uma dinâmica socioeconômica que inflige à população menos favorecida um acúmulo de penalidades históricas que agravam a desigualdade social e gera uma sobrediscriminação social.

Rodrigues (1988) aponta o Estado como principal responsável pela manutenção daquilo que Saito (1996) denominou de sobrediscriminação social. Ao atuar de forma heterogênea no espaço urbano ele acentua a "valorização diferencial" das áreas que, juntamente com incentivos privados, produzem projetos e ações que só aumentam as desigualdades (GOTTDIENER, 1997). O efeito dessa ação ocasiona o aparecimento da especulação fundiária urbana (VIEIRA, 2005). Assim, a cotação do preço dos imóveis fica diretamente ligada às localizações que, por conter vantagens ou desvantagens locacionais, passam a exercer forte influência no preço do solo (MELAZZO, 1993).

\subsubsection{Espaços Verdes como Equipamentos Urbanos}

Para tornar os espaços verdes urbanos instrumentos que possam minimizar as desigualdades sociais é preciso tratá-los como equipamento urbano, melhorando a qualidade de vida no seu entorno. Isso pois, os espaços verdes também tem uma função social relacionada à atividade de lazer, recreação, sociabilização e promoção 
de atividades culturais e educacionais (BARGOS; MATIAS, 2011). A Figura 13 mostra o Parque Olhos D`Água, situado em Brasília, ao qual cumpre a referida função social.

Nesse sentido, cabe destacar o conceito de equipamento urbano conforme a Associação Brasileira de Normas Técnicas - NBR 9284: "designa todos os bens públicos ou privados, de utilidade pública, destinado à prestação de serviços necessários ao funcionamento da cidade" (ABNT, 1986, p.1).

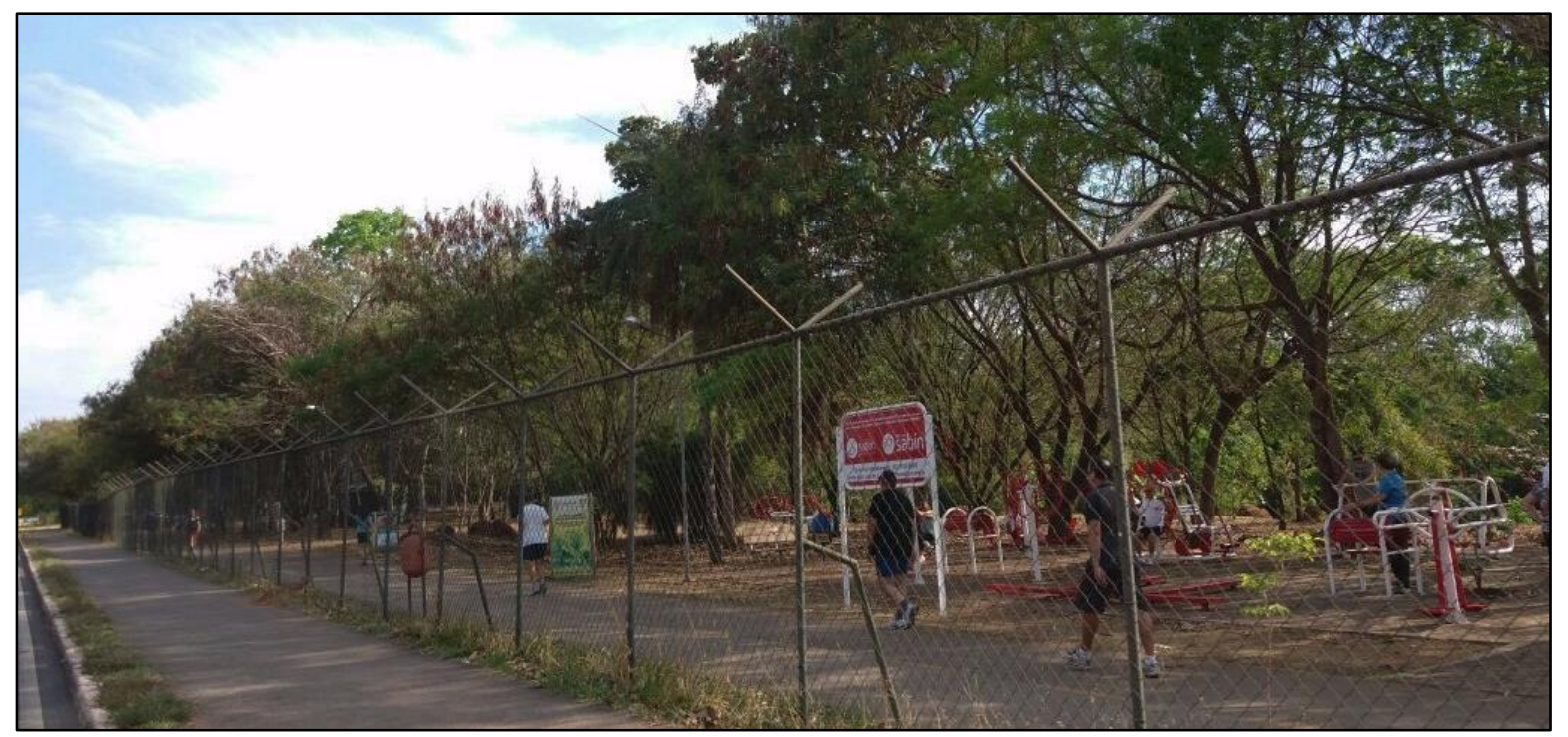

Figura 13 - Parque Olhos D’Água - Brasília, Asa Norte.

Fonte: Autor (2017)

Porém, pra entender o que são serviços necessários à cidade, é preciso analisar a Lei do Parcelamento do Solo (6.766/79) - art. $5^{\circ}$, parágrafo único, o qual restringe os equipamentos urbanos aqueles relacionados a infraestrutura necessária à expansão da cidade, como: "escoamento das águas pluviais, iluminação pública, esgotamento sanitário, abastecimento de água potável, energia elétrica pública e domiciliar e vias de circulação" (BRASIL, 1979).

Ao cumprir funções socioambientais essenciais que vão desde o auxilio à drenagem urbana, tamponamento do microclima, à redução da erosão e poluição do ar, tem-se claro que os espaços verdes necessitam compor a infraestrutura das cidades. Nesse ponto, ao se analisar conjuntamente os conceitos legal e técnico de equipamentos urbanos, depreende-se que elas deveriam ser consideradas bens de utilidade pública necessárias para o funcionamento e para o planejamento sustentável das cidades. 
Segundo Francis (1989), os espaços verdes urbanos podem ser vistos como "espaços participativos", ou seja, elementos nucleares da vida urbana que reflitam culturas, crenças e valores. A forma mais concreta e efetiva seria pensar esses locais em comunidades carentes de infraestrutura urbana, associadas a outros equipamentos de uso coletivo como centros comunitários de cultura, área esportivas, postos de saúde, escolas ou pontos de práticas de exercícios ao ar livre.

Assim, constata-se a importância dos espaços verdes e principalmente daquelas que possam ser utilizadas de forma sustentável garantindo qualidade de vida. Nesse ponto, reitera-se que independente do uso dado aos espaços verdes nas cidades, eles irão cumprir com sua função ecológica (regulação do microclima, retenção de água no solo), mas essa tese almeja evidenciar a potencialidade desses espaços quando possuem condições mínimas de serem utilizadas pela sociedade para lazer, esporte, cultura, etc. Assim, ao associar outros equipamentos urbanos de uso coletivo, tais áreas passam a ser consolidadas como equipamentos urbanos essenciais para a população.

No mesmo sentido Jacobs (2011) argumenta que não basta estabelecer um espaço verde para a garantia da sua vitalidade e ao entorno. A valorização de um bairro não é correlacionada apenas com a presença dos espaços verdes. Para tanto, a autora cita que eles precisam ter vitalidade que depende dos seguintes elementos: diversidade de uso da área (área para esportes, descanso, feiras, bancos para descanso), riqueza espacial (lagos, árvores em boa quantidade, jardins), centro bem definido (estrutura de apoio administrativo, com banheiros, bebedouros e placas informativas) e delimitação espacial (cerca ou marcos que defina os limites da área) (JACOBS, 2011).

Ao estabelecer a vitalidade, os espaços verdes têm maior probabilidade de funcionar como equipamentos urbanos à sociedade. Assim muitos dos seus benefícios sociais têm sido estudados, analisados e comprovados cientificamente. Amato-Lourenço et al. (2016) fizeram um levantamento de pesquisas que provam a relação positiva entre a disponibilidade dos espaços verdes urbanos para a qualidade de vida.

$O$ referido estudo levantou pesquisas internacionais que afirmam que a proximidade dos espaços verdes com as pessoas vão além dos serviços ecossistêmicos. Por exemplo: associa-se a presença dessas áreas com maior longevidade aos praticantes de caminhada nos espaços verdes urbanos (TAKANO; 
NAKAMURA; WATANABE, 2002), a menores índices de obesidade em crianças que moram perto de parques (DADVAND et al., 2014) e a maior saúde mental para quem visita parques urbanos (VAN DEN BERG et al., 2016).

O fato é que o uso dos espaços verdes diminui o estresse, aumenta a coesão social e a prática de esportes como caminhada, corrida, ciclismo, etc. Não à-toa, muitas cidades do mundo têm investido em programas pró-espaços verdes de maneira a melhorar a qualidade de vida, como Nova York, com o renomado "One Million Trees" (MTNYC, 2013). Da mesma forma que a população necessita de saneamento, eletricidade e vias de circulação é cada vez mais evidente que uma cidade deve propiciar qualidade de vida e nesse sentido os espaços verdes nas cidades se mostram fundamentais à qualidade de vida.

Além da questão de qualidade de vida, ressalta-se a importância econômica de se investir nos espaços verdes urbanos. Estudo publicado pelo Serviço Florestal Americano (NOWAK et al., 2010) mostra que as 3,8 bilhões de árvores situadas em espaços verdes urbanos nos Estados Unidos (EUA) foram avaliadas em 2,4 trilhões de dólares pelos seus benefícios prestados, como: redução da poluição atmosférica, custos associados ao aquecimento e arrefecimento dos prédios, emissões de carbono e retenção da água da chuva (NOWAK et al., 2010).

No estudo mais local, em Portland (estado do Oregon, EUA), os referidos benefícios foram avaliados em 1,53 bilhões de dólares para a cidade (DONOVAN; BUTRY, 2010). Considerando o investimento de apenas 15 milhões de dólares por ano para manter e estabelecer novas EVU, os autores afirmam que esse investimento aumenta a renda da cidade ao reduzir gastos com infraestrutura urbana e em situações de emergências, como alagamentos e desmoronamento. Esse aumento de renda é mais que suficientes para aumentar os espaços verdes e para amortizar o investimento inicial (DONOVAN; BUTRY, 2010).

Apesar da importância dos espaços verdes, a análise realizada por Rolnik et al. (2015) em duas regiões metropolitanas (São Paulo e Campinas) mostrou que o maior programa habitacional brasileiro (Minha Casa, Minha Vida - MCMV) se caracteriza por assentar os moradores de baixa renda em periferias monofuncionais. Ou seja, garantem apenas o ato de morar num espaço homogêneo: com casas iguais, dispostas em linhas geométricas de forma a otimizar a distribuição das moradias com pouco ou quase nenhum espaço verde. 
Assim, os empreendimentos estão localizados em zonas sem oferta de emprego, condições precárias de infraestrutura e insuficiência de equipamentos urbanos, como os espaços verdes (ROLNIK et al., 2015). A Figura 14 mostra um conjunto habitacional do MCMV (Brenno Garcia - Gravataí), nota-se a ausência de árvores dentro do empreendimento, em contraste com a área vizinha.

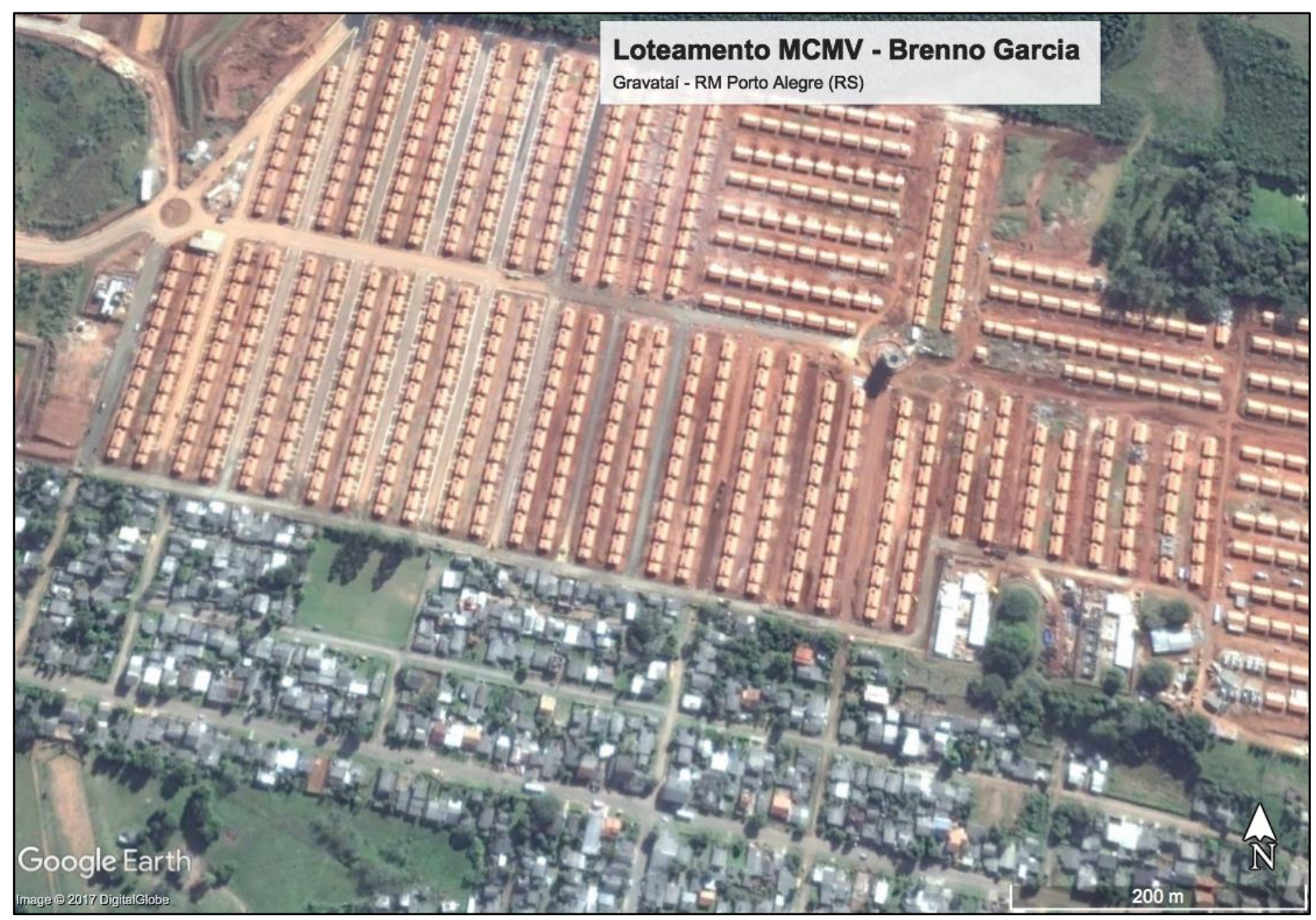

Figura 14 - Conjunto habitacional do Minha Casa Minha Vida: Brenno Garcia - Gravataí (RS) Fonte: Google-Earth (2017)

Contraditoriamente, são nas áreas com maior renda que há maior demanda de projetos e planos para implantação de espaços verdes. Além de aparentemente estarem em áreas mais ricas, há o agravante dos espaços verdes serem cada vez mais privadas, como por exemplo, condomínios residenciais, edifícios polifuncionais e clubes de lazer, em contraste com praças, parques, vias arborizadas ou outros espaços de uso público e coletivo (LOBODA; DE ANGELIS, 2009).

O desejo de tornar um bairro em "sustentável" ou "ecologicamente correto", escondem outras contradições. Por exemplo: espaços verdes amplos e fechados, cercando os condomínios e empreendimentos comerciais e industriais (Figura 15). 
Esse fato evidencia que os espaços verdes servem, também, para segregar camadas sociais.

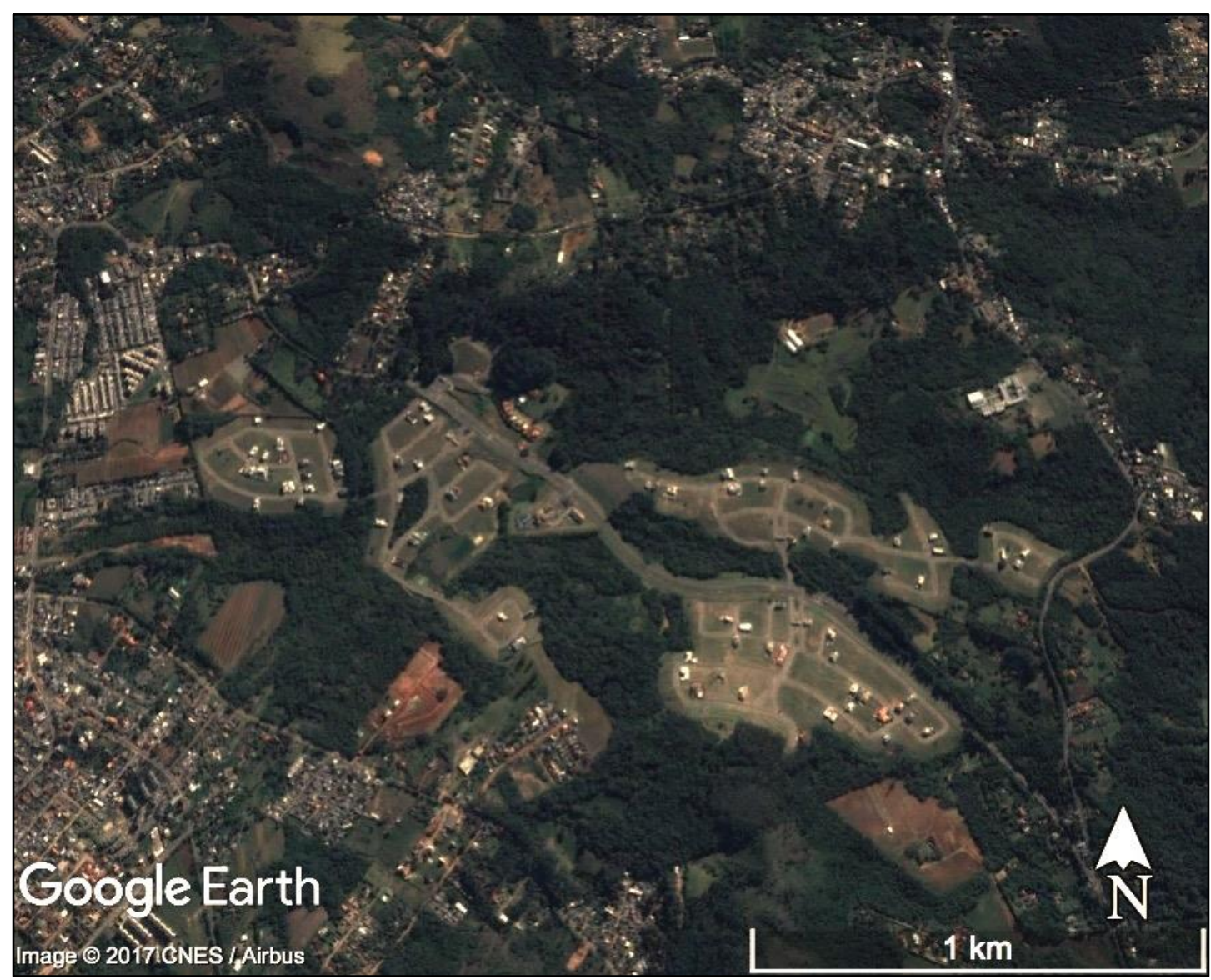

Figura 15 - Condomínio Alphaville cercado de espaços verdes - Porto Alegre.

Fonte: Google-Earth (2017)

Estudo de Solecki; Welch (1995) confirma a afirmação anterior ao analisar parques que separam dois bairros de índices socioeconômicos díspares na cidade de Boston (EUA). "When an urban park functions as a boundary, it impoverishes neighborhoods because it often leads to less use of the open space resource, which then can become a derelict landscape" (SOLECKI; WELCH, 1995, p. 93). No Brasil é comum, em várias cidades, dois bairros de rendas distintas, serem separados por um parque. Neste caso, o espaço verde simboliza a manutenção da separação, impossibilitando a aproximação das pessoas (HENRIQUE, 2009).

No campo teórico, a obra "A Linguagem e a Sociedade" de Lefebvre (1966) cita a dimensão simbólica para explicar tais representações tão usuais do ambiente urbano, onde o verdadeiro conteúdo permanece oculto. No caso dos espaços verdes, há uma tendência de estabelecê-los como sinônimo de melhoria de 
qualidade de vida e algo que lhe confere status. Não à toa se propagam títulos de cidade verde, sustentável, dentre outros. Um título é algo simbólico que na prática, não quer dizer que os espaços verdes contribuem para melhor qualidade de vida de todos, uma vez que não questiona-se a distribuição e utilização por todos os citadinos.

Tão importante quanto criar e manter os espaços verdes como equipamentos urbanos é promover o que Harvey (1980) denomina de apropriação justa dos espaços públicos. Ou seja, pensar na apropriação desses espaços dentro de um projeto de emancipação coletiva, e não como um forma de exploração econômica, segregação socioespacial ou marketing ecológico.

Nesse sentido, políticas para minimizar o efeito da segregação socioespacial são usualmente relacionadas com a construção de escolas, hospitais, disponibilidade de serviços públicos e oportunidades de emprego (BUENO; GUIDUGLI, 2004). Porém, apesar do potencial dos espaços verdes, iniciativas de implantação de parques ou praças nas periferias como meio de enfrentamento das desigualdades sociais (incluindo a segregação socioespacial) ainda não é uma prática das gestões urbanas.

Vale aqui citar a conclusão final do trabalho de Haase et. al (2017, p. 46): "Green spaces need to be distributed evenly in a city and furnished by diverse vegetation e to make sure that all inhabitants not only have equal access but also equal benefits". Para os referidos autores é importante propor a distribuição mais igualitária dos espaços verdes urbanos, sobretudo quando se busca a sustentabilidade nas cidades conjugada com a inclusão social.

Desta feita, poder-se-ia minimizar a sobrediscriminação social referida por Saito (1996), uma vez que os espaços verdes quando bem distribuídos e estabelecidos como equipamentos urbanos podem reduzir as penalidades históricas das populações menos favorecidas ao propiciarem espaços de lazer, esporte e cultura.

Assim como Carlos (1992, p. 26) caracteriza a cidade como um "modo de viver, pensar, mas também de sentir", os espaços verdes estando dentro das cidade também requerem ter vitalidade, ou seja serem dinâmicos, atraentes, com segurança e infraestrutura adequada. Assim, os espaços verdes urbanos podem ser apropriados, fazendo parte das cidades e integrados à sociedade. 


\subsubsection{Exemplos de Resistência e Luta ao Direito da Cidade}

Em se tratando de políticas socioespaciais, o Estado tem o poder de mudar a estrutura, a função e o sentido dos lugares. Há portanto uma institucionalização tendenciosa na reprodução do espaço, uma vez que o Estado age sob a égide do capital (CARLOS, 2001). Um exemplo recente e marcante deste tipo de ação do Estado foi a remoção de moradias de população de baixa renda para construção de obras para a copa do mundo nas cidades-sede do evento de futebol (CASTRO; NOVAES, 2014).

O cotidiano passa a requerer novos espaços para o trabalho, consumo, eventos. Como consequência: os prédios de industrias e casas antigas tornaram-se escritórios, shoppings, lojas, igrejas e até garagens para carros que já não cabem nas ruas. Novos centros são criados, não integram pessoas e ainda aprofundam as contradições socioespaciais (CARLOS, 1992).

Assim, a expansão urbana acontece com a transformação dos espaços como: praças, bosques urbanos e construções antigas acabam sendo relegados ou substituídos, com a construção de ruas, viadutos, obras estruturantes, edifícios, shoppings, estádios. Exemplo marcante da transformação dos espaços foi a demolição da mansão Matarazzo na capital paulista.

Mesmo com o tombamento da antiga mansão para futuras instalações do Museu do Trabalhador, os interesses privados prevaleceram. Como o tombamento foi realizado à contragosto dos proprietários, houve uma reação planejada, através da explosão do porão do prédio. Essa ação comprometeu a estrutura da mansão e possibilitou reverter a ação de tombamento e concretizar a venda do imóvel. Após a venda, foi efetivada a construção de mais um shopping e torres comerciais na avenida Paulista (GARCIA, 2010). Assim, o prédio histórico rodeado de amplo espaço verde que teria fins culturais para à coletividade foi transformado em mais uma área privada e de consumo. 


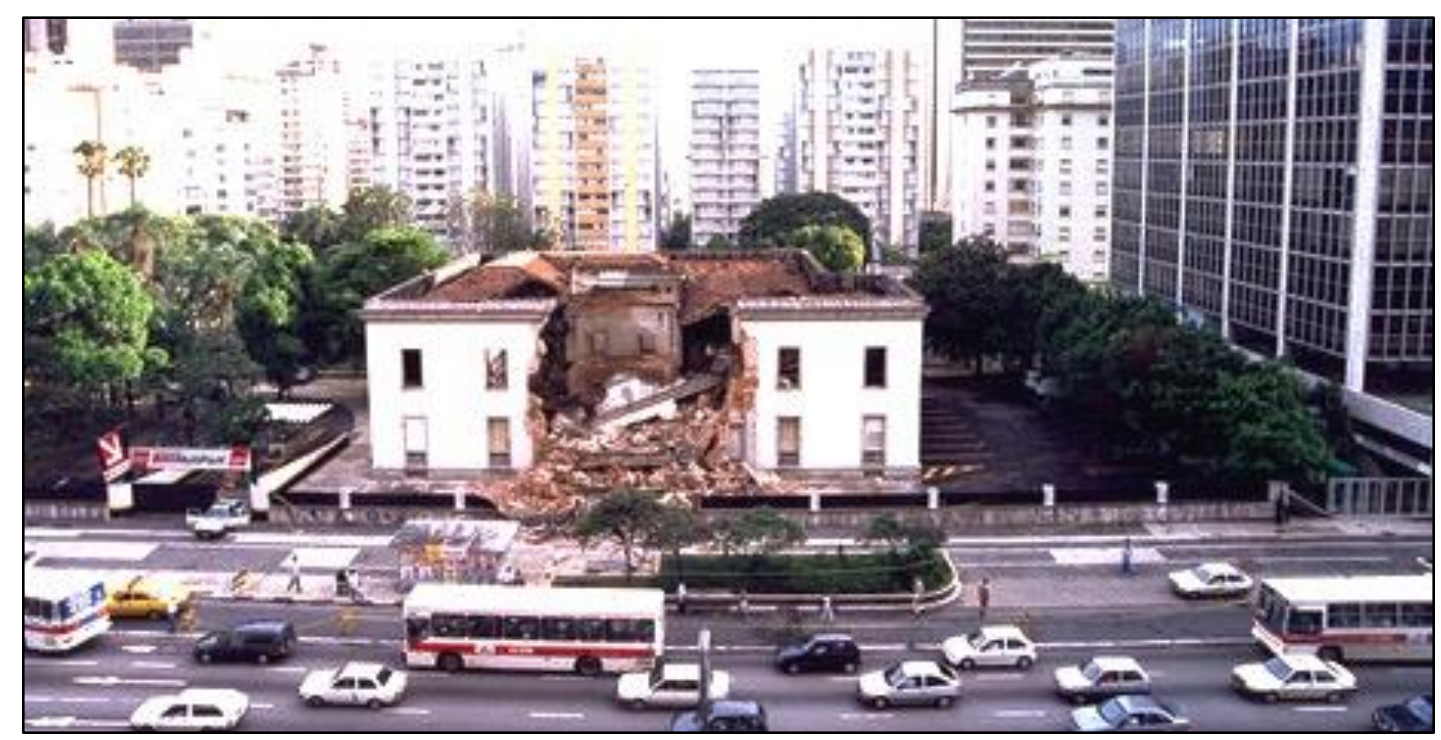

Figura 16 - Explosão do porão da mansão Matarazzo.

Fonte: Edu Garcia (1994). www.acervo.estadao.com.br

Com tantos shoppings e áreas de consumo, o homem se prende àquilo que Gorz (1999) denomina de tempo e espaço da mercadoria. O autor analisa que nos momentos livres de trabalho a sociedade se prende aos lugares de compras para saciar ou inflar o desejo de consumo. Os espaços propícios para isso, são os templos do consumismo, inverso da noção de liberdade das práticas de lazer, desporto ou conversa (PADILHA, 2009).

Nos espaços de consumo, como os shoppings, as pessoas ficam mais distantes da vida coletiva e das experiências do convívio em grupo. O que prevalece é a vontade da posse, baseado no poder de compra conquistado após duras jornadas de trabalho. Assim, as relações no tempo livre realizadas nos shoppings leva ao distanciamento das pessoas (PADILHA, 2009).

Fora dos shoppings, percebe-se que os espaços atingem dimensões inéditas, possibilitadas e induzidas pelo transporte motorizado, metrôs subterrâneos (quando os tem), além de novas vias rodoviárias. Assim, a circulação de pessoas e mercadorias assume a condição de função urbana preponderante e peça-chave do circuito produtivo do espaço urbano que se torna cada vez mais homogêneo com o cinza das vias e dos prédios (CARLOS, 2004).

Embora o espaço urbano tenda à homogeneização, ele apresenta diferenças, podendo ter como um símbolo os espaços verdes. Essas diferenças são como fragmentos que testemunham resistência aquilo que Carlos (2004) denomina de processo de homogeneização do espaço urbano. 
Dado que o espaço urbano é meio e produto de uma reprodução social que acontece de forma contraditória (CARLOS, 1992), podemos entender assim, que os espaços verdes disponíveis nas cidades como locus de apropriação e atividades de socialização como formas de resistência ao modo de vida capitalista. Um bom exemplo disso é o parque Trianon localizado na avenida Paulista, cercado de bancos, prédios comerciais e empresariais, além das avenidas lotadas de carros.

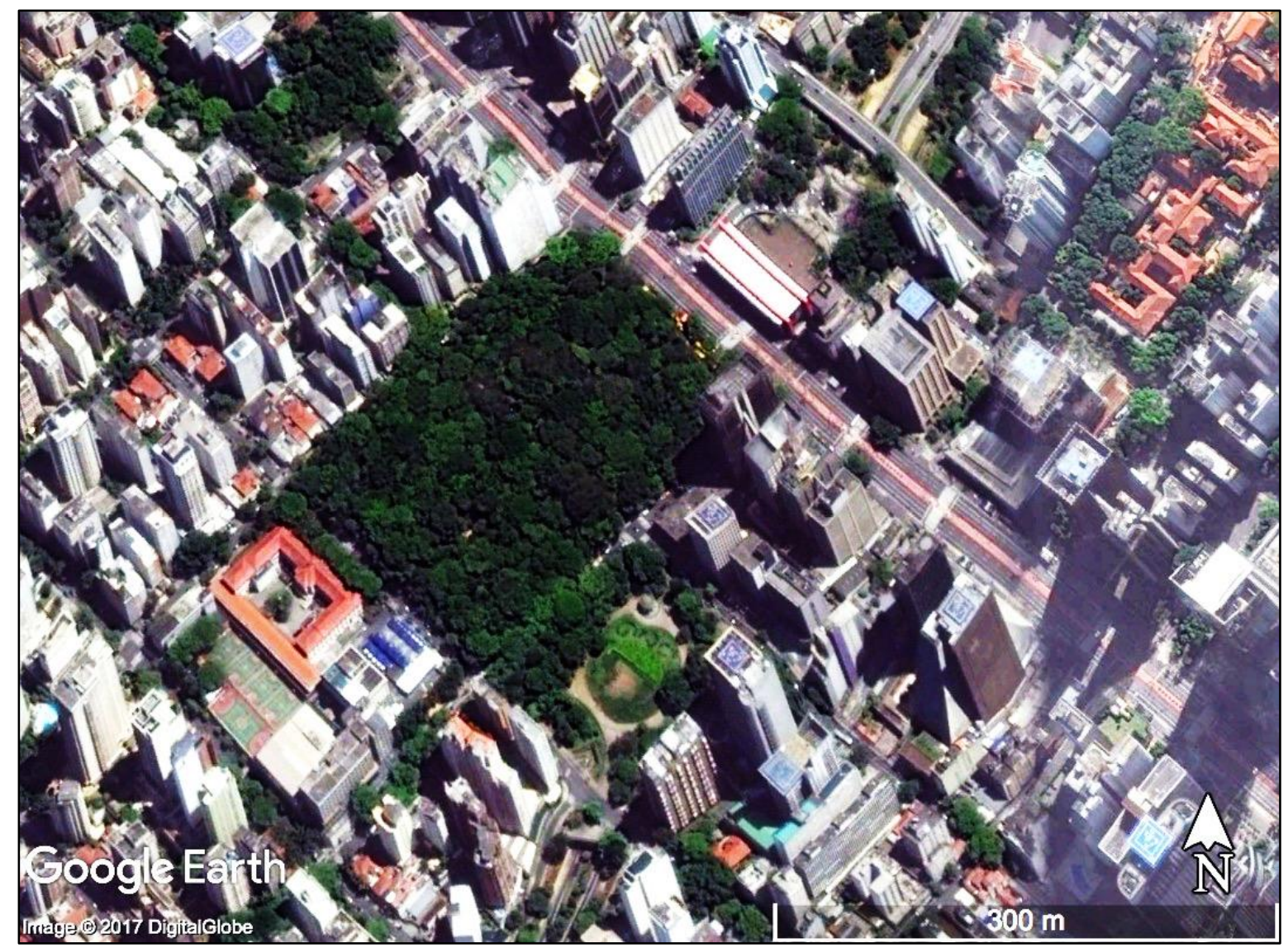

Figura 17 - Parque Trianon. Avenida Paulista. São Paulo (SP)

Fonte: Google-Earth (2017)

Vivemos uma rotina mecânica onde empobrecemos os espaços e esmigalhamos o tempo (CARLOS, 2004). A vida nos grandes centros urbanos se distancia ao viver com emoções e aos simples hábitos sociais, como: conversar com o vizinho, passear ao ar livre, coletar frutas, sentar no banco da praça. Cada vez mais, tais práticas são excluídas da vida cotidiana. Por isso, precisamos dos espaços verdes como resistência ao processo programado da vida de consumo.

Nesse ponto, ao analisarmos a apropriação dos espaços verdes nas cidades, visando maior sociabilidade, ressalta-se também a importância da re-apropriação do tempo livre. Tal ação foi proposta por Gorz (1999) que na prática passa pela 
redução do tempo voltado à lógica do trabalho, o que inclui além do tempo de trabalhar, o tempo para se chegar e sair do emprego e o tempo de consumismo. Assim, o autor propõe um tempo livre possível aos indivíduos desenvolver capacidades intelectuais, de invenção e de prazer (GORZ, 1999).

No mesmo sentido, o sociólogo Ivan Illich trabalha o conceito de convivialidade, ou seja as relações sociais de criatividade e autônomas (ILLICH, 1973). Em outras palavras, trata-se de ir além de estabelecer espaços e momentos de lazer e diversão, que podem ser mercantilizados. A convivialidade é a afirmação da sociabilidade e seus prazeres como atividades significativas para a vida (ILLICH, 1973).

Shaftoe (2012) ao trabalhar o conceito de "espaços conviviais" remete aos locais públicos e abertos onde as pessoas podem se encontrar seja para práticas sociais (conversas, práticas de esporte) ou vaguear, afirmando esses espaços como a essência da urbanidade. Nessa ótica, Illich (1973, p. 13) chama de sociedade convivencial "uma sociedade em que a ferramenta moderna está a serviço da pessoa integrada na coletividade e não a serviço de um corpo de especialistas".

Dada a potencialidade social dos espaços verdes urbanos, como ferramentas de convivialidade, faz-se necessário planejar sua distribuição e o seu uso mais igualitário, de tal forma que possam estar inseridas em todos os bairros ou comunidades. A existência de espaços verdes tornam, eles e o seu entorno, mais valorizados e mais procurados (HILDEBRAND et al., 2011), de modo que quando bem distribuídos e postos como equipamentos urbanos, geram benefícios ecológicos e sociais, quer sejam parques ou praças públicas.

Por isso, Blanco-Bello; Victoria-Cogollo (2013) clamam para a necessidade do fortalecimento dos movimentos de resistência que atuem na defesa dos espaços públicos (como os EVU), principalmente nas áreas mais periféricas das cidades. As autoras afirmam que esses movimentos serão mais efetivos se irem além da radicalização e aportarem nas suas reinvindicações reflexões e discussões críticas sobre a importância social desses espaços (BLANCO-BELLO; VICTORIACOGOLLO, 2013).

Por sua vez, o Estado precisa ir além da disponibilização dos espaços de interesses coletivos. A conscientização da população sobre a importância desses espaços e a sua efetivação como equipamento urbano promotores de 
desenvolvimento são tarefas necessárias (BLANCO-BELLO; VICTORIA-COGOLLO, 2013).

Quanto às mobilizações populares relacionados a distribuição igualitária dos espaços verdes, é importante lembrar uma campanha espontânea surgida no Rio de Janeiro ainda na década de 1980 junto às Associações de Moradores, que reivindicavam inclusive com pichações nos muros: "um bairro, uma praça" (SAITO, comunicação pessoal). No ano de 2012 em Belo Horizonte, nas vésperas das eleições municipais, um grupo de ativistas sociais, espalhou cartazes pela cidade com essa e outras reivindicações relacionadas ao acesso democrático aos espaços públicos (REGALDO et al., 2015).

As frases, sem assinatura, se lançavam livres para serem captadas e capturadas por qualquer nome, rosto ou partido. Sem reivindicação de autoria, as palavras veiculadas pelos cartazes coloridos procuravam resgatar, no deserto político em que nos encontramos, o vinculo entre as palavras e as coisas. Enquanto coisas, as palavras desenham propostas, imaginários, paisagens e práticas de código aberto: disponíveis à livre apropriação, à concretização no território e, inclusive, ao intercâmbio nacional (REGALDO et al., 2015).

A campanha tornou-se permanente e além dos cartazes ganhou espaço nas redes sociais através do uso das hashtags: \#parquesabertos24h, \#umapraçaporbairro, \#nadarepescarnoarrudas, \#ônibussemcatraca, \#carrosforadocentro. Em 2017, com base nesse campanha a Revista Piseagrama4 espalhou cartazes similares pelas as ruas de Lisboa (Figura 18), defendendo que a campanha "constitui uma rede de compartilhamentos física e de longo prazo" (REGALDO et al., 2015).

\footnotetext{
4 Piseagrama é uma publicação sem fins lucrativos sobre espaços públicos. Além da revista semestral, os idealizadores realizam ações em torno de questões de interesse público como debates, micro-experimentos urbanísticos, oficinas, campanhas e publicação de livros. Site para mais informações: piseagrama.org
} 


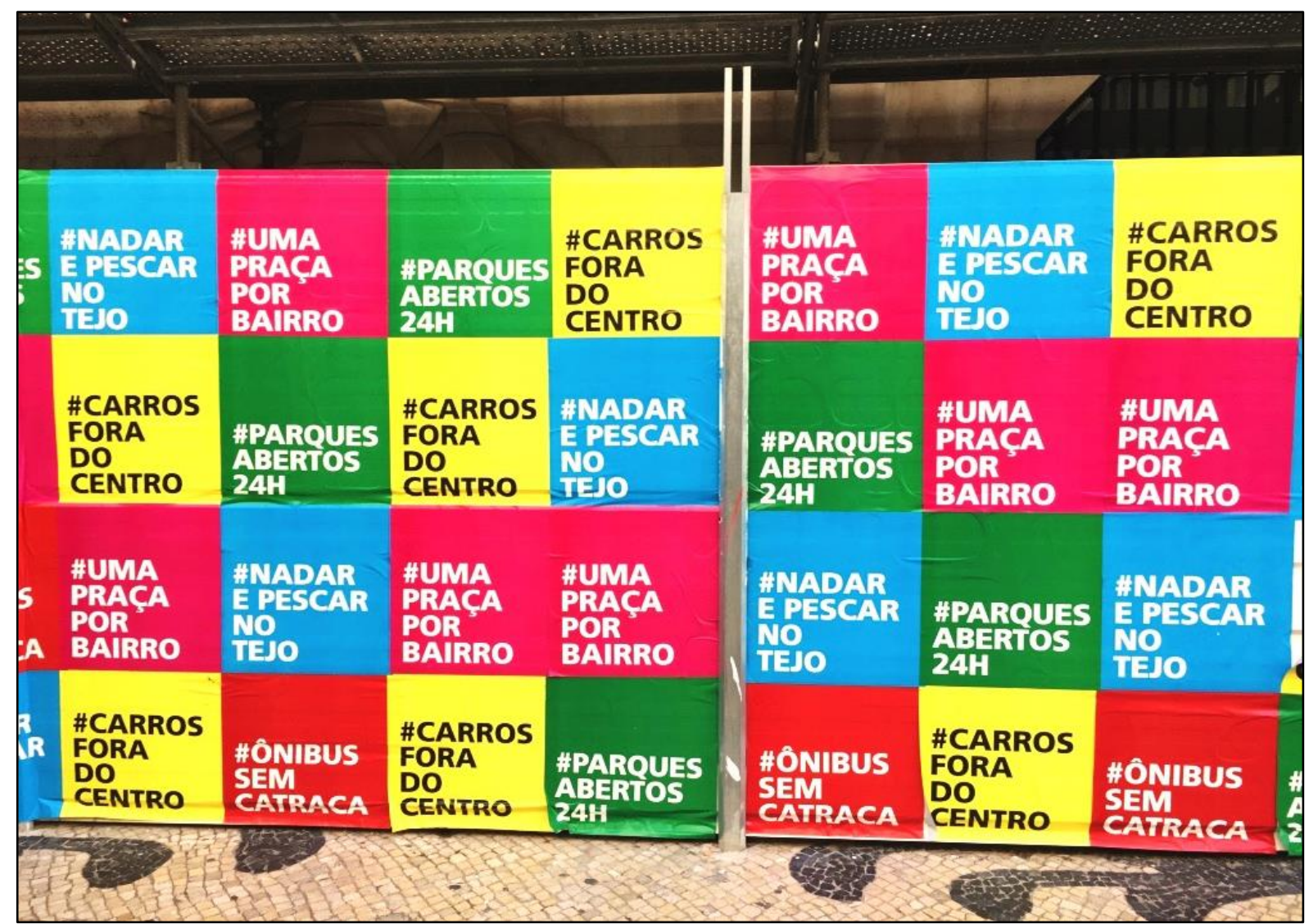

Figura 18 - Campanha da revista Piseagrama na cidade de Lisboa (Portugal).

Fonte: Saito, Carlos Hiroo (2017)

As frases refletem demandas por uma cidade mais sustentável e democrática. Destaca-se que além de pedirem por mais praças, demandam parques abertos 24 horas, o que evidencia que a população tem uma necessidade maior de espaços verdes urbanos e livres. Com intervenções artísticas, a campanha atua no campo da política, "injetando possibilidades no imaginário urbanístico e fomentando com que os sujeitos da cidade protagonizem, consciente ou distraidamente, mas sobretudo corriqueiramente, a difusão das ideias" (REGALDO et al., 2015).

A mudança na forma de usufruir a cidade e demandar espaços mais sustentáveis e democráticos corrobora a afirmação de Jacobs (2011) de que as cidades têm como característica a diversidade de usos. É importante destacar as funções dos espaços além do trabalho, seja para o descanso, lazer, prática de esportes ou exercício da convialidade (JACOBS, 2011). A sociedade mesmo presa a rotina trabalho-casa-consumo busca alternativas. O planejamento urbano precisa catalisar e nutrir a diversidade de relações funcionais, ou relações de usos que vão além da lógica do trabalho-consumo (JACOBS, 2011). Assim os espaços verdes se mostram com áreas ideais para ampliar tal diversidade. 
Por isso, falar em espaços verdes é ir além de seus benefícios socioambientais para à sociedade. Os espaços verdes estão inseridos no Estatuto da Cidade como zonas prioritárias para os municípios garantirem a sustentabilidade urbana (BRASIL, 2001). Dessa forma, são considerados como objeto do direito à cidade, sendo símbolo de um espaço livre de interesses do capital, propício ao lazer, esporte e a participação dos citadinos à atividades democráticas.

O direito à cidade para Lefebvre é a forma superior dos direitos: direito à liberdade, à individualização na socialização, ao habitat e habitação. O direito à obra (atividade do participante) e o da apropriação se unem no direito à cidade (LEFEBVRE, 2008b).

Assim, os espaços verdes urbanos ao serem entendidos como locus da liberdade para execução de atividades de sociabilidade, de lazer e convivialidade, se mostram como ferramenta essenciais para a garantia do direito às cidade. Nesse sentido, Plata; Vilchis; Vázquez (2018) consideram os espaços verdes como elementos estratégicos para proporcionar a justiça ambiental, equidade e inclusão social.

Green areas have qualities that lead to improved living conditions, as they contribute to the construction of inclusive urban environments with a healthy environment conducive to coexistence, quality of life and social well-being (PLATA; VILCHIS; VÁZQUEZ, 2018, p.294).

Um exemplo recente e importante da luta da população pelo direito à cidade tendo como elemento chave um espaço verde, foram os protestos no Parque Gezi (Turquia), uma vez que este parque (um dos poucos espaços verdes de Istambul) seria transformado em um enorme shopping que abrigaria até uma réplica de um quartel otomano. Farro; Demirhisar (2014) relatam que os protestos começaram de forma pacífica, em maio de 2013, com um grupo pequeno de ambientalistas que acamparam no Parque Gezi.

A repressão policial contra os protestos fez com que mais e mais manifestantes se juntassem ao movimento pró-Parque Gezi (FARRO; DEMIRHISAR, 2014). Assim, os autores destacam que além do aumento de pessoas os protestos passaram a realizar questionamentos quanto ao autoritarismo do governo e das elites que queriam impor seu controle sobre a vida das pessoas. Assim, o protesto que começou pela defesa de um espaço verde transformou num 
amplo movimento democrático contra o governo turco (FARRO; DEMIRHISAR, 2014).

The Gezi movement announces the formation of new collective movements that denounce the precariousness of individual life and the fragmentation of social life and raise new challenges for the reconstruction of a social life free from the control of neoliberal and financial speculation, affirming the human dignity of individuals aiming at their subjective assertion in the context of a new democracy. The challenges of the Gezi Park are hence announced in the same terms as the others that were launched at the beginning of the Arab Spring in Tunisia and Egypt or the Occupy Wall Street movement in North America and the $15 \mathrm{M}$ movement in the EU (FARRO; DEMIRHISAR, 2014, p. 185).

No Brasil, um exemplo de luta por espaço verde foi a ampliação do Parque Olhos D`água, localizado na Asa Norte de Brasília (DF). Através da mobilização dos moradores do entorno e frequentadores do parque, por meio de manifestações, protestos e abaixo-assinados, a sociedade conseguiu barrar a construção de edifícios comerciais na entre-quadra 212/213 Asa-Norte (PEREIRA; PATO, 2016).

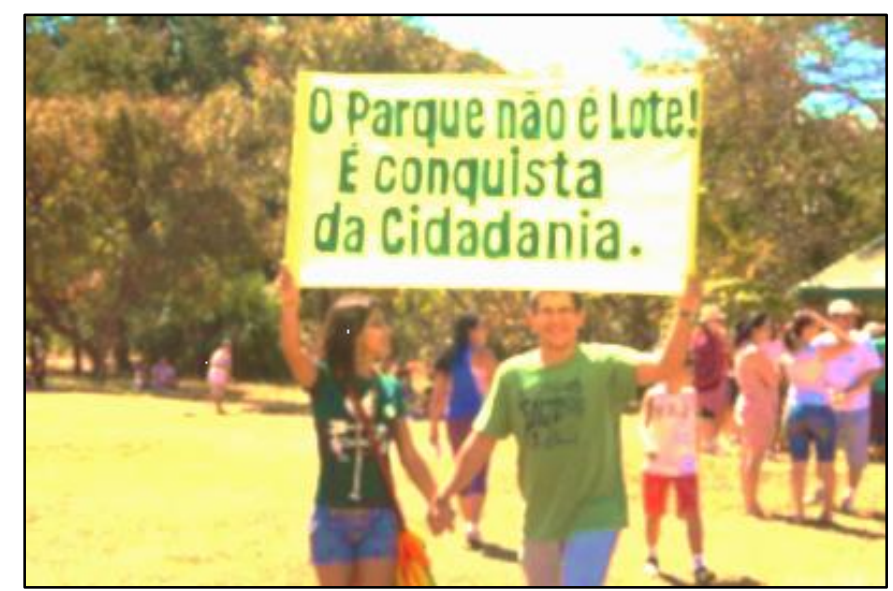

Figura 19 - Mobilização contra a construção de edifícios em áreas de proteção ambiental Fonte: https://chicosantanna.wordpress.com. Autor: Chico Santana (2012)

A mobilização da sociedade fez o poder público anexar ao parque a referida área, de grande vulnerabilidade ambiental, com nascentes, curso d’água e vegetação nativa (PEREIRA; PATO, 2016). A área foi anexada por meio do decreto legislativo Lei $n^{\circ} 33.588$ (DISTRITO-FEDERAL, 2012) que desapropriou o espaço e ampliou a área do parque em 30\% (7 hectares) do tamanho original. A Figura 20 mostra a atual delimitação (cor rosa), sendo que área ampliada corresponde a expansão fora do retângulo do lado esquerdo inferior. 


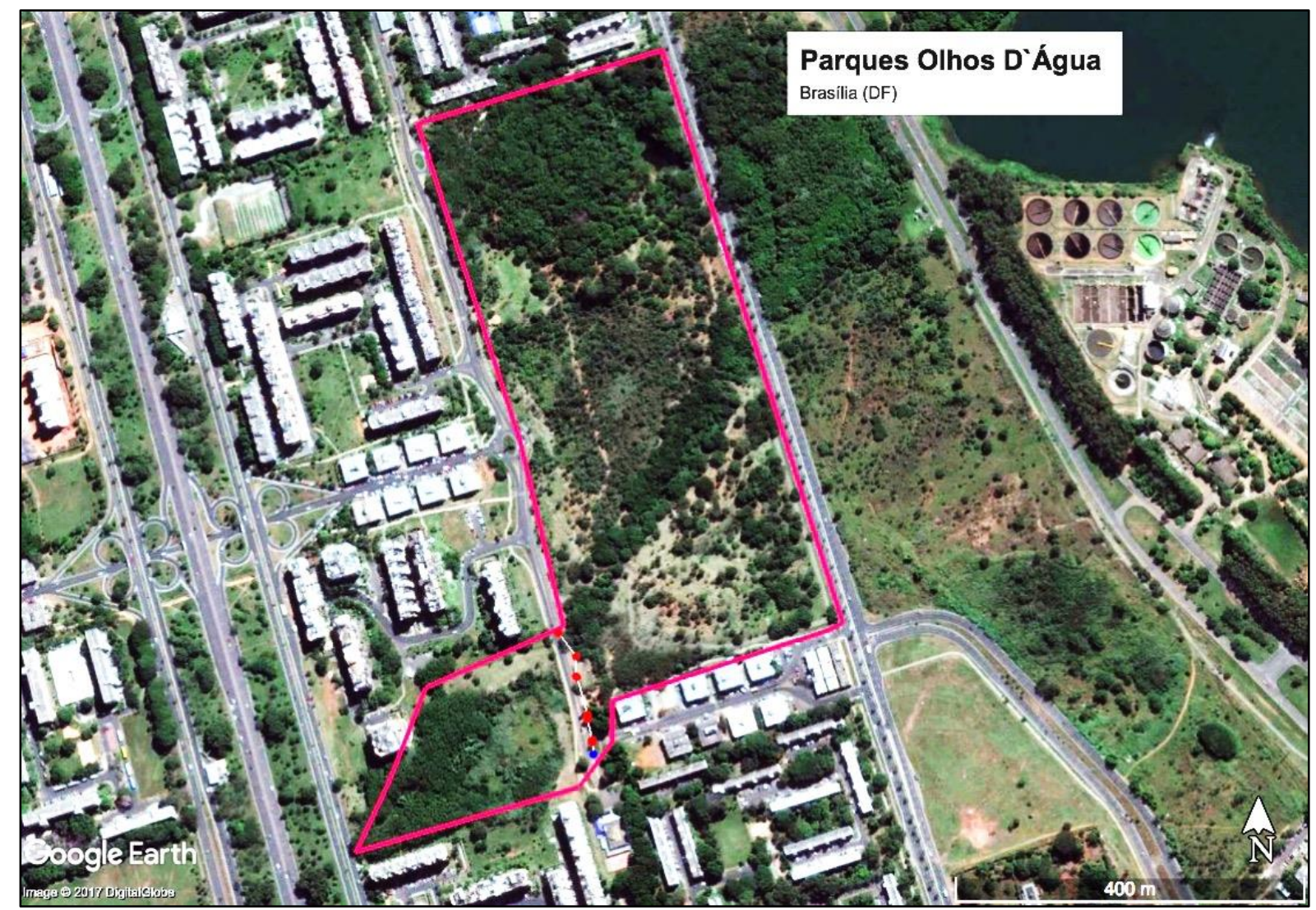

Figura 20 - Parque Olhos D`Água Em rosa o atual limite.

Fonte: Google-Earth (2017)

Outro exemplo marcante é o caso do Parque Augusta em São Paulo, no qual uma área de $24 \mathrm{mil} \mathrm{m}^{2}$ originalmente de uma tradicional escola (Colégio Des Oiseaux) que foi demolida na década de 1970 (Figura 21). A área é considerada como um símbolo de resistência contra a especulação imobiliária. Várias propostas de empreendimentos (hotéis, torres comerciais, estacionamento) foram pautadas e não seguiram a diante, frente a luta da sociedade pelo uso público e gratuito do espaço (SOUZA NASRAUI; LUCIO, 2016). 


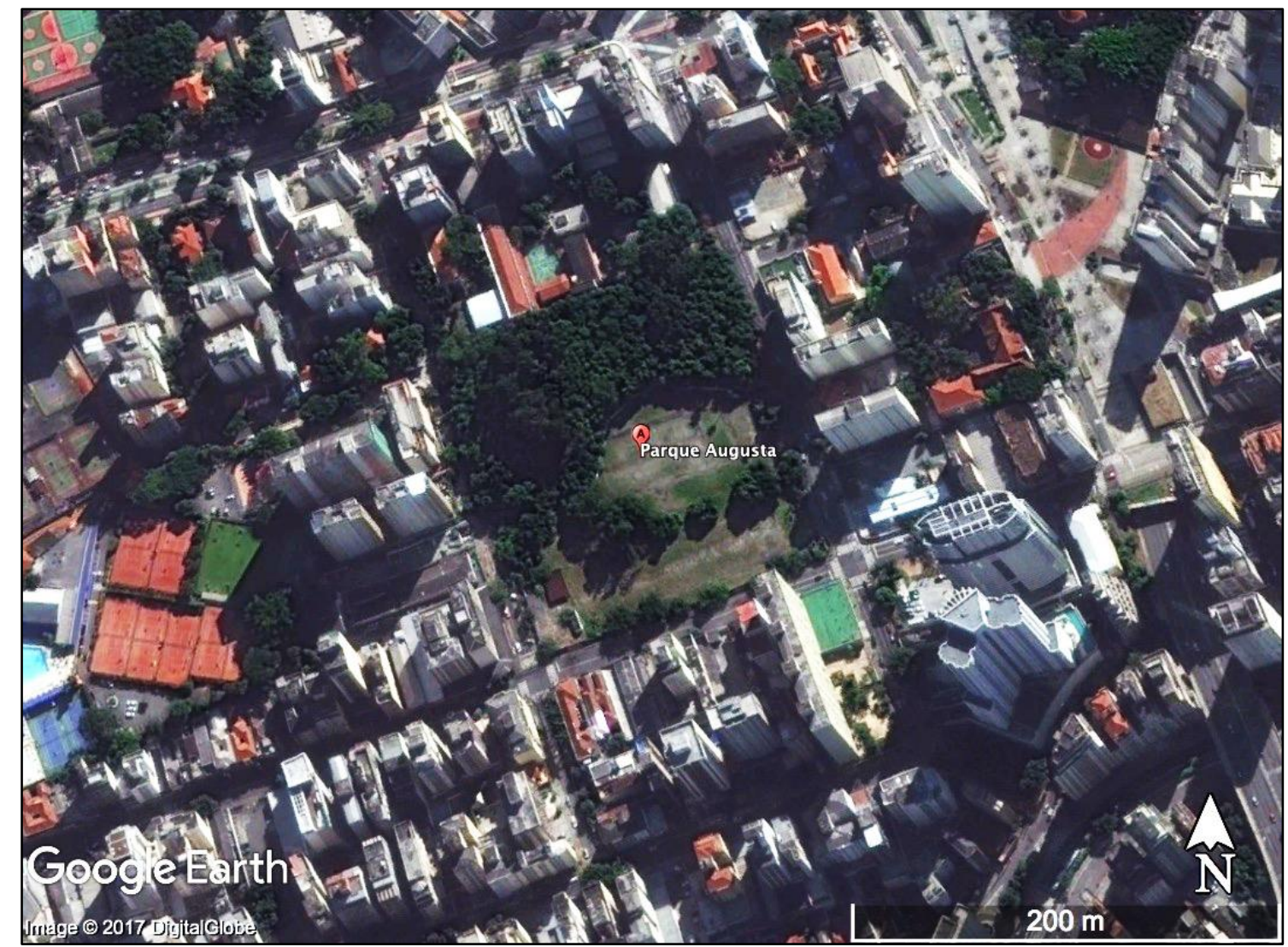

Figura 21 - Parque Augusta. Centro de São Paulo (SP)

Fonte: Google-Earth (2007)

Atualmente a prefeitura paulistana está em negociação para doar (forma de recompensa acordada com Ministério Público) áreas públicas às empreiteiras antigas proprietárias. Além disso, a prefeitura conta com $\mathrm{R} \$ 80$ milhões para reformas e efetivar a inauguração do parque, no entanto a gratuidade não é uma garantia uma vez que a atual gestão municipal não quer arcar com os custos de manutenção (RIBEIRO, 2017).

Conclui-se, portanto, que os espaços verdes urbanos estão na pauta na luta pelo direito à cidade. Parte da população está atenta à importância desses espaços, como meio de estabelecer cidades mais sustentáveis. Frente a falta compromisso do poder público, urgem os movimentos de luta e resitência por espaços verdes urbanos, locus de atividades democráticas, lazer e qualidade de vida. 


\section{DEFINIÇÃO DAS ÁREAS ANALISADAS}

Definir o conjunto das cidades analisadas na tese requereu o melhor entendimento de termos: cidades e municípios no âmbito das áreas urbanas. Uma vez que as definições legais não se convergem, a tese definiu como cidade os setores censitários ${ }^{5}$ do tipo urbano, classificados pelo IBGE. Essa definição possibilitou abarcar na análise os distritos de muitos municípios, que apesar de pequenos fazem parte da malha urbana.

Para tornar a análise mais robusta estabeleceu-se no recorte da pesquisa as regiões metropolitanas (no caso do Distrito Federal, englobou-se a Região Integrada de Desenvolvimento Econômico). Assim, ao definir as capitais a serem analisadas, agregou-se as cidades que fazem parte dessas regiões como forma de tornar a investigação do problema mais ampla e factível à realidade, uma vez que a presença e ausência dos EVU transbordam as fronteiras políticas das cidades metropolitanas.

\subsection{Município, Cidade e Setor Censitário}

O historiador Fernand Braudel, um dos pioneiros na análise das cidades, ainda jovem, realizou um ensaio (publicado em 1922 - como memorial de fim de curso) sobre sua cidade natal, Bar-Le-Duc (BRAUDEL, 1989). O trabalho indicou o quão difícil é definir o que é uma cidade. A simples indicação do espaço como cidade lhe trouxe um problema, uma vez que, pelos parâmetros quantitativos (número da população e área da cidade) Bar-Le-Duc não passava de um vilarejo influenciado pela capital, Paris. Para os moradores, no entanto, era sim uma cidade. O prestígio à cidade natal é algo comum e esperado em diversas culturas e que não pode ser dispensado para uma análise (DEAECTO, 2008).

Fundamentos demográficos norteiam muitas definições de cidade. Ao verificar as diretrizes oficiais e estatísticas de diversos países é possível encontrar parâmetros que qualificam um espaço urbano como cidade. Assim, o recenseamento dos Estados Unidos toma o limiar de 2.500 habitantes como critério para estabelecer uma comunidade urbana estabelecida num espaço, ora

\footnotetext{
5 Setor censitário é a unidade territorial estabelecida, situada em um único quadro urbano ou rural, com dimensão e de domicílios que permitam o levantamento por um recenseador. Assim sendo, cada recenseador procederá à coleta de informações tendo como meta a cobertura do setor censitário que Ihe é designado. Para o Censo Demográfico de 2010 foram delimitados cerca de 314 mil setores censitários (IBGE 2010).
} 
denominado de cidade. Na Europa, a Conferência Europeia da Estatística em Praga, tomou como limiar de 10 mil habitantes para a mesma definição (CASTELLS, 1983).

No Brasil, a definição legal de cidade é fruto do Estado Novo (Governo Getúlio Vargas - 1937 a 1945). O Decreto-Lei nº 311 de 1938, transformou em cidades todas as sedes municipais existentes, independentemente de suas características estruturais, funcionais, de localidade, tamanho ou densidade demográfica (VEIGA, 2001). Como mostra a Figura 22, o municípios de Viamão, pelo Decreto-Lei 311 de 1938 apenas a área em rosa é considerada cidade. As áreas em amarelo, mesmo possuindo núcleos urbanos, foram denominados de distritos.

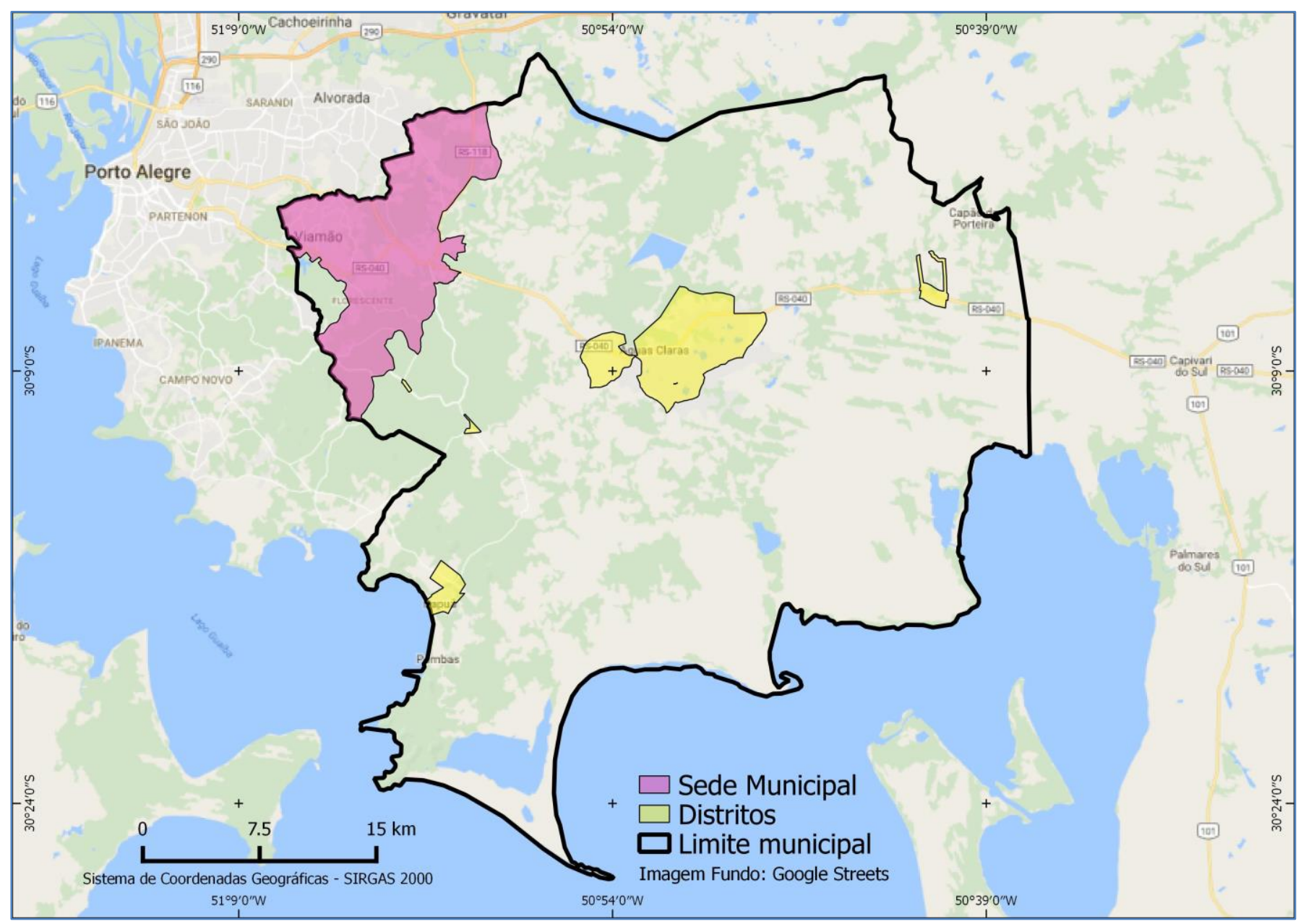

Figura 22 - Município de Viamão (RS). Denominação de cidade e distritos conforme o Decreto-Lei 311 de 1938. 
Todavia, ressalta-se que no Brasil é comum utilizar a denominação cidade como sinônimo de município (ente federativo, como os estados e a união). Nesse sentido, é importante elucidar que independente da denominação, todo município é dotado de áreas urbanas, além dessas a maioria apresentam áreas rurais. O IBGE (Instituto Brasileiro de Geografia e Estatística), ao definir e mapear os setores censitários fez a delimitação entre os de tipo urbano e rural. Ressalta-se que um município pode ter áreas urbanas nos seus distritos, ou seja, fora da sede municipal (cidade).

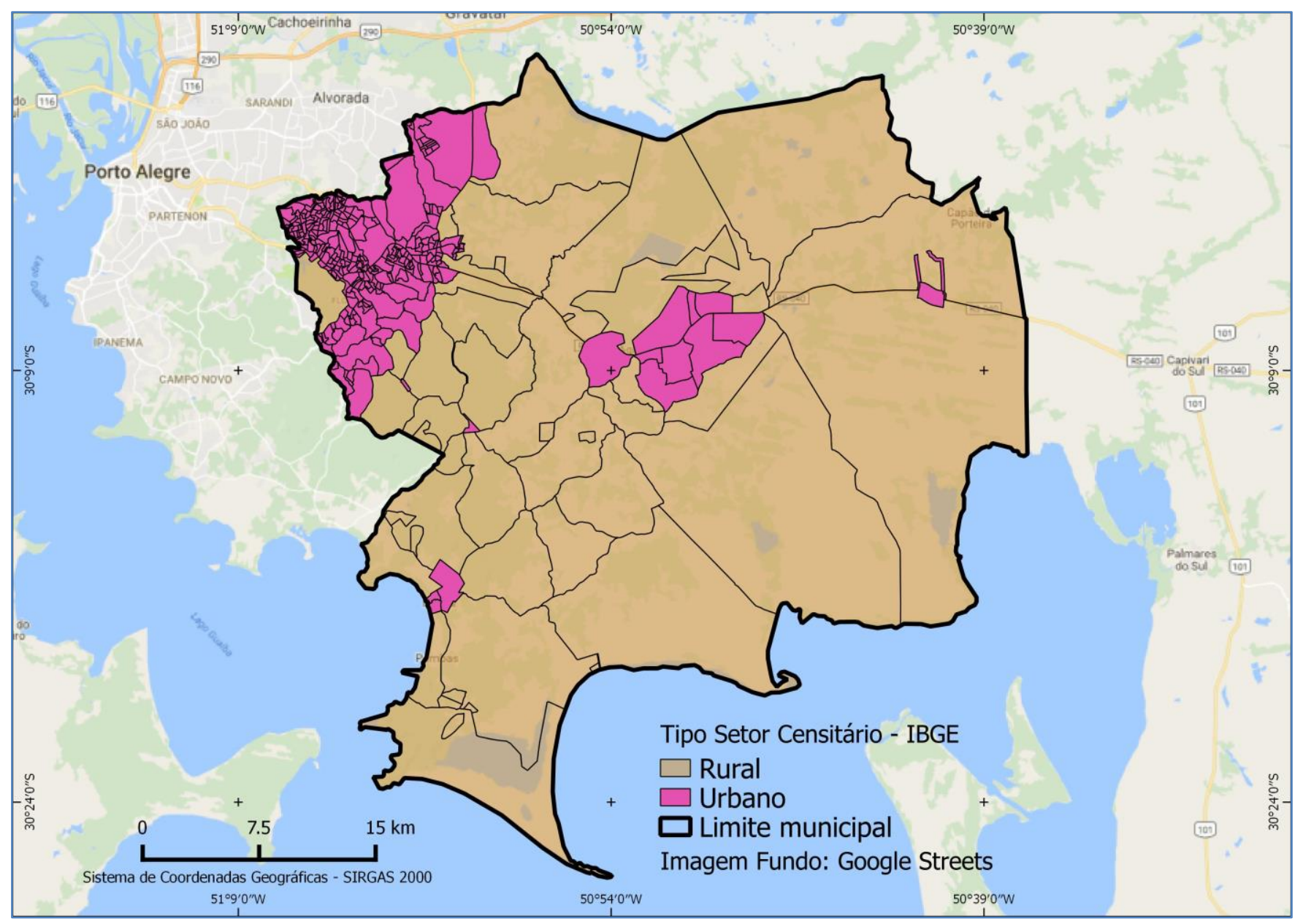

Figura 23 - Município de Viamão (RS). Setores censitários, tipo urbano e rural definidos pelo IBGE.

$\mathrm{Na}$ prática, é necessário cautela ao analisar dados quando se tratam de cidades. Mesmo sendo estabelecidas áreas urbanas nas sedes e nos distritos, há uma diferenciação na prestação de serviços. Como exemplo, há serviços públicos que existem nas sedes (cidades), mas não existem em outros setores censitários, como coleta seletiva de recicláveis e tratamento de esgoto sanitário. É comum que municípios implantem primeiramente os serviços na sede (cidade) e aos poucos 
passem a implantá-la nos distritos e após nas áreas rurais, pois a expansão do serviço demanda mais recursos técnicos e financeiros.

Assim, conclui-se que o contingente populacional não legitima um espaço a ser denominado de cidade, mas sim a questão da autonomia federativa enquanto município. Como resultado, existem mais de 5 mil municípios no Brasil, cuja população varia de 825 (Serra da Saudade - MG) a 12 milhões de habitantes (São Paulo - SP). Sendo que de toda população, mais de $80 \%$ residem em setores urbanos.

Nota-se nos gráficos (Gráficos 3 e 4) a seguir que a maioria dos municípios brasileiros (quase $90 \%$ ) possuem população de até 50 mil pessoas. Ou seja, o Brasil é um país em que a maioria dos municípios possui baixa demografia. Em contrapartida, apenas $33 \%$ da população reside nessas cidades pequenas (até 50 mil habitantes). Assim, a maioria das pessoas (quase $70 \%$ da população) residem onde o processo de urbanização encontra-se mais avançado, assim como os problemas socioambientais.

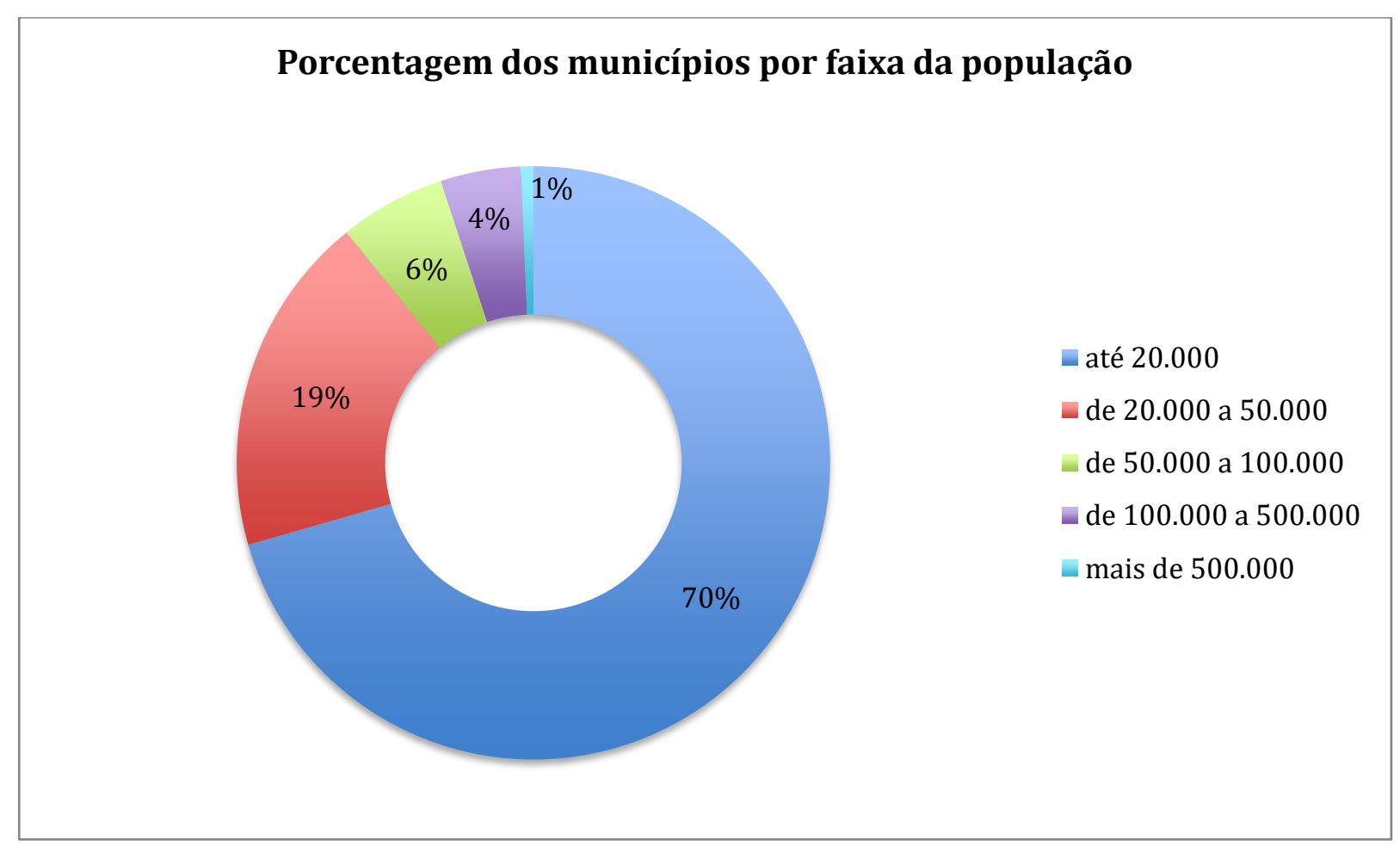

Gráfico 3 - Porcentagem dos municípios segregados por faixa da população Fonte: IBGE (2010) 


\section{Porcentagem de habitantes por municípios (segregados por faixa da população)}

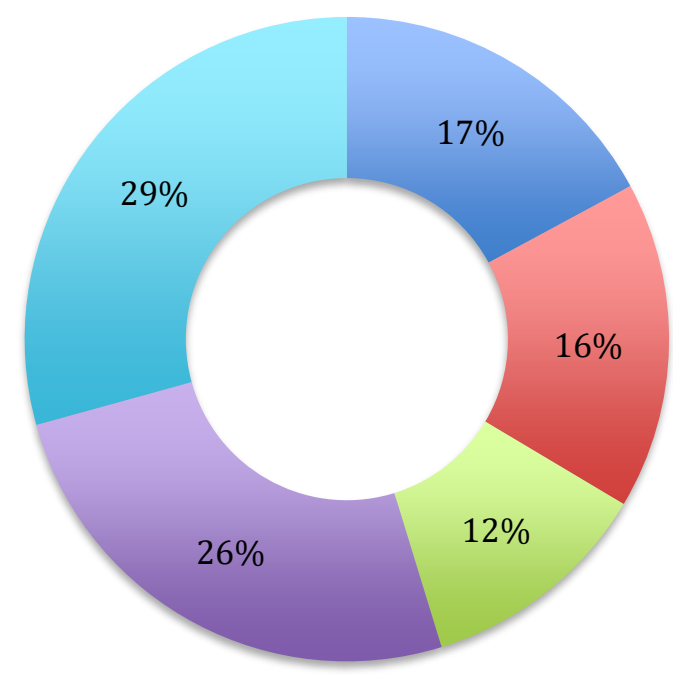

até 20.000

de 20.000 a 50.000

de 50.000 a 100.000

de 100.000 a 500.000

mais de 500.000

Gráfico 4 - Porcentagem de habitantes por municípios segregados por faixa da população Fonte: IBGE (2010)

Dada a amplitude e complexidade do termo cidade e sua possível confusão com o termo município, a tese irá definir como cidade toda localidade que o IBGE considera setor censitário do tipo urbano. Exclui-se, portanto, os setores censitários rurais. Os demais setores, independente de ser sede ou distrito municipal, serão tratados como cidade (Figura 24). 


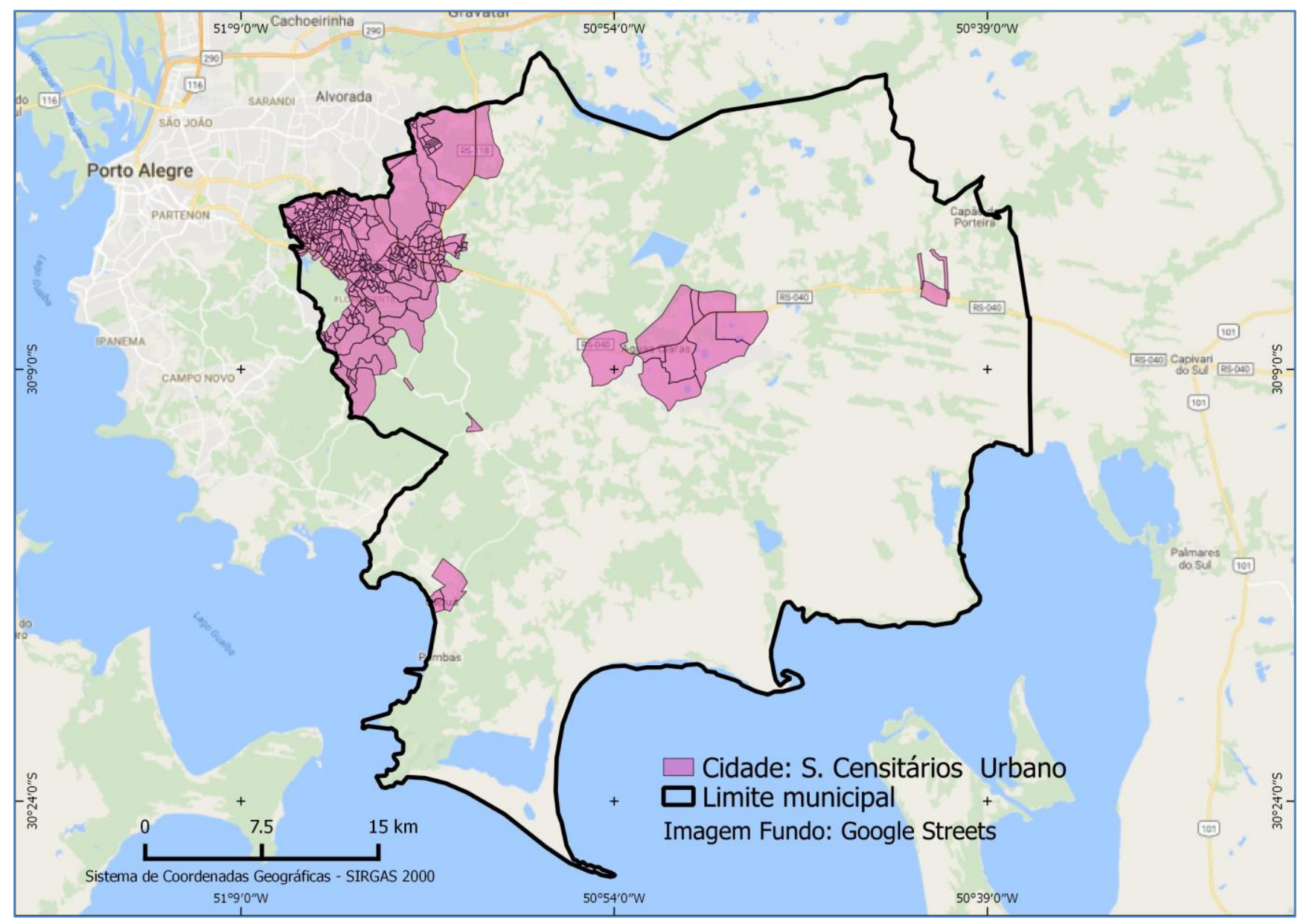

Figura 24 - Município de Viamão (RS). Cidade: Setores censitários tipo urbano (rosa).

Nota-se que a definição de cidade utilizada nesta pesquisa não vai de encontro com o estabelecido pela lei (Pelo Decreto-Lei 311 de 1938). No entanto essa generalização do termo cidade se faz necessária para ampliar a análise aos distritos que apesar de pequenos têm características de ambientes urbanos. Denominar os setores censitários do tipo urbano como cidade facilita a discussão e ao mesmo tempo possibilita integrar a mais importante base de dados demográficos do Brasil na análise.

\subsection{Escolha das Cidades Analisadas}

Considerando que a tese tem como objetivo investigar o estabelecimento da relação entre a incidência dos espaços verdes com índices socioeconômicos, seria importante analisar aquelas cidades que apresentam maior desigualdade de renda. Isso, porque existe uma tendência de que nos locais onde há maior nível de renda, os níveis sociais (educação, saúde, infraestrutura) também serem maiores . 
Dos vários estudos e rankings que se propõem em mostrar o grau de desigualdade de renda em uma sociedade, os que utilizam o coeficiente de Gini6 têm sido bastante aplicados. Isso, porque é uma medida de desigualdade calculada por meio de uma análise de razão, ao invés de uma variável representativa da maioria da população, tais como renda per capita ou do produto interno bruto (HOFFMANN, 1998).

Ressalta-se que a escolha do coeficiente de Gini foi apenas um critério para a escolha amostral da tese. Para estudos mais específicos é importante que este índice seja relacionado com outros, como: a renda per capita, Índice de Desenvolvimento Humano (IDH), Produto Interno Bruto (PIB). Para locais onde a pobreza é predominante, o Índice de Gini pode indicar baixa desigualdade de renda porém não reflete em boas condições de vida. Exemplo disso: a Etiópia possui um índice que indica baixa desigualdade de renda $(0,29)$ mas o PIB per capita é de apenas U\$706,00, enquanto a Singapura apresenta um índice alto de desigualdade de renda $(0,42)$ porém o PIB per capita ultrapassa U\$50.000,00 (BANCOMUNDIAL, 2015).

Assim, a escolha amostral passou primeiramente pela análise do ranking de desigualdade de renda baseado no coeficiente de Gini das capitais das Unidades da Federação. Esse recorte se justifica também, porque as capitais apresentam os municípios com maior densidade demográfica, relevância político-econômica e apresentam os problemas mais visíveis decorrentes do processo de urbanização.

Ao analisar o ranqueamento das capitais de acordo com coeficiente de Gini ano de 2010 (Quadro 1), observou-se que as capitais da região nordeste apresentaram o maior índice (maior desigualdade de renda). Para obter uma amostra mais representativa optou-se por escolher uma capital por região segundo a divisão geopolítica do IBGE. Dessa forma, considerando o recorte espacial geopolítico e o coeficiente de Gini, as capitais escolhidas com maior desigualdade de renda foram: Brasília, Recife, Manaus, São Paulo e Porto Alegre.

Com o objetivo de ampliar a amostra e propiciar maior representatividade à tese, optou-se por incluir no escopo da tese, as regiões metropolitanas das cinco

\footnotetext{
${ }^{6}$ O coeficiente de Gini é uma medida de desigualdade desenvolvida pelo estatístico italiano Corrado Gini e publicada no documento "Variabilità e Mutabilità" em 1912. Esse índice consiste em um numero entre 0 e 1 , onde 0 corresponde à completa igualdade de renda (onde todos têm a mesma renda) e 1 corresponde à completa desigualdade (onde uma pessoa tem toda a renda, e as demais nada têm). A construção do coeficiente de Gini é baseado na "Curva de Lorenz" (GINI, 1912).
} 
capitais, uma de cada região do Brasil. No caso de Brasília, foram inseridos os municípios que integram a RIDE-DF e Entorno. É importante para a análise a ampliação da amostra, uma vez que as capitais apresentam grandes adensamentos populacionais cujos problemas socioeconômicos e ambientais ultrapassam os limites político locais.

\begin{tabular}{|c|c|c|}
\hline \multirow{5}{*}{ 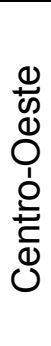 } & Capitais & GINI \\
\hline & Campo Grande & 0,572 \\
\hline & Goiânia & 0,5908 \\
\hline & Cuiabá & 0,6008 \\
\hline & Brasília & 0,637 \\
\hline \multirow{9}{*}{ 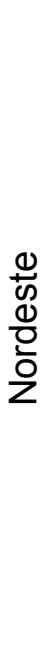 } & Teresina & 0,6171 \\
\hline & Natal & 0,6217 \\
\hline & São Luís & 0,6266 \\
\hline & Fortaleza & 0,6267 \\
\hline & João Pessoa & 0,6287 \\
\hline & Aracajú & 0,6341 \\
\hline & Maceió & 0,6378 \\
\hline & Salvador & 0,6449 \\
\hline & Recife & 0,6894 \\
\hline \multirow{7}{*}{$\frac{\stackrel{0}{t}}{\text { ¿ }}$} & Porto Velho & 0,5745 \\
\hline & Palmas & 0,5914 \\
\hline & Boa Vista & 0,5936 \\
\hline & Macapá & 0,6037 \\
\hline & Rio Branco & 0,6121 \\
\hline & Belém & 0,6284 \\
\hline & Manaus & 0,6334 \\
\hline \multirow{4}{*}{ 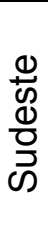 } & Belo Horizonte & 0,6106 \\
\hline & Vitória & 0,6124 \\
\hline & Rio de Janeiro & 0,6391 \\
\hline & São Paulo & 0,6453 \\
\hline \multirow{3}{*}{$\overline{\bar{\sigma}}$} & Florianópolis & 0,5474 \\
\hline & Curitiba & 0,5652 \\
\hline & Porto Alegre & 0,6144 \\
\hline
\end{tabular}

Quadro 1 - Coeficiente de Gini da renda domiciliar per capita, segundo capital Fonte: IBGE (2010) 
Como resultado, a Figura 25 espacializa os municípios da amostra dessa tese.

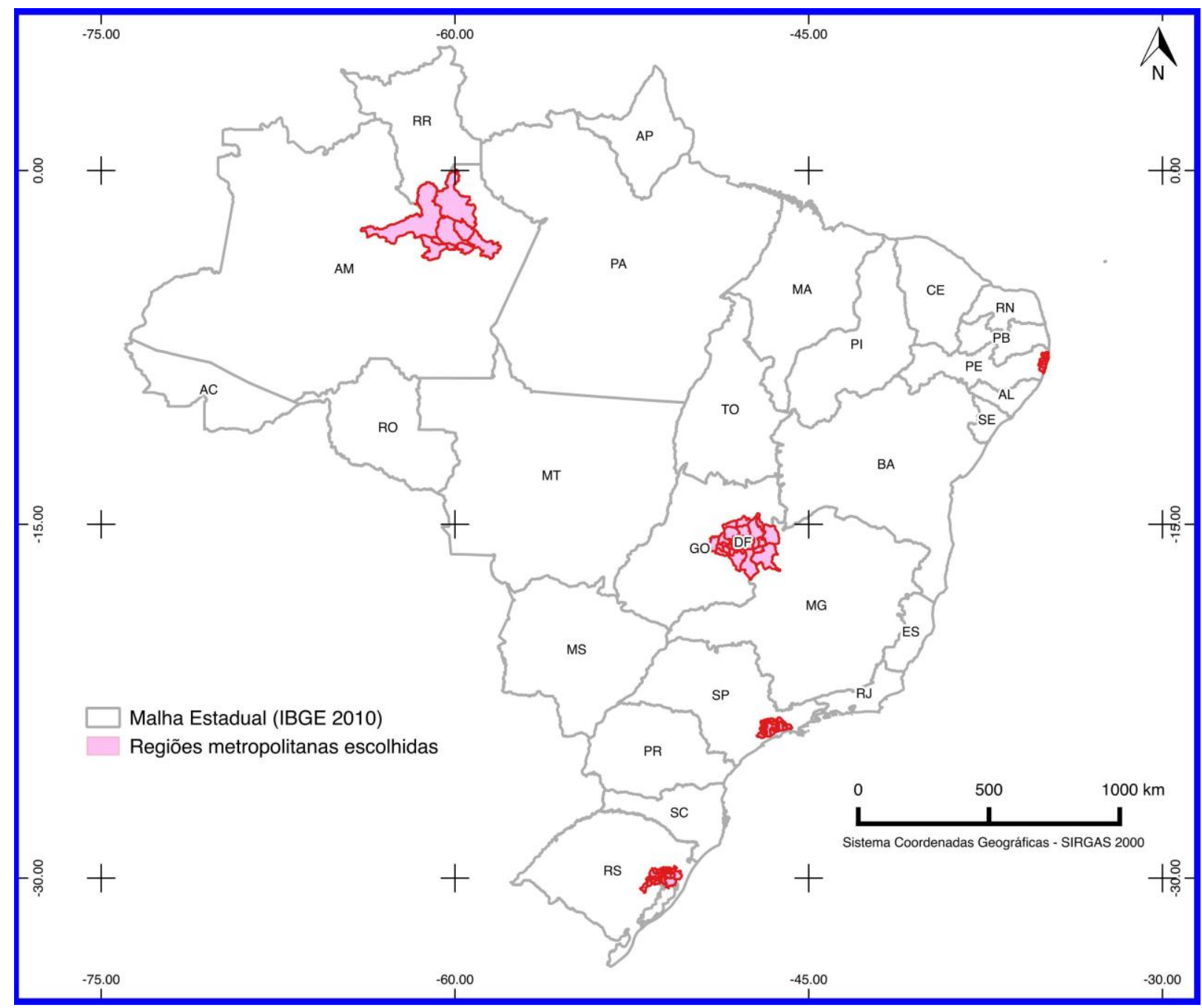

Figura 25 - Localização dos municípios analisados

No total, foram analisadas e mapeadas as áreas urbanas de 114 municípios mais o Distrito Federal que abrangem a área de $11.117,78 \mathrm{~km}^{2}$ e uma população de 31,91 milhões de habitantes, correspondente a $16,65 \%$ do total da população brasileira e 20\% da população urbana (IBGE, 2010). A Tabela 2 mostra a área e a população analisadas de cada RM e RIDE-DF e Entorno. 
Tabela 2 - Descrição da área mapeada e população inserida na área. Ano Base: 2010

\begin{tabular}{lllll}
\hline RM / RIDE & Área $\mathbf{~ k m}^{\mathbf{2}}$ & Pop. (milhões) & \% Área $\mathbf{k m}^{\mathbf{2}}$ & \% Pop. \\
\hline RIDE/DF e entorno & $2.104,47$ & 3,55 & 18,93 & 11,13 \\
RM Manaus & $1.023,97$ & 1,97 & 9,21 & 6,17 \\
RM Porto Alegre & $2.538,75$ & 4,09 & 22,84 & 12,81 \\
RM Recife & 885,54 & 3,38 & 7,97 & 10,59 \\
RM São Paulo & $4.565,05$ & 18,92 & 41,06 & 59,3 \\
\hline Total & $\mathbf{1 1 . 1 1 7 , 7 8}$ & $\mathbf{3 1 , 9 1}$ & $\mathbf{1 0 0}$ & $\mathbf{1 0 0}$ \\
\hline \hline
\end{tabular}

Fonte: Elaborada pelo autor

Ademais, a amostra compreende municípios de todas as faixas de população ${ }^{7}$ segregadas de acordo o censo demográfico (IBGE, 2010). A inclusão de municípios pertencentes a todas as faixas traz à discussão, também, aqueles com menor população (até 50 mil habitantes), os quais representam quase $90 \%$ do total do país, segundo IBGE (2010). São esses pequenos municípios que têm maior potencial de planejar seu crescimento urbano aliado ao desenvolvimento sustentável por meio da inclusão dos espaços verdes como equipamentos urbanos.

\subsection{Região Metropolitana - Histórico}

O conceito de Região Metropolitana (RM) está diretamente associado ao termo metrópole e ao processo de urbanização e metropolização. No caso específico brasileiro, a problemática da urbanização que emergiu anos 1970, se caracterizou pela aceleração do ritmo da urbanização sem correspondência com o crescimento econômico e distribuição de renda (MOURA; LIBARDI; BARION, 2011).

Para Castells (1983) o processo de urbanização na América Latina se caracterizou pela ausência da relação direta entre emprego e crescimento urbano. Esse fato causou grande desequilíbrio na infraestrutura urbana além da carência de empregos e de serviços básicos para as novas populacionais e, consequentemente, reforçando a segregação socioespacial.

Especificamente, o processo de metropolização ocorre a partir da concentração populacional que é consequência direta da alta taxa de urbanização de cidade menores em torno de uma grande cidade. Assim, a metrópole constitui um

\footnotetext{
${ }^{7}$ Faixa de População - IBGE: (a) municípios com população maior do que 200 mil habitantes; (b) municípios com população maior do que 50 mil e menor ou igual a 200 mil habitantes; (c) municípios com população maior do que 20 mil e menor ou igual a 50 mil habitantes; (d) municípios com população menor ou igual a 20 mil habitantes.
} 
núcleo. De forma representativa a Figura 26 mostra a RM de Recife, onde a cidade núcleo está representada pela cor amarela e ao seu redor há várias outras cidades (em rosa), mantendo uma interdependência econômica, além do movimento pendular de sua população (FREITAS, 2012).

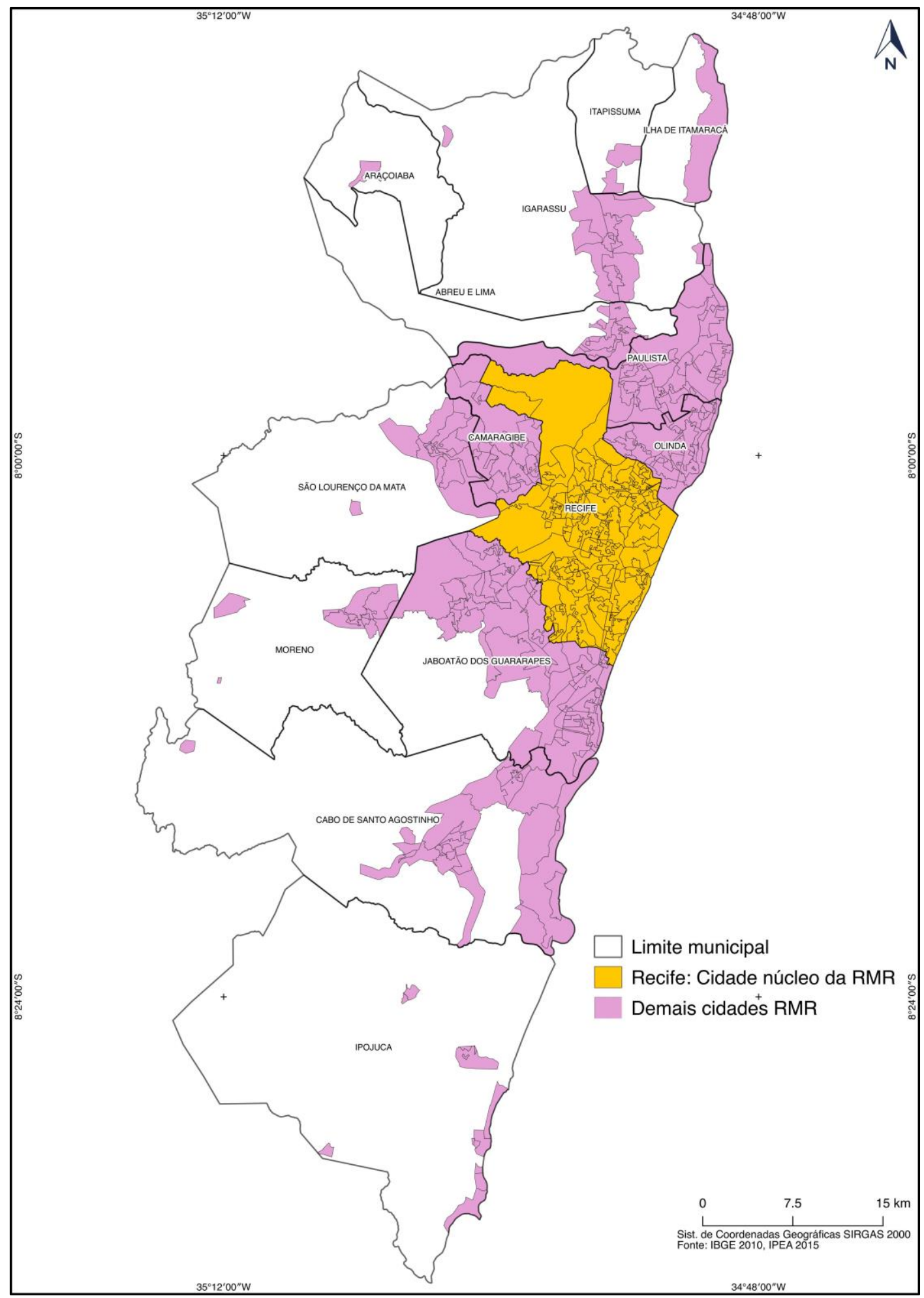

Figura 26 - Região Metropolitana de Recife. Em amarelo a cidade núcleo, Recife. 
Complementar ao processo de metropolização, insere-se o processo de conurbação urbana. Que é a fusão das áreas urbanas de vários municípios limítrofes, formando uma macha urbana única e contínua, ultrapassando os limites políticos de cada município (FREITAS, 2012). A Figura 27 mostra a conurbação urbana da RM de Recife, a qual engloba nove das onze cidades componentes da RM.

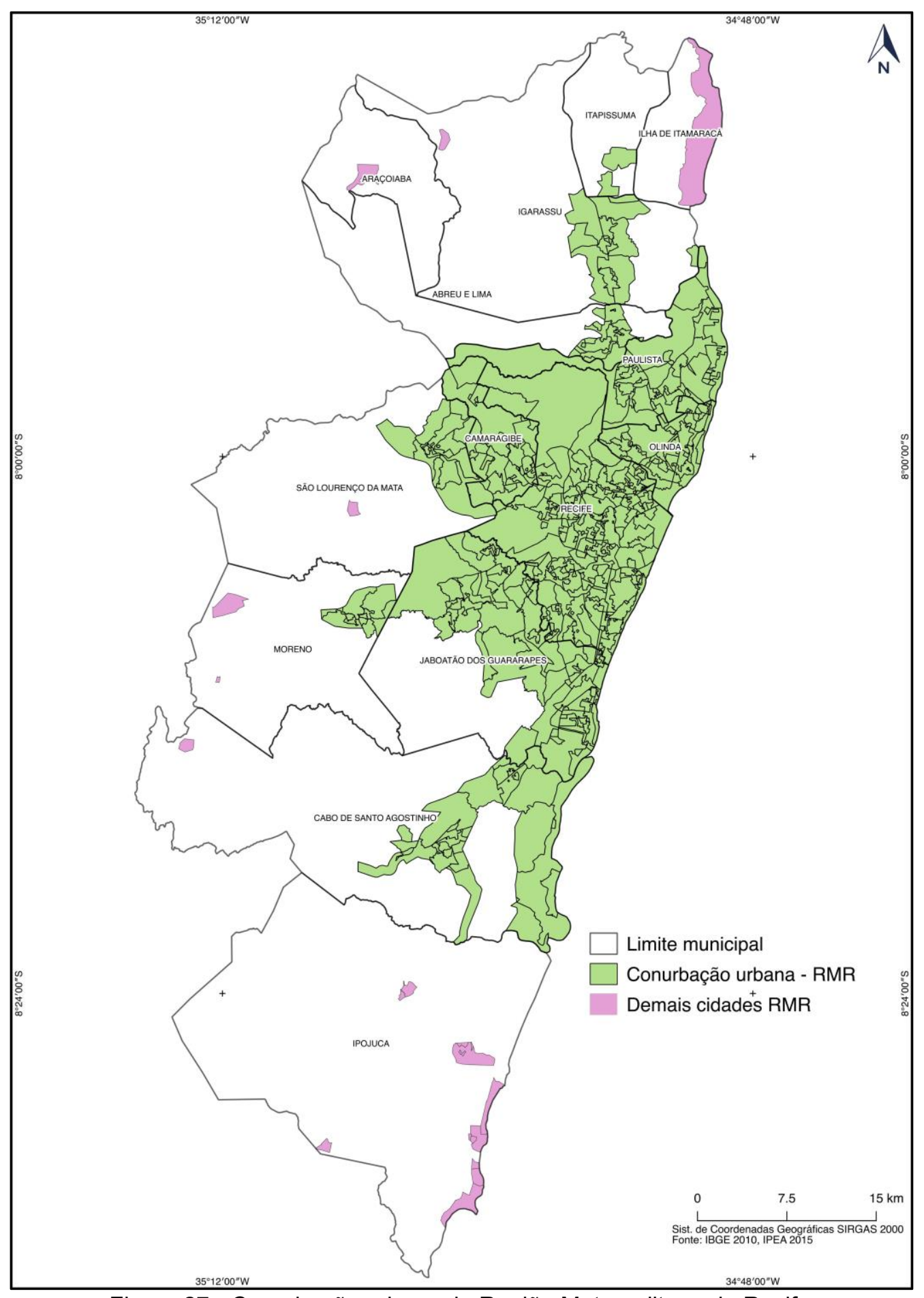

Figura 27 - Conurbação urbana da Região Metropolitana de Recife. 
A combinação dos processos de urbanização, de metropolização e de conurbação deu origem às regiões metropolitanas. Esse fato passou a ser institucionalizado pelo poder público, visando à gestão mais efetiva de serviços que dependem de ações integradas entre os municípios pertencentes de tais regiões (FREITAS, 2012).

A metropolização teve início a partir da Revolução Industrial, na Inglaterra, no século XIX. E foi nesse país que houve a primeira institucionalização de Região Metropolitana, em torno de Londres. Criada em 1888, ela foi denominada de London County Council (ALVES, 2009). Assim, seguiram a ideia do reconhecimento legal desse fenômeno, os gestores de Tóquio, Cidade do México, Buenos Aires, Toronto, Los Angeles, Barcelona. No Brasil, ao longo dos últimos 40 anos foram institucionalizadas mais de 60 RM (FREITAS, 2012).

Rolnik; Somekh (2002) relatam que no Brasil, o processo de institucionalização passou por quatro fases. A primeira trata-se das ações pioneiras de nível estadual, como por exemplo a criação do Grupo Executivo da Grande São Paulo (Gegran) articulada pelo Governo do Estado de São Paulo em 1967. O que inspirou o surgimento de órgãos similares em Porto Alegre, Belém, Salvador e Belo Horizonte, que expressava um reconhecimento, por parte das unidades da federação, de que a gestão metropolitana demandava tratamento administrativo mais integrado entre os municípios, governo estadual e federal.

A segunda fase remete-se aos anos 1970, fruto da política de desenvolvimento urbano do regime militar (1967-1985). As RMs foram institucionalizadas por legislação federal após a Constituição de 1967 da emenda Constitucional $n^{\circ} 1$ de 1969 que deram suporte à regulação por meio da Lei Federal complementar $n^{\circ} 14$ de 1973. Por esse ato foram criadas oficialmente as RMs de São Paulo, Belo Horizonte, Porto Alegre, Recife, Salvador, Curitiba, Belém e Fortaleza (ROLNIK; SOMEKH, 2002).

Souza (2004) argumenta que nesse momento as escolhas institucionais das RMs foram associadas ao autoritarismo e à centralização do regime militar que as instituiu. Dessa forma não foram considerados fundamentos básicos da democracia como a participação e a transparência, tampouco remeteu a importância da gestão compartilhada e o respeito das relações intergovernamentais.

Rolnik; Somekh (2002) narra que na década de 1980 dois fatos marcaram a estrutura das RMs posta pelo regime militar. O primeiro foi a forte crise econômica 
que levou a extinção das estatais e políticas urbanas que geriam as RMs criadas. As entidades metropolitanas foram assim relegadas, no primeiro momento, ou até mesmo extintas. O segundo fato foi processo de democratização que trouxe de volta o anseio democrático e criou novos rumos para a gestão metropolitana.

Assim, a terceira fase de institucionalização teve início com a Constituição Federal de 1988, que instituiu aos estados federados a competência de institucionalização de suas regiões metropolitanas (ROLNIK; SOMEKH, 2002). Contudo, Soares (2013) relata que ao passar a competência aos estados, o processo tornou-se um modo excessivo, sem a demarcação de critérios mínimos para a definição e institucionalização de regiões metropolitanas o que gerou diversas distorções. Assim, a lista de RM é alterada quase que mensalmente e muitos estados são praticamente "estados metropolitanos", como a Paraíba que conta com 12 RM e Santa Catarina que possui 11 RM.

Além das RMs, destaca-se o surgimento das Regiões Integradas de Desenvolvimento (RIDE) que foram oficialmente instituídas nos artigos 21 (inciso IX), 43 e 48 (inciso IV) da Constituição Federal (BRASIL, 1988). A RIDE possui arranjos federativos mais complexos que as RMs por ser formada por municípios pertencentes a mais de uma Unidade da Federação, portanto criada apenas sob legislação federal, que delimita os municípios integrantes e fixa as competências assumidas pelo colegiado da RIDE. São três as RIDEs existentes: Distrito Federal e entorno, Petrolina-Juazeiro e Grande Teresina. Atualmente está em tramitação no congresso federal a criação da RIDE Cariri-Arararipe.

O descompasso entre o processo de institucionalização das RMs e RIDE e a inexistência de uma instância que colocasse em prática a gestão metropolitana deu início à quarta fase, nos anos de 1990 (ROLNIK; SOMEKH, 2002). Para executar a gestão metropolitana iniciou-se um processo de associações supra-municipais, assim como a formação de redes nacionais além da institucionalização de consórcios intermunicipais (MOURA; LIBARDI; BARION, 2011). Para avançar na gestão compartilhada essas novas formações criadas requeriam e requerem, portanto, um arcabouço legal.

Um passo para a gestão compartilhada fluir foi a Política Nacional de Desenvolvimento Regional (PNDR), institucionalizada em 2007 pelo Decreto no 6.047/2007 (BRASIL, 2007). A política trouxe conceitos intrínsecos à gestão regional, como: "complexo geoeconômico", "mesorregião diferenciada" e "consórcio 
público". A política foi um passo para facilitar as ações integradas e políticas públicas orientadas à melhoria do capital social, gestão participativa, mobilização e articulação entre as instituições (públicas e privadas) e a sociedade civil. Porém, por lei a execução da PNDR ficou restrita às seguintes áreas prioritárias: o Semiárido, a Faixa de Fronteira e as RIDEs.

Apesar da importância, a PNDR não atuou na gestão dos problemas urbanos dentro das maiores e maioria das metrópoles no Brasil. Dado o entrave e complexidade da gestão coletiva da maioria das funções públicas de tais metrópoles, foi instituído o Estatuto da Metrópole, pela Lei Federal $n^{\circ} 13.089$ de 2015 afim de criar diretrizes mínimas para a gestão urbana compartilhada nas metrópoles brasileiras (BRASIL, 2015).

Parte essencial do Estatuto da Metrópole é o Plano de Desenvolvimento Urbano Integrado (PDUI). Pela lei ele deverá conter as diretrizes a projetos estratégicos e ações prioritárias de investimentos, macrozoneamento, diretrizes quanto ao uso e ocupação do solo urbano e normas para a articulação das políticas intersetoriais (BRASIL, 2015). Ressalta-se que o PDUI não substitui o Plano Diretor (Estatuto das Cidades), mas complementa-o.

Nota-se que análise das RMs abarca um amplo contexto histórico e político. Para a análise dos espaços verdes urbanos no recorte das quatro RMs e RIDE-DF e Entorno é importante assimilar tais aspectos para o entendimento dos resultados e para o delineamento das possíveis soluções. 


\section{ANÁLISE DOS ESPAÇOS VERDES URBANOS}

Existem inúmeras metodologias de análise dos EVU. Ao propor analisar quatro RMs e a RIDE-DF e Entorno buscou-se métodos automatizados e amparados em estudos pretéritos. Para tanto, utilizou-se dos Sistemas de Informações Geográficas e de análises geoestastítica para analisar os EVU e correlaciona-los com índices socioambientais. A seguir uma breve revisão do métodos mais utilizados para análise dos EVU, os procedimentos básicos adotados e a descrição dos materiais e métodos aplicados na análise.

\subsection{Estado da Arte}

Mesmo que a preocupação mais importante de quem planeja a urbe ainda esteja centrada nas características socioeconômicas (criar alternativas de melhoria nos níveis de saúde, educação, emprego) é importante considerar os espaços verdes no planejamento e ordenamento territorial das cidades. Assim, a importância dos elementos naturais vem sendo estudada e discutida sob critérios estruturais e de funcionalidade (COSTA, 2012).

Critérios estruturais são estudados quanto à localização, à quantidade e distribuição dos espaços verdes por município, ao número de indivíduos arbóreos, à quantidade de parques, à densidade de área verdes por habitantes (DE JESUS, 2005; BARGOS; FONSECA, 2012). O critério funcional relaciona a existência de serviços indispensáveis relacionados com a presença dos espaços verdes. Reiterase aqui que quando apropriadas e são de fato utilizadas, os seus benefícios vão além do ganho ecológico e refletem na qualidade de vida.

A integração desses critérios é essencial para o planejamento e a discussão da importância dos espaços verdes urbanos (ARGAÑARAZ; LORENZ, 2010; SMANIOTTO COSTA, 2008). A estrutura (distribuição, localização, concentração) influi diretamente nas funções - econômica, estética, social e ecológica (OLIVEIRA, 1983). Daí a importância de que a análise dos espaços verdes incorpore aspectos socioambientais e conceitos relacionados à qualidade, à quantidade, à distribuição desses espaços (JESUS, 2005).

Gold (1980) ressalta que a melhor forma de planejar os espaços verdes urbanos é por meio da integração dos critérios estruturais e funcionais. Para o autor, é importante primeiro inventariar, analisar e projetar informações estruturais e assim 
correlacionar tais dados com o perfil socioeconômico das pessoas, tempo de lazer, atividades de recreação - num espaço e numa área geográfica. Essas correlações servem como critérios ou indicadores para avaliar necessidades sociais e prioridades de uma comunidade no uso dos espaços verdes.

A partir desse tipo de planejamento, alguns espaços vêm sendo criados ou manejados à luz de aspirações da melhora de qualidade de vida, por meio da recreação, da preservação da vegetação, da preservação dos recursos hídricos e da própria sociabilidade (LOBODA; DE ANGELIS, 2009). Tais aspirações são decorrência da ascensão de uma percepção ambiental por parte da sociedade que, ao ganhar status, passou a constar nos planos de gestão urbana.

Assim, a importância dos espaços verdes vem sendo materializada em construções e nos investimentos de praças e parques nos centros urbanos (COSTA; COLESANTI, 2011). Porém, há que se considerar de que a disponibilização desses espaços não é feita de forma igualitária à todos cidadãos ou à todos bairros. De forma empírica, observa-se que as periferias possuem menos espaços verdes com infraestrutura de uso, assim como áreas de lazer e descanso como praças e parques.

Dados os benefícios de estabelecer espaços verdes como equipamentos urbanos, principalmente aos mais pobres, faz necessário, além de quantificar, investigar a sua distribuição e uso. Assim, Carlos (1992, p. 24) enfatiza que ao analisar um fenômeno urbano é importante investigar "a forma, a aparência, a manifestação do fenômeno e ao mesmo tempo a representação das relações sociais reais". Assim, o fenômeno urbano pode ser visível, possível de ser apreendido, analisado, logo entendido.

Uma imagem de satélite, ou um mapa dos espaços verdes urbanos dela derivada, auxilia num primeiro instante a quantificar e aferir a distribuição e as suas formas. Para analisá-las como um fenômeno, a tese correlacionou com dados socioeconômicos a cada mancha de espaço verde. Assim, a análise booleana (área que tem e não tem) passou a outro nível, intimamente ligada a uma representação que implica na qualidade dos espaços urbanos com espaços verdes.

Ante o exposto, a quantificação e as análises dos espaços urbanos podem ser realizadas por meio de classificação de imagens de satélite, representados usualmente por mapas de uso da terra. Através dos Sistema de Informações Geográficas (SIG), cada feição de área verde do mapa pode ser quantificada por 
área e analisada no espaço e também ser inter-relacionada com dados socioeconômicos, gerando-se assim indicadores dependentes e independentes da demografia.

Os indicadores mais frequentes, quando se trabalha com espaços verdes urbanos são dependentes da demografia. São calculados em termos da superfície de área verde por habitante (IAV = Índices de Áreas Verdes) ou do percentual do solo ocupado pela arborização (PAV = Percentual de Áreas Verdes) (HENKEOLIVEIRA, 1996). A medida mais difundida em estudos acadêmicos é o IAV, já que ele tem reflexos diretos quanto à qualidade de vida (HENKE-OLIVEIRA, 2001).

A relação dos espaços verdes urbanos com a demografia permite análises e discussões sociais. Por exemplo, quando ocorre elevada densidade populacional, para além das preocupações de saúde, saneamento, educação e mobilidade, há discussões que analisam o bem estar social com a presença ou ausência dos espaços verdes urbanos.

A título de exemplo, os fatores psicológicos, a poluição, a perda de identidade são facilmente relacionados com a ausência desses espaços (ACIOLY; DAVIDSON, 1998). Por outro lado, outros estudos, correlacionam a presença dos espaços verdes com fatores negativos, como: a incidência transmissão da dengue (RODRIGUES et al., 2002) e o aumento de criminalidade conjugado uso de drogas ilícitas em espaços verdes sem infraestrutura (TOLENTINO; DE CASTRO FERREIRA; DINIZ, 2014).

Henke-Oliveira (2001) ressalta que a estimativa da quantidade de espaços verdes per capita permite inferir aspectos de qualidade de vida, mas não necessariamente sobre qualidade ambiental. O IAV pode ser elevado em determinada região, não pela maior abundância de espaços arborizados (maior qualidade ambiental), mas pela baixa densidade populacional. Daí a importância de investigar não apenas o valor absoluto do índice, mas a relação entre os espaços verdes e o número de habitantes, e principalmente a distribuição desses espaços nas cidades.

Outros estudos discutem aquilo que se poderia chamar de "índices mínimos de cobertura vegetal". Cavalheiro e Del Picchia (1992) definem o índice de $12 \mathrm{~m}^{2}$ de espaço verde/habitante como o ideal. De acordo com Macedo (1995) esse valor é o mais difundido, uma vez que teria sido considerado pela ONU (Organização das Nações Unidas) como padrão ideal de áreas de vegetação para as cidades. 
A Sociedade Brasileira de Arborização Urbana (SBAU) propôs $15 \mathrm{~m}^{2} \mathrm{de}$ espaço verde por habitante como o índice mínimo (SBAU, 1996). Outro valor também bastante divulgado no Brasil é o de $40 \mathrm{~m}^{2}$ de espaço verde por habitante, proposto por Medeiros (1975) que seria o mínimo para o planejamento urbano para a recreação. Algumas cidades com índices superiores aos relatados utilizam os seus espaços verdes para a construção de imagens positivas e para a divulgação de slogans como "cidade ecológica" ou "cidade verde" (BOVO; AMORIM, 2011).

Cavalheiro; Nucci (1998) afirmam que não existe um consenso entre os diversos índices mínimos de espaços verdes, porém há de destacar que a maioria das cidades brasileiras encontram-se muito aquém dos valores mínimos destacados. "Na verdade o índice não deve ser encarado como um valor absoluto e isolado em si, mas sim como um ponto de reflexão sobre o planejamento do sistema de espaços livres" (CAVALHEIRO; NUCCI, 1998, p. 297).

É importante ressaltar que analisar apenas para o índice dependente da demografia e associá-lo à qualidade de vida é insuficiente (GUZZO, 2004). Medeiros (1995) alerta que ocorre um uso irrestrito e irresponsável destes índices como referência. $\mathrm{O}$ autor relata que muitos estudos e análises "tem levado a se considerar canteiros centrais de avenidas ou rotatórias como elementos do sistema urbano de áreas verdes colocando no mesmo pé de igualdade de praças e parques" (MEDEIROS, 1975, p. 17).

Desta forma, Macedo (1995) afirma que o índice não informa, necessariamente, o estado em que esses espaços verdes urbanos se encontram, ou como estão sendo utilizados, nem como são distribuídos no espaço urbano. Um escore alto de IAV para uma determinada cidade pode estar relacionado com a presença de vegetação apenas nos bairros ricos ou estar limitada a uma área de proteção ambiental constituída e que não é utilizada pela população.

\subsection{Procedimentos Básicos}

Dada a necessidade de uma discussão que vá além da descrição de índices, Benini (2009) destaca a importância de considerar as características próprias de cada assentamento. Em resumo, as informações obtidas sobre os espaços verdes serão analisadas quantitativamente e correlacionadas qualitativamente com informações socioeconômicas dos setores censitários analisados, baseadas na informações do censo demográfico (IBGE, 2010b). 
Existem inúmeras metodologias de aferição dos espaços verdes urbanos, desde mapeamento de imagens de satélite de altas resoluções espaciais, à contagem e inventariamento de cada indivíduo arbóreo. As diferentes formas de avaliar acarretam em diferentes resultados implicando em diferentes rankings de cidades verde. Por exemplo, ao inventariar de todos os indivíduos arbóreos, produzse um resultado em escala mais detalhada, sendo possível trabalhar com arborização de ruas e avenidas. Para tanto, precisam-se de mais recursos: técnicos, humanos e financeiros.

Ao se propor trabalhar com espaços verdes urbanos, no seu amplo sentido, visando os benefícios ecológico e sociais, áreas pequenas e de arborização urbana não entrarão na análise dessa tese, como: arborização de calçamentos e pequenas vias públicas arborizadas, quintais. Nesta pesquisa, os EVU segue a definição de amplas áreas de vegetação sem ou pouca cobertura do solo e com poucas áreas edificadas. Essa forma garante que esses espaços funcionem como equipamentos urbanos criando possibilidades de usufruto pela população para lazer, esporte e cultura, por exemplo.

Além disso, na presente tese, as imagens de satélite utilizadas possuem limitação técnica de resolução 5 metros, o que impossibilita maior detalhamento na classificação da imagem. Assim, visando maior acurácia, somente áreas maiores do que $625 \mathrm{~m}^{2}$ (área de um polígono de 5 pixels de lado da imagem RapidEye) foram mapeadas e analisadas na pesquisa (Figura 28). 


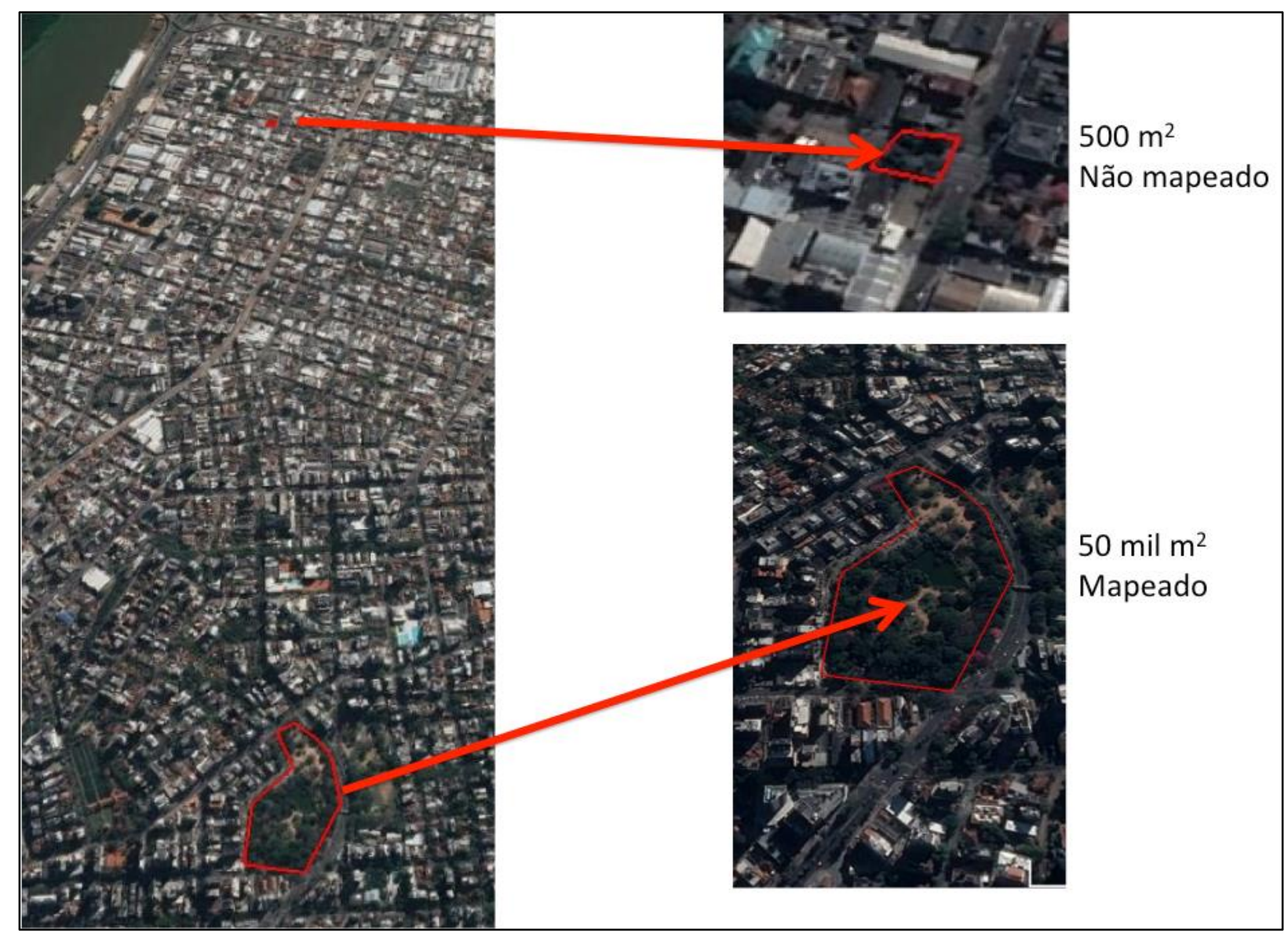

Figura 28 - Exemplo de áreas menores de $625 \mathrm{~m}^{2}$ e maiores. Porto Alegre (RS) Fonte: Google-Earth (2017)

Cabe ressaltar que a análise dos espaço verdes urbanos por meio de imagem de satélite foi realizada em gabinete e não houve conferências ou testes de acurácia à campo, uma vez que o recorte espacial da tese que abrange áreas urbanas de 114 municípios mais o Distrito Federal, com extensão territorial total superior a 11 mil km². Assim, considerando a impossibilidade de verificação das áreas mapeadas em campo, a pesquisa utilizou também dados oficiais de delimitação de unidades de conservação da natureza - UC (inclui parques nacionais, áreas de proteção ambiental, reserva biológica). O objetivo foi propiciar análise com maior precisão quanto às formas de utilização, proteção, importância dos espaços verdes urbanos (Figura 29). 


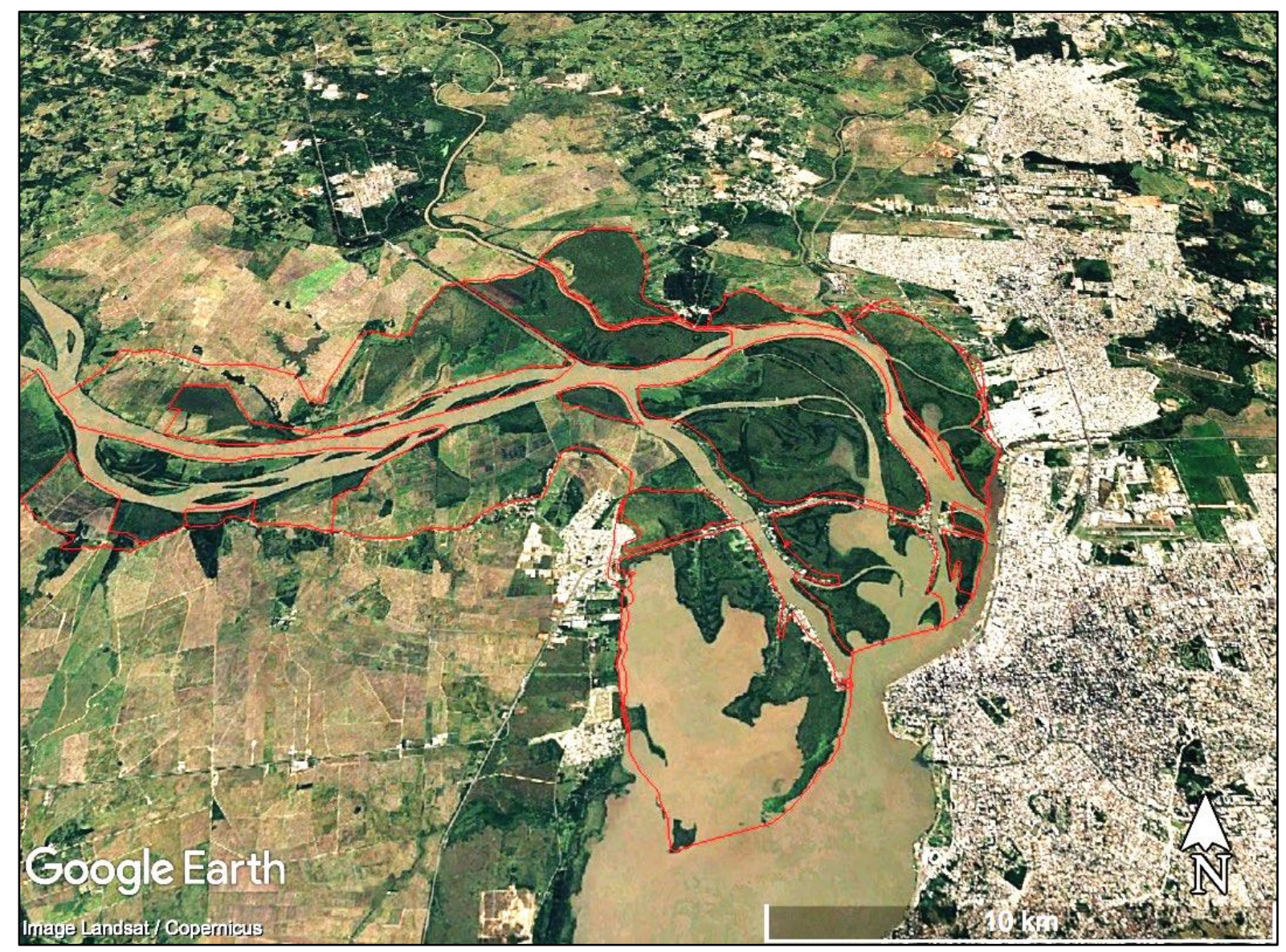

Figura 29 - Exemplo de área protegida dentro da área urbana analisada

Parque Estadual Delta do Jacuí. Porto Alegre (RS). Em vermelho a delimitação oficial (SNUC, 2010). Fonte: Google-Earth (2007)

Por fim ressalta-se que os espaços verdes urbanos mapeados não foram analisadas de acordo com a forma de uso (parque, praça, área de preservação, sem uso). Portanto, os espaços verdes urbanos foram tratadas como cobertura vegetal (ou predominantemente) no espaço de $625 \mathrm{~m}^{2}$, assim foram analisadas quantitativamente e correlacionadas com dados socioambientais para a análise da hipótese. A análise restrita dos espaços verdes que funcionam como equipamentos urbanos não entrou na análise, embora fossem discutidas. 


\subsection{Material e Métodos}

\subsubsection{Softwares}

Para integrar os resultados obtidos do levantamento da cobertura vegetal e assim estabelecer análises relacionadas aos espaços verdes urbanos fez uso de Sistemas de Informações Geográficas (SIG). Para espacialização e análise das informações georreferenciadas: setores censitários, informações socioeconômicas e espaços verdes, utilizou-se os seguintes softwares: IDRISI Taiga (classificação dos espaços verdes a partir de imagens de satélite), QUANTUM GIS - QGIS (geoprocessamento: edição dos arquivos de EVU, cruzamento com dados socioeconômicos e produção de mapas) e GeoDa (análises geoespaciais: correlação com dados socioeconômicos).

\subsubsection{Imagem de Satélite: RapidEye}

Foram utilizadas as imagens do satélite RapidEye, cedidas pelo MMA e adquiridas pelo Governo Federal para a execução do programa de Cadastramento Ambiental Rural (CAR) junto ao INCRA. As imagens estão disponíveis no Geocatálago (http://geocatalogo.mma.gov.br - plataforma digital gerida pelo MMA) e têm acesso controlado. As imagens são disponibilizadas após pedido (via e-mail) a todos órgão públicos (federais, estaduais, municipais, distritais e universidades públicas). O pedido é viabilizado com o cadastramento da instituição e descrição do motivo de uso da imagem.

As imagens utilizadas foram geradas no ano de 2011 (diferentes meses) para todo o território nacional. As imagens são ortorretificadas (procedimento de remoção de distorções provenientes de erros de coordenadas, geometria da imagem e efeito do relevo), georreferenciadas e com resolução espacial de 5 metros (tamanho do lado de cada pixels) (SANTIAGO; CINTRA, 2013).

As imagens do RapidEye possuem cinco bandas espectrais com a mesma resolução espacial, sem a necessidade de fusionamento de bandas, o que na prática implica na integridade das características espectrais na e redução no tempo de processamento da imagem. Além da resolução de 5 metros, o satélite RapidEye se diferencia dos demais por estar equipado como uma banda-extra denominada de RedEdge que é especifica para o monitoramento de atividade 
fotossintética da vegetação. Essa banda facilita a discriminação dos vários tipos de vegetação (variações de porte de arbóreas, tipos de herbáceas e arbustiva) seja na obtenção de índices ou mapas que remetam ao comportamento espectral da vegetação.

Embora seja uma boa imagem para a classificação da vegetação, constatou-se que para ambientes urbanos a discriminação fica comprometida dada a maior mistura espectral, normal de ambientes urbanos. Como relataram Foresti; Pereira (1986), o ambiente urbano é de difícil classificação, uma vez que é composto de vários materiais, incluindo os vários tipos de vegetação, construções e cobertura de prédios de vários materiais, assim a pavimentação asfáltica. A composição química e a estrutura física desses materiais fazem com que cada um possua respostas espectrais diferentes.

Ressalta-se ainda, que a resposta espectral da vegetação é altamente influenciada pelas variações climáticas, pela poluição atmosférica e pela deficiência de água em períodos prolongados de estiagem. Desta feita, após vários testes, constatou-se que apenas manchas maiores de $625 \mathrm{~m}^{2}$ (área de 5 pixels) teria maior confiabilidade e acurácia de ser definida como vegetação, ora denominada de espaços verdes urbanos.

Afora a mistura espectral notou-se outro grande problema na classificação das imagens de áreas urbanas: a forte presença de nuvens e sombras principalmente nas cidade litorâneas e amazônicas. O problema foi contornado com a edição e reclassificação de cada polígono de sombra e/ou nuvem com apoio imagens disponíveis no Google-Earth do mesmo ano base: 2011.

\subsubsection{Setores Censitários: Delimitação Espacial}

Afora as imagens de satélite, a principal base de dados utilizada foi a dos setores censitários referente ao último censo demográfico (IBGE, 2010). Essa base de dados é fornecida no site do IBGE (http://mapas.ibge.gov.br/bases-ereferenciais/bases-cartograficas.html) e está segregada por UF. Esses dados são do tipo vetorial, disponíveis no formato: .shapefile. São dados digitalizados que possuem a delimitação espacial georreferenciada, além dos dados alfanuméricos (tabela de atributos) referentes as informações básicas de cada setor censitário: Código do setor, Código e nome do município do município, Tipo, etc. (Figura 30). 


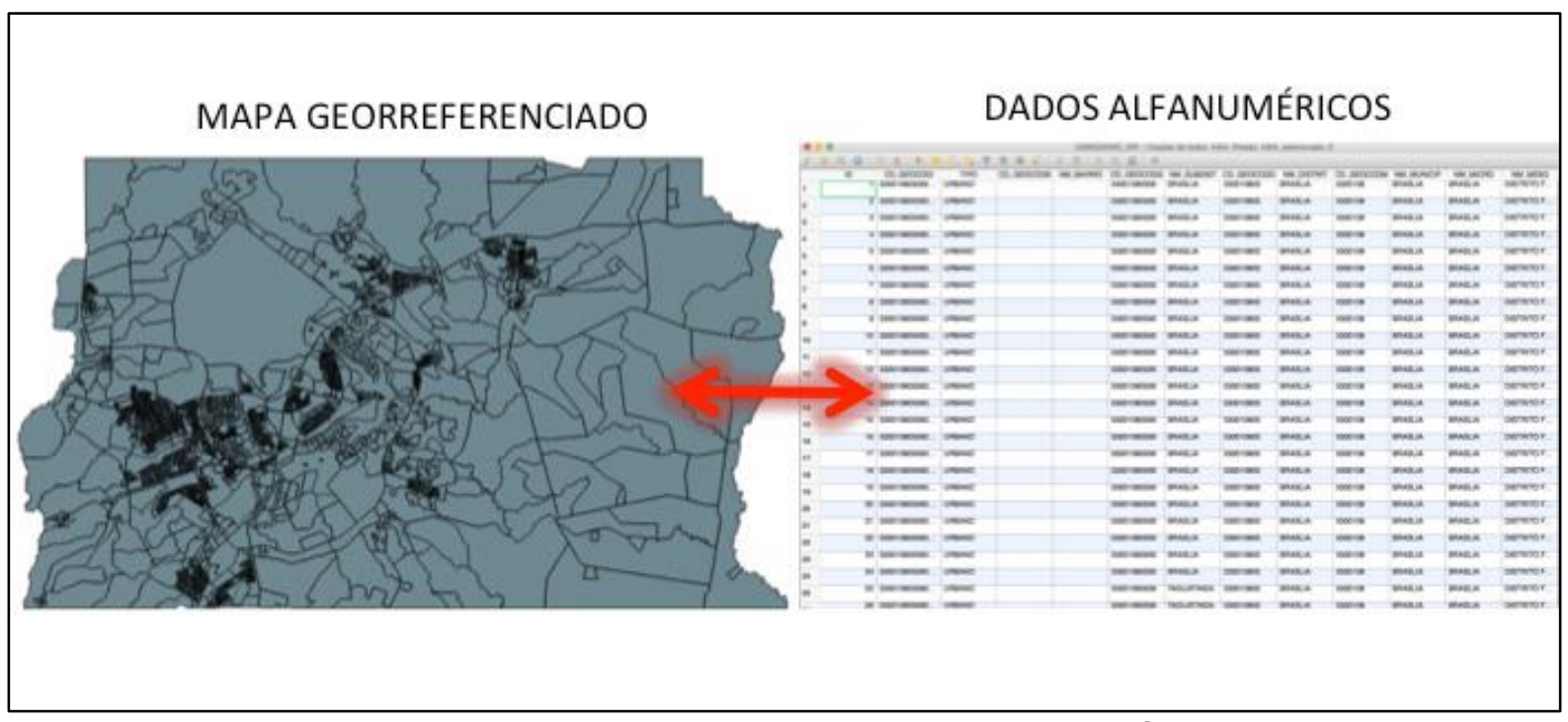

Figura 30 - Integração dos dados espacializados e dados alfanuméricos

Além dos dados do setores censitários em formato vetorial, também foram obtidas no site do IBGE as planilhas dos dados "agregados por setor censitário". As planilhas dos dados agregados contém mais de 1200 variáveis quantificadas a partir censo demográfico por UF, sobre a população brasileira. Dessas planilhas foram utilizados os dados de população por setor e código da situação ${ }^{9}$ dos setores censitários.

Após realizar o download dos referidos dados, realizou-se uma filtragem no software QGIS para excluir as cidades que não seriam analisadas. Após esse procedimento, foi incluído a partir da função "join" do software QGIS os dois campos (colunas) dos dados agregados (população por setor censitário e situação do setor).

Os setores censitários classificados como rural também foram filtrados e removidos do conjunto, restando assim os setores censitários do tipo: urbano. $\mathrm{Na}$ primeira análise visual, constatou-se alguns buracos em meio às áreas urbanas como parques e espaços verdes (Figura 31).

\footnotetext{
8 Os agregados por setores censitários são gerados a partir dos microdados do universo do Censo Demográfico 2010 e são formados por 21 planilhas nos formatos: exl ou csv. Elas estão separadas em pastas de cada Unidade da Federação, contendo mais de 1.200 variáveis.

${ }^{9}$ Os setores censitários apresentam códigos de situação que remetem à subdivisão do tipo do setor (rural e urbano). O tipo urbano é segregado pelos códigos 1, 2 e 3 que indicam: 1) - Área urbanizada de cidade ou vila; 2) - Área não urbanizada de cidade ou vila; 3 - Área urbana isolada
} 


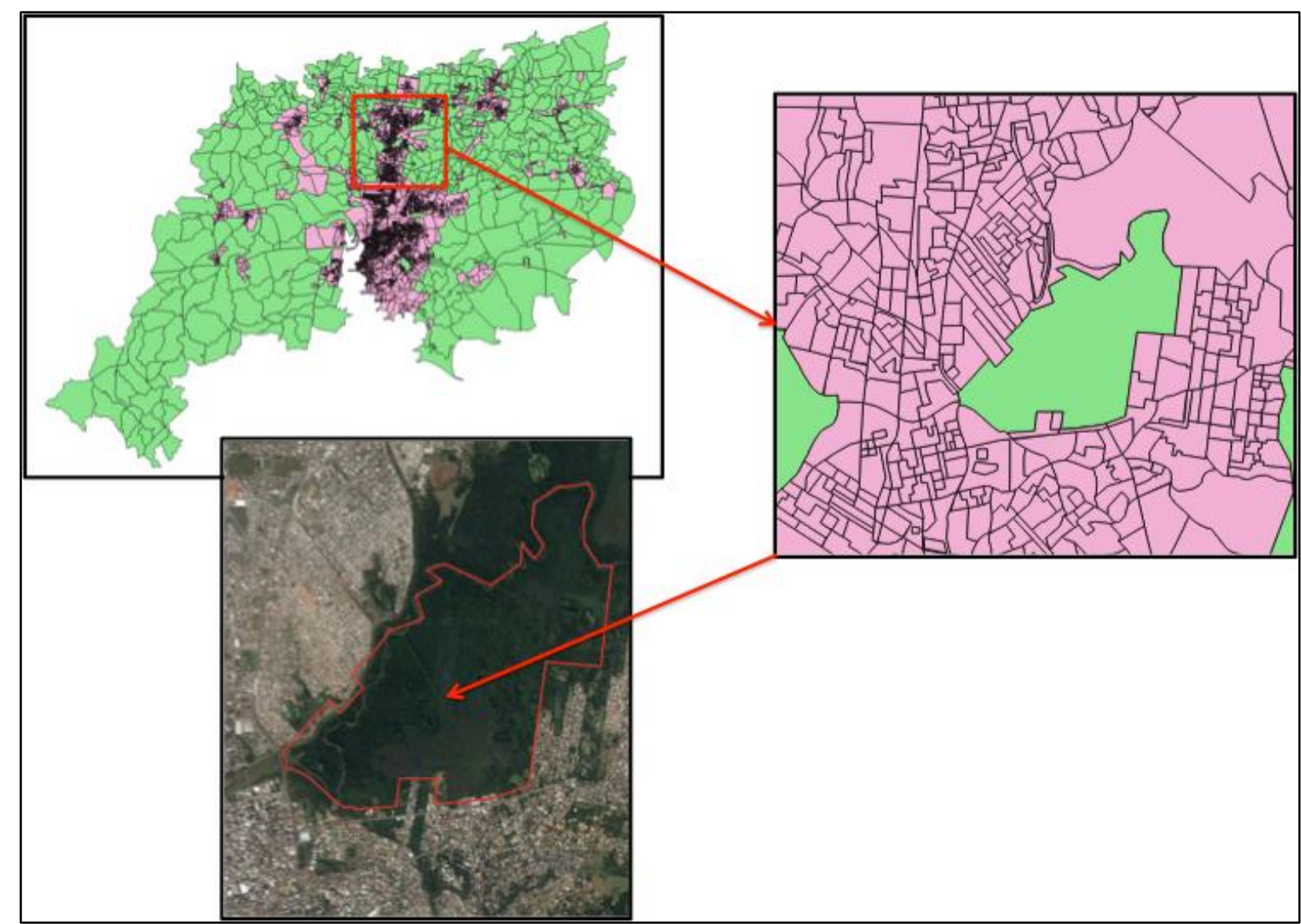

Figura 31 - Setores censitários rurais dentro da área urbana

Numa análise detalhada desses "buracos", verificou-se que todos correspondiam a setores classificados pelo IBGE como tipo rural, imersos na malha urbana. Alguns não apresentaram o código da situação do setor, estes mesmos não apresentavam população residente, como mostra a figura a seguir (Figura 32). 


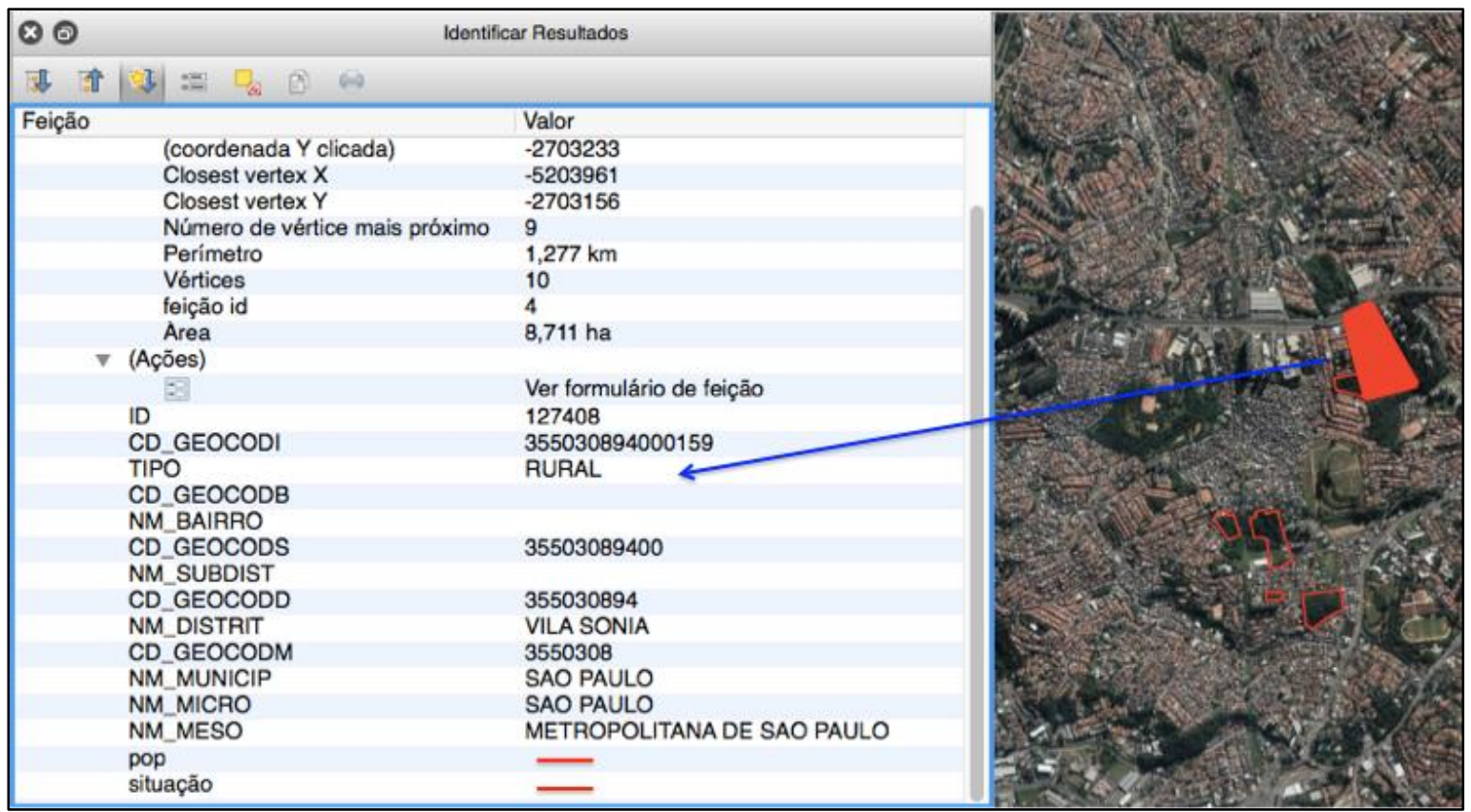

Figura 32 - Metadados dos setores censitários rurais junto à malha urbana

Diante desse problema, optou-se por incluir esses "buracos" na análise uma vez que sua ausência comprometeria a análise final. Os vazios adicionados correspondem a espaços verdes, de tamanho significativo: 170,07 km², imersas na área urbana visivelmente consolidada.

A Figura 33 sintetiza os principais procedimentos, ora relatados, para a delimitação final das áreas de análise, tomando como exemplo a RM de Porto Alegre. 


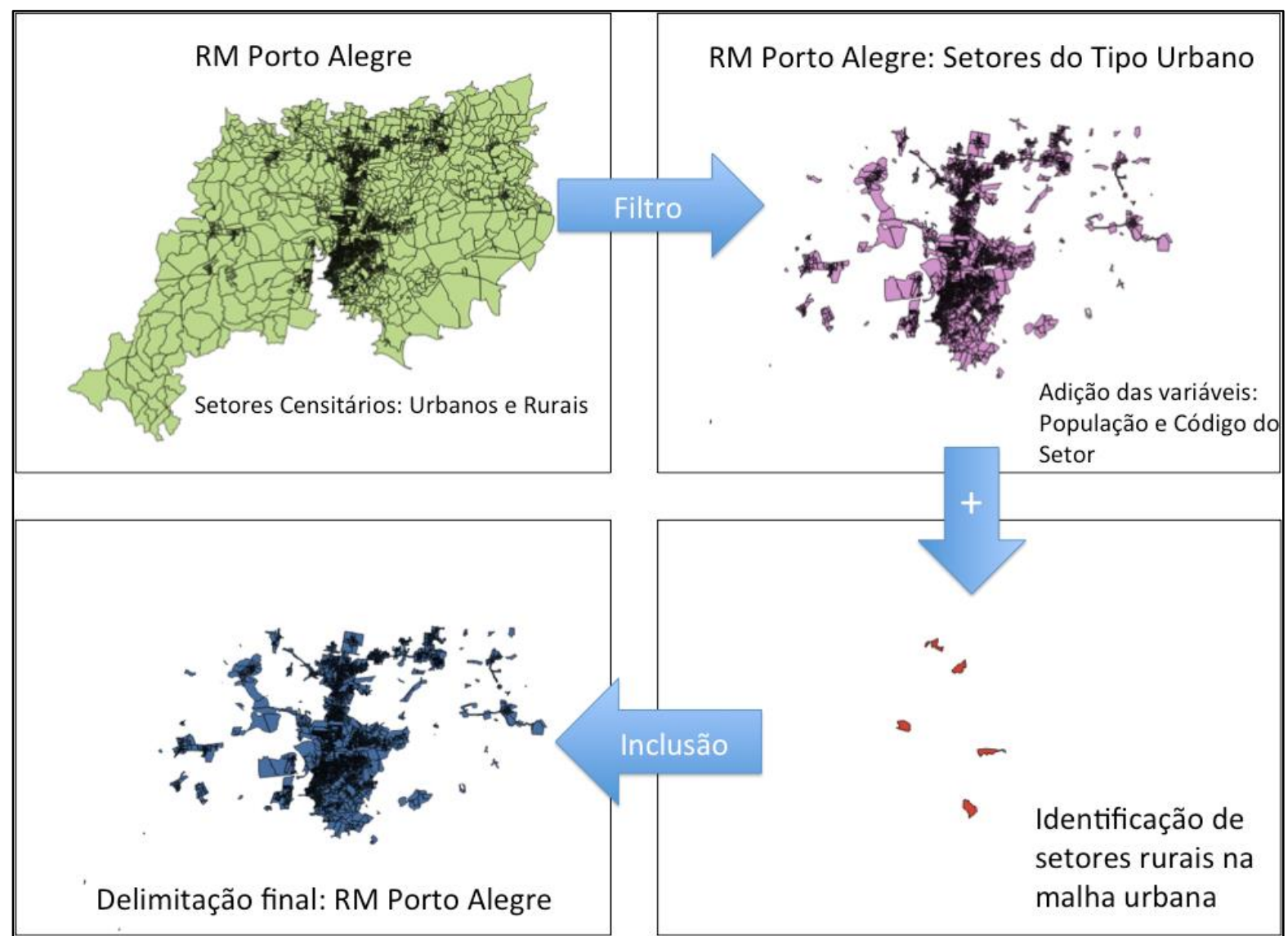

Figura 33 - Inclusão dos setores rurais presentes no interior da malha urbana

Coloca-se aqui em discussão que o IBGE, responsável pela principal base de dados socioeconômicos e demográficos, classifica alguns setores do tipo urbano como rural, seja pela ausência da população, seja por presença predominante dos espaços verdes. Isso serve de um alerta ao IBGE e a todo e qualquer usuário de sua base de dados, principalmente ao ser utilizada para estudos de cunho interdisciplinar e de interesses diversos que não sejam meramente demográficos.

\subsubsection{Dados socioeconômicos: Índice de Vulnerabilidade Social (IVS)}

Os dados socioeconômicos utilizados na tese são derivados dos dados agregados do setores censitários do IBGE, considerada a principal base de dados demográficos do Brasil. A partir das diversas variáveis socioeconômicas disponíveis na base de dados do censo, o Instituto de Pesquisa Econômica e Aplicada (IPEA) vem trabalhando nos últimos anos na elaboração de índices que remetam e sintetizem a realidade social do Brasil (IPEA, 2015).

O mais recente e importante índice elaborado pelo IPEA e instituições parceiras, a partir da base de dados do IBGE, é o Indicador de Vulnerabilidade Social (IVS). Ao tratar de Vulnerabilidade Social, o índice coloca em pauta um 
conceito cada vez mais útil em se tratando de políticas públicas (IPEA, 2015). A definição de vulnerabilidade social que o IVS se fundamenta diz respeito ao acesso, à ausência ou à insuficiência dos ativos.

O IVS constitui-se num instrumento de identificação das falhas de oferta de bens e serviços públicos no território nacional. Nesta medida, este índice foi pensado para dialogar com o desenho das políticas sociais brasileiras, uma vez que atesta a ausência ou insuficiência de "ativos" que, pela própria Constituição Federal de 1988 (CF/1988), deveriam ser providos aos cidadãos pelo Estado, nas suas diversas instâncias administrativas (IPEA, 2015, p. 8).

\section{Os dados relacionados ao IVS estão descritos no Quadro 2.}

\begin{tabular}{|c|c|c|}
\hline Subíndices & Variável - dados agregados IBGE & Peso (\%) \\
\hline \multirow{3}{*}{$\begin{array}{l}\text { Infraestrutura } \\
\text { Urbana }\end{array}$} & $\begin{array}{l}\text { 1) Percentual da população que vive em domicílios urbanos sem o } \\
\text { serviço de coleta de lixo }(0-100 \%)\end{array}$ & 30 \\
\hline & $\begin{array}{l}\text { 2) Percentual de pessoas em domicílios com abastecimento de água } \\
\text { e esgotamento sanitário inadequados }(0-100 \%) \text {; }\end{array}$ & 30 \\
\hline & $\begin{array}{l}\text { 3) Percentual de pessoas em domicílios vulneráveis à pobreza e que } \\
\text { gastam mais de uma hora até o trabalho no total de pessoas } \\
\text { ocupadas, vulneráveis e que retornam diariamente do trabalho (0- } \\
100 \%) \text {. }\end{array}$ & 40 \\
\hline \multirow{8}{*}{$\begin{array}{l}\text { Capital } \\
\text { Humano }\end{array}$} & 1) Mortalidade até um ano de idade & 12,5 \\
\hline & 2) Percentual de crianças de 0 a 5 anos que não frequenta a escola & 12,5 \\
\hline & $\begin{array}{l}\text { 3) Percentual de crianças de } 6 \text { a } 14 \text { anos que não frequenta a escola } \\
(0-100 \%)\end{array}$ & 12,5 \\
\hline & $\begin{array}{l}\text { 4) Percentual de mulheres de } 10 \text { a } 17 \text { anos de idade que tiveram } \\
\text { filhos }(0-100 \%)\end{array}$ & 12,5 \\
\hline & $\begin{array}{l}\text { 5) Percentual de mães chefes de família, sem fundamental completo } \\
\text { e com pelo menos um filho menor de } 15 \text { anos de idade, no total de } \\
\text { mães chefes de família }(0-100 \%)\end{array}$ & 12,5 \\
\hline & $\begin{array}{l}\text { 6) Taxa de analfabetismo da população de } 15 \text { anos ou mais de idade } \\
(0-100 \%)\end{array}$ & 12,5 \\
\hline & $\begin{array}{l}\text { 7) Percentual de crianças que vivem em domicílios em que nenhum } \\
\text { dos moradores tem o ensino fundamental completo }(0-100 \%)\end{array}$ & 12,5 \\
\hline & $\begin{array}{l}\text { 8) Percentual de pessoas de } 15 \text { a } 24 \text { anos que não estudam, não } \\
\text { trabalham e são vulneráveis à pobreza, na população total dessa } \\
\text { faixa etária (0-100\%) }\end{array}$ & 12,5 \\
\hline \multirow{5}{*}{$\begin{array}{l}\text { Renda e } \\
\text { Trabalho }\end{array}$} & $\begin{array}{l}\text { 1) Proporção de vulneráveis à pobreza (pessoas com renda } \\
\text { domiciliar per capita igual ou inferior a meio salário mínimo) }(0-100 \%)\end{array}$ & 20 \\
\hline & $\begin{array}{l}\text { 2) Taxa de desocupação da população de } 18 \text { anos ou mais de idade } \\
(0-100 \%)\end{array}$ & 20 \\
\hline & $\begin{array}{l}\text { 3) Percentual de pessoas de } 18 \text { anos ou mais sem fundamental } \\
\text { completo e em ocupação informal }(0-100 \%)\end{array}$ & 20 \\
\hline & $\begin{array}{l}\text { 4) Percentual de pessoas em domicílios vulneráveis à pobreza e } \\
\text { dependentes de idosos }(0-100 \%)\end{array}$ & 20 \\
\hline & $\begin{array}{l}\text { 5) Taxa de atividade das pessoas de } 10 \text { a } 14 \text { anos de idade (0- } \\
100 \% \text { ) }\end{array}$ & 20 \\
\hline
\end{tabular}

Quadro 2 - Síntese da formulação do IVS (IPEA, 2015) 
O IVS é, portanto, um instrumento construído a partir de dados socioeconômicos do IBGE que possibilita analisar e compreender as desigualdades socioespaciais. O grande diferencial desse índice é a sua disponibilização na escala intramunicipal, diferentemente de outros importantes como o IDHM (Índice de Desenvolvimento Humano Municipal) que retrata apenas a escala municipal. Por outro lado, não é tão restrito quanto os setores censitários do IBGE que representam a área onde um recenseador realiza o seu levantamento de dados.

A escala de aplicação do IVS reúne conjunto de setores censitários de mesmas características socioeconômicas (Figura 34), denominados de Unidades de Desenvolvimento Humano - UDH ${ }^{10}$. Essa unidade amostral viabiliza a discussão e análise de desigualdades socioespaciais e seus efeitos sobretudo na realidade intramunicipal e principalmente nos aglomerados urbanos como as RMs e RIDE.

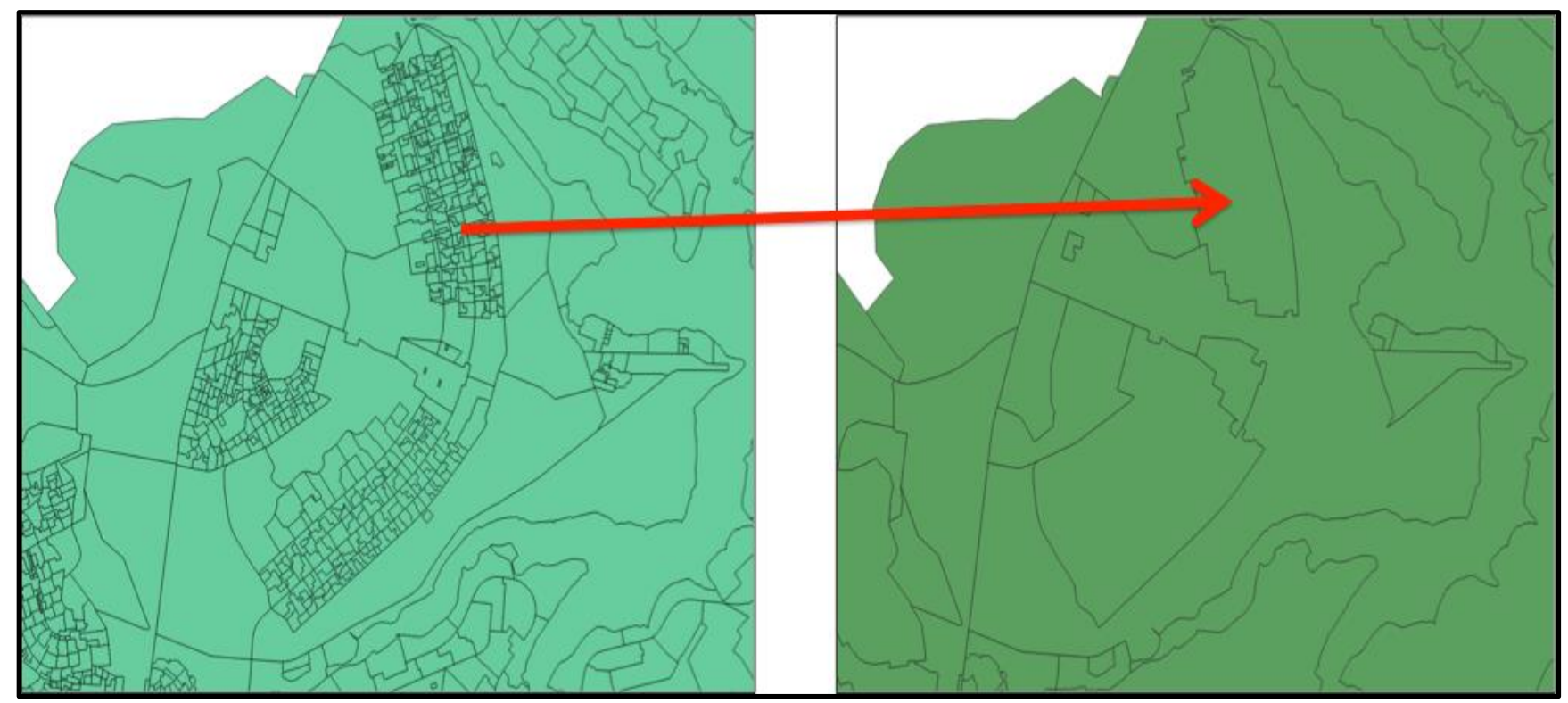

Figura 34 - Exemplo da ponderação das UDHs. Vários setores censitários da Asa Norte formam uma UDH

10 As UDHs foram delineadas buscando gerar áreas mais homogêneas, do ponto de vista das condições socioeconômicas. Embora já existam as "áreas de ponderação", estabelecidas pelo IBGE, ressalta-se que essas focam a melhor forma de obtenção e otimização de áreas a coleta de dados do censo demográfico. As UDHs são construídas com o objetivo de melhor captar a diversidade de situações relacionadas com o desenvolvimento humano que ocorre no interior dos espaços intrametropolitanos, notadamente em seus grandes municípios, para desvendar o que é escondido pelas médias municipais agregadas (IPEA, 2012). 
Em resumo, o IVS agrupa a cada unidade amostral (UDH) três subíndices: infraestrutura urbana, capital humano e renda e trabalho em dezesseis variáveis obtidas no censo demográfico do IBGE. O Quadro 2 descreveu os subíndices, assim como o peso atribuído para a formulação do IVS que é o resultado da média aritmética dos subíndices estabelecidos com o mesmo peso. O IVS foi normatizado entre 0 e 1, quanto mais próximo a 1, maior é a vulnerabilidade social (Figura 35).

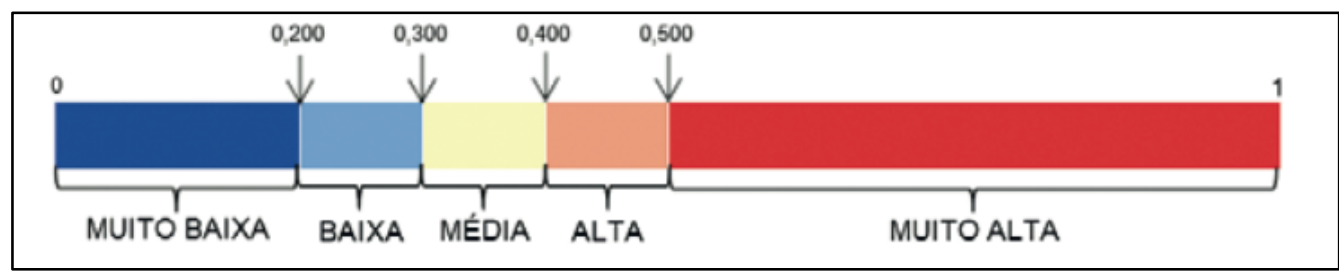

Figura 35 - Categorização oficial do Índice de Vulnerabilidade Social (IPEA, 2015)

O IVS encontra-se disponível no recorte das Unidades de Desenvolvimento Humano (UDH) para as principais RM do país (incluindo a RIDE-DF e Entorno). Para os demais municípios o IVS encontra-se apenas na escala municipal. O IPEA disponibiliza o IVS por UDH e municípios em formato exl (excel) e também no formato (.shapefile) no site: http://ivs.ipea.gov.br/index.php/pt/mapa.

Após realizar o download dos arquivos espacializados do IVS para o conjunto das UDHs das RMs e RIDE analisadas, os mesmos foram recortados no limite externo dos setores censitários analisados. Por fim, foi acrescentado nesse arquivo o campo "população por UDH" e "código da situação por UDH". O campo foi preenchido a partir da base de dados dos setores censitários através da função "join" (QGIS), gerando assim o arquivo final para a análise socioeconômica. A Figura 36 exemplifica tais operações. 


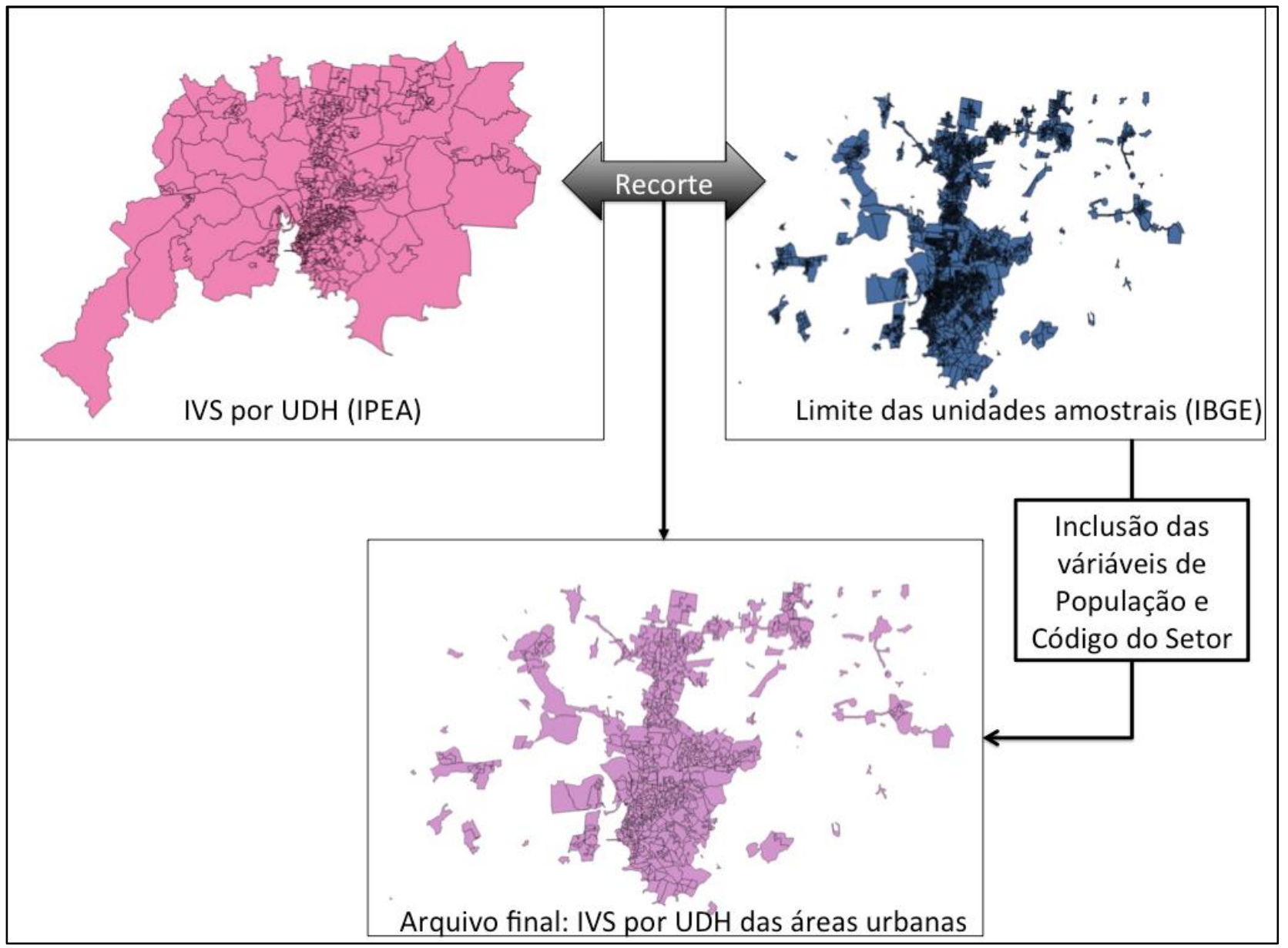

Figura 36 - Geração do arquivo base para a análise socioeconômica. Dados para Região Metropolitana de Porto Alegre.

Apesar do arquivo oficial do IVS (IPEA, 2015) ser uma derivação dos setores censitários, relata-se que esse não possui os dados alfanuméricos dos dados do IBGE. Dai a necessidade das referidas operações mostradas na Figura 36.

\subsubsection{Mapeamento dos Espaços Verdes Urbanos}

O método utilizado para mapeamento dos espaços verdes na tese foi adaptado ao método utilizado no projeto: "Mapeamento da Cobertura Vegetal e Corpos D`Água em cidades Brasileiras - MMA/UnB” (MMA, 2012). A seguir a descrição do método de mapeamento dos EVU.

Primeiramente, ressalta-se que existem vários métodos para mapear a vegetação a partir de imagens de satélites. A maioria utiliza o NDVI (Normalized Difference Vegetation Index) que analisa e indica a condição da vegetação natural ou agrícola nas imagens geradas por sensores remotos. Esse índice é 
bastante útil para medir a intensidade de atividade clorofiliana, inclusive comparando vários períodos distintos gerando mapas ou índices.

Geralmente, os softwares de sensoriamento remoto apresentam plugins específicos que calculam o NDVI e geram mapas classificados conforme o grau da atividade clorofiliana. Quanto mais vermelho, maior o grau da atividade clorofiliana, sendo assim possível associar o índice de NDVI às coberturas agrícolas ou naturais.

Para mapear os EVU nas cinco regiões do Brasil, optou-se por um método menos específico, uma vez que o NDVI poderia excluir várias áreas com pouca cobertura vegetal ou mesmo com vegetação, como por exemplo os espaços verdes na região centro-oeste em períodos de seca. Assim, foi realizada a classificação e análise de todas as respostas espectrais da imagem de satélite, no caso RapidEye.

A classificação de todas as respostas espectrais pode ser realizada de forma automática, no geral o software realiza a tarefa de analisar atributos numéricos de um pixel de cada banda de imagem, após entrada de parâmetros e metodologias desejáveis. A classificação automática é mais precisa por utilizar dados matemáticos e tratar cada pixel isoladamente, podendo também utilizar mais que três bandas para realizar a classificação, no presente estudo pôde-se utilizar todas as cinco bandas de imagem RapidEye fornecidas.

A classificação automática pode ser supervisionada e não-supervisionada (INPE, 2003). A classificação não-supervisionada de imagens pode ser definida como um processo automático de criação de grupos naturais dentro de um intervalo de dados espectrais, sem a utilização de informação prévia sobre as características desses grupos (MARQUES; ARANHA, 2000).

A classificação não supervisionada realizada de forma automática é a forma que tornou possível a execução de todo o mapeamento proposto no escopo da tese. Isso porque a área a ser mapeada é superior a $11 \mathrm{mil} \mathrm{Km}^{2}$, o que inviabilizaria o procedimento de classificação não automático.

O método de classificação não-supervisionada utilizado nessa tese foi executado através de análise de cluster, para as 5 bandas espectrais da imagem RapidEye, no software IDRISI-Taiga. O algoritmo implementado nesse software 
é baseado no proposto por Richards (1986). O tipo de classificação cluster foi o Broad: isto equivale a buscar os picos em um histograma unidimensional, no qual o pico é definido como um valor de frequência maior que a de seus vizinhos de cada lado. Uma vez identificados os picos, todos os valores observados são associados ao pico mais próximo e as divisões entre as classes tendem a cair no ponto médio entre os picos (EASTMAN, 2006). Quanto ao nível de saturação, utilizou a grandeza de $1 \%$. Por fim, foi definido o número máximo de 12 clusters (classes) para o classificador automático gerar.

Após gerar mapas com 12 clusters (12 classes), as mesmas pré-definidas no "Projeto MMA-UnB", os mesmos foram comparados no software QGIS à imagem verdade (RapidEye) de modo a realizar a reclassificação e agrupamento seguindo princípios de fotointerpretação. As doze classes possíveis para rotular (Quadro 3) abrangem o máximo de estratos possíveis a serem identificados em todos os tipos de ambientes urbanos. Como o alvo da tese era apenas os espaços verdes urbanos, utilizou-se apenas os itens $6,7,8$ da tabela a seguir, sendo as mesmas classificadas como EVU.

\begin{tabular}{|l|l|l|}
\hline Código & \multicolumn{1}{|c|}{$\begin{array}{c}\text { Classes definidas no } \\
\text { Projeto MMA-UnB }\end{array}$} & \multicolumn{1}{c|}{ Tese } \\
\hline 1 & Água & sem classificação \\
\hline 2 & Área úmida & sem classificação \\
\hline 3 & Área urbanizada & sem classificação \\
\hline 4 & Areia / Duna & sem classificação \\
\hline 5 & Solo exposto & sem classificação \\
\hline $\mathbf{6}$ & Vegetação herbácea & Espaço verde urbano \\
\hline $\mathbf{7}$ & Vegetação arbórea & Espaço verde urbano \\
\hline $\mathbf{8}$ & Vegetação arbustiva & Espaço verde urbano \\
\hline 9 & Áreas livres de edificações & sem classificação \\
\hline 10 & Nuvem & sem classificação \\
\hline 11 & Sombra & sem classificação \\
\hline 0 & Indefinido & sem classificação \\
\hline
\end{tabular}

Quadro 3 - Classes mapeadas na tese conforme adaptação metodologia utilizada no projeto de mapeamento cobertura vegetal de cidades brasileira (Projeto parceria entre MMA-UnB)

No que tange a fotointerpretação e classificação das imagens alguns elementos são de grande importância, tais como: cor/tonalidade, forma, tamanho (relativo ou absoluto), associação, textura, padrão, profundidade/altura e sombra 
(Quadro 4). O conjunto desses elementos forma uma gama de alvos com caraterísticas próprias que após o imageamento e classificação das informações resultarão em mapas com as informações desejadas. A experiência do fotointérprete, nessa parte do trabalho, é fator condicional para a efetividade e alto nível de acurácia no resultado final.

\begin{tabular}{|l|l|}
\hline Princípios de fotointerpretação & Exemplo de aplicação \\
\hline Cor/tonalidade & $\begin{array}{l}\text { Vegetação tem coloração verde, diferindo de piscinas } \\
\text { (azuis) e do asfalto (cinza escuro). }\end{array}$ \\
\hline Forma & $\begin{array}{l}\text { A forma dos muros é linear, diferindo do aspecto } \\
\text { globoso dos jardins e copas de árvores. }\end{array}$ \\
\hline Tamanho (relativo ou absoluto) & $\begin{array}{l}\text { Sabendo-se a escala de uma fotografia podemos } \\
\text { saber o tamanho absoluto dos objetos e inferir sobre } \\
\text { sua origem e categorização. O tamanho relativo pode } \\
\text { ser usado para distinguir um caminhão de um veículo } \\
\text { de passeio. }\end{array}$ \\
\hline Associação & $\begin{array}{l}\text { Pátios com grande quantidade de carros } \\
\text { provavelmente representam área de estacionamento } \\
\text { ou manutenção de veículos }\end{array}$ \\
\hline Textura & $\begin{array}{l}\text { Áreas de gramados e pastagens diferem em textura } \\
\text { daquelas ocupadas por vegetação arbórea e/ou } \\
\text { arbustiva, com textura tipicamente rugosa. }\end{array}$ \\
\hline Padrão & $\begin{array}{l}\text { Padrões de distribuição homogénea das árvores } \\
\text { devem estar associados com presença de pomares } \\
\text { comerciais ou arborização de rua. Vegetação de } \\
\text { áreas verdes públicas e particulares tem padrão de } \\
\text { distribuição agregada ou irregular. }\end{array}$ \\
\hline Profundidade / Altura & $\begin{array}{l}\text { O uso de estereoscópio permite perceber diferença } \\
\text { na altura e profundidade dos elementos. }\end{array}$ \\
\hline Sombra & $\begin{array}{l}\text { Superfícies como calçadas não apresentam sombra } \\
\text { própria ou projetada, diferindo de objetos } \\
\text { tridimensionais, como árvores, muros e casas. }\end{array}$ \\
\hline
\end{tabular}

Quadro 4 - Princípios de fotointerpretação utilizados para mapeamento dos espaços verdes Fonte: Henke-Oliveira (2001)

Após a fotointerpretação das classes dos espaços verdes urbanos foi realizado o reagrupamento e reclassificação das classes no software IDRISI Taiga. Ao executar a classificação, gerou o mapa final dos espaços verdes em formato vetorial do tipo "MIF" (arquivo vetorial oficial do software). A posteriore o mesmo arquivo foi exportado em formato shapefile (Figura 37). 


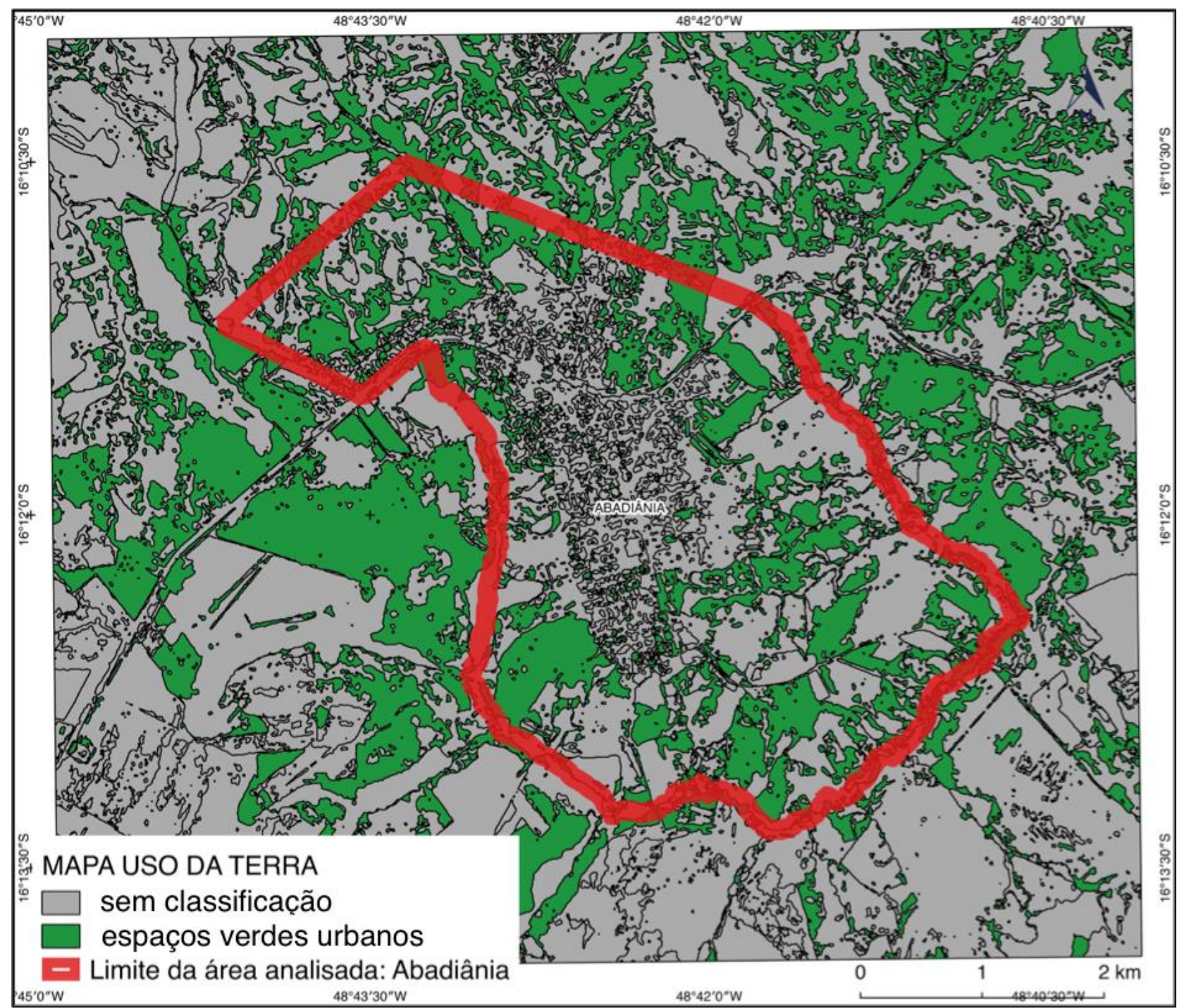

Figura 37 - Mapa dos espaços verdes urbanos para a cidade de Abadiânia

\subsubsection{Recorte dos Arquivos dos Espaços Verdes Urbanos}

Como mostra a Figura 38, o mapa dos espaços verdes urbanos foi executado nas coordenadas máximas e mínimas das áreas analisadas (RM e RIDE-DF e Entorno). O primeiro passo na edição dos mapa foi o recorte nas áreas analisadas, definidas pelas áreas urbanas dos setores censitários do IBGE (2010). Assim, fez-se uso da função recortar do software QGIS, a qual gerou o mapa dos espaços verdes urbanos no recorte dos setores censitários urbanos, nesta tese considerados cidade.

O passo seguinte da edição foi a auditoria dos polígonos dos espaços verdes urbanos (edição manual dos polígonos classificados erroneamente). Dado o elevado grau de automação na classificação das imagens de satélite, erros intrínsecos a confusão espectral, além da presença de nuvens e sombras, exigiu o processo de 
auditoria e edição vetorial (realizada também no software QGIS). A auditória permitiu elevar a acurácia do mapeamento refletindo em análises mais precisas.

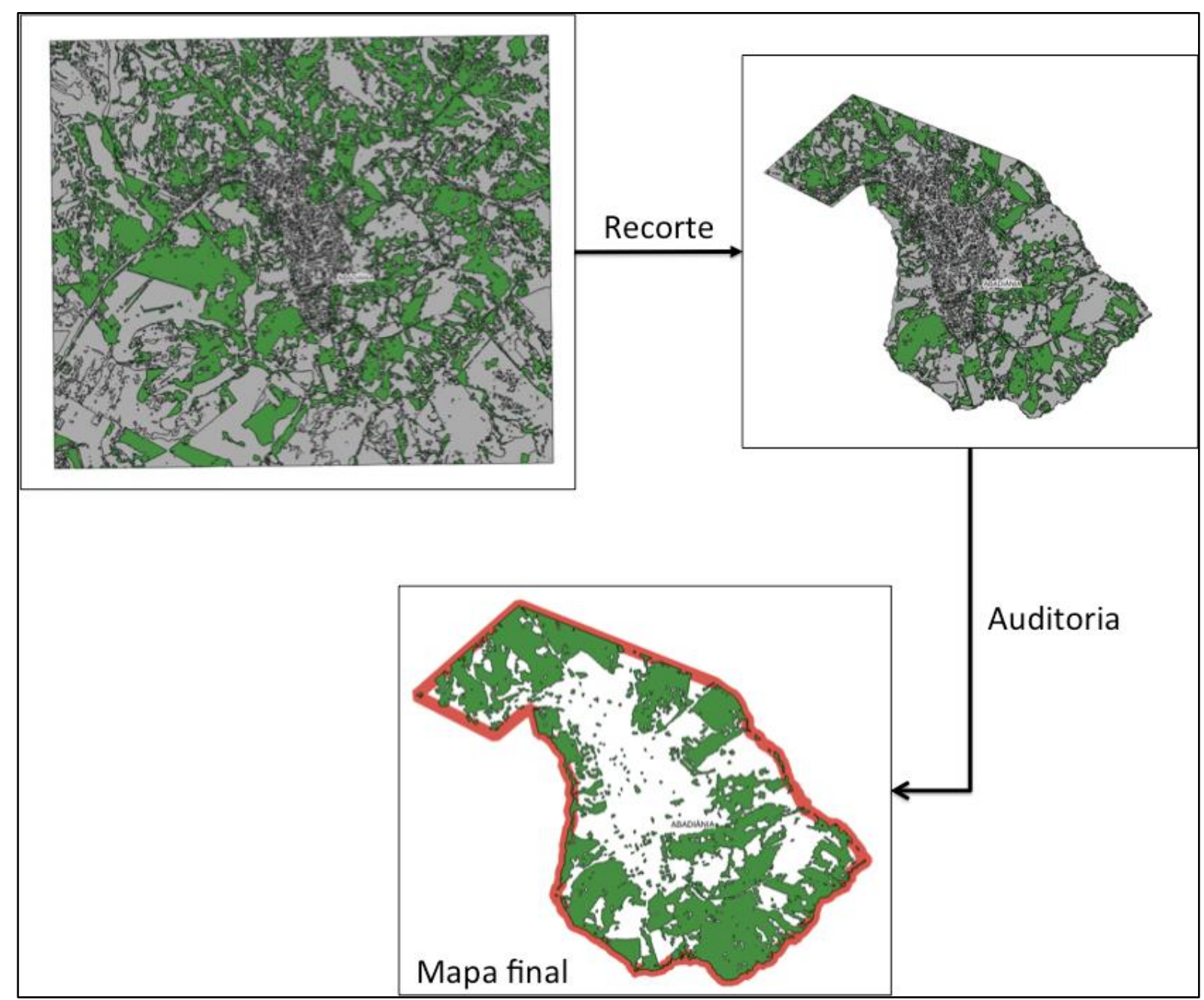

Figura 38 - Mapa final dos espaços verdes urbanos para a cidade de Abadiânia

Concluída a fase de auditoria dos espaços verdes urbanos de cada município, os arquivos foram unidos a cada RM ou RIDE a que pertence. No final gerou-se cinco arquivos no formato shapefile dos espaços verdes urbanas assim denominados: EVU_RM_MANAUS.shp, EVU_RM_PORTO_ALEGRE.shp, EVU_RM_RECIFE.shp, EVU_RM_SAO_PAULO, EVU_RIDE_DF_ENTORNO.shp.

\subsubsection{Espaços Verdes Urbanos nas Unidades de Desenvolvimento Humano}

Além do arquivo de espaços verdes no limite externo das amostras, a análise de cobertura vegetal também se deu no recorte das UDHs. Para tanto, o mapa de espaços verdes (item anterior - 3.3.6) foi recortado no software QGIS com o mapa gerado no item 4.3.4 (IVS no enquadramento das UDHs) para gerar o mapa de EVU 
nos limites das UDHs. Após o recorte, a dimensão de cada espaço verde foi recalculada no próprio QGIS, tomando metros quadrados como unidade métrica. Por fim, o valor absoluto das áreas dos espaços verdes (em metros quadrados) para cada UDH foi adicionado ao arquivo original (item 3.3.4). A Figura 39 ilustra esquematicamente o referido procedimento.

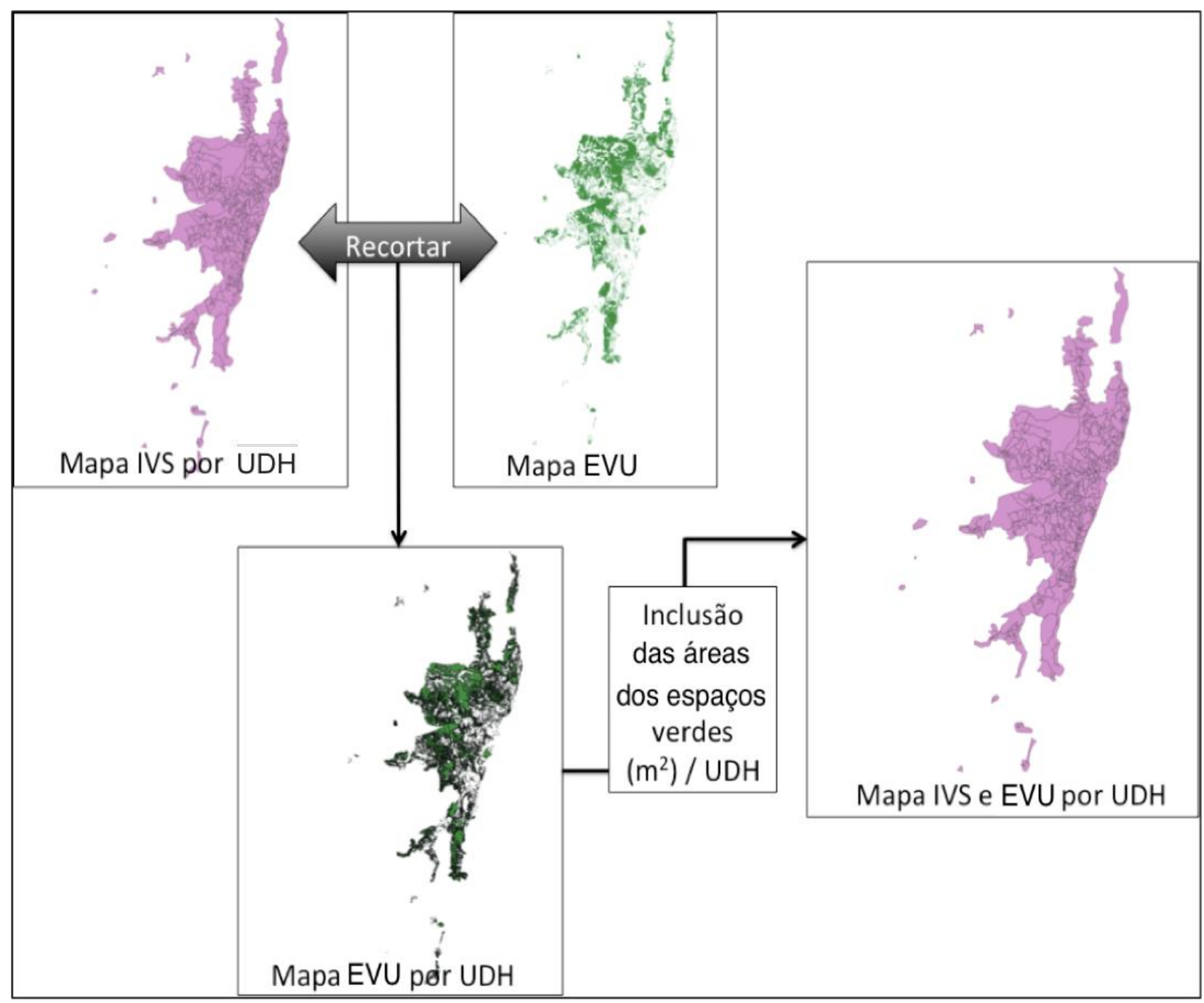

Figura 39 - Mapa de vulnerabilidade social e espaços verdes urbanos por unidade de desenvolvimento humano para a Região Metropolitana de Recife.

Esse procedimento serviu para simplificar o número de arquivos e efetivar análises sequentes, como: análise dos espaços verdes urbanos por habitantes, porcentagem de EVU nas UDHs, correlação espacial entre IVS e espaços verdes.

\subsubsection{Correlação Espacial: Espaços Verdes Urbanos e Vulnerabilidade Social}

A principal análise estatística proposta no escopo da tese diz respeito à correlação entre a quantidade dos espaços verdes urbanos e a vulnerabilidade 
social. Para mensurar essa correlação representada pelas variáveis: IVS (IPEA, 2015) e \% EVU dentro das UDHs foi realizada a análise exploratória de dados espaciais (AEDE).

Esse método considera a distribuição e o relacionamento dos dados no espaço. A AEDE é aplicada nos estudos dos processos de difusão espacial, por indicar padrões de autocorrelação a partir da dependência espacial entre os objetos geográficos (ANSELIN, 1994). A escolha desse método se justifica pela possibilidade de mapear e visualizar a distribuição espacial dos EVU correlacionada com a vulnerabilidade social para assim responder a hipótese: os espaços verdes urbanos estão concentrados em áreas com melhores índices sociais (menor vulnerabilidade social)?

Esse metodologia é usual para dados espacializados, uma vez que representa a maneira mais simples de apresentar informações que se correlacionam espacialmente por meio de mapas coloridos, facilitando análises dos padrões espaciais existentes (ANSELIN et al., 1996). Para efetivar a AEDE é necessário calcular a associação espacial das variáveis que podem ser realizados por índices que aferem esta autocorrelação (Índice de Moran), diagrama de espalhamento e distribuição espacial em mapas (ANSELIN et al., 1996).

Esses cálculos identificam os agrupamentos de objetos cujo os elementos possuem valores altos e baixos, áreas de transições, além de situações atípicas (ANSELIN et al., 1996). Vários softwares de SIG executam essas operações, na tese foi utilizado o software livre GeoDa (desenvolvido pela Universidade de Chicago) dada sua facilidade de manuseio e sua especificidade para esse tipo de análise (ANSELIN; SYABRI; KHO, 2006).

O uso de métodos de AEDE requer que a localização esteja associada a áreas que estão delimitadas por polígonos (ANSELIN, 1994). No presente caso os polígonos estão representados pelas UDHs que são georeferenciados e contém as informações alvo da correlação (IVS e \% EVU). Esse tipo de análise é bastante aplicada para investigar eventos agregados nas cidades, por exemplo incidência de doenças em áreas sem saneamento, crimes e ausência de serviços públicos, acidentes de carros e falta de sinalização, etc. (MILLER, 1999; PÁEZ; SCOTT, 2005).

Miller (1999) cita os cuidados essenciais para fazer uso de métodos de AEDE. O mais importante é procurar entender os padrões espaciais das possíveis 
variáveis a serem correlacionadas para garantir que as correlações sejam factíveis. Por exemplo, no caso dos EVU e a vulnerabilidade social, a hipótese dessa tese remete a existência de áreas com baixa vulnerabilidade social e maiores quantidades de espaços verdes. Complementar à hipótese, considera-se que existirá áreas com alta vulnerabilidade social e poucos espaços verdes. Afora esses cenários hipotéticos poder-se-á encontrar mais dois padrões: alta vulnerabilidade social e grande quantidade de espaços verdes e baixa vulnerabilidade social e pouca quantidade de espaços verdes. Nos quatro casos, os cenários mostraram bastante indutivos e constatáveis empiricamente.

Outro ponto levantado por Miller (1999), a respeito às unidades amostrais, retoma na necessidade de se entender o grau de agregação dessas unidades, além de verificar a compatibilidade da escala dos dados a serem correlacionados. No caso das UDHs, relata-se novamente que elas aglutinam vários setores censitários, com grau de ponderação que leva em conta as características socioeconômicas desses setores. Assim, as UDHs são mais abrangentes do que os setores censitários, reúnem vários bairros, vilas ou setores de características socioeconômicas semelhantes.

Antes de explicar o uso da autocorrelação espacial para efetivar a AEDE na tese, é importante ressaltar a não-utilização da correlação, no contexto da estatística clássica. A definição de correlação é em respeito ao relacionamento de duas variáveis, no presente caso porcentagem de EVU e IVS nas UDHs, a partir do gráfico de dispersão (regressão linear simples). Após testes preliminares, verificou a inexistência de dependência estatística pela estatística clássica. Resultado possível de ser visualizado pela Figura 40. 


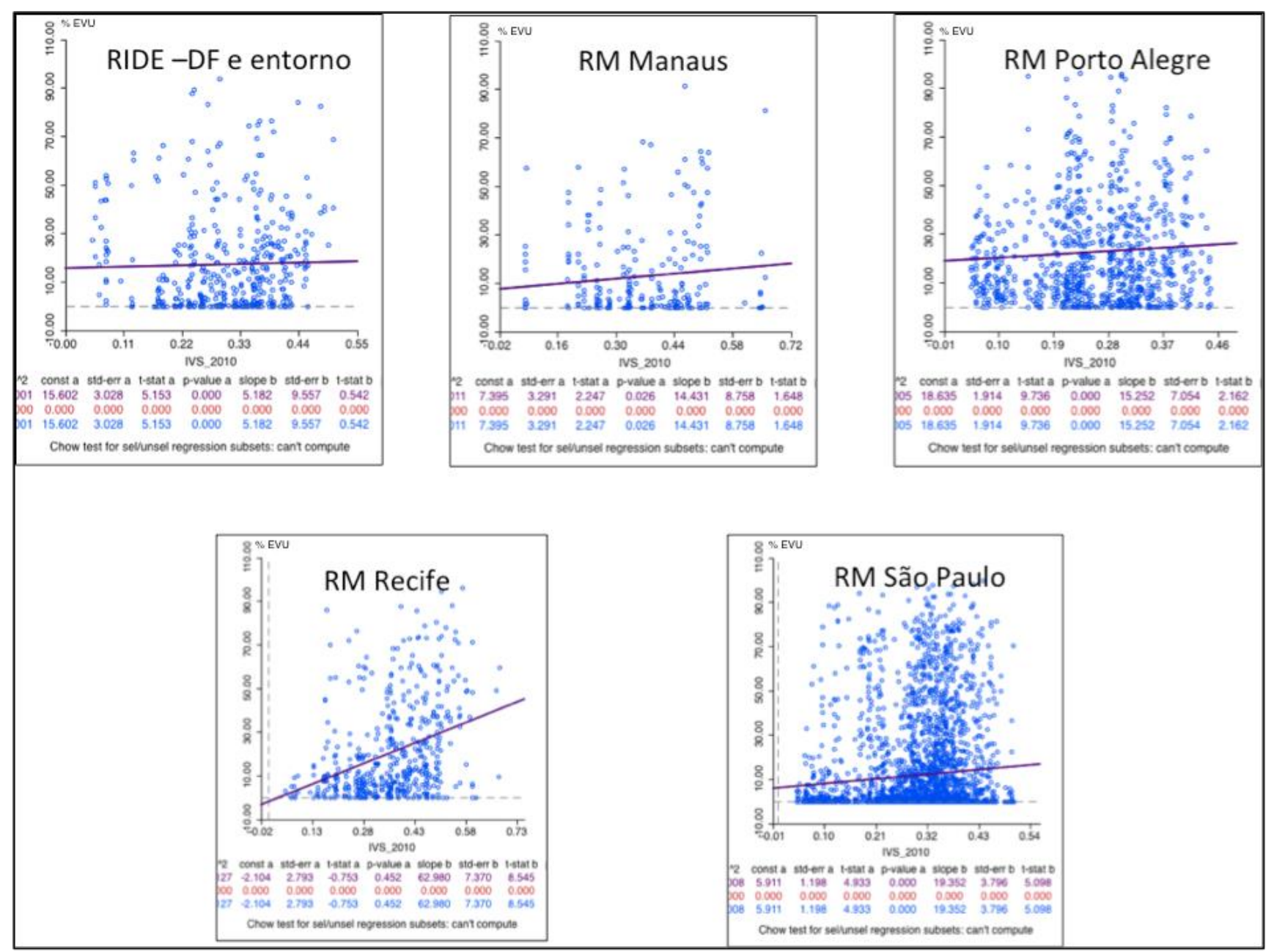

Figura 40 -Regressão linear simples nas Regiões Metropolitanas analisadas na RIDE-DF e Entorno Nota-se grande dispersão dos dados em relação à curva de dispersão (linha roxa), o que não indica correlação.

Pela estatística clássica, quanto mais as variáveis encontrarem espalhadas às virtuais curvas de dispersão, menor é a correlação. Pelos testes executados (Figura 40) constatou-se que pela estatística clássica, as relações entre as variáveis, não se mostraram dependentes.

Como a hipótese visa eventuais correlações espaciais ao nível de localização, buscou-se ir além da estatística clássica e se adentrar na geoestastítica, especificamente na autocorrelação espacial, que correlaciona as variáveis no espaço. O cálculo de autocorrelação evidencia o quanto o valor de uma (ou mais) variável em uma região (UDH) é semelhante com a do vizinho mais próximo, e ao mesmo tempo, o quão é diferente do vizinho mais distante (ANSELIN, 1994). Neste caso, o âmbito espacial (localização de cada UDH) é considerado na análise.

Para a análise da hipótese, esse tipo de análise mostrou-se factível uma vez que ela conseguiria responder o quanto a vulnerabilidade social é dependente da 
presença dos espaços verdes urbanos e principalmente indicar a localização (distribuição) das UDH que apresentaram maior ou menor dependência. Assim a função de autocorrelação espacial na tese foi calcular o nível de dependência entre duas variáveis (\% EVU e IVS) no conjunto das unidades amostrais (UDH).

\subsubsection{Matriz de Proximidade Espacial}

O primeiro passo para executar a autocorrelação espacial foi a construção da Matriz de Proximidade Espacial. Essa matriz aponta para o tipo de relação espacial de cada UDH, podendo ser ligada pela lista de vizinhos de cada polígono, pela distância entre eles, e também pela conectividade ponderada pelo comprimento da fronteira comum (ANSELIN, 1995).

O software GeoDa disponibiliza essa matriz de forma automática, após o preenchimento dos campos das seguintes variáveis: Método de escolha (distância ou grau de conectividade) e seus respectivos parâmetros (ANSELIN; SYABRI; KHO, 2006). A escolha do método depende do problema a ser analisado (CÂMARA; CARVALHO, 2004). Estudo de Zhang et al. (2008), por exemplo, ao analisar dados de poluição, utilizaram o método de "vizinhança por distância" uma vez que se sabia a distância dos raios de propagação dos agentes poluentes. No caso desta pesquisa, utilizou-se método de grau de conectividade por um vizinho mais próximo, método mais usual em estudos ambientais urbanos (PÁEZ; SCOTT, 2005).

\subsubsection{Autocorrelação Espacial Local Bivariada}

Existem dois tipos de autocorrelação espacial: a global e a local. Ambas são calculadas a partir do Índice de Moran (MORAN, 1950) e são analisadas com uma (univariada) ou duas (bivariada) ou várias variáveis (multivariada) (ANSELIN, 1994). $\mathrm{Na}$ presente pesquisa foram analisadas duas variáveis, portanto uma análise bivariada.

Esse índice compara as variáveis de uma unidade amostral (UDH) com a média dessas variáveis de seus vizinhos, assinalados na matriz de proximidade. Quanto mais próximo de +1 , maior a dependência espacial positiva, mais próximo de -1 maior a dependência espacial negativa e se igual a zero significa ausência de dependência espacial (ANSELIN, 1995).

Analisando o Índice de Moran frente à hipótese espera-se que ele esteja mais próximo de -1. Uma vez que, de acordo com a hipótese, a correlação espacial 
ocorre com duas variáveis inversamente proporcionais: quanto maior a vulnerabilidade social, menor a quantidade dos espaços verdes (e vice-versa).

Voltando aos tipos de autocorrelação espacial, ressalta-se que a diferença deles é que os indicadores globais de autocorrelação espacial (Índice de Moran) fornecem um valor único para a caracterização da associação espacial de toda a área analisada (ANSELIN, 1995). Assim, quando se trabalha com muitas unidades amostrais, é provável que possa acontecer diferentes situações de associação espacial e que encontre locais onde a dependência espacial é ainda maior.

Destarte, os indicadores locais fornecem um valor para cada subárea e com isso identificam agrupamentos de unidades amostrais com características semelhantes (clusters), discrepantes (outliers), possibilitando analisar mais de um regime espacial (ANSELIN, 1995).

Ao calcular o Índice de Moran Local (no caso, bivariado), o software GeoDa fornece a o mapa de autocorrelação local (LISA - Índice Local de Associação Espacial). Esse mapa (Figura 41) informa a decomposição da autocorrelação global, o que permite visualizar o comportamento da dependência espacial (ANSELIN, 1995).

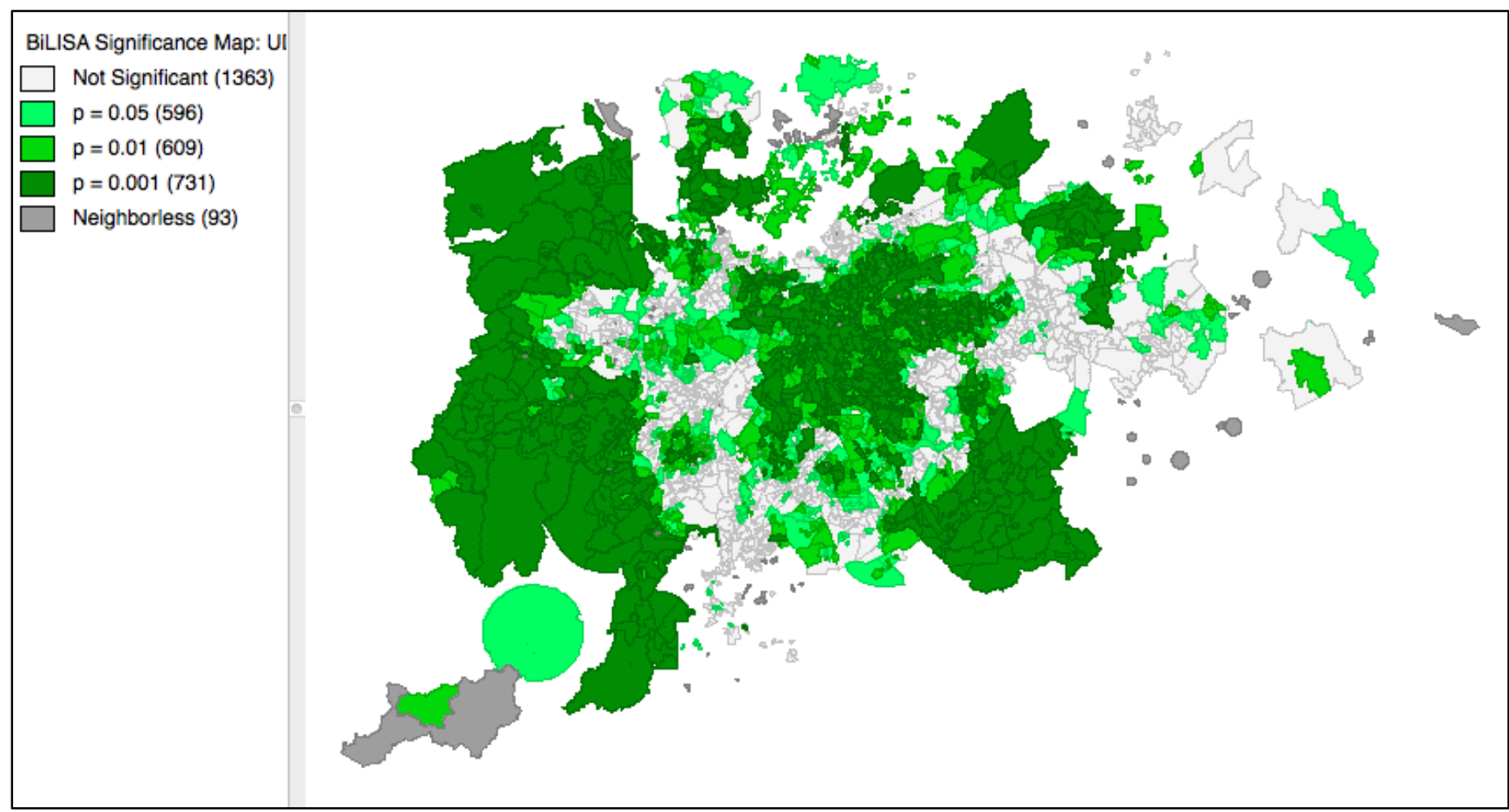

Figura 41 - Mapa LISA. Exemplo: Região Metropolitana de São Paulo

As variações de verde indicam as áreas que tiveram significância: verde escuro a 0,1\%; verde médio a $1 \%$ e verde claro a $5 \%$ 
Em síntese, ele mapeia as áreas que tiveram significância, com intervalo de confiança a 95,0\%; 99,0\% e 99,9\% da autocorrelação analisada. Além destas, ele mapeia também aquelas sem significância e aquelas que não foram analisadas por não apresentarem vizinhos (representadas na cor cinza) (ANSELIN, 1995). Para a presente pesquisa foram consideradas todas as UDH com grau de significância maior do que $95 \%$.

\subsubsection{Diagramas de Espalhamento de Moran e Mapas de Cluster}

Ao aplicar a autocorrelação local bivariada (\% EVU e IVS) no software GeoDa, o resultado é fornecido em três produtos: mapa LISA que indica as áreas com significância maiores de $95 \%$ ( $p>0,05)$, o diagrama de espalhamento das amostras analisadas e o mapa de cluster (mapeia as UDHs conforme a disposição delas no diagrama e a significância) (ANSELIN; SYABRI; KHO, 2006). A Figura 42 ilustra como esses produtos se relacionam.

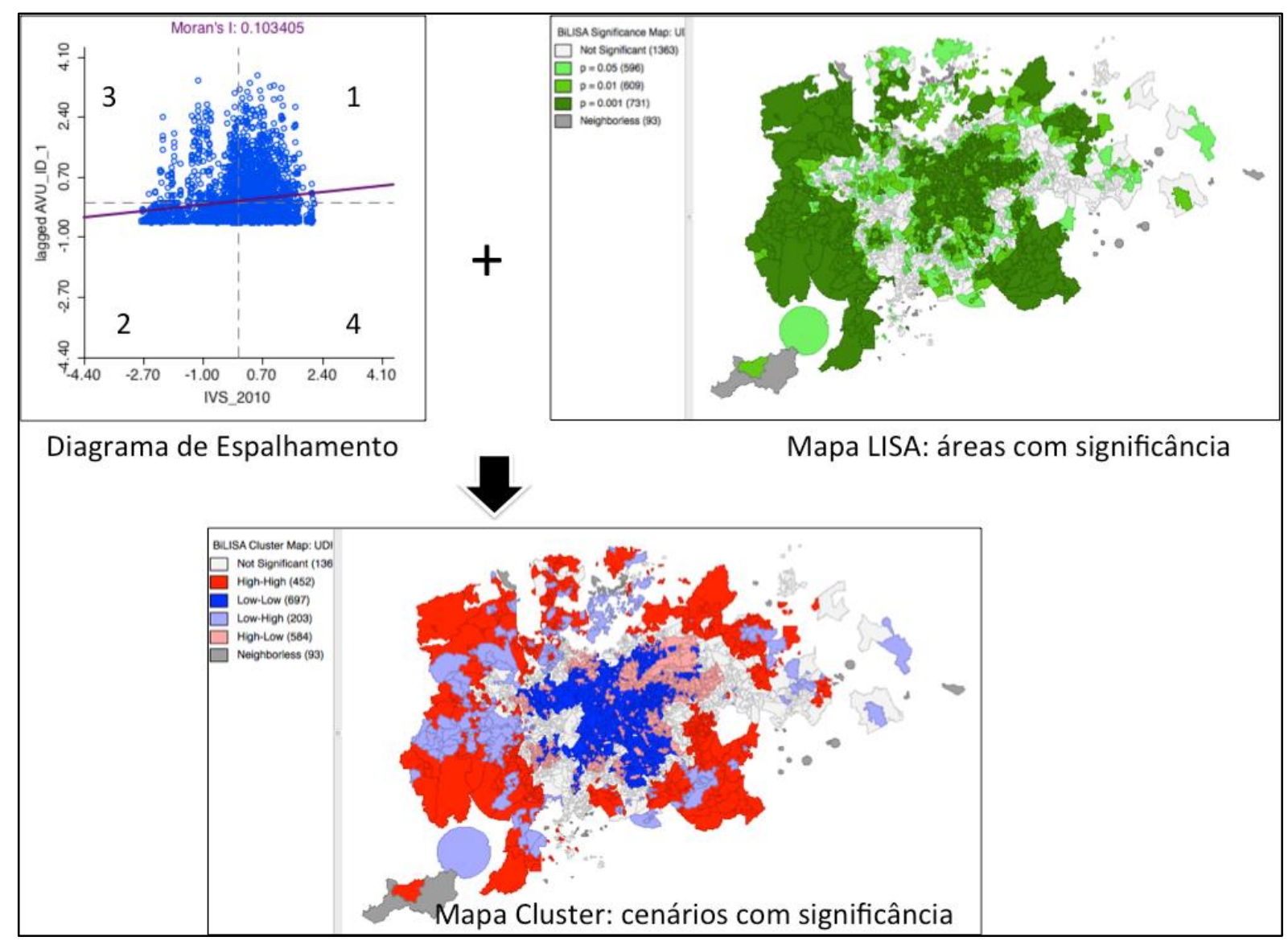

Figura 42 - Produtos gerados na análise de autocorrelação local bivariada. Software: GeoDa. 
O diagrama de espalhamento é construído com valores normalizados (valores de atributos após subtração de sua média e divididos pelo desvio padrão) e é mais uma forma de visualizar a dependência espacial. Pelo diagrama, observa-se que o Índice de Moran corresponde ao coeficiente de regressão linear (inclinação da reta), que pelos cálculos geométricos corresponde à tangente do ângulo da reta de regressão (ANSELIN, 1995; CÂMARA et al, 2004).

O diagrama de espalhamento é dividido em quadrantes (ANSELIN, 1995). No âmbito das discussões desta pesquisa, esses quadrantes foram denominados como cenários e atribuídos cores: verde, vermelho, laranja, amarelo, conforme ilustra a Figura 43. A seguir, a interpretação focada nos possíveis cenários esperados.

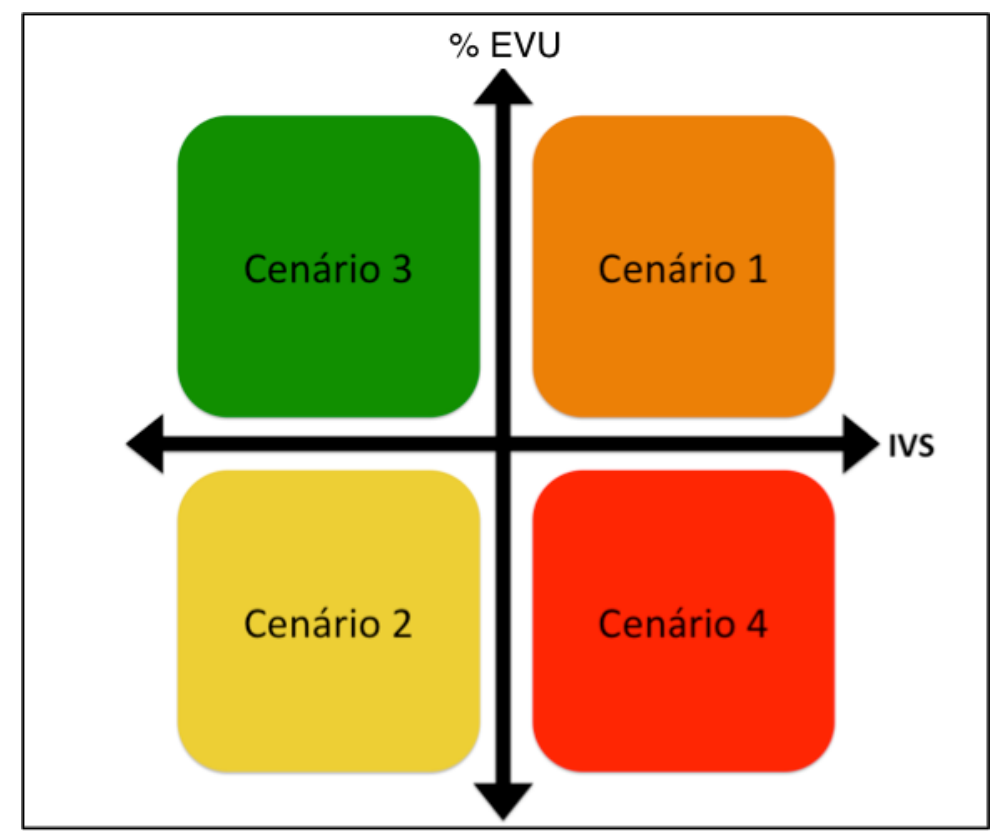

Figura 43 -Diagramação dos possíveis cenários esperados

- Cenário 1 (laranja): Alta Vulnerabilidade Social e Alta Porcentagem de EVU (valores positivos, médias positivas).

- Cenário 2 (amarelo): Baixa Vulnerabilidade Social e Baixa Porcentagem de EVU (valores positivos, médias positivas).

Pela análise geoestastítica esses cenários indicam as UDHs de associação espacial positiva, no qual uma localização possui vizinhos com valores semelhantes. Por exemplo, no Cenário 1 estão as UDHs com valores dos atributos acima da média global e os seus vizinhos também possuem esses atributos. No Cenário 2 , ocorre o oposto, nele estão as áreas com atributo e média dos vizinhos abaixo da média global (ANSELIN, 1995). 
- Cenário 3 (verde): Baixa Vulnerabilidade Social e Alta porcentagem de EVU (valores negativos, médias positivas).

- Cenário 4 (vermelho): Alta Vulnerabilidade Social e Baixa Porcentagem de EVU (valores positivos, médias negativas).

As UDHs desses dois últimos cenários representam a hipótese da tese. Notase que a hipótese representa a metade dos cenários possíveis. Pela análise geoestastítica esses cenários indicam as UDHs de associação espacial negativa, onde existem clusters espaciais com valores diferentes entre a localidade e sua vizinhança. Por exemplo, no Cenário 3 um local com indicador acima da média global é vizinho de outros que possuem indicadores abaixo dessa média, e viceversa para o Cenário 4 (ANSELIN, 1995).

Retomando ao mapa de LISA, ressalta-se que ele indica as UDHs que apresentaram significância e insignificância na autocorrelação. O software GeoDa permite selecionar aquelas UDHs entre regimes espaciais diferentes (significantes e sem significância) no mapa LISA que reflete nos pontos do diagrama de espalhamento (ANSELIN; SYABRI; KHO, 2006). Observa-se que as UDHs com significância estão mais distantes da reta de regressão (Figura 44).

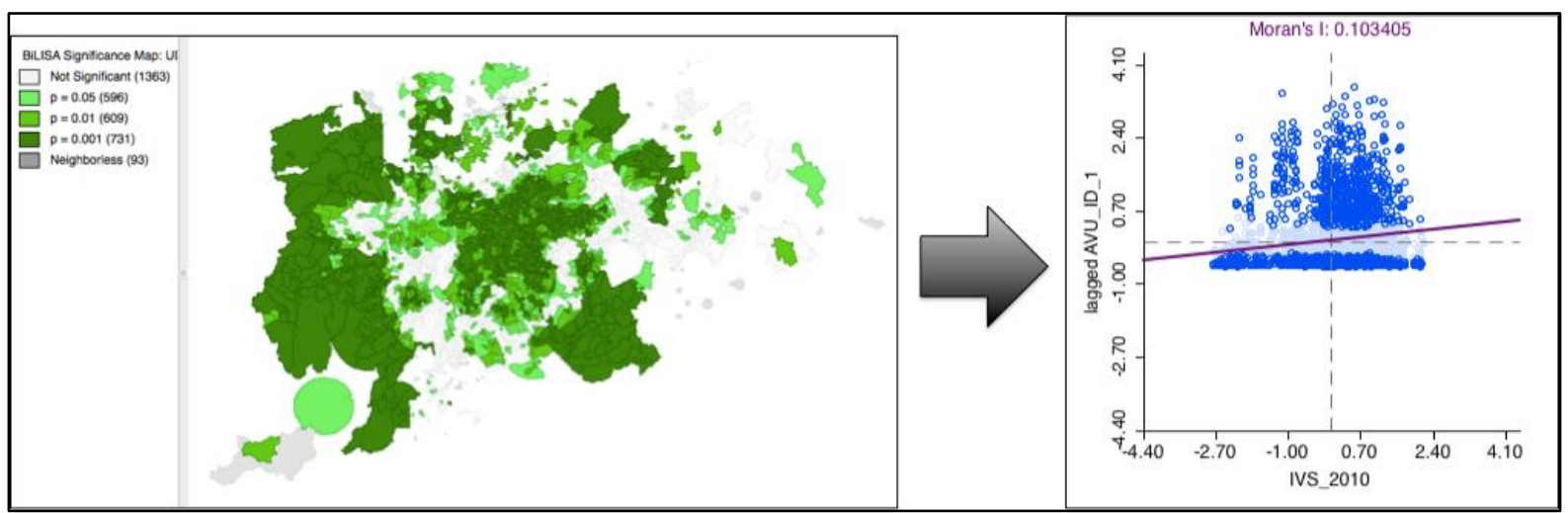

Figura 44 - Seleção das unidades de desenvolvimento humano (UDH) com significância geoestastítica ( $p>0,05-$ UDHs na tonalidade verde)

As UDHs consideradas significativas (intervalo de confiança maior de 95\%) compõem o Mapa Cluster estabelecendo a categorização dos referidos cenários. A metodologia de elaboração desse mapa, assim como as análises sucedidas estão descritas no item 3.3.9.10. 


\subsubsection{Mapas e Análises}

\subsubsection{Mapas de Localização}

O primeiro mapa realizado para a análise foi o de localização. Esse mapa auxiliou na contextualização histórica, geográfica e socioeconômica de cada amostra. Para tanto, utilizou-se de imagens de satélite disponíveis no próprio softwares QGIS (imagens Google). Embora as imagens disponíveis apresentem baixa resolução espectrais, elas se mostraram as mais efetivas (acesso livre, mais leves, fácil manipulação) para ilustrar o retrato de cada área analisada. Para compor o mapa, utilizou-se o arquivo elaborado no item 4.3.7 (IVS e EVU por UDH) sobreposto à imagem de satélite.

\subsubsection{Mapas de Densidade Demográfica}

A densidade demográfica (relação da quantidade de população por área) foi realizada no recorte das UDHs. Para calcular essa variável foi criado um novo campo na base de dados alfanuméricos do arquivo final de análise (item 4.3.7). Para facilitar a sua visualização ela foi calculada na seguinte unidade métrica: número de habitantes por quilômetros quadrados.

A categorização desse mapa foi realizada em três classes para as amostras de menores densidades demográficas (RIDE-DF e Entorno e RM de Manaus). Para as demais amostras foram categorizadas em quatro classes. $\mathrm{O}$ número e o limite das classes foram definidos após vários testes.

\begin{tabular}{|c|l|l|}
\hline Amostras & Classes & Hab/km2 \\
\hline RM Manaus; & 1 & $1-300$ \\
\cline { 2 - 3 } RIDE-DF e \\
Entorno & 2 & $300-1000$ \\
\cline { 2 - 3 } & 3 & superior a 1000 \\
\hline RMs Porto & 1 & $1-300$ \\
\cline { 2 - 3 } Alegre; Recife; & 2 & $300-1000$ \\
\cline { 2 - 3 } São Paulo & 3 & $1000-5000$ \\
\cline { 2 - 3 } & 4 & superior a 5000 \\
\hline
\end{tabular}

Os valores definidos (Quadro 5) mostraram representar com maior simplicidade (menos quantidade de classes possíveis) as variações da densidade demográfica no espaço urbano. 


\subsubsection{Mapas de Vulnerabilidade Social}

O mapa de vulnerabilidade social foi realizado a partir da categorização do IVS (ano base: 2010) do arquivo gerado no item 3.3.7 (IVS e EVU por UDH). A categorização seguiu os padrões utilizados pelo IPEA (2015) - item 3.3.4, Figura 35.

\subsubsection{Mapas dos Espaços Verdes Urbanos}

O mapa dos EVU foi espacializado a partir do mapa explicitado no item 4.3.6 (mapa final dos espaços verdes urbanos). Para facilitar a visualização ele está sobreposto ao mapa das UDHs e aos limites municipais. A primeira análise desse mapa foi realizada a partir do ranqueamento dos EVU por cidade, afim de aferir a quantidade de EVU por cidade (quilômetros quadrados), assim como a porcentagem de EVU em relação a cada cidade.

\subsubsection{Mapas dos Espaços Verdes Urbanos dm Áreas Protegidas: Unidades de Conservação da Natureza e Áreas de Proteção de Mananciais}

Esse mapa especializou as EVU dentro das Unidade de Conservação da Natureza (UCs) definidas pelo Sistema Nacional de Unidades de Conservação da Natureza (SNUC), além das Áreas de Proteção de Mananciais (APM). Para tanto, realizou-se no software QGIS o procedimento de intersecção dos EVU com os limites disponíveis das áreas protegidas disponibilizados no site do Instituto Chico Mendes de Biodiversidade (ICMBio) ou, no caso das APM: Companhia de Ambiental de São Paulo (CETESB) e Companhia de Saneamento Ambiental do Distrito Federal (CAESB). Detentoras da base de dados de APM de São Paulo e Brasília (Figura 45). 


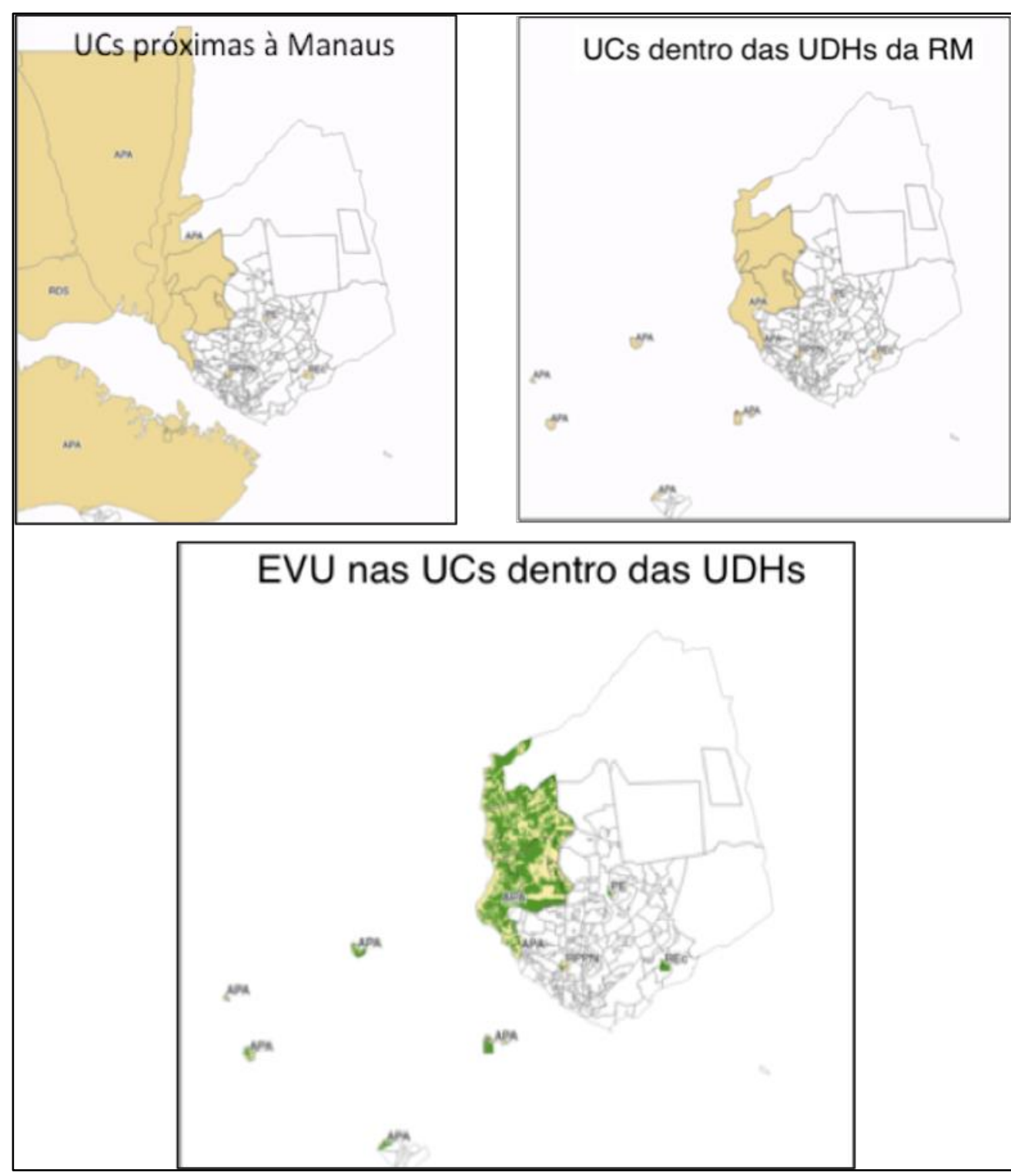

Figura 45 - Procedimento para gerar o mapa de Espaços Verdes Urbanos (EVU) dentro das Unidades de Conservação da Natureza (UCs) nas Unidades de Desenvolvimento Humano (UDHs)

Além do mapa, as informações tabuladas dessa intersecção foram discutidas afim de investigar as maiores categorias de UCs que apresentaram mais EVU, assim como as cidades que apresentaram maior quantidade de espaços verdes, dentro de áreas protegidas, no caso: UCs e APMs.

\subsubsection{Mapas da Porcentagem dos Espaços Verdes Urbanos por Unidade de Desenvolvimento Humano}

As análises mais detalhadas dos espaços verdes seguiram o recorte das UDHs. Acredita-se que esse enquadramento mostre com maior veracidade a disponibilidade de EVU, assim como sua relação por habitantes. Uma vez que, no recorte municipal (considerando todos os setores analisados por município) a 
quantidade de espaços verdes fica diluída, desconsiderando eventuais concentrações populacionais em regiões sem espaços verdes ou concentração de espaços verdes sem população significativa.

O mapa que informa a proporção dos espaços verdes por UDH utilizou-se do seguinte campo de categorização: "\% de EVU por UDH". Esse campo foi criado a partir da relação porcentual da quantidade dos EVU pela área de UDH. O número e o limite de classes foram definidos após vários testes (Quadro 6).

\begin{tabular}{|l|l|l|}
\hline Classes & \% EVU /UDH & Descrição da proporção \\
\hline 1 & $0-30$ & pouca \\
\hline 2 & $30-60$ & média \\
\hline 3 & $60-100$ & grande \\
\hline
\end{tabular}

Quadro 6 - Categorização da \% das EVU nas UDHs

Os valores definidos mostraram representar com maior simplicidade (pouca, média e grande quantidade de EVU) as possíveis variações. Destaca-se que terceira classe não variou em $30 \%$ de EVU, como as demais. Isto porque são pouquíssimas as UDH com mais de $90 \%$ de EVU, sendo estas consideras outliers e englobadas na última classe.

\subsubsection{Mapas dos Espaços Verdes Urbanos por Habitante (Análise Demográfica)}

Considerando novamente as UDHs como unidades amostrais, o presente mapa especializou a quantidade de EVU por habitante. Assim, foi criado o campo "EVU / Habitante" na base de dados alfanumérica. O próprio software QGIS realizou o cálculo da referida proporção.

A categorização tomou como base o valor mínimo estabelecido pela Sociedade Brasileira de Arborização Urbana $\left(15 \mathrm{~m}^{2}\right)$, como o tamanho mínimo necessário para cada habitante (Quadro 7).

\begin{tabular}{|l|l|l|}
\hline Classes & EVU $\left(\mathbf{m}^{\mathbf{2}}\right) /$ Habitante & Descrição \\
\hline 1 & 0 & não possui \\
\hline 2 & $0-15$ & menor do que o recomendado \\
\hline 3 & $15-100$ & além do recomendado \\
\hline 4 & $100-1000$ & além do recomendado \\
\hline 5 & superior a 1000 & muito além do recomendado \\
\hline
\end{tabular}

Quadro 7 - Categorização do mapa dos espaços verdes urbanos por habitantes 
As demais classes foram categorizadas após testes, aos quais definiram o mínimo de classes às quais demostrasse com maior clareza as diferenças de disponibilidade de EVU por habitantes no espaço. É importante destacar a classe 1 que indica a ausência de EVU na UDH

\subsubsection{Mapas do Tamanho dos Fragmentos dos Espaços Verdes Urbanos}

Para espacializar e analisar o tamanho dos fragmentos do Mapa dos EVU (item 3.3.6) foi aplicada uma classificação de três categorias do campo "área" de cada fragmentos de EVU mapeado, utilizando-se o método de desvio padrão, disponível no software QGIS.

A escolha desse método foi devido a variação no tamanho médio dos fragmentos das cinco amostras (nas quatro RM e a RIDE-DF e Entorno). Determinar classes fixas para todas as amostras poderia gerar análises equivocadas. Por exemplo, os fragmentos de Manaus são muito maiores do que os das demais cidades. Certamente uma eventual fixação de classes, apenas Manaus iria possuir fragmentos grandes.

O método de desvio padrão do QGIS, obedece a curva normal de distribuição, a partir do valor médio limita-se à direita e a esquerda dois limites de acordo com o desvio padrão para definir três classes. Elas foram estabelecidas da seguinte forma: fragmentos pequenos, fragmentos médios e fragmentos grandes.

\subsubsection{Mapas de Kernel dos Fragmentos Pequenos}

Os fragmentos classificados como pequenos da classificação por desvio padrão foram os que apresentaram a maior quantidade. A maior frequência de ocorrência conjugada ao tamanho reduzido comprometem análises visuais, como por exemplo: encontrar a área de maior concentração dos fragmentos pequenos.

Para possibilitar e facilitar a análise visual, utilizou-se da ferramenta denominada "Kernel Densinty" do software QGIS. Essa ferramenta gera "mapas de calor" (ou mapa de Kernel) embasada em um método estatístico de estimação de curvas de densidade.

O método estatístico utilizado nessa ferramenta analisou o ponto central de cada fragmento. Silverman (1986) explica o método, ao qual para cada ponto, o algoritmo identifica aqueles que estão a uma distância menor ou igual ao raio do círculo centrado nele. No presente caso foi arbitrado a distância de 1000 metros 
como valor do raio. Para cada ponto encontrado dentro do círculo é aplicada uma função matemática de 1 , na posição do ponto, a 0 , na fronteira da vizinhança. $O$ resultado da soma acumulada é transferida a cada pixel de um arquivo raster (matricial). Assim, o valor para cada pixel é a soma dos valores kernel sobrepostos, e divididos pela área de cada raio de pesquisa (SILVERMAN, 1986).

$\mathrm{Na}$ prática, esse mapa facilita visualizar a localização das áreas de maior quantidade de EVU de menor tamanho. Isso auxilia na análise, pois visualmente quando detectada uma faixa com uma tonalidade ou cor mais intensa, no caso, verde escuro, pode-se inferir que nessa área existe uma concentração elevada de fragmentos pequenos, e quanto mais clara a cor, menos concentrados.

\subsubsection{Mapas de Correlação Espacial: Espaços Verdes Urbanos e Vulnerabilidade Social}

O mapa que representa a correlação espacial entre a porcentagem dos espaços verdes urbanos e vulnerabilidade social (\%EVU x IVS) deriva-se do Mapa de Cluster (item 4.8.4.3). O mapa de cluster gerado no software GeoDa foi exportado para o software QGIS, no formato vetorial (.shapefile). Neste software foi possível categorizar os cluster (UDHs com significância geoestastítica) de acordo com os cenários esperados e elaborar os mapas de correlação espacial. As cores das classes seguiram o padrão explanado no item 4.8.4.3 (verde, vermelho, amarelo e laranja).

A partir desse mapa foi possível investigar a dimensão da área e populacional desses cenários com significância. Para facilitar a discussão dos resultados, os valores em percentual (área e população) foram tabulados e representados em figura semelhantes ao diagrama de dispersão de Moran (Figura 46). 


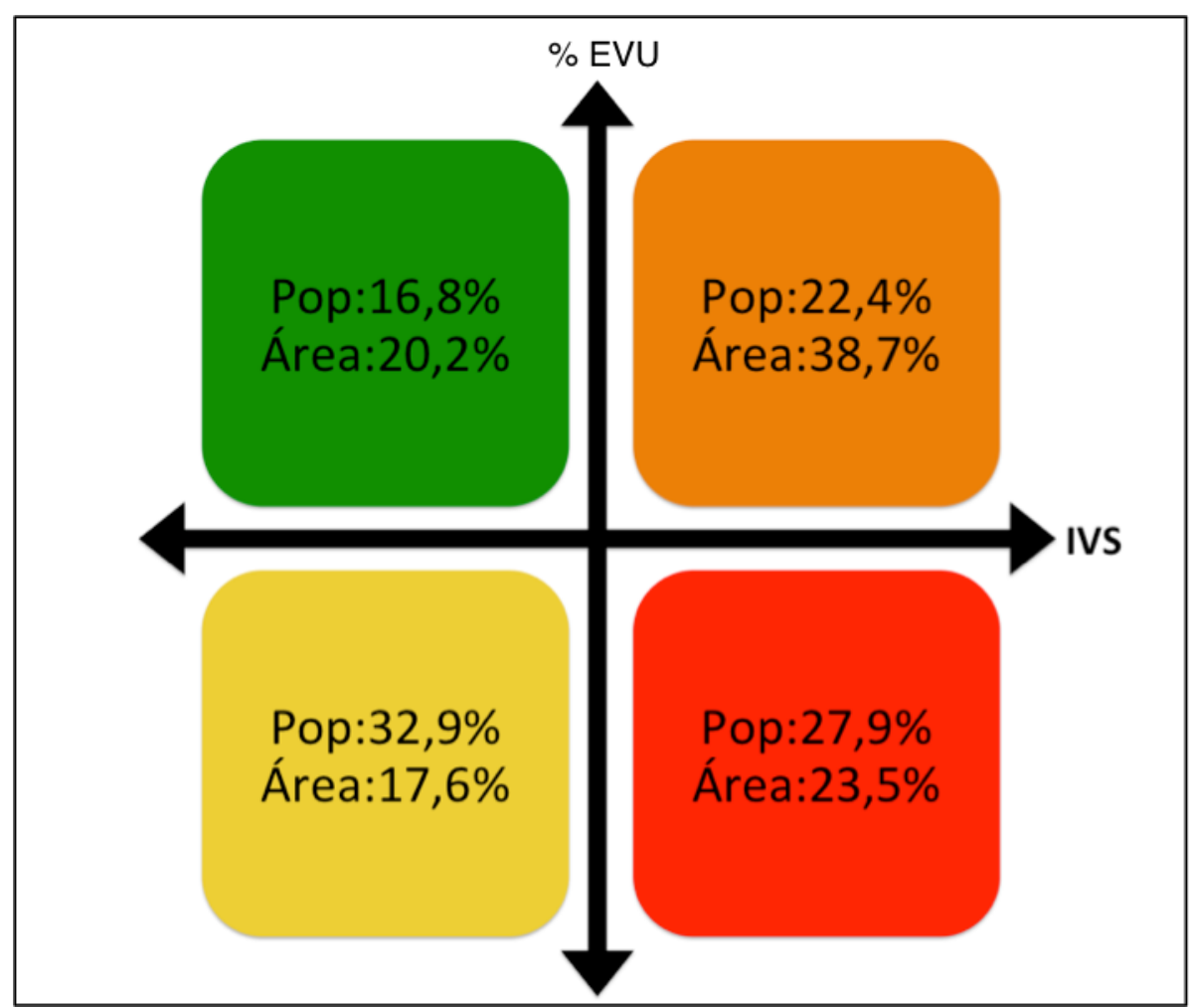

Figura 46 - Cenários com significância (porcentagem da população e da área analisada)

No diagrama (Figura 46) foram inseridos os dados normalizados da população e da área que apresentaram significância. Nota-se que a soma dos porcentuais população e da áreas do diagrama é igual a $100 \%$. Isso foi realizado pra facilitar a análise entre os cenários que apresentaram significância. 


\section{ESPAÇOS VERDES URBANOS NAS CIDADES ANALISADAS}

\subsection{Região Integrada de Desenvolvimento Econômico do Distrito Federal e Entorno}

A Figura 47 apresenta a RIDE-DF e Entorno, evidenciando as áreas analisadas (rosa), conforme o recorte proposto. A RIDE-DF e Entorno conta com 22 municípios, sendo 19 goianos e três mineiros, além do Distrito Federal. De acordo com a Figura 47, as UDHs analisadas têm a área de $2.104,46 \mathrm{~km}^{2}$ que correspondem a apenas $3,72 \%$ de toda a área da RIDE-DF e Entorno. Isso indica que a área correspondente aos setores censitários do tipo rural é muito maior do que a urbana.

Da área analisada, 58,84\% está no Distrito Federal (DF), 36,91\% em Goiás e apenas $4,24 \%$ em Minas Gerais. Além disso, a figura evidencia que existe uma conurbação urbana formada pelas cidades de Brasília, Cidade Ocidental, Luziânia, Novo Gama e Valparaíso de Goiás, que corresponde a $67,83 \%$ de toda área analisada. Os demais setores censitários analisados estão dispersos na RIDE-DF e Entorno.

Somados os habitantes das UDHs, a população chega a 3,55 milhões, o que corresponde a 95,38\% do total de habitantes da RIDE-DF e Entorno. Percebe-se a grande concentração populacional na área analisada, em oposição aos 4,62\% dos habitantes nos setores censitários do tipo rural, que residem em 95,38\% do território.

Com base nos dados do último censo (IBGE, 2010), a população analisada da RIDE-DF e Entorno representa 1,84\% da população brasileira e 24,93\% da população do Centro-Oeste. A densidade populacional (número de habitantes por área de cada UDH analisada) é mostrada na Figura 48. 


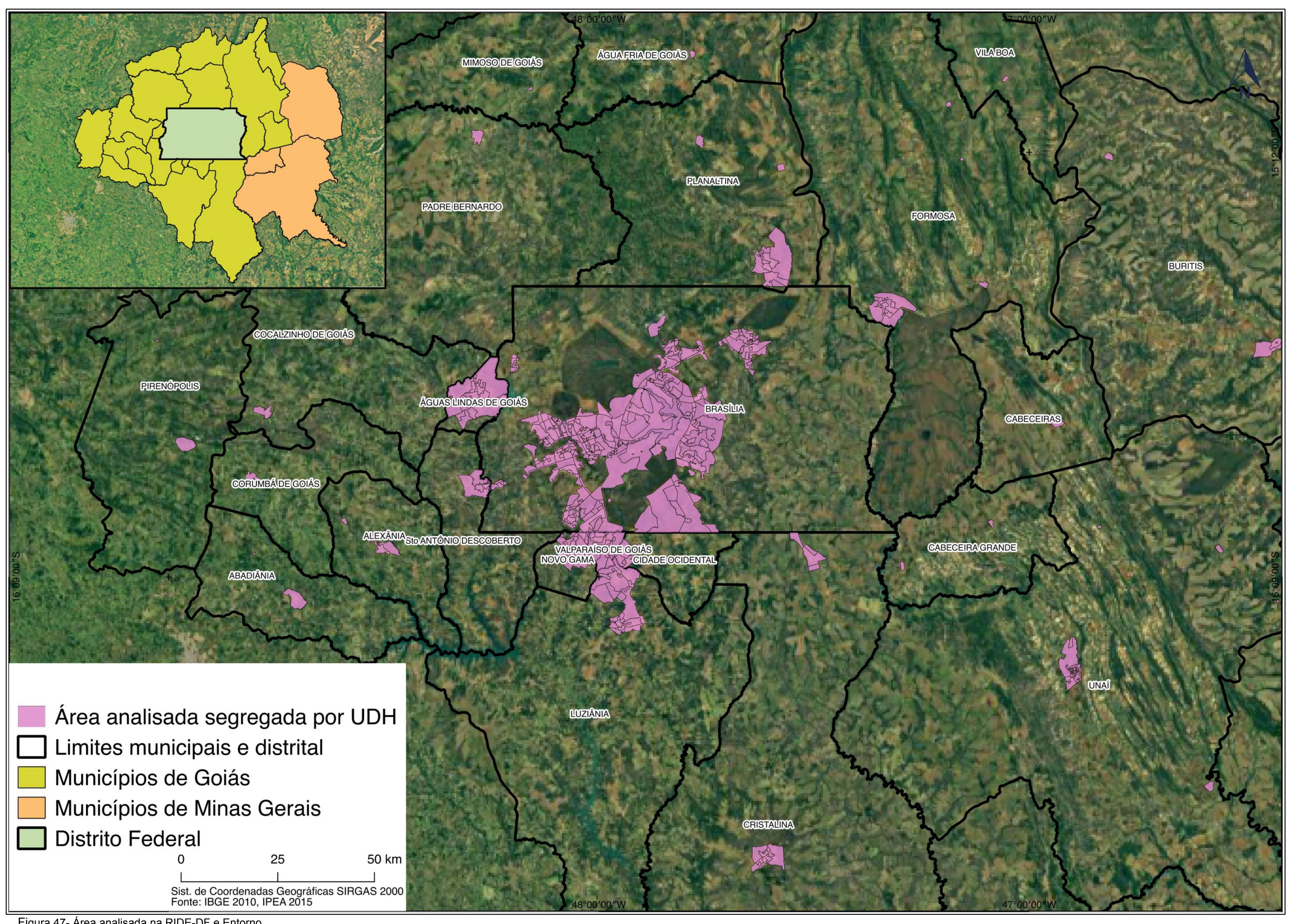

Figura 47- Área analisada na RIDE-DF e Entorno 


\subsubsection{Urbanização na RIDE-DF e Entorno}

A RIDE-DF e Entorno apresentam especificidades relacionadas ao processo de desenvolvimento econômico, ao planejamento territorial e à gestão urbana que a diferencia das demais ocupações urbanas brasileiras (CAIADO, 2013). Brasília, por ser construída de forma planejada para tornar-se a nova capital da República, estabeleceu as atividades político-administrativas como prioritárias para o seu desenvolvimento econômico (STEINBERGER, 1999).

Além de ser centro político nacional, Steinberger (1999) cita que Brasília foi planejada como parte da solução dos problemas relacionados à falta de integração do território nacional, principalmente na região centro-oeste. Por isso, a autora menciona que Brasília foi pensada como polo de desenvolvimento regional. Em tese, a cidade deveria permitir e incentivar atividades econômicas capazes de irradiar desenvolvimento ao DF e aos municípios próximos. Na realidade, fruto da omissão conjugada dos governos federal e local não houve grandes incentivos econômicos frente a chegada de milhares de migrantes à nova capital federal (FERREIRA; PENNA, 1996).

A Figura 48 mostra que os maiores adensamentos populacionais estão na porção oeste do DF, nas cidades de Águas Claras, Ceilândia, Samambaia, Taguatinga, Riacho Fundo, Recanto das Emas e Vicente Pires. Nessa área habitam quase 1 milhão de pessoas, correspondendo a 25\% da população da RIDE-DF e Entorno. Vasconcelos et al. (2006) atribui essa grande densidade ao elevado fluxo de migrantes que chegaram até os anos 2000 (nordestinos, mineiros e goianos), que deram preferência a tais localidades, uma vez que o custo de vida era mais acessível do que áreas do Plano Piloto. 


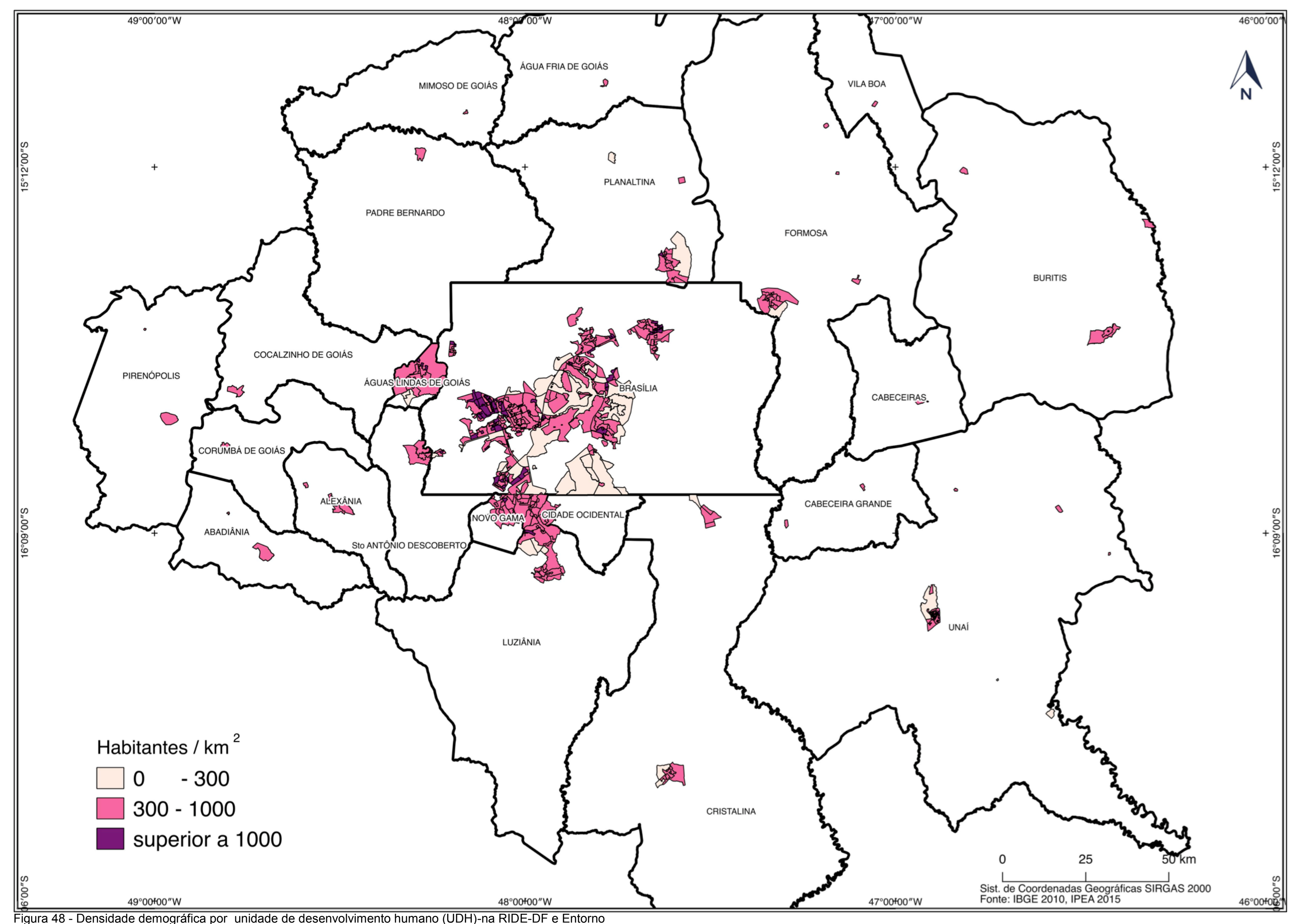


Na década de 1990, começaram a surgir políticas limitantes das forças de mercado no DF. Assim, espaços urbanos fora do quadrilátero do DF tornaram a ser alvo de uma ampla expansão conforme relata Vasconcelos et al. (2006):

A oferta de pequenos lotes, a baixos preços e longos prazos para
pagar, atraiu a população que pagava aluguéis nos núcleos satélites
da capital. Naquele momento, o migrante pobre que chegou ao
aglomerado tende a buscar nessa periferia sua moradia, o que o
obriga a se deslocar a grande distância para o trabalho localizado no
centro (VASCONCELOS et al., 2006, p. 8).

Observa-se portanto uma considerável densidade populacional das UDHs nas cidades limítrofes ao DF (todas no estado de Goiás), popularmente chamadas de cidades do entorno, que compreendem: Cidade Ocidental, Cristalina, Formosa, Águas Lindas de Goiás, Luziânia, Novo Gama, Planaltina, Santo Antônio do Descoberto e Valparaíso de Goiás. Somados, os habitantes dessas cidades, totaliza-se 820 mil pessoas, cerca de $20 \%$ da população da RIDE-DF e Entorno (IBGE, 2010).

Destaca-se as cidades de Águas Lindas de Goiás e Luziânia onde residem cerca de 160 mil habitantes em cada cidade e Valparaíso de Goiás com mais de 130 mil habitantes (IBGE, 2010). No estudo sobre a porcentagem de migrantes que chegaram no DF e entorno na década de 1990, Vasconcelos et al. (2006) afirmam que Águas Lindas de Goiás e Valparaíso de Goiás apresentam os maiores vetores de migração, sendo suas populações formadas, respectivamente, de $84,4 \%$ e $60,4 \%$ de migrantes.

A conurbação urbana que reúne: Distrito Federal, Cidade Ocidental, Novo Gama e Valparaíso de Goiás, habitam mais de 2,6 milhões de pessoas, representando 76,98\% da população de toda RIDE-DF e Entorno (IBGE, 2010). Dessa $83,97 \%$ da população reside no DF, 6,03\% em Luziânia, 4,13\% em Valparaíso de Goiás, 3,45\% em Novo Gama e 1,62\% em Cidade Ocidental.

O principal centro (Asa Norte, Asa Sul, Lago Norte, Lago Sul e proximidades) concentrou a maioria da atividades administrativas e econômicas. Além de sediar a administração pública federal e distrital, com seus inúmeros órgãos públicos, autarquias, tribunais, secretarias e embaixadas, o centro também concentrou as atividades econômicas do terciário moderno (CIDADE, 1999). Verifica-se assim a presença das maiores redes de lojas varejistas, os maiores shoppings, inúmeros 
escritórios, hospitais, escolas, universidades, empresas prestadoras de serviços às estatais, etc.

É nessa área onde o IBGE denomina subdistrito Brasília (Asa Norte, Asa Sul, Granja do Torto, Lago Norte, Lago Sul, Noroeste, Sudoeste, Taquari) que está o espaço de maior infraestrutura urbana, disponibilidade de serviços e sede de órgãos públicos. Nessa área habitam apenas $5 \%$ da população total, um pouco mais de 200 mil pessoas.

A concentração econômica no centro reflete diretamente no nível de renda dos moradores, nas maiores oportunidades de vagas de trabalho, nas melhores áreas residenciais e na maior disponibilidade dos equipamentos urbanos (CIDADE, 1999). Para ratificar a afirmação anterior, o último censo mostrou que a renda média mensal por domicílio no DF, correspondente a $\mathrm{R} \$ 2.097,83$, é uma das maiores das cidades brasileiras, bem maior que a RIDE-DF e Entorno, que apresenta valor médio mensal de $\mathrm{R} \$ 1.664,94$, e ambos apresentam rendimento superior da média nacional (R\$ 949,99).

Ressalta-se aqui também os dados censitários (IBGE, 2010) sobre o PIB da RIDE-DF e Entorno que evidencia a concentração econômica do DF. Dos R 160 bilhões de PIB da RIDE, o DF concentra 93,57\%, o que caracteriza uma fortíssima desigualdade de renda entre o DF e as demais cidades (IBGE, 2010). Porém é importante ressaltar que a distribuição dentro do território do DF apresenta grandes desigualdades socioeconômicas.

Ao analisar a participação dos setores econômicos no PIB da região, no ano de 2010 , destaca-se o setor de serviços, com $81,06 \%$ da participação no valor total do PIB (IBGE, 2010). O DF apresenta participação ainda maior neste setor, com 82,84\%. Dos demais setores, destaca-se o industrial, nos municípios de Alexânia, Cabeceira Grande e Luziânia que corresponde a cerca de 30\% do PIB. No setor agropecuário, destacam-se os municípios de Água Fria de Goiás, Cabeceiras, Cristalina e Mimoso de Goiás, que têm este setor respondendo a mais da metade dos seus PIBs (IBGE, 2010).

Constata-se assim, que a ausência de indústrias ou outro setor econômico forte não fez muita falta para o desenvolvimento econômico, sobretudo para o Distrito Federal. Para Ferreira; Penna (1996) as áreas mais periféricas, a ausência de indústrias, não criou a polarização de empregos como ocorre em outras cidades. 
Assim, a maioria das cidades situadas fora do centro da RIDE-DF e Entorno ficaram na dependência da função residencial para expandir atividades econômicas, ligadas ao comércio de bens de conveniência e algumas atividades manufatureiras tradicionais que não exigem ampla oferta de empregos, como confecções de roupas e pequenas fábricas (CIDADE, 1999). Após a consolidação dessas atividades nas novas áreas urbanas, a valorização e especulação imobiliária, gerou um ciclo que foi empurrando parte da população às periferias cada vez mais longínquas (FERREIRA; PENNA, 1996).

Afora a ausência da diversidade econômica, Doyle (1996) cita o monopólio estatal na terra urbana pelo governo do Distrito Federal (DF) como outro importante fator que reflete nas atuais características urbanas à RIDE- DF e entorno. Embora haja o monopólio estatal, o governo distrital age como uma inciativa privada favorecendo a especulação imobiliária e não disponibilizando condomínios populares próximos ao centro (GOUVÊA, 1995).

Aquilo que poderia favorecer a uma maior equidade social e um maior acesso à moradia, aos serviços e equipamentos urbanos essenciais, tornou um empecilho ao desenvolvimento regional. Para agravar a situação, sob a lógica da velha política clientelista, durante vários anos o governo distrital valeu-se do monopólio da terra para doar lotes e moradias em áreas mais periféricas e afastadas do centro (DOYLE, 1996).

Como afirma Peluso (2003a), a política de assentamentos só deu importância ao assentado porque ele era eleitor. O resultado dessa prática foi o surgimento de grandes assentamentos populares sem planejamento adequado, refletindo em baixa qualidade de vida e inúmeros problemas de ordem social. Assim muitos assentamentos transformaram em cidades, como: Ceilândia, Recanto das Emas, Riacho Fundo, Samambaia, Santa Maria e São Sebastião (PELUSO, 2003a)

Além de fins eleitorais, a doação das áreas públicas nas periferias também visou erradicar as invasões formadas na área planejada. Nesse sentido, Romero (2001) enfatiza o mal desempenho do Estado na regulação e gestão do uso do solo urbano, principalmente na implantação e operação de infraestrutura e serviços urbano básicos, como a moradia. Observa-se assim, que a política habitacional no DF preocupou-se apenas na oferta de espaços para moradias, ratificando mais uma vez o Plano Piloto como centro polarizador tornando cada vez mais perceptível a segregação socioespacial (FERREIRA; PENNA, 1996). 
Mesmo por motivos específicos, o resultado final do processo de urbanização na RIDE-DF e Entorno se concretizou de forma semelhante às demais metrópoles nacionais: centro com mais infraestrutura urbana e disponibilidade de serviços essenciais em contraste com as periferias. Isso não quer dizer que o planejamento urbano não foi executado. Paviani (2005) reitera que o surgimento dos novos núcleos no território, mesmo que na periferia, foram induzidos pelo planejamento urbano que privilegiou apenas parte da população, os mais ricos.

Por isso, Ferreira; Penna (1996) rechaçam a ideia dicotômica: centroperiferia, uma vez que a periferia não existe sem o centro e é para mantê-lo que elas existem, assim formam a unidade da cidade segmentada em classes sociais e segregada espacialmente. Esse fato gera aquilo que Paviani (2005) denomina de perspectivas distintas para a periferia e o Plano-Piloto e adjacências (centro). Enquanto no centro aparece soluções urbanísticas e arquitetônicas, na periferia urge as carências, os descompromissos, a demora e ausência de serviços básicos. Por isso, Paviani (2005, p. 194) denomina o DF como "espaço de exclusão social, propício a todas as formas de violência".

Ao aplicar o Índice de Vulnerabilidade Social (IVS - IPEA, 2015) na área analisada (Figura 49), observa-se claramente índices díspares que refletem a discussão anterior. O centro tem menores IVS (azul) enquanto as periferias os maiores índices (laranja e vermelho). 


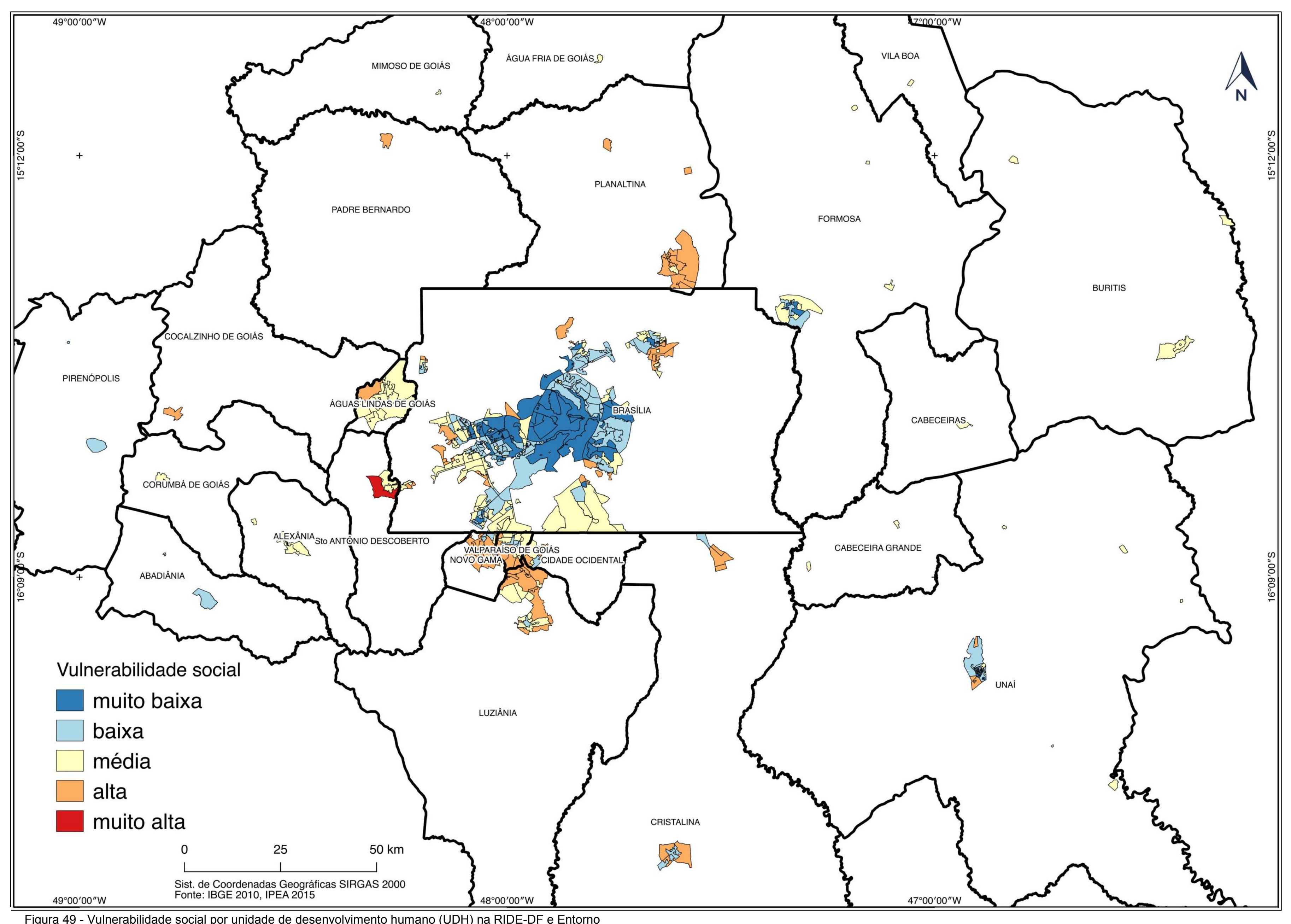

Figura 49 - Vulnerabilidade social por unidade de desenvolvimento humano (UDH) na RIDE-DF e Entorno 
As disparidades socioespaciais podem ser melhor exemplificadas ao descrever os seguintes extremos. Um lado representado pelo Lago Sul (Figura 50), com baixa vulnerabilidade social (IVS: 0,05), de acordo com a última pesquisa por amostras de domicílios (PNAD, 2014) realizada pela Companhia de Planejamento do DF, o Lago Sul apresenta um Índice de Desenvolvimento Humano (IDH) de 0,945 . Se fosse um país ele estaria no topo da lista, a frente da Noruega e da Suécia, países que lideram o ranking de IDH. Quanto à distribuição de renda, o Lago Sul com menos de $1 \%$ da população do DF concentra $40 \%$ da renda total da capital federal (CODEPLAN, 2016).

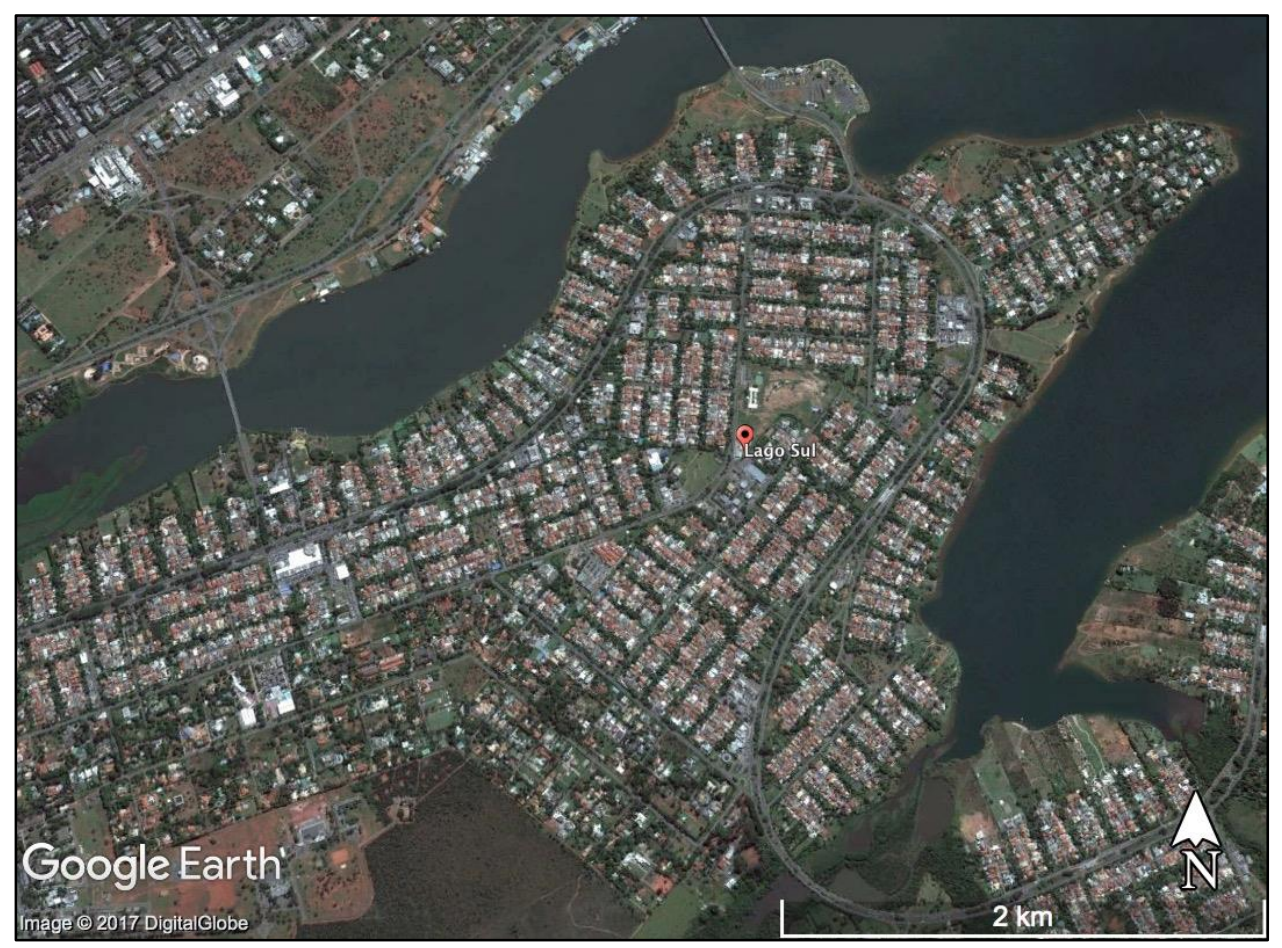

Figura 50 - Imagem aérea Lago Sul - Brasília.

Fonte: Google-Earth (2017)

Do outro extremo, encontra-se o maior aglomerado subnormal do Distrito Federal e um dos maiores no Brasil. Área pertencente à região administrativa de Ceilândia, conhecida como Condomínio Sol Nascente (Figura 51). Segundo dados do censo demográfico (IBGE, 2010), a área possui quase 57 mil moradores vivendo sem infraestrutura e serviços básicos. A falta de saneamento básico, o número elevado de criminalidade e a ausência do Estado na prestação dos serviços básicos, refletem no elevado IVS: 0,45. 


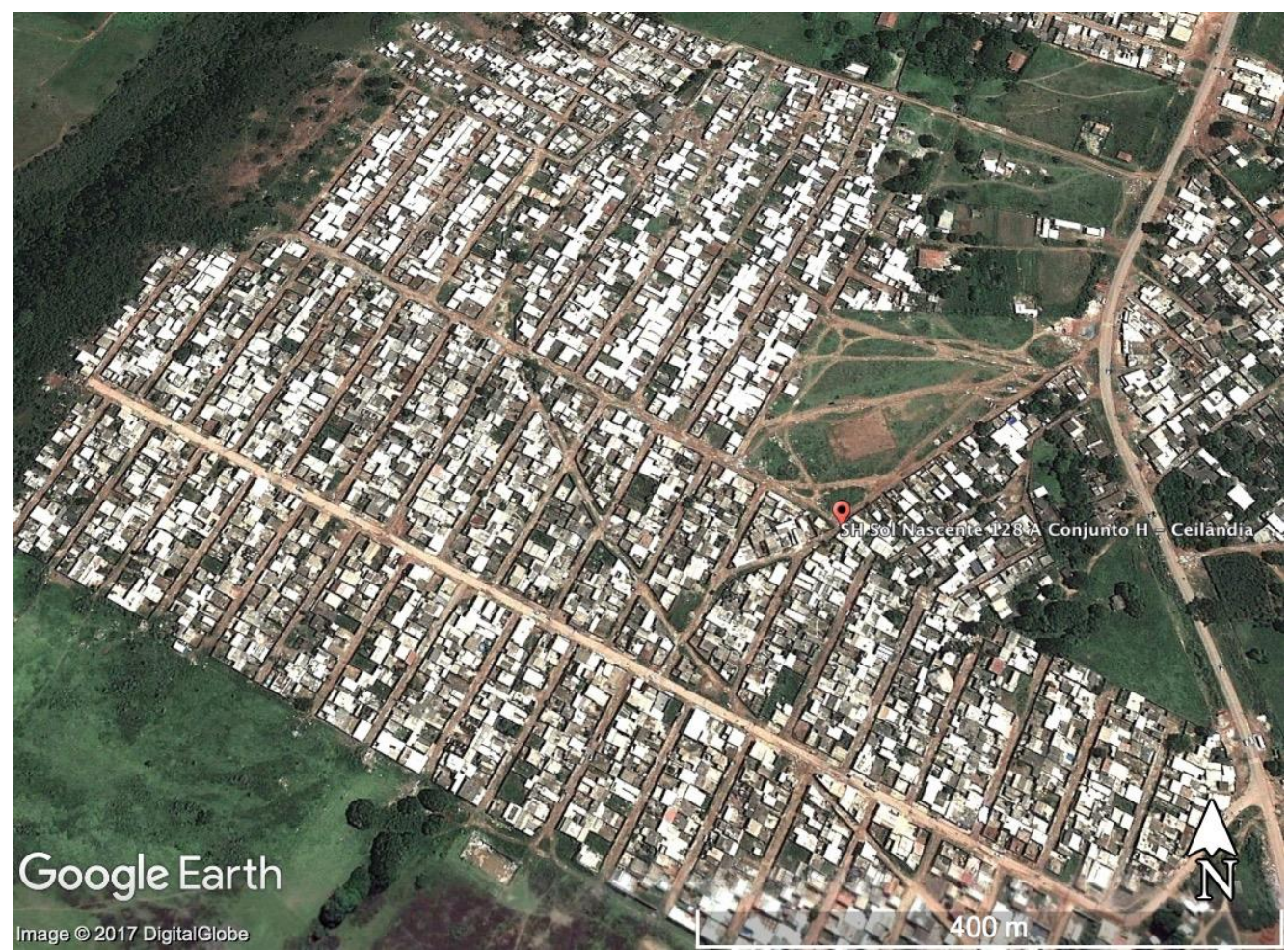

Figura 51 - Imagem aérea Condomínio Sol Nascente - Ceilândia (DF).

Fonte: Google-Earth (2017)

É importante ressaltar que a maior parte das áreas com elevado IVS não estão nas regiões administrativas do DF, mas transbordam para a sua fronteira. A falta de dinamismo econômico do entorno resultam na alta vulnerabilidade social. $\mathrm{O}$ resultado disso é o crescimento do setor informal e o aumento da dependência econômica ao centro. Assim verifica-se os fluxos pendulares na busca de oportunidades, de postos de trabalho e na prestação de serviços básicos como saúde e educação (FONTOURA, 2012).

Enquanto a vulnerabilidade social se sobressai nas cidades do entorno, a população fica cada vez mais refém da violência urbana. De acordo com o último estudo publicado pelo IPEA (2017), sobre violência nas cidades, os municípios de Luziânia e Novo Gama listam entre os 30 mais violentos do país (CERQUEIRA et al., 2017). Estudo feito por Costa; Souza (2012) relata que nos municípios de Águas Lindas de Goiás, Valparaíso de Goiás e Luziânia ocorrem 62,8\% dos homicídios de toda RIDE-DF e Entorno. Entre 2000 e 2010, os municípios limítrofes do DF apresentaram aumento de $59,3 \%$ nas taxas de homicídios, com destaque para Valparaíso (168\%) e Águas Lindas de Goiás (137\%).

Ao abordar tal problemática, é comum remeter como causas, quase que exclusivamente, à falta de oportunidade de emprego, ao déficit educacional nas 
áreas de grande vulnerabilidade social e a ausência do Estado na prestação de serviços básicos. No entanto, é importante analisar a carência de espaços de lazer e de práticas culturais, esportivas e educativas que promovam cidadania e bemestar social, como maneiras de minimizar a violência urbana e as desigualdades sociais.

No caso da capital federal, Romero (2005) ao analisar a quantidade de áreas de lazer no DF, verificou que o Plano Piloto tem quase 105 vezes mais espaços de lazer do que a região administrativa de Ceilândia. A autora qualifica a desigualdade de acesso a espaços de lazer nas áreas periféricas do DF como constrangedora. Dada tal problemática, apesar da grande quantidade dos espaços verdes no Distrito Federal, elas não são utilizadas por todos, tampouco são estabelecidas como equipamentos urbanos, principalmente na periferia.

Como já discutido, os espaços verdes têm enorme potencial para promoção social. Identificar e localizar os espaços verdes na RIDE-DF e Entorno, é o primeiro passo para estruturar planos que garantam sua vitalidade e uso conforme enunciado por Jacobs (2011), buscando assim maior qualidade de vida à população sob viés da sustentabilidade.

Reitera-se portanto que "o projeto modernista da capital federal, que carregava uma utopia de determinismo espacial foi desfeita pela realidade social do país e adaptou-se às diferenças promovidas e reforçadas pelo modelo socioeconômico brasileiro" (CIDADE, 1999, p. 249). "A cidade que nasceu para ser una e igualitária a partir do Plano Piloto" (PAVIANI, 2005, p. 193) ainda promove uma forte desigualdade social e a desigualdade de uso dos espaços públicos, como os espaços verdes urbanos.

Por isso, a análise dos espaços verdes urbanos na RIDE-DF e Entorno vem ao encontro da aspiração dessa cidade a ser "vivida" por todos os seus habitantes e humanizada, longe dos mecanismos que promoveram a e reforçam todos os tipos de desigualdades. 


\subsubsection{Espaços Verdes Urbanos na RIDE-DF e Entorno}

O mapeamento identificou a porção de $635,95 \mathrm{~km}^{2}$ de espaços verdes urbanos no recorte proposto (Figura 53). Esse valor corresponde a $30,22 \%$ da área analisada da RIDE-DF e Entorno. A tabela a seguir mostra a proporção das áreas analisadas e dos EVU por Unidade da Federação (UF).

A maior parte dos EVU concentram-se no Distrito Federal com a área de $401,01 \mathrm{~km}^{2}$, o que representa $63 \%$ de todos os EVU da RIDE-DF e Entorno. Em termos de porcentagem, existem cidades goianas com maior porcentagem de espaços verdes, como: Abadiânia, Mimoso de Goiás e Santo Antônio de Descoberto, porém as áreas territoriais dessas cidades não chegam $10 \%$ a de Brasília, vide Tabela 3.

Tabela 3 - Dados dos dos espaços verdes urbanos nas cidades a da RIDE-DF e Entorno

\begin{tabular}{|c|c|c|c|c|c|}
\hline UF & Cidades & Área km² & EVU km² & \% EVU/Área & $\%$ EVU/UF \\
\hline $\mathrm{DF}$ & Brasília & 1238,28 & 401,01 & 32,38 & 63,06 \\
\hline & Abadiânia & 16,14 & 7,81 & 48,38 & \\
\hline & Alexânia & 19,41 & 6,85 & 35,3 & \\
\hline & Cabeceiras & 4,34 & 1,27 & 29,36 & \\
\hline & Cidade Ocidental & 25,15 & 5,29 & 21,04 & \\
\hline & Cocalzinho de Goiás & 8,72 & 1,52 & 17,39 & \\
\hline & Corumbá de Goiás & 5,34 & 1,29 & 24,2 & \\
\hline & Cristalina & 65,19 & 19,62 & 30,1 & \\
\hline & Formosa & 66,43 & 9,34 & 14,05 & \\
\hline & Água Fria de Goiás & 2,32 & 0,8 & 34,36 & \\
\hline \multirow[t]{11}{*}{ GO } & Águas Lindas de Goiás & 152,75 & 34,31 & 22,46 & 34,53 \\
\hline & Luziânia & 127,6 & 35,55 & 27,86 & \\
\hline & Mimoso de Goiás & 0,85 & 0,46 & 53,96 & \\
\hline & Novo Gama & 60,9 & 14,95 & 24,55 & \\
\hline & Padre Bernardo & 8,01 & 1,35 & 16,82 & \\
\hline & Pirenópolis & 13,31 & 5,88 & 44,16 & \\
\hline & Planaltina & 100,65 & 39,47 & 39,21 & \\
\hline & Santo Antônio do Descoberto & 36,85 & 14,08 & 38,21 & \\
\hline & Valparaíso de Goiás & 61,41 & 19,31 & 31,44 & \\
\hline & Vila Boa & 1,47 & 0,42 & 28,32 & \\
\hline & Buritis & 33,35 & 8,51 & 25,52 & \\
\hline \multirow[t]{3}{*}{ MG } & Cabeceira Grande & 3,36 & 0,19 & 5,68 & 2,42 \\
\hline & Unaí & 52,63 & 6,68 & 12,69 & \\
\hline & Total & 2104,47 & 635,95 & 30,22 & 100,00 \\
\hline
\end{tabular}

Fonte: Elaborada pelo autor 


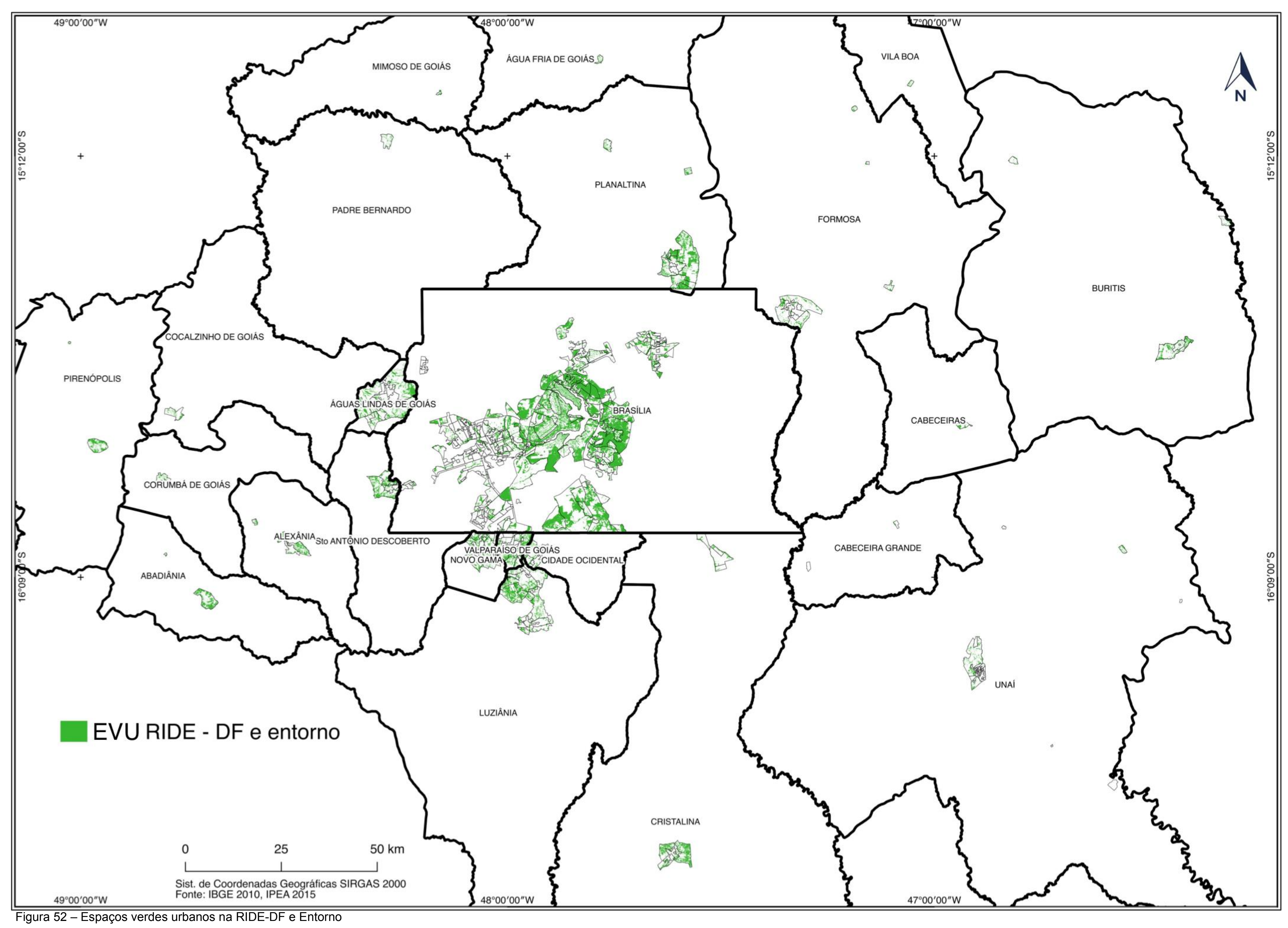


A cidade que apresentou menor quantidade de espaços verdes foi Cabeceira Grande (MG). De acordo com o último censo (IBGE, 2010), esta cidade possui base econômica bastante ligada ao agronegócio (34\% do PIB municipal). A figura 53 mostra que o município tem extensas áreas de monocultura que adentram até nos limites urbanos analisados, refletindo na baixa quantidade dos EVU.

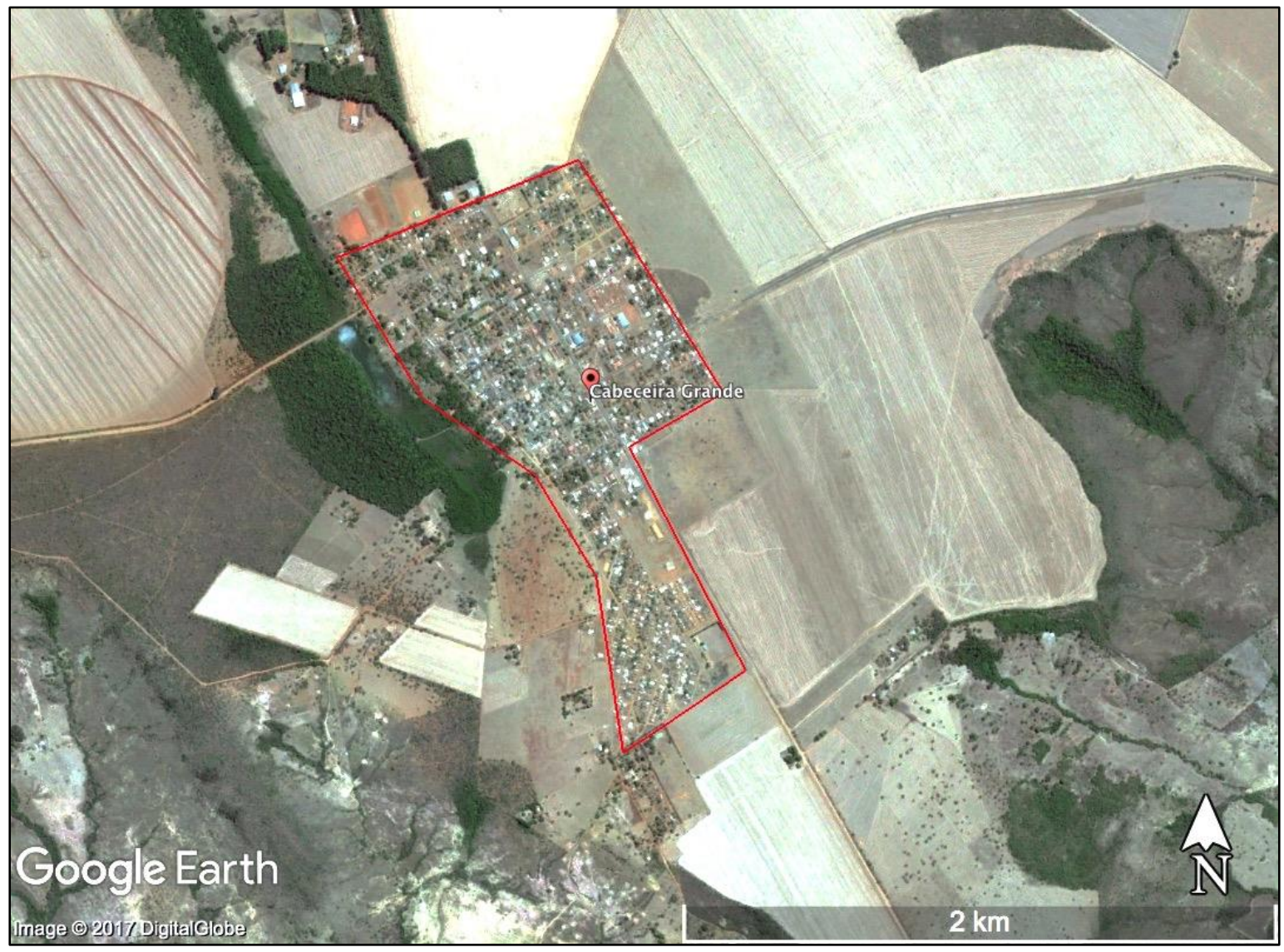

Figura 53 - Imagem áreas de Cabeceira Grande (MG). Monoculturas cercam a cidade. Fonte: Google-Eart (2017)

Pelo mesmo motivo, verifica-se poucos EVU em Unaí (MG), com apenas $12,69 \%$ e nas cidades goianas de Formosa com 14,05\% e Padre Bernardo com $16,82 \%$. 


\subsubsection{Espaços Verdes Urbanos e Áreas Protegidas (UCs e APM)}

Quanto aos espaços verdes urbanos analisados como áreas protegidas, destaca-se que o Distrito Federal apresenta aproximadamente $90 \%$ do território ocupado por Unidades de Conservação da Natureza (UC). Considerando toda área analisada da RIDE-DF e Entorno, 68,60\% é área protegida (Figura 54), por critérios do Sistema Nacional de Unidades de Conservação da Natureza (SNUC), instituído pela Lei Federal nº 9.985 (BRASIL, 2000).

No caso específico do Distrito Federal, a preservação do território foi algo planejado e recorrente desde sua construção (PELUSO, 2003a). Para a referida autora, o motivo principal foi evitar a instalação de núcleos populacionais próximos do Plano Piloto, com o objetivo de manter o centro urbano de acordo com o planejado. O segundo motivo, era preservar os recursos naturais indispensáveis para o funcionamento da cidade planejada, sobretudo os recursos hídricos (PELUSO, 2003a).

Assim, o Parque Nacional de Brasília foi a primeira área protegida criada em 1961 para preservar as Águas Emendadas, lugar de dispersão das bacias do São Francisco, Paraná e Paraguai (PELUSO, 2003a). Inúmeros espaços verdes foram legalmente assegurados à preservação ambiental ao longo dos quase 60 anos de Brasília. No entanto, os instrumentos legais para a efetiva atuação dos órgãos governamentais têm seguido "o predomínio dos interesses individuais sobre os coletivos e transformando, paulatinamente, os espaços públicos em territórios privados" (PELUSO, 2003a, p. 23).

Marques (2015) ressalta que no DF, as áreas protegidas são diferenciadas e vão além dos espaços protegidos listados conforme as doze categorias da Lei do SNUC (BRASIL, 2000). A partir da criação do Sistema Distrital de Unidades de Conservação da Natureza - SDUC (DISTRITO-FEDERAL, 2010) foram criadas unidades que somente existem no DF, como: os parques ecológicos (PEc), de uso múltiplo e reservas ecológicas (REc).

A Tabela 4 mostra a quantidade de área protegida e de EVU dentro do recorte proposto. Das áreas protegidas, apenas $32 \%$ é considerada EVU. No entanto, observa-se a importância das áreas protegidas, uma vez que $72,68 \%$ de todos os EVU mapeados na RIDE-DF e Entorno, estão dentro delas. 


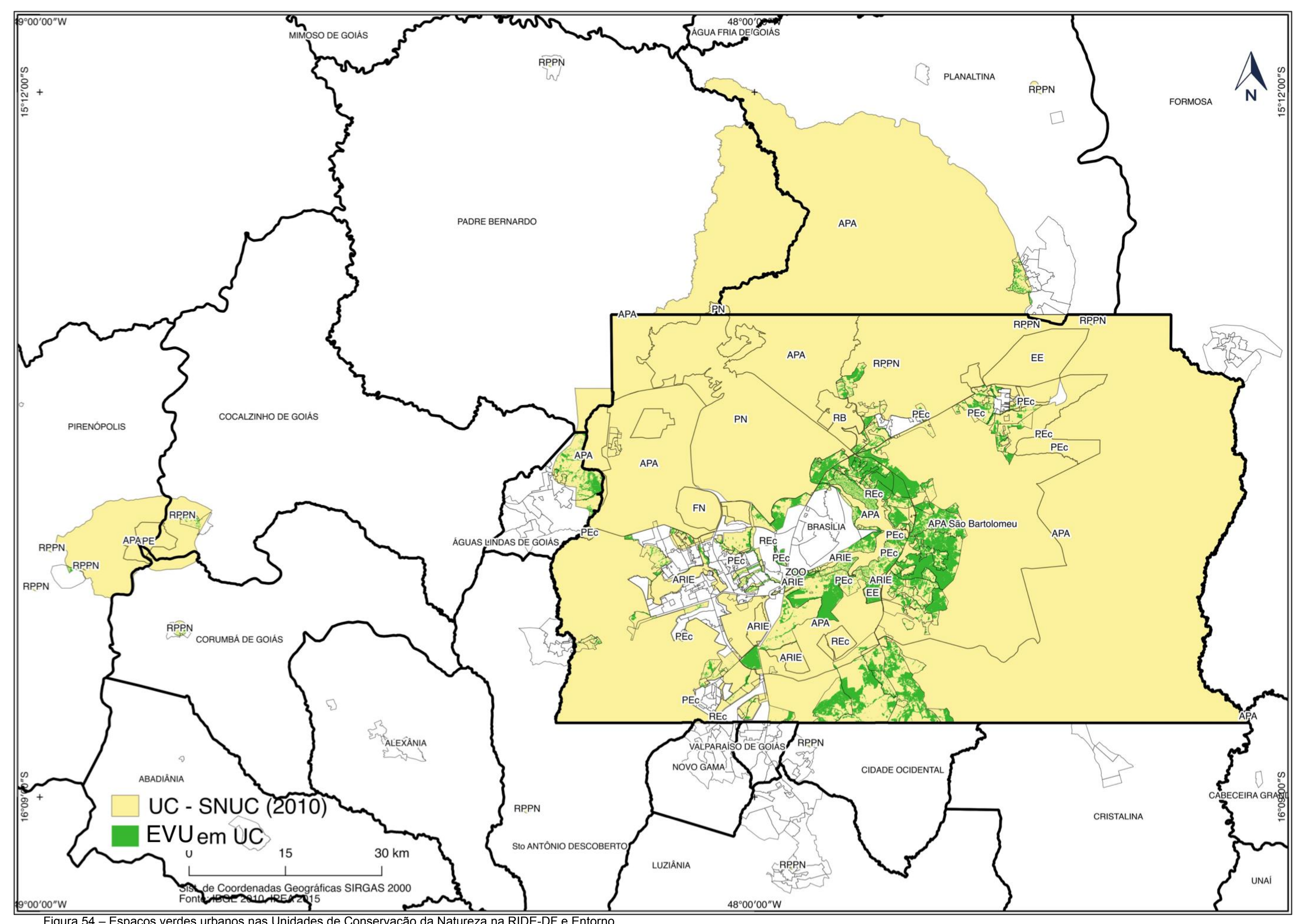

Figura 54 - Espaços verdes urbanos nas Unidades de Conservação da Natureza na RIDE-DF e Entorno 
Tabela 4 - Espaços verdes urbanos nas Unidades de Conservação da Natureza na RIDE-DF e Entorno

\begin{tabular}{llll}
\hline Nome da Área Protegida & Área $\mathrm{km}^{2}$ & EVU km & \% EVU/Área \\
\hline APA da Bacia do Rio Descoberto & 108,89 & 22,69 & 20,84 \\
APA da Bacia do Rio São Bartolomeu & 83,64 & 31,69 & 37,89 \\
APA da Serra dos Pireneus & 22,03 & 7,39 & 33,56 \\
APA Bacias do Gama e Cabeça de Veado & 385,41 & 114,31 & 29,66 \\
APA do Cafuringa & 28,68 & 9,94 & 34,67 \\
APA do Lago Paranoá & 156,61 & 98,63 & 62,98 \\
APA do Planalto Central & 427,58 & 118,44 & 27,70 \\
ARIE JK & 47,94 & 5,10 & 10,65 \\
ARIE Paranoá Sul & 34,78 & 19,24 & 55,31 \\
EE de Águas Emendadas & 1,09 & 0,15 & 14,22 \\
PEc de Sobradinho & 11,88 & 2,42 & 20,34 \\
PEc do Bosque dos Eucaliptos & 3,62 & 1,03 & 28,43 \\
PEc do Guará & 20,98 & 5,84 & 27,85 \\
PEc e Vivencial da Lagoa J Medeiros & 10,04 & 3,16 & 31,42 \\
PEc e Vivencial de Candangolândia & 11,77 & 3,47 & 29,47 \\
PEc e Vivencial do Retirinho & 18,77 & 4,03 & 21,47 \\
PEc Águas Claras & 7,21 & 1,09 & 15,18 \\
REc do Gama & 1,95 & 0,03 & 1,74 \\
REc do Guará & 2,51 & 1,28 & 50,79 \\
RPPN Fazenda Cachoeirinha & 8,01 & 1,35 & 16,82 \\
RPPN Fazenda Santa Mônica & 5,34 & 1,29 & 24,20 \\
RPPN Itapuã & 29,24 & 6,22 & 21,28 \\
RPPN Sítio Estrela Dalva & 15,63 & 3,43 & 21,93 \\
\hline Total & $\mathbf{1 4 4 3 , 6 0}$ & $\mathbf{4 6 2 , 2 2}$ & $\mathbf{3 2 , 0 2}$ \\
\hline Total UDH Analisadas & 2104,47 & 635,95 & 30,22 \\
\% Total Área Protegida/Total Analisado & 68,60 & 72,68 & \\
\hline \hline
\end{tabular}

Fonte: Elaborada pelo autor

Conforme mostra a Tabela 5, as maiores UCs, assim como os maiores EVU no interior delas encontram-se na categoria de Área de Proteção Ambiental (APA) - (SNUC, 2010). Na prática, a classificação de APA cobre a maior parte analisada da RIDE-DF e Entorno, chegando a $84,02 \%$ do território. Do total dos EVU mapeados, $403,09 \mathrm{~km}^{2}$ (correspondente a $63 \%$ dos EVU) estão dentro de APA.

Pelo SNUC (BRASIL, 2000), a APA permite o uso "controlado" e visa conservar a biodiversidade e disciplinar de forma conciliada a ocupação humana e o uso dos recursos naturais. Devido às características do uso da terra atrelado ao grau de ocupação, a APA apresenta o menor nível de proteção (VIANA; GANEM, 2005). 
Tabela 5 - Espaços verdes urbanos por tipo de Unidade de Conservação da Natureza na RIDE-DF e entorno

\begin{tabular}{llllll}
\hline Tipo & Área $\mathrm{km}^{2}$ & EVU km & \% Área & \%EVU & \% EVU /Área \\
\hline APA & 1212,84 & 403,09 & 84,02 & 87,21 & 33,24 \\
ARIE & 82,72 & 24,34 & 5,73 & 5,27 & 29,42 \\
EE & 1,09 & 0,15 & 0,08 & 0,03 & 13,76 \\
PEc & 84,27 & 21,04 & 5,84 & 4,55 & 24,97 \\
REc & 4,46 & 1,31 & 0,31 & 0,28 & 29,37 \\
RPPN & 58,22 & 12,29 & 4,03 & 2,66 & 21,11 \\
\hline Total & $\mathbf{1 4 4 3 , 6}$ & $\mathbf{4 6 2 , 2 2}$ & $\mathbf{1 0 0}$ & $\mathbf{1 0 0}$ & $\mathbf{3 2 , 0 2}$ \\
\hline \hline
\end{tabular}

Fonte: Elaborada pelo autor

A justificativa da criação de APA relaciona-se com a tentativa de deter pressões de alterações do uso de áreas já ocupadas que possuem alto grau de fragilidade ambiental. Na prática, apesar de fazerem parte do SDUC (DISTRITO-FEDERAL, 2010), SNUC (BRASIL, 2000) e envolverem quase todo território do Distrito Federal, elas têm pouca importância na conservação da biodiversidade e não se mostram eficazes para manter usos tradicionais do solo (MARQUES, 2015).

Exemplo disso é alta a concentração de condomínio privados (regularizados e irregulares) nas APAs do Distrito Federal. Penna (2016) ao analisar a fragmentação do ambiente urbano do DF, destaca a APA do rio São Bartolomeu onde se localizam os parcelamentos privados mais consolidados, a maioria implantados de forma ilegal. Nesse sentido Peluso (2003b) afirma que ao longo da história de Brasília, as áreas de conservação da natureza são alvos de constante ataque de interesses particulares em oposição a importância dessas áreas à coletividade, seja para lazer ou para preservação de recursos indispensáveis, como a água.

Em se tratando de água, o DF apresenta legislação exclusiva para proteção dos mananciais. Através do Plano de Ordenamento Territorial do DF (PDOT-DF) Lei Complementar $\mathrm{n}^{\circ} 17$ (DISTRITO-FEDERAL, 1997) ficaram constituídas as Áreas de Proteção de Mananciais - APM, posteriormente regulamentadas pelo Decreto 18.585 (DISTRITO-FEDERAL, 1997b). A APM destina-se à conservação, recuperação e manejo das bacias hidrográficas situadas à montante dos pontos de captação de água, sendo vedado o parcelamento do solo urbano ou rural nestas áreas.

A Figura 55 e a Tabela 6 mostra o quanto de APM foi mapeada no recorte proposto. Em termos de porcentagem, $8,20 \%$ do território do DF é considerada APM. Da área analisada, a proporção é menor, alcançando a 5,55\%. Dos EVU analisados no DF, 
$5,77 \%$ encontra-se dentro desse tipo de área protegida. As APMs com EVU mais representativas foram: Córrego Catetinho $\left(9,47 \mathrm{~km}^{2}\right)$ e Taquari $\left(5,13 \mathrm{~km}^{2}\right)$.

Tabela 6 - Espaços verdes urbanos nas Áreas de Proteção de Mananciails na RIDE-DF e Entorno

\begin{tabular}{llll}
\hline APM & Área $\mathrm{km}^{2}$ & $\mathrm{EVU} \mathrm{K \textrm {K } ^ { 2 }}$ & $\%$ EVU/Área \\
\hline Barragem do Descoberto & 1,27 & 0,73 & 57,59 \\
Bartolomeu jusante & 0,85 & 0,42 & 49,45 \\
Bartolomeu montante & 2,41 & 1,29 & 53,38 \\
Brazlândia & 0,19 & 0,00 & 0,00 \\
Cachoeirinha & 13,76 & 2,96 & 21,54 \\
Contagem & 0,07 & 0,00 & 0,00 \\
Corguinho & 0,48 & 0,00 & 0,00 \\
Córrego Alagado & 5,73 & 1,97 & 34,35 \\
Córrego Catetinho & 22,70 & 9,47 & 41,70 \\
Córrego Crispim & 2,91 & 0,00 & 0,03 \\
Córrego Currais & 10,78 & 1,02 & 9,50 \\
Córrego Fumal & 0,41 & 0,00 & 0,34 \\
Córrego Olho D'água & 5,84 & 0,00 & 0,03 \\
Córrego Quinze & 0,09 & 0,02 & 23,89 \\
Mestre D'armas & 1,11 & 0,03 & 2,76 \\
Ponte de Terra & 0,14 & 0,07 & 51,99 \\
Taquari & 5,43 & 5,13 & 94,49 \\
\hline Total & 68,74 & 23,12 & 33,63 \\
\hline Total Analisado (DF) & 1238,28 & 401,01 & \\
\% Total APM / Total Analisado & 5,55 & 5,77 & \\
\hline \hline
\end{tabular}

Fonte: Elaborada pelo autor 


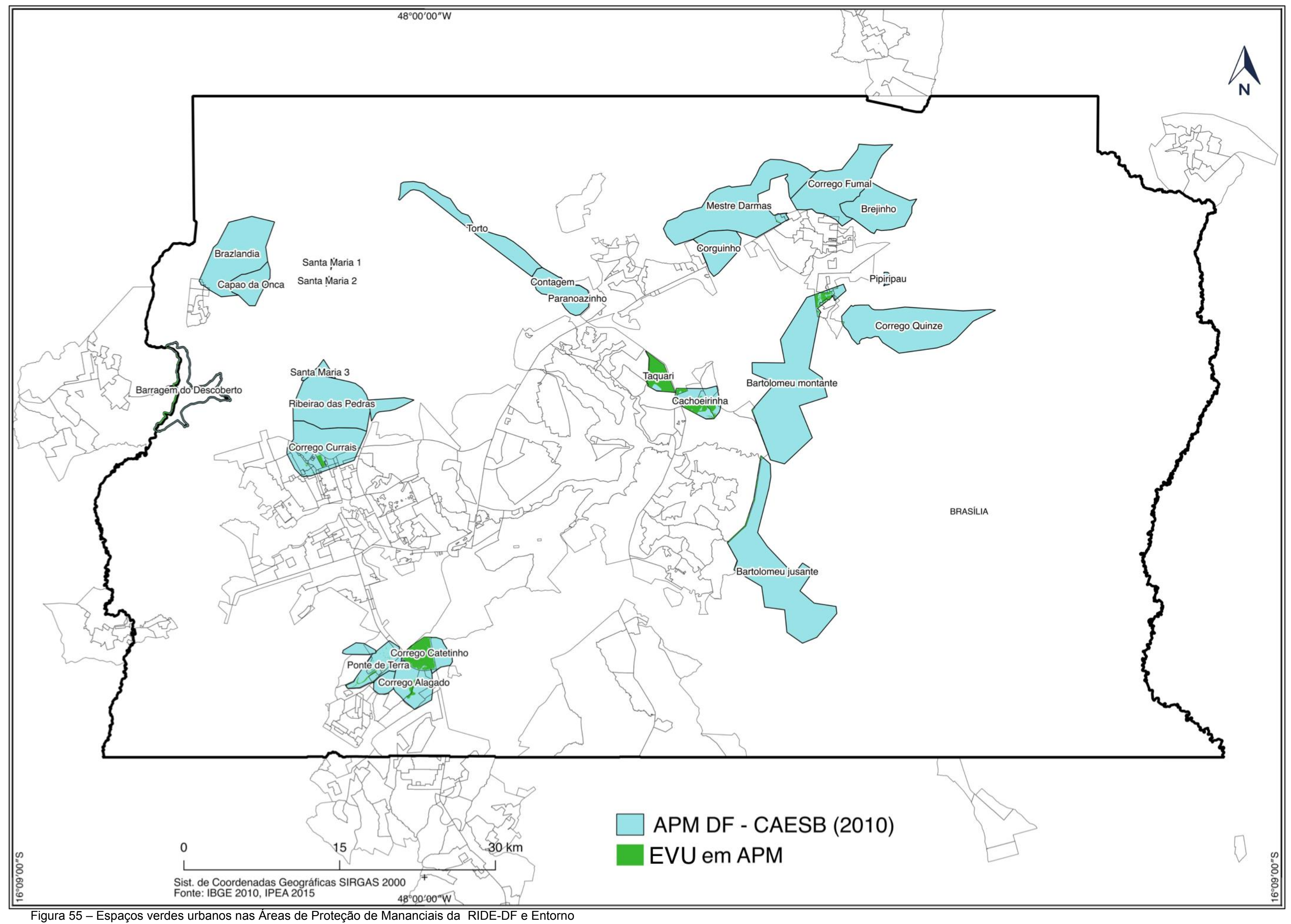

Figura 55 - Espaços verdes urbanos nas Áreas de Proteção de Mananciais da RIDE-DF e Entorno 


\subsubsection{Espaços verdes urbanos nas unidades de desenvolvimento humano}

Quanto à concentração dos espaços verdes por UDH, a Figura 57 mostra uma grande concentração no Plano Piloto, variando de $30 \%$ a $60 \%$ dos EVU. O planejamento da capital proposto por Lúcio Costa, explica os valores elevados. Segundo a definição do próprio urbanista, a cidade planejada foi criada "de uma parte, técnica rodoviária, de outra, técnica paisagística de parques e jardins. Brasília, capital aérea e rodoviária, cidade parque ${ }^{11 "}$ (COSTA, 1991, p. 34).

Várias cidades no mundo tentaram aplicar o conceito de cidade parque, mas de acordo com Silva (2003), o Plano Piloto de Brasília é um dos raros exemplos em que foi aplicado na sua totalidade. Seguindo os princípios de cidade parque, os construtores conseguiram edificar o Plano Piloto, com uma zona de proteção não edificável no seu entorno, contendo bosques e florestas. No interior da área planejada, os estacionamentos das superquadras foram cobertos por áreas verdes, assim como as áreas adjacentes às vias, seus cruzamentos e os espaços entre prédios residenciais e/ou comerciais (Figura 56).

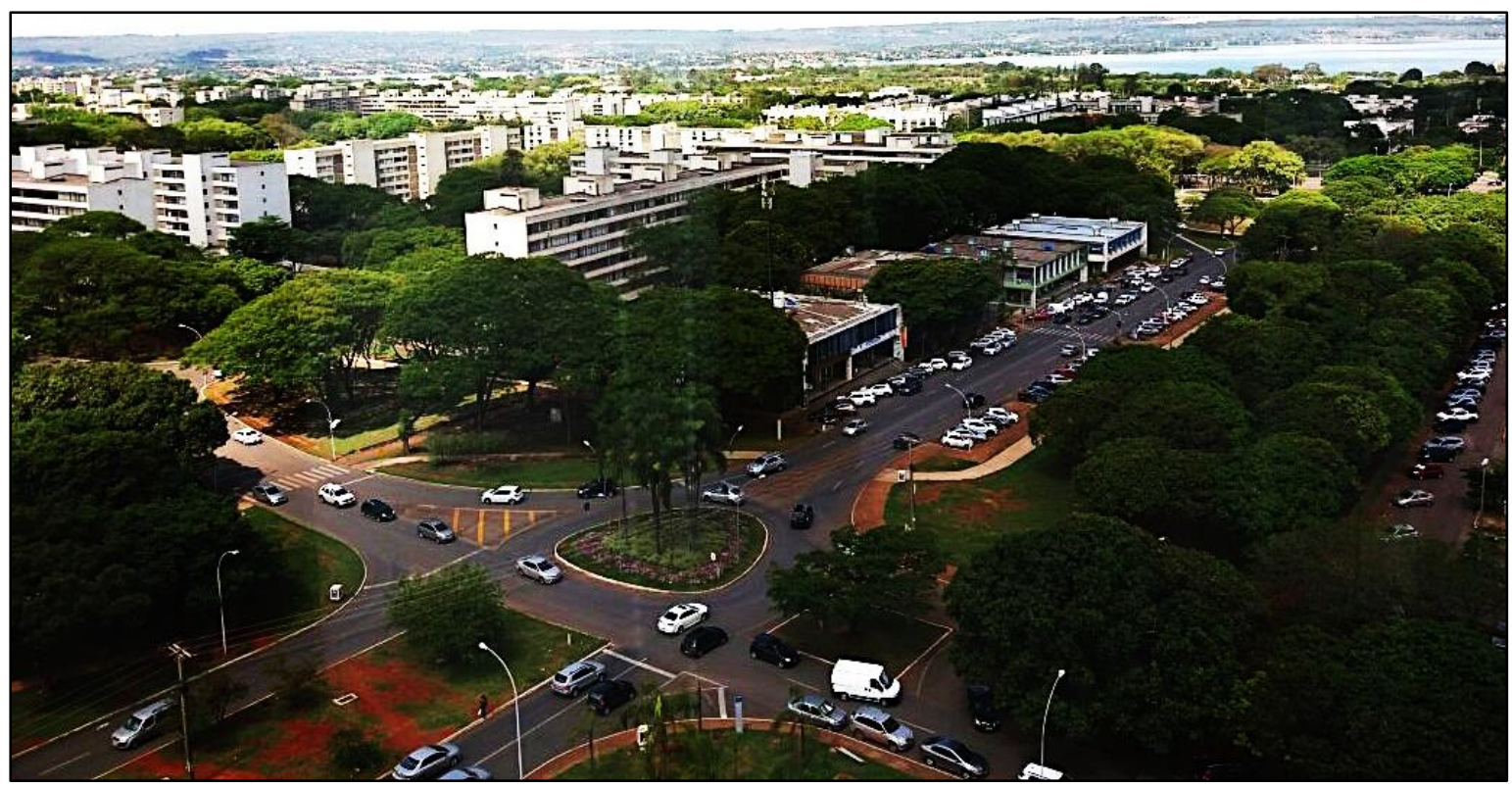

Figura 56 - Espaços verdes urbanos nas super-quadras do Plano-Piloto. Quadra 102 Norte. Fonte: Lins, Cláudia (2017)

11 O conceito de "cidade parque" foi estabelecido na Carta de Atenas - 1933. A carta reuniu postulados a partir de concepções modernistas discutidos nos Congressos Internacionais de Arquitetura Moderna. Os princípios da Carta são: as cidades devem cumprir a função de habitar, trabalhar, recrear e circular, sob um conjunto de edifícios e casas arborizadas, convivendo harmonicamente com a natureza, priorizando o verde (CORBUSIER; GIRAUDOUX, 1993). 


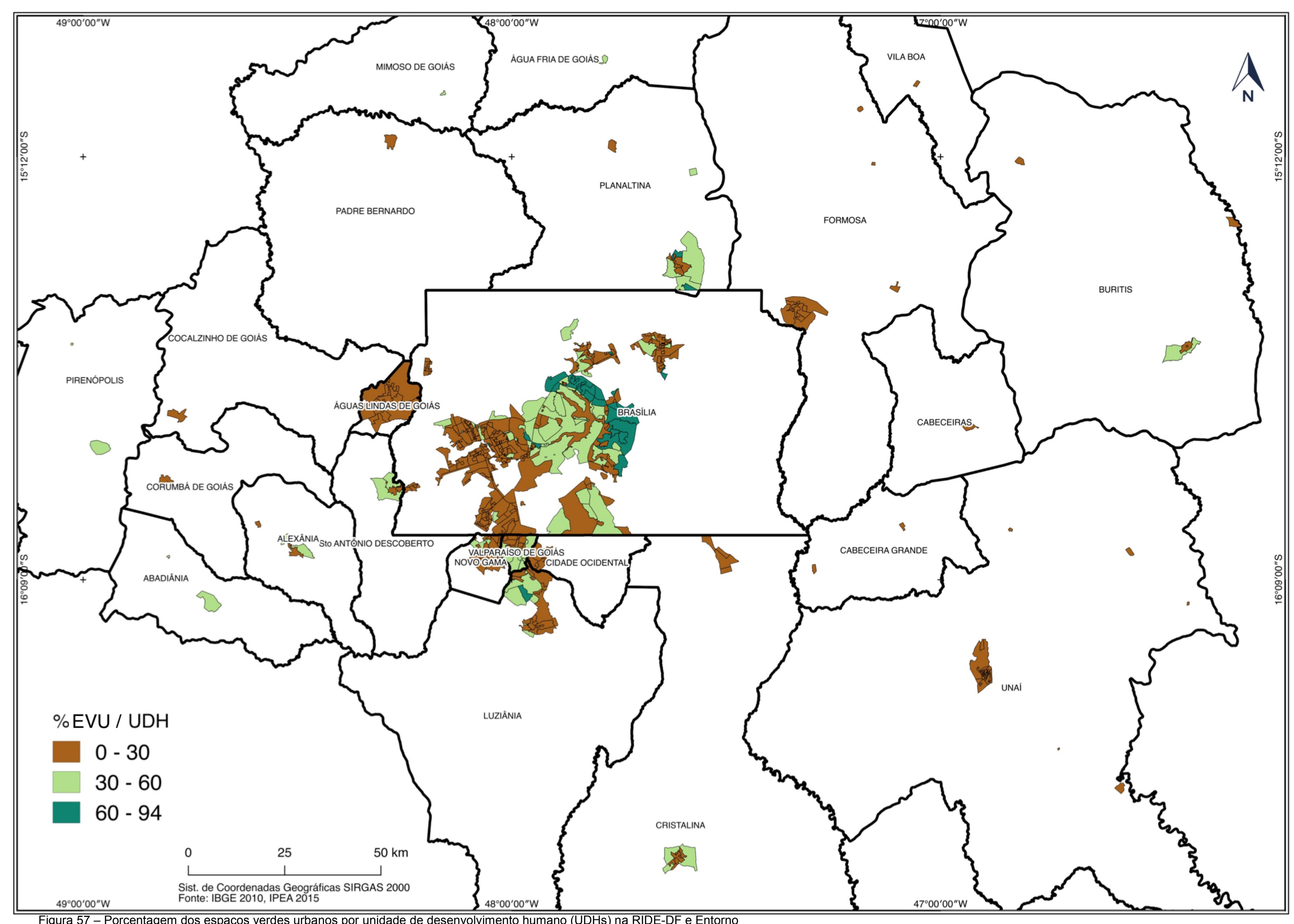


Além do Plano Piloto, destaca-se a quantidade elevada dos EVU (entre 60\% a 94\%) nas UDHs na porção leste de Brasília (Granja do Torto, Taquari, Condomínios do Itapoã, Jardim Botânico e condomínio próximos). O fato do valor estar elevado precisa ser analisado sob o seguinte fator metodológico: a maioria dessas UDHs estão localizadas em situação do setor qualificadas pelo IBGE como “ situação 2".

Conforme a descrição das variáveis do último censo a "situação setor 2" corresponde a:

área não urbanizada de vila ou cidade, setor urbano situado em áreas localizadas dentro do perímetro urbano de cidades e vilas reservadas à expansão urbana ou em processo de urbanização; áreas legalmente definidas como urbanas, mas caracterizadas por ocupação predominantemente de caráter rural (IBGE, 2011, p. 39).

Apesar da descrição do IBGE remeter a "área não urbanizada", o que se verifica é que essas áreas são "núcleos urbano informais consolidados ${ }^{12 ", ~}$ considerando o "tempo de ocupação, localização das vias de circulação e a presença de equipamentos urbanos, mesmo que precários" (BRASIL, 2017 - Art. 11, inciso III). O fato é que nessa região, há um número elevado de condomínios privados que avançam sobre áreas urbanas e rurais, em terras particulares ou públicas griladas (GANEM et al., 2008).

Destaca-se principalmente a ocupação irregular de condomínios sobre as APAs do Rio São Bartolomeu e do Lago Paranoá, direcionando a expansão urbana para uma região onde os planos diretores proíbem á expansão urbana (GANEM et al., 2008). A proibição visa minimizar riscos da urbanização em uma área ambientalmente frágil, decorrente da ampla presença de vegetação nativa de cerrado sob acentuada declividade e a presença de matas ciliares protegendo importantes cursos d'água.

\footnotetext{
12 Conceito estabelecido pela Lei Federal no 13.465 - Lei que trata da Regularização Fundiária Rural e Urbana (BRASIL, 2017). O texto traz novas normas para a regularização fundiária urbana (Reurb) e rural. No artigo 11, a lei cria o seguintes conceitos: a) núcleo urbano informal, que são os clandestinos, irregulares ou aqueles nos quais, atendendo à legislação vigente à época da implantação ou regularização, não foi possível realizar a titulação de seus ocupantes; b) núcleo urbano informal consolidado: aquele de difícil reversão, considerados o tempo da ocupação, a natureza das edificações, a localização das vias de circulação e a presença de equipamentos públicos.
} 
Embora o próprio governo distrital, por meio do Plano Diretor de Ordenamento Territorial do Distrito Federal (PDOT - DF) descreva essa área como de expansão urbana descontrolada (SEDUMA, 2007), a tendência é que ocorra a regularização fundiária da maioria dos condomínios ali instalados. O surgimento de legislações como a Lei no 13.465 (BRASIL, 2017), além da pressão dos moradores e de agentes imobiliários frente a irreversibilidade no processo de ocupação, indicam que os condomínios tendem a serem regularizados, aumentando a expansão urbana onde a cobertura vegetal ainda é extensa.

O que se verifica no Distrito Federal, nessa área em particular, é que apesar de existirem instrumentos legais para a manutenção de terras livres como patrimônio da cidade, como um bem coletivo, os mesmos mostraram-se ineficientes. De acordo com Peluso (2003a), ainda perdura no DF a prática de apropriação privada de territórios vazios para a produção de riquezas, representado no caso pelos condomínios de classe média instalados em áreas de proteção ambiental.

As UDHs dos municípios do entorno com maior quantidade de espaços verdes destacam-se Abadiânia, Cristalina e Pirenópolis. Atenção se dá ao município de Cristalina (Figura 58), que possui perfil econômico ligado ao agronegócio, porém possui uma quantidade considerável $(30,1 \%)$ de EVU. Verifica-se sobretudo a presença de áreas de vegetação nativa de cerrado nas bordas da sede municipal, muito correlacionada a presença de relevo declivoso, que de certa forma inviabiliza a agricultura de larga escala. 


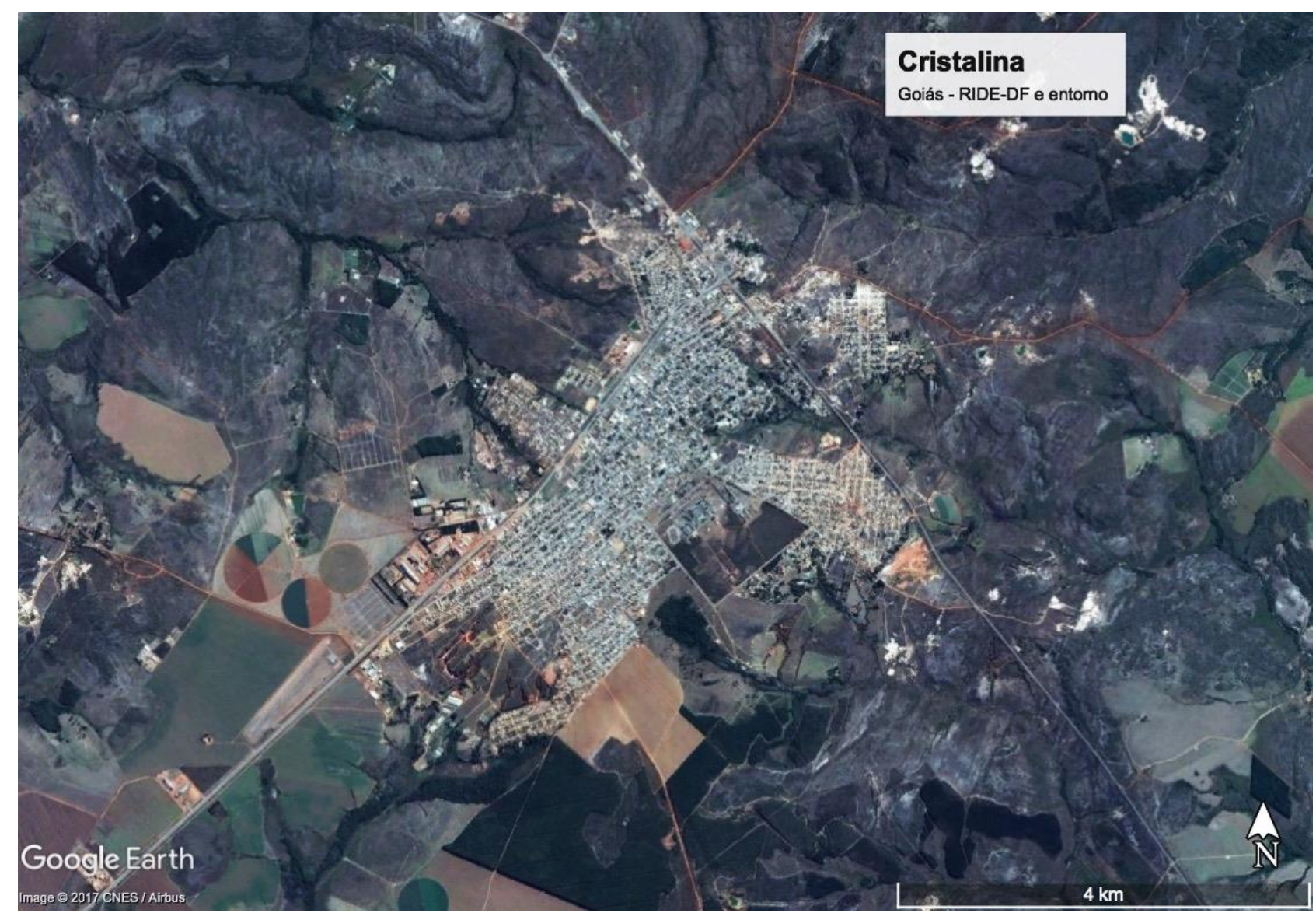

Figura 58 - Cristalina, presença de cerrado nas bordas (cores acinzentadas) Fonte: Google-Earth (2017)

As UDHs com menor quantidade de EVU concentram-se na sua maioria na porção oeste da conurbação urbana da RIDE-DF e Entorno, com destaque para as UDHs localizadas nas cidades de Ceilândia, Águas Claras, Samambaia, Taguatinga, Vicente Pites, Riacho Fundo, Recanto das Emas, Gama e Santa Maria. Como já relatado, são áreas de grande densidade populacional. Ademais, nestes locais o planejamento urbano não priorizou a presença de espaços verdes urbanos, diferentemente da área central do Distrito Federal. 


\subsubsection{Análise Dependente da Demografia}

Quanto a relação dos espaços verdes urbanos por demografia, a Figura 59 traz tal proporcionalidade nas unidades amostrais (UDH - IPEA) relacionando a quantidade de EVU por habitantes. O mapa sintetiza as análises anteriores, indicando que há uma concentração populacional agregada a baixa quantidade de EVU nas UDHs localizadas na porção oeste do DF.

As áreas em vermelho mostram onde a relação de EVU por habitantes é igual a zero. Nesse caso as respectivas UDHs não apresentam EVU. Representam essa classe as UDHs nas seguintes localidades: Brazlândia, Ceilândia, Planaltina (DF), Riacho Fundo, Recando das Emas, Samambaia e Taguatinga.

Em laranja são áreas onde a quantidade dos EVU por habitante é inferior aos $15 \mathrm{~m}^{2}$, valor recomentado pela Sociedade Brasileira de Arborização Urbana SBAU. Elas estão localizadas majoritariamente nas seguintes cidades do DF: Ceilândia, Samambaia, Taguatinga, Riacho Fundo, Gama, Santa Maria, Planaltina e São Sebastião. Além dessas cidades do DF, destaca-se as UDHs localizadas no centro de Águas Lindas de Goiás, Formosa, Novo Gama, Planaltina (GO), Unaí e Valparaíso de Goiás.

As demais classes, em amarelo, verde-claro e verde-escuro expressam de forma graduada maior quantidade dos espaços verdes por habitante. Variando de 15 a $100 \mathrm{~m}^{2}$ nas áreas em amarelo, $100 \mathrm{~m}^{2}$ a $1000 \mathrm{~m}^{2}$ nas áreas em verde-claro e superior de $1000 \mathrm{~m}^{2}$ em verde-escuro. Por essa classificação observa-se que a Asa Norte possui menor proporção de EVU por habitantes em relação a Asa Sul. O fato da UDH da Asa Sul contemplar o maior parque urbano do DF (Parque da Cidade Sarah Kubitschek) justifica essa diferença na classificação.

Destaca-se também a porção sul da conurbação urbana correspondente às cidades de Cidade Ocidental, Luziânia, Valparaíso e Novo Gama, que apresentam grande número de habitantes, alta vulnerabilidade social, porém alta quantidade de espaços verdes por habitantes em decorrência a presença de vegetação nativa, sobretudo de mata ciliares e vegetação nativa nas áreas não consolidadas. 


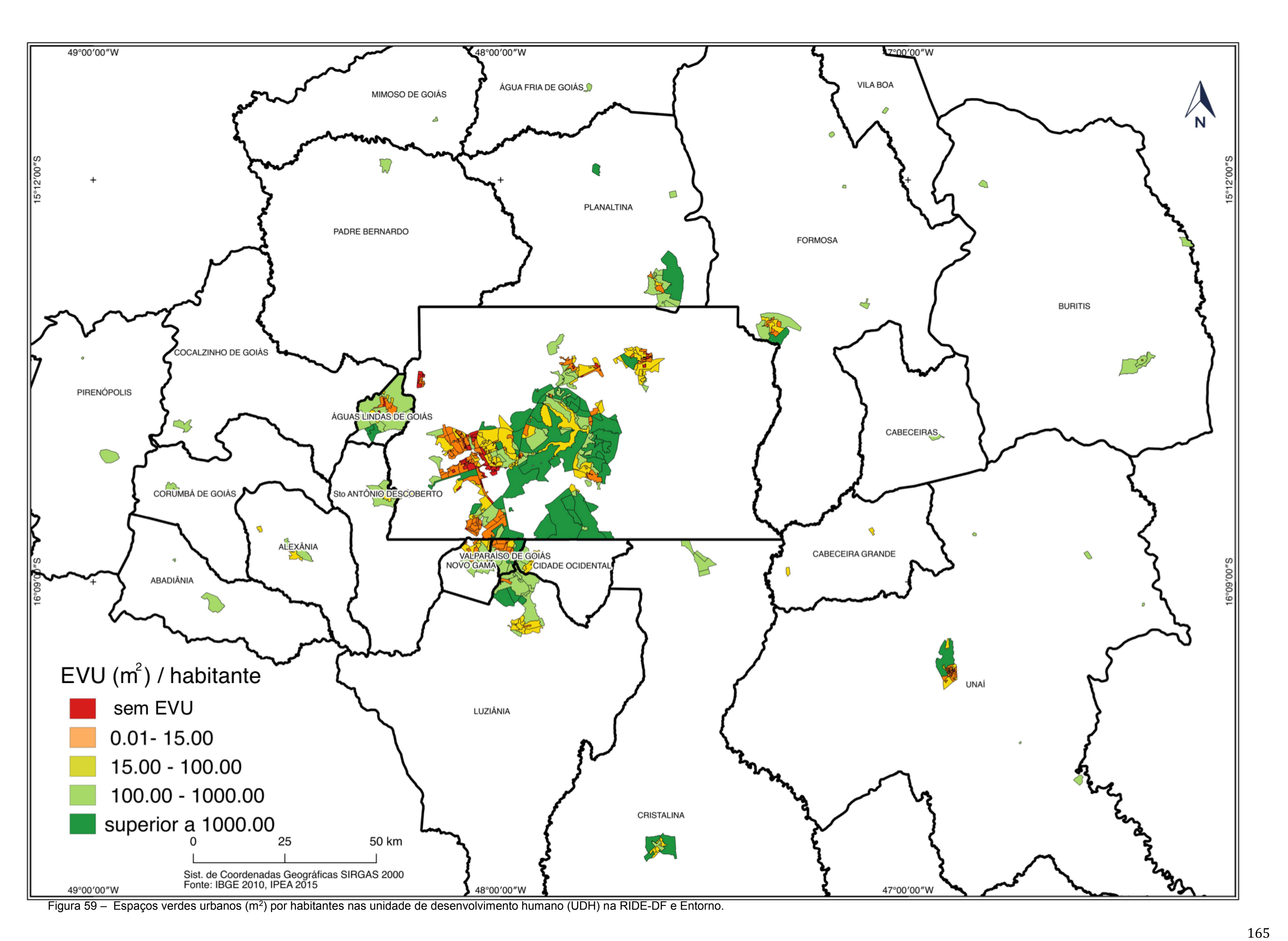




\subsubsection{Tamanho e Distribuição dos Fragmentos dos Espaços Verdes Urbanos}

Ao categorizar o tamanho dos fragmentos dos espaços verdes da RIDE-DF e Entorno, por área, em três classes (pequenas, intermediárias e grandes) de acordo com a curva normal de distribuição, estabelecendo o desvio padrão como limite das classes obteve-se a seguinte categorização (Tabela 7).

Tabela 7 - Categorização do tamanho dos fragmentos dos espaços verdes urbanos

\begin{tabular}{ll}
\hline $\mathrm{EVU}\left(\mathrm{km}^{2}\right)$ & Classe de fragmentos \\
\hline $0,00-0,37$ & Pequenos \\
$0,37-32,44$ & Intermediários \\
$32,44-36,99$ & Grandes \\
\hline \hline Fonte: Elaborada pelo autor &
\end{tabular}

A Figura 60 enfatiza que os maiores fragmentos (na cor amarelo) estão localizados no Plano Piloto e na sua porção leste. O fragmento dentro do Plano Piloto corresponde a cobertura vegetal implantada no planejamento na cidade parque idealizada por Lúcio Costa. A vegetação mapeada nessa classe é aquela formada por amplos gramados e árvores espalhadas, ambos distribuídos por todo Plano Piloto: adjacentes às vias e estacionamento, nos canteiros centrais dos eixos rodoviários, nos parques urbanos (Parque da Cidade e Olhos d`Água), no cemitério, nas residências oficiais (embaixadas e palácios) e nas áreas de recreação à borda do Lago Paranoá. 


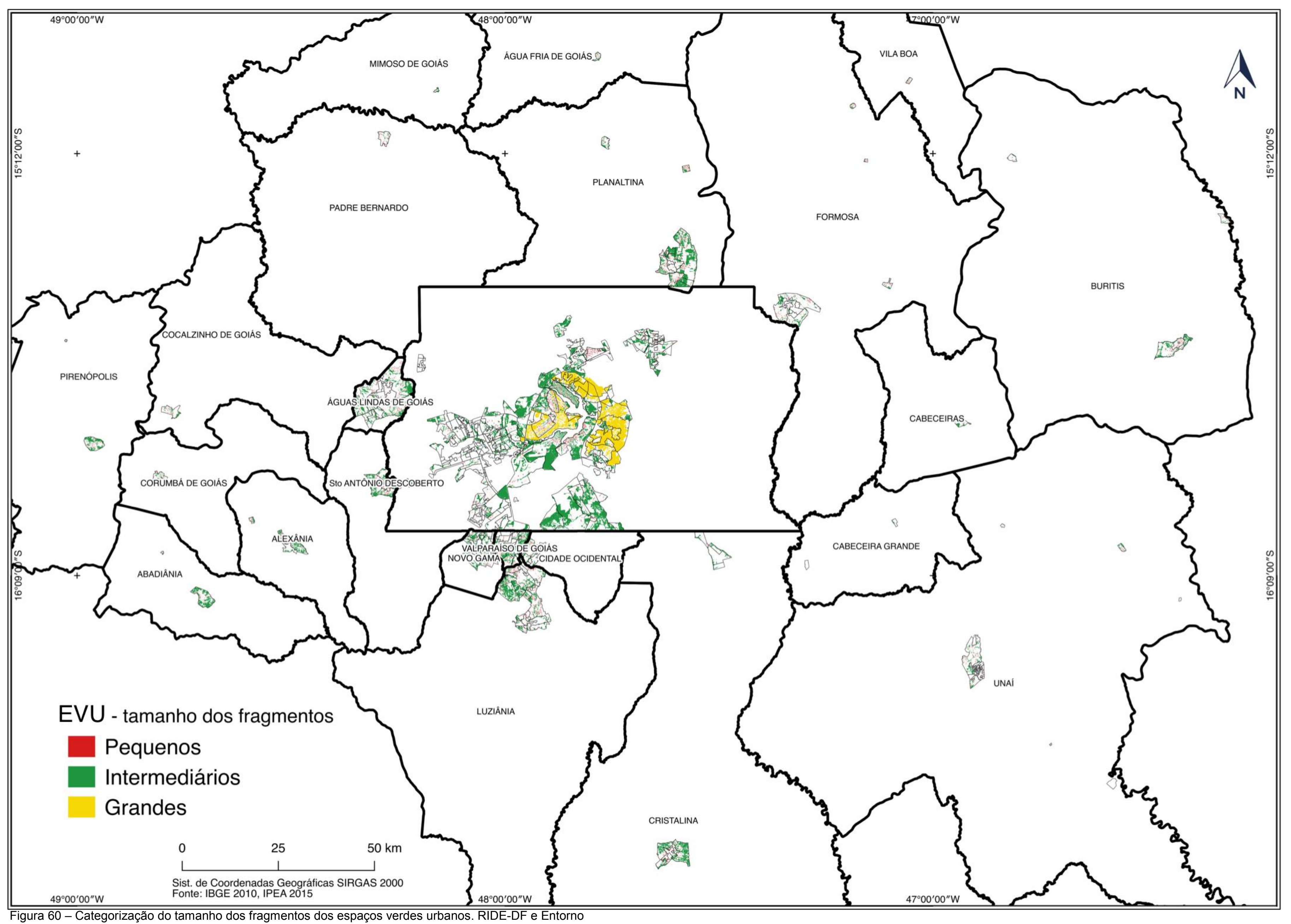


Os demais fragmentos grandes estão localizados na porção leste do Plano Piloto, correspondem na sua maioria à áreas de vegetação nativa de cerrado, além de florestas plantadas. Como já mencionado, esses fragmentos estão localizados em áreas protegidas por legislação federal (BRASIL, 2000) e são consideradas áreas ambientalmente frágeis. São nessas áreas que ocorrem fortes pressões do setor imobiliário, principalmente pelos condomínios residenciais.

Quanto à utilização dos espaços verdes no interior do Plano Piloto vale destacar uma recente intervenção em áreas públicas sem infraestrutura (cercas, jardins, lagos, bancos). Mesmo com vários parques consolidados, clubes e áreas específicas disponíveis ao uso coletivo, a população tem feito uso de canteiros centrais e espaços livres de edificações para a promoção de eventos alternativos (festivais gastronômicos, de música) seja para um grande número de pessoas ou mesmo para realizar "picknicks", festas infantis ou encontros de amigos (Figura 61). Contraditoriamente, nessas mesmas áreas, verifica-se a presença de moradores de rua, que se instalam em barracas e vivem em situação de extrema vulnerabilidade social.

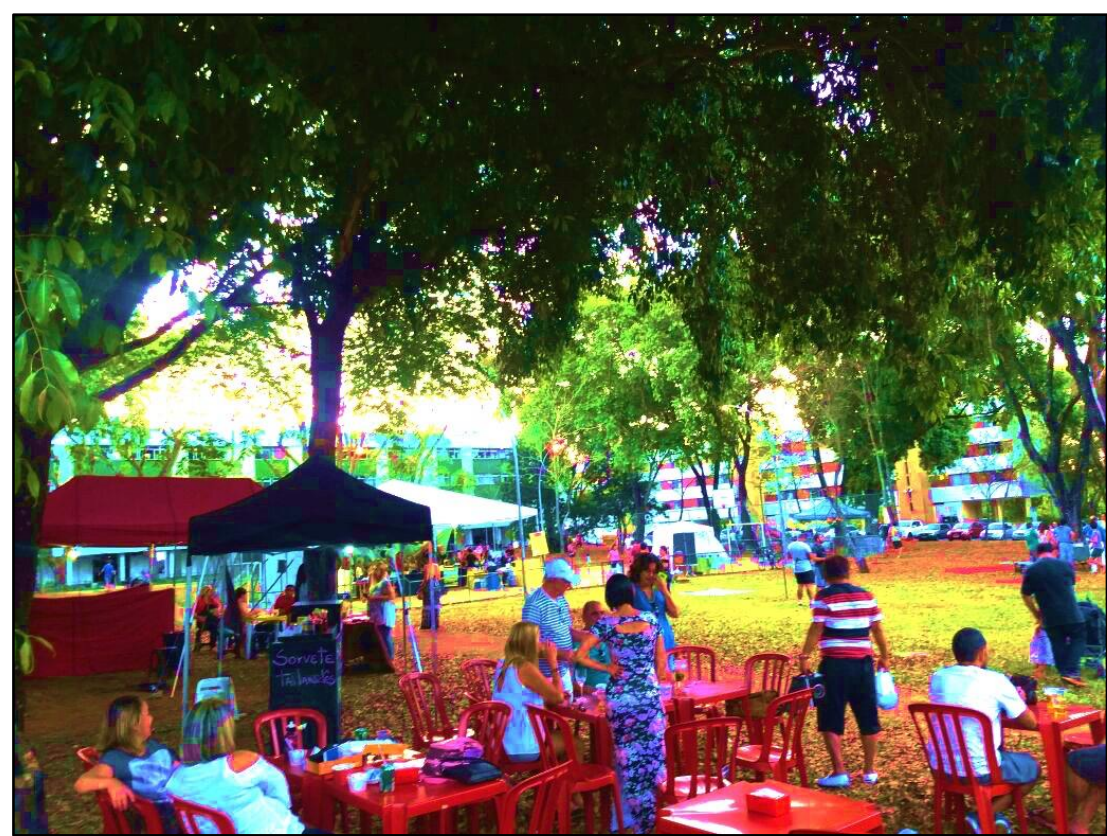

Figura 61 - Comemoração do dia da criança SQN 416 (Asa Norte) Fonte: Lins, Claudia (2017)

As classes intermediárias (fragmentos na cor verde) que variam de $0,37 \mathrm{~km}^{2}$ até $32,44 \mathrm{~km}^{2}$, devido a forma alongada e afilada, representam na sua maioria áreas de matas de galeria e de canteiros de vias. Os fragmentos de forma alongada 
(Figura 62) na mesma direção das drenagens indicam com clareza, principalmente nas áreas fora do Plano Piloto, que eles estão relacionados com as APP, protegidas por legislação federal (BRASIL, 2012) e que necessitam de maior atenção dada a importância ecológica dessa vegetação.

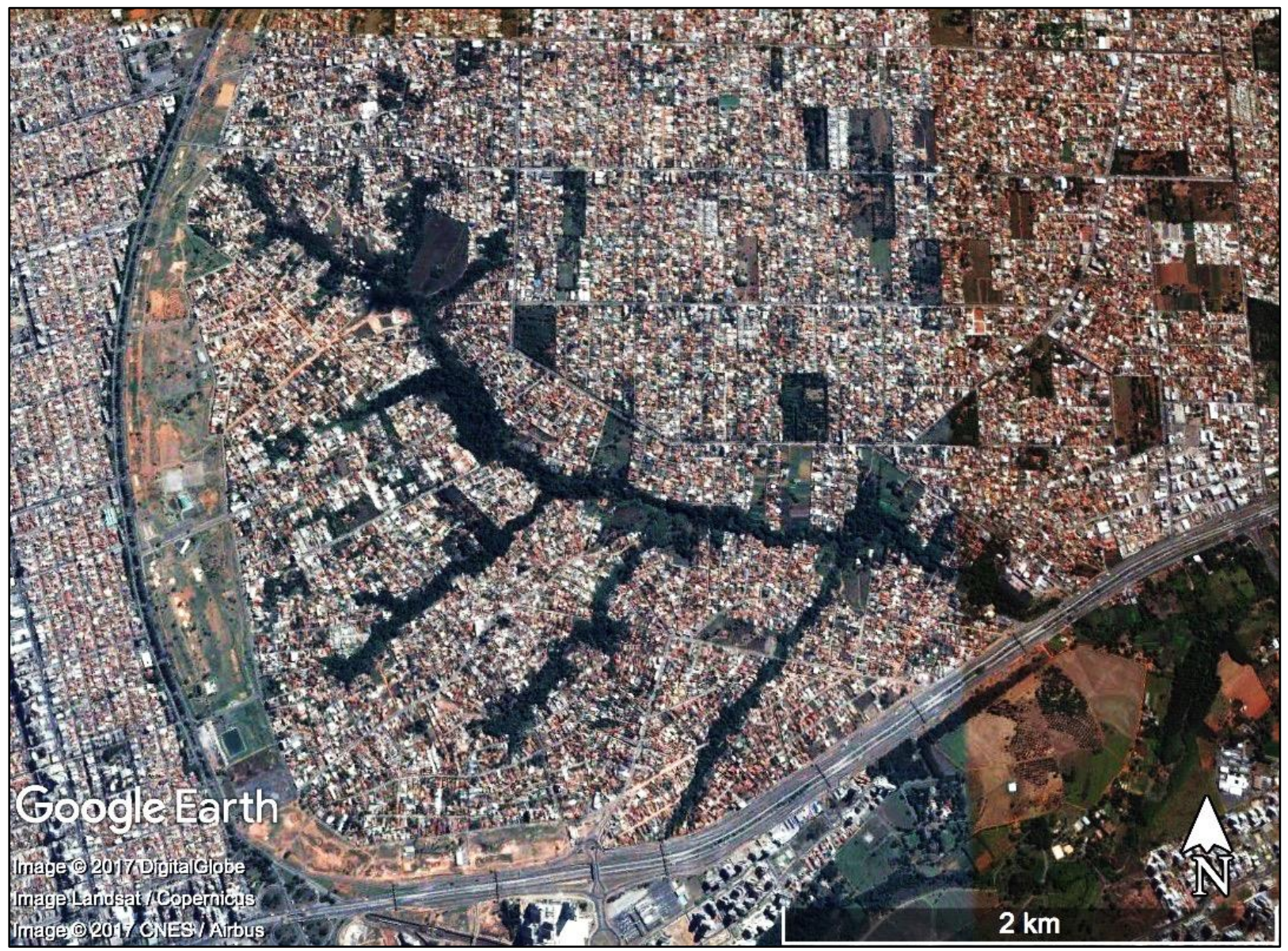

Figura 62 - Exemplo de fragmento alongado da classe intermediário. Local: Vicente Pires - DF. Fonte: Google-Earth (2017)

Em se tratando de matas ciliares, algumas áreas específicas do DF merecem maior atenção: Vicente Pires, Ceilândia (Sol Nascente) e Riacho Fundo I. De acordo com o último Plano Diretor de Ordenamento Territorial do DF (PDOT - DF), essas localidades há zonas de ocupação desordenada sob as matas de galerias (SEDUMA, 2007). Assim, Fontoura (2012) relaciona tais ocupações com alguns danos ambientais, como: o assoreamento que reduz a vazão dos riachos na maior suscetibilidade à erosão e aumento de alagamentos.

Além dos fragmentos afilados, verifica-se também a presença de blocos maiores de vegetação no Park Way, Lago Sul e Santa Maria. Entre esses blocos existe uma extensa área de florestas públicas e áreas de pesquisa (Reserva da 
Marinha, Reserva do IBGE, Jardim Botânico, Fazenda Água Limpa), de tal forma que esses fragmentos representam a borda dessa área (Figura 63). Caso semelhante ocorre na Granja do Torto, onde há ocorrência de um considerável bloco de área verde, que na verdade é borda do Parque Nacional de Brasília.

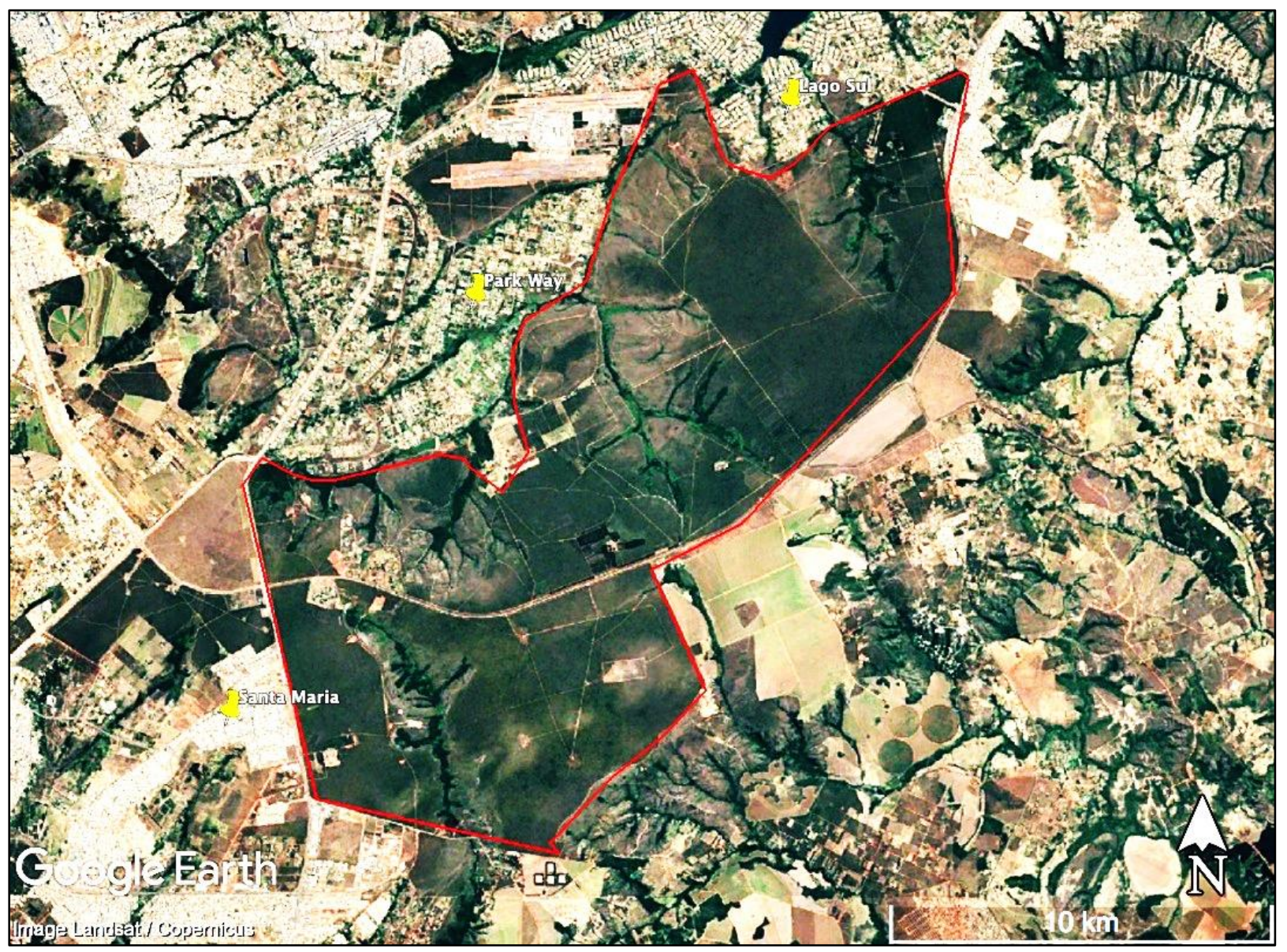

Figura 63 - Blocos de Florestas Protegidas no Distrito Federal Fonte: Google-Earth (2017)

A classe dos menores fragmentos varia de zero a $0,37 \mathrm{~km}^{2}$ (Tabela 6). Ao plotar essas áreas na Figura 60, nota-se a dificuldade de visualizar e analisar sua distribuição devido ao seu menor tamanho. Ao gerar o mapa de Kernel (mapa de calor) ao ponto central de cada polígono, fica mais fácil visualizar as áreas com maior probabilidade de ter áreas menores (Figura 64).

Para o planejamento que visa a importância dos espaços verdes como equipamentos urbanos é importante a análise da Figura 64 para verificar as áreas de maior ou menor ocorrência. No caso da RIDE-DF e Entorno destaca-se Sobradinho I e Asa Norte, Asa Sul, Lago Norte e Lago Sul com maiores incidências dessas áreas menores. 


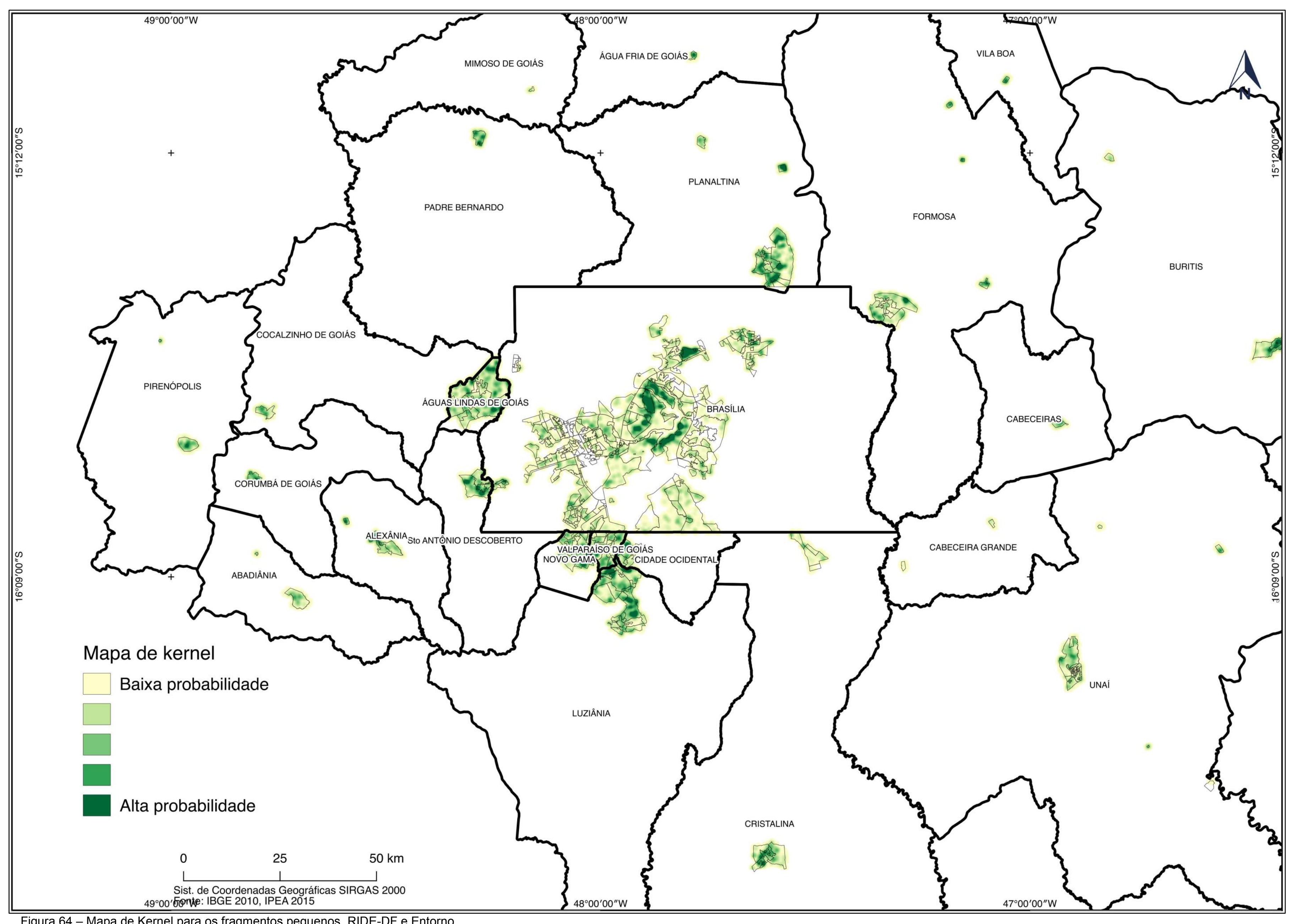


Em campo verifica-se que Sobradinho I possui ampla cobertura vegetal relacionada a um planejamento urbano da cidade que implantou espaços verdes, popularmente chamadas de faixas verdes, paralelas às ruas asfaltadas nas quadras residenciais. A Asa Norte, que visivelmente apresentou maior área de incidência de fragmentos pequenos, possui maior quantidade de espaços livres de edificação em relação as demais áreas do Plano Piloto.

Outra área que merece destaque é a porção sul da conurbação urbana da RIDE-DF e Entorno, que compreende as cidades de Cidade Ocidental, Valparaíso de Goiás, Luziânia e Novo Gama. Essa classe de fragmentos encontra-se na área de expansão urbana e espalhadas pelos novos loteamentos dessas cidades. Tomando que nessa mesma área, no geral, apresentam-se altos IVS (Figura 65), é importante evidenciar a importância da manutenção dessas pequenas manchas associadas à presença de outros equipamentos urbanos que aumente a qualidade de vida.

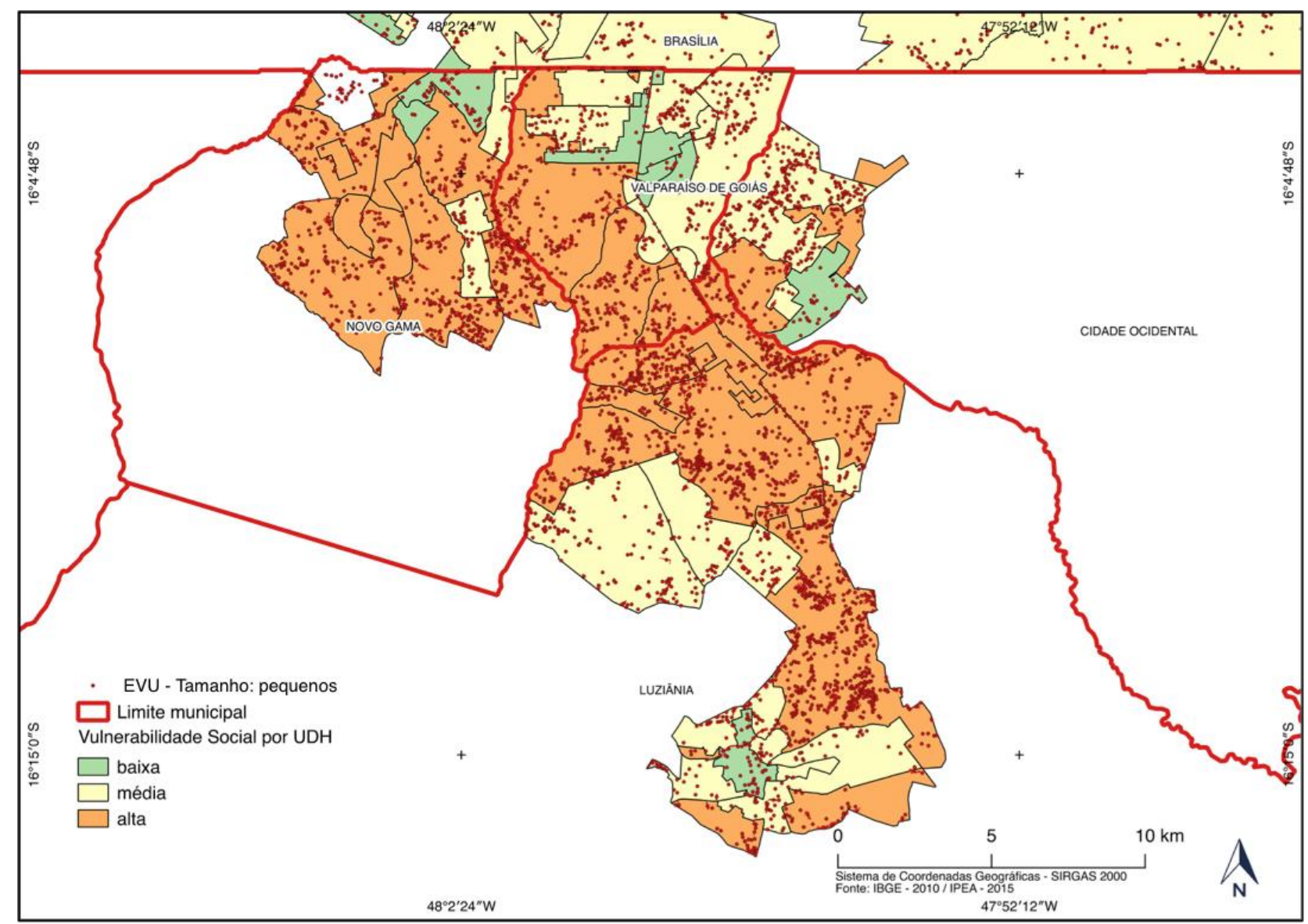

Figura 65 - Grande incidência de fragmentos pequenos em áreas de alta vulnerabilidade social nas cidades de Valparaíso, Cidade Ocidental, Novo Gama e Luziânia. 


\subsubsection{Correlação dos Espaços Verdes Urbanos e Vulnerabilidade Social}

Quanto à correlação espacial entre IVS e porcentagem dos EVU nas UDHs, de todo conjunto amostral da tese, as cidades da RIDE-DF e Entorno apresentaram baixa correlação, próximo à zero. Apesar disso, foi o único caso em que as UDHs correlacionaram-se e apresentaram o Índice de Moran com valor negativo: -0,01 (Gráfico 5). Isso significa que uma pouca quantidade de UDH corroborou a hipótese: áreas com melhores índices sociais (menor IVS) apresentam mais EVU, e viceversa.

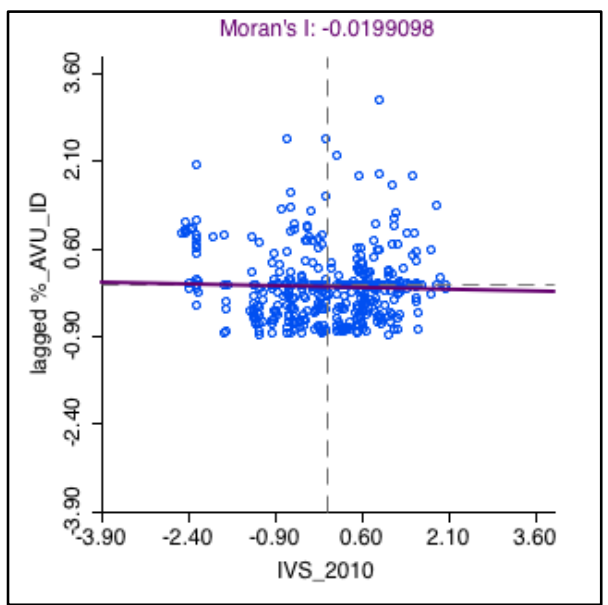

Gráfico 5 - Diagrama de espalhamento de Moran na RIDE-DF e Entorno

Do total de 437 UDHs da RIDE-DF e Entorno, 75\% não apresentaram significância na análise de correlação geoespacial. O Gráfico 6 destaca as UDHs sem significância, observando que são aquelas mais próximas ao eixo da variável representada pelo IVS (horizontal). Na prática, representam as UDHs que apresentam valores onde a quantidade da porcentagem dos EVU não variou tanto conforme às variações de IVS. 


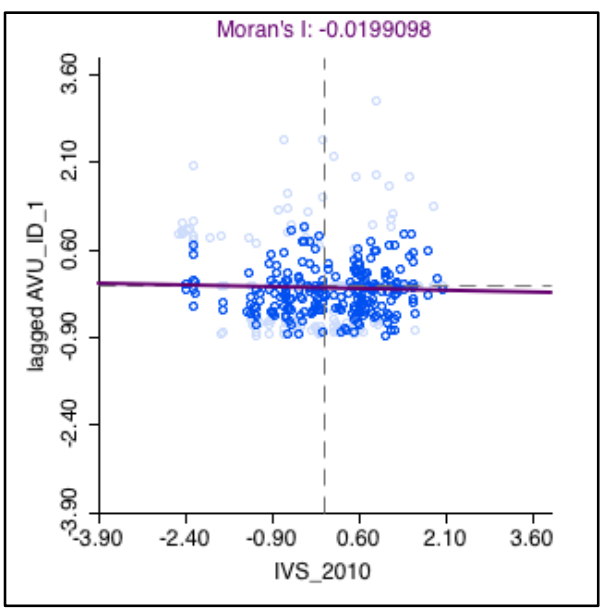

Gráfico 6 - UDHs sem significância na RIDE-DF e Entorno

O Gráfico 7 indica as 88 UDHs dentro das que não apresentaram significância, uma vez que essas UDHs não apresentaram vizinhança, logo não influenciaram na análise de correlação espacial. No gráfico de correlação, essas UDHs dispostas em cima do eixo da variável dependente, representada pelo IVS.

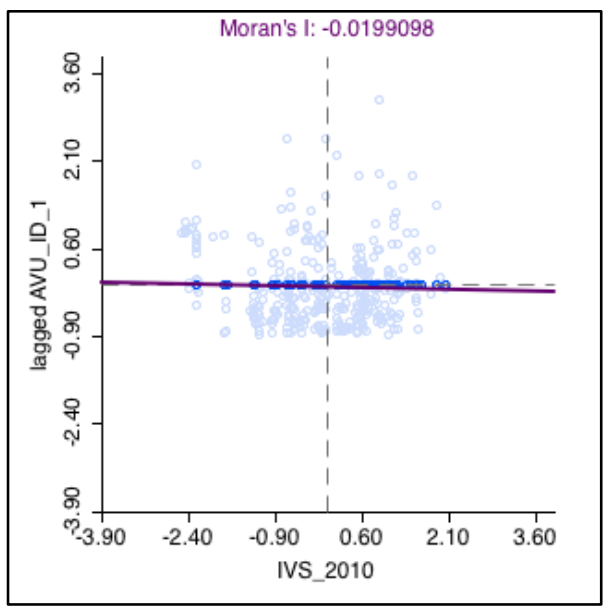

Gráfico 7 - UDHs sem vizinhança na RIDE-DF e Entorno

O Gráfico 8 destaca as 110 UDHs que apresentaram significância na correlação geoestastítica, o que representa $25 \%$ do total. O mesmo gráfico indica que são os pontos mais dispersos na correlação espacial. Verifica-se que a dispersão desses pontos (representado pelas UDHs) são determinantes para a inclinação da curva de correlação, refletindo no valor negativo do índice de Moran. 


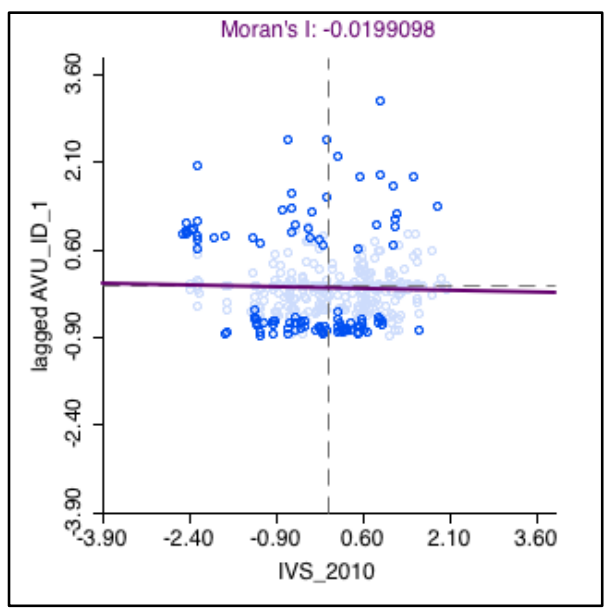

Gráfico 8 - UDHs com significância na RIDE-DF e Entorno

Ao analisar os resultados frente à hipótese é necessário destacar os cenários esperados: A) UDH com grande porcentagem de EVU e IVS baixo e B) UDH com baixa porcentagem de EVU e IVS alto. Esses dois cenários estão representados na cor verde (cenário A) e cor vermelha (cenário B) nas Figuras 65 e 66. Porém, esses cenários compõem $54 \%$ das unidades amostrais (59 UDH) que apresentaram significância na correlação.

Porém cabe destacar que haver significância na correlação não implica corroborar a hipótese. Assim sendo, os demais 46\% das UDHs representam os cenários opostos à hipótese: $\mathrm{C}$ ) UDH com grande porcentagem de EVU e IVS alto e D) UDH com baixa porcentagem de EVU e IVS baixo. Esses dois cenários estão representados na cor laranja (cenário C) e cor amarela (cenário D) nas Figuras 65 e 66.

Uma vez que a correlação é baseada na quantidade e grau de vizinhança das unidades amostrais, no caso as UDHs, as áreas que se correlacionam podem ser melhor analisadas ao inferir sobre a dimensão de área e população, conforme mostram a Figura 66 e a Tabela 8. A Figura 67 espacializa as áreas que apresentaram correlação significativa. 
Tabela 8 - Resumo dos resultados da correlação aplicada na RIDE-DF e Entorno

\begin{tabular}{llllll}
\hline Correlação & UDH $\left(q^{\text {tde }}\right)$ & IVS med & \%EVU/UDH & $\%$ ÁREA & \% POP \\
\hline ALTA-ALTA (laranja) & 12 & 0,4 & 14,05 & 4,13 & 2,12 \\
ALTA-BAIXA (vermelho) & $\mathbf{2 9}$ & $\mathbf{0 , 3 5}$ & $\mathbf{7 , 5 5}$ & $\mathbf{4 , 9 2}$ & $\mathbf{1 5 , 3 5}$ \\
BAIXA-BAIXA (amarelo) & 39 & 0,23 & 4,31 & 2,84 & 8,72 \\
BAIXA-ALTA (verde) & $\mathbf{3 0}$ & $\mathbf{0 , 1 6}$ & $\mathbf{3 7 , 7 6}$ & $\mathbf{1 7 , 4 9}$ & $\mathbf{1 3 , 7 8}$ \\
SEM SIGNIFICÂNCIA & 327 & 0,32 & 19,51 & 70,63 & 60,04 \\
\hline HIPÓTESE (vermelho + verde) & $\mathbf{5 9}$ & & & $\mathbf{2 2 , 4 1}$ & $\mathbf{2 9 , 1 2}$ \\
OPOSTO DA HIPÓTESE (laranja + amarelo) & 51 & & & 6,96 & 10,84 \\
\hline \hline
\end{tabular}

Fonte: Elaborada pelo autor

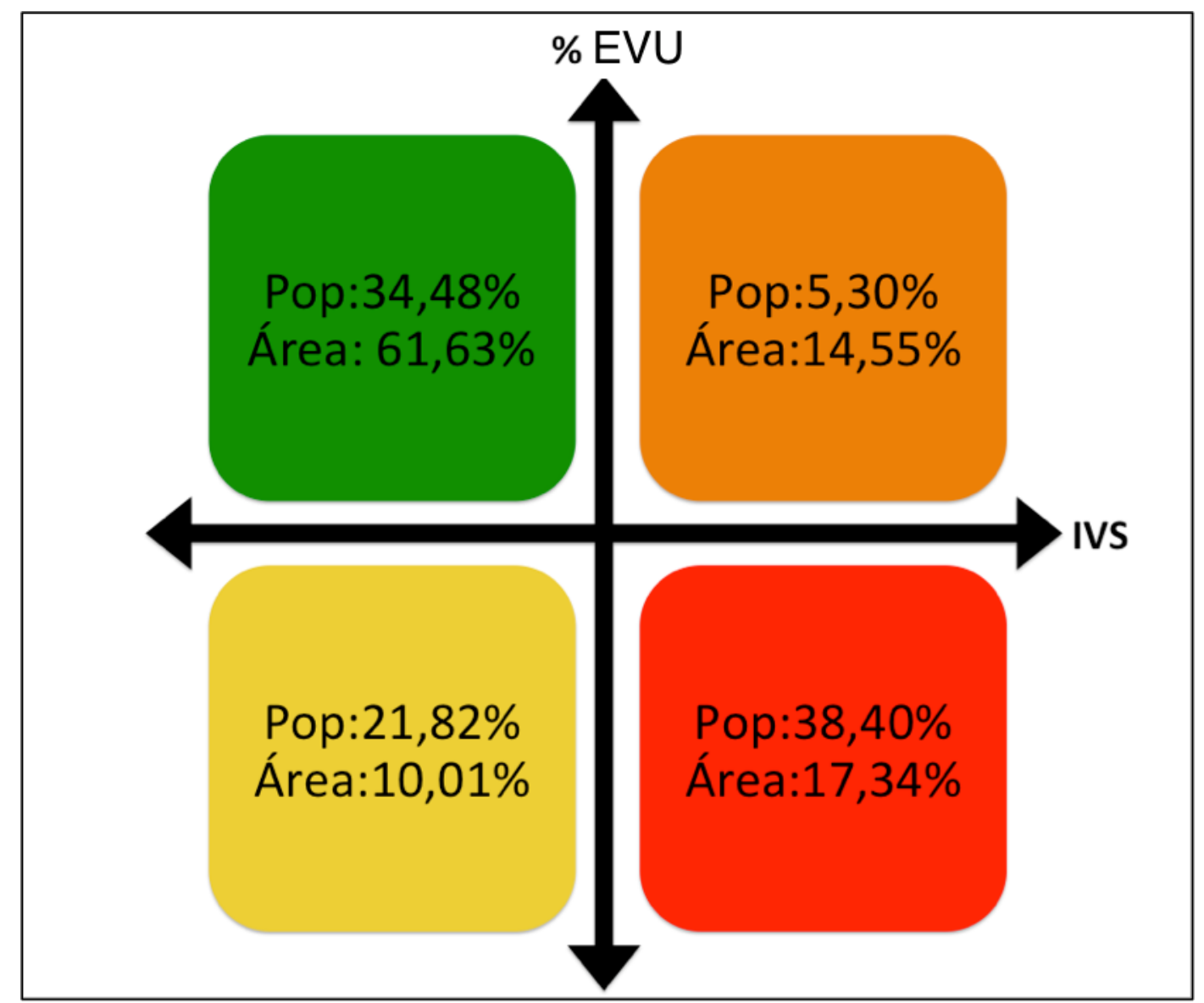

Figura 66 - Porcentual de área e população nas UDHs com significância. RIDE-DF e Entorno 


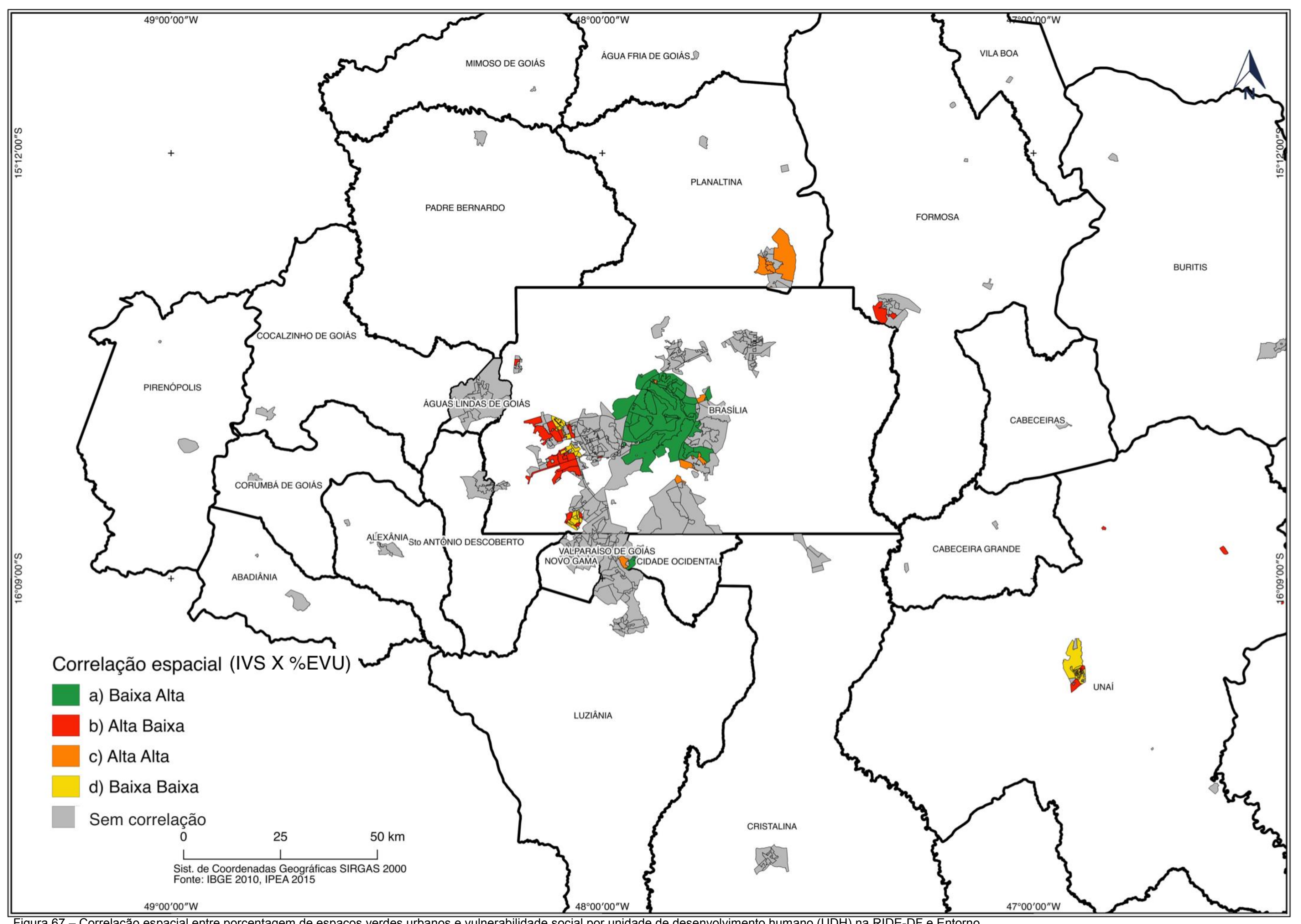


O cenário $A$, representado pela área na cor verde (Figuras 66 e 67) está concentrada no centro da RIDE-DF e Entorno. Ele está representado, majoritariamente, pelo Plano Piloto, Jardim Botânico, Taquari e condomínios localizados nas APAs do São Bartolomeu e Lago Paranoá. Esse cenário corresponde a $17,49 \%$ da área analisada da RIDE-DF e Entorno, concentrando $13,78 \%$ da população. O conjunto de UDH em verde apresentou IVS médio de 0,16 e $37,76 \%$ de EVU. Esses valores indicam que a área planejada como cidade parque, assim como os condomínios instalados na parte leste do Plano Piloto apresentam forte correlação entre: muitos EVU e baixa vulnerabilidade social (altos índices socioeconômicos)

O cenário $B$, representado pela área em vermelho (Figuras 66 e 67) está concentrada, majoritariamente, no lado oeste do DF, especificamente nas cidades de Samambaia, Ceilândia, Riacho Fundo, Gama e Brasilândia. Além dessa área, verificou-se esse cenário em UDH de Unaí (MG) e Formosa (GO). A Tabela 8 e a Figura 66 mostram que apesar do cenário corresponder a 4,92\% de toda área analisada, existe uma população de $15,37 \%$ da RIDE-DF e Entorno, quase a mesma quantidade do cenário $A$, ratificando mais uma vez a densidade populacional nessa área.

O conjunto de UDH em vermelho apresentou IVS médio de 0,35 (alta vulnerabilidade) e $7,55 \%$ de EVU. Esses valores indicam que parte específica da área periférica da RIDE-DF e Entorno, localizada na porção oeste do DF, apresenta forte correlação espacial entre: poucos EVU e alta vulnerabilidade social (baixos índices socioeconômicos).

Os cenários A e B refletem a hipótese. Mesmo que representando pouco mais de $10 \%$ das UDHs correlacionadas, esses cenários abrangem $29,12 \%$ da população e 22,41\% da área analisada. Tão importante quanto os valores numéricos é a indicação onde há carência de EVU atrelada à vulnerabilidade social, contrapondo a um cenário de muitos EVU e de baixa vulnerabilidade social. Nesses cenários pode-se afirmar que a desigualdade social é visível e pode ser representada pela presença e ausência dos EVU.

Para o planejamento que vise aumentar os EVU nas cidades, a presente análise torna visível a abrangência da área que mais necessita de investimentos (cenário B - em vermelho) em oposição a área que possui amplos EVU bons índices socioeconômicos. Se no cenário B, forem implantadas como equipamentos 
urbanos, como já explanado, os EVU têm potencial de trazer serviços socioambientais refletindo em melhores condições de vida, bem-estar social atrelado ao ganho ambiental.

Quanto aos cenários opostos à hipótese, verifica-se certa magnitude no cenário D (em amarelo), onde residem 8,72\% da população total da RIDE-DF e Entorno numa área de $2,84 \%$ da área total analisada. Esse cenário apresentou baixo IVS-médio $(0,23)$ e baixa porcentagem de EVU $(4,31 \%)$. Observa-se nesse caso que as UDHs estão localizadas nas mesmas cidades do cenário $B$ (em vermelho).

Reforça-se que: não é por estar longe do centro que todos os territórios serão homogêneos, com índices de vulnerabilidade social altos. Esse fato indica que existem desigualdades sociais dentro das periferias. Elas possuem centros comerciais e empresariais com maior infraestrutura, melhor renda per capta, oportunidades de emprego e outras áreas com condições opostas. O que se verificou nesse caso é que a diferença de vulnerabilidade social em algumas áreas periféricas não influenciou na quantidade dos EVU. Considerando os cenários B e D, os espaços verdes urbanos não indicam desigualdade social.

O cenário C (laranja), também oposto à hipótese, indicou 12 UDH com baixa magnitude quanto a quantidade populacional (2,49\%), numa área de $4,13 \%$ da RIDE-DF e Entorno. Tais UDHs estão localizadas nas cidades de Planaltina, Valparaíso de Goiás, Condomínios do Itapoã, alguns condomínios do Jardim Botânico, parte de São Sebastião e do Varjão.

Por análise visual em imagens de satélite, observa-se que nas 12 UDH a alta quantidade de EVU remetem à áreas nativas de cerrado, onde ocorre uma ocupação urbana desordenada. Nesse cenário, os EVU são áreas de risco: próximas ou dentro das APP, locais com áreas de riscos de alagamentos, desmoronamento e erosão. Nesse cenário, tão importante quanto os EVU como locus de lazer e convivência são as medidas para salvaguardá-los, visando o controle e gestão da ocupação territorial e a preservação ambiental dessas áreas frágeis.

Quanto aos resultados médios de IVS e porcentagem dos EVU das correlações com significância, os valores indicaram que a relação entre vulnerabilidade social e quantidade de EVU não é linear. Afora o cenário A que houve alta relação entre alta porcentagem de EVU e baixo IVS (como o esperado na 
hipótese), os demais cenários não acompanharam essa lógica. Assim, o cenário com maior vulnerabilidade social não apresentou menor quantidade de EVU e o que apresentou menor quantidade de EVU não foi o que apresentou maior vulnerabilidade social (Figura 66).

Tal fato indica que a ausência e presença dos espaços verdes urbanos por si não refletem índices socioeconômicos (no caso, vulnerabilidade social). Isso ratifica que a presença dos EVU só trará ganhos socioambientais se houver uma articulação com outras políticas públicas que promovam bem-estar e melhoria de índices socioeconômicos. Além da questão social, pontua-se a importância do controle ambiental seja por legislação ou mecanismos de fiscalização e monitoramento dos EVU de tal forma que eles não sejam áreas de riscos e vulnerabilidade e, sim equipamentos urbanos. 


\subsection{Região Metropolitana de Manaus}

A Região Metropolitana de Manaus (RMM) apresenta oito municípios. Considerando a área urbana e rural, ela é a maior RM do grupo amostral com $101.474,05 \mathrm{~km}^{2}$. A área urbana analisada é de $1.023,71 \mathrm{~km}^{2}$ e não chega a $1 \%$ de toda RMM. A Figura 68 indica a RMM e a área urbana analisada.

O maior adensamento das UDHs analisadas da RMM é a cidade de Manaus que corresponde a $85 \%$ da área analisada. As demais cidades, além de serem menores, estão dispersas pela RM. Verifica-se na RMM a inexistência de uma conurbação urbana formada por mais de uma cidade. Elas estão distantes entre si e por isso é importante citar a forma diferenciada de integração das cidades amazônicas conforme orienta Becker; Stenner (2008).

Usando a prerrogativa da Constituição Federal (BRASIL, 1988), por meio da Lei Complementar Estadual n 52 de 2007, a Assembleia Legislativa do Amazonas criou a RMM. Lima (2014) relata que a questão técnica e conceitual não pesou na definição dessa RM, uma vez que a RMM inexiste uma conurbação urbana de mais de uma cidade, bem como possui baixo fluxo de pessoas e mercadoria entre os núcleos urbanos. Por isso o autor afirma que a RMM atendeu muito mais a interesses políticos do que critérios técnicos.

Dado os baixos índices sociais (renda ${ }^{13}$, educação, saúde) e a carência de infraestrutura urbana (saneamento básico, drenagem urbana, pavimentação, estradas) da RMM, Lima (2014) afirma que com validade jurídica, a criação da RMM facilitou a captação de recursos destinados às RM (LIMA, 2014). Um exemplo disso foi a captação de recursos por meio do Programa de Aceleração de Crescimento (PAC) para a construção da Ponte Rio Negro que liga Manaus e Iranduba. Apenas nessa obra foram investidos mais de R\$ 1 bilhão de recursos federais (SOUSA, 2013).

13 De acordo com o último censo (IBGE, 2010) a renda média mensal por domicílio na RMM correspondente a $\mathrm{R} \$ 725,17$, sendo uma das menores das RM brasileiras e inferior ao da média nacional $(\mathrm{R} \$ 949,99)$. 


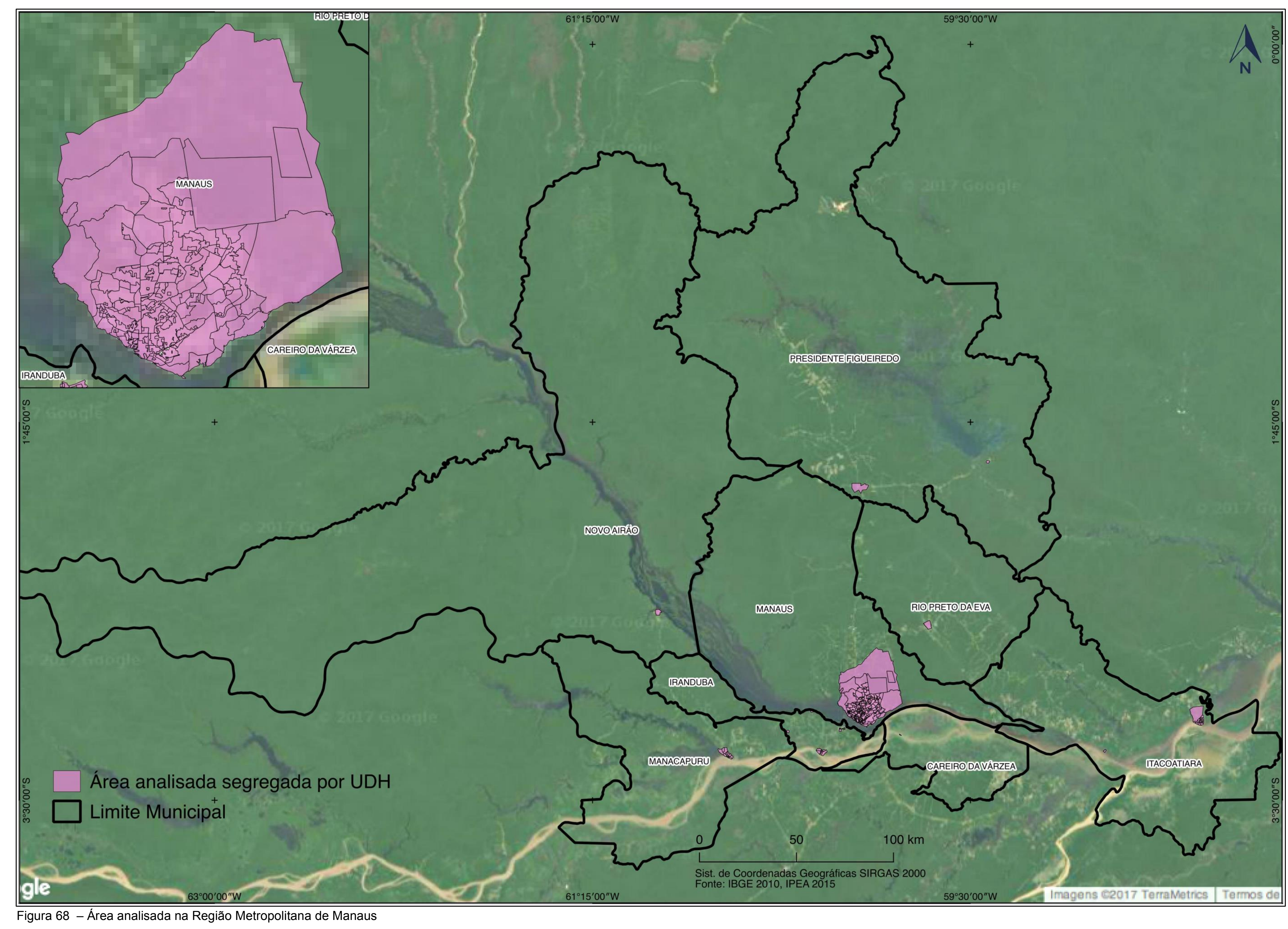


O fato é que a RMM possui uma estrutura de urbanização diferenciada. As especificidade das municipalidades extensas possibilitou o surgimento de núcleos urbanos distantes, com baixa intensidade de trocas comerciais e movimentos pendulares (LIMA, 2014).

Nesse sentido, Becker; Stenner (2008) citam que as cidades na Amazônia, principalmente as pequenas, são carentes de conectividade e rodeadas por ecossistemas sensíveis. O principal meio de integração entre as cidades são os rios, uma vez que conectam a região com mercados maiores, são meio de transporte de milhares de pessoas, dão escoamento aos produtos das atividades extrativistas e agrícolas e assentam populações ribeirinhas de forma dispersa no território. Manaus, por sua vez, é dotada de uma posição geográfica privilegiada que influiu no seu desenvolvimento desde os tempos de ocupação até os dias atuais, conforme cita Ab'Sáber:

Colocada exatamente entre a Amazônia Ocidental e a Oriental, num ponto do principal eixo da navegação fluvial do Brasil, é uma espécie de elo entre a navegação fluvial, rudimentar e extensiva, e as grandes rotas marítimas de cabotagem. Possui, por essa razão, uma situação geográfica absolutamente privilegiada em face das extensões amazônicas e do gigantesco quadro de drenagem da bacia hidrográfica regional (AB'SÁBER, 1953, p. 18).

\subsubsection{Urbanização na Região Metropolitana de Manaus}

Segundo Ab'Sáber (1953), Manaus surgiu no século XVII como um forte à margem esquerda do rio Negro, próximo à confluência com rio Amazonas, em local habitado pela tribo indígena Manau. Tornou-se cidade em 1856, mas ainda sem importância econômica. Nesse período, a sua população era majoritariamente indígena que ainda realizava atividades típicas e costumes tradicionais. Esses hábitos caracterizavam a movimentação da vida urbana (AB'SÁBER, 1953).

Com advento do ciclo da borracha, final do século XIX, Manaus transformouse devido ao seu crescimento econômico e demográfico (AB'SÁBER, 1953). De 1889 para 1920 , sua população saltou de 10 mil para 75 mil habitantes, crescimento representativo para uma pequena cidade distante de todos os principais centros comerciais e pouco desenvolvida (AB'SÁBER, 1953).

Por quase um século, Manaus foi uma das principais cidades brasileiras, possuindo a borracha, extraída dos seringais espalhados pela floresta amazônica, como a principal base econômica (AB'SÁBER, 1953). Assim, o referido autor relata: 
Manaus cresceu sob o impulso de uma economia de coleta extensiva, dependendo de correntes de imigração interna, de um mecanismo de circulação moroso ligado exclusivamente aos rios e tendo que dividir as glórias de metrópole com a cidade de Belém (AB'SÁBER, 1953, p. 24).

Parte da população de Manaus enriqueceu vertiginosamente, elevando suas exigências de consumo (BECKER; STENNER, 2008). Assim, os autores relatam que a cidade se modernizou refletindo na edificação urbana com prédios públicos nos padrões europeus, aterramento de igarapés, construção de palacetes residenciais, largas avenidas, praças, além do suntuoso teatro de ópera e do porto.

Mesquita (2009) narra que a alta arrecadação de impostos provenientes da exploração da borracha propiciou a execução de tais obras que visavam a estética, infraestrutura e modernização urbana, a fim de inserir Manaus no rol das cidades "civilizadas". Nesse período os espaços verdes "limitavam-se aos jardins e praças públicas, sobretudo na área central” (MESQUITA, 2009, p. 212).

O declínio do ciclo da borracha (início do século $X X$ ) decorrente da competição asiática, trouxe estagnação às principais cidades que dependiam do mercado da borracha (BECKER; STENNER, 2008). Por décadas, a Amazônia permaneceu como uma "ilha" isolada do restante do país. Manaus também sofreu e inúmeros problemas urbanos tornaram-se latentes, o principal foi a falta de energia elétrica que deixou a cidade às escuras frequentemente (AB'SÁBER, 1953).

Mesmo diante a estagnação do ciclo da borracha, Manaus que perdeu seu status no cenário nacional e mundial, manteve sua importância regional, sendo "a grande porta de ocidentalização para as regiões equatoriais da Amazônia brasileira" (AB'SÁBER, 1953, p. 26). Assim, a localização estratégica e a presença do Porto de Manaus, Ihe garantiram ser um importante centro comercial e de distribuição de mercadorias, mesmo diante à crise.

Após o período de declínio e estagnação econômica, muitas cidades foram criadas e outras cresceram na região norte, por ação direta do Estado com o Projeto de Integração Nacional (PIN), fruto do regime militar (1967-1985). Com objetivos econômicos de ampliar o mercado interno além dos interesses de ocupar e ter controle do imenso território amazônico, o incentivo à imigração e povoamento de novas cidades foi uma estratégia geopolítica (BECKER, 1984).

A autora relata que o governo militar concedeu incentivos fiscais e créditos a juros menores para estimular a ocupação e a instalação de empresas e indústrias 
na região Amazônica. Com isso, várias cidades da Amazônia registraram as maiores taxas de crescimento urbano no Brasil nas últimas décadas do século $X X$. Assim, a indução da imigração estabeleceu a Amazônia como uma fronteira urbana antes mesmo da fronteira agrícola (BECKER, 2005).

A expansão urbana em Manaus se consolidou, na década de 1960, com a implantação da Zona Franca (ZFM) e da SUFRAMA (Superintendência da Zona Franca de Manaus) (BECKER; STENNER, 2008). Junto com o novo crescimento econômico de Manaus, viabilizado pela ZFM, várias cidades surgiram e se estabeleceram com a política de dinamização da economia na região norte. Os novos núcleos urbanos mesmo que distantes e pequenos tiveram papel crucial de organizar o mercado de trabalho e assegurar a circulação de mercadorias e garantia de força de trabalho (BECKER; STENNER, 2008).

Com a ZFM, Manaus assumiu uma nova função estratégica atrelada ao desenvolvimento industrial. Assim, a cidade "tornou-se um porto fluvial livre e núcleo de localização de projetos industriais, dinamizando-se sua economia" (BECKER; STENNER, 2008, p. 107). Os autores afirmam que o crescimento populacional da cidade foi o maior registrado na sua história. Considerando período de anterior a instalação da ZFM, a cidade registrou um salto de 100 mil habitantes (década de 1960) para quase 2 milhões de pessoas em 2010.

Pelo censo de 2010, a área urbana de Manaus contava com 1,8 milhões de habitantes. A Figura 68 apresenta a densidade demográfica da RMM, evidenciando a densidade demográfica por UDH da área analisada. Observa-se a concentração populacional nas UDHs na capital Manaus, onde moram 90,73\% dos habitantes, dos mais de 1,97 milhões de pessoas das cidades analisadas. A população analisada da RMM representa 1,04\% da população brasileira, 12,45\% da população do região norte e 56,73\% dos residentes no estado do Amazonas (IBGE, 2010). Destaca-se sobretudo a área central (centro-sul) da capital onde há maior concentração populacional.

Ao analisar a dinâmica populacional do estado do Amazonas, Oliveira; Shor (2009), relataram a tendência à concentração de pessoas na capital. Atualmente, a população de Manaus supera a metade população de todo o estado. Assim, os referidos autores explicitam a necessidade de oferta de equipamentos urbanos que garanta condições mínimas de sobrevivência. 


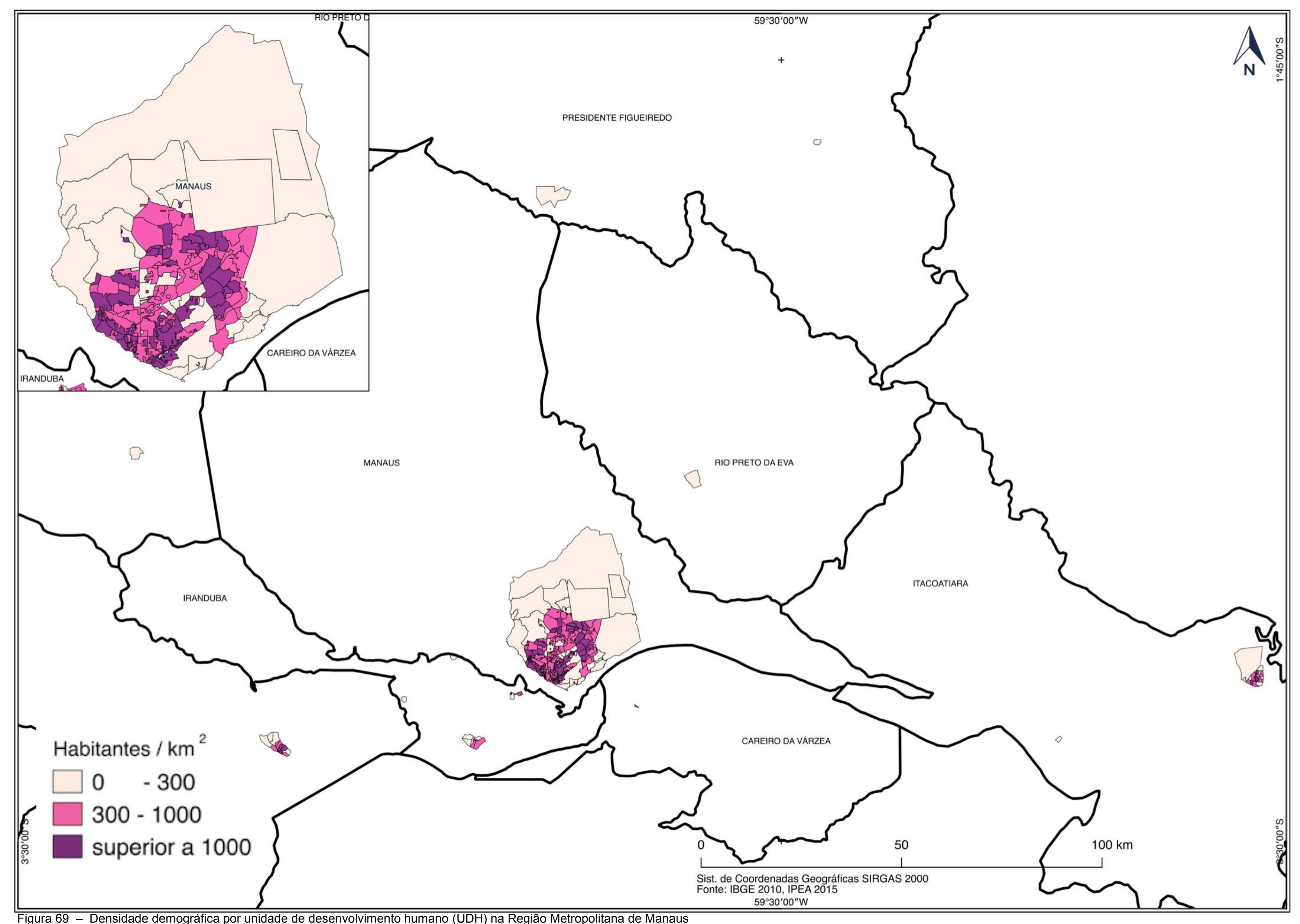


Mesmo que se tenha obtido êxito na geração de emprego e crescimento econômico, a implantação da ZFM não foi acompanhado de planejamento urbano capaz de receber o amplo contingente de população. Becker; Stenner (2008) citam que apenas na década de 1980 chegaram mais de 100 mil migrantes em Manaus à procura de emprego.

Nas indústrias da ZFM, estabeleceu-se uma nova força de trabalho constituída por levas de moradores das zonas rurais que migraram para Manaus e cidades vizinhas (SCHERER; MENDES FILHO, 2004). Na perspectiva dos migrantes que residiam em municípios longínquos e isolados, com poucas oportunidades de emprego, educação e saúde, a ZFM constituiu em uma possibilidade de vida melhor. Porém, nem todos migrantes foram absorvidos pelas indústrias, aos quais se renderam ao setor informal, situação que ampliou as desigualdades socioeconômicas (SCHERER; MENDES FILHO, 2004).

Esse processo gerou um cenário urbano de ocupação de zonas periféricas da cidade de Manaus e de suas cidades vizinhas, onde os mais pobres foram empurrados para as margens de igarapés e para as áreas ambientalmente precárias (SCHERER; MENDES FILHO, 2004). Assim, Becker; Stenner (2008, p.110) afirmam que a "Zona Franca dinamizou Manaus, e a dinâmica urbana alterou a Zona Franca, o que vem gerando efeitos no seu entorno".

Oliveira; Schor (2009) citam que nas últimas décadas a malha urbana de Manaus expandiu ao longo da margem do rio Negro, distribuindo-se pelos seus extensos platôs no sentido norte-leste, com a predominância de invasões de habitações precárias, e no sentido oeste com a predominância de condomínios de alto padrão. Com isso, identifica-se as áreas de segregação socioespacial: as periferias geralmente às margens dos igarapés habitam as classes sociais de baixo poder aquisitivo e os locais privilegiados em infraestrutura urbana residem os mais ricos (SOUZA; OLIVEIRA, 2003).

Além de Manaus, as cidades de Itacoatiara e Manacapuru possuem maior infraestrutura urbana e de serviços para atendimento da população local e dos municípios vizinhos. Assim, elas se apresentam como polos devido a sua localização e maior desenvolvimento urbano (OLIVEIRA; SCHOR, 2009).

As demais cidades que compõem a RMM se mantém com a atividade agrícola e extrativismo, cuja produção abastece a capital. Elas apresentam um grau de desenvolvimento muito menor e grande fragilidade socioeconômica, devido 
ausência de diversidade de agentes geradores de renda e a facilidade de migração (CAVALCANTE; FRANCHI; LOPES, 2015). Nesses locais, o acesso a bens e serviços tornaram-se difícil, aumentando as vulnerabilidades sociais.

A desigualdade gerada com o processo de crescimento econômico excludente na RMM é visível na Figura 70. Observa-se que as áreas mais periféricas de Manaus e as demais cidades da RMM apresentam os maiores índices de vulnerabilidade social (IPEA, 2015). O centro de Manaus e algumas partes específicas como a "orla da Ponta Negra" (porção oeste da capital) refletem de modo mais claro a desigualdade socioespacial na malha urbana (OLIVEIRA; SCHOR, 2009).

Por outro lado, as áreas periféricas, as margens dos igarapés ou mesmo nas cidades vizinhas tornaram-se uma alternativa de sobrevivência aos mais pobres. $\mathrm{O}$ processo de ocupação dos igarapés tornou um processo de degradação ambiental, principalmente pela ausência de saneamento básico (SOUZA; OLIVEIRA, 2003). Assim a paisagem da RMM retrata contradições inerentes a dois crescimentos: 0 primeiro o crescimento econômico, puxado pela ZFM e o outro, o crescimento da periferização em meio a floresta (OLIVEIRA; SCHOR, 2009).

Ressalta-se aqui, também, os dados censitários (IBGE, 2010) sobre o PIB da RMM que evidencia, novamente, a concentração econômica da capital Manaus. Dos $\mathrm{R} \$ 51$ bilhões de PIB da RMM, Manaus concentra 94,55\%, o que caracteriza uma elevada desigualdade de renda entre a capital e as demais cidades da região metropolitana (IBGE, 2010). Ao analisar a participação dos setores econômicos no $\mathrm{PIB}$, no ano de 2010, destaca-se o setores de indústrias e serviços, sendo a indústria com $39,82 \%$ e os serviços com $38,41 \%$ de participação no valor total do PIB da RMM (IBGE, 2010). 


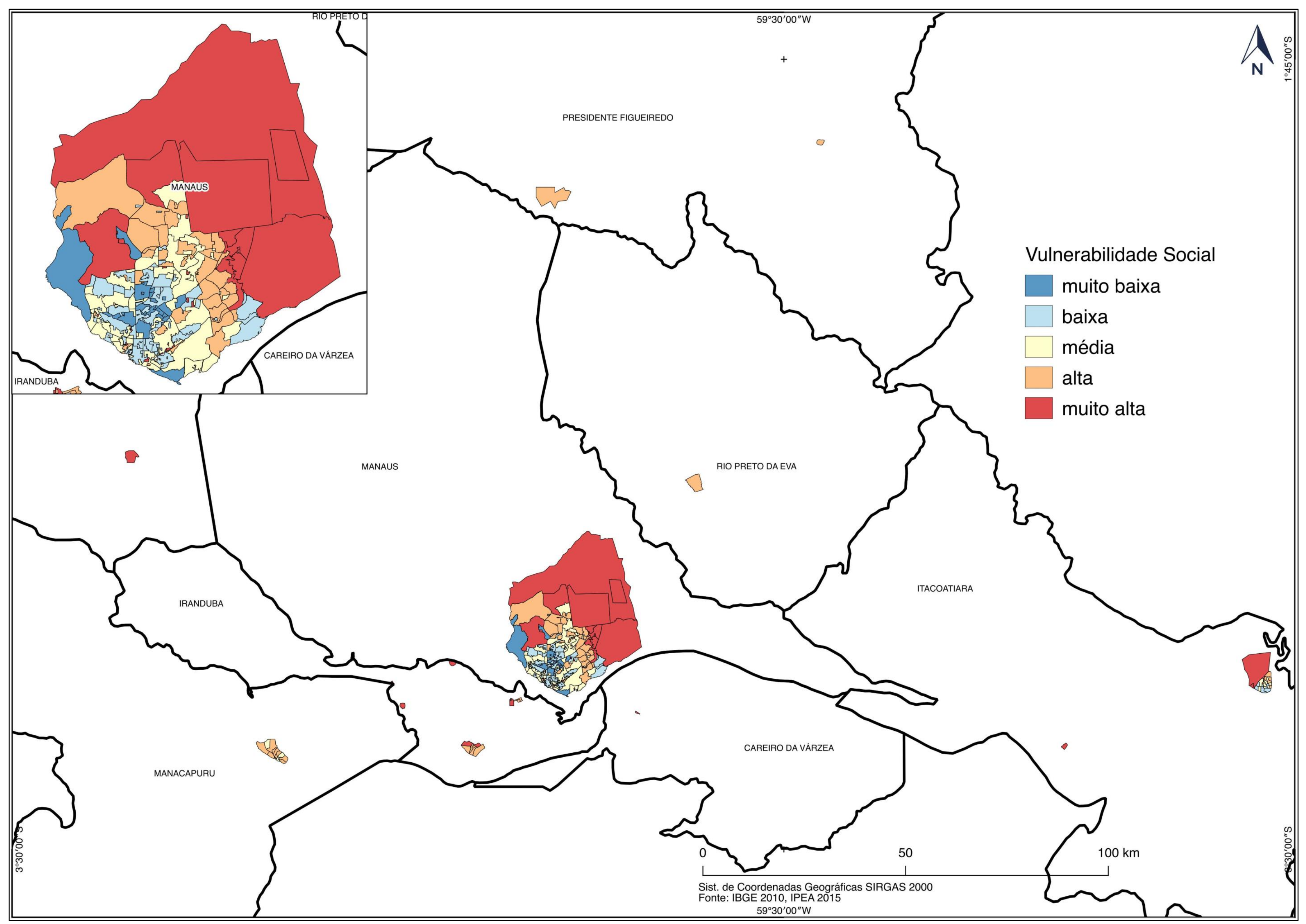

Figura 70 - Vulnerabilidade social nas unidades de desenvolvimento humano (UDH) na Região Metropolitana de Manaus 
A RMM tem o desafio de articular uma enorme área com dinâmicas ligadas aos rios, áreas rurais de várzea e terra-firme, além das demandas urbanas advindas de Manaus. Facilitar as conexões entre as cidades da RMM é apenas um desafio que pode ajudar a estruturar as cidades menores (CAVALCANTE; FRANCHI; LOPES, 2015).

Moraes et al. (2014) relatam que o crescimento de Manaus nas últimas décadas conjugado com a ineficiência de politicas públicas de planejamento urbano, trouxe uma série de problemas socioambientais, derivados principalmente da perda dos espaços verdes urbanos. Essa perda contribuiu para acentuação de ilhas de calor, especialmente nos lugares mais impactados pela urbanização, além de alagamentos e desabamentos de encostas (MORAES et al., 2014).

Souza; Oliveira (2003) indicam que os desmatamentos às margens dos igarapés além dos efeitos ambientais aumentaram os índices de doenças, sobretudo as de veiculação hídrica (cólera, amebíase, hepatite infeciosa). Uma vez que o desmatamento aumenta a erosão, leva ao assoreamento dos igarapés, ao acúmulo de lixo e esgoto. Quando a vazão do rio aumenta, proliferam-se as doenças (SOUZA; OLIVEIRA, 2003).

Além da melhoria da infraestrutura urbana que vise a saúde, é importante ressaltar a importância do estabelecimento de áreas de lazer e sociabilidade, como os espaços verdes como equipamentos urbanos para melhoria da qualidade de vida. Na pesquisa realizada por Souza; Oliveira (2003) em uma ocupação no Igarapé Quarenta (Manaus), 92\% dos entrevistados responderam não possuírem nenhuma forma de lazer. "Essa realidade confirma que a cidade é uma mercadoria cara inacessível a uma grande maioria menos favorecida" (SOUZA; OLIVEIRA, 2003, p. 93).

Estudar a importância dos espaços verdes em uma região onde há abundância de florestas pode parecer contraditório. Porém, dado os problemas socioambientais da RMM, elencar a importância dos EVU como espaços diferenciados de participação pode ser uma ponte de integração entre qualidade de vida e a redução das desigualdades sociais. 


\subsubsection{Espaços Verdes Urbanos na Região Metropolitana de Manaus}

O mapeamento identificou a porção de $608,29 \mathrm{~km}^{2}$ de espaços verdes urbanos no recorte proposto (Figura 71). Esse valor corresponde a quase $60 \%$ da área analisada da RMM. A tabela a seguir mostra a proporção das áreas analisadas e dos EVU.

Tabela 9 - Espaços verdes urbanos nas cidades da Região Metropolitana de Manaus

\begin{tabular}{lllll}
\hline UF & Cidades & Área $\mathbf{k m}^{2}$ & EVU $\mathbf{k m}^{2}$ & \% EVU/Área \\
\hline \multirow{6}{*}{ AM } & CAREIRO DA VÁRZEA & 0,31 & 0,01 & 01,76 \\
& IRANDUBA & 19,00 & 11,46 & 60,31 \\
& ITACOATIARA & 54,34 & 25,57 & 47,05 \\
& MANACAPURU & 22,06 & 3,89 & 17,64 \\
& MANAUS & 879,46 & 559,35 & 63,60 \\
& NOVO AIRÃO & 7,21 & 1,54 & 21,38 \\
& PRESIDENTE FIGUEIREDO & 30,41 & 24,11 & 79,31 \\
& RIO PRETO DA EVA & 11,19 & 7,36 & 65,81 \\
\hline Total & & 1023,97 & 608,29 & 59,41 \\
\hline \hline
\end{tabular}

Fonte: Elaborada pelo autor

A maior parte dos EVU concentram-se em Manaus com a área de 559,35 $\mathrm{km}^{2}$, o que representa $92 \%$ de todos os EVU da RMM. Em termos de porcentagem de EVU, em relação à área analisada, existem cidades com maior proporção, como: Presidente Figueiredo e Rio Preto da Eva, porém as áreas territoriais analisadas dessas cidades não chegam $5 \%$ a de Manaus, vide Tabela 9.

A cidade que apresentou menor quantidade de EVU foi Careiro da Várzea (cidades a leste de Manaus), com pouco mais de 1\% de EVU da área analisada (Figura 71). Ressalta-se que a pequena cidade fica a maior parte do período das cheias com mais de $80 \%$ do seu território inundado. 


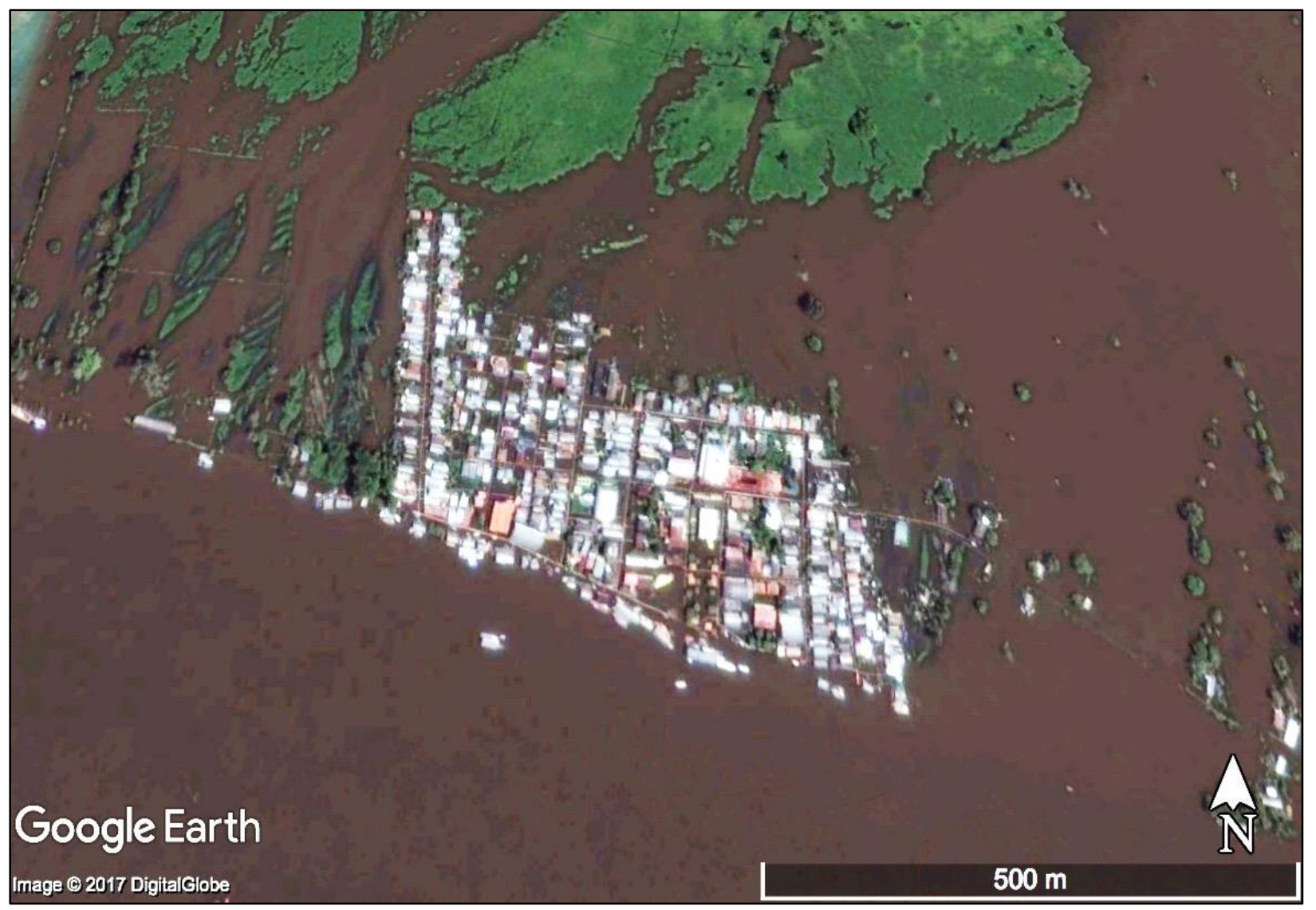

Figura 71 - Careiro da Várzea (RMM). Abril de 2017

Fonte: Google-Earth (2017)

Na Figura 71, a área em marrom indica água se adentrando na cidade. Com as frequentes cheias a cidade se adaptou e priorizou a construção de casas mais elevadas e sistemas de pontes e caminhos sobre a água (NOGUEIRA, 2010). Esse fato justifica a inexistência des espaços verdes no interior do pequeno núcleo urbano. 


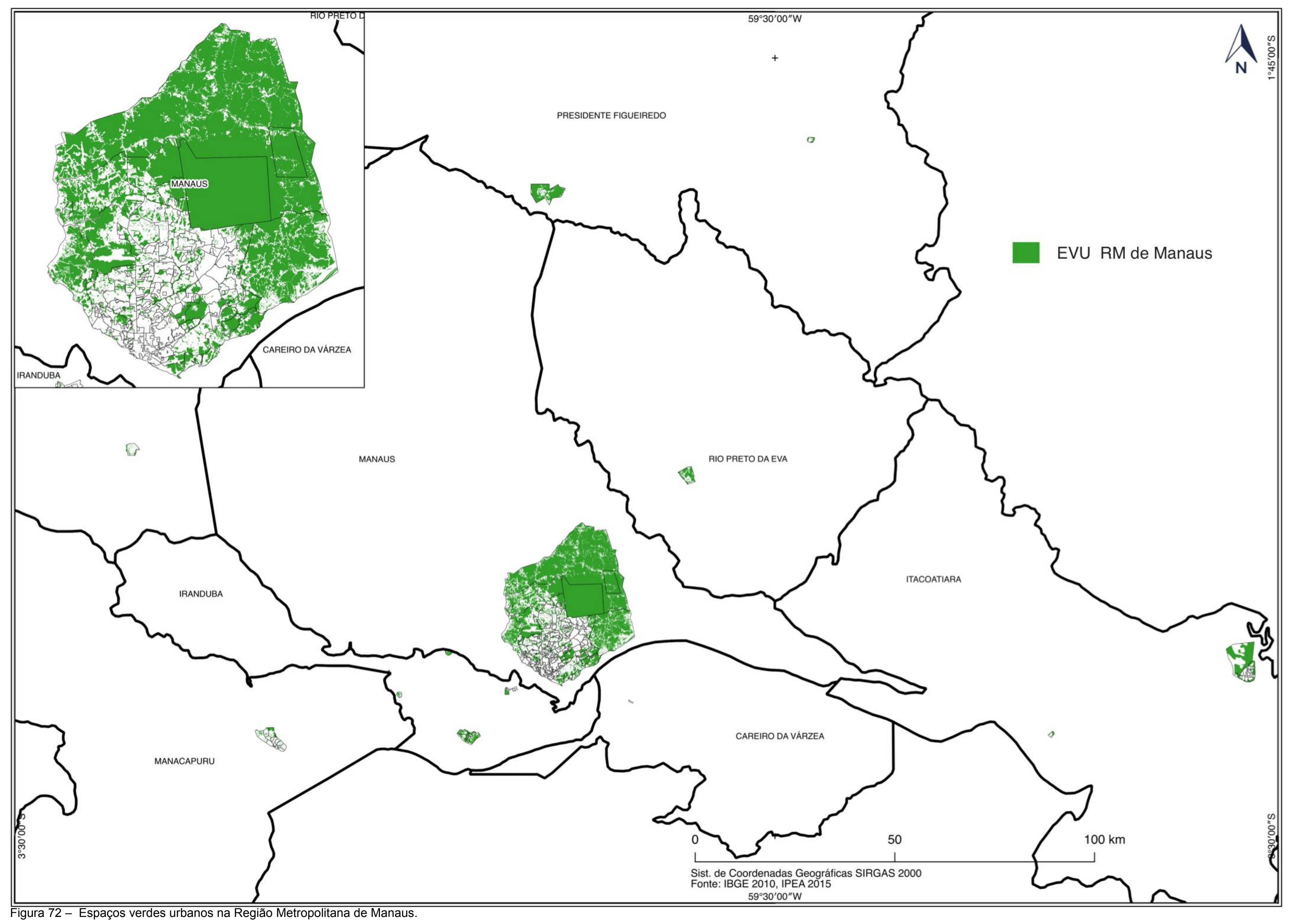




\subsubsection{Espaços Verdes Urbanos e Unidades de Conservação da Natureza}

Dado o potencial dos espaços verdes, Moraes et al. (2014) afirmam que Manaus possui uma quantidade baixa de parques e áreas protegidas na área urbana. A maioria dos espaços verdes destinados à parque urbano, por exemplo, foram iniciativas recentes, após os anos 2000. Os mesmos autores citam os principais parques da capital: Zoológico do CIGS (Centro de Instrução de Guerra na Selva - Exército Brasileiro), Parque Municipal do Mindu, Bosque da Ciência, Jardim Botânico Adolpho Ducke, Parque Municipal do Idoso, Parque dos Bilhares, Parque Lagoa do Japiim, Parque Senador Jéfferson Péres e Parque da Criança.

Além de serem poucos, Moraes et al. (2014) relatam a distribuição desigual dos citados parques na cidade de Manaus. Eles concentram-se no eixo central sentido Norte - Sul, justamente nas áreas mais valorizadas e onde reside a população com maior poder aquisitivo (Figura 73).

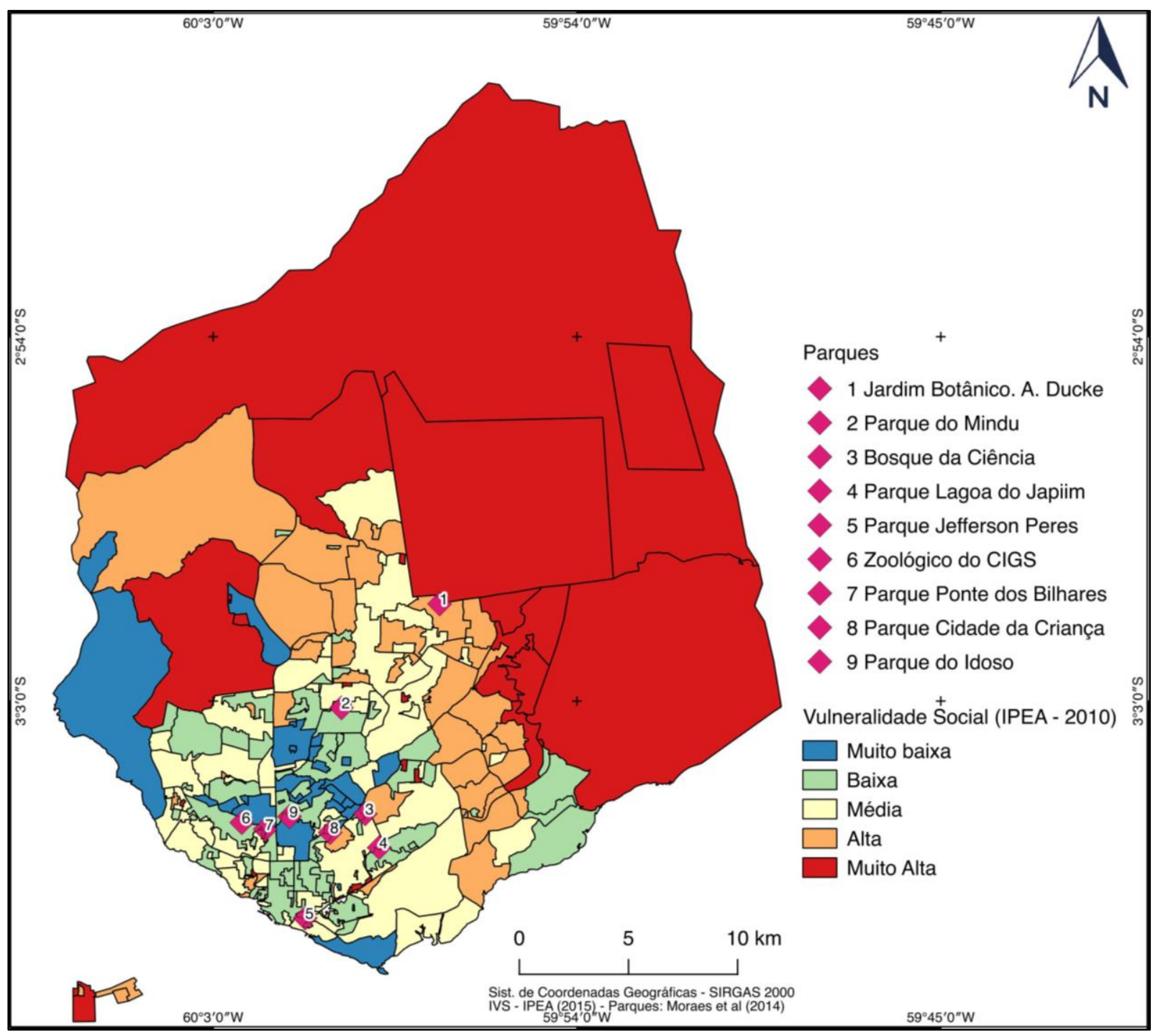

Figura 73 - Parques da cidade de Manaus sobrepostos ao mapa de vulnerabilidade social 
Além desses parques, é importante mencionar a Reserva Florestal Adolpho Ducke, a ampla área verde ao norte de Manaus. Ela foi criada em 1963 pela Lei estadual no 41 de 16 de fevereiro de 1963 (AMAZONAS, 1963), que concedeu uma área de $100 \mathrm{Km}^{2}$ de floresta da Reserva do Governo do Amazonas ao INPA Instituto Nacional de Pesquisas da Amazônia (OLIVEIRA et al., 2008). Ela continua sendo administrada pelo INPA e foi declarada como Reserva Ecológica, porém não faz parte do SNUC (BRASIL, 2000).

Ao ser administrada pelo INPA, a Reserva Ducke tem servido como campo para realização de inúmeras pesquisas científicas que envolvem o bioma Amazônia. Logo, se entrasse no rol das UCs poderiam sofrer restrições. Por outro lado, ela não se beneficia das vantagens desse sistema, ao qual the concederia o direito legal à manutenção de uma zona tampão ou amortecimento (OLIVEIRA et al., 2008).

Atualmente várias ocupações têm se instalado nos seus limites, gerando um processo de fragmentação e degradação florestal. Uma das medidas para conter o avanço da ocupação desordenada foi a criação do Jardim Botânico Adolpho Ducke, dentro da reserva. Ele é considerado o maior do mundo, correspondendo a $5 \%$ da área protegida (MORAES et al., 2014).

Além dos citados parques da capital Manaus, destacam-se as UCs conforme o banco de dados do SNUC, disponível no site do ICMBio (2010). A Tabela 10 e a Figura 74 indicam as UCs no recorte proposto da RMM. Nota-se que $16,95 \%$ da área analisada estão no enquadramento das UCs. Dessa área, quase $85 \%$ são considerados EVU, isso mostra que a cobertura vegetal das UCs dentro da área analisada é elevada. 
Tabela 10 - Espaços verdes urbanos nas Unidades de Conservação da Natureza

\begin{tabular}{llll}
\hline Nome da Área Protegida & Área $\mathrm{km}^{2}$ & $\mathrm{EVU} \mathrm{km}$ & \% EVU/Área \\
\hline APA Caverna do Maroaga & 17,64 & 13,97 & 79,17 \\
APA Margem do Rio Negro-Paduari-Solimões & 13,61 & 4,07 & 29,86 \\
APA Tarumã Ponta-Negra & 132,97 & 122,59 & 92,19 \\
Parque Estadual (PE) Sumaúma & 0,52 & 0,30 & 59,12 \\
PN de Anavilhanas & 0,85 & 0,024 & 2,83 \\
REc de Sauim-Castanheira & 1,29 & 0,94 & 73,35 \\
RPPN Bela Vista & 1,08 & 0,10 & 8,83 \\
RPPN Fazenda Betel & 0,56 & 0,55 & 99,95 \\
\hline Total & $\mathbf{1 6 8 , 5 2}$ & $\mathbf{1 4 2 , 5 4}$ & $\mathbf{8 4 , 5 9}$ \\
\hline Total UDH Analisada & 1023,97 & 608,29 & 59,41 \\
\% Total Área Protegida/Total Analisado & 16,46 & 23,43 & \\
\hline \hline
\end{tabular}

Fonte: Elaborada pelo autor

Quanto a categoria mais representativa de UC, destacam-se as APAs, com 95\% de EVU (Tabela 10). Como já enunciado, essa categoria permite vários tipos de intervenção e ocupações populacionais. A APA com maior magnitude de UC e espaços verdes é a APA Tarumã Ponta-Negra, localizada a oeste da cidade de Manaus. É nessa área que Oliveira; Schor (2009) relatam a enorme pressão imobiliária e a nova expansão urbana de condomínios e edificações da classe média-alta manauara. 


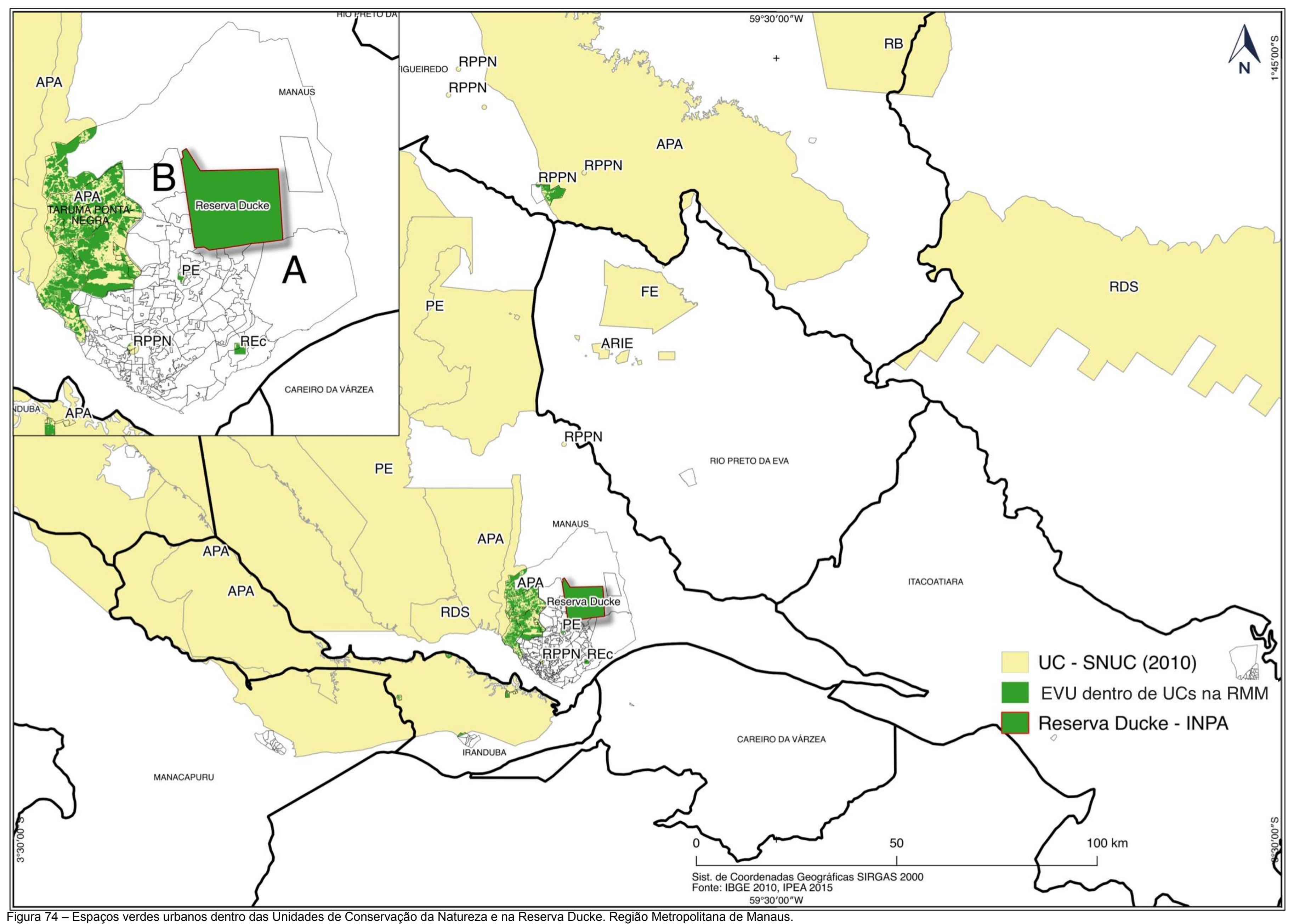




\subsubsection{Espaços Verdes Urbanos nas Unidades de Desenvolvimento Humano}

Quanto à concentração dos espaços verdes urbanos por UDH, a Figura 75 mostra uma grande concentração na porção norte e leste de Manaus, variando de $60 \%$ a $99 \%$ de EVU. De acordo com Nogueira; Sanson; Pessoa (2007) as zonas norte e leste passaram por processo de ocupação somente após a década de 1980 . Antes disso essas áreas mantinham-se fora do processo de urbanização, sendo frequentadas para atividades de lazer, como a pesca.

Após a década de 1980, começou-se a verificar impactos significativos do processo de ocupação desordenada nestas áreas. Embora os espaços verdes cubram a maior parte da zona norte, Nogueira; Sanson; Pessoa (2007) registraram a perda da cobertura florestal, como o maior responsável dos impactos verificados nessas áreas, como: assoreamento dos igarapés e desmoronamentos nas encostas do rios e vales.

Registra-se ainda, que na zona norte, os setores censitários que formam as UDHs, ainda são classificados pelo IBGE como situação 2, ou seja são considerados "área não urbanizada" (IBGE, 2011, p.39). Pela Lei Federal n 13.645, podem ser considerados "núcleos urbano informais consolidados", considerando o "tempo de ocupação, localização das vias de circulação e a presença de equipamentos urbanos, mesmo que precários" (BRASIL, 2017 - Art. 11, inciso III). 


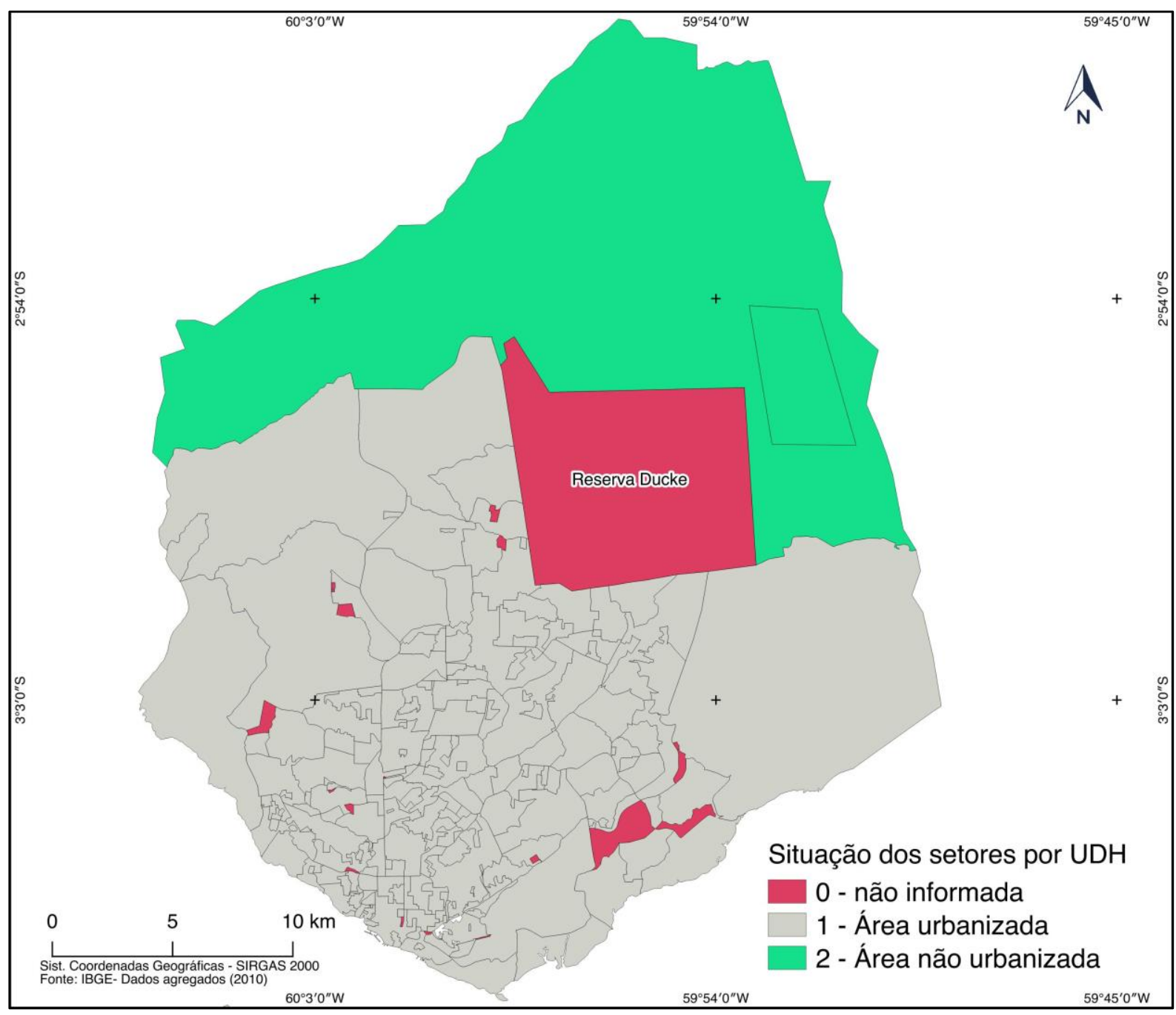

Figura 75 - Classificação dos setores censitários de Manaus por situação.

Oliveira et al. (2008) relatam a expansão urbana que ocorre de forma irregular nessa área, ameaçando inclusive a Reserva Ducke. Mesmo assim, os autores afirmam que o próprio Estado estimula e executa a construção de condomínios populares nessa região. Embora distante do centro e ambientalmente relevante, é na zona Norte que o poder público apresenta a nova fronteira expansão urbana, principalmente para classe trabalhadora que sonha em ter a casa própria (NOGUEIRA; SANSON; PESSOA, 2007). 


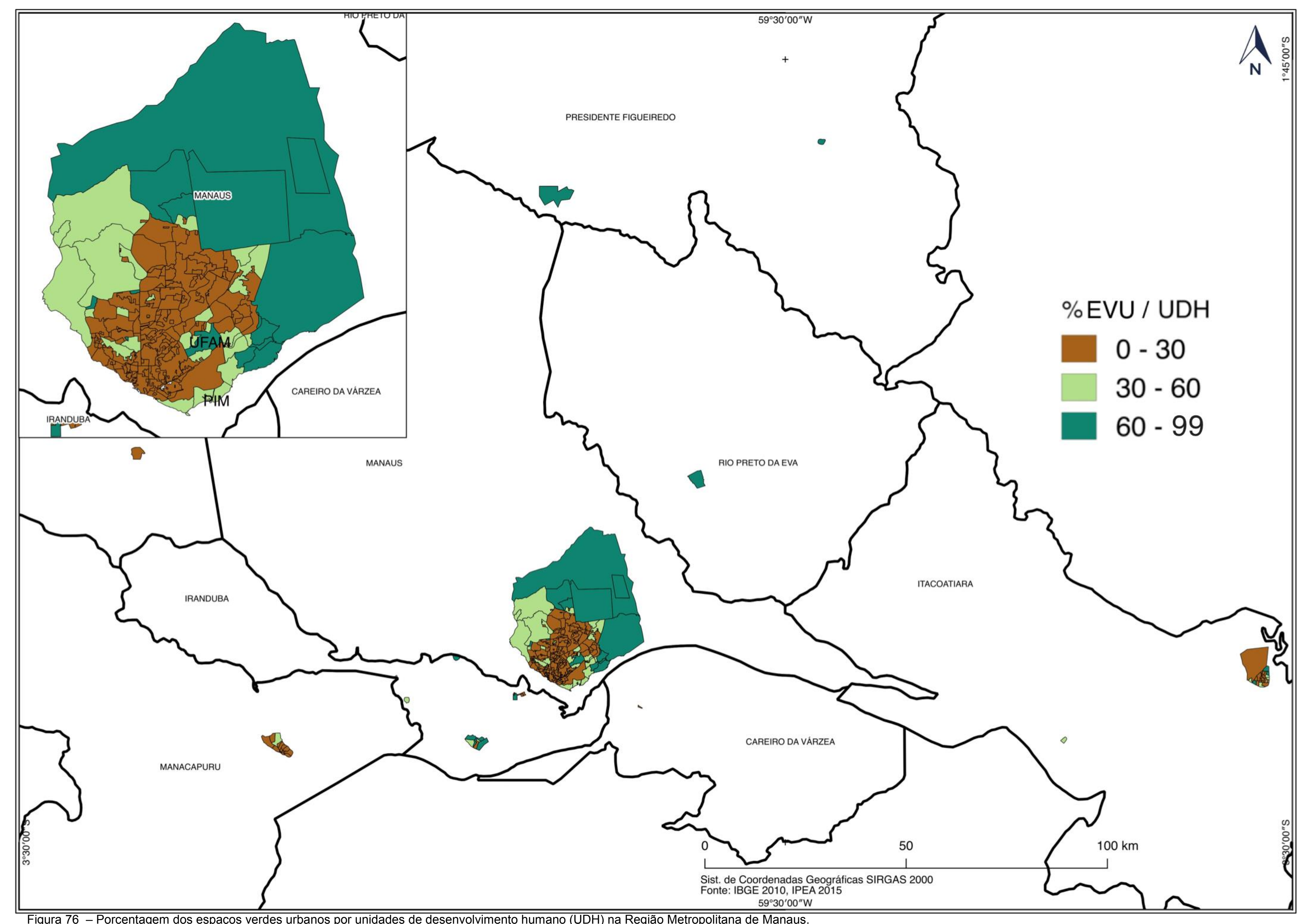


Na porção leste também observa-se a presença de ampla cobertura vegetal conjugada a um processo de ocupação irregular nos igarapés. Nogueira; Sanson; Pessoa (2007) citam ali as maiores invasões da capital, que têm causado graves problemas de ordem ambiental e social. Como resultado, as comunidade vivem rodeadas de verde, mas sem estrutura urbana básica, como: saneamento-básico, transporte e lazer. Afora essa alta quantidade dos EVU na porção leste, cita-se a UDH situada no campus da Universidade Federal do Amazonas (UFAM), porção centro-leste da Figura 76, que também apresenta ampla cobertura vegetal.

A classe intermediária, com porcentagem variando de $30 \%$ a $60 \%$ de EVU encontra-se majoritariamente na porção oeste, local de ocorrência do condomínios da classes média-alta manauara. Nessa área, existe um controle rígido quanto ao desmatamento assim como a edificação das moradias, medidas impostas pelo mercado e pelo Estado afim de garantir maior conforto a quem "escolhe" morar ali. Dessa forma, a zona oeste é um dos espaços de maior especulação imobiliária para empreendimentos de alto custo (NOGUEIRA; SANSON; PESSOA, 2007).

Destaca-se também a ocorrência da classe intermediária do lado leste (mais ao sul), local onde instalou-se a maioria das indústrias da ZFM (após de 2002: Polo Industrial de Manaus - PIM), armazéns e refinaria. É uma área com grandes estruturas e edificações para fins industriais e logísticos. Sendo uma área planejada, de alta vigilância e administrada pela SUFRAMA, os amplos espaços de cobertura vegetal na referida área se mantém (NOGUEIRA; SANSON; PESSOA, 2007).

A classe com menor proporção de EVU (0 a 30\%) encontra-se no centro-sul de Manaus, local historicamente de maior densidade populacional. A cobertura vegetal nessa área foi analisada por Gontijo (2008) através de idas a campo e análises imagens de satélite de alta resolução $(60 \mathrm{~cm})$. A autora concluiu que os fragmentos florestais da área mais ocupada de Manaus são de origem bastante variadas (remanescente de florestas nativas, plantadas e capoeiras) e se localizam espalhados por todo centro e em sua grande maioria não possuem utilidade social (praças ou parques).

Quanto a proporção de EVU nas demais cidades da RMM, destaca-se que Iranduba apresentou o mesmo padrão de Manaus: centro com pouca quantidade e áreas mais periféricas maior quantidade. As demais cidades da RMM variaram bastante quanto a quantidade de EVU. Careiro da Várzea, Itacoatiara, Manacapuru, Novo Airão apresentaram em média baixa proporção de EVU (0 a 30\%). Rio Preto 
da Eva apresentou a quantidade intermediária (30 a 60\% de EVU). Enquanto Presidente Figueiredo registrou mais de $60 \%$ de EVU.

\subsubsection{Análise Dependente da Demografia}

A Figura 77 traz a proporcionalidade dos espaços verdes urbanos por habitantes nas unidades amostrais (UDH - IPEA) relacionando a quantidade de EVU por habitantes. O mapa sintetiza as análises anteriores, indicando que há uma concentração populacional agregada a baixa quantidade de EVU nas UDHs localizadas no centro-sul de Manaus.

Destacam-se as áreas em vermelho, onde a relação de EVU por habitantes é igual a zero. Nesse caso as respectivas UDHs não apresentam espaços verdes. Representam essa classe as UDHs localizadas no centro histórico de Manaus e em áreas mais ao norte, locais de grande densidade demográfica. Nota-se que elas não estão concentradas em apenas uma região.

As áreas em laranja representam os locais onde a quantidade de EVU por habitante é inferior aos $15 \mathrm{~m}^{2}$, valor recomentado pela Sociedade Brasileira de Arborização Urbana - SBAU. Elas estão localizadas também no centro de Manaus, sobretudo na porção mais ao sul, onde encontra-se o Porto de Manaus.

As demais classes, em amarelo, verde-claro e verde-escuro expressam de forma graduada maior quantidade de espaços verdes por habitante. Variando de 15 a $100 \mathrm{~m}^{2}$ nas áreas em amarelo, $100 \mathrm{~m}^{2}$ a $1000 \mathrm{~m}^{2}$ nas áreas em verde-claro e superiores de $1000 \mathrm{~m}^{2}$ em verde-escuro. 


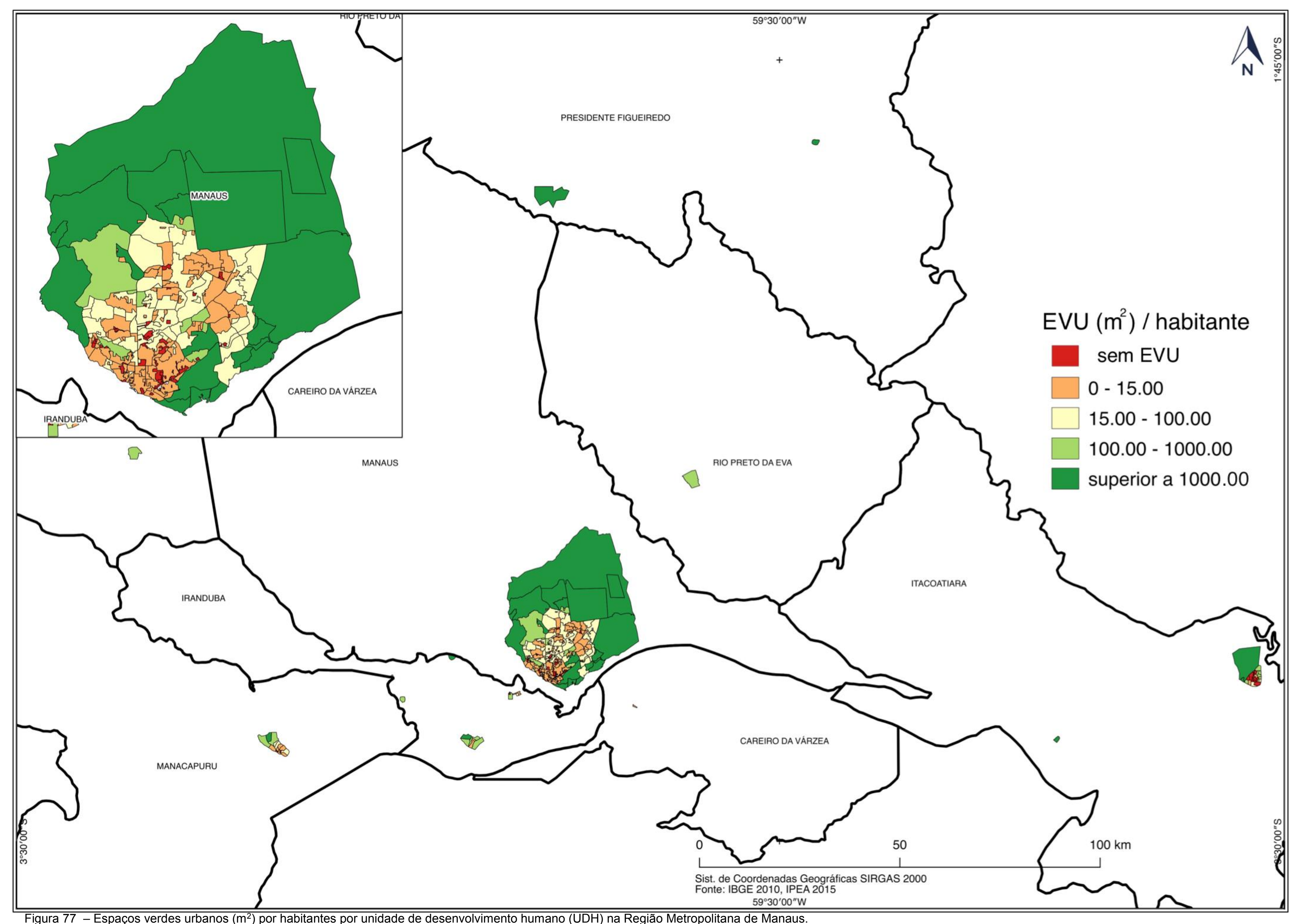




\subsubsection{Tamanho e Distribuição dos Fragmentos dos Espaços Verdes Urbanos}

Ao categorizar o tamanho dos espaços verdes da RMM, por área, em três classes (pequenas, intermediárias e grandes) de acordo com a curva normal de distribuição e estabelecendo o desvio padrão como limite das classes, obteve-se a seguinte categorização (Tabela 11).

Tabela 11 - Categorização do tamanho dos fragmentos dos espaços verdes urbanos

\begin{tabular}{ll}
\hline EVU $\left(\mathrm{km}^{2}\right)$ & Classe de fragmentos \\
\hline $0,00-16,04$ & Pequenos \\
$16,04-306,57$ & Intermediários \\
$306,57-408,37$ & Grandes \\
\hline \hline \multicolumn{2}{l}{ Fonte: Elaborada pelo autor }
\end{tabular}

A Figura 78 mostra que a classe de fragmentos grandes é composta por apenas um fragmento (na cor verde) localizado na porção norte de Manaus. Esse fragmento corresponde a floresta Amazônica, onde o núcleo urbano ainda não avançou. Mesmo dentro dos limites urbanos ressalta-se a sua importância ecológica, sobretudo pelo tamanho significativo de vegetação nativa e sua provável alta biodiversidade. Daí a importância da presença da Reserva A. Ducke não apenas pelas pesquisas desenvolvidas mas como uma barreira para conter a nova fronteira de expansão urbana numa área ambientalmente relevante.

A classe dos fragmentos intermediários também representam, nas demais cidades, a floresta Amazônica, onde a área urbana não avançou. Em Manaus essa classe apresentam os grande fragmentos de floresta dentro da malha urbana nas seguintes localidades: na porção oeste (local dos condomínios de luxo), na porção leste mais ao sul (indústrias do Polo Industrial de Manaus - PIM) e outros mais ao centro, como no campus da Universidade Federal do Amazonas (UFAM) e a área do exército (CIGS).

A análise dos menores fragmentos foi feita a partir do mapa de Kernel (Figura 79). Chama-se atenção para os focos de calor localizados nas UDHs com maior vulnerabilidade social. Destaca-se assim, a porção sul da UDH (A) denominada de Puraquerara, que possui um alto IVS $(0,51)$ e as UDHs (B) localizadas na porção centro-norte denominadas: Santa Etelvina, Monte das Oliveiras, Colônia Terra Nova, Novo Israel. Nessas o IVS também é alto $(0,48)$. 


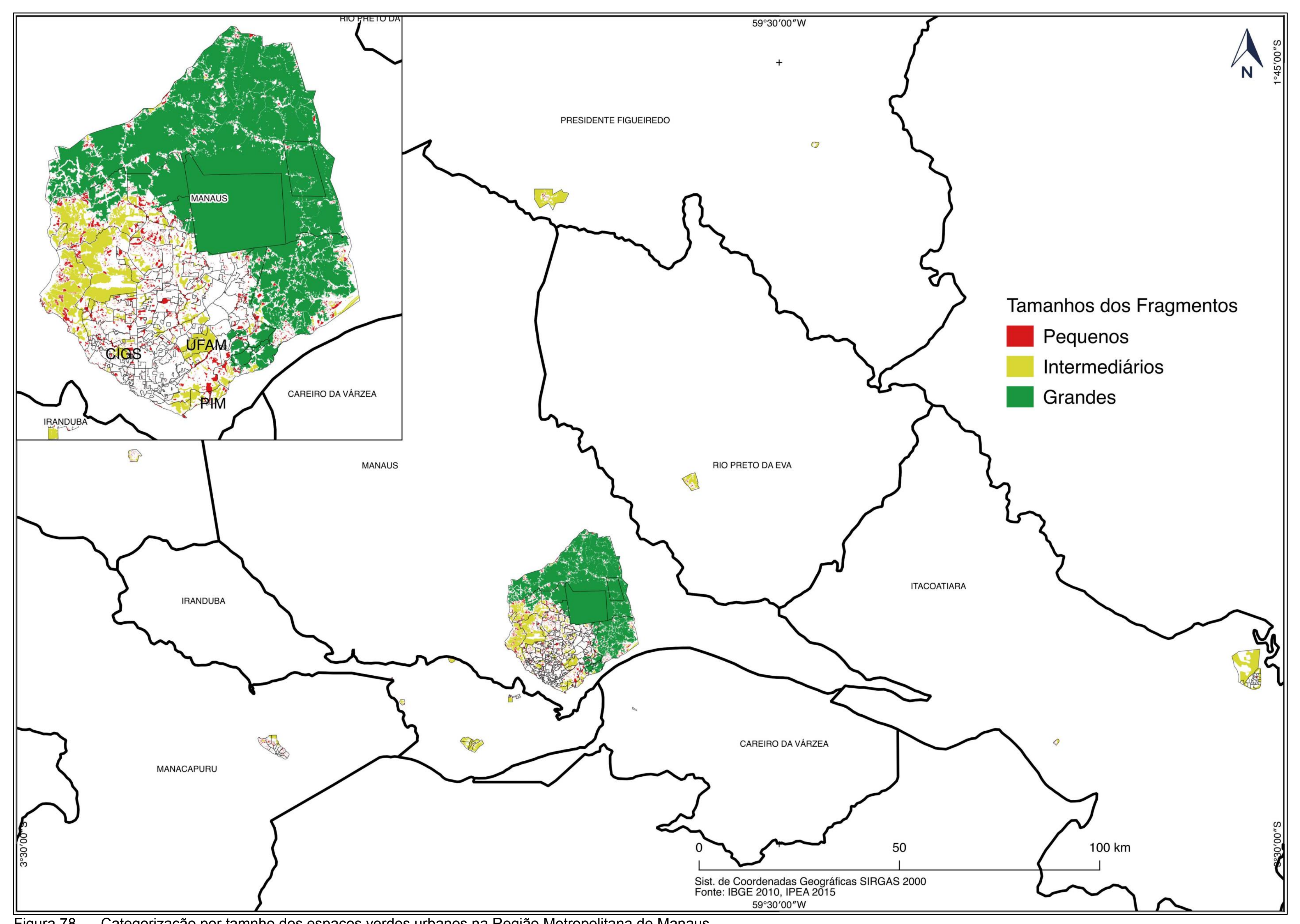

Figura 78 - Categorização por tamnho dos espaços verdes urbanos na Região Metropolitana de Manaus. 


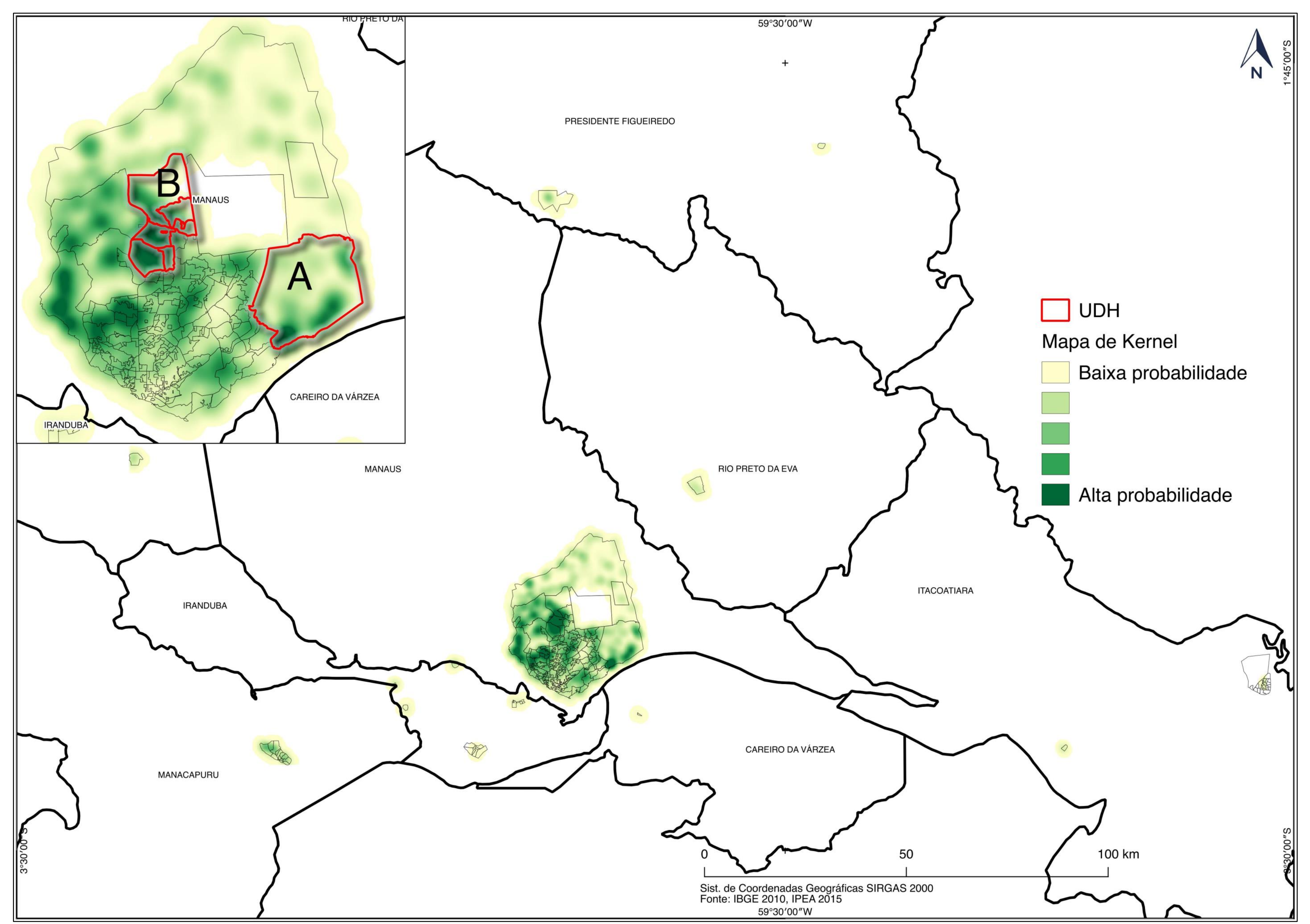

Figura 79 - Mapa de kernel dos fragmentos pequenos na Região Metropolitana de Manaus. 
A UDH (A) denominada de Puraquequara é um bairro situado às margens do Rio Amazonas, zona leste de Manaus, identificada por muitos como área rural (Figura 80). "Apesar de pertencer geograficamente à zona urbana, o bairro conserva elementos culturais próprios de populações rurais" (COELHO, 2006, p. 192). Exemplo desses elementos, a autora cita: a prática da pesca e agricultura como fonte de renda, uso de transporte fluvial e as casas simples com amplos quintais com bastante frutíferas, hortas e criação de animais.

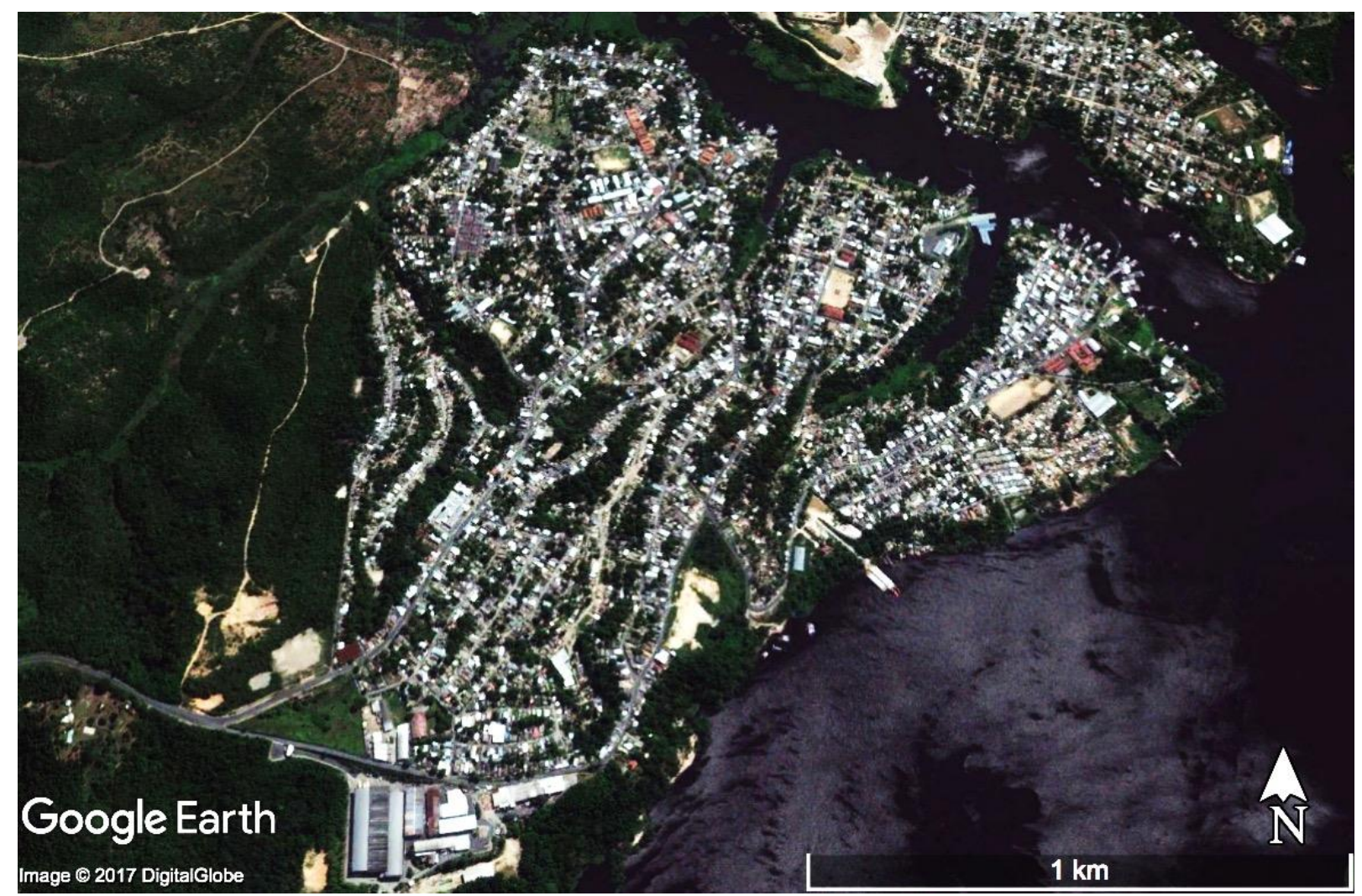

Figura 80 - Bairro da Puraquequara - Manaus

Fonte: Google-Earth (2017)

Em Puraquequara, infere-se que a grande quantidade de fragmentos pequenos estão relacionados aos grandes quintais e principalmente pelo modo de vida da população local que os mantém. Nesse caso, destaca-se a presença significativa de pequenos fragmentos dos EVU por ação direta dos moradores, mesmo com a UDH (A) possuindo alto índice de vulnerabilidade social, o que reflete na pouca infraestrutura urbana e em baixos índices sociais (renda, educação e saúde).

Quanto as UDHs localizadas na porção centro-norte, Souza (2014) indica que essa área durante as décadas de 1970 e 1980 foi considerada como "vazio urbano" 
e atualmente é o maior vetor de ocupação urbana, seja por condomínios populares ou invasões. Assim, os espaços verdes "foram e vem sendo desmatados para atender as demandas de moradia" (SOUZA, 2014 p.57).

Seguindo essa lógica os pequenos fragmentos mapeados na UDH (B) têm grandes chances de desaparecerem, para serem transformados em conjuntos habitacionais ou em ocupações irregulares. Dado o elevado índice de vulnerabilidade social, é importante ressaltar a presença desses fragmentos para que eles sejam inseridos na política de planejamento territorial como equipamentos urbanos promotores de bem estar social e qualidade de vida.

\subsubsection{Correlação: Espaços Verdes Urbanos Vulnerabilidade Social}

A correlação espacial entre IVS e porcentagem de EVU nas UDH da RMM apresentou o Índice de Moran com valor positivo: 0,13 (Gráfico 9). Assim, essa amostra mostrou uma correlação que refuta a hipótese: áreas com melhores índices sociais (menor IVS) apresentam maior porcentagem de EVU, e vice-versa.

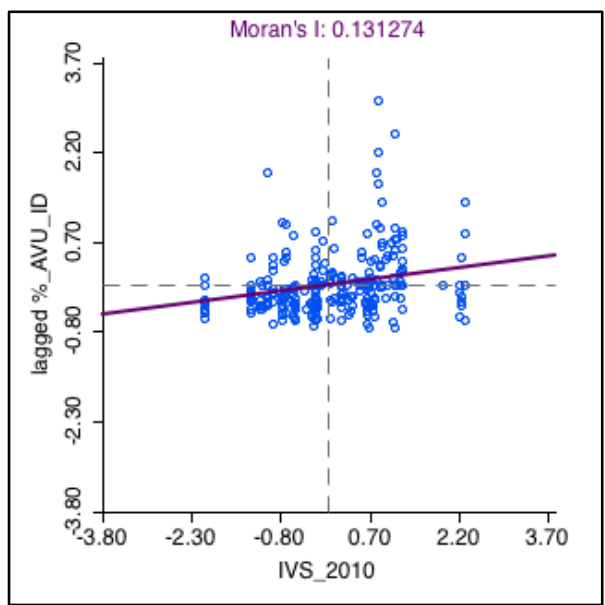

Gráfico 9 - Diagrama de espalhamento de Moran na RMM

Do total de 274 UDH da RMM, 75\% não apresentaram significância na análise proposta. A Gráfico 10 destaca as UDHs sem significância, observando que são aquelas mais próximas ao eixo da variável representada pelo IVS (horizontal). $\mathrm{Na}$ prática representam as UDHs que apresentam valores onde a quantidade de EVU não variou tanto conforme às variações de IVS. 


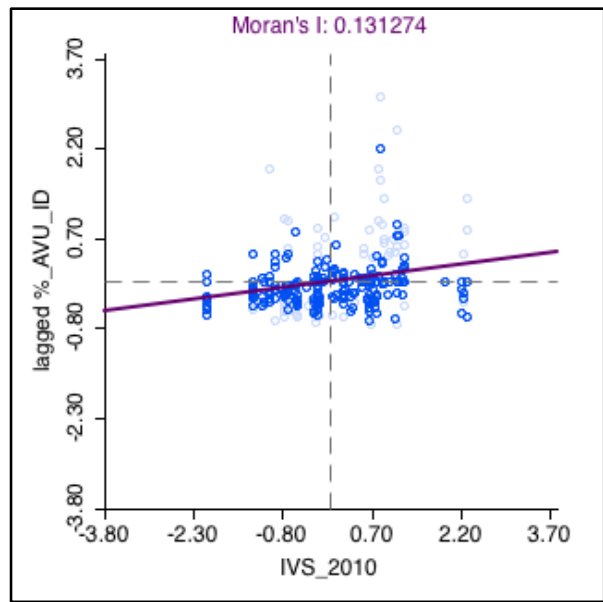

Gráfico 10 - UDHs sem significância na RMM

O Gráfico 11 indica as 36 UDH que não apresentam significância por não apresentarem vizinhança, logo não influenciaram na análise de correlação espacial. No gráfico de correlação, essas UDHs dispostas em cima do eixo da variável dependente, representada pelo IVS.

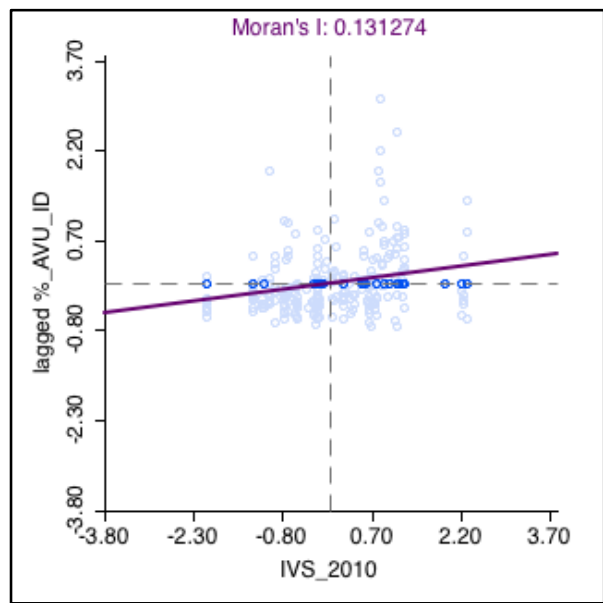

Gráfico 11 - UDHs sem vizinhança na RMM

O Gráfico 12 destaca as 68 UDH que apresentaram significância na correlação geoestastítica, o que representa $25 \%$ do total. O Gráfico indica que são os pontos mais dispersos na correlação espacial. Verifica-se que o espalhamento desses pontos (representado pelas UDHs) são determinantes para a inclinação da curva de correlação, refletindo o valor positivo do Índice de Moran. 


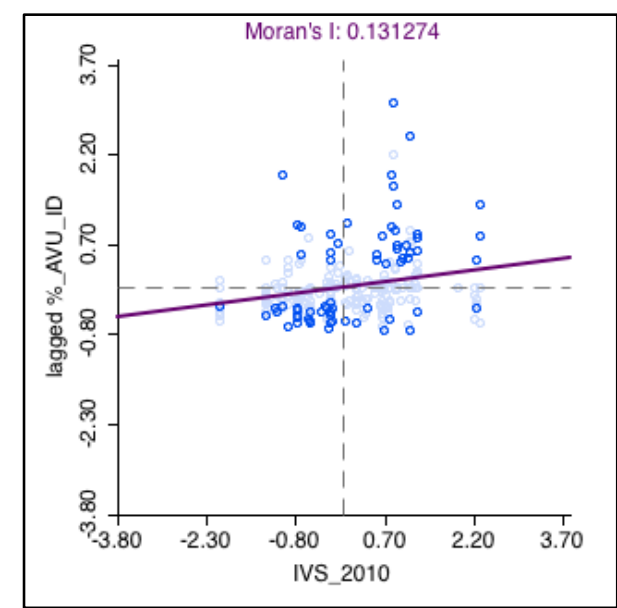

Gráfico 12 - UDHs com vizinhança na RMM

Porém cabe destacar que haver significância na correlação não implica corroborar a hipótese. Ao analisar os resultados frente a hipótese, é necessário destacar os cenários esperados: a) UDH com grande porcentagem de EVU e IVS baixo e b) UDH com baixa porcentagem de EVU e IVS alto. Esses dois cenários estão representados na cor verde (cenário A) e cor vermelha (cenário B) nas Figuras 80 e 81 . Esses cenários compõe 25\% das unidades amostrais (17 UDH) que apresentaram significância na correlação. Essas 17 UDH corroboram a hipótese da tese, ainda que o Índice de Moran tenha dado positivo.

Os demais $75 \%$ das UDHs, que também apresentaram significância na análise geoestastítica, representam os cenários opostos à hipótese: c) UDH com grande porcentagem de EVU e IVS alto e d) UDH com baixa porcentagem de EVU e IVS baixo. Esses dois cenários estão representados na cor laranja (cenário c) e cor amarela (cenário d) nas Figuras 80 e 81.

Uma vez que a correlação é baseada na quantidade e grau de vizinhança das unidades amostrais (UDH) as áreas que se correlacionam podem ser melhor analisadas ao inferir sobre a dimensão de área e população, conforme mostram a Figura 81 e a Tabela 12. A Figura 82 espacializa as áreas que apresentaram correlação significativa. 
Tabela 12 - Resumo dos resultados da correlação aplicada na Região Metropolitana de Manaus

\begin{tabular}{llllll}
\hline Correlação & $\mathrm{UDH}\left(\mathrm{q}^{\text {tde }}\right)$ & $\mathrm{IVS}$ med & \%EVU/UDH & \% ÁREA & $\%$ POP \\
\hline ALTA-ALTA (laranja) & 25 & 0,49 & 35,40 & 48,56 & 18,30 \\
ALTA-BAIXA (vermelho) & $\mathbf{8}$ & $\mathbf{0 , 4 7}$ & $\mathbf{5 , 9 8}$ & $\mathbf{0 , 3 7}$ & $\mathbf{1 , 7 5}$ \\
BAIXA-BAIXA (amarelo) & 26 & 0,26 & 6,96 & 3,37 & 13,38 \\
BAIXA-ALTA (verde) & $\mathbf{9}$ & $\mathbf{0 , 2 7}$ & $\mathbf{3 0 , 0 0}$ & $\mathbf{2 , 2 6}$ & $\mathbf{2 , 4 7}$ \\
SEM SIGNIFICÂNCIA & 206 & 0,35 & $\mathbf{1 5 , 3 0}$ & $\mathbf{4 5 , 4 4}$ & 64,10 \\
\hline HIPÓTESE (vermelho + verde) & $\mathbf{1 7}$ & & & $\mathbf{2 , 6 3}$ & $\mathbf{4 , 2 2}$ \\
OPOSTO DA HIPÓTESE (laranja + amarelo) & 51 & & & 51,93 & 31,67 \\
\hline \hline
\end{tabular}

Fonte: Elaborada pelo autor

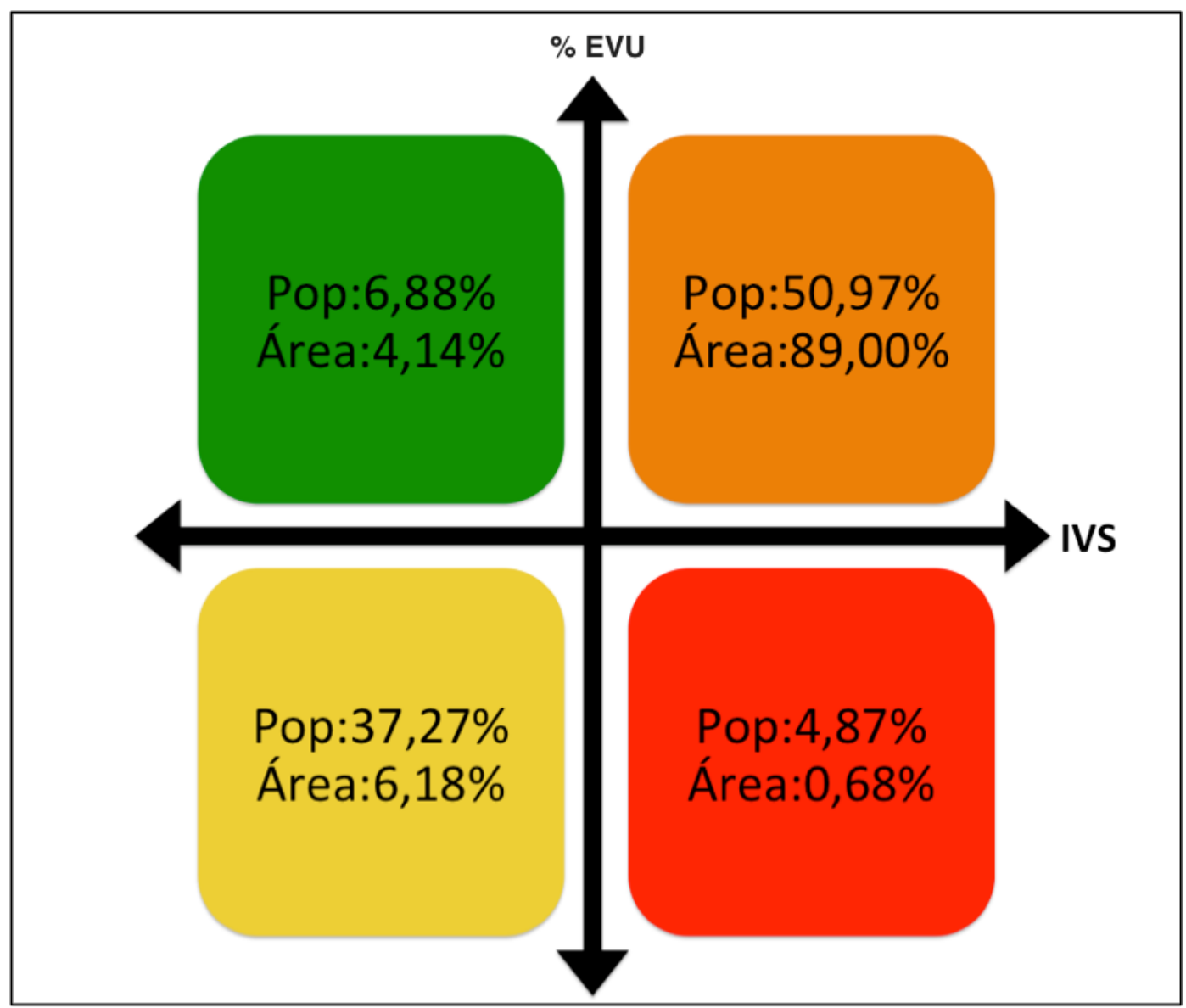

Figura 81 - Porcentual de área e população das UDHs com significância. RMM 


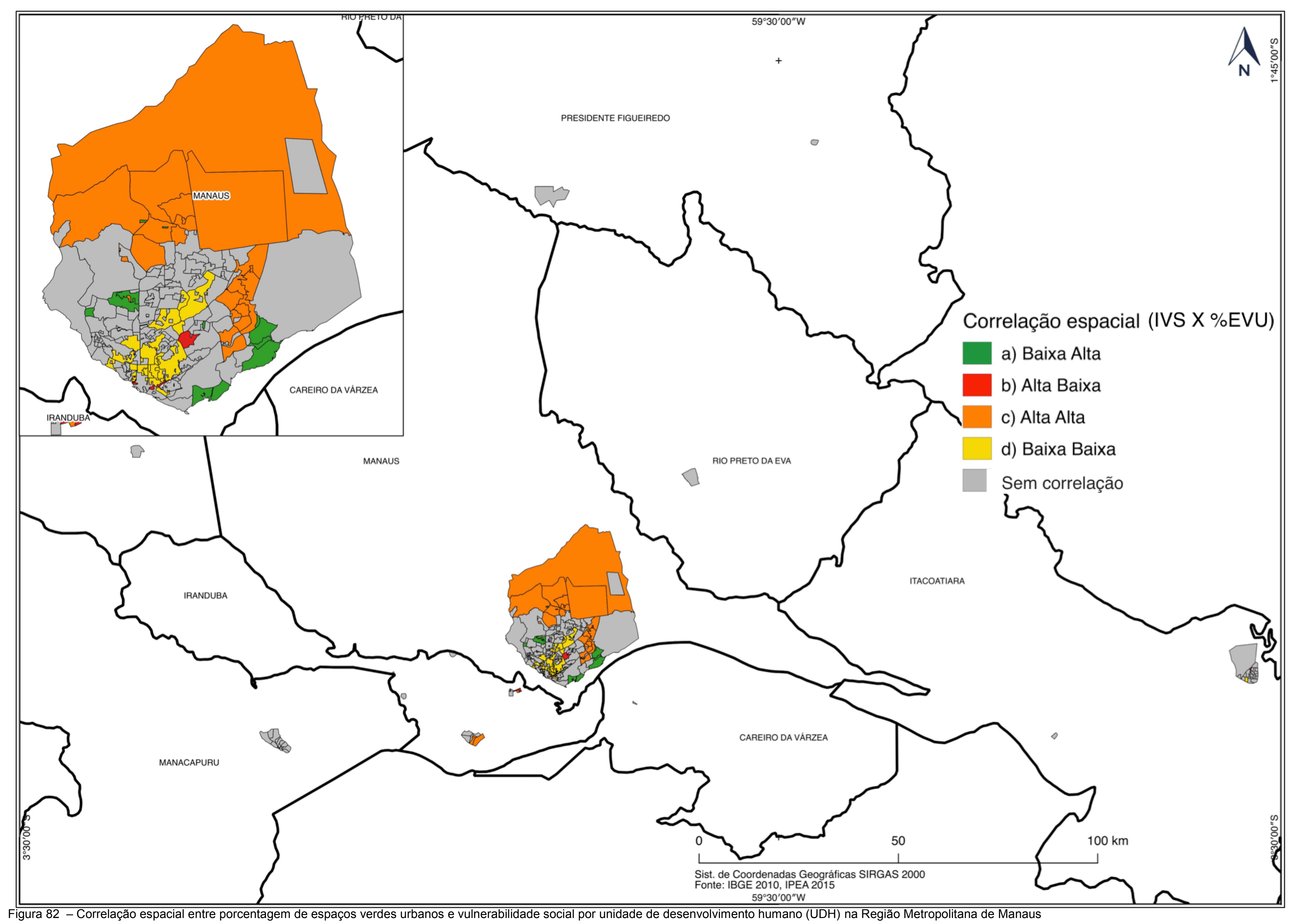


O cenário $C$, representado pela área em laranja (Figuras 81 e 82) foi o que mostrou maior magnitude em termos de população (18,3\% da RMM) e área $(46,56 \%$ da RMM). Ele está concentrado na porção norte e centro-leste de Manaus, além de parte da cidade de Iranduba. Esse cenário corresponde a 25 UDH com IVS-médio de 0,49 e $35,40 \%$ de EVU. Esses valores indicam que este cenário apresenta forte correlação entre: muitos espaços verdes urbanos e alta vulnerabilidade social.

A magnitude em termo de área deve ser observada com cuidado, principalmente para a zona norte, uma vez que ela está ocupada por extensa área de floresta, inclusive a Reserva A. Ducke. Assim, as ocupações urbanas nessa área são realizadas seguindo as opções de acesso, no caso, estradas e rios. O fato de ter grande área e alta porcentagem de EVU não indica que a população tem acesso à toda área, tampouco às suas EVU.

Quanto a porção centro-leste, o mapeamento de áreas de riscos feito por Molinari; Vidal; Macedo (2015) indicam que essa área foi a que apresentou maior zonas de erosão na cidade de Manaus $(89,7 \%)$. Os autores justificam como causa a perda de cobertura vegetal conjugada a grande densidade de drenagens numa formação geomorfológica em forma de vale (MOLINARI; VIDAL; MACEDO, 2015). Para agravar a situação, Cassiano (2013) relata que nessa mesma área há coexistência da grande incidência de desastres naturais com alta vulnerabilidade social refletindo nos maiores bolsões de pobreza e marginalidade de Manaus.

Embora a quantidade de EVU seja expressiva no cenários C (laranja), elas não estão estabelecidas como equipamentos urbanos. Ecologicamente a extensa cobertura florestal é considerada a matriz no processo de ocupação urbana e fragmentação da floresta, sendo a única barreira contra a expansão urbana. Ao falar em espaços verdes nesse cenário é preciso enfatizar a importância do controle ambiental seja por legislação ou mecanismos de fiscalização e monitoramento de tal forma que elas continuem na cidade, garantindo a qualidade da infraestrutura urbana, assim como a qualidade de vida.

O segundo cenário em magnitude quanto à população e áreas foi o cenário D, representado pela cor amarela (Figuras 81 e 82). Ele está concentrado, majoritariamente, no centro-sul de Manaus, especificamente na área de ocupação mais antiga da cidade. A Tabela 12 e a Figura 81 mostram que apesar do cenário corresponder a $3,37 \%$ de toda área analisada, existe uma população expressiva de $13,38 \%$ da RMM, ratificando mais uma vez a alta densidade populacional nessa 
área. $\mathrm{O}$ conjunto de UDH em amarelo apresentou IVS-médio de 0,26 (baixa vulnerabilidade) e 6,96\% de EVU. Esses valores indicam que a parte mais antiga de Manaus, apresenta correlação geoestastítica entre: poucos espaços verdes urbanos e baixa vulnerabilidade social (altos índices socioeconômicos)

Além dessa correlação, estudo realizado por Souza (2012) mostra que ausência de espaços verdes e o crescimento da malha urbana traz modificações das características da atmosfera e no microclima local na cidade de Manaus, como: elevação na temperatura em superfície, queda na umidade relativa e conteúdo de agua na atmosfera e modificações no escoamento em superfície. O padrão observado na área centro-sul evidencia a formação de llhas de calor, onde a área mais urbanizada tende a aquecer primeiro e mais lentamente e resfria-se depois e mais rapidamente que as áreas mais arborizadas (CORREAA, 2013; SILVA, 2009; SOUZA, 2012).

Os cenários $\mathrm{C}$ e $\mathrm{D}$ refletem o oposto da hipótese. Eles estão representados por $75 \%$ das 68 UDH que tiveram significância e correspondem a $51,93 \%$ da área analisada e 31,67 da população da RMM. No caso da RMM, para a maior parte da área analisada, a presença dos EVU refletem em alta vulnerabilidade social. Esse resultado indica que os EVU por si não implicam em áreas bem desenvolvidas socialmente. Daí a necessidade da articulação das políticas públicas que promovam bem-estar e melhoria de índices sociais, estabelecendo como elemento chave dessa articulação os espaços verdes como equipamentos urbanos.

Quanto aos cenários referentes à hipótese, verifica-se certa magnitude no cenário $\mathrm{A}$ (em verde), onde residem $2,47 \%$ da população numa área de $2,26 \%$ da área total analisada. Esse cenário apresentou valor baixo de IVS-médio $(0,27)$ e alta porcentagem de EVU (30\%). Observa-se nesse caso que as UDHs estão localizadas na porção centro-oeste e leste.

O cenário $B$ (vermelho), também condizente com a hipótese, indicou 8 UDH com baixa magnitude quanto a quantidade populacional $(1,75 \%)$, numa área pequena da RMM (0,37\%). A UDH mais representativa (área de 2,2 $\mathrm{km}^{2}$ ), corresponde ao bairro do Coroado, localizado nas proximidades da UFAM. Atualmente é um dos bairros mais populosos da capital e com poucas área verdes.

Barbosa (2009) narra que esse bairro surgiu com invasões em antigas áreas de florestas da UFAM. "Seus ocupantes necessitaram desbravar as matas do Campus Universitário para poder se instalarem e aos poucos foram substituindo o 
verde predominante na paisagem pelo colorido das edificações" (BARBOSA, 2009, p. 118). A autora cita ainda a sua boa localização: próximo do centro e da maioria das indústrias, sendo um bairro bastante habitado por quem trabalha no PIM. Ademais, ele é bem servido de equipamentos urbanos, como escolas, creches, e pavimentação urbana. No entanto a presença desses equipamentos e a boa localização não refletem em boas condições de vida (BARBOSA, 2009).

Para os cenários hipotéticos, mais importante quanto os valores numéricos é a indicação onde há carência de EVU atrelada à vulnerabilidade social, contrapondo a um cenário de muita área verde e de baixa vulnerabilidade social. Embora os valores não tenham grande magnitude, nesses cenários a desigualdade social é visível e pode ser representada pela presença e ausência de EVU.

Para o planejamento que vise indicar locais para aumentar os EVU nas cidades, a presente análise torna visível a abrangência da área que mais necessita de investimentos (cenário B - vermelho). Se implantados conforme equipamento urbanos, como já explanado, os espaços verdes urbanos poderão trazer benefícios refletidos em melhores condições de vida e bem-estar social atrelados ao ganho ambiental. 


\subsection{Região Metropolitana Porto Alegre}

A Região Metropolitana de Porto Alegre (RMPA) conta com 32 municípios. A área urbana analisada corresponde a $21 \%$ dos $11.980 \mathrm{~km}^{2}$ de toda RM. A maior cidade é a capital Porto Alegre apresentando 21,75\% do total (Figura 82). Observase um adensamento de cidades no eixo central, ratificando a importância da amostragem ultrapassar os limites municipais das capitais. Verifica-se também nesse eixo, uma conurbação urbana formada por 26 cidades cobrindo $76,38 \%$ da área analisada e $92 \%$ da população. As demais cidades, apesar de dispersas, não estão distantes da conurbação. Outra característica dessa amostra, é que foram analisadas todas as UDHs das cidades de Porto Alegre, Canoas, Cachoeirinha e Alvorada, indicando a inexistência de setores censitários rurais nesses municípios.

Para Soares; Fedozzi (2016), a RMPA configura-se como uma das principais concentrações urbanas e industriais do Brasil. De acordo com dados censitários (IBGE, 2010), a RM possui um PIB de R\$ 110,50 bilhões representando $44,4 \%$ do PIB estadual.

Nos anos de 1960 o fenômeno metropolitano já era presente através dos processos de conurbação e industrialização dos seus núcleos urbanos, próximos da capital (SOARES; FEDOZZI, 2016). A necessidade de planejamento das funções metropolitanas fez com que a RMPA fosse uma das primeiras aglomerações metropolitanas a ser institucionalizada no país (ALONSO, 2008).

O referido autor cita que as primeiras medidas de institucionalização foram mediante iniciativas de caráter regional, simultaneamente com São Paulo, Salvador e Belo Horizonte, em 1967. A institucionalização a nível de lei ocorreu em 1973, através da Lei Federal Complementar $\mathrm{n}^{\circ} 14$ (BRASIL, 1973). Originalmente, a RMPA se constituiu com 14 municípios, expandiu-se em 1989, através de mudanças na Constituição Estadual, ficando com 22 e atualmente é composta por 32 municípios. Mammarella; Barcellos (2005) relatam que os últimos municípios integrados à RMPA (Montenegro, Charqueadas, São Jerônimo, Taquara, Arroio dos Ratos, Capela de Santana, Araricá, Nova Santa Rita, Rolante e Santo Antônio da Patrulha) mantém áreas rurais de tamanho significativo e não possuem grande integração com as demais cidades da RMPA. 


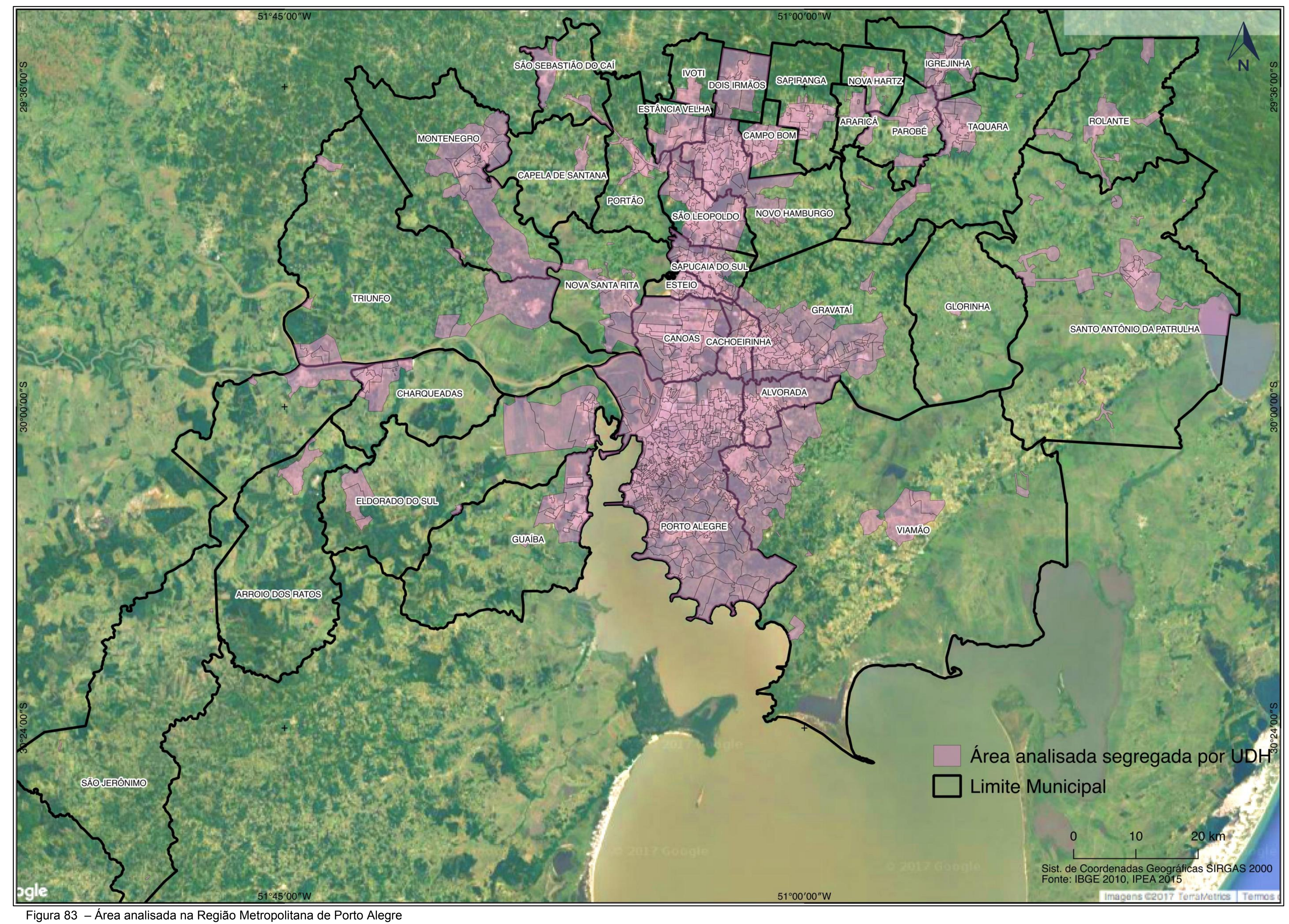




\title{
4.3.1 Urbanização na Região Metropolitana de Porto Alegre
}

\author{
Para Ab'Sáber (1965), a "grande Porto Alegre" foi uma das poucas \\ aglomerações urbanas brasileiras que nos meados do século $X X$ alcançou um \\ desenvolvimento espacial e adquiriu um aspecto metropolitano. Afora esse \\ desenvolvimento, a autor cita como peculiaridade da região: o sítio urbano complexo \\ e diversificado.
}

A Grande Porto Alegre situa-se numa área relativamente complexa, onde se intercruzam ou se aproximam elementos de relevo pertencentes a diversas províncias morfoestruturais do Rio Grande, fato que desdobra o número de elementos topográficos que participam do sítio urbano metropolitano (AB'SÁBER, 1965, p. 4).

A complexidade do sítio urbano, se deve aos seguintes compartimentos topográficos:

1. Maciço de Porto Alegre; 2. Depressão Periférica; 3. Delta digitado do Jacuí; 4. Morros, colinas e planícies de além Guaíba. Interligando esses quatro compartimentos topográficos, ora servindo para separá-los, ora para uni-los, está presente permanentemente o organismo fluvial do baixo Jacuí e do estuário interiorizado do Guaíba (AB'SÁBER, 1965, p. 7).

Afora as características topográficas, Ab'Sáber relata a importância da posição geográfica para o estabelecimento da capital gaúcha como importante núcleo urbano, que lhe favoreceu tornar-se um centro regional e uma área metropolitana.

\begin{abstract}
Ali terminava aquela espécie de estuário residual que possibilitava a penetração da navegação marítima antiga até um ponto relativamente interiorizado da zona sublitorânea gaúcha; mas ali, acima de tudo, através do uso de embarcações menores, fazia-se uma transição para a navegação fluvial (AB'SÁBER, 1965, p. 7).
\end{abstract}

Bakos (2013) narra que desde os seus primórdios, Porto Alegre se desenvolveu economicamente através de intensa atividade comercial. Atividade garantida sobretudo pelo seu porto, que além de estar bem localizado, possuía boa profundidade e uma barreira natural às embarcações contra o vento. O êxito comercial levou a uma concentração populacional na depressão central (atual RMPA). Ainda em 1870, 64\% da população gaúcha ali se estabeleceu (BAKOS, 2013).

Para Almeida (1992), o porto garantiu expandir as exportações e as trocas comerciais, levando Porto Alegre a se tornar um centro regional. Assim, os comerciantes e atacadistas de Porto Alegre assumiram o controle da vasta rede 
comercial que era composta por pequenos comerciantes rurais, transportadores de mercadoria e comerciantes intermediários. Essa rede trouxe prosperidade econômica aos núcleos urbanos dela envolvida e principalmente à parcela da burguesia comercial (ALMEIDA, 1992).

Porto Alegre e as cidades vizinhas ganharam impulso no crescimento populacional após a chegada dos imigrantes alemães e italianos. Em um século eles ocuparam às margens dos cinco rios que convergem para o estuário do Guaíba, constituindo a "zona colonial" (BAKOS, 2013). Além dos imigrantes, as cidades atraíram migrantes do meio rural e de outros centros urbanos gaúchos devido a "multiplicação de suas fábricas, casas de comércio e serviços relacionados com a educação e aparelhos de Estado, que ali se encontravam por ser a capital“ (BAKOS, 2013, p. 26).

De 1870 a 1930, a consolidação econômica de Porto Alegre e cidades vizinhas, trouxe além do significativo núcleo populacional, uma importante diversificação na oferta de serviços urbanos, como serviços de água, iluminação pública, transporte (bondes), telefonia, faculdades, bancos (públicos e privados) e modernização do porto (ALMEIDA, 1992).

Em 1924, foram realizadas obras que, para Bakos (1998), constituíram como marcas do positivismo na gestão municipal. Dentre as obras, a autora cita a abertura das avenidas Júlio de Castilho e Borges de Medeiros, amplas reformas de serviços urbanos da capital (sobretudo de mobilidade), a arborização das vias públicas e a criação de espaços livres denominados de "jardins gaúchos de recreio público" (BAKOS, 2013).

Rodrigues; Marcellino (2011) relatam que a implantação desses jardins foi uma experiência pioneira na América Latina, sendo seguido por várias cidades, principalmente uruguaias e argentinas. Os "jardins de recreio" tinham o diferencial em dar oportunidade para a prática recreativa e esportiva orientada, tendo em vista a educação de crianças e jovens, com a finalidade de redução na criminalidade infantil.

No idos da década de 1940, Singer (1977) relata que surge no Rio Grande do Sul, as primeiras grandes indústrias: fábricas metalúrgicas e têxtis. O fator decisivo para o surgimento foi o aporte do capital da burguesia comercial. As primeiras fábricas atendiam ao mercado local e regional e foram instaladas no Parque Fabril de Porto Alegre. Assim, Oliveira (1996) afirma que o nordeste gaúcho (localidade da 
RMPA), se configurou espacialmente com uma grandes aglomeração urbana (em torno de Porto Alegre). Ali as atividades agrícolas se tornaram cada vez menos expressivas, à medida que se acelerou o processo de industrialização (OLIVEIRA, 1996).

Porto Alegre foi pioneira na expansão industrial gaúcha. Na década de 1960 começaram a se destacar outros municípios, como: Novo Hamburgo, São Leopoldo e Canoas que impulsionaram na região do Vale do Rio dos Sinos com a indústria coureiro-calçadista (CARRION, 1989). Nessa mesma época, a autora destaca que foi inaugurada em Canoas a Refinaria Alberto Pasqualini, promovendo maior diversificação industrial na região, com a instalação de indústria dos ramos químico, elétrico, metalurgia e mecânica.

Na década de 1970 surgem mais indústrias no eixo norte, sobretudo em Sapucaia e Esteio. Com a construção da BR-290, ligando Porto Alegre à BR-101 (litorânea), favoreceu-se a implantação de indústrias no eixo leste-nordeste, precisamente em Gravataí, Cachoeirinha e Alvorada (CARRION, 1989).

$O$ crescimento da atividade industrial trouxe uma crescente demanda de terra, haja vista o decorrente crescimento populacional. Assim, o processo de urbanização e conurbação urbana, ganhou impulso ainda na década de 1940, quando o poder público e privado, lançaram inúmeros loteamentos nos municípios que integram a RMPA, sobretudo em: Canoas, Novo Hamburgo e São Leopoldo, além de antigas vilas que hoje situam as cidades de Cachoeirinha e Alvorada (CARRION, 1989).

Os primeiros loteamentos populares foram feitos em áreas inadequadas com terras inundáveis, zonas de riscos de erosão e desmoronamento (CARRION, 1989). Barcellos (2004) cita como exemplos, os lotes situados nos bairros Niterói e Vila Rio Branco, junto à divisa de Cachoeirinha com Porto Alegre.

Assim, no início da década de 1950 surgem restrições legais por parte dos municípios quanto à implantação de loteamentos (CARRION, 1989). No entanto, a autora cita que apenas em Porto Alegre e Canoas tais exigências foram postas em prática, tornando ainda mais elevados os preços dos terrenos no núcleo metropolitano.

Assim, Barcellos (2004) destaca que a ausência de regulamentação gerou a ocupações urbanas inapropriadas na RMPA, com alto crescimento populacional em áreas com sérias deficiências de infraestrutura. Dessa forma, a autora relata que a 
população pobre foi se deslocando para bairros periféricos da capital e para as cidades vizinhas, que tinham profundas carências de serviços e equipamentos básicos, orientando um vetor de expansão na direção leste-nordeste e oestenoroeste (sentido Guaíba) (BARCELLOS, 2004)

Nos últimos 20 anos a RMPA vem passado por transformações econômicas ${ }^{14}$ e sociopolíticas, sob um processo de realocação das indústrias que mudaram da capital Porto Alegre para a periferia da RMPA, interior do estado e outras regiões do país. Essa realocação foi fruto da politica de descentralização da indústria nacional associada à falta de espaço, aluguéis e salários altos. Esses fatos ocasionaram mudanças estruturais no território da RMPA e favoreceu o surgimento das periferias, invasões com moradias precárias (SOUZA; SOUZA, 2004).

Assim, Oliveira (1996) ao analisar a RMPA destacou que os municípios da periferia dessa região vem aumentando seu contingente populacional e a capital vem perdendo peso demográfico no Estado. A Figura 84 mostra como está distribuída a população de 4,09 milhões da RMPA de acordo com os dados do último censo demográfico. De acordo com tais dados a RMPA contava com 36,58\% dos habitantes do estado gaúcho que perfaz $14,29 \%$ da população da região sul e 2,05\% dos brasileiros (IBGE, 2010).

Pela Figura 84, nota-se que a densidade demográfica é elevada em vários municípios da RMPA e ultrapassa os limites dos antigos núcleos (Porto Alegre, Canoas, Novo Hamburgo). Assim a RMPA apresenta aquilo que Soares; Fedozzi (2015, p. 351) denominam de "forte coesão espacial".

${ }^{14}$ De acordo com os dados censitários (IBGE, 2010), o setor de serviços item a maior participação no PIB da RMPA com 56,74\%, a indústria em consta com $27,21 \%$ de representatividade. A cidade com maior participação no PIB é Porto Alegre, com $38 \%$ de representatividade, tendo o setor de serviços como o mais importante ( $70 \%$ do PIB). 


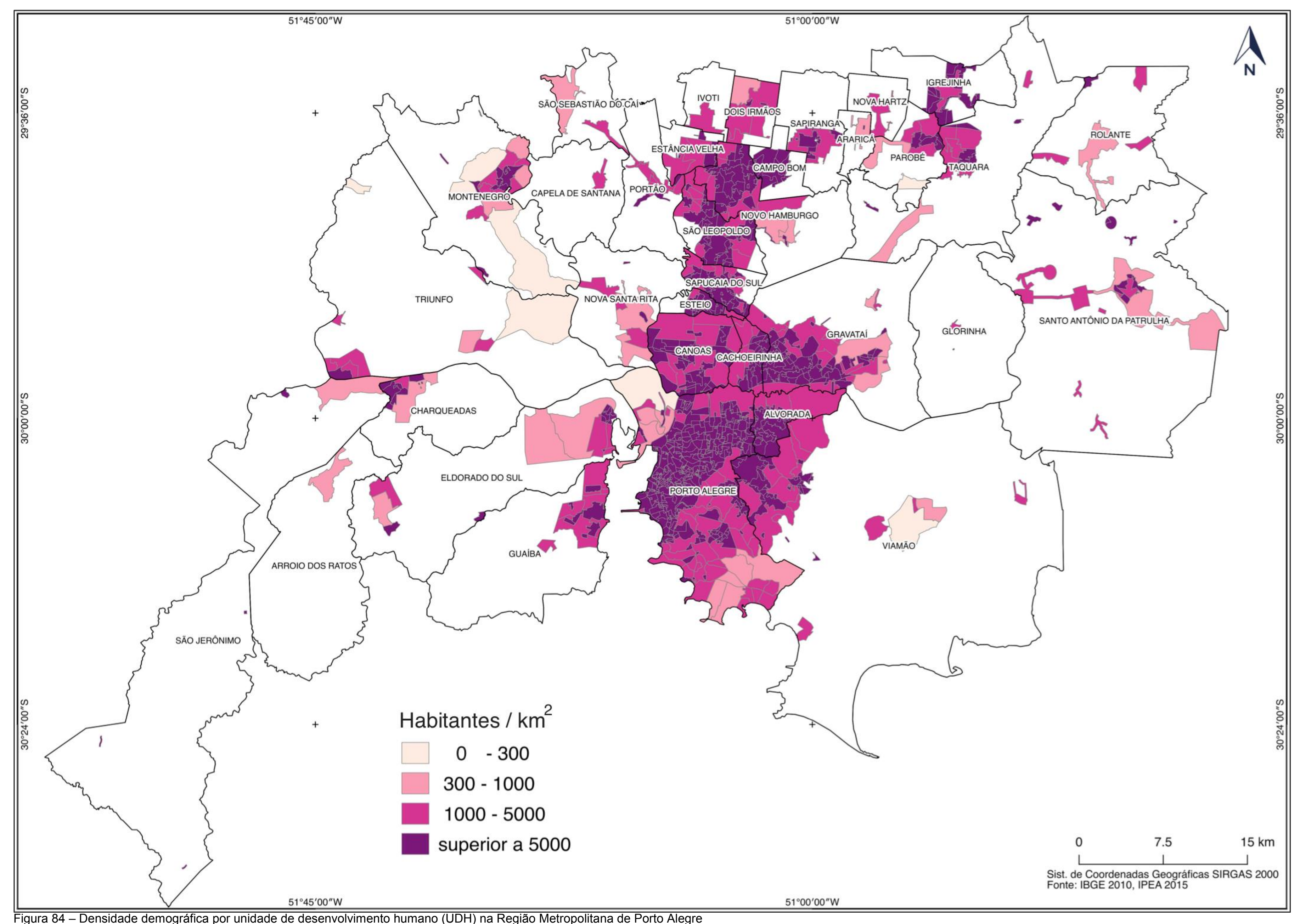


Para Soares; Fedozzi (2015), o processo de desconcentração da população nas cidades do núcleo metropolitano da RMPA é uma das principais mudanças na malha urbana das últimas décadas. Este processo tem levado à "policentralidade metropolitana", reflexo do fortalecimento do setor terciário (comércio e serviços), sobretudo nos municípios mais populosos e de economia mais dinâmica.

O declínio da economia industrial, sobretudo na década de 1990 trouxe, além do desemprego, manifestações no território como as relatadas por Oliveira (1996, p. 290): "segregação da moradia, distribuição desigual dos equipamentos e serviços urbanos, até deterioração ambiental". Enquanto as principais cidades (Porto Alegre, Canoas, Novo Hamburgo, São Leopoldo) se reestruturam economicamente com a saída das indústrias, outros municípios caracterizados como cidades-dormitórios (Alvorada, Viamão, Guaíba, Cachoeirinha e Gravataí) passaram por severas dificuldades geradas pelo baixo nível de atividade econômica (ROMANINI; MELLO, 2010).

A Figura 85 indica a vulnerabilidade social por UDH (IPEA, 2015) nas cidades da RMPA. Verifica-se que no geral a RMPA possui baixa ${ }^{15}$ vulnerabilidade social, porém os municípios referidos anteriormente possuem UDH com maior vulnerabilidade social. Nesses núcleos urbanos, Romanini; Mello (2010) relatam que os parcelamentos do solo ocorreram de forma desordenada e em sítios inadequados à ocupação residencial. Além disso, o crescimento populacional nessas localidades foram dependentes dos municípios polos da RMPA (Porto Alegre, Canoas, Novo Hamburgo, São Leopoldo). Assim, a alta vulnerabilidade social reflete a base econômica insuficiente e problemas estruturais urbanos.

Além da alta vulnerabilidade social em municípios específicos e dos problemas recorrentes das grandes RM brasileiras (trânsito caótico, aumento da violência urbana, carência de serviços básicos), a RMPA enfrenta dificuldades decorrentes da crise financeira do estado do Rio Grande do Sul.

\footnotetext{
${ }^{15}$ De acordo com dados censitários (IBGE, 2010), a RMPA possui um elevado nível renda mensal por domicílio, com o valor médio de $\mathrm{R} \$ 1126,99$, valor superior à média nacional ( $R \$ 949,99$ ).
} 


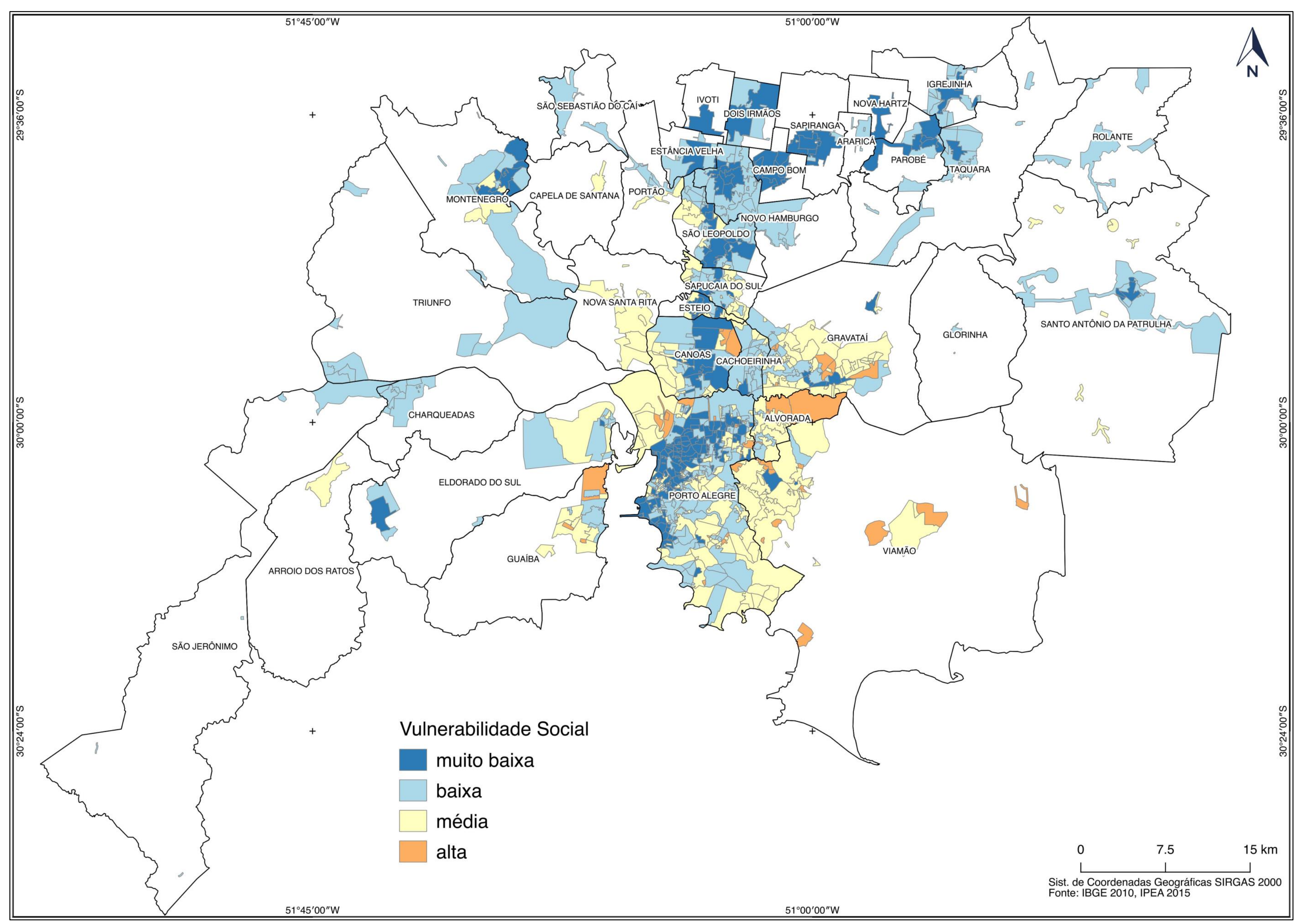

Figura 85 - Vulnerabilidade social por unidade de desenvolvimento humano (UDH) na Região Metropolitana de Recife. 
Azevedo et al. (1996) relatam que, após a década de 1970, o estado gaúcho manteve uma estrutura de gastos incompatíveis com a geração de receitas próprias e recorreu a empréstimos para cobrir os seus déficits. $O$ endividamento do estado gaúcho tem gerado uma contínua redução da capacidade de investimento que se reflete na deterioração de sua infraestrutura, e por consequência, no desincentivo à realização de investimentos privados no estado (AZEVEDO et al., 1996).

O esgotamento do modelo de gestão e planejamento das cidades e do estado, acompanhado da diminuição da capacidade decisória do estado frente a uma dívida pública que ultrapassa $\mathrm{R} \$ 57$ bilhões (BACEN, 2016) fez com que os entes públicos buscassem novas formas de gestão. Uma das iniciativas para efetivar a participação da sociedade foi a gestão participativa. Após 1989, nos municípios gaúchos e também no âmbito do estado, tem surgido práticas inovadoras das quais a mais conhecida e analisada é o Orçamento Participativo (OP) de Porto Alegre, já adotado por vários municípios, principalmente os da RMPA (SILVA, 2003).

Ao analisar as políticas de lazer em Porto Alegre, após a implantação do OP, Rodrigues; Marcellino (2011) verificou que, antes, os espaços de lazer (praças e parques) estavam concentrados nas zonas centrais e ricas da capital. A partir das demandas populares, praças com módulos esportivos foram construídas em zonas mais periféricas, correspondendo a uma das políticas centrais da administração local. Esse fato ratifica, a importância dos espaços verdes perante à vontade dos cidadãos, principalmente aqueles que moram nas periferias.

Considerando o cenário de crise econômica, que ampliou as desigualdades socioeconômicas na RMPA, ressalta-se a importância de investigar os EVU como promotores de qualidade de vida. Assim, a análise dos aspectos socioeconômicos conjugados com a presença dos espaços verdes dessa RM pode contribuir para o planejamento urbano e gestão das cidades visando a disponibilidade dessas áreas como equipamentos urbanos à quem mais precisa.

\subsubsection{Espaços Verdes Urbanos da Região Metropolitana de Porto Alegre}

O mapeamento identificou a porção de $745,09 \mathrm{~km}^{2}$ de espaços verdes urbanos no recorte proposto (Figura 86 ). Esse valor corresponde a quase $30 \%$ da 
área analisada da RMPA. A Tabela 13 mostra a proporção das áreas analisadas e dos espaços verdes urbanos na RMPA.

Tabela 13 - Espaços verdes urbanos por cidade na Região Metropolitana de Porto Alegre

\begin{tabular}{|c|c|c|c|c|}
\hline UF & Cidades & Área $\mathrm{Km}^{2}$ & EVU km² & \% EVU/Área \\
\hline & ALVORADA & 71,95 & 17,06 & 23,71 \\
\hline & ARARICÁ & 8,58 & 1,66 & 19,37 \\
\hline & ARROIO DOS RATOS & 15,31 & 1,84 & 12,02 \\
\hline & CACHOEIRINHA & 44,31 & 8,91 & 20,11 \\
\hline & CAMPO BOM & 24,56 & 11,60 & 47,24 \\
\hline & CANOAS & 132,50 & 20,04 & 15,13 \\
\hline & CAPELA DE SANTANA & 5,85 & 0,92 & 15,80 \\
\hline & CHARQUEADAS & 31,36 & 5,10 & 16,26 \\
\hline & DOIS IRMÃOS & 54,09 & 32,43 & 59,96 \\
\hline & ELDORADO DO SUL & 119,11 & 10,90 & 9,15 \\
\hline & ESTEIO & 18,02 & 2,87 & 15,93 \\
\hline & ESTÂNCIA VELHA & 31,58 & 15,24 & 48,27 \\
\hline & GLORINHA & 1,50 & 0,07 & 4,47 \\
\hline & GRAVATAÍ & 166,71 & 27,51 & 16,50 \\
\hline & GUAÍBA & 64,29 & 15,58 & 24,24 \\
\hline & IGREJINHA & 34,71 & 24,31 & 70,02 \\
\hline \multirow{19}{*}{ RS } & IVOTI & 11,33 & 4,64 & 40,93 \\
\hline & MONTENEGRO & 147,53 & 66,70 & 45,21 \\
\hline & NOVA HARTZ & 15,45 & 2,79 & 18,09 \\
\hline & NOVA SANTA RITA & 51,71 & 12,58 & 24,34 \\
\hline & NOVO HAMBURGO & 108,65 & 40,89 & 37,64 \\
\hline & PAROBÉ & 43,21 & 8,89 & 20,58 \\
\hline & PORTÃO & 18,22 & 5,82 & 31,93 \\
\hline & PORTO ALEGRE & 552,06 & 190,75 & 34,55 \\
\hline & ROLANTE & 38,24 & 14,59 & 38,16 \\
\hline & St. ANTÔNIO DA PATRULHA & 110,95 & 7,78 & 7,01 \\
\hline & SAPIRANGA & 27,78 & 4,10 & 14,75 \\
\hline & SAPUCAIA DO SUL & 47,13 & 20,73 & 43,99 \\
\hline & SÃO JERÔNIMO & 27,45 & 6,00 & 21,87 \\
\hline & SÃO LEOPOLDO & 83,54 & 33,72 & 40,36 \\
\hline & SÃO SEBASTIÃO DO CAÍ & 63,01 & 30,01 & 47,62 \\
\hline & TAQUARA & 58,73 & 17,02 & 28,98 \\
\hline & TRIUNFO & 100,85 & 18,65 & 18,49 \\
\hline & VIAMÃO & 208,47 & 63,36 & 30,39 \\
\hline & Total & 2538,75 & 745,09 & 29,34 \\
\hline
\end{tabular}

Fonte: Elaborada pelo autor 


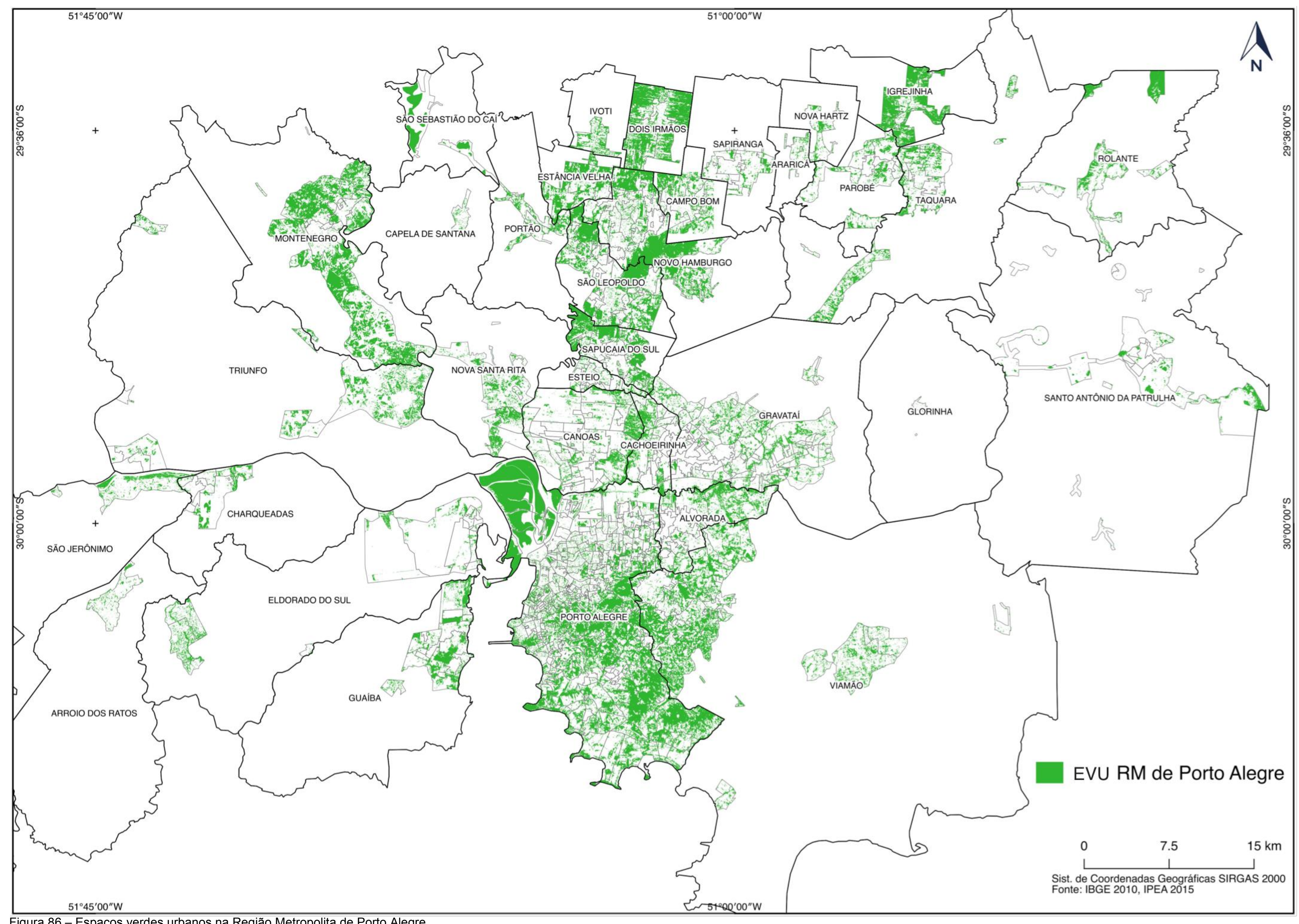


Porto Alegre possui a maior quantidade de EVU com 190,75 com km², o que representa $25 \%$ de todas EVU da RMPA. Em termos de porcentagem de EVU em relação à área urbana analisada, as cidades do norte da RMPA apresentaram as maiores proporções, uma vez que estão localizados no sopé da Serra Gaúcha. Destacam-se Igrejinha (70,02\%), Dois Irmãos (59,96\%), Estância Velha $(48,27 \%)$, São Sebastião do Caí (47,62\%), Campo Bom (47,24\%) e Montenegro (45,21\%). Ao abordar as descrição geográfica da Serra Gaúcha feita por Ab'Sáber; Marigo (2006) entende-se os motivos pela ampla cobertura floresta nos municípios ali localizados.

Área de terreno declivoso, dotados de solos pobres, recobertos de matas subtropicais. No processo de colonização regional, os imigrantes alemães tiveram de desenvolver a atividade agrária nessa faixa piemôntica complexa da Serra Gaúcha. O solo era fraco, mas havia água abundante e possibilidades de ocupar áreas da serra, a nordeste, a partir da cidadezinha de Dois Irmãos, em direção a Nova Petrópolis, Gramado e Canela. (AB'SÁBER; MARIGO, 2006, p. 35)

As cidades que apresentaram menor quantidade de espaços verdes urbanos foram Glorinha $(4,47 \%)$, Santo Antônio da Patrulha $(7,01 \%)$, Eldorado do Sul $(9,15 \%)$ e Arroio dos Ratos $(12,02 \%)$. Elas estão mais distantes da conurbação urbana da RMPA e possuem base econômica bastante dependente à agricultura. Sendo Eldorado do Sul, Santo Antônio da Patrulha e Glorinha grandes produtores de arroz (NUNES, 2011) e Arroio dos Ratos conhecida como a capital da melancia (LIMA, 2014).

Das cidades consideradas núcleo da RMPA (Porto Alegre, Canoas, Novo Hamburgo e São Leopoldo), apenas Canoas apresentou baixa proporção de EVU, com $15,13 \%$, as demais variaram de $34 \%$ a $40 \%$. As cidades consideradas dormitório (Alvorada, Viamão, Guaíba, Cachoeirinha e Gravataí) possuem menos quantidade de EVU. Sendo que Gravataí apresentou a menor quantidade $16,5 \%$, as demais variaram de 20 a $30 \%$.

\subsubsection{Espaços Verdes Urbanos nas Unidades de Conservação da Natureza}

Quanto à origem dos espaços verdes urbanos na RMPA, vale destacar o trabalho da Secretaria de Meio Ambiente de Porto Alegre (SMAM) que quantificou todos os espaços verdes geridos pelo município, inclusive a quantidade de árvores na área urbana (1,3 milhão). O site da SMAM informa que a cidade disponibiliza 608 praças (somando $4,5 \mathrm{~km}^{2}$ ), 354 áreas verdes complementares (áreas públicas sem 
estrutura das praças mas com ampla de cobertura vegetal - área de $0,9 \mathrm{~km}^{2}$ ), nove parques municipais (somando 2,5 km²), além de três unidades de conservação da natureza, com área de $13 \mathrm{~km}^{2}$ (SMAM, 2013).

A SMAM informa também que a cidade possui duas áreas mantidas pelo governo estadual: Parque Estadual Delta do Jacuí $\left(44,22 \mathrm{~km}^{2}\right)$ e o Jardim Botânico de Porto Alegre $\left(0,44 \mathrm{~km}^{2}\right)$. Quanto a área de gestão federal, relata-se a Reserva Ecológica do Morro Santana, área gerida pela Universidade Federal do Rio Grande do Sul - UFRGS (SMAM, 2013). Destaca-se que essas informações não estão disponíveis de forma espacializada (mapas ou arquivo arquivos georreferenciados) e que são referentes à toda área municipal (urbano e rural) de Porto Alegre.

A Tabela 14 e a Figura 87 indicam os EVU na área analisada da RMPA dentro de UCs, de acordo com a base de dados do SNUC, disponível pelo site do ICMBio (2010). Da área analisada da RMPA, 8,48\% é UC, que concentra 72,34 km² de EVU, correspondendo a $9,71 \%$ de todos os EVU mapeados.

As maiores categorias de UC dentro da área analisada são: APA do Banhado Grande, do Delta do Jacuí e o Parque Estadual (PE) do Delta do Jacuí, que juntas correspondem a $98 \%$ do total. As demais dizem respeito às três Reservas do Patrimônio Natural (RPPN) que possuem em torno de $1 \mathrm{~km}^{2}$, além de um Refúgio da Vida Silvestre (RVS), localizado em Viamão, que possui $0,25 \mathrm{Km}^{2}$.

A porcentagem dos EVU dentro dessas áreas protegidas é de apenas $33,62 \%$, isso porque as mais representativas, pertencem a categoria (APA) que permitem ocupação. Quanto à maior proporção de EVU em área protegida, destacase o PE Delta do Jacuí que possui mais de $65 \%$ de cobertura vegetal.

Tabela 14 - Espaços verdes urbanos em Unidades de Conservação da Natureza

\begin{tabular}{llll}
\hline Nome da Área Protegida & Área $\mathrm{km}^{2}$ & EVU km & \% EVU/Área \\
\hline APA do Banhado Grande & 131,28 & 28,37 & 21,61 \\
APA do Delta do Jacuí & 21,18 & 5,13 & 24,24 \\
PE do Delta do Jacuí & 59,10 & 38,51 & 65,16 \\
RPPN Costa do Serro & 1,09 & 0,06 & 5,81 \\
RPPN Prof. Delamar Harry dos Reis & 1,17 & 0,16 & 13,86 \\
RPPN Sítio Porto da Capela & 1,09 & 0,02 & 1,70 \\
RVS Banhado dos Pachecos & 0,25 & 0,08 & 32,36 \\
\hline Total & $\mathbf{2 1 5 , 1 7}$ & $\mathbf{7 2 , 3 4}$ & $\mathbf{3 3 , 6 2}$ \\
\hline Total UDH Analisada & 2538,75 & 745,09 & 29,35 \\
\% Total Área Protegida/Total Analisado & 8,48 & 9,71 & \\
\hline \hline
\end{tabular}

Fonte: Elaborada pelo autor 


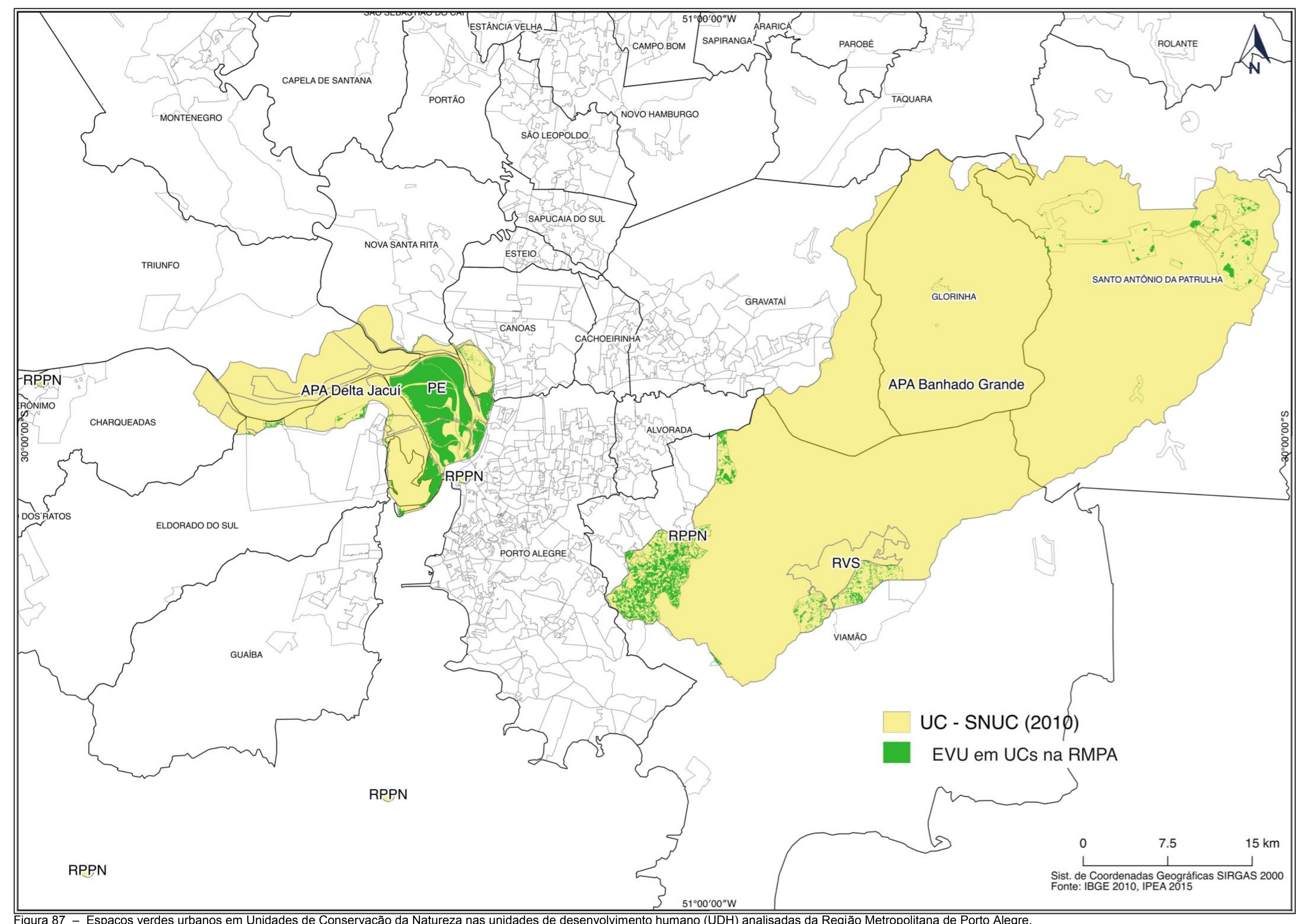

Figura 87 - Espaços verdes urbanos em Unidades de Conservação da Natureza nas unidades de desenvolvimento humano (UDH) analisadas da Região Metropolitana de Porto Alegre. 
Vale lembrar que por estar entremeada ao Delta do Jacuí, o PE possui um vasto conjunto de recursos hídricos (rios, arroios, sacos, reservatórios) que junto com a vegetação ocupam quase toda a área protegida. Assim, Chiappetti (2005) ratifica a importância ambiental desse parque, dada a sua grande biodiversidade, porém como esta circulado pela RMPA, apresenta grandes pressões.

Quanto aos espaços verdes no interior do PE Delta do Jacuí, Chiappetti (2005) destaca sobretudo o papel da vegetação de ser filtro natural para a melhoria da qualidade da água que chega no Delta do Jacuí bastante poluída. Sendo que os mais poluídos são: rio dos Sinos (origem industrial) e o rio Gravataí (esgoto doméstico). Além de filtro, a vegetação garante proteção às cheias nos locais banhados pelo Delta do Jacuí (CHIAPPETTI, 2005).

De acordo com Oliveira; Porto (1999) a paisagem natural do PE do Delta do Jacuí está fortemente ameaçada devido ao padrão de uso do solo dentro e nas áreas do entorno. Os autores destacam a ocupação de aglomerados subnormais nas áreas mais baixas e alagadiças, áreas de grandes riscos de desastres principalmente em épocas de cheia.

Além de habitações precárias e em áreas de riscos, Suetergaray; Schàffer, (2015) citam as habitações tradicionais e construções de alto padrão junto às margens do PE, onde os clubes e associações náuticas desenvolvem atividades esportistas. As autoras citam ainda que antes se praticava natação nas águas do Delta do Jacuí, como estão poluídas elas foram transferidas para as piscinas dos clubes.

Ao analisar a ação antrópica no PE Delta do Jacuí, Chiappetti (2005) contabilizou mais de quinze mil pessoas que residem no parque. Além disso há focos de criação de suínos, de bovinos e produção de arroz no seu entorno. Além desses pontos, existe uma zona crítica, mais ao sul do PE (Ilha do Pavão) onde existe um aterro sanitário (CHIAPPETTI, 2005).

Diante dessa pressão, a Lei Estadual $n^{\circ} 12.371$ aumentou os limites do PE e criou APA Delta do Jacuí, com superfície de 22,8 mil hectares (RIO GRANDE DO SUL, 2005). Sendo uma Unidade de Uso Sustentável é permitida a ocupação humana sob condições sustentáveis. Oliveira et al. (2011) relatam que criação da APA foi ao encontro da necessidade de priorizar políticas de saneamento básico, fiscalização e controle das moradias irregulares, tanto às localidades mais vulneráveis quanto as de luxo que estão privatizando o uso da orla. 
Vale destacar também a APA do Banhado Grande, situada na depressão central da RMPA. Guasselli; Etchelar; Belloli (2013) tratam essa APA como uma das áreas úmidas mais importantes do Rio Grande do Sul. Os banhados presentes nessa APA são reguladores naturais do fluxo do rio Gravataí. Os autores relacionam a sua importância à uma esponja que em épocas de cheias amortece as enchentes e nas estiagens é fonte de água.

Para Carvalho; Ozorio (2007), a maior ameaça aos banhados é a produção extensiva de arroz. $\mathrm{O}$ autores relataram os seguintes impactos negativos causados pela rizicultura: drenagem excessiva das águas e construção de canais de irrigação, retirada de vegetação nativa, compactação e salinização do solo, erosão, assoreamento, além de envenenamento da fauna e flora devido ao uso de agrotóxicos em larga escala.

Pela Figura 87, nota-se que a APA do Banhado Grande cobre de Glorinha e Santo Antônio da Patrulha, além de boa parte da área urbana de Viamão. Como já relatado, esses municípios são grandes produtores de arroz, sendo que a maior área dos EVU, dentro dessa APA, está na cidade de Viamão.

\subsubsection{Espaços Verdes Urbanos nas Unidades de Desenvolvimento Humano}

A Figura 88 mostra a proporção dos EVU por UDH. Os locais com menores porcentagem de EVU estão nos centros das principais cidades da RMPA (cidades núcleo e dormitório). Nessas cidades observa-se visualmente que existe a relação entre alta densidade populacional e poucos espaços verdes verdes (0 a 30\%). Assim, as cidades de Gravataí, Cachoeirinha, Canoas, Alvorada, Nova Santa Rita, Guaíba, Esteio, além das áreas centrais das cidades de Porto Alegre, São Leopoldo e Novo Hamburgo possuem baixa porcentagem EVU e alta densidade demográfica. 


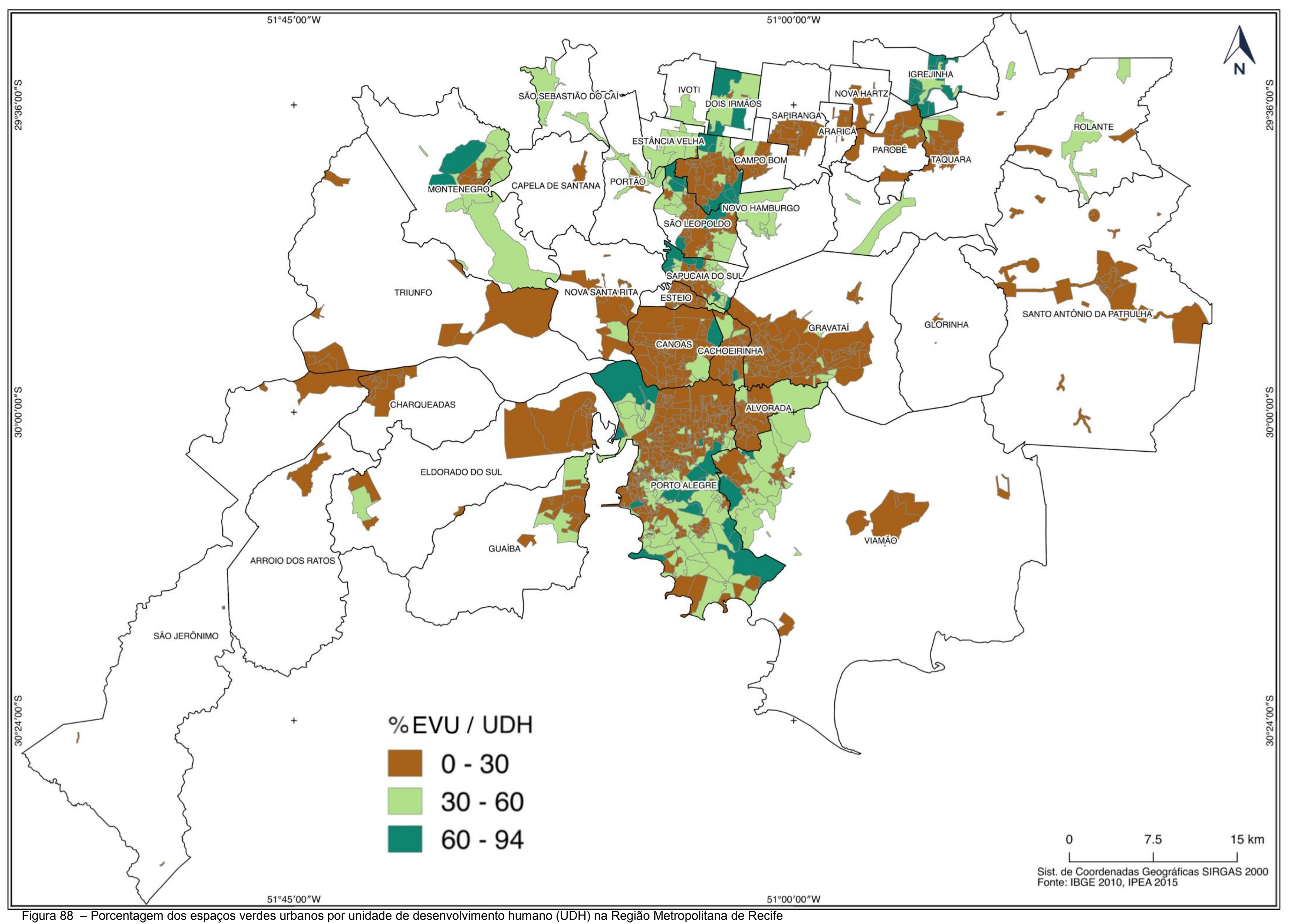


Além desses centros populosos, destaca-se a baixa porcentagem de EVU em cidades de base econômica apoiada pela agricultura. Isso explica o motivo das áreas de Santo Antônio da Patrulha, Glorinha (Figura 89), parte de Viamão, Eldorado do Sul, Charqueadas, Arroio dos Ratos e Trinfo possuírem baixa porcentagem de EVU. Por análise visual de imagens de satélites, observam-se áreas agrícolas (sobretudo de arroz) dentro das áreas analisadas.

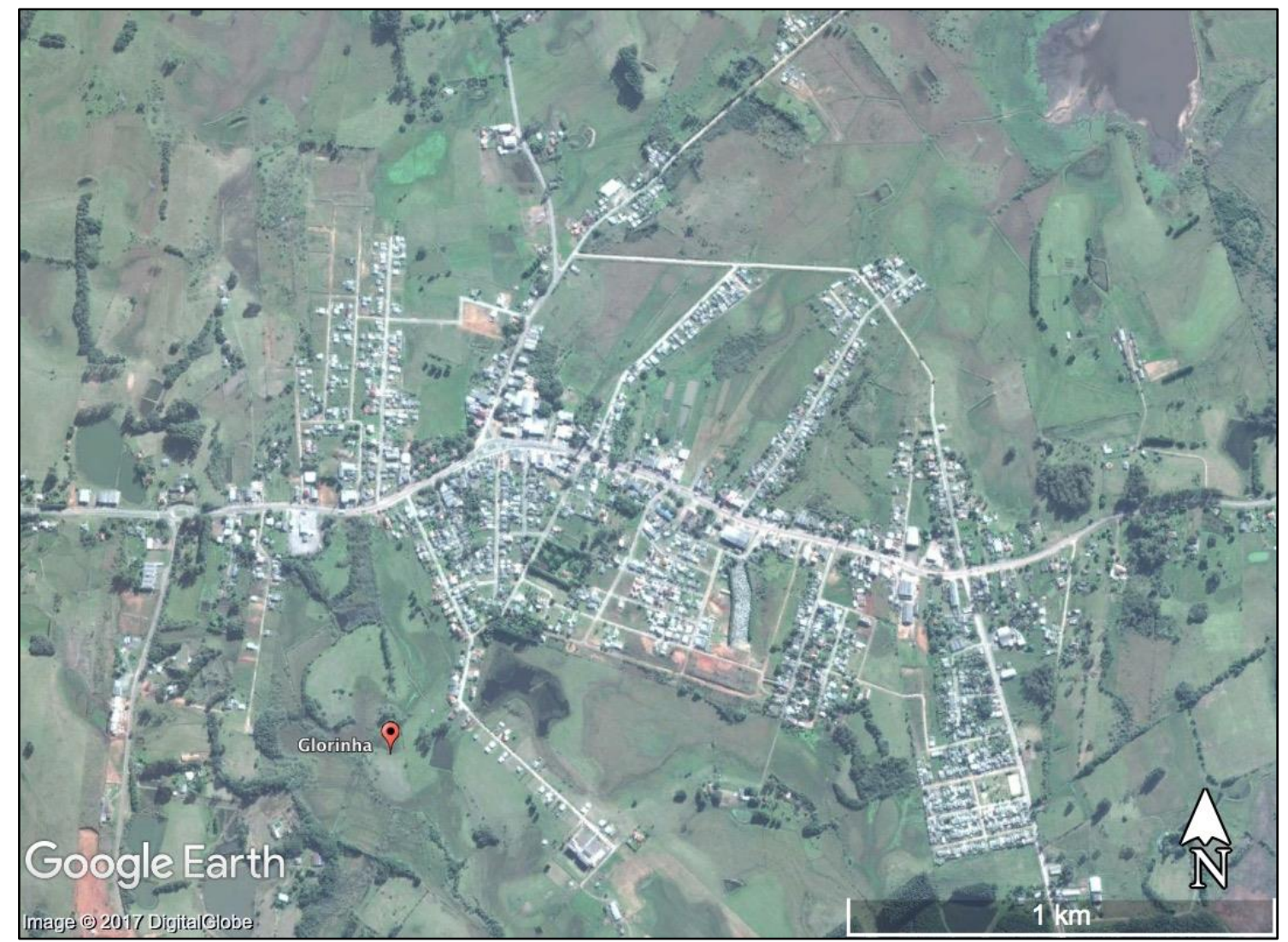

Figura 89 - Glorinha: Extensas plantações de arroz na área urbana

Fonte: Google-Earth (2017)

Verificou-se também baixa porcentagem de EVU (0 a $30 \%$ ) em algumas cidades ao norte da RMPA, no sopé da Serra Gaúcha. O fato do relevo ser bastante acidentado restringiu o tamanho de algumas áreas urbanas, logo a expansão urbana se deu em áreas menores. É o caso de Capela de Santana, Araricá, Sapiranga, Nova Hartz, Parobé e Taquara. A urbanização desenvolvida em menores áreas, acarreta no maior avanço sobre os espaços verdes para edificar habitações, comércio, prédios públicos, etc. Ainda assim, verificam-se algumas cidades do norte da RMPA com maiores porcentagem de EVU (30 a 60\%), como: São Sebastião do Caí, Estância Velha, Portão e Ivoti. 
As UDHs com maior quantidade de espaços verdes urbanos (60 a 94\%) estão distribuídas pela RMPA: ao norte da RMPA, em planícies inundáveis às margens do rio dos Sinos, nas proximidades do PE Delta do Jacuí, à beira do Guaíba, áreas de morro (localizadas sudeste e nordeste de Porto Alegre abrangendo inclusive a cidade de Viamão) e nas periferias de Canoas e Cachoeirinha.

Como já discutido, as UDHs ao norte da RMPA, possuem amplos espaços verdes por estarem no sopé da Serra Gaúcha, onde as características topográficas inviabilizam agricultura e pecuária extensiva ou ocupações de moradias em amplas áreas. Assim, as cidades maiores, e com baixa densidade populacional apresentaram áreas com grande quantidade de EVU, como: Dois Irmãos, Igrejinha e Montenegro.

As UDHs com grande quantidade de EVU localizadas nas cidades de Novo Hamburgo, São Leopoldo e Sapucaia do Sul estão relacionadas às grandes planícies inundáveis do rio dos Sinos. Segundo Penteado (2011) ainda predominam grandes áreas com formações de vegetação pioneiras de influência fluvial, que suportam às inundações em regimes de cheia (Figura 90).

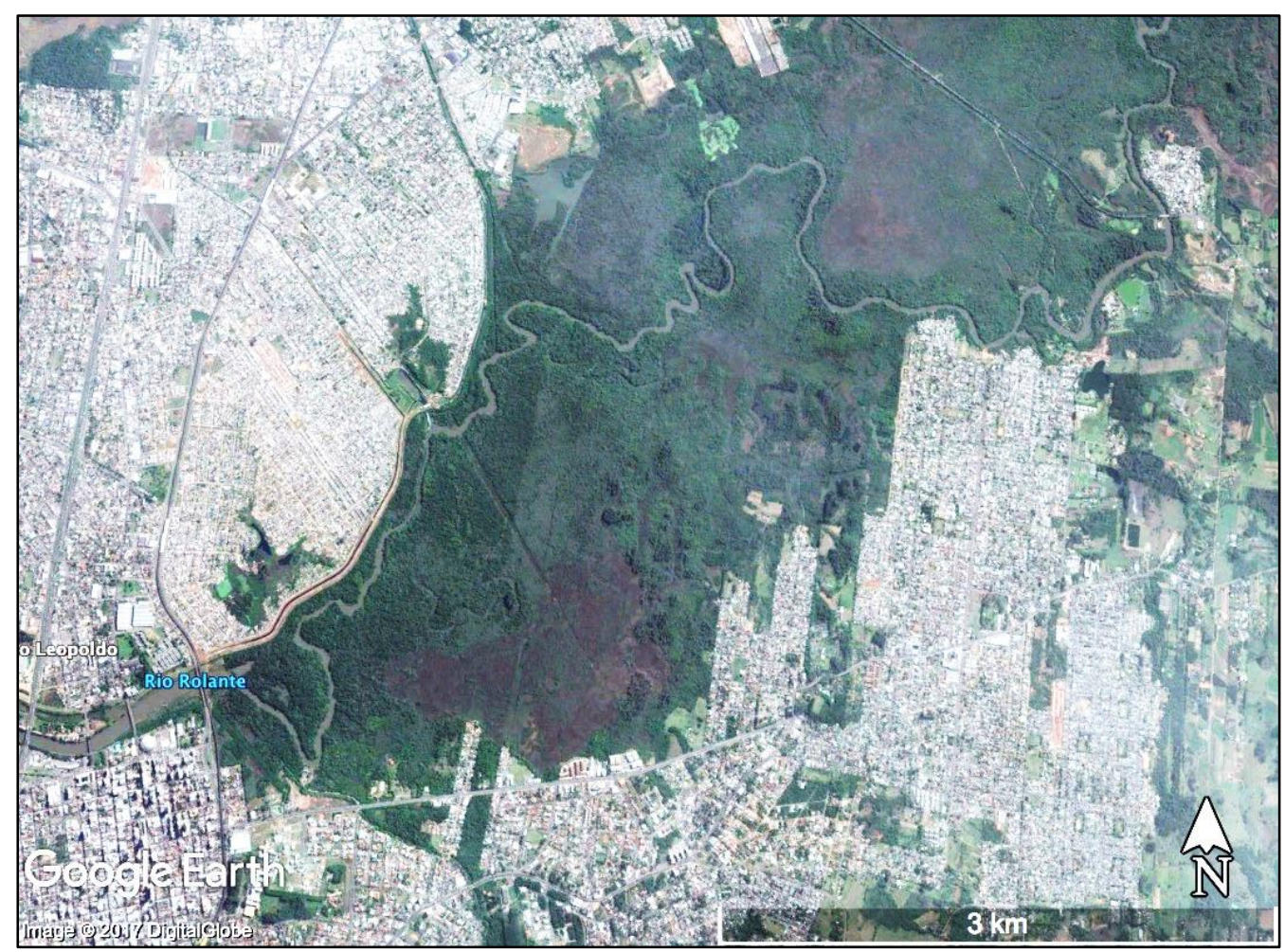

Figura 90 - Planície inundável entre Novo Hamburgo e São Leopoldo

Fonte: Google-Earth (2017) 
A UDH com grande quantidade de espaços verdes na cidade de Canoas está localizada no Parque Municipal Fazenda Guajuviras (área de 4,4 km²). Sobrinho (2005) relata que a maior parte do parque é coberto por eucaliptos, mas há áreas consideráveis de vegetação nativa (campos e matas). O maior impacto negativo desse parque é a presença do depósito de resíduos urbanos de Canoas (SOBRINHO, 2005).

A UDH com grande quantidade de EVU na cidade de Cachoeirinha está localizada no "Mato do Júlio". De acordo com informações do site da Prefeitura Municipal de Cachoeirinha (PMC), além da ampla espaço verde no meio da cidade, o terreno possui um importante prédio histórico, a "Casa dos Batistas" (Figura 91), a segunda residência mais antiga do estado gaúcho no estilo colonial açoriano (PMC, 2017). Devido a importância ambiental e histórica, a prefeitura municipal intenta realizar o tombamento da propriedade, porém esbarra na negativa dos herdeiros (PMC, 2017).

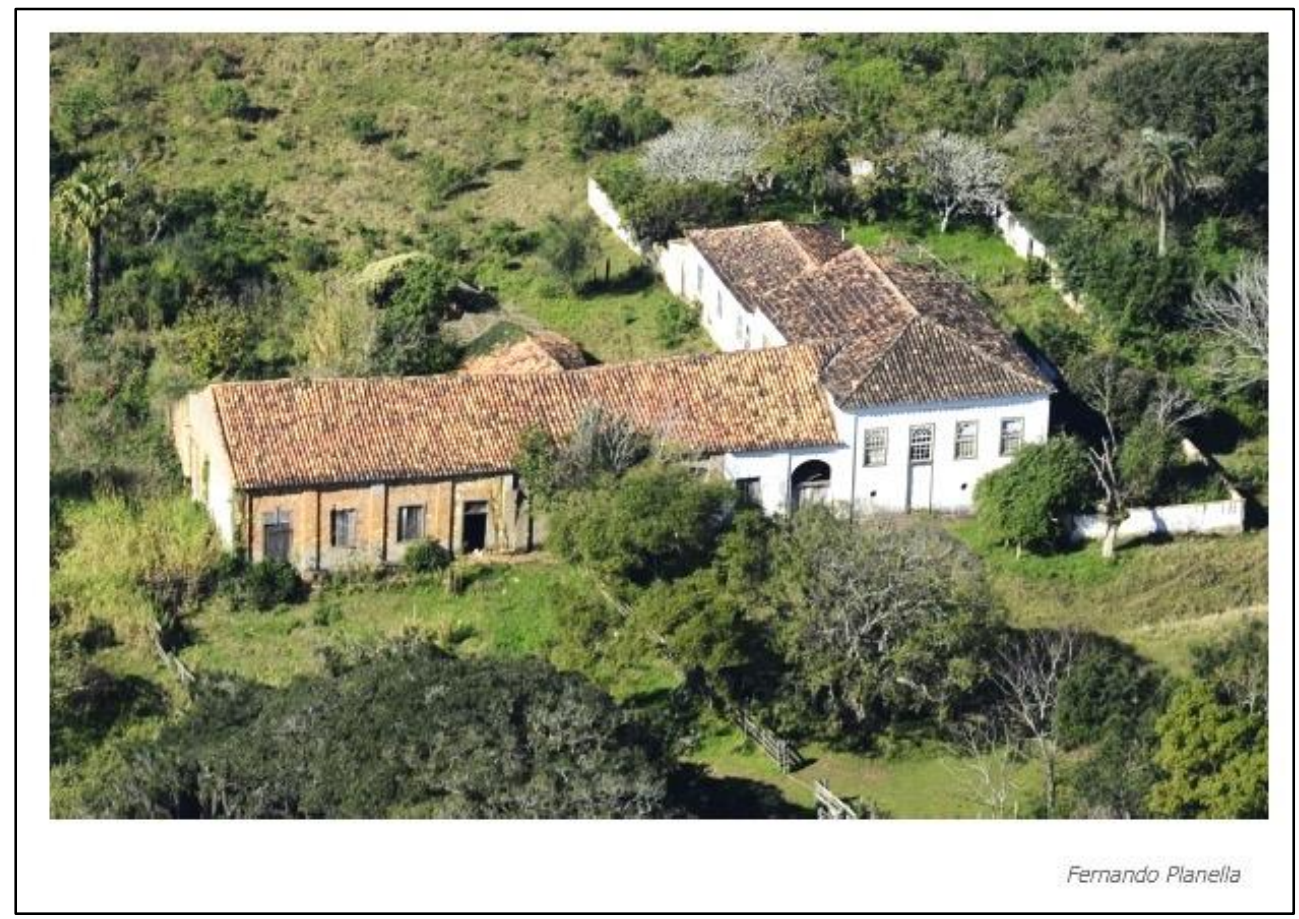

Figura 91 - "Casa dos Batistas". Cachoerinha (RMPA)

Fonte: Prefeitura Municipal de Cachoeirinha. PMC (2017). Autor: Fernando Planella

Porto Alegre possui a maior quantidade de UDH com grande quantidade de EVU (60 a 96\%) na RMPA. As localizadas nas proximidades do PE Delta do Jacuí, como já discutido, possuem ampla cobertura vegetal devido a presença do Parque e da APA do Delta do Jacuí. Além da vegetação, ressalta-se a grande quantidade de 
água que forma o Delta (CHIAPPETTI, 2005). A ampla cobertura hídrica justifica que as UDHs da parte sul do PE não se encontrem na referida classe.

Quanto à orla do rio Guaíba destaca-se as UDHs localizadas no Morro do Osso e na Ponta Grossa (Figura 92). Nessas localidades há ocorrência de amplas áreas cobertas de vegetação, cujos morros de formações graníticas impossibilitam maiores expansões urbanas (PORTO et al., 1999). Os autores narram a importância dessas áreas como sítio ecológico de alta biodiversidade e colocam a urbanização dos bairros da zona sul como a maior ameaça.

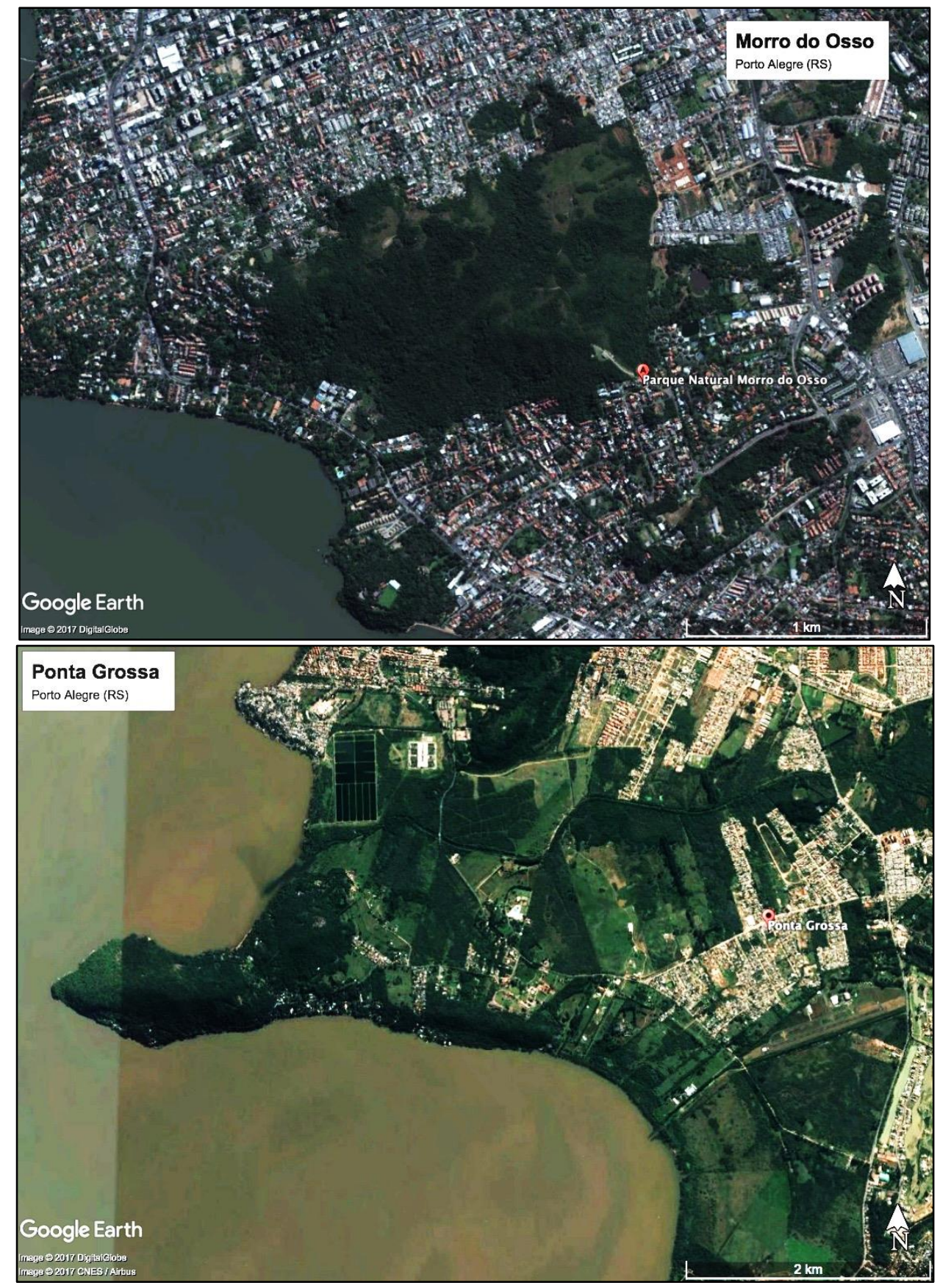

Figura 92 - Morro do Osso (superior); Ponta Grossa (inferior).

Fonte: Google-Earth (2017) 
Nota-se assim, que geomorfologia explica a existência da maioria das UDHs com grande quantidade de EVU, uma vez que a RMPA possui muitas áreas de morros e zonas de inundações por conta do rio Guaíba. Dessa forma, Carrion (1989, p. 231) relata que "o processo de ocupação da RMPA foi orientado pelo padrão histórico de assentamento, pelas facilidades de acesso viários e pela topografia da área".

Destarte, Andrade (2011) afirma que o processo de ocupação de Porto Alegre teve preferência de lugares planos e secos. Por possuir áreas bem drenadas, o centro da cidade foi ocupado primeiro e a expansão da zona sul e leste (áreas com grande quantidade de morros) foi mais lenta, não avançando tanto sobre os espaços verdes como na zona centro-norte (ANDRADE et al., 2011).

Na porção leste de Porto Alegre destaca-se o Morro Santana (Figura 93), onde a Universidade Ferderal do Rio Grange do Sul (UFRS) tem um campus (Campus do Vale). Esse morro é o ponto culminante da cidade (311 metros de altitude) com mais de $10 \mathrm{~km}^{2}$ de área, sendo $70 \%$ pertencentes à UFRGS (PORTO et al., 1999). Apesar da ampla cobertura de vegetação nativa (mata atlântica e campos sulinos), os autores citam como impactos negativos: os cortes ilegais de madeira e as queimadas. Porém, é a expansão urbana nas suas proximidades, tanto em Porto Alegre quanto em Viamão, que trazem maiores ameaças ao morro (PORTO et al., 1999). 


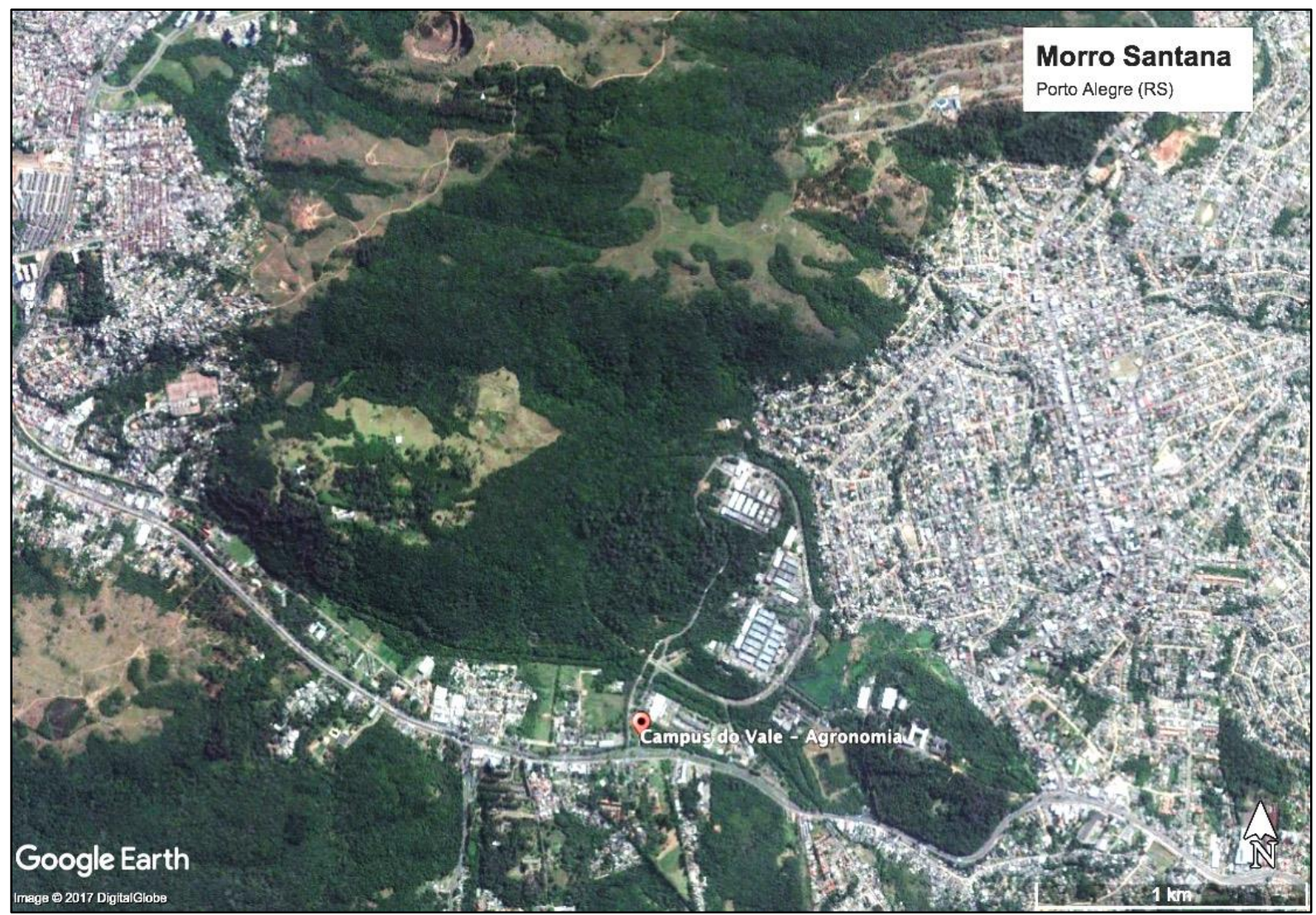

Figura 93 - Morro Santana (Campus do Vale - UFRGS)

Fonte: Google-Earth (2017)

Ao sul do Morro de Santana, Oliveira (2012) cita a presença de nove morros assim denominados: Tiririca, Companhia, da Cruz, da Polícia, da Glória, Teresópolis, Pedra Redonda, Pelado, Belém Velho e Pasmado. Eles também estão localizados em UDH que apresentaram grande quantidade de EVU. Apesar de ampla cobertura vegetal, a autora mostrou no seu estudo que a área onde estão localizados foi a que apresentou maior avanço de área urbana, precisamente 2,82 $\mathrm{km}^{2}$ de área urbana em dez anos (1991-2002).

$\mathrm{Na}$ divisa entre Porto Alegre e Viamão situa-se o Parque Municipal Saint Hilaire, criado ainda na década de 1940 (Figura 94). Com mais de $10 \mathrm{~km}^{2}$ é uma importante área verde dotada de boa infraestrutura para o lazer da capital e cidades próximas (PORTO et al., 1999), o que reflete na alta quantidade de EVU onde está localizado. Os autores relatam que a área é composta de campos sulinos, matas nativas e nascentes de vários arroios que cortam a capital. 


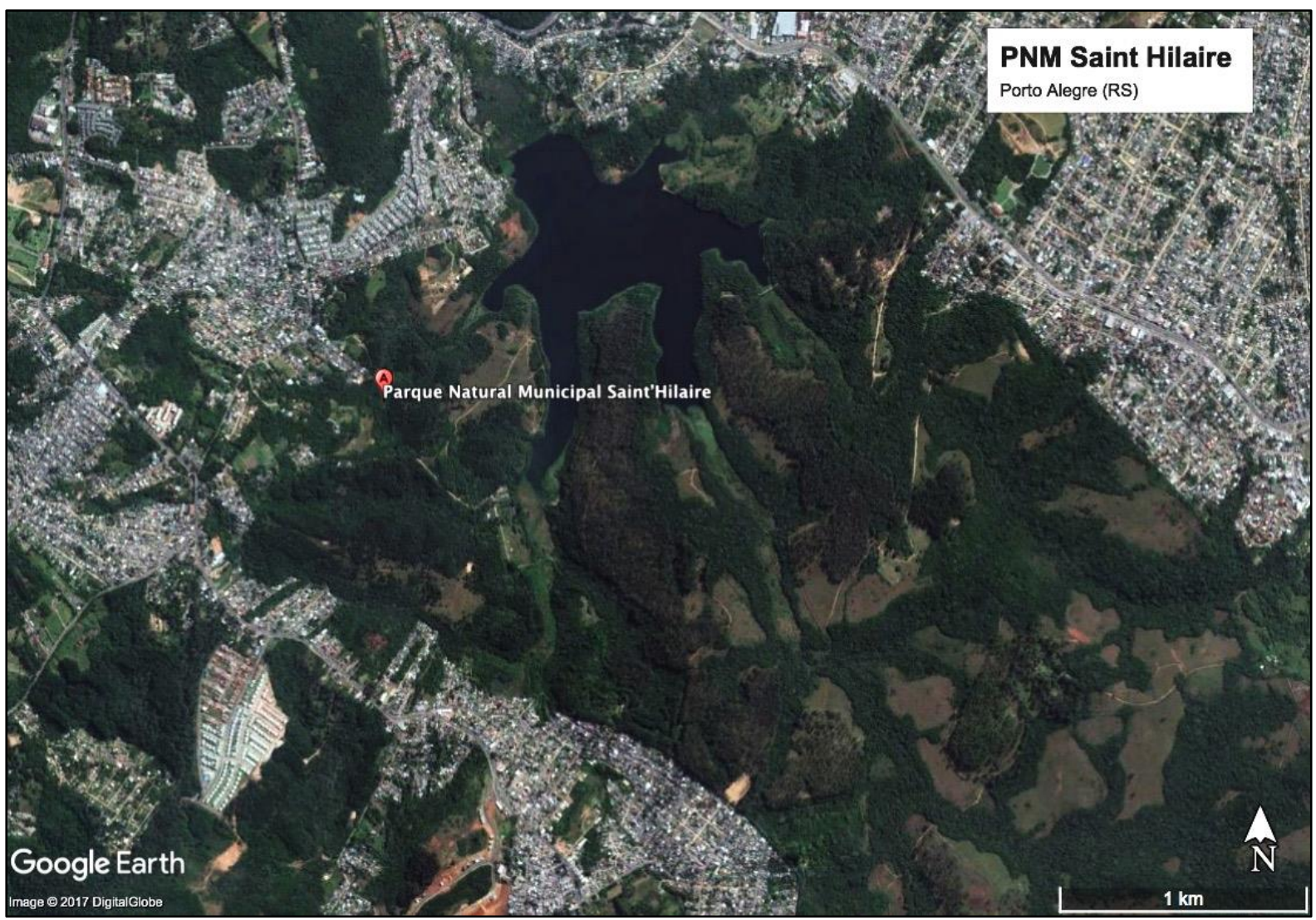

Figura 94 - Parque Natural Municipal Saint Hilaire

Fonte: Google-Earth (2017)

Já no limite municipal, na porção sul-sudeste (bairro do Lajeado) está cravada a maior área de morro de Porto Alegre, o morro São Pedro (PORTO et al., 1999). Junto com morro da Extrema e o morro Taquara, os três ocupam áreas representativas de UDH com grande quantidade de EVU. Assim, os autores citam que Porto Alegre possui vários morros de formação granítica, localizados sobretudo na porção sul-sudeste da capital (PORTO et al., 1999).

Voltando analisar a Figura 88, observa-se que a porção sul e sudeste de Porto Alegre, assim como parte considerável de Viamão apresentam quantidade intermediária de EVU (60-90\%). São áreas de expansão urbana, porém os fatores geomorfológicos (formação de morros graníticos), ora citados, dificultam extensas ocupações. As demais UDH que apresentaram essa classe pode-se afirmar que são áreas mais periféricas, fora dos centros urbanos mais habitados, como ocorre em: Montenegro, Portão, Taquara, Novo Hamburgo e São Leopoldo.

Os morros de Porto Alegre e Viamão, além de estruturarem a paisagem, possuem papel fundamental na conservação dos recursos naturais (PORTO et al., 1999). Os autores relatam que são neles que se encontram os remanescentes mais 
significativos de vegetação nativa, sendo último refúgio da fauna silvestre. Embora a topografia limite a expansão urbana, a maioria dos morros apresentam mosaicos: área urbana, rural e vegetação nativa. Para agravar, Oliveira (2012) relata que nessas áreas de morros, ocorreram os maiores avanços da malha urbana, no período de 1991 até 2002.

Pontua-se que a expansão urbana que ocorre nos morros é algo que deveria ser evitado, uma vez que são áreas de riscos devido à declividade, maior susceptibilidade à desmoronamentos e ao maior escoamento superficial de água. Ademais, considerando a sua importância ambiental, Porto et al. (1999) cita a necessidade de iniciativas da sociedade civil e do poder público para articular ações e políticas que reflitam na proteção da área.

\subsubsection{Análise Demográfica}

Ao analisar a Figura 95, observa-se que poucas são as UDHs na RMPA que não possuem EVU (em vermelho), além de pequenas estão distribuídas. As UDHs com até $15 \mathrm{~m}^{2}$ de EVU (laranja) estão localizadas exatamente nos centros urbanos mais consolidados da RMPA, o que ratifica análises anteriores quanto a relação entre alta densidade populacional e baixa quantidade de EVU. Conclui que esses centros da RMPA possuem baixa quantidade de EVU por habitantes, com quantidade menor ao valor recomentado pela Sociedade Brasileira de Arborização Urbana - SBAU $\left(15 \mathrm{~m}^{2}\right)$. 


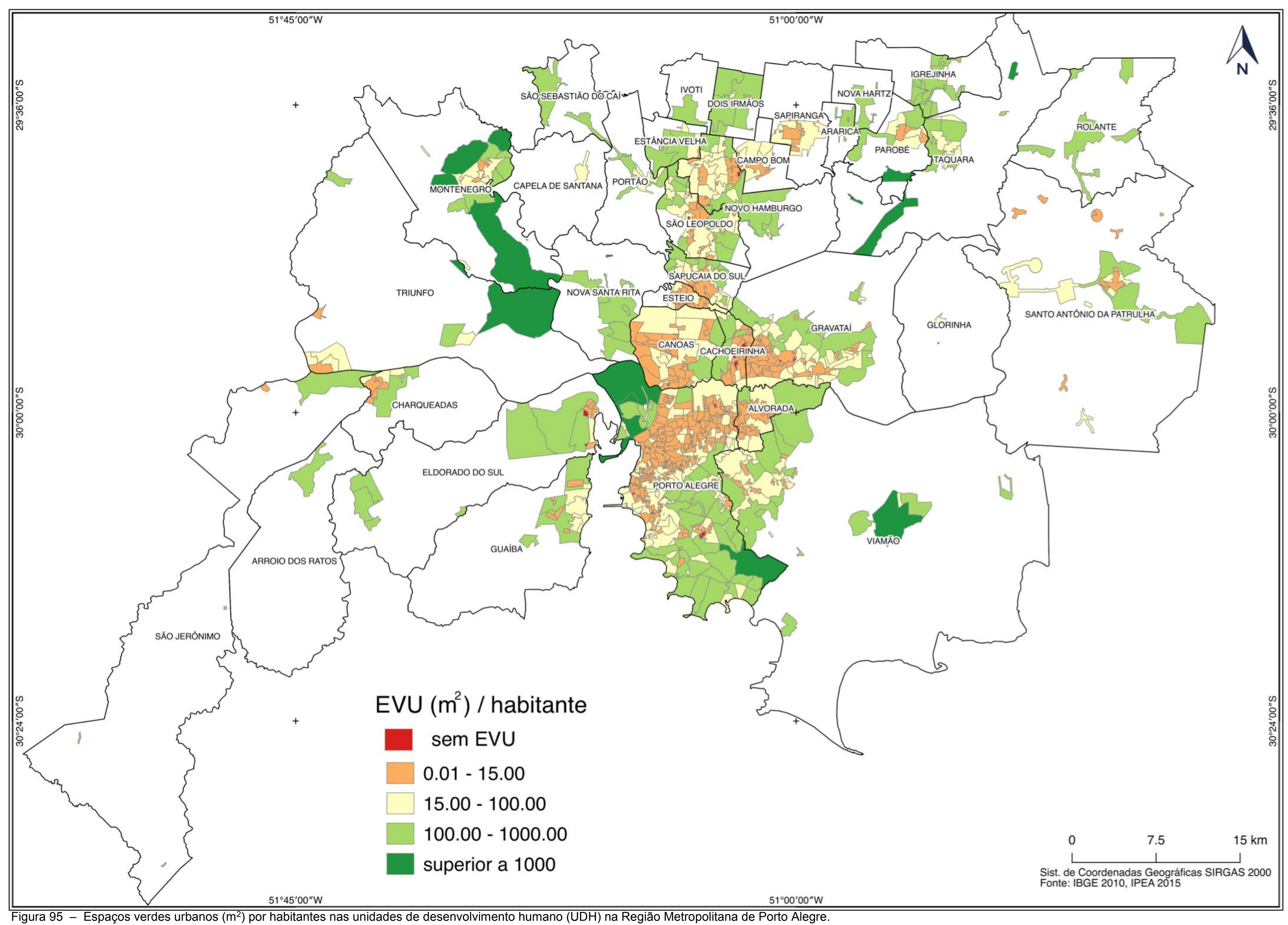


As demais classes, em amarelo, verde-claro e verde-escuro expressam de forma graduada maior quantidade de espaços verdes por habitante. Variando de 15 $\mathrm{m}^{2}$ a $100 \mathrm{~m}^{2}$ (em amarelo), $100 \mathrm{~m}^{2}$ a $1000 \mathrm{~m}^{2}$ (verde-claro) e superior de $1000 \mathrm{~m}^{2}$ (verde-escuro). Por essa classificação observa-se visualmente que a quantidade de espaços verdes por habitante aumenta dos centros mais urbanizados para as bordas.

Quanto às áreas com maior quantidade de EVU por habitantes, destacam-se as UDHs próximas ao PE do Delta do Jacuí, e na UDH próxima ao Morro São Pedro (sudeste da capital) áreas com amplas cobertura vegetal, além das UDHs localizadas nas cidades de Viamão, Montenegro, Taquara, Viamão. Nesses casos é importante ressaltar que apesar das mesmas UDHs apresentarem baixa porcentagem de EVU (0-30\%) são áreas com baixa densidade populacional.

\subsubsection{Tamanho e Distribuição dos Fragmentos dos Espaços Verdes Urbanos}

Ao categorizar o tamanho dos EVU da RMPA, por área, em três classes (pequenas, intermediárias e grandes) de acordo com a curva normal de distribuição e estabelecendo o desvio padrão como o limite das classes, obteve-se a seguinte categorização (Tabela 15).

Tabela 15 - Categorização do tamanho dos fragmentos dos espaços verdes urbanos

\begin{tabular}{ll}
\hline $\mathrm{EVU}\left(\mathrm{km}^{2}\right)$ & Classe de fragmentos \\
\hline $0,00-0,21$ & Pequenos \\
$0,21-77,36$ & Intermediários \\
$77,36-104,57$ & Grandes \\
\hline \hline Fonte: Elaborada pelo autor
\end{tabular}

A Figura 96 mostra que a classe de fragmentos grandes (na cor verde) localiza-se na porção sudeste de Porto Alegre e centro-oeste de Viamão. Esses fragmentos correspondem à vegetação dos morros graníticos, onde a malha urbana não consolidou. Ressalta-se assim sua importância ecológica, sobretudo pelo tamanho significativo de vegetação nativa (ANDRADE et al., 2011). 


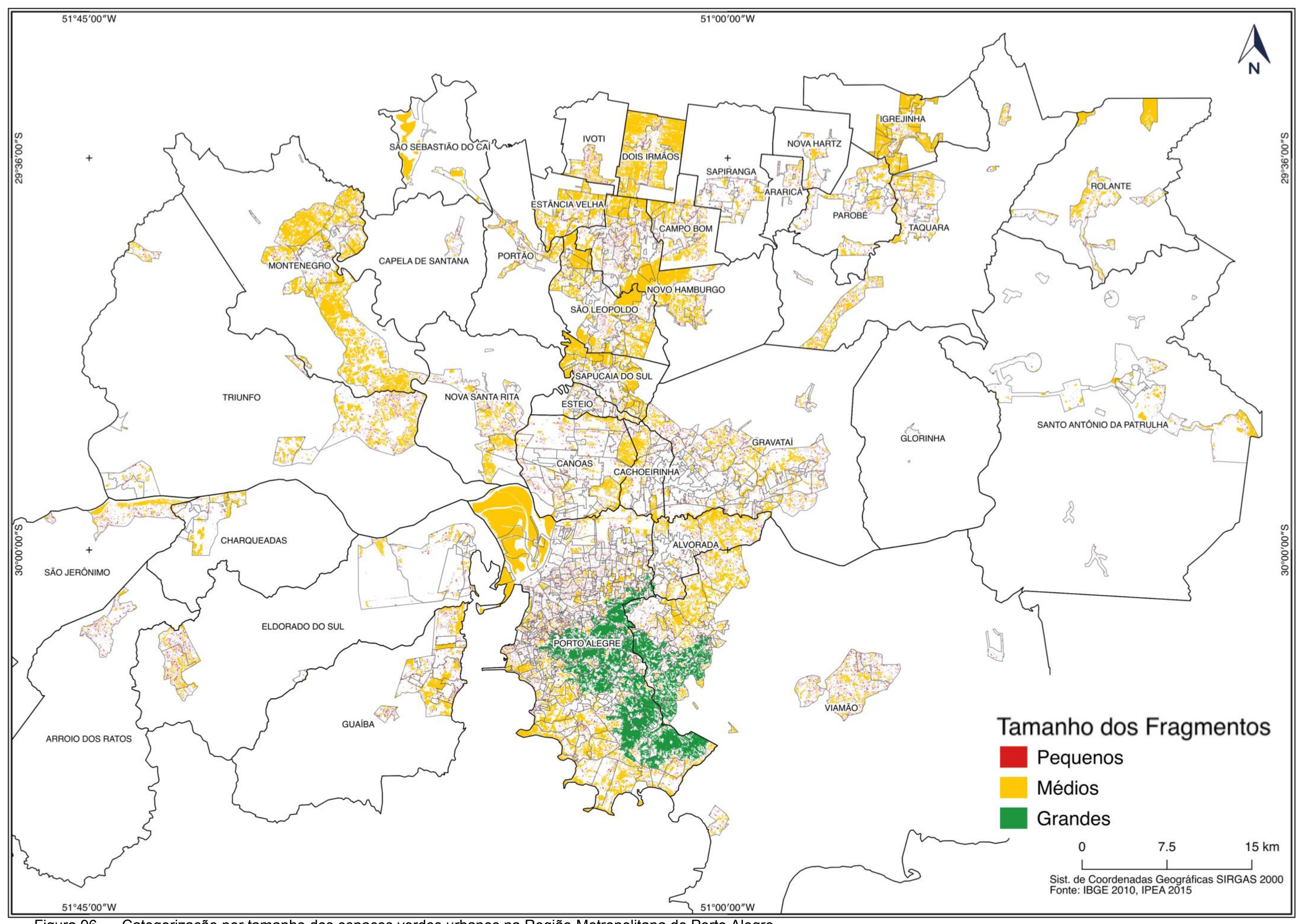

Figura 96 - Categorização por tamanho dos espaços verdes urbanos na Região Metropolitana de Porto Alegre 
É importante ressaltar o trabalho de Martin; Meira (1998) que analisaram a cobertura vegetal dos 44 morros da capital por fotografias aéreas. Apesar de fazer quase vinte anos da publicação do estudo, ressalta-se o padrão de conservação já encontrado na época: 32 morros (70\%) possuíam mais de $50 \%$ de cobertura vegetal nativa, que junto com vegetação exótica (principalmente pinos) formavam grandes fragmentos verdes na porção sudeste da capital.

Hasenack; Setubal (2011) citam que a maioria dos morros apresentam uma vegetação rasteira nativa no topo, dando a falsa impressão de desmatamento. Assim os autores explicam essa curiosidade: a forma convexa nos topos de morro facilita o escoamento da água, devido a um processo adaptativo formou-se na topo uma vegetação nativa tipicamente rasteira que tolera a escassez hídrica.

A classe dos fragmentos intermediários (em amarelo) também representa lugares onde a área urbana não avançou tanto. Eles são representados majoritariamente pela vegetação do PE do Delta do Jacuí, da orla do Guaíba, a vegetação da planícies inundáveis do rio dos Sinos e vegetação de terreno declivoso da Serra Gaúcha (municípios a norte da RMPA).

Além desses, contam com fragmentos que visualmente dão continuidade aos fragmentos grandes (em verde) no sentido sudoeste e nordeste. Nesse caso a diferença é que nessa classe intermediária ocorreu maior fragmentação sobretudo da áreas urbanas (Porto Alegre) e áreas rurais (Viamão). Além de mais fragmentada, estudo de Hasenack et al., (2008) relata que na região sudoeste da capital, concentra a maior quantidade de espécies exóticas, fruto da grande intervenção humana na área .

A análise dos menores fragmentos foi feita a partir do mapa de Kernel (Figura 97). As zonas com maior probabilidade de encontrá-los foram os centros de Porto Alegre, Novo Hamburgo, São Leopoldo e Ivoti. Acredita-se que nesses casos a abundância de fragmentos sejam reflexos da arborização urbana bastante consolidada, uma vez que possuem mais de $625 \mathrm{~m}^{2}$, número considerado elevado para arborização urbana.

Também observaram-se focos de calor em áreas urbanas onde ocorre algum tipo de produção agrícola, como nas cidades de Gravataí, Viamão, Arroio dos Ratos, Eldorado do Sul, Triunfo e São Jerônimo. Nessas cidades os fragmentos pequenos dizem respeitos aos remanescentes florestais em meio à matriz agrícola. 


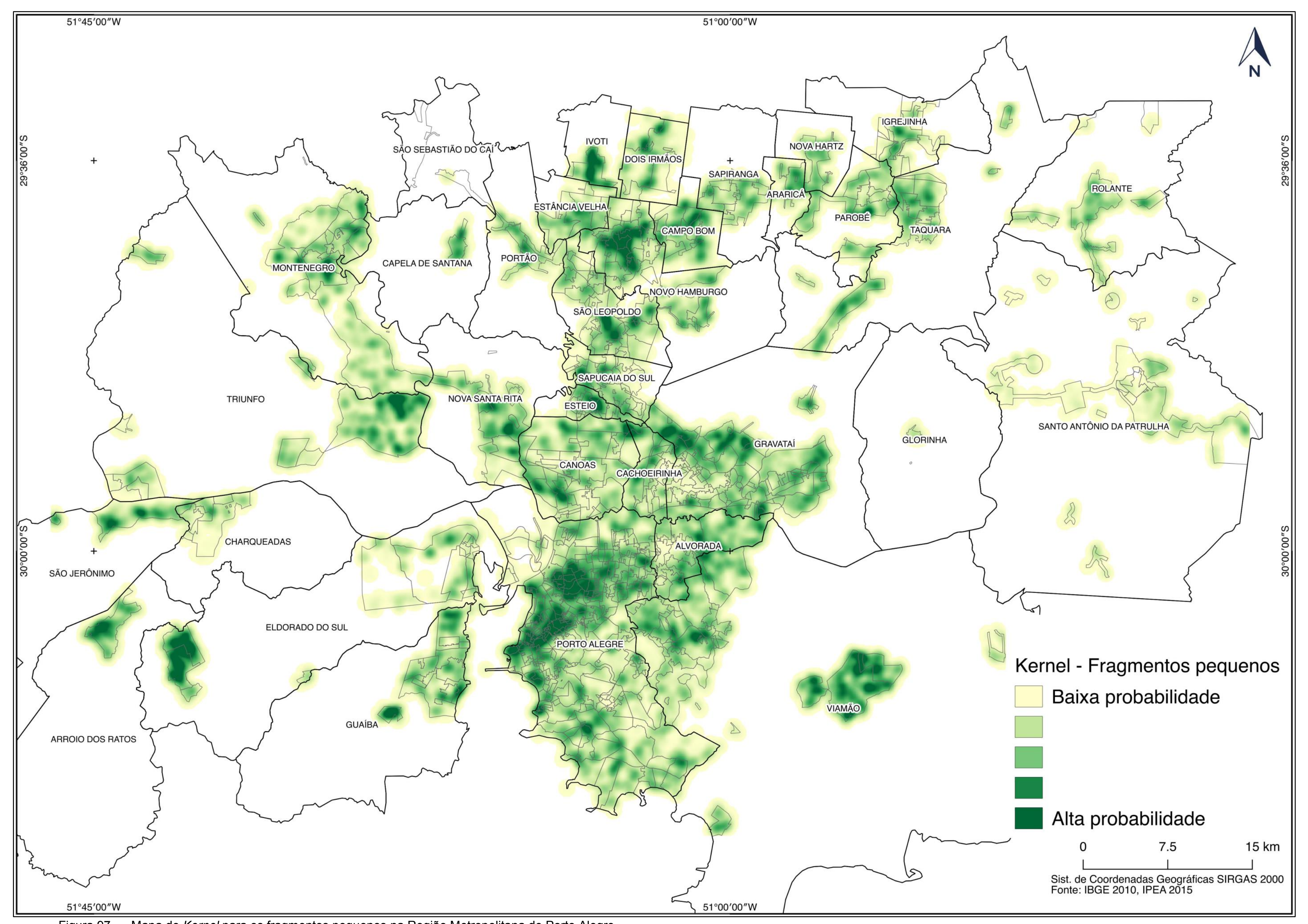

Figura 97 - Mapa de Kernel para os fragmentos pequenos na Região Metropolitana de Porto Alegre 
Em se tratando de arborização urbana, é importante destacar o pioneirismo de Porto Alegre na política de valorização das árvores em vias públicas, por meio do Plano Diretor de Arborização Urbana, publicado no ano 2000 e republicado em 2006 no Diário Oficial de Porto Alegre (COMAM, 2006). Esse plano é um documento técnico realizado pelo Conselho Municipal de Meio Ambiente (COMAM), que normatizou um conjunto de regras e medidas para o manejo, preservação e expansão dos espaços verdes nas vias públicas.

Além de dados, medidas e critérios oficiais para a arborização urbana, o plano apresenta metas para tornar Porto Alegre cada vez mais arborizada. Umas das medidas mais audaciosas do plano é a manutenção de, no mínimo, 40\% de área vegetada nos passeios públicos (COMAM, 2006). Apesar de não ter efeito de lei, ele se mostra como um importante instrumento de planejamento e incentivo à presença de árvores na área urbana.

Ademais, a rua popularmente chamada como a mais bonita do mundo está em Porto Alegre: Rua Gonçalo de Carvalho, situada no centro da capital (Figura 98). A sua beleza se deve às mais de 100 árvores plantadas nas calçadas de pedra de granito, ainda na década de 1930, por funcionários de uma cervejaria localizada nas proximidades (HELM, 2011). As copas das árvores se uniram formando um longo e belo túnel verde, transformando-o em um dos mais belos cartões postais da cidade.

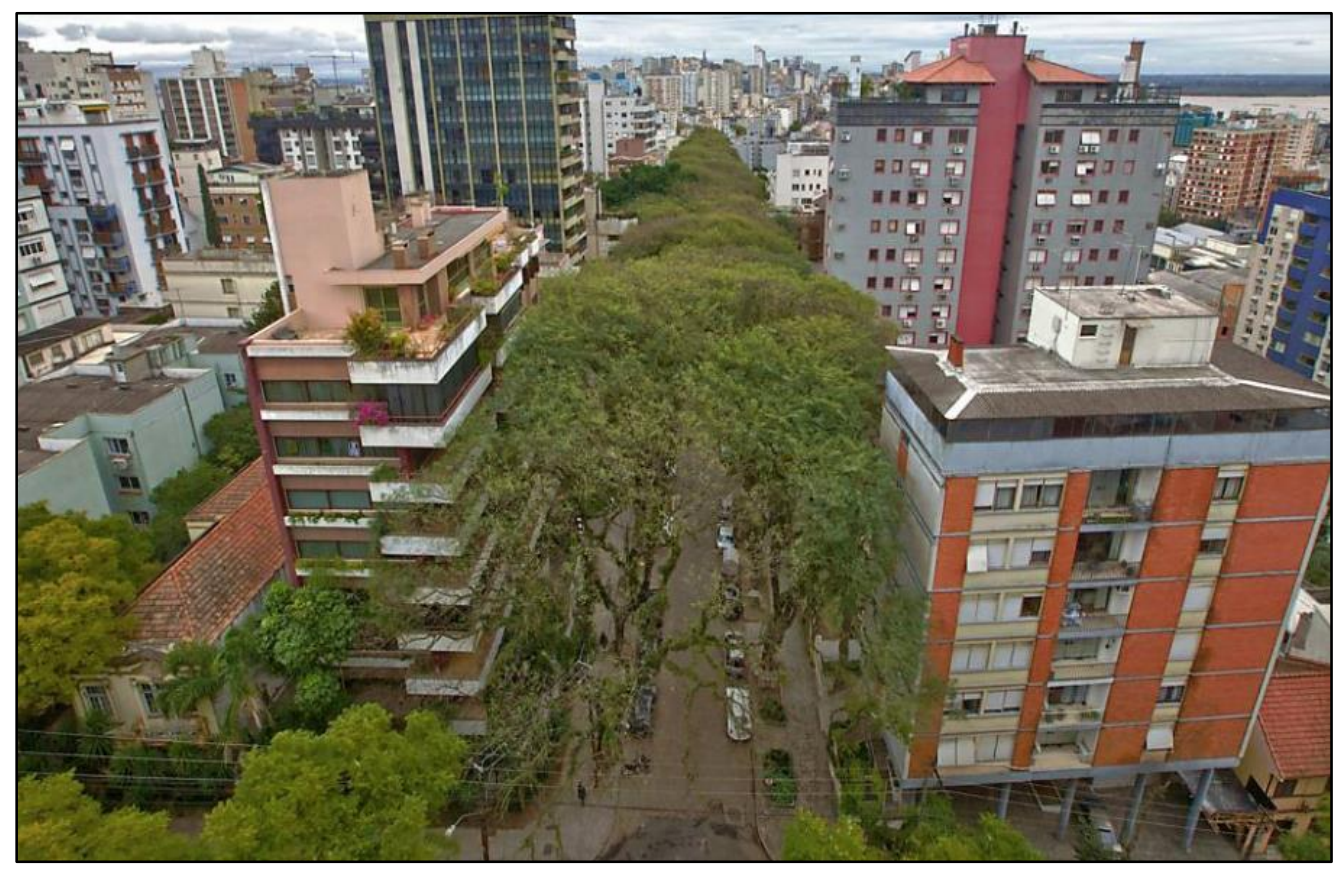

Figura 98 - Rua Gonçalo de Carvalho

Fonte: fotografia.folha.uol.br Autor: Jefferson Bernardes (2011) 
Diante da ameaça de construção de um edifício (shopping) que necessitaria alargar a rua e retirar algumas árvores, nos anos de 2005 e 2006, houve uma mobilização popular contra a obra que traria impactos à rua e às árvores (HELM, 2011). A Figura 99 mostra um cartaz de uma das mobilizações em prol da rua Gonçalo de Carvalho.

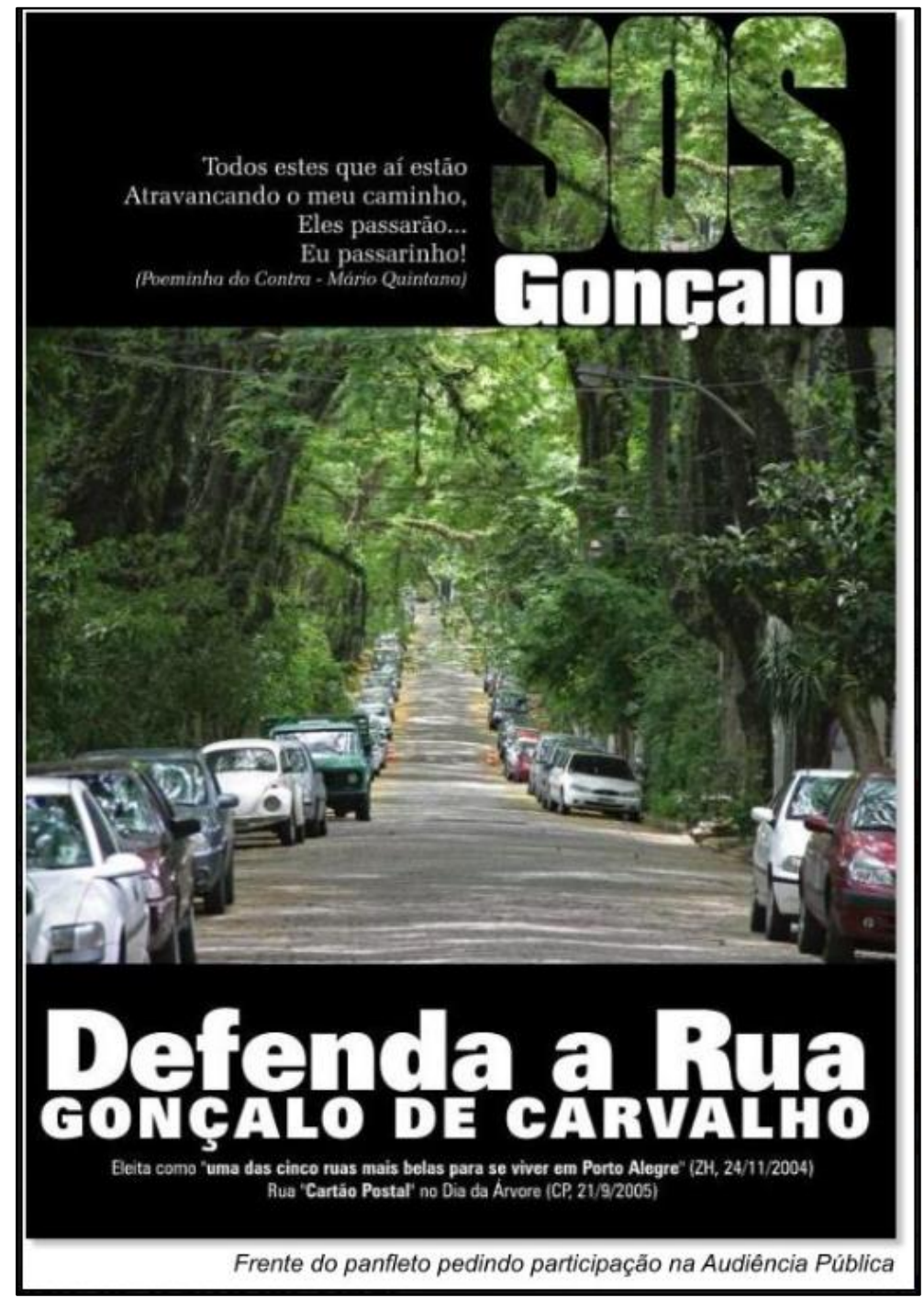

Figura 99 - Cartaz da mobilização popular contra a construção de um shopping Fonte: http://goncalodecarvalho.blogspot.com.br/

Helm (2011) cita que através de protestos e da criação de um blog (http://goncalodecarvalho.blogspot.com.br/) a sociedade civil conseguiu se articular e fazer que os órgãos competentes barrassem a obra. Além de barrar, o poder público municipal se atentou à importância e decretou a rua Gonçalo de Carvalho como Patrimônio Cultural, Histórico e Ecológico da cidade, medida inédita no Brasil (HELM, 2011). 


\subsubsection{Correlação: Espaços Verdes Urbanos e Vulnerabilidade Social}

A correlação espacial entre IVS e porcentagem de EVU na RMPA apresentou o Índice de Moran de 0,05 (Gráfico 13). O valor positivo indica que a maioria das UDHs refutaram a hipótese: áreas com melhores índices sociais (menor IVS) apresentam maior quantidade de EVU, e vice-versa.

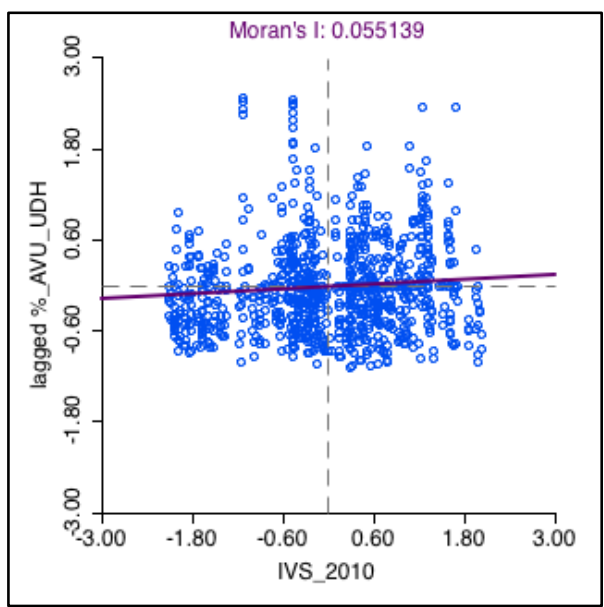

Gráfico 13 - Diagrama de Espalhamento de Moran. RMPA

Do total de 968 UDH da RMPA, 76,54\% não apresentaram significância na análise proposta. O Gráfico 14 destaca as UDHs sem significância, observando que são aquelas mais próximas ao eixo da variável representada pelo IVS (horizontal). $\mathrm{Na}$ prática representam as UDHs onde a quantidade de EVU não variou significativamente conforme às variações de IVS.

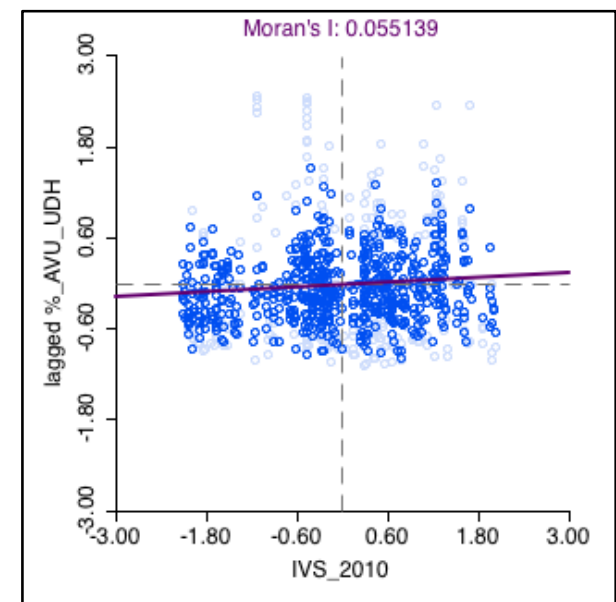

Gráfico 14 - UDH sem significância. RMPA 
O Gráfico 15 indica as 99 UDH que não apresentam significância por não apresentarem vizinhança, logo não influenciaram na análise de correlação espacial. No gráfico de correlação, essas UDHs dispostas em cima do eixo da variável dependente, representada pelo IVS.

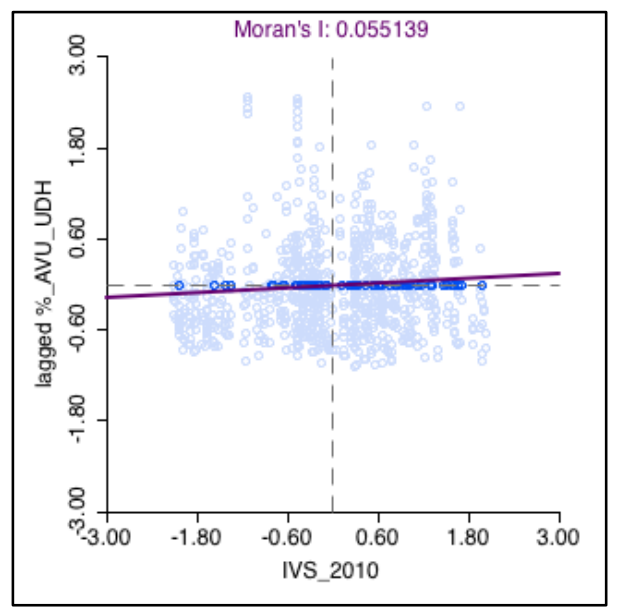

Gráfico 15 - UDH sem vizinhança. RMPA

O Gráfico 16 destaca as 227 UDHs que apresentaram significância na correlação geoestastítica, o que representa $23,45 \%$ do total. O mesmo indica que são os pontos mais dispersos no gráfico. Verifica-se que o espalhamento desses pontos (representado pelas UDHs) são determinantes para a inclinação da curva de correlação, refletindo o valor positivo do Índice de Moran.

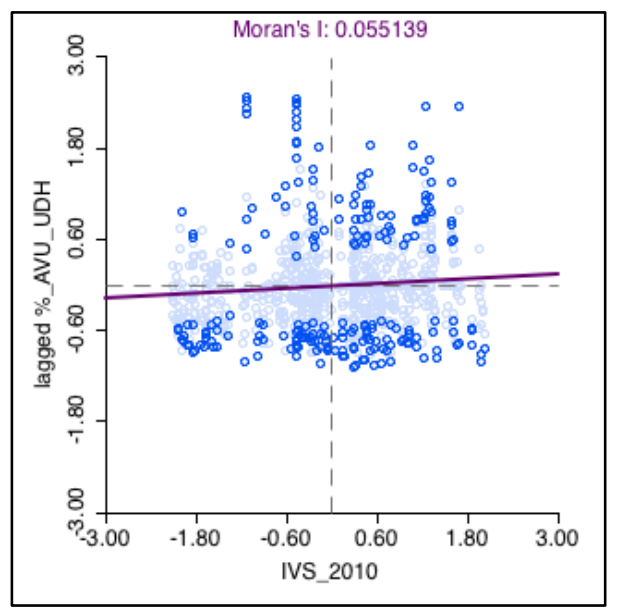

Gráfico 16 - UDH com significância. RMPA

Porém, haver correlação não significa corroborar a hipótese. Ao analisar os resultados frente a hipótese, é importante destacar, novamente, os cenários esperados: a) UDH com grande porcentagem de EVU e IVS baixo e b) UDH com 
baixa porcentagem de EVU e IVS alto. Esses dois cenários estão representados na cor verde (cenário A) e cor vermelha (cenário B) nas Figuras 100 e 101. Esses cenários compõe $46,7 \%$ das unidades amostrais (106 UDH) que apresentaram significância na correlação.

Os demais $53,3 \%$ das UDHs, que também apresentaram significância na análise geoestastítica, representam os cenários opostos à hipótese: c) UDH com grande porcentagem de EVU e IVS alto e d) UDH com baixa porcentagem de EVU e IVS baixo. Esses dois cenários estão representados na cor laranja (cenário $\mathrm{C}$ ) e cor amarela (cenário D) nas Figuras 100 e 101.

Uma vez que a correlação é baseada na quantidade e grau de vizinhança das unidades amostrais, no caso as UDHs, as áreas que se correlacionam podem ser melhor analisadas ao inferir sobre a dimensão de área e população, conforme mostram a Figura 100 e a Tabela 16. A Figura 101 espacializa as áreas que apresentaram correlação significativa. 
Tabela 16 - Resumo da análise geoestastítica na Região Metropolitana de Porto Alegre

\begin{tabular}{llllll}
\hline Correlação & \multirow{2}{*}{ UDH (qtde) } & IVS med & $\begin{array}{l}\text { \%EVU/UD } \\
\text { H }\end{array}$ & $\begin{array}{l}\text { ÁREA } \\
\text { \% POP }\end{array}$ \\
\hline ALTA-ALTA (laranja) & 56 & 0,33 & 42,34 & $\mathbf{8 , 6 1}$ & 9,35 \\
ALTA-BAIXA (vermelho) & $\mathbf{6 3}$ & $\mathbf{0 , 3 3}$ & $\mathbf{1 1 , 3 7}$ & $\mathbf{5 , 2 3}$ & $\mathbf{1 1 , 6 6}$ \\
BAIXA-BAIXA (amarelo) & 65 & 0,16 & $\mathbf{7 , 9 9}$ & 3,90 & 13,78 \\
BAIXA-ALTA (verde) & $\mathbf{4 3}$ & $\mathbf{0 , 1 9}$ & $\mathbf{5 3 , 8 5}$ & $\mathbf{4 , 4 8}$ & $\mathbf{7 , 0 4}$ \\
SEM SIGNIFICÂNCIA & 741 & 0,25 & $\mathbf{2 1 , 4 1}$ & $\mathbf{7 7 , 7 9}$ & 58,17 \\
\hline HIPÓTESE (vermelho + verde) & $\mathbf{1 0 6}$ & & & $\mathbf{9 , 7 1}$ & $\mathbf{1 8 , 7 1}$ \\
OPOSTO DA HIPÓTESE (laranja + amarelo) & 121 & & & 12,51 & $\mathbf{2 3 , 1 3}$ \\
\hline \hline
\end{tabular}

Fonte: Elaborada pelo autor

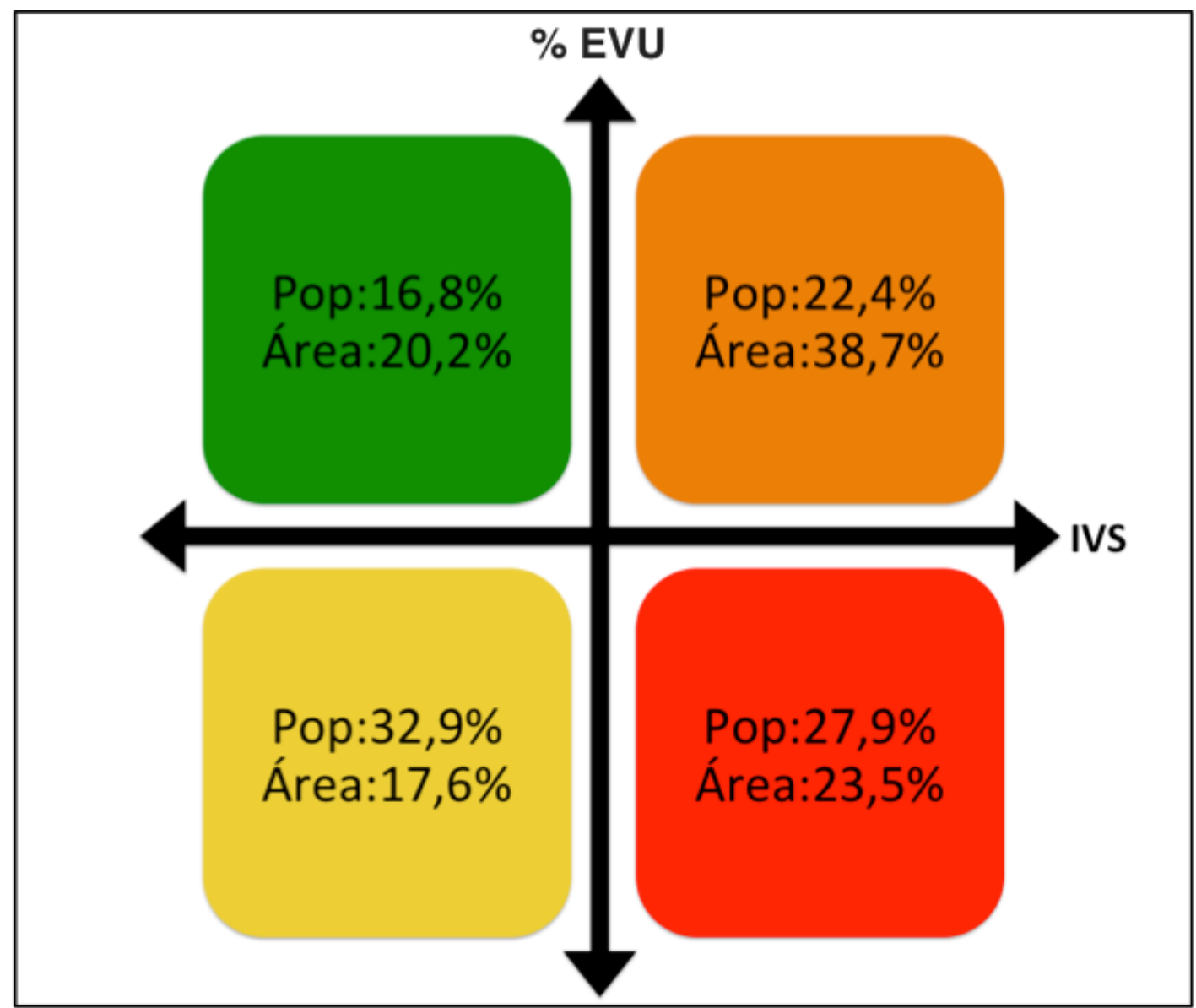

Figura 100 - Porcentual de área e população das UDHs com significância. RMPA 


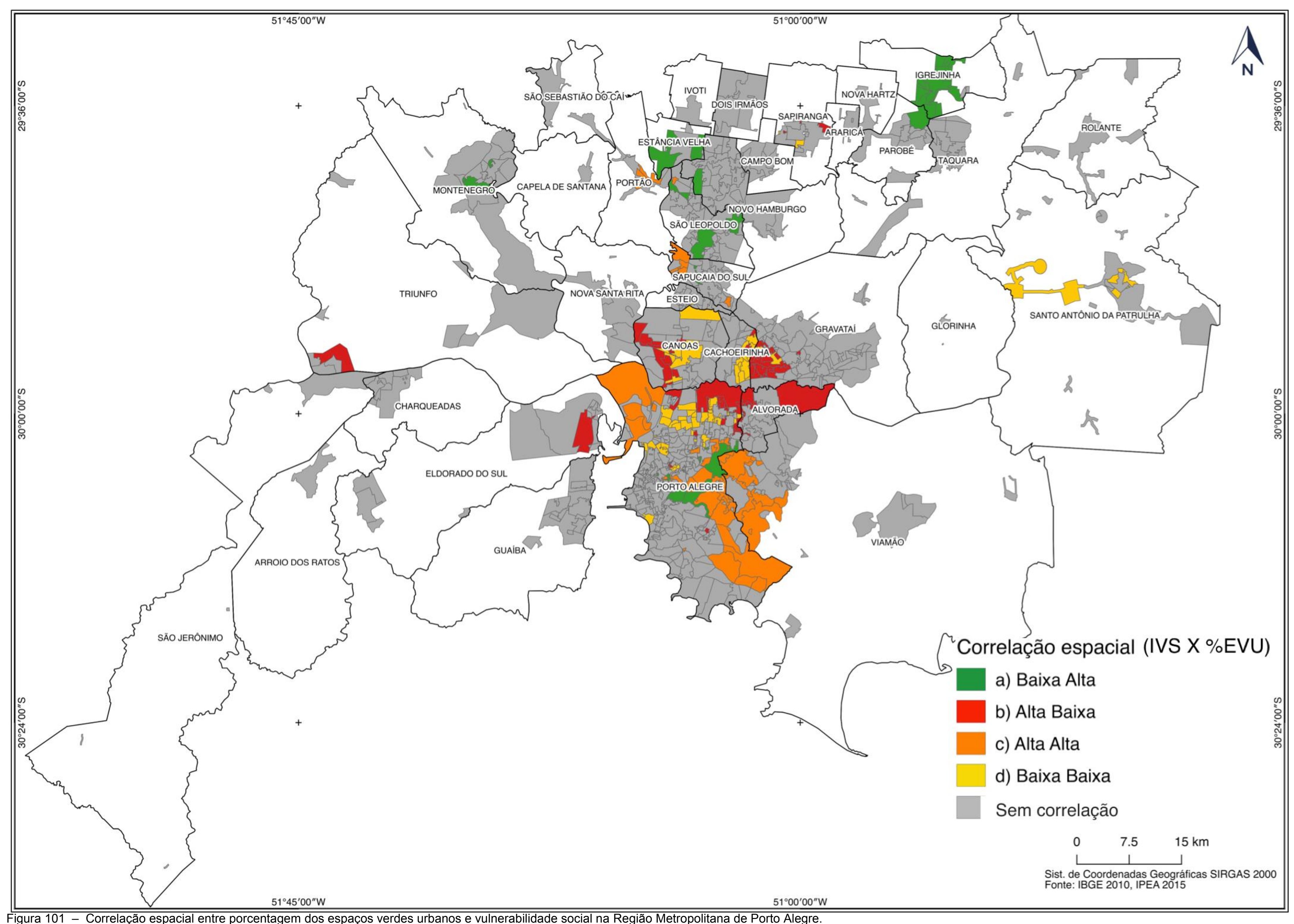


O cenário $\mathrm{C}$, representado pela área em laranja foi o que mostrou maior magnitude em termos de área $(38,7 \%$ das UDHs com significância e $8,61 \%$ da RMPA). Nele residem $9,35 \%$ dos habitantes da RMPA (22,4\% das áreas com significância) - Figura 100. Ele está distribuído da seguinte maneira: na porção sudeste da RMPA (morros graníticos de Porto Alegre e Viamão), nas UDHs do PE Delta do Jacuí, nas planícies inundáveis do Rio dos Sinos (Sapucaia do Sul), e em algumas UDHs de Portão e Novo Hamburgo. O cenário $C$ corresponde a $56 \mathrm{UDH}$ com IVS-médio de 0,33 e 42,34\% de EVU. Esses valores indicam que este cenário apresenta forte correlação entre: muitos espaços verdes urbanos e alta vulnerabilidade social.

A magnitude em termo de área deve ser observada com cuidado, principalmente para as UDHs situadas no PE Delta do Jacuí, uma vez que ela é uma área protegida, com grande cobertura de vegetação e água. Quanto à porção sudeste (morros graníticos), ressalta-se a dificuldade de acesso e à expansão urbana dado as especificidades geomorfológicas (morros graníticos).

$\mathrm{O}$ fato de ter grande área e alta porcentagem de EVU não indica que a população tem acesso e pode fazer uso da área, embora traga benefícios como: melhoria da qualidade do ar e temperatura mais amenas. Pontua-se portanto, que mesmo que a quantidade dos espaços verdes urbanos seja expressiva no cenário $C$ (laranja), ressalta-se a importância ecológica e a vulnerabilidade social.

Os EVU nesse cenário são prioritários para se estabelecer medidas de controle ambiental, seja por legislação ou mecanismos de fiscalização e monitoramento de tal forma que elas continuem no espaço urbano, garantindo a qualidade da infraestrutura urbana.

$O$ cenário em maior magnitude quanto à população foi o cenário $D$, representado pela cor amarela (Figuras 100 e 101). Ele está concentrado, majoritariamente, nas áreas mais urbanizadas de Porto Alegre, Canoas, Cachoeirinha e Sapiranga além da área urbana-agrícola de Santo Antônio da Patrulha. A Tabela 16 e a Figura 100 mostram que apesar do cenário corresponder a menor área $(3,90 \%$ da área analisada da RMPA e 17,6\% das UDHs com significância) existe uma população expressiva de $13,78 \%$ da RMPA, ratificando mais uma vez a alta densidade populacional nessa área.

O conjunto de UDH em amarelo apresentou IVS-médio de 0,16 (baixa vulnerabilidade) e 7,99\% de EVU (o menor valor em relação à todos os cenários). 
Esses valores indicam que parte dos espaços analisados com maior densidade demográfica, além de parte da cidade de Santo Antônio da Patrulha, apresentam correlação espacial entre: poucos espaços verdes urbanos e baixa vulnerabilidade social.

No caso específico de Porto Alegre, Scussel; Sattler (2010) relatam que a taxa de verticalização ( $\mathrm{n}^{\circ}$ de apartamentos $/ \mathrm{n}^{\circ}$ de domicílios) é o dobro no centro em relação às demais áreas da cidade. $O$ último censo demográfico também ratifica a magnitude dessa taxa ao afirmar que $46,7 \%$ dos domicílios da capital são apartamentos (IBGE, 2010). Esses dados ajudam a entender a abrangência desse cenário na região central de Porto Alegre, onde há zonas com muitos prédios e carência de espaços verdes (maiores do que $625 \mathrm{~m}^{2}$ ) em uma área com baixa vulnerabilidade social.

Scussel; Sattler (2010) mostram que há uma perspectiva do aumento da verticalização, sobretudo após aprovação do Plano Diretor de 1999 que passou a permitir a construção de edifícios maiores nas áreas centrais da capital que antes eram de no máximo seis andares. Na análise realizada, no Bairro Menino Deus, por exemplo, os autores constaram que a verticalização acentuada, trouxe inúmeros problemas que vão além da redução das árvores nas calçadas e lotes, como por exemplo: aumento no tráfego, maior poluição (sonora, visual e atmosférica) e diminuição das áreas com exposição solar - problema sério considerando o período de inverno e intensa chuva (SCUSSEL; SATTLER, 2010).

Os cenários $C$ e $D$ refletem o oposto da hipótese. Eles foram os mais representativos dentre as UDHs que tiveram significância na correlação geoestastítica (56\%) e correspondem a $12,51 \%$ da área analisada e $23,13 \%$ da população da RMPA. No caso da RMPA, a análise geoestastítica mostrou que no geral a presença dos espaços verdes urbanos não refletem baixa vulnerabilidade social. Esse resultado indica novamente que os EVU por si não pode ser postos como sinônimo de qualidade de vida. Daí a necessidade da articulação das políticas públicas que promovam bem-estar social, melhoria da infraestrutura urbana e melhoria de índices sociais, estabelecendo os EVU como elemento chave dessa articulação enquanto equipamentos urbanos.

Quanto aos cenários referentes à hipótese, verifica-se certa similaridade na abrangência espacial, pois ambos cobrem cerca de $5 \%$ da área analisada da RMPA. Atenção chama-se para o cenário $B$ (em vermelho), que apresentou valor 
alto de IVS-médio $(0,33)$ e baixa porcentagem de EVU $(5,23 \%)$. Ele contem uma população representativa (11,66\% da população da RMPA) e é formado por UDH localizadas nas áreas periféricas, porém não distantes às UDH do cenário $D$ (amarelo), indicando que as periferias estão próximas das áreas centrais (bons índices socioeconômicos).

Atenção deve-se ter para as maiores UDH desse cenário localizadas a leste de Alvorada, norte de Porto Alegre, oeste de Canoas e oeste Eldorado do Sul. Nesses casos, visivelmente há amplos espaços verdes, porém representados por extensas áreas de cultivo de arroz à beira dos principais cursos hídricos. Conforme já explicitado na metodologia, essas áreas antrópicas agrícolas não foram classificadas como EVU.

Ao analisar as áreas de inundação do Rio Gravataí, Scheren (2014) relata que a rizicultura cresce na região e traz como principal impacto o uso excessivo de água e agrotóxicos. Além disso, o autor relata a extensa área de ocupação irregular nas planícies de inundação do rio Gravataí, principalmente em Porto Alegre, Alvorada, Cachoeirinha e Gravataí. Nessas áreas não há saneamento básico e os habitantes ficam bastantes vulneráveis às inundações (SCHEREN, 2014). A descrição desse cenário reflete a carência de condições mínimas de sobrevivência a uma área que pela legislação (Novo Código Florestal - Brasil, 2012) deveria estar protegida.

O cenário $\mathrm{A}$ (verde), também referente à hipótese, indicou que nela residem $7,04 \%$ dos habitantes da área analisada da RMPA. As UDHs estão distribuídas pela RMPA da seguinte forma: centro-leste de Porto Alegre, centro de São Leopoldo, nordeste de Parobé, áreas periféricas de Estância Velha, e toda área analisada de Igrejinha.

Em Porto Alegre as UDHs do cenário A (verde) estão localizadas majoritariamente nos seguintes bairros: Belém Velho, Campus da UFRGS e Loteamento Mário Quintana. Nessas localidades conforme já explanado há presença de vários morros graníticos que impedem o avanço da malha urbana sobre os espaços verdes urbanos.

Destaca-se o bairro Belém Velho, um dos mais antigos núcleos habitacionais da cidade (Figura 102). Ele possui uma baixa densidade populacional e de acordo com Teixeira; Souza (2012) é um importante núcleo rural dentro do espaço urbano. Para promover a conservação do patrimônio rural, ambiental e cultural, os autores 
citam que a prefeitura municipal implantou o roteiro turístico "Caminhos Rurais" na área próxima a este bairro. O roteiro engloba propriedades rurais que se estruturaram para receber turistas, seja para conhecer hortas, pomares, paisagens naturais ou degustar de vinhos, frutas e comidas típicas (TEIXEIRA; SOUZA, 2012).

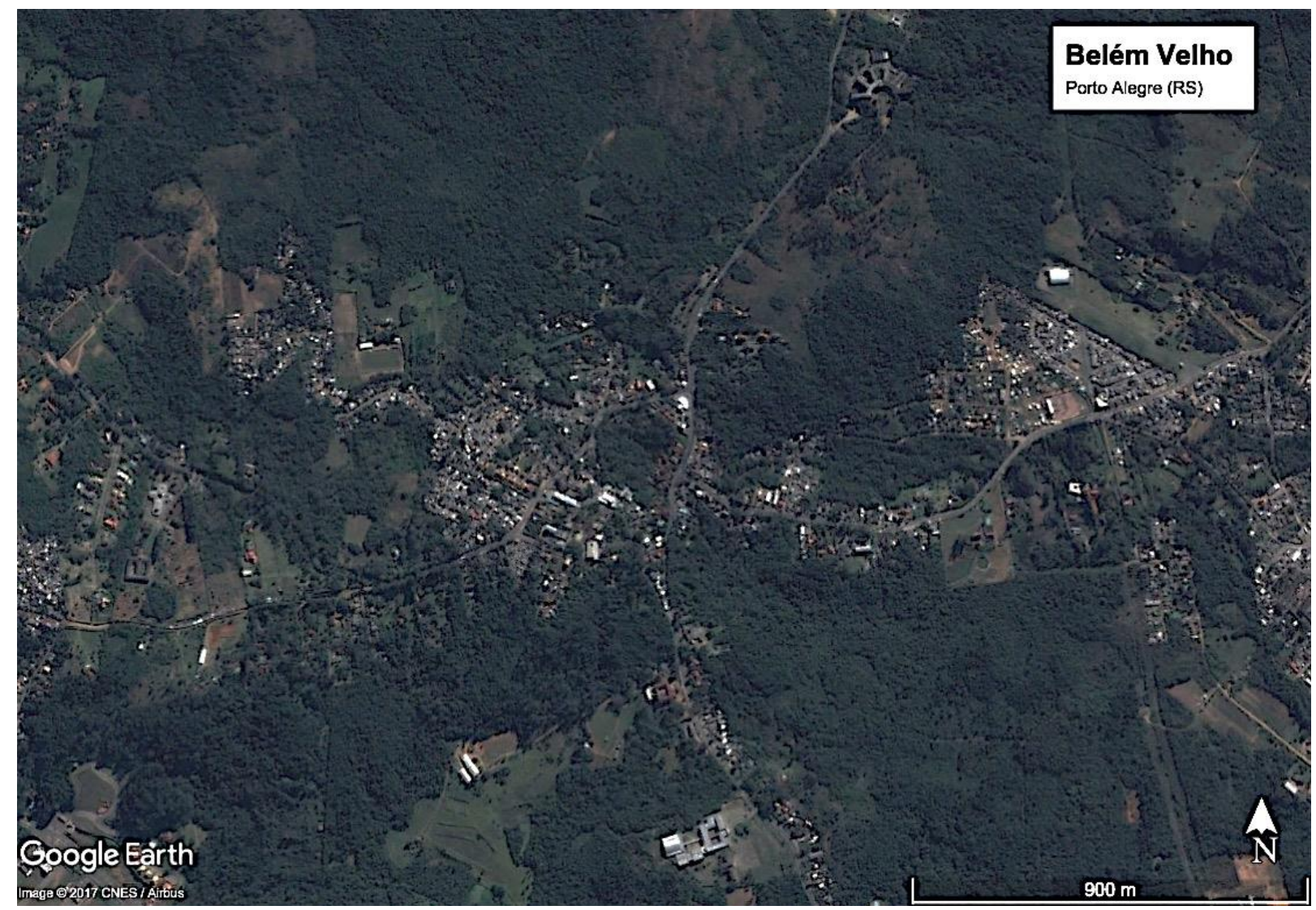

Figura 102 - Bairro "rural" Belém Velho. RMPA

Fonte: Google-Earth (2017)

Quanto às UDH das cidades de Estância Velha e Igrejinha, relata-se novamente que o resultado está relacionado à proximidade da Serra Gaúcha, logo apresentam grande quantidade de EVU conjugados à baixa vulnerabilidade social. Outro motivo, além do fator topográfico, que justifica a ocorrência desse cenário é a base econômica atrelada à indústria do setor coureiro-calçadista, que em ambas cidades é a principal geradora de empregos e renda municipal (SPRICIGO, 2007).

No caso de Igrejinha (Figua 103), a agricultura (setor que mais demanda de área e avança sobre os espaços verdes) não chega a $1 \%$ do PIB municipal ${ }^{16}$ (IBGE, 2010). Ademais, todas as UDHs da cidade ficaram no cenário A (verde),

16 O setor mais representativo do PIB do município de Igrejinha é a industria com 48,19\% de participação, sendo a indústria de calçados a mais importante (IBGE, 2010). 
sendo um bom exemplo da efetividade da manutenção dos EVU para o desenvolvimento socioeconômico da cidade.

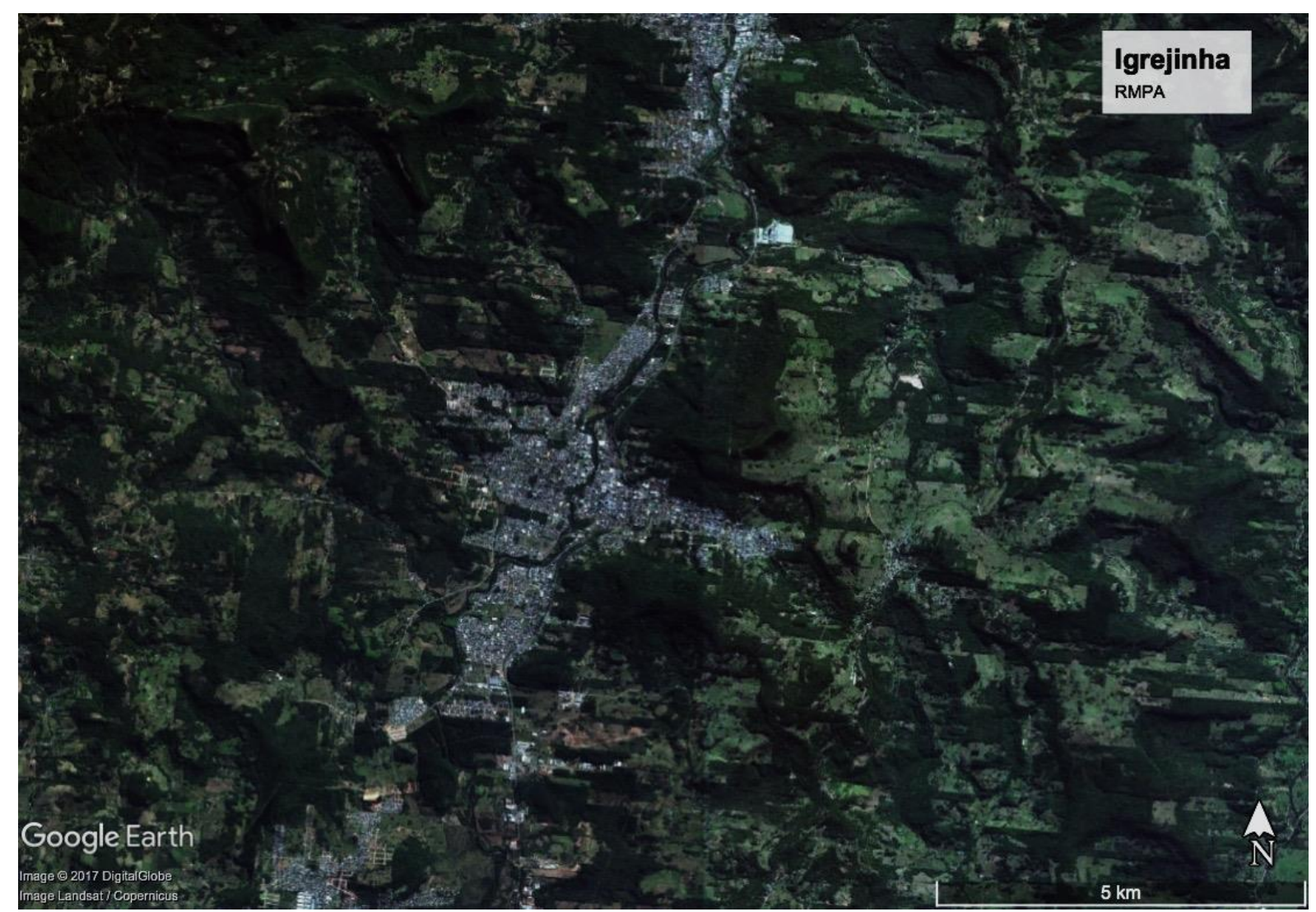

Figura 103 - Cidade de Igrejinha. RMPA

Fonte: Google-Earth (2017)

Para os cenários hipotéticos, mais importante do que os valores numéricos é a indicação onde há carência de EVU atrelada à vulnerabilidade social, contrapondo a um cenário de muitos EVU e de baixa vulnerabilidade social. Mesmo não ocupando a maioria do território, esses cenários tornam visível a desigualdade social, que pode ser representada pela presença e ausência dos EVU.

Para o planejamento que vise indicar locais para aumentar a cobertura vegetal nas cidades, a presente análise evidencia a abrangência da área que mais necessita de investimentos (cenário B - vermelho). Se implantadas conforme equipamento urbanos, como já explanado, os espaços verdes urbanos poderão trazer serviços socioambientais, baseando-se em princípios sustentáveis, refletindo em melhores condições de vida. 


\subsection{Região Metropolitana de Recife}

A origem institucional da RMR ocorreu em 1973, pela Lei Federal $n^{\circ} 14$ (BRASIL, 1973), originalmente composta por nove municípios. A emancipações de antigos distritos (Araçoiaba, Itapissuma, Abreu e Lima, Camaragibe) e a inclusão de Ipojuca remontam a atual configuração (BITOUN et al., 2012).

A identificação do fenômeno metropolitano já era observado no início da década de 1950. Conforme relata Baltazar (1951), na década de 1950 Recife já era uma cidade transmunicipal e conurbada com os municípios vizinhos (Olinda, Jaboatão do Guararapes e Paulista). De acordo com autor essa configuração se identificava como aglomerado metropolitano de alto nível de integração.

Essa configuração ganha maior importância quanto à sua localização privilegiada no nordeste brasileiro, uma vez que ocupa posição central em relação às principais e maiores metrópoles nordestinas (Salvador e Fortaleza) das quais dista cerca de 800 km (BITOUN; MIRANDA; SOUZA, 2006).

A área analisada corresponde a $31,96 \%$ de toda RMR, sendo Recife a maior cidade com 218,50 km², correspondendo a 24,67\% do total analisado. A Figura 104 mostra a RMR, observa-se um adensamento das UDHs ao longo do litoral da região metropolitana (área em rosa). Já a área não-urbana (verde) é conhecida historicamente pela aptidão agrícola, principalmente a cana de açúcar. Essa caracterização ratifica a realizada por Ab'Sáber (2003):

O nordeste se enquadraria no conceito de bacia urbana, em um quadro de múltiplas cidades e vilas, dependentes política e administrativamente das grandes cidades costeiras (Recife, Fortaleza e Salvador, sobretudo). Os espaços de especialização agrícola (monocultores) envolveriam os subespaços remanescentes de diferentes ciclos econômicos (AB'SÁBER, 2003, p. 98).

Observa-se que apenas três cidades (Araçoiaba, Ilha de Itamaracá e Ipojuca) não fazem parte da conurbação urbana da RMR. Outra característica importante é que as cidades de Recife, Olinda e Paulista têm toda área municipal inseridas no recorte proposto. 


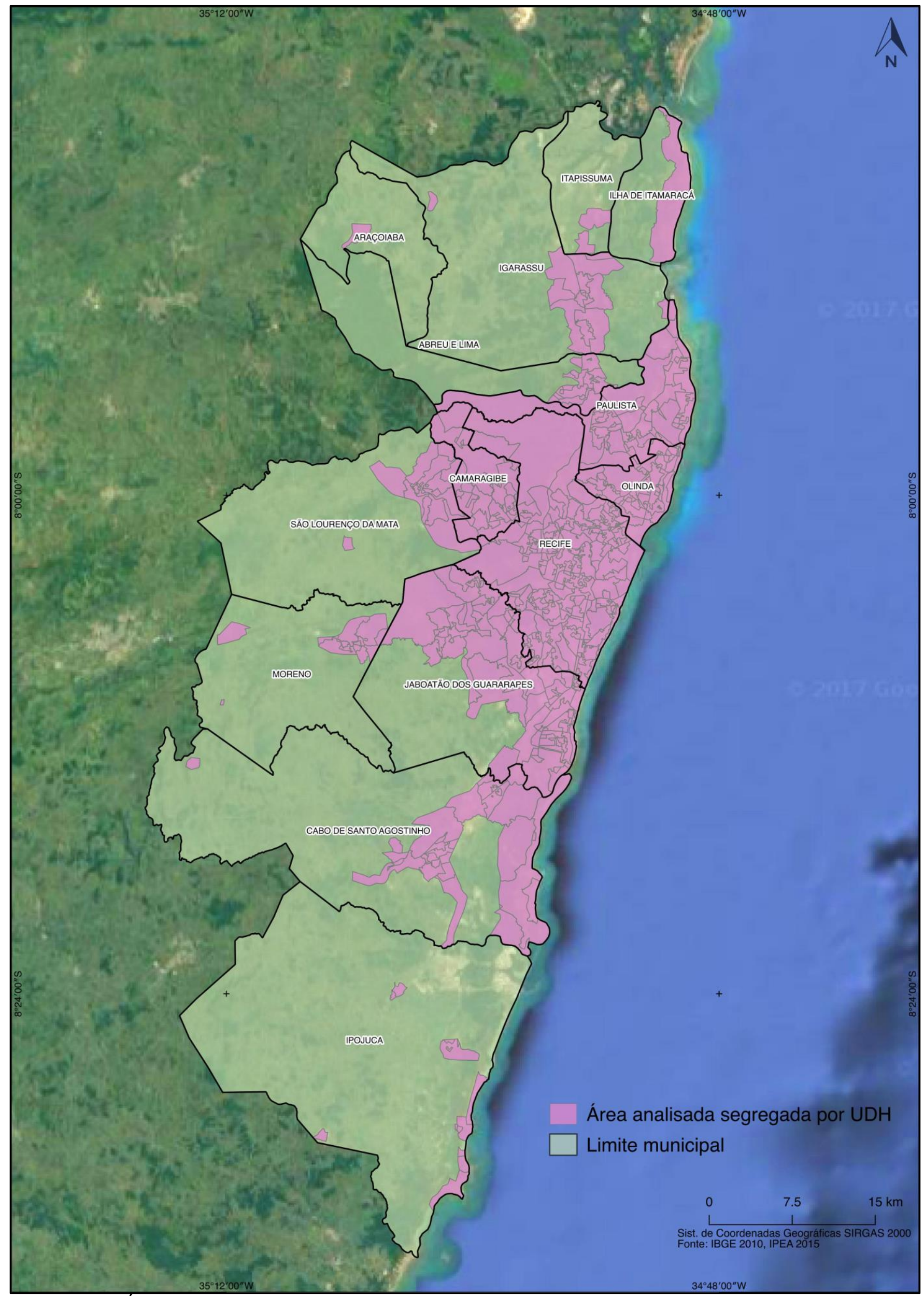

Figura 104 - Área analisada na Região Metropolitana de Recife. 
Quanto ao contingente populacional, destaca-se que a RMR "polariza a maior faixa contínua de altas densidades populacionais da região nordestina, que se dispõe ao longo do litoral, desde a cidade de Natal até a de Aracajú" (BITOUN; MIRANDA; SOUZA, 2006, p. 13). Ademais, os autores citam que além das cidades da RMR, Recife envolve uma rede de mais de 120 cidades, o que a diferencia das demais metrópoles nordestinas que não apresentam número tão elevado de cidades próximas (BITOUN; MIRANDA; SOUZA, 2006).

A Figura 105 mostra a densidade populacional por UDH, de acordo com dados do último censo (IBGE, 2010). Dos quase 3,4 milhões de habitantes da área analisada da RMR $36 \%$ reside em Recife. De acordo com os referidos dados censitários (IBGE, 2010), a população analisada da RMR representa $40,80 \%$ da população residente em Pernambuco, $6,76 \%$ da população da região nordeste e $1,88 \%$ dos brasileiros. Bitoun et al. (2012) ao analisar a dinâmica demográfica nos últimos censo, relata que a participação relativa de Recife vem caindo gradativamente, enquanto que a população do seu entorno vem crescendo. 


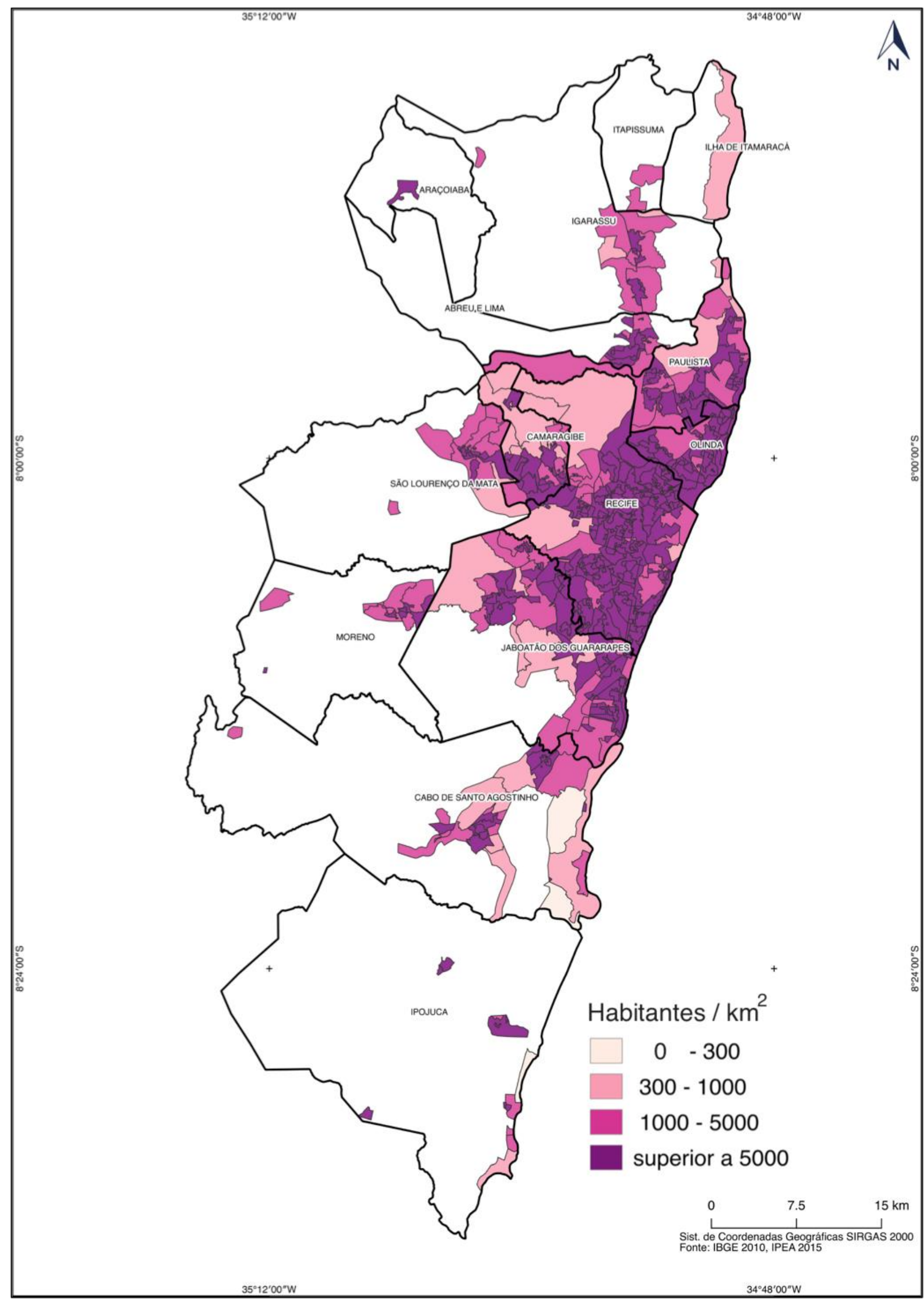

Figura 105 - Densidade demográfica por unidade de desenvolvimento humano (UDH) na Região Metropolitana de Recife 
Para Bitoun et al. (2012), Recife é considerada cidade polo dado seu dinamismo econômico frente as demais (maior $\mathrm{PIB}^{17}$ e maiores oportunidades de emprego). Os autores consideram as cidades de Jaboatão do Guararapes, Olinda, Paulista e Camaragibe aquelas com maior integração com a cidade polo (avaliada pelos fluxos pendulares, deslocamento, dependência econômica e evolução demográfica). Assim, a Figura 105 corrobora tal descrição ao apresentar as maiores densidades demográficas em uma mancha contínua que perpassam as referidas cidades.

\subsubsection{Urbanização da Região Metropolitana de Recife}

A ocupação da RMR foi iniciada pelos núcleos mais antigos, Recife e Olinda (BITOUN; MIRANDA; SOUZA, 2006). Desde a formação dos primeiros núcleos da RMR, se observou-se um embate entre o avanço das cidades e seu aporte físico, sobretudo as planícies e os seu rios (ALMEIDA; CORRÊA, 2012). Para entender a complexidade do sítio urbano da grande Recife é importante rever a descrição feita por Ab'Sáber (2000):

Enseadas rasas e altos tabuleiros ondulados. Costa dos recifes areníticos, encarcerando. Enseada expressiva, em um setor de recorte das barreiras e interiorização da retroterra marcada por tabuleiros. Área de restingas sincopadas na linha de costa e recifes areníticos na faixa infra-praiana. Domínio hidrográfico dos rios Capiberibe e Beberibe (AB'SÁBER, 2000, p. 39).

Sob esta estrutura física, Bitoun; Miranda; Souza (2006) relatam que a RMR se constituiu cercada por morros e tabuleiros, por onde se distribuíam os mais antigos engenhos de açúcar do Brasil. Assim, Costa (1960) cita que nas planícies litorâneas do Recife, apareceram os primeiros núcleos urbanos, intimamente ligados às várzeas do rio Capibaribe sendo nomeados por nomes de antigos engenhos.

O principal centro da RMR, Recife, é considerada uma "cidade-anfíbia", como relatado por Oliveira, p. 38 (1942): "o que não é água, foi água ou lembra a água, sendo essa a razão por que a crismaram de cidade-anfíbia". Almeida; Corrêa (2012) destacam que a vasta rede hídrica constituída por inúmeros canais, rios, restingas, mangues e igarapés caracterizam o ambiente físico da malha urbana da RMR.

17 De acordo com dados do censo demográfico, o PIB da RMR é cerca de R\$ 61 bilhões, sendo o setor de serviços o mais representativo com participação de $61,35 \%$ seguido da indústria com $20 \%$ do PIB. A capital, Recife, com PIB de R\$30 bilhões corresponde a cerca de $48 \%$ do PIB da RMR (IBGE, 2010). 
Apesar da grande densidade e ramificação do sistema de drenagem impor sérias restrições, o desenvolvimento do espaço urbano de Recife e das cidades vizinhas se deu à custa das modificações ambientais do sistema hídrico. Sobre ou no entorno das águas surgiram os principais empreendimentos urbanos, dentre eles o porto que movimentou vários ciclos econômicos (ALMEIDA; CORRÊA, 2012).

Com a invasão holandesa (1630), Recife tornou-se capital da capitania de Pernambuco. A experiência holandesa à ocupações urbanas sobre a água facilitou tornar a planície de Recife como sede da possessão flamenga (ALMEIDA; CORRÊA, 2012). Durante os 24 anos de domínio holandês no Recife, Maurício de Nassau (administrador da capitania) engendrou inúmeras obras urbanas: palácios, pontes, parques, museus, sistemas de canais, sobretudo na cidade Maurícia, construída na ilha Antônio Vaz, conforme narrado por Sevcenko (1996):

Naquele ponto, construiu uma cidade bastante complexa, que era uma
mistura de cidade, no sentido propriamente da urbanização europeia,
mas também de jardim botânico, porque reunia uma seleção de
espécies de toda parte, em especial de espécies trazidas do sertão
brasileiro. Nassau premiava generosamente quem lhe trazia as espécies
mais variadas, mais estranhas, mais exóticas, das regiões mais
afastadas do sertão, do interior do país. Portanto ali ele construiu toda
uma série de alamedas, jardins cheios de amenidades, fontes e
inclusive monumentos e salas onde se pra- ticavam jogos. Assim, a ilha
Maurícia foi uma verdadeira obra-prima da ocupação holandesa do
nordeste açucareiro, e era propriamente a menina dos olhos de Maurício
de Nassau (SEVCENKO, 1996, p. 112).

Após a expulsão dos holandeses, Andrade (1979) relata que Recife e as cidades próximas passaram por um novo crescimento após a abertura dos portos às nações amigas, por Dom João VI (início do século XIX). Essa abertura possibilitou o crescimento econômico, muito ligado ao comércio do açúcar, algodão e couro (ANDRADE, 1979).

No mesmo período, ocorreu a modernização do espaço urbano, muito relacionado com a construção de linhas férreas e de estradas. Essas obras que visavam a integração dos engenhos com o centro comercial e portuário auxiliou na estruturação urbana de Recife e das cidades próximas (BITOUN; MIRANDA; SOUZA, 2006).

A abertura de ruas e a construção de pontes à custa do aterro de mangues e rios também foi uma marca no início do século XIX (MARINHO; LEITÃO; LACERDA, 2007). Ao mesmo tempo, os autores citam que surgem melhoramentos urbanos em relação ao abastecimento de água. Datam dessa época as melhorias no sistema de 
transporte da cidade, o que dinamizou a expansão urbana na RMR, originando a atual configuração. Muitas das obras de abastecimento e drenagem urbana que funcionam hoje em Recife e Olinda são desse período (MARINHO; LEITÃO; LACERDA, 2007).

O crescimento econômico da cidade foi seguido pelo aumento da população local, que em 1837 era de 46 mil pessoas e passa a 116 mil em 1872 (ANDRADE, 1979). O crescimento populacional foi intensificado após a abolição dos escravos, em 1888. O contingente de ex-escravos que migraram para Recife em busca de trabalho gerou um aumento considerável na construção de habitações improvisadas sobre os manguezais - ou seja, nas áreas menos valorizadas (ALMEIDA; CARVALHO, 2009).

O incremento populacional trouxe severos problemas socioambientais às cidades que formam a RMR, sobretudo a capital Recife. De todos os problemas metropolitanos, habitação e saneamento básico, são os mais latentes no histórico urbano da RMR, deixando a população em alto nível vulnerabilidade social (ALMEIDA; CARVALHO, 2009).

Esses problemas atingem, com maior grau, a população mais pobre que historicamente passou a utilizar dos manguezais como fonte de sua subsistência, originando o que Castro (2007) denominou de "ciclo do caranguejo". De forma resumida, Andrade (1979) narra este ciclo:

O crustáceo era pescado pelos habitantes dos mocambos que o utilizavam como alimento; posteriormente, esses habitantes faziam seus dejetos no rio e esses seriam utilizados pelos crustáceos para sua alimentação. Havia, assim, uma associação homem-rio-caranguejo, que permitia a manutenção de uma grande massa populacional que foi se avolumando, a ponto de consistir cerca de $30 \%$ da população da cidade, em 1940. (ANDRADE, 1979, p. 94).

Para atenuar a insalubridade urbana, no início do século $X X$, o governador de Pernambuco convidou o famoso engenheiro sanitarista Francisco Saturnino de Brito para elaborar um plano de saneamento para o Recife (CARNEIRO, 2010). Assim, a autora relata que o referido engenheiro executou obras importantes e pontuais, como a construção de canais de escoamento e drenagem de águas poluídas margeando as avenidas que foram arborizadas, além da construção de parques em áreas inundáveis.

$\mathrm{Na}$ década de 1920, foram inaugurados pelo poder público vários espaços arborizados, como a praça do Derby, praça Chora Menino, praça do Entroncamento, 
a praça Sérgio Loreto e o Largo da Paz e da Encruzilhada (MOREIRA, 1994). Segundo o autor o conjunto de obras foi determinado pelos interesses da elite local, que construiu suas mansões no entorno desses espaços verdes.

$\mathrm{Na}$ década de 1930 foi inaugurado o primeiro parque público de Recife: Parque 13 de Maio, considerado um marco no urbanismo da cidade (CARNEIRO, 2010). A inauguração da maior área verde, cercada de importantes prédios públicos e localizada na área central atendeu aos anseios da população e aos parâmetros urbanísticos e arquitetônicos inovadores (MOREIRA, 1994).

De 1935 à 1937, o paisagista Roberto Burle Marx assumiu a chefia do Setor de Parques e Jardins de Pernambuco (CARNEIRO, 2010). Com uma concepção moderna de jardins, o paisagista deu espaço às espécies nativas e "agregou a seus jardins valores artísticos, ecológicos e educativos", algo inédito no país (CARNEIRO, 2010, p.70). Nesse momento foram construídas ou revitalizadas mais de dez praças. A praça "Euclides da Cunha" construída em 1935, foi um dos marcos da obra do artista no Recife, que primou no uso de plantas da caatinga (CARNEIRO, 2010).

Mesmo com as referidas obras, na década de 1970, por meio do denominado Plano de Desenvolvimento Local Integrado de Recife, constatou-se a carência dos espaços verdes (parques urbanos) na capital (CARNEIRO, 2010). Conforme relata a autora, na época a cidade necessitaria de no mínimo 256 parques urbanos, para atender os 1,2 milhões de habitantes. Valor que nunca foi alcançado, segundo dados da prefeitura de Recife (ano base: 2016), sendo que a cidade conta com dezenove parques (RECIFE, 2016).

Para agravar a situação, nas décadas de 1960 e 1970, ocorreu um processo migratório intenso devido as sucessivas crises da economia canavieira e as recorrentes secas do nordeste (PONTUAL, 2001). A autora explica que antes as cidades eram ocupadas quase que completamente à beira dos rios, o que ela denomina de morfologia tentacular. Assim, com o crescimento demográfico houve um maior adensamento urbano e a ocupação de antigos vazios, sobretudo áreas de mangue e alagados (PONTUAL, 2001).

O incremento populacional ampliou as desigualdades sociais e a degradação socioambiental na RMR (ALMEIDA; CORREAA, 2012). Tais problemas se espalharam para os municípios vizinhos de Recife, e se agravou com o mercado de terras que se apropria das melhores parcelas da cidade, levando os mais pobres às áreas mais precárias (ALMEIDA; CORRÊA, 2012), como indica a figura a seguir. 


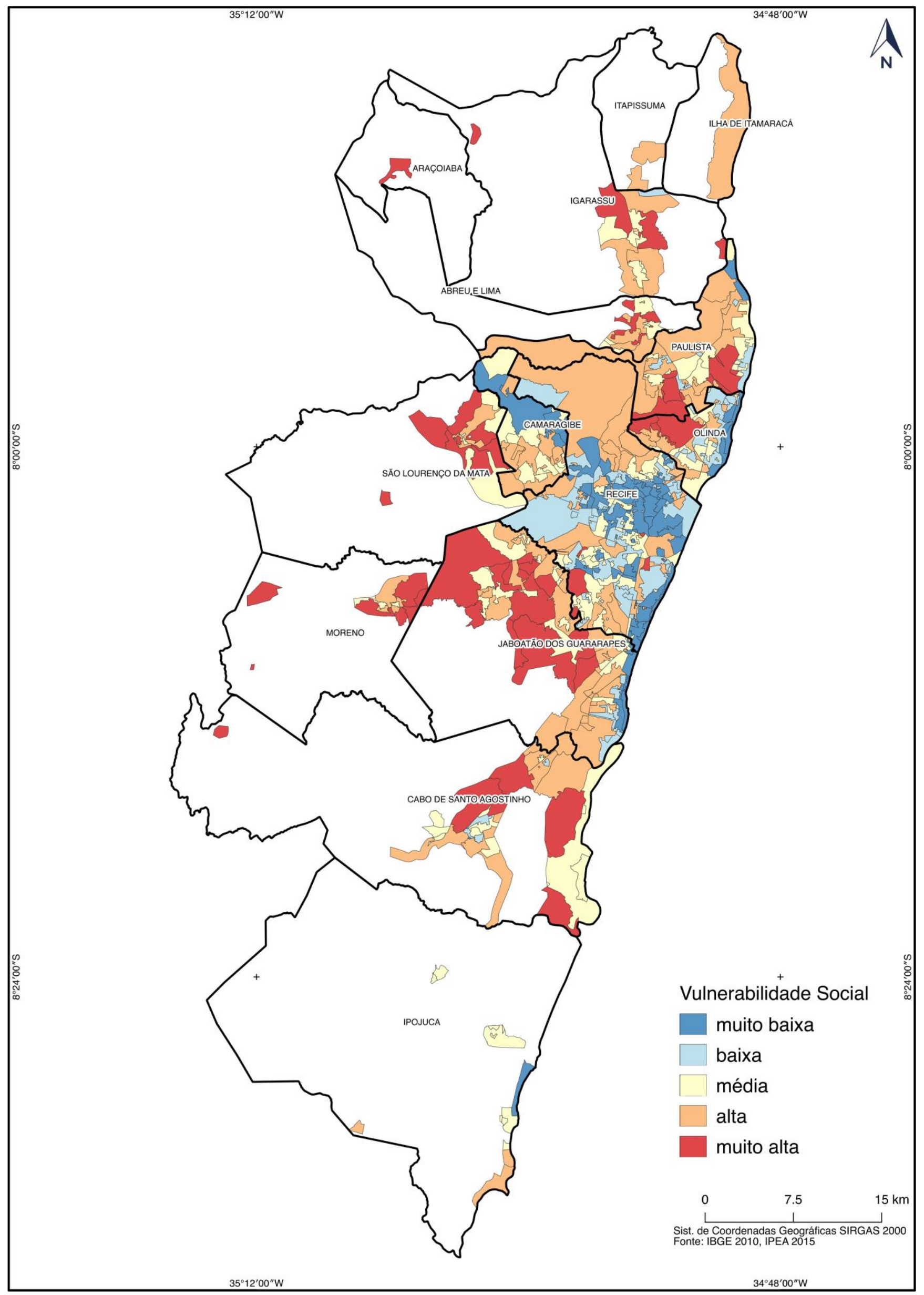

Figura 106 - Vulnerabilidade social por unidade de desenvolvimento humano (UDH) na Região Metropolitana de Recife 
A Figura 106 ratifica a análise anterior ao aplicar o índice de vulnerabilidade social (IPEA, 2015) na área analisada. Nas áreas em azul (baixa vulnerabilidade social), Marinho; Leitão; Lacerda (2007) relatam a concentração do comércio e de serviços diversificados. Ademais, a área engloba os polos turísticos do litoral e uma parcela significativa de Recife.

As maiores áreas de vulnerabilidade social (em vermelho escuro) estão na borda oeste da RMR, sobretudo nas cidades de Jaboatão dos Guararapes, Moreno, São Lourenço da Mata e Cabo de Santo Agostinho. São áreas distantes do centro (Recife) e com inúmeras ocupações nos morros (RAMALHO; MELLO; CAVALCANTE, 2015)

De acordo com os referidos autores, a vulnerabilidade social da área oeste da RMR é reflexo da baixa renda ${ }^{18}$ da população e da economia essencialmente primária e terciária. Para tentar minimizar a vulnerabilidade social da área, foi construído o estádio de futebol para a copa do mundo de futebol (que faria parte de um amplo complexo esportivo e administrativo) (RAMALHO; MELLO; CAVALCANTE, 2015). Porém, os autores afirmam que as obras foram insuficientes devido a ausência de políticas públicas que atendam as reais demandas sociais: educação, saúde, moradia, segurança e lazer.

Afora o estádio, a RMR passou por um novo dinamismo econômico nas últimas décadas, através da instalação de indústrias e do Porto de Suape - maior porto do Norte/Nordeste brasileiro (SOUZA, 2015). Em conjunto se iniciou uma série de projetos de valorização e criação de polos turísticos que dão suporte à consolidação da faixa litorânea como área de lazer, lugar de veraneio e de moradias de alto padrão (MARINHO et al., 2007).

Apesar do novo dinamismo econômico, a pobreza e os problemas urbanos são visíveis e contundentes na RMR. Diferentemente da maioria das RMs, onde os mais pobres foram "varridos" para a periferia, em Recife há uma presença significativa de favelas em áreas centrais e valorizadas pelo capital imobiliário como nos seguintes aglomerados suburbanos: Coelho, Brasília-Teimosa e Afogados (BARROS FILHO, 2013). Dessa forma, a análise dos EVU e a sua distribuição na

18 De acordo com dados censitários, a RMR possui um dos menores nível renda mensal por domicílio, com valor médio de RS 753,06 . Valor este menor ao da média nacional que é de $\mathrm{R} \$ 949,99$ (IBGE, 2010). 
RMR poderá ganhar maior importância ao ser discutida na possibilidade da integração de um mesmo espaço para diferentes camadas sociais.

\subsubsection{Espaços verdes urbanos na Região Metropolitana de Recife}

O mapeamento identificou a porção de $344,69 \mathrm{~km}^{2}$ de espaços verdes urbanos no recorte proposto (Figura 107). Esse valor corresponde a quase $40 \%$ da área analisada da RMR. A Tabela 17 mostra a proporção das áreas analisadas e dos EVU na RMR.

Recife foi a cidade com maior quantidade de EVU com 83,73 km² (37,84\% de EVU), o que representa $25 \%$ de todos os EVU da RMR. Em termos de porcentagem de EVU em relação à área analisada, as cidades de Cabo de Santo Agostinho (40,1\%), Abreu e Lima (41,91\%), Paulista (47,37\%), Igarassu (52,76\%) e São Lourenço da Mata $(56,06 \%)$ apresentaram as maiores proporções. Em uma análise visual em imagens de satélite, percebe-se que os espaços verdes dessas cidades estão relacionadas aos morros à oeste da RMR e a vegetação de restinga, à beira dos rios principais. 
A cidade que apresentou menor quantidade de espaços verdes urbanos foi Araçoiaba $\left(0,24 \mathrm{~km}^{2}\right)$. Essa é a menor cidade da RMR e os espaços verdes mapeados estão situados nas suas bordas. Essa manchas são referentes às matas nativas (mata atlântica) que se adentram nos limites analisados. Observa-se também pequenos espaços verdes, não mapeados, referentes à arborização urbana e de quintais domiciliares.

\begin{tabular}{|c|c|c|c|c|}
\hline UF & Cidades & Área $\mathrm{Km}^{2}$ & $\mathrm{EVU} \mathbf{k m}^{2}$ & $\begin{array}{l}\% \\
\text { EVU/Área }\end{array}$ \\
\hline \multirow{15}{*}{ PE } & ABREU E LIMA & 15,62 & 6,55 & 41,91 \\
\hline & ARAÇOIABA & 2,55 & 0,24 & 9,42 \\
\hline & CABO DE SANTO AGOSTINHO & 108,54 & 43,52 & 40,1 \\
\hline & CAMARAGIBE & 69,9 & 23,08 & 33,01 \\
\hline & IGARASSU & 42,86 & 22,61 & 52,76 \\
\hline & IPOJUCA & 24,37 & 8,99 & 36,9 \\
\hline & ILHA DE ITAMARACÁ & 32,42 & 14,23 & 43,89 \\
\hline & ITAPISSUMA & 6,42 & 1,66 & 25,93 \\
\hline & JABOATÃO DOS GUARARAPES & 158,54 & 53,06 & 33,46 \\
\hline & MORENO & 19,43 & 5,71 & 29,36 \\
\hline & OLINDA & 42,22 & 10,61 & 25,13 \\
\hline & PAULISTA & 98,58 & 46,69 & 47,37 \\
\hline & RECIFE & 221,27 & 83,73 & 37,84 \\
\hline & SÃO LOURENO DA MATA & 42,82 & 24,01 & 56,06 \\
\hline & Total & 885,54 & 344,69 & 38,92 \\
\hline
\end{tabular}

Fonte: Elaborada pelo autor 


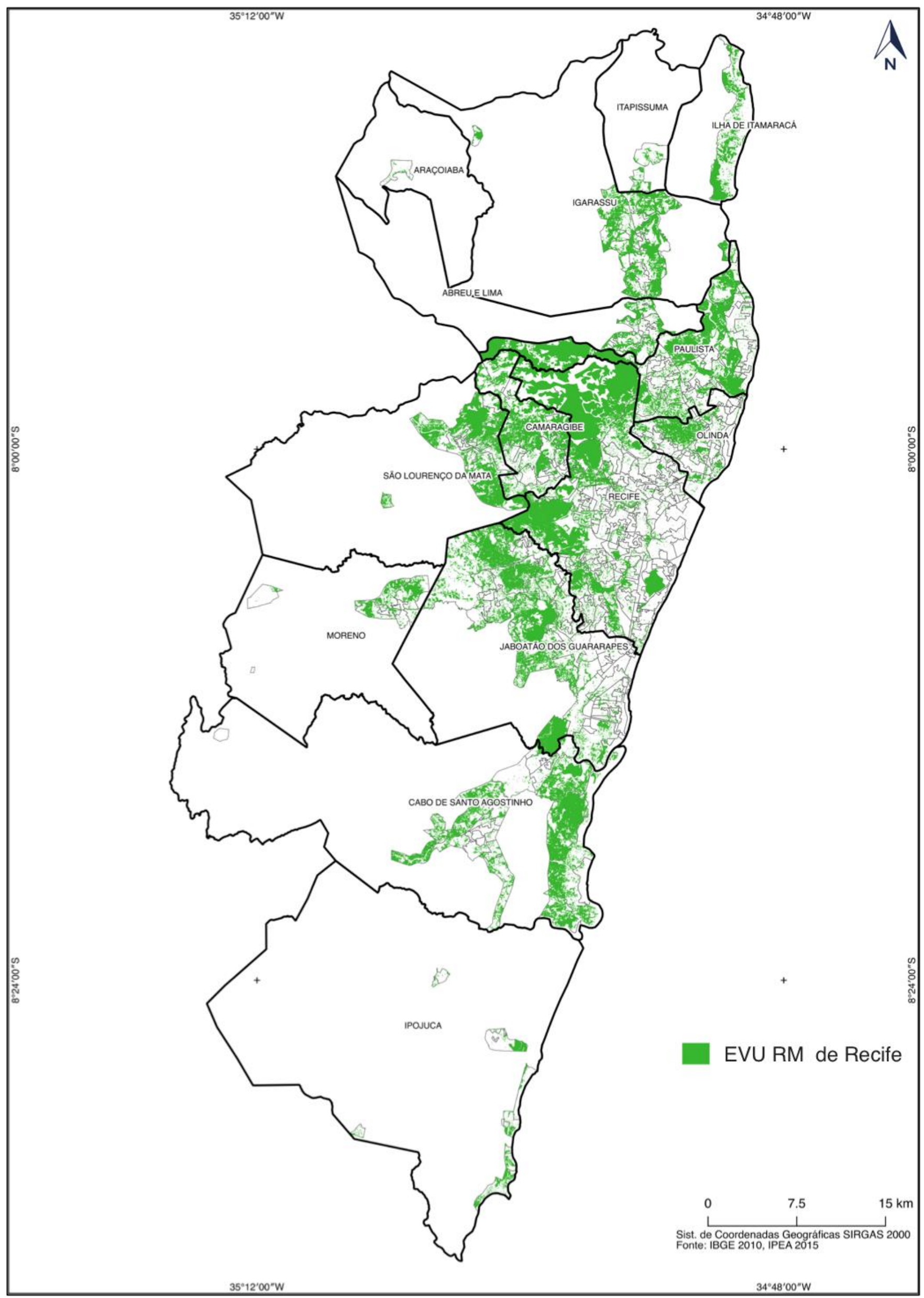

Figura 107 - Espaços verdes urbanos na Região Metropolitana de Recife 


\subsubsection{Espaços Verdes Urbanos nas Unidades de Conservação da Natureza}

Quanto ao tipo dos espaços verdes urbanos na RMR, destaca-se que a prefeitura de Recife mapeou todas os espaços verdes (praças, parques e áreas verdes) mantidas por ela.

Ao analisar a base de dados georreferenciada e disponibilizada no site da prefeitura (http://dados.recife.pe.gov.br/dataset/parques-e-pracas), verifica-se que a cidade contém 19 parques (com área total de $1 \mathrm{~km}^{2}$ ), além de 413 praças (com área total de $1 \mathrm{~km}^{2}$ ) e 67 áreas verdes complementares (áreas públicas sem estrutura das praças e parques, mas com ampla cobertura vegetal - área total de $0,2 \mathrm{~km}^{2}$ ).

A soma de todas essas áreas corresponde a apenas $0,25 \%$ da área analisada de Recife. A Figura 108 espacializa esses dados sobre o mapa de vulnerabilidade social. Nota-se, visualmente, que a maioria dos parques e praças estão nas áreas em azul (baixa vulnerabilidade social). 


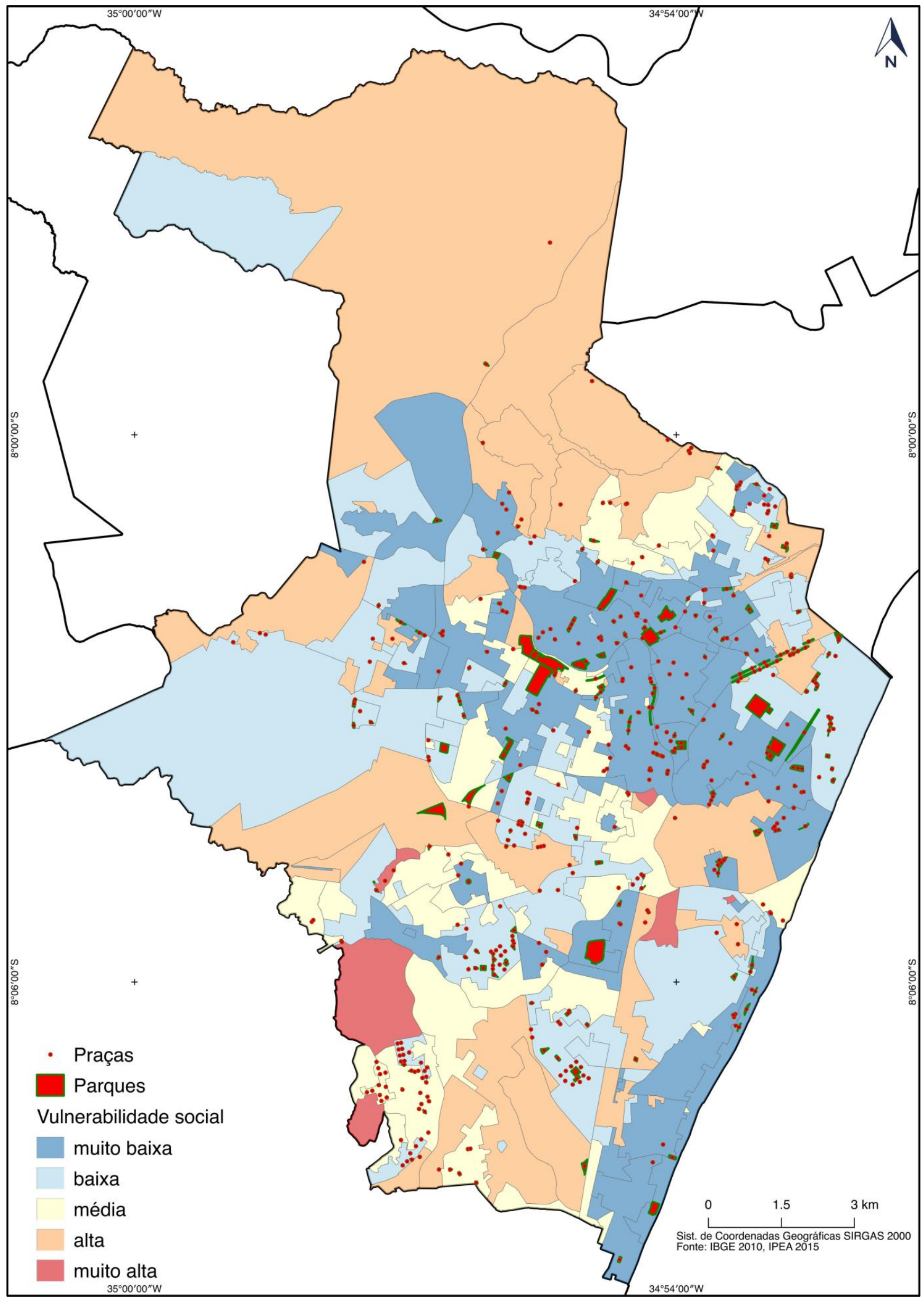

Figura 108 - Espaços verdes mantidos pela prefeitura sobrepostas ao mapa de vulnerabilidade social 
A Tabela 18 e a Figura 109 indicam os EVU na área analisada da RMR no interior de UC, de acordo com a base de dados do SNUC, disponível no site do ICMBio (2010). Da área analisada da RMR, 16,08\% é UC e concentra $92,40 \mathrm{~km}^{2} \mathrm{de}$ EVU, correspondendo a $27,61 \%$ de todps EVU mapeados.

As maiores UCs dentro da área analisada são as APAs: Aldeia-Beberibe e da Santa Cruz, que juntas correspondem a $91,24 \%$ do total. As demais UCs, no recorde proposto, diz respeito a quatro Refúgios da Vida Silvestre (RVS) que juntos possuem $6,58 \mathrm{~km}^{2}$, além de um Parque Estadual (PE) com 4,32 km² e uma Estação Ecológica (EEc) com $1,57 \mathrm{~km}^{2}$.

A porcentagem dos EVU dentro dessas áreas protegidas é de $64,90 \%$, isso considerando que as mais representativas pertencem a categoria APA e permitem ocupação humana. Quanto à menor proporção de EVU em UC, destaca-se a APA de Santa Cruz, com apenas $35,07 \%$. O valor é baixo porque a APA engloba as cidades de llha de Itamaracá e Itapissuma.

Tabela 18 - Espaços verdes urbanos dentro de Unidades de Conservação da Natureza

\begin{tabular}{llll}
\hline Nome da Área Protegida & Área $\mathrm{km}^{2}$ & $\mathrm{EVU} \mathrm{km}^{2}$ & $\% \mathrm{EVU} /$ Área \\
\hline EEc CAETÉS & 1,57 & 1,55 & 98,76 \\
PE DOIS IRMÃOS & 4,32 & 4,09 & 94,67 \\
APA ALDEIA-BEBERIBE & 99,10 & 70,19 & 70,83 \\
APA DE SANTA CRUZ & 30,82 & 10,81 & 35,07 \\
RVS MATA DO ENGENHO UCHÔA & 1,77 & 1,50 & 84,43 \\
RVS MATA DE MUSSAÍBA & 3,14 & 2,85 & 90,73 \\
RVS MATA DO CURADO & 1,01 & 0,80 & 78,66 \\
RVS MATA SÃO JOÃO DA VÁRZEA & 0,66 & 0,63 & 95,48 \\
\hline Total & $\mathbf{1 4 2 , 3 8}$ & $\mathbf{9 2 , 4 0}$ & $\mathbf{6 4 , 9 0}$ \\
\hline Total UDH Analisada & 885,54 & 334,64 & 37,79 \\
\% Total Área Protegida/Total Analisado & 16,08 & 27,61 & \\
\hline \hline
\end{tabular}

Fonte: Elaborada pelo autor

Ao analisar as áreas protegidas no estado de Pernambuco, Azevêdo (2015) ressalta que o estado dispõe de um Sistema Estadual de Unidade de Conservação da Natureza (SEUC), instituído pela Lei Estadual nº 13.787 (PERNAMBUCO, 2009), que complementa o SNUC (BRASIL, 2000). Ademais, a autora relata que a criação de áreas protegidas no estado é anterior ao SEUC e SNUC, por meio da Lei Estadual no 9.931 (PERNAMBUCO, 1989) que criou as Áreas de Proteção Ambiental Estuarianas de Pernambuco. No rol dessas áreas, a partir do Decreto Estadual $n^{\circ}$ 32.488 foi criada a APA de Santa Cruz (PERNAMBUCO, 2008). 


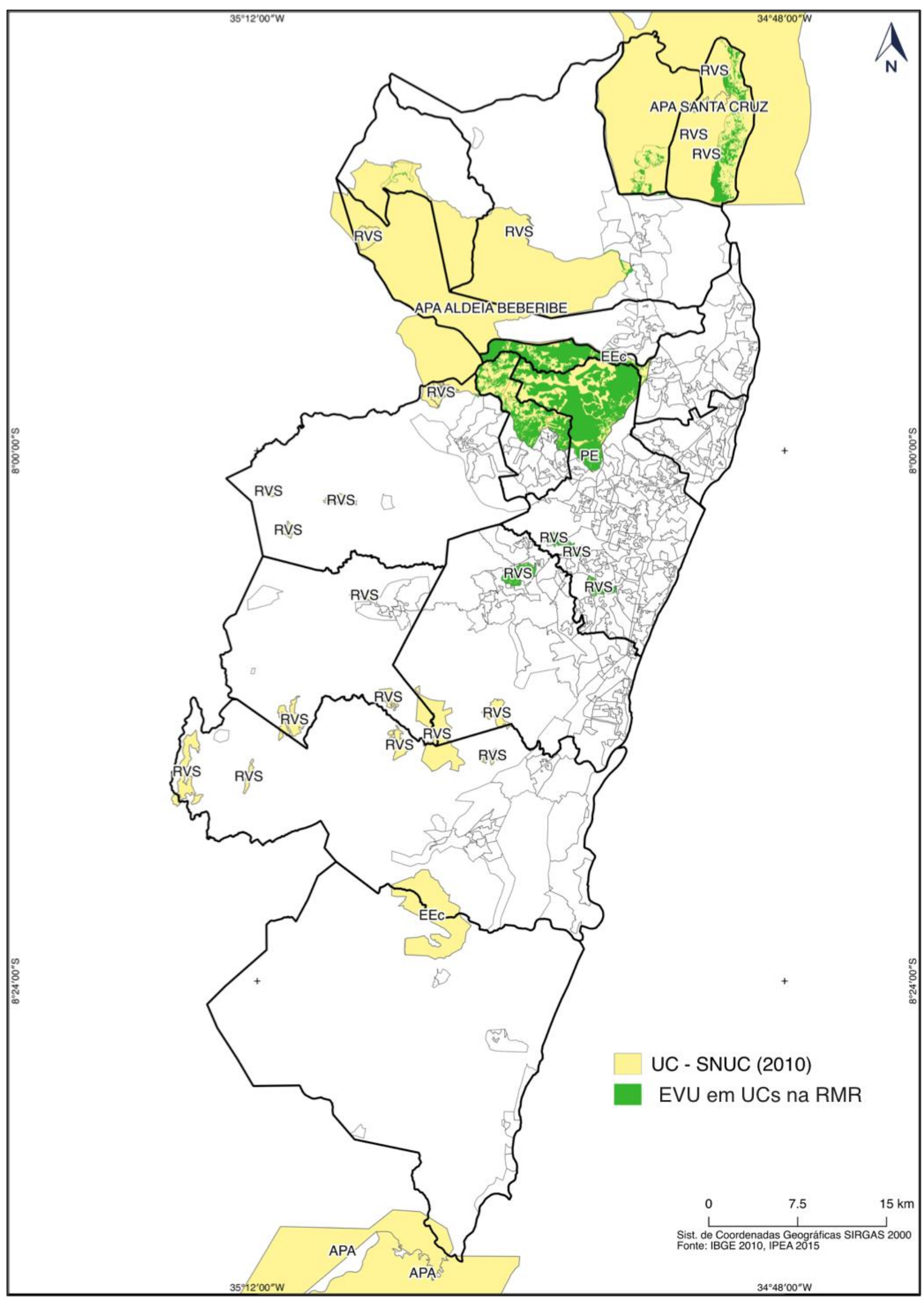

Figura 109 - Espaços verdes urbanos em Unidades de Conservação da Natureza na Região Metropolitana de Recife 
De acordo com o seu Zoneamento Ambiental (ZA) (FADURPE, 2010), a APA de Santa Cruz, localizada ao norte da RMR, é um estuário com amplas áreas alagadiças, num ambiente rico de nutrientes e de matéria orgânica, propício aos manguezais e ecossistema que resistem à alta salinidade. Assim, a APA possui alta biodiversidade com vasto conjunto de recursos hídricos (rios, alagados) entremeados à vegetação da mata atlântica, restinga e manguezais (FADURPE, 2010).

As atividades humanas com maior impacto ao ecossistema da APA de Santa Cruz são os amplos cultivos de coqueiros e de cana de açúcar (FADURPE, 2010). O documento técnico (ZA) relata que as áreas de coqueiral ocupam grandes extensões das paisagens, ocorrendo desde os trechos mais próximos da praia chegando até o limite das áreas de manguezais. Além dos coqueirais, reitera-se o impacto das cidades de Itapissuma, Ilha de Itamaracá, Goiana e de assentamentos rurais como ações antrópicas com grande impacto (FADURPE, 2010).

A APA Aldeia-Beberibe, criada pelo Decreto n 34.692 (PERNAMBUCO, 2010), está inserida dentro de sete cidades da RMR: Recife Abreu e Lima, Camaragibe, Araçoiaba, Igarassu, Paulista e São Lourenco da Mata. A maior parte dos EVU mapeados nessa APA estão em Recife, Paulista e Camaragibe (98\%).

Dentro da APA, estão inseridas cinco UC de Proteção Integral, dentre elas a Estação Ecológica de Caetés (Paulista) e o Parque Estadual Dois Irmãos (Recife). Ressalta-se que o SNUC estabelece, quando existem várias áreas protegidas próximas, justapostas ou sobrepostas, a necessidade de uma gestão integrada e participativa, buscando a sustentabilidade do território (BRASIL, 2000).

Azevêdo (2015) destaca a importância dos recursos hídricos na APA AldeiaBeberibe. A autora destaca que a Lei Estadual n 9.860 (PERNAMBUCO, 1986) inseriu o território da APA como prioritário para a proteção dos mananciais de interesse da RMR. Pela lei, a área possui as condições geográficas (relevo, vegetação, precipitação e ocupação do solo) favoráveis à retenção de grande volume de água e em qualidade compatível para o consumo humano, sobretudo à população da RMR (PERNAMBUCO, 1986).

Cabe salientar que a maior parte do abastecimento hídrico da RMR provém desta APA, através de captações nos rios Pilão, Utinga, Pitanga, Paratibe e Beberibe, bem como da Barragem de Botafogo (AZEVÊDO, 2015). Assim, a autora 
destaca a importância da APA para o abastecimento hídrico e reforça a necessidade de conservação da vegetação, elemento essencial à recarga dos mananciais.

Em se tratando dos espaços verdes na APA Aldeia-Beberibe, o estudo de Tabarelli; Melo; Lira (2006) destaca que ela concentra $20 \%$ da mata atlântica remanescente de Pernambuco. Mesmo com essa magnitude de espaços verdes, Azevêdo (2015) reitera que a APA apresenta uma matriz bastante heterogênea, composta por áreas de plantio de cana-de-açúcar e principalmente adensamentos urbanos que se alastram no território.

A atual parte urbanizada é popularmente denominada de Aldeia e envolve parte das cidades de Camaragibe, Recife, São Lourenço da Mata, Araçoiaba, Paudalho, Paulista e Abreu e Lima. Com exceção de Paudalho, as demais compõem a RMR (SILVA, 2015). Azevêdo (2015) relata que a área apresenta um relevo de morros e coberto por amplas machas de vegetação nativa, isso justifica a malha urbana bastante dispersa.

Silva (2015) narra que o território da APA Aldeia-Beberibe foi ocupada há séculos passados por antigos engenhos (Timbi e Camaragibe) e no século $X X$ passou a ter chácaras e granjas. A municipalização de Camaragibe na década de 1980 acelerou a ocupação e urbanização da área da Aldeia (SILVA, 2015). As amplas áreas de fazendas, granjas e áreas naturais são uma "possibilidade de negação ao urbano metropolitano tornando-se um convite a quem buscava um espaço alternativo e de fuga à crescente problemática recifense" (SILVA, 2015, p. 38). Assim surgiram os primeiros loteamentos fechados horizontais com espaço de lazer e refúgio da RMR. A referida autora destaca que o perfil dos condomínios não são de luxo, muitos não apresentam asfaltamento nem saneamento básico (Figura 110). 


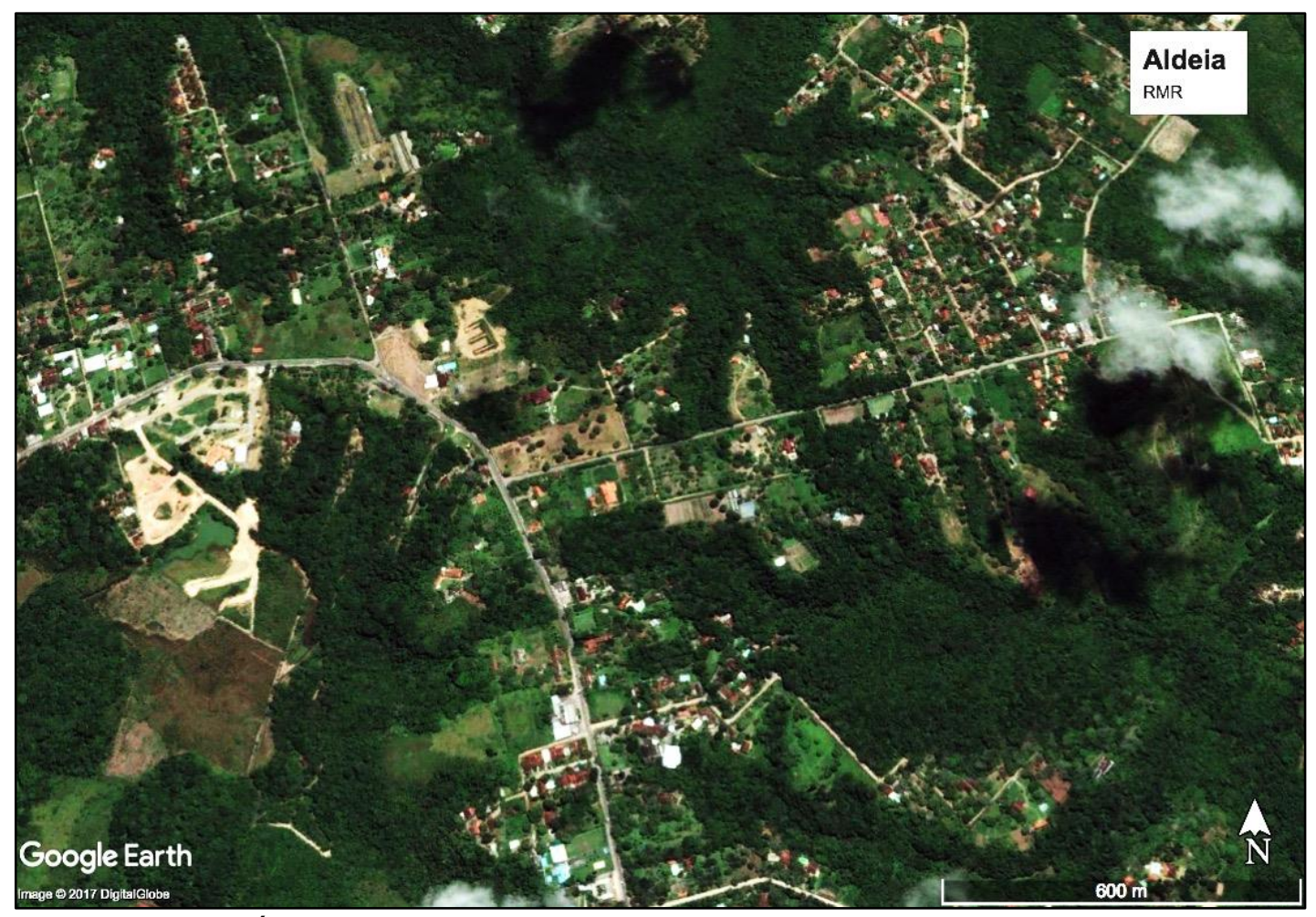

Figura 110 - Área de condomínios a oeste da RMR

Fonte: Google-Earth (2017)

Ao mesmo tempo, as áreas rejeitadas pelo mercado foram sendo aos poucos ocupadas por famílias mais pobres, sobretudo ex-trabalhadores rurais da zona da mata e/ou atuais funcionários dos condomínios horizontais, como os caseiros, jardineiros, empregadas domésticas (SILVA, 2015). Nesse sentido, Azevêdo (2015) cita as ocupações inadequadas e irregulares em áreas baixas (próximas aos cursos d'água) e morros que trazem severos problemas socioambientais principalmente em épocas de chuvas.

Afora as APAs, Fonseca; Silva (2017) destacam a ação do estado de Pernambuco para a manutenção de importantes fragmentos florestais nas áreas urbanas metropolitanas a partir da criação das Reservas de Florestas Urbanas RMR como uma categoria do grupo das unidades de conservação de uso sustentável do SEUC. Destaca-se aqui uma importante medida de gestão dos espaços verdes a nível de RM.

A partir da Lei Estadual n 14.324 (PERNAMBUCO, 2011) foram criadas oito florestas urbanas na RMR (Figura 110). Pela lei, o objetivo principal dessas florestas urbanas é propiciar o envolvimento da comunidade, seja no uso responsável, seja na gestão participativa visando a manutenção desses importantes espaços verdes (FONSECA; SILVA, 2017). 


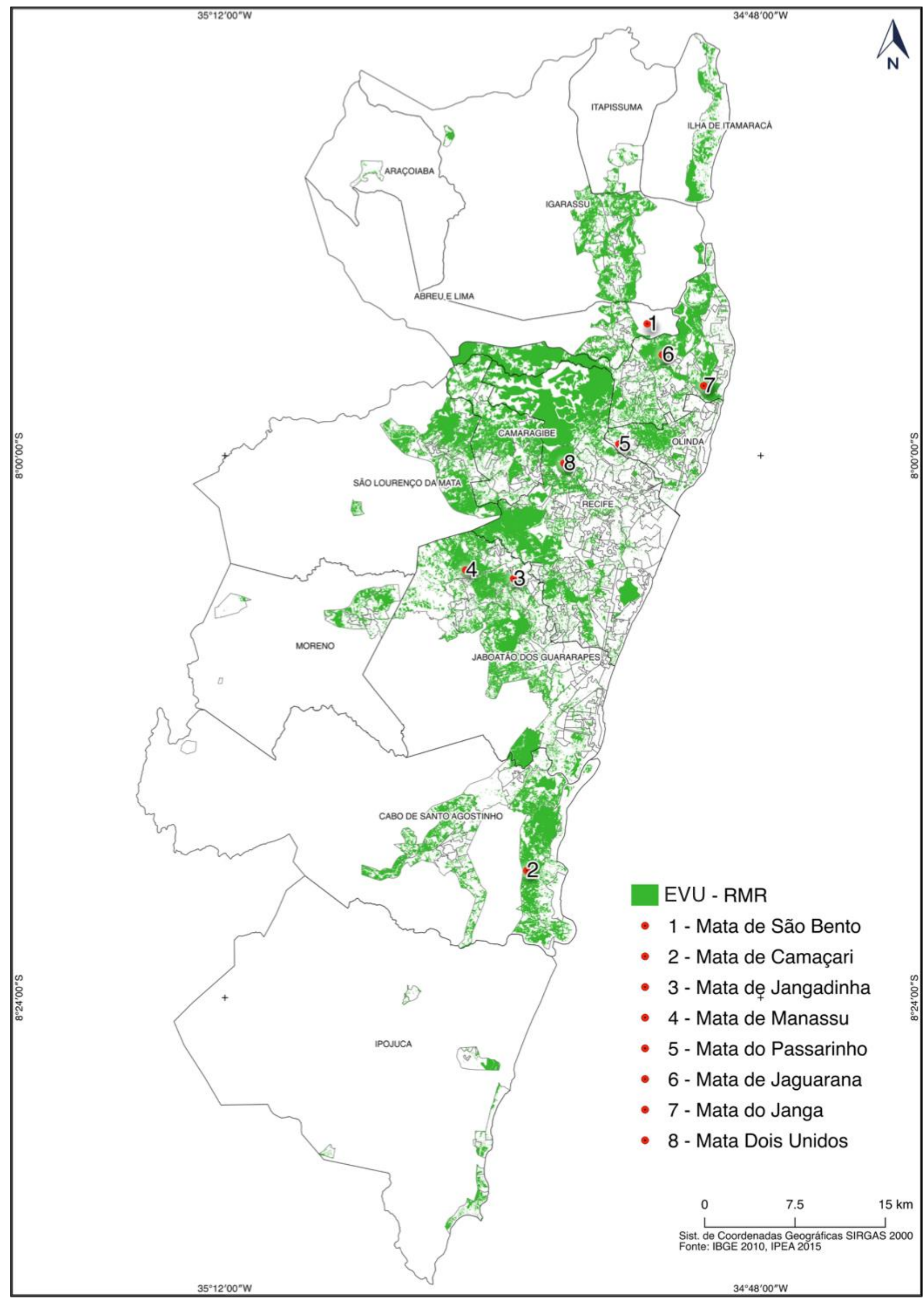

Figura 111 - Florestas Urbanas na Região Metropolitana de Recife estabelecidas por lei estadual 
Não foram encontrados arquivos georreferenciados dos limites dessas florestas de forma a viabilizar análise sobre a quantidade de EVU no seu interior. No entanto, com auxilio do Google-Earth plotou-se um ponto central de cada floresta urbana. Nota-se que elas estão nas áreas mais periféricas da RMR. A floresta urbana Mata São Bento (em Abreu e Lima) foi o único caso onde sua área está fora do recorte analisado.

\subsubsection{Espaços Verdes Urbanos nas Unidades de Desenvolvimento Humano}

A Figura 112 mostra a proporção dos EVU por UDH. As menores porcentagem de EVU estão localizadas nas áreas de elevada densidade demográfica das principais cidades da RMR. A maior mancha da classe $0-30 \%$ de EVU (em marrom) localiza-se na área mais próxima do litoral da RMR e se espalha nas cidades de Recife, Olinda, Paulista e Jaboatão do Guararapes. Além dessa grande mancha, destaca-se a presença dessa classe ao sul de Camaragibe e na região central de Cabo de Santo Agostinho, Abreu e Lima e Igarassu. Nesses casos são áreas mais populosas.

Nas cidades de Itapissuma, Araçoiaba, além dos distritos das cidades de Moreno, Cabo de Santo Agostinho observa-se também pouca porcentagem de EVU (classe em marrom). Nesse contexto, pondera-se que os limites analisados são pequenos, fazendo com que a ocupação se dê por toda área desses distritos, reduzindo assim os EVU.

As UDHs com maior porcentagem de espaços verdes urbanos (60 a 96,2\%) estão distribuídas pela RMR. Observa-se que as maiores UDH dessa classe estão na APA Aldeia-Beberibe, localizadas a oeste das cidades de Paulista e Recife, além das cidades de Camaragibe e São Lourenço da Mata. Como já discutido, é uma área de morros com amplas áreas de vegetação de mata atlântica que nas últimas décadas tem-se instalados condomínios horizontais. 


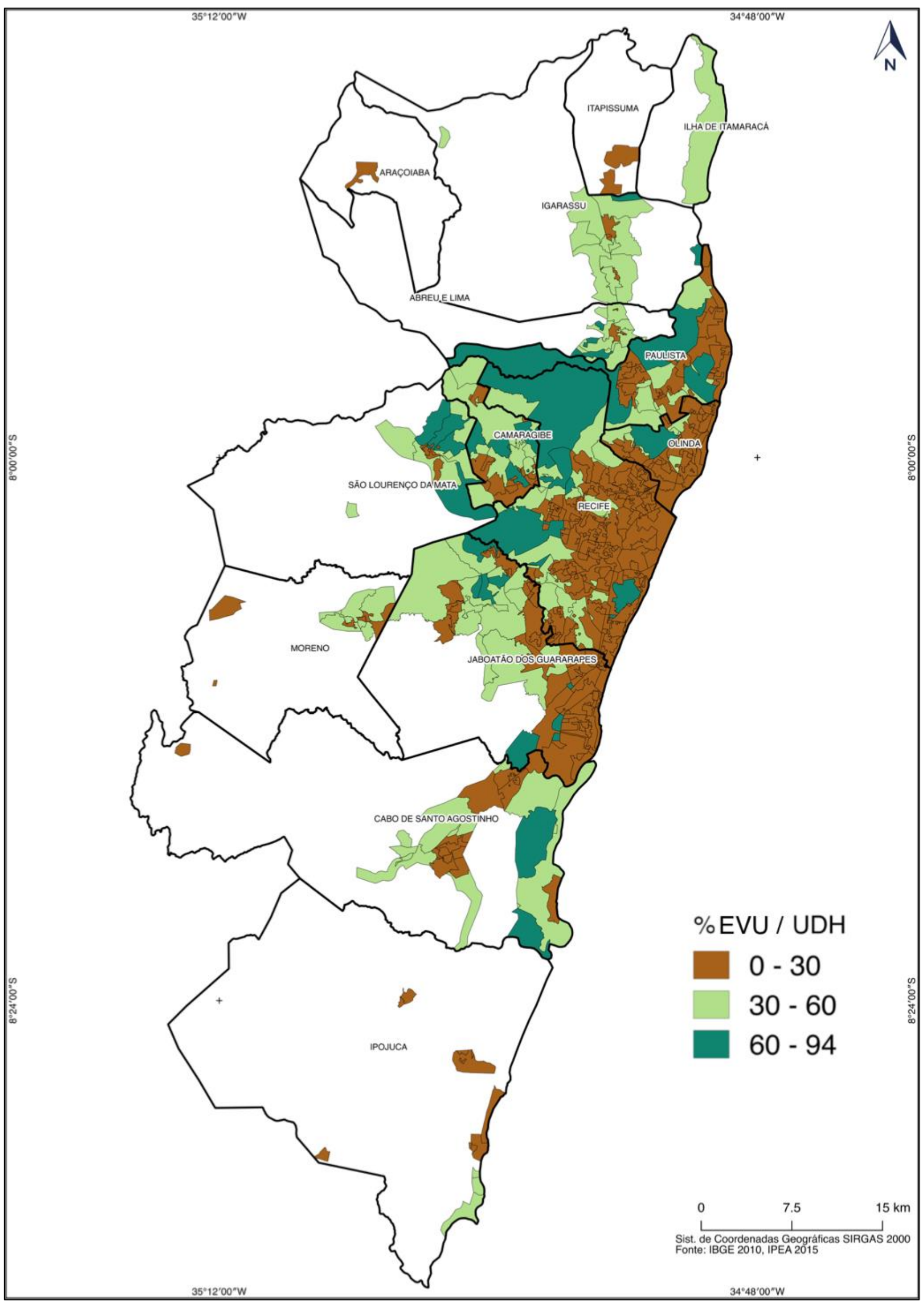

Figura 112 - Porcentagem dos espaços verdes urbanos nas unidade de desenvolvimento humano na Região Metropolitana de Recife 
Outra área com bastante UDH com alta porcentagem de EVU (verde escuro) encontra-se entre as cidades de Recife, Camaragibe, São Lourenço da Mata e Jaboatão dos Guararapes. Constituem as UDHs da referida classe fragmentos da mata atlântica assim denominados: Mata da Várzea (Recife), Mata do Círculo Militar (Recife e São Lourenço da Mata), Mata Mamucaia e Mamassu (ambas em Jaboatão dos Guararapes).

Barros; Lombardo (2013) relatam que tais áreas, juntamente com a área da Aldeia, fazem parte de um amplo cinturão verde de Recife que se estende às cidades vizinhas. Os autores afirmam que são áreas de antigos engenhos de cana de açúcar, além de áreas militares, onde ainda se mantém os maiores remanescentes florestais de mata atlântica na RMR (BARROS; LOMBARDO, 2013). Nesse cinturão também encontram-se as UDHs da classe intermediária (30-60\%), evidenciando que é uma zona de ampla cobertura vegetal, dada as características geográficas (relevo de morros) e históricas (áreas rurais, plantação de cana de açúcar).

Além dos fragmentos de mata atlântica, destacam-se grandes fragmentos de vegetação típica de manguezais na RMR onde também se encontram-se UDH com maior quantidade de espaços verdes (60\% - 94\% de EVU). Como por exemplo, Mangue da Barra da Jangada (Jaboatão dos Guararapes) e o Parque dos Manguezais (área de $3 \mathrm{~km}^{2}$ ) localizado na zona sul bairro de Recife.

A prefeitura de Recife considera o Parque dos Manguezais como a maior área de manguezal urbano do mundo e pertence a Marinha do Brasil (SMA, 2012). Martins; Melo (2007) ressaltam a importância socioambiental desta área uma vez que controla as marés, evitando maiores enchentes em épocas de chuvas, além disso é um berçário dos ecossistemas associados.

Outra UDH com grande porcentagem de EVU encontra-se a noroeste da cidade de Olinda formada pelos bairros: Águas Compridas, Aguazinha e Sapucaia. A área foi caracterizada por Moraes (1962), no seu artigo sobre as toponímias de Olinda, como "uma zona de chãs de perto de setenta metros de altitude, outrora coberta de matas (Mata de Mirueira), ao longo da linha seca de divisa, entre Olinda e Paulista, do marco do Berenguer à nascente do Fragoso" (MORAES, 1962, p. 454).

A área próxima à Mata de Mirueira (mata atlântica) teve seu processo de povoamento com a instalação do Hospital Colônia da Mirueira (conhecido como "hospital do leproso") em 1936 (ALENCAR, 2016). O referido autor narra que os 
bairros localizados nessa área são os mais pobres de Olinda, além de ser uma área de grande vulnerabilidade social dada a quantidade de moradias em áreas de riscos de alagamentos e deslizamentos. Anualmente constatam-se desastres em virtude das chuvas e das habitações localizadas em locais inadequados (ALENCAR, 2016).

A presente análise também verificou que três florestas urbanas compõem os EVU nas UDHs analisadas na RMR. Sendo duas na cidade de Paulista (Mata do Janga, Mata de Jaguarana) e uma em Cabo de Santo Agostinho (Mata de Camaçari).

A floresta urbana Mata do Janga está localizada na divisa dos municípios de Olinda e Paulista e é uma zona estuarina do rio Paratibe. Nessa floresta estão inseridas propriedades privadas, porém o decreto municipal nº 94 (PAULISTA - PE, 1985) concedeu à área título de utilidade pública de interesse social.

O estudo realizado por Souto; Feliciano; Marquezin (2009) relata que um dos maiores impactos na Mata do Janga é a grande quantidade de lixo jogada pela comunidade vizinha, denominada de Tururu. Assim os autores discutem a necessidade de orientação dos moradores no que diz respeito ao reconhecimento a importância desse fragmento de mata atlântica visando a sua conservação (SOUTO; FELICIANO; MARQUEZIN, 2009).

A floresta urbana Mata de Jaguarana está localizada mais ao norte da Mata do Janga. Ela é a maior área protegida do município de Paulista com 3,3 km², onde há predomínio de vegetação da mata atlântica com árvores de grande porte e um relevo de declividade acentuada (CAVALCANTE FILHO et al., 2013). Os mesmos autores relatam que no interior da floresta existem três propriedades privadas, com situação fundiária indefinida.

Cavalcante Filho et al. (2013) relata que em ambas florestas (Janga e Jaguarana) não se encontram nenhum tipo de demarcação (cerca), sinalização ou algum tipo de fiscalização para minimizar as pressões antrópicas. Assim, são informados como impactos negativos: queimadas, parcelamento, invasão de moradores e extração de areia.

A floresta urbana Mata de Camaçari é um importante fragmento de mata atlântica subperenifólia: mata densa, folhas largas, troncos delgados, solo coberto de húmus (ALBUQUERQUE, 2007). A autora destaca peculiaridade da diversidade geomorfológica dessa floresta (terraços, baixas colinas e áreas com sedimentos terrígenos) e sua importância para a proteção aos mananciais e fauna regional. 
Albuquerque (2007) afirma que o maior impacto negativo da Mata de Camaçari é a ocupação na praia do Paiva do seu lado leste, sobretudo de casas de veraneio onde o fluxo turístico é intenso nos meses de dezembro a maio. Dado a sua fragilidade geomorfológica, a expansão da área urbana sobre essa floresta tem aumentado o número de erosões, formação de ravinas e de barramentos de água pluvial (ALBUQUERQUE, 2007). A autora explica que esses barramentos geram o "banho de lama" em várias áreas próximas às florestas, resultado da combinação da argila natural com água da chuva.

\subsubsection{Análise Demográfica}

A Figura 113 indica que poucas são as UDHs na RMR que não possuem EVU (em vermelho). Elas estão distribuídas nas áreas mais populosas de Recife, Jaboatão dos Guararapes, Cabo de Santo Agostinho e Abreu e Lima, além de um distrito de Moreno.

As UDHs com até $15 \mathrm{~m}^{2}$ de EVU (laranja) estão localizadas nos centros mais populosos da RMR (faixa litorânea) o que ratifica análises anteriores quanto à densidade populacional e quantidade dos espaços verdes urbanos. Nota-se que esses centros da RMR possuem baixa cobertura vegetal por habitantes, com quantidade menor ao valor recomentado pela Sociedade Brasileira de Arborização Urbana - SBAU (15 $\left.\mathrm{m}^{2}\right)$.

As classes em amarelo, verde-claro e verde-escuro expressam de forma graduada maior quantidade dos espaços verdes por habitante. Variando de $15 \mathrm{~m}^{2}$ a $100 \mathrm{~m}^{2}$ nas áreas em amarelo, $100 \mathrm{~m}^{2}$ a $1000 \mathrm{~m}^{2}$ nas áreas em verde-claro e superior de $1000 \mathrm{~m}^{2}$ em verde-escuro. Por essa classificação, observa-se visualmente que a quantidade dos espaços verdes por habitante aumenta dos centros mais urbanizados (área litorânea) para as bordas (área de morros).

Quanto às áreas com maior quantidade de EVU por habitantes, destacam-se as UDHs presentes no cinturão verde (BARROS; LOMBARDO, 2013), sobretudo aquelas com presença de áreas protegidas: APA Aldeia-Beberibe, APA Santa Cruz, além das Floresta Urbanas (Mata de Jaguarana, Mata de Camaçari, Mata de Manassu). 


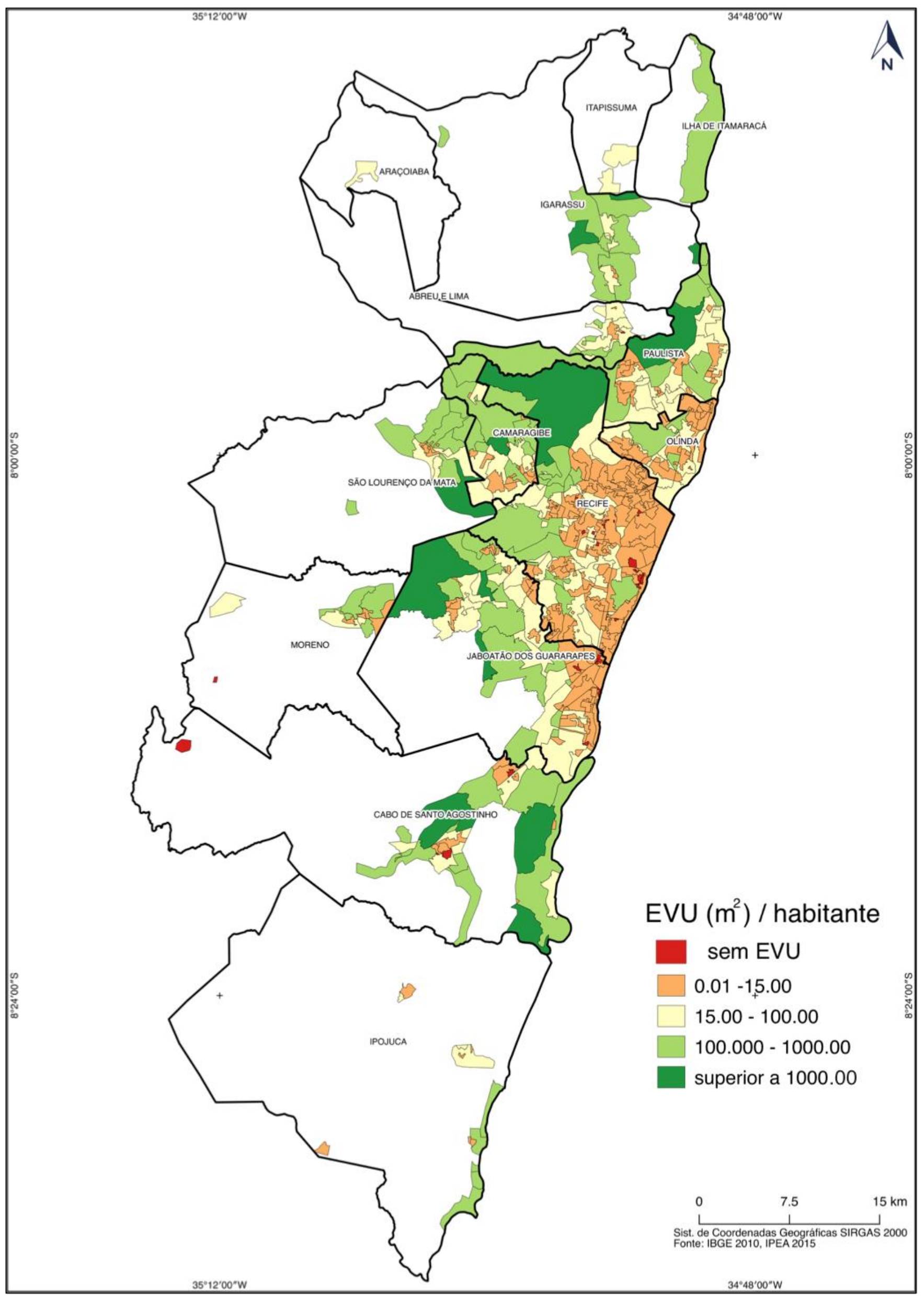

Figura 113 - Espaços verdes urbanos $\left(\mathrm{m}^{2}\right)$ por habitantes nas Unidades de Desenvovimento Humano 


\subsubsection{Tamanho e Distribuição dos Fragmentos dos Espaços Verdes Urbanos}

Ao classificar o tamanho dos espaços verdes da RMR por área, em três categorias (pequenas, intermediárias e grandes) de acordo com a curva normal de distribuição, estabeleceu-se o desvio padrão como limite das classes e obteve-se a seguinte classificação (Tabela 19).

\begin{tabular}{|c|c|}
\hline $\mathrm{EVU}\left(\mathrm{km}^{2}\right)$ & Classe dos fragmentos \\
\hline $0,00-0,03$ & Pequenos \\
\hline $0,03-55,23$ & Intermediários \\
\hline $55,23-89,08$ & Grandes \\
\hline
\end{tabular}

A Figura 114 mostra que a classe de fragmentos grandes é composta de fragmentos (na cor verde) localizados na porção oeste da RMR, ora mencionada por Barros; Lombardo (2013) de cinturão verde. Esses fragmentos correspondem à vegetação dos morros tabulares, onde localiza-se a APA Aldeia-Beberibe e os principais fragmentos de mata atlântica.

Quanto à APA Aldeia-Beberibe, de acordo com seu Plano de Manejo (MUNIZ et al., 2012), engloba os maiores remanescentes de mata atlântica no estado de Pernambuco, dentre eles o maior fragmento com área próxima de $88 \mathrm{~km}^{2}$, valor semelhante ao encontrado na Tabela 19.

A classe de fragmentos intermediários (cor amarelo) diz respeito aos fragmentos de mata atlântica, além de importantes manguezais da RMR. Eles estão concentrados em áreas com menor densidade populacional e onde há a presença da APA de Santa Cruz, Florestas Urbanas (Mata de Janga e Jaguarana - Paulista) na porção norte e a Floresta Urbana Mata de Camaçari na porção sul. 


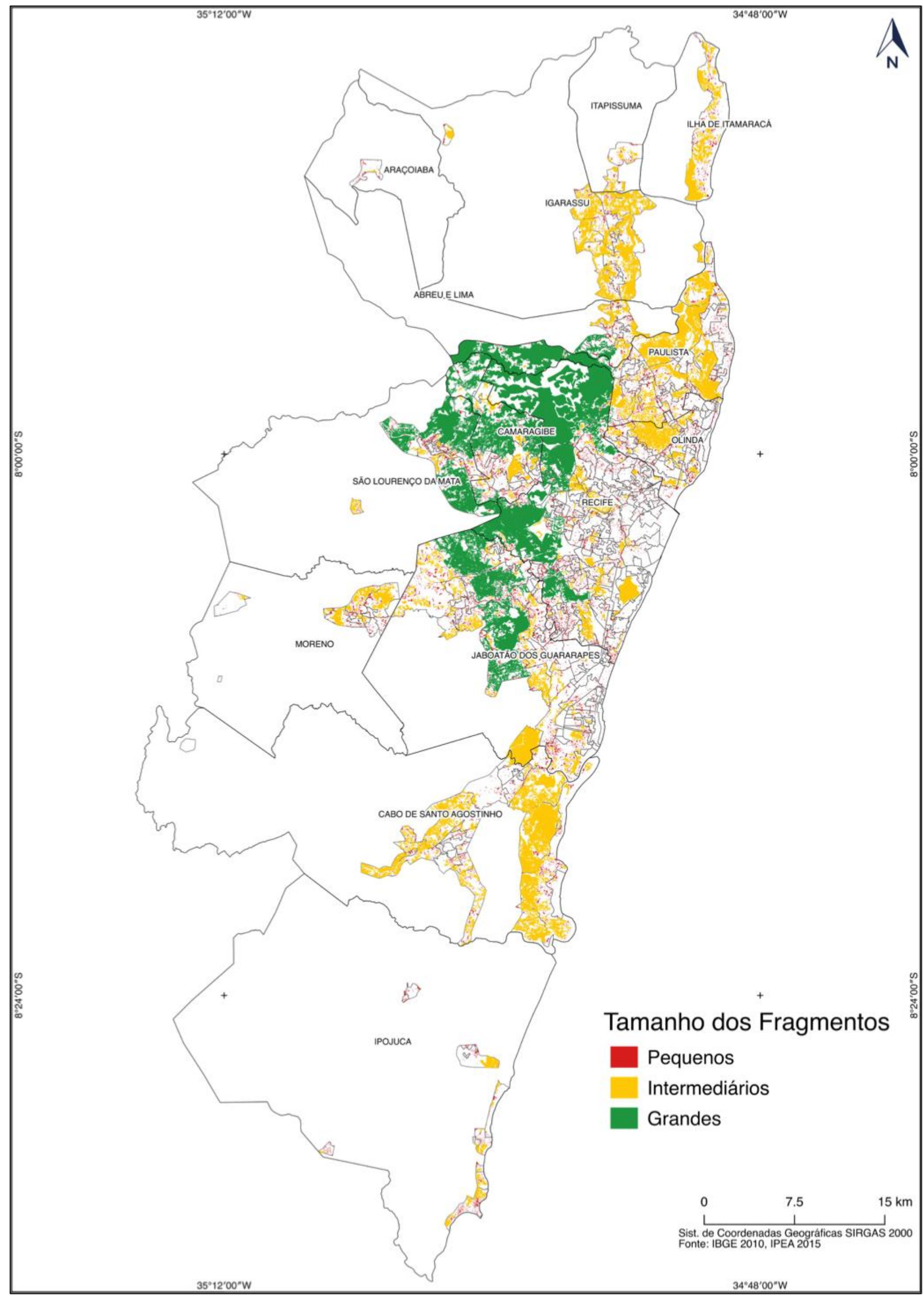

Figura 114 - Classificação do tamanho dos espaços verdes urbanos na Região Metropolitana de 
Os menores fragmentos foram analisados a partir do mapa de kernel (Figura 114). O mapa indica as áreas com maior probabilidade de encontrar tais fragmentos, uma vez que são os mais frequentes e difícil de analisá-los caso a caso.

Destacam-se dois focos com grande probabilidade: Unidades Residenciais (sul de Recife, divisa com Jaboatão dos Guararapes) e condomínios horizontais (São Lourenço da Mata e Camaragibe) na APA Aldeia-Beberibe. Nesse último caso, como já explanado, os condomínios da Aldeia são áreas de lazer localizadas em morros a oeste da RMR. Os pequenos fragmentos na área da Aldeia estão relacionados aos espaços verdes (pomares, frutíferas) das casas dos referidos condomínios.

As Unidades Residenciais (UR) originaram-se a partir de uma política do regime militar (1967-1985) de realocação de mocambos e de desalojados de enchentes, principalmente da região central de Recife (GIRÃO, 2007; LIMA et al., 2014). Elas foram distribuídas, sobretudo, pelos bairros da região sul e sudeste, na fronteira com Jaboatão dos Guararapes, onde as UR se espalharam formando novos bairros. 


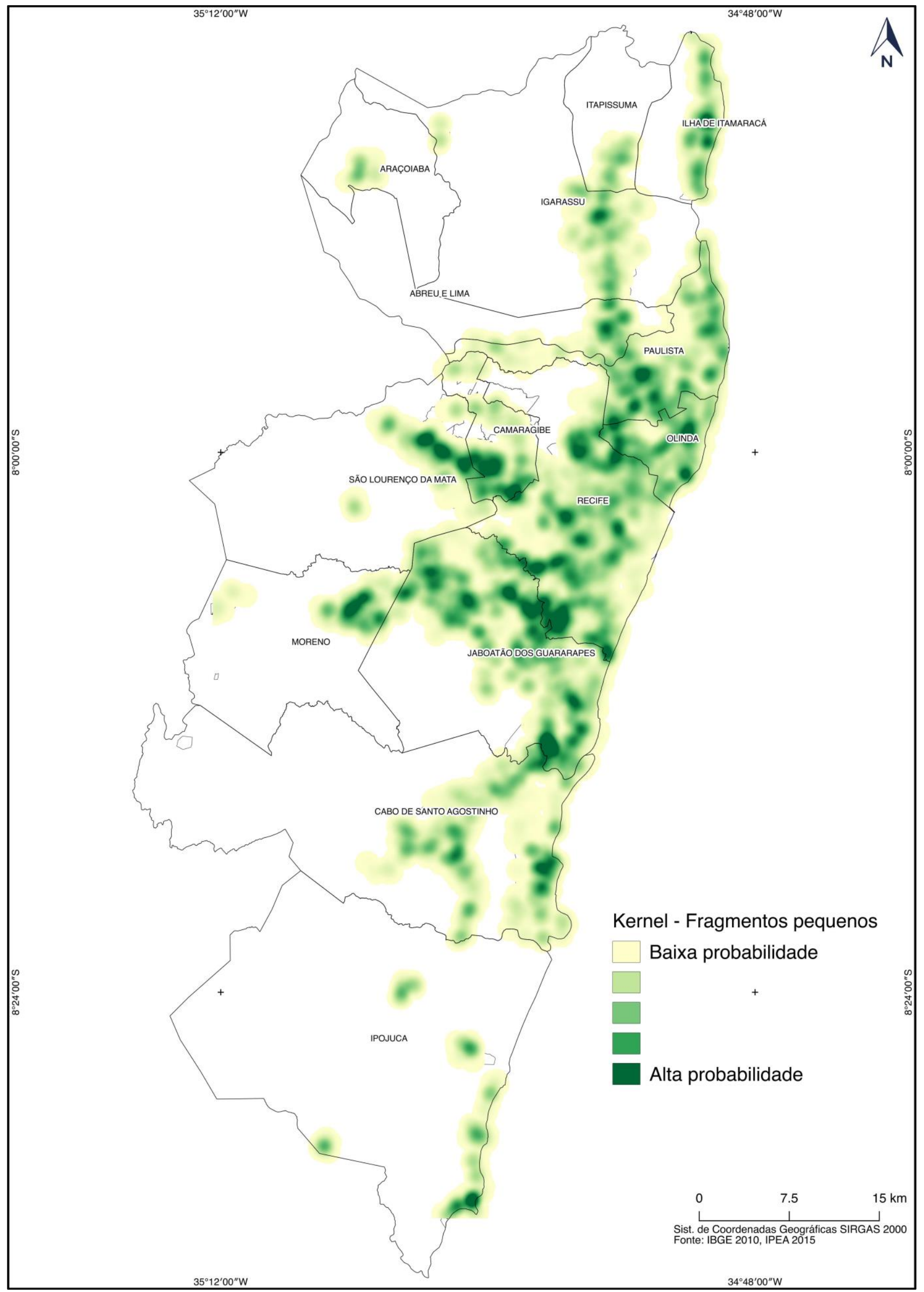

Figura 115 - Mapa de Kernel para os menores fragmentos da Região Metropolitana de Recife 
Girão (2007) cita que as primeiras UR foram construídas em áreas de morros no bairro do lbura (zona sul). No seu limite está um dos bairros mais populosos da RMR, bairro da COHAB de Jaboatão dos Guararapes, também construído pelo estado como moradia popular (GIRÃO, 2007). O autor afirma que nessas áreas há uma elevada concentração de pessoas de baixa renda que necessitavam aproveitar ao máximo os espaços, seja para fins residencial (aumentar quartos e cômodos para familiares) ou comercial (construção de cômodos para aluguel).

Assim, os espaços verdes existentes indicados na Figura 116 remetem às encostas onde não foi possível a construção de moradias. Destarte, Girão (2007) narra que o processo de ocupação na referida área tem como histórico a devastação da cobertura vegetal dos morros, que acrescido do fator declividade potencializa os riscos de deslizamentos e erosões, problemas recorrentes nas áreas de morros da zona sul e sudoeste de Recife.

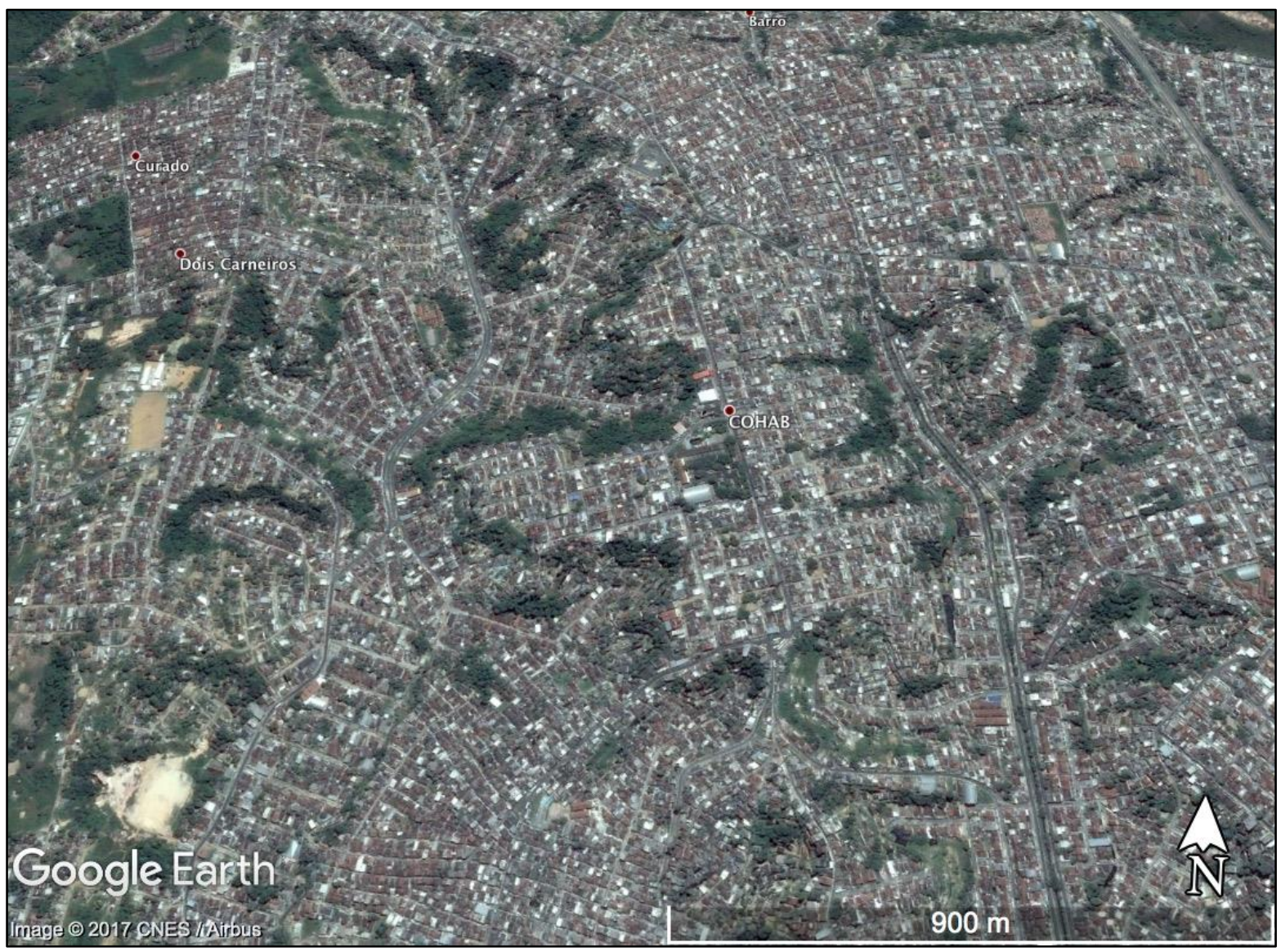

Figura 116 - Bairro da COHAB (Jaboatão dos Guararapes) Fonte: Google-Earth (2017)

Ao analisar dois bairros (Tebijó e Sanchos) que se desenvolveram após a implantação das UR, Lima (2011) relata que eles foram ocupadas após intervenções 
estatais de melhoria (aterros às margens dos cursos d’água, pavimentação) e implantação de equipamentos urbanos básicos (escola, iluminação, abastecimento de água, metrô). A autora narra que nas últimas décadas os bairros passaram por profunda especulação imobiliária, sendo alvo de empreendimentos verticais para a classe média. Um fato curioso é que que esses novos empreendimentos estão colocando os espaços verdes do bairro no marketing imobiliário (LIMA, 2011).

\subsubsection{Correlação: Espaços Verdes Urbanos e Vulnerabilidade Social}

A correlação espacial entre IVS e porcentagem de EVU na RMR apresentou o Índice de Moran de 0,17 (Gráfico 17). O valor positivo indica que essa amostra apresentou uma correlação geoestastítica que em grande parte refuta a hipótese: áreas com melhores índices sociais (menor IVS) apresentam maior quantidade de EVU, e vice-versa.

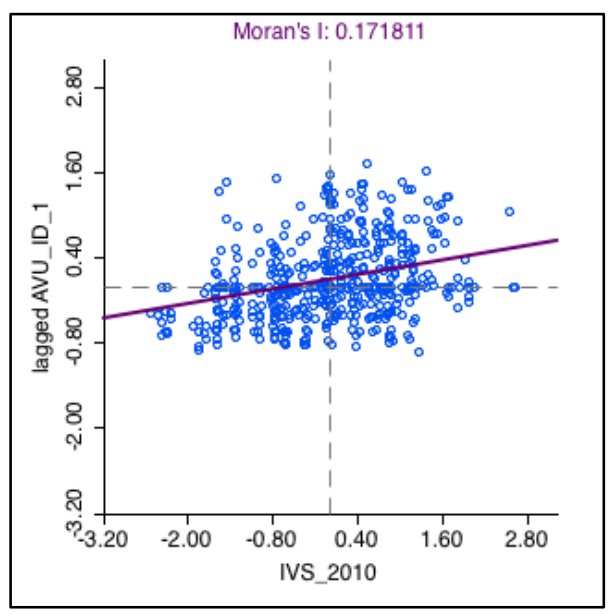

Gráfico 17 - Diagrama de Espalhamento de Moran. RMR

Do total de 504 UDHs da área analisada da RMR, 62,50\% não apresentaram significância na análise geoestastítica. O Gráfico 18 destaca as UDHs sem significância, observando que são aquelas mais próximas ao eixo da variável representada pelo IVS (horizontal). Na prática representam as UDHs onde a quantidade de EVU não variou significativamente conforme às variações de IVS. 


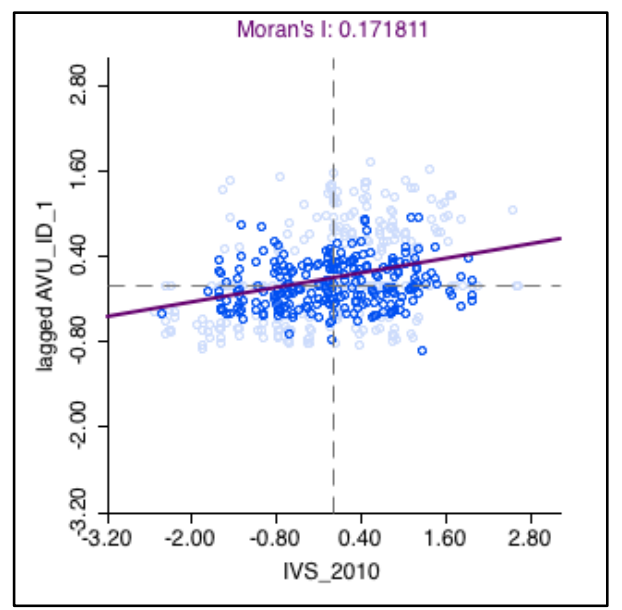

Gráfico 18 - UDHs sem significância. RMR

O Gráfico 19 indica as 71 UDHs (14,01\%) que não apresentam significância por não apresentarem vizinhança, logo não influenciaram na análise de correlação espacial. No gráfico de correlação, essas UDHs dispostas em cima do eixo da variável dependente, representada pelo IVS.

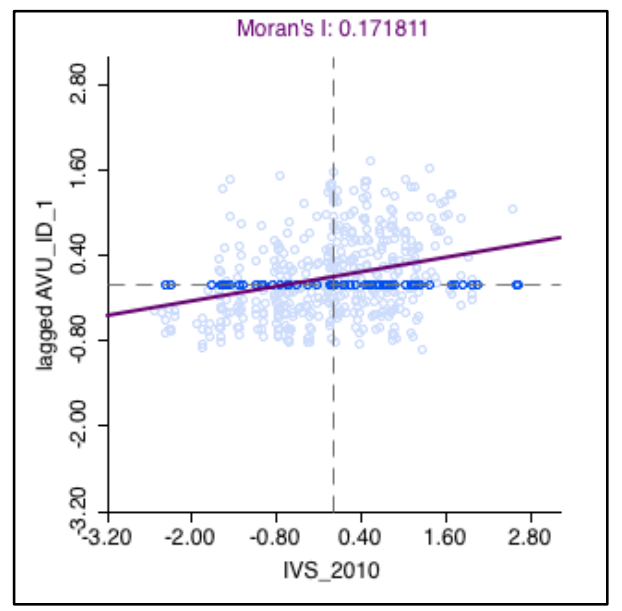

Gráfico 19 - UDHs sem vizinhança. RMR

O Gráfico 20 destaca as 189 UDHs que apresentaram significância na correlação geoestastítica, o que representa $37,50 \%$ do total. Porém, ressalta-se que haver significância não implica corroborar a hipótese, conforme será evidenciado posteriormente. Nesse sentido, o Gráfico indica que os pontos mais dispersos no gráfico são os que apresentam significância. Verifica-se que o espalhamento desses pontos (representado pelas UDHs) são determinantes para a inclinação da curva de correlação, refletindo o valor positivo do Índice de Moran. 


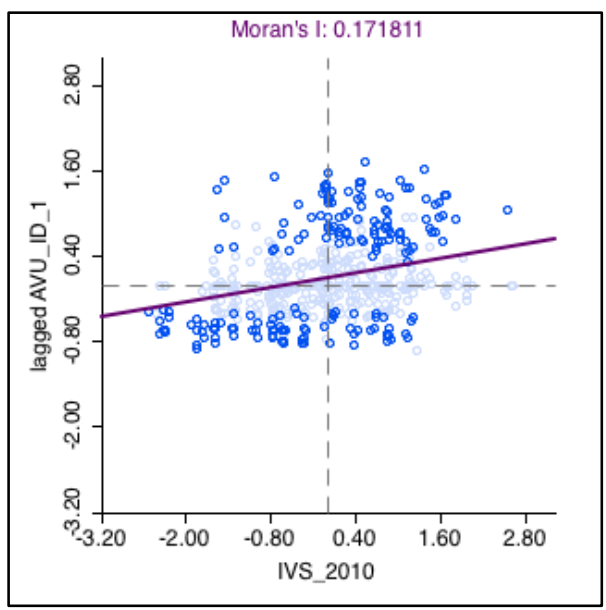

Gráfico 20 - UDHs com significância. RMR

Ao analisar os resultados frente a hipótese, é importante destacar, novamente, os cenários esperados: a) UDH com grande porcentagem de EVU e IVS baixo e b) UDH com baixa porcentagem de EVU e IVS alto. Esses dois cenários estão representados na cor verde (cenário $A$ ) e cor vermelha (cenário $B$ ) nas Figuras 117 e 117. Esses cenários compõem 27,51\% das unidades amostrais (52 das 504 UDH) que apresentaram significância na correlação.

Os demais $72,49 \%$ das UDHs (137) representam os cenários opostos à hipótese: c) UDH com grande porcentagem de EVU e IVS alto e d) UDH com baixa porcentagem de EVU e IVS baixo. Esses dois cenários estão representados na cor laranja (cenário C) e cor amarela (cenário D) nas Figuras 117 e 118.

Uma vez que a correlação é baseada na quantidade e grau de vizinhança das unidades amostrais, no caso as UDHs, as áreas que se correlacionam podem ser melhor analisadas ao inferir sobre a dimensão de área e população, conforme mostram a Figura 117 e a Tabela 20. A Figura 118 espacializa as áreas que apresentaram correlação significativa. 
Tabela 20 - Resumo dos resultados da análise geoestastítica na Região Metropolitana de Recife

\begin{tabular}{llllll}
\hline Correlação & $\begin{array}{l}\text { UDH } \\
\text { (qtde) }\end{array}$ & IVS med & $\begin{array}{l}\text { \%EVU/UD } \\
\text { H }\end{array}$ & $\begin{array}{l}\text { ÁREA } \\
\text { \% POP }\end{array}$ \\
\hline ALTA-ALTA (laranja) & 76 & 0,45 & 35,86 & 26,41 & 19,28 \\
ALTA-BAIXA (vermelho) & $\mathbf{2 5}$ & $\mathbf{0 , 4 3}$ & $\mathbf{1 2 , 8 4}$ & $\mathbf{4 , 0 9}$ & $\mathbf{7 , 9 5}$ \\
BAIXA-BAIXA (amarelo) & 61 & 0,20 & $\mathbf{7 , 3 2}$ & 5,68 & 11,39 \\
BAIXA-ALTA (verde) & $\mathbf{2 7}$ & $\mathbf{0 , 2 9}$ & $\mathbf{3 0 , 4 8}$ & $\mathbf{5 , 7 7}$ & $\mathbf{2 , 9 4}$ \\
SEM SIGNIFICÂNCIA & 315 & 0,36 & $\mathbf{1 9 , 0 5}$ & $\mathbf{5 8 , 0 5}$ & $\mathbf{5 8 , 4 3}$ \\
\hline HIPÓTESE (vermelho + verde) & $\mathbf{5 2}$ & & & $\mathbf{9 , 8 6}$ & $\mathbf{1 0 , 9 0}$ \\
OPOSTO DA HIPÓTESE (laranja + amarelo) & 137 & & & 32,09 & 30,68 \\
\hline
\end{tabular}

Fonte: Elaborada pelo autor

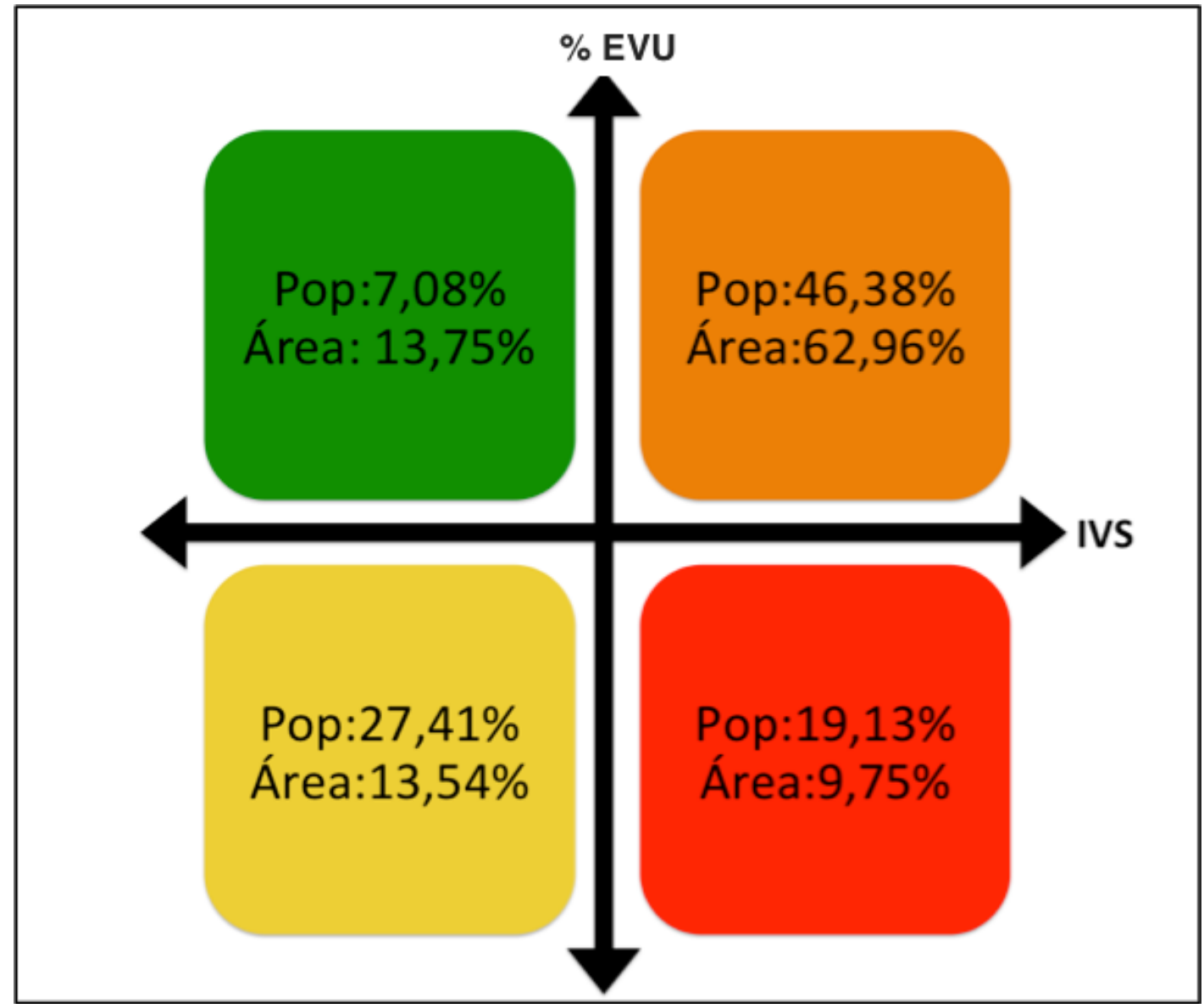

Figura 117 - Porcentual de área e população das UDHs com significância. RMR 


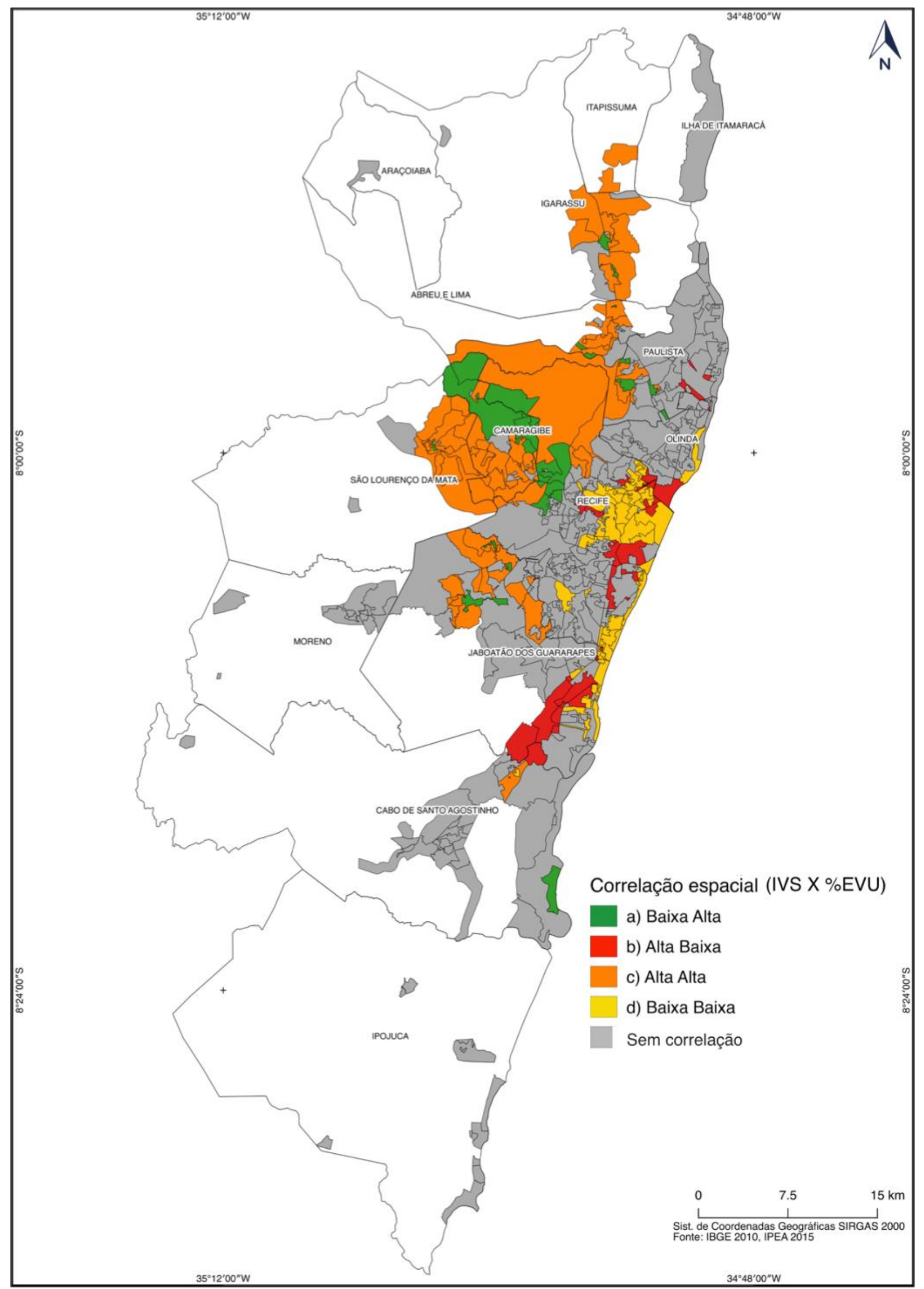

Figura 118 - Correlação entre porcentagem dos espaços verdes urbanos e vulnerabilidade social RM Recife 
O cenário $C$, representado pela área em laranja (Figuras 117 e 118) foi o que mostrou maior magnitude em termos de área (62,96\% das UDHs com significância e $26,41 \%$ da RMR). Nele residem 19,28\% dos habitantes da RMR (46,38\% das áreas com significância). Ele está distribuído na porção oeste da RMR. Como já discutido, esta área é considerada como cinturão verde, onde há presença de morros com remanescentes florestais e plantações de cana de açúcar. $O$ cenário $C$ corresponde a 76 UDH com IVS-médio de 0,45 e 35,86\% dos EVU. Esses valores indicam que este cenário apresenta forte correlação entre muitos espaços verdes e alta vulnerabilidade social.

A magnitude em termos de área deve ser observada com cuidado, mesmo que a quantidade de espaços verdes seja expressiva no cenário C (laranja), ressalta-se a importância ecológica (APA Aldeia-Beberibe) e a fragilidade geográfica (morros). Ademais, o fato de ter grande área e alta porcentagem de cobertura vegetal não indica que a maioria da população usufrui socialmente dos espaços verdes.

Pode-se afirmar que nesse cenário, a vegetação ainda é considerada a matriz no processo de ocupação urbana e fragmentação da floresta dos morros, sendo o relevo o principal fator que ajuda a mantê-la. Os EVU nesse cenário são prioritários para se estabelecer medidas de controle ambiental, seja por legislação ou mecanismos de fiscalização e monitoramento de tal forma que eles continuem no espaço urbano, garantindo sobretudo a qualidade da infraestrutura urbana.

O segundo cenário em maior magnitude quanto à área foi o cenário $D$, representado pela cor amarela (Figuras 117, 118). Ele está concentrado, majoritariamente, nas áreas mais urbanizadas da RMR, seguindo o sentido do litoral. A Tabela 20 e a Figura 117 mostram também que existe uma população expressiva de $11,39 \%$ da RMR, ratificando mais uma vez a alta densidade populacional nessa área.

O conjunto de UDH em amarelo apresentou IVS-médio de 0,2 (baixa vulnerabilidade) e $7,99 \%$ de EVU, sendo o menor valor em relação à todos os cenários. Esses cenário indica que parte dos espaços analisados com maior densidade demográfica (área mais próxima ao litoral) apresenta correlação espacial entre: poucos espaços verdes e baixa vulnerabilidade social.

Ao analisar o centro expandido de Recife (bairros do Recife, Santo Antônio, São José e Santo Amaro), Serafim (2008) relata uma presença considerável de 
praças e parques na região (20\% de toda a cidade), provavelmente áreas menores de $625 \mathrm{~m}^{2}$, as quais não foram englobadas na presente análise. No entanto, a autora destaca a decadência e o abandono dessas áreas, assim como dos prédios históricos. Por isso, ela propõe a criação e restauração de áreas de lazer com ampla cobertura vegetal a partir da articulação de outras políticas, sobretudo a de segurança pública, a fim de alcançar benefícios socioambientais e a valorização histórico cultural (SERAFIM, 2008).

Quanto às áreas mais próximas ao litoral, ao analisar a área urbanizada da praia de Boa Viagem (Recife), Costa et al. (2008) relataram que a pressão do mercado imobiliário, dado o potencial turístico, tem estimulado a construção de prédios e estes cada vez mais altos. Os autores citam ainda que a expansão urbana "vertical" se alastra ao litoral sul de Recife, chegando a Jaboatão dos Guararapes, no bairro da Piedade. Essa verticalização traz inúmeros danos socioambientais, como: ausência de espaços verdes, aumento do fluxo de carros, aumento na impermeabilização do solo, imobilização das dunas e erosão da praia (COSTA et al., 2008).

Os cenários $C$ e D refletem o oposto da hipótese. Eles foram os mais representativos dentre as UDHs que tiveram significância geoestastítica $(72,48 \%$ das UDHs) e correspondem a $32,09 \%$ da área analisada e $30,68 \%$ da população da RMR. No caso da RMR, a análise geoestastítica mostrou que, no geral, a presença de espaços verdes urbanos não influencia a vulnerabilidade social.

Quanto aos cenários referentes à hipótese, verifica-se certa similaridade na abrangência espacial, ambos cobrem cerca de $5 \%$ da área analisada da RMR. $O$ cenário $B$ (em vermelho) apresentou valor de IVS-médio $(0,43)$ e baixa porcentagem de EVU (12,84\%). Ele contém uma população de $7,95 \%$ do total da RMR e é formado por UDH localizadas nas áreas periféricas, porém não tão distantes às UDH do cenário $D$ (amarelo), além de algumas nas áreas centrais de Paulista e ao sul de Jaboatão dos Guararapes.

As maiores UDH desse cenário estão localizadas em Jaboatão dos Guararapes, nos seguintes bairros: Cajueiro Seco, Comportas, Prazeres, Candeias e Pontezinha. Atenção se dá ao bairro Cajueiro Seco, uma vez que Ribeiro; Pontual (2009) relatam que ele foi considerado um exemplo da ação do estado à reforma urbana, no primeiro governo de Miguel Arraes (1963-1964). As autoras relatam ainda que o governo estadual objetivava eliminar os bolsões de pobreza, assim contratou 
o arquiteto Acácio Gil Borsoi para planejar a construção de casas populares em estrutura de taipas pré-fabricadas (RIBEIRO; PONTUAL, 2009).

Para Souza (2010) o grande diferencial do Cajueiro Seco foi a realização planejamento e construção de forma participativa, utilizando-se inclusive como mãode-obra os próprios moradores. No projeto inicial haviam centros comunitários, oficinas, lavanderia comunitária, conjunto comercial, escola para crianças e adultos, posto de saúde, além de áreas livres e espaços verdes (SOUZA, 2010).

O projeto comunitário e participativo do Cajueiro Seco não foi à frente. Souza (2010) afirma que o regime militar o considerou como ícone da "comunização" em Pernambuco e por isso foi combatido, a partir de repressões de quaisquer iniciativas de sociabilidade da comunidade. Assim, o bairro se configurou como mais um bairro periférico semelhante aos demais da RMR (SOUZA, 2010). "As áreas previstas no projeto urbanístico como livres ou verdes foram ocupadas por construções irregulares, nas quais se sente a falta dos alinhamentos e espaçamentos entre as casas" (SOUZA, 2008, p. 201).

As demais UDH do cenário B (vermelho) são importantes aglomerados subnormais de Recife, institucionalizadas como Zonas Especiais de Interesse Social $(\text { ZEIS })^{19}$, como: Afogados, Ilha do Destino (Boa Viagem), Campo Grande, Aritana, Coqueiral, Pina, Santo Amaro, Coque, Coelho. Todas localizadas em áreas de Mangue e estuários dos rios Capiberibe e Beberibe.

Para Miranda; Moraes (2007), a maior importância da institucionalização desses bairros como ZEIS foi dar espaço à gestão participativa além de possibilitar a população de baixa renda permanecer em suas comunidades (áreas centrais), com equipamentos urbanos e serviços básicos de saúde, educação e transporte.

O cenário $A$ (verde), também referente à hipótese, indicou que nela residem apenas 2,94\% dos habitantes da área analisada da RMR. As maiores UDH desse cenário estão na área denominada de Aldeia (oeste da RMR). Como já discutido são áreas de condomínio horizontais, consideradas refúgio à vida urbana principalmente da classe média de Recife. O IVS nesse cenário não é o valor mais baixo

\footnotetext{
19 Recife foi pioneira no estabelecimento de ZEIS. Em 1983 a lei municipal de Uso e Ocupação do Solo reconheceu as ZEIS como parte integrante da cidade. Em 1987 ocorreu a regulamentação das ZEIS à partir da leis do PREZEIS que institucionalizou os canais de gestão urbana, colocando a população como parte das decisões a serem tomadas, sobretudo quanto aos problemas específicos de cada ZEIS (ROLNIK, 1998).
} 
encontrado, ratificando que esses condomínios não são elitizados, conforme relatou Silva (2015).

Chama-se aqui atenção da proximidade dessas UDHs às do cenário $C$ (laranja). Esse fato indica que a presença de amplos espaços verdes, por si, não refletem na vulnerabilidade social, uma vez que áreas de mesma caraterísticas apresentaram características socioeconômicas distintas. Portanto, é importante reportar a outros fatores geográficos (relevo, presença de cursos d'água, infraestrutura urbana), além do histórico de ocupação para inferir sobre a vulnerabilidade social.

Os cenários hipotéticos, mesmo não ocupando a maioria do território, possibilitam visualizar a desigualdade social conjugada a presença e ausência dos espaços verdes. Para a gestão urbana que vise a manutenção e implantação de EVU é importante a indicação da sua carência atrelada à vulnerabilidade social. Por outro lado, ao dar visibilidade ao cenário de muitos espaços verdes e com baixa vulnerabilidade social estabelece-se um exemplo a ser seguido, aonde o desenvolvimento socioeconômico caminha com o ambiental. 


\subsection{Região Metropolitana de São Paulo}

A Região Metropolitana de São Paulo (RMSP) é a maior RM do Brasil e reúne 39 municípios. A área analisada concentra uma população de 18,92 milhões de habitantes numa área de 4,5 mil km². De acordo com os dados censitários (IBGE, 2010), a população analisada na RMSP representa $10,20 \%$ da população brasileira, $24,21 \%$ dos residentes na região sudeste e $47,16 \%$ dos que vivem no estado de São Paulo.

A Figura 119 apresenta a RMSP, evidenciando as áreas urbanas analisadas por meio das UDHs. Observa-se uma alta concentração dessas unidades, sobretudo na região central (área da capital paulista). No caso da RMSP, vinte cidades possuem todo o território municipal na área analisada, indicando o alto grau de urbanização dessa RM.

Como já explanado, a institucionalização da RMSP iniciou-se em 1967, com a criação do Grupo Executivo da Grande São Paulo (Gegran), articulada pelo Governo do Estado de São Paulo. Por meio Lei Federal complementar nº 14 (BRASIL, 1973), a RMSP foi legalmente institucionalizada.

Para Bógus; Véras (2000) o processo de metropolização da RMSP foi impulsionado a partir da descentralização industrial, na metade do século $X X$, com a mudança das indústrias da capital para outros municípios. Esse processo gerou um aumento do contingente populacional das cidades vizinhas, atribuindo a RMSP uma configuração de enormes disparidades.

O município central - São Paulo - concentra o pólo dinâmico e avançado, sede do capital financeiro transnacional, que coloca lado a lado arranha-céus, bairros sofisticados e bairros populares, vazios urbanos à espera de valorização, especulação imobiliária, riqueza e pobreza, geralmente segregados em áreas bem marcadas. Tais disparidades se reproduzem nos 39 municípios metropolitanos, perfazendo uma região que se estende por uma vasta área de 8.000 quilômetros quadrados, dos quais mais de $50 \%$ situam-se em áreas de proteção de mananciais, ocupadas irregularmente por loteamentos populares, com a muda conivência do poder público (BÓGUS; VÉRAS, 2000, p. 84). 


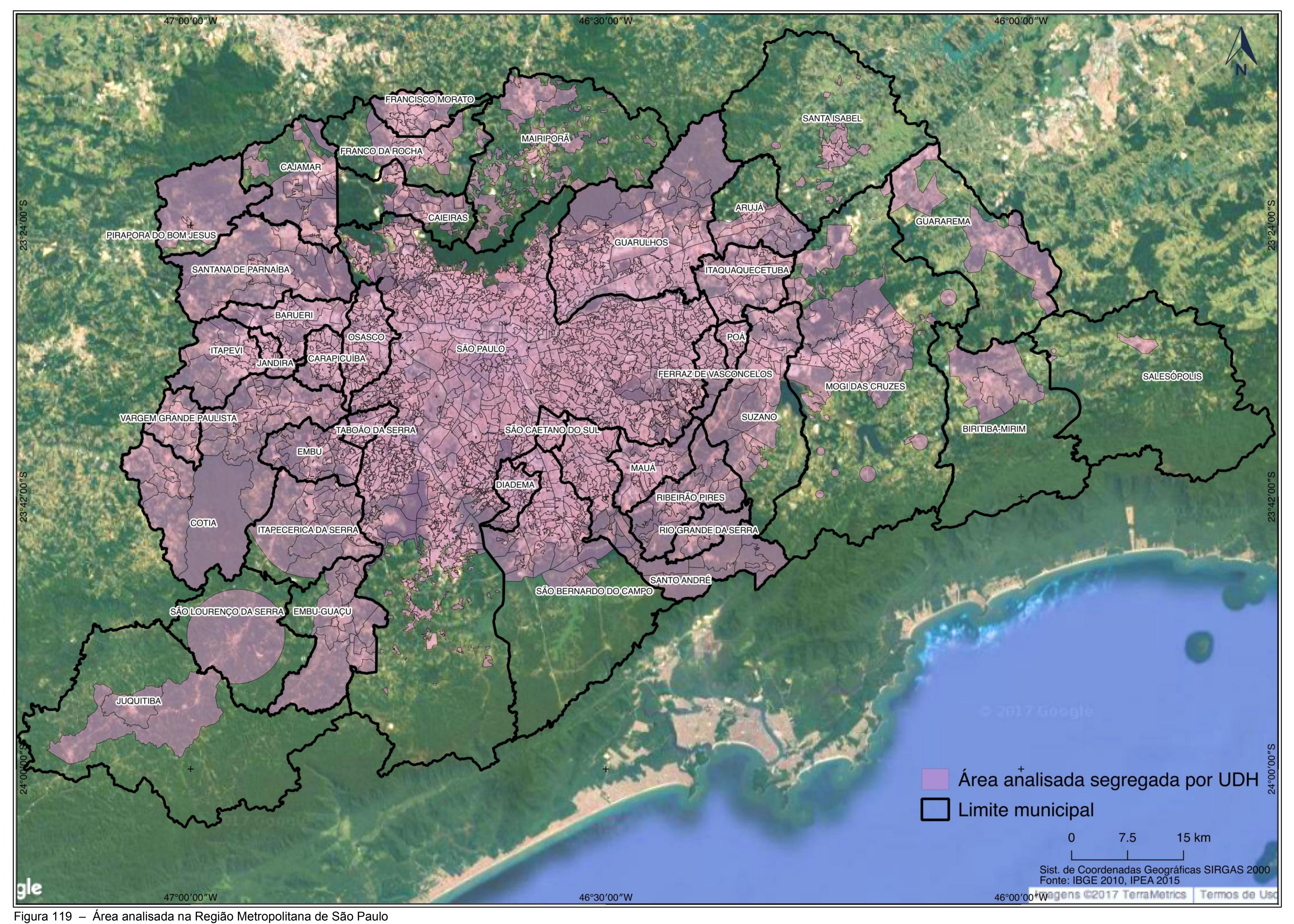


Ab'Sáber (1975) afirma que o inchaço da RMSP deve-se "à industrialização e às dimensões do mercado de trabalho de um organismo urbano gigante, dotado de uma capacidade inesgotável de atração de mão-de-obra” (AB'SÁBER, 1975, p. 2). Não à-toa, a RMSP ultrapassou as previsões urbanísticas e acumula a várias décadas uma série de problemas urbanos e ambientais que refletem na qualidade de vida (AB'SÁBER, 1975).

Para Ab'Sáber (2004), São Paulo é um organismo "urbano-industrial" altamente relacionado com suas características geográficas, sobretudo pelos rios Tietê e Pinheiros que meandram amplas planícies. Assim, Bórgus; Véras (2000) descrevem a mancha urbana da RMSP:

Composta de morros, ladeiras e fundos de vales para onde descem as violentas chuvas de verão, que escoam, finalmente, para três grandes rios, verdadeiros esgotos a céu aberto, o Tietê e seus afluentes, Pinheiros e Tamanduateí (BÓGUS; VÉRAS, 2000, p. 84)

Destarte, Ab'Sáber (2004b) explana sobre o espaço físico do sítio urbano de São Paulo que influenciou diretamente no progresso econômico e nas características socioambientais da RMSP:

É um sistema de colinas numa espécie de primeiro planalto, muito próximo da zona portuária, a menos de $100 \mathrm{~km}$ do litoral. Basta vencer 50 ou $70 \mathrm{~km}$ e já estamos dentro do porto de Santos, após a barreira da Serra do Mar. O Planalto Paulistano é um extraordinário entroncamento de rotas naturais: rotas para o Vale do Paraíba; rotas que, após a transposição de umas pequenas serrinhas entre Jundiaí e São Roque, nos colocam na depressão periférica paulista a apenas 60 ou $80 \mathrm{~km}$, no máximo, das periferias ocidentais de São Paulo. Ou, ainda, a partir da depressão periférica paulista, podemos seguir caminho de Goiás e o caminho do sul. Podíamos seguir todos os caminhos interiores, já que só muito recentemente houve desdobramentos da circulação, incorporando outros eixos, sobretudo o Vale do Ribeira, na direção de todo o Cone Sul do continente. Ampliação de rotas, de esferas de influência, de intercâmbio social e cultural, de tentáculos e de relações no campo das ideias na busca dos projetos (AB'SÁBER, 2004b, p. 226).

O fato é que a atual configuração socioeconômica ${ }^{20}$ e espacial da metrópole paulista é fruto da "sua posição geográfica e de uma história econômica, de evolução dinâmica, ligada ao desenvolvimento da hinterlândia e à multiplicação das

20 Dados censitários mostram que a RMSP apresenta o maior PIB das regiões metropolitanas brasileiras ( $R \$ 701$ bilhões), equivalente a cerca de $20 \%$ do PIB nacional. A cidade com maior participação no PIB da RMSP é a capital, São Paulo, com valor de R\$ 443 bilhões, representando cerca de $63 \%$ do PIB da RMSP. O setor mais representativo é o de serviços com $62,02 \%$, seguido pela indústria com $20 \%$ de participação no PIB (IBGE, 2010). 
indústrias de transformação de seu parque manufatureiro" (AB'SÁBER, 1954). De forma resumida, Ab'Sáber (2004) narra o histórico da principal cidade da RMSP:

Cidade que foi a cidadela dos jesuítas e dos bandeirantes. A cidade do início do processo industrial e do começo da era ferroviária, refletindo todo o ciclo do café. $\mathrm{E}$, depois, a cidade cujos capitais acumulados extravasam do ciclo do café para o ciclo industrial. $\mathrm{E}$ depois a metrópole cosmopolita e industrializada de nossos dias, que se encontra em um marcante processo de desindustrialização, a par com um excepcional desenvolvimento do mercado (AB'SÁBER, 2004b, p. 226).

\subsubsection{Urbanização na Região Metropolitana de São Paulo}

Fundada pelos jesuítas e bandeirantes, no século XVI, a Vila de São Paulo era um pequeno núcleo urbano com várias igrejas cercada por algumas fazendas que ao longo do tempo foram se multiplicando ( $A B^{`}$ 'SÁBER, 2004c). Foi no século XIX e XX que São Paulo "à sombra do desenvolvimento econômico do café, cresceu desmesuradamente, controlando a um tempo a expansão ferroviária no planalto, a imigração estrangeira e uma industrialização crescente" (AB'SÁBER, 1953, p. 227).

Ab'Sáber (2004c) relata que o processo de urbanização na metrópole paulista se consolidou com a bonança econômica do auge do ciclo do café, nos meados do séc. XIX. Assim, vários fazendeiros construíram suas mansões nos bairros nobres da cidade (Campos Elíseos, Higienópolis e Cerqueira César) devido a facilidade e conforto, uma vez que a capital já contava com faculdades, bancos, hospitais e importantes centros comerciais (AB'SÁBER, 2004d).

Para a aristocracia, a cidade precisava de ares de modernidade, planejamento e higienização. Por isso, no início do século XX. São Paulo se transformou com a construção de largas avenidas, parques e jardins (LOTITO, 2000). A autora relata ainda a construção de várias mansões na avenida Paulista com amplos jardins, além de clubes refinados, como o Jockey Clube, como iniciativas de aparelhamento da cidade para o agrado da elite paulistana.

A concentração econômica da maioria dos barões do café na capital gerou uma rede bancaria expressiva, que indiretamente propiciou o surgimento do maior parque industrial brasileiro (AB'SÁBER, 2004d). Assim, o referido autor relata: 
Entre a Primeira Guerra Mundial e as vésperas da Segunda, o parque industrial paulista cresceu ao longo das ferrovias que cruzavam a cidade, em posição marcadamente intraurbana. Do que resultou a implantação e grande adensamento de bairros proletários à margem dos principais eixos ferroviários, enquanto a alta burguesia e a classe média em ascensão se alojava nos altos (Pacaembu, Morumbi) e encostas de colinas, distantes das estações, dos quartéis e dos bairros de trabalhadores industriais. Os subúrbios paulistanos foram pontilhados por industrias (muitas delas altamente poluidoras) e loteamentos populares, inicialmente malsucedidos. Seria depois - nas últimas três décadas - que ocorreria o maior adensamento periurbano metropolitano da face da Terra. Dos modestos e pacatos subúrbios passou-se para as imensas periferias, desconectadas de um sistema racional de circulação urbana. Novas faixas de industrialização foram criadas ao longo das modernas rodovias que a cidade viu nascer a partir de 1940-1950 (AB'SÁBER, 2004d, p. 272).

Assim, Ab'Sáber (2004c) relata que em um século (metade do séc. XIX até a metade do séc. $\mathrm{XX}$ ) São Paulo conquistou e ocupou todo o sistema de colinas, no compartimento de planalto.

A cidade cresceu por saltação, de colina para colina, ao longo da margem esquerda do Tietê, fugindo dos terrenos brejosos, alagadiços e malsãos dos fundos dos vales. Poupavam-se os vales por incapacidade tecnológica de conquistá-los para o espaço urbano de uma cidade em pleno surto de desenvolvimento. A produção do espaço urbano era necessariamente sincopada a partir do último quartel do século, quando a cidade escapa dos limites topográficos da colina central (AB'SÁBER, 2004e).

Quanto ao crescimento populacional, Taschner; Bógus (2001) ressaltam que esse foi proporcional ao crescimento econômico, sendo o auge da industrialização (décadas de 1950 até 1970) o maior aumento no número de habitantes. Em 1970 a RMSP respondia por mais de $40 \%$ da produção industrial brasileira, e mais de $70 \%$ da produção estadual (TASCHNER; BÓGUS, 2001a). Jannuzzi (2004) registra o salto populacional na RMSP desse período, de 2,6 milhões para 8,15 milhões.

A partir da década de 1970 as taxas de crescimento populacional apresentaram um arrefecimento (JANNUZZI, 2004). O autor relata como motivos, a crise econômica na década de 1980, a descentralização industrial, além da violência e a perda de qualidade de vida na capital paulista.

Ainda assim a RMSP se mantém como a maior malha urbana e populacional brasileira. A Figura 120 mostra a densidade populacional na RMSP, indicando forte concentração populacional por toda RM, principalmente em São Paulo e nas cidades limítrofes. 


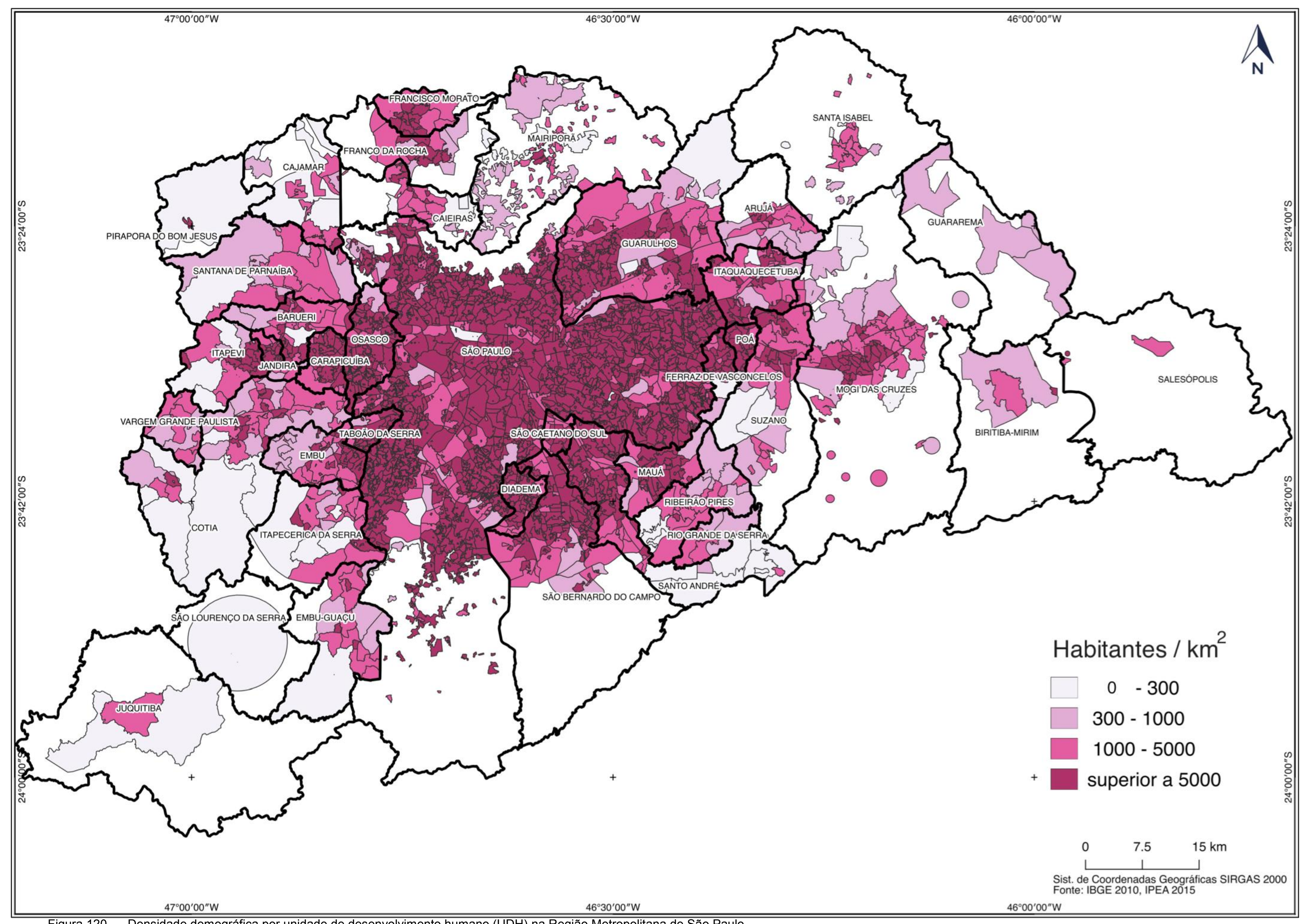

Figura 120 - Densidade demográfica por unidade de desenvolvimento humano (UDH) na Região Metropolitana de São Paulo 
Apesar do status econômico ${ }^{21}$, as ocupações ilegais e as periferias na RMSP têm sido as que mais crescem em relação às outras RMs (TORRES et al., 2003). Saraiva; Marques (2007) dão a dimensão dessa periferização: em uma década (1980 até 1990) a população que morava em aglomerados subnormais da cidade de São Paulo saltou de $1 \%$ para $9 \%$ do total dos habitantes.

O fato é que nos últimos anos, a chamada "cidade informal" cresceu mais que a "regular" (BÓGUS; TASCHNER, 1999). Os novos domicílios em aglomerados subnormais e loteamentos clandestinos superam os lançamentos do mercado imobiliário e a produção de unidades habitacionais pelo poder público (TORRES et al., 2003).

Bógus; Taschner (1999) relacionam a essa periferização, o processo de desconcentração industrial onde muitas indústrias localizadas no RMSP transferiram suas plantas para o interior paulista ou outros estados, nas décadas de 1980 e 1990. Mesmo com a transferência, as indústrias ainda exercem um papel importante junto com as atividades terciárias, destacando-se o comércio e os setor de serviços, sobretudo os de armazenamento e distribuição de mercadorias, situados em Guarulhos e dos municípios do ABC (BÓGUS; VÉRAS, 2000). Complementarmente, Araujo (2001) destaca a concentração do sistema bancário e o desenvolvimento de serviços ligados à tecnologia da informação como grandes propulsores econômicos da RMSP.

Bógus; Véras (2000) citam que em muitas cidades acentuou-se o papel de "dormitórios", onde o crescimento populacional foi exponencial, não acompanhado por melhorias socioeconômicas. Como exemplo, citam as cidades de Arujá, Caieiras, Cajamar, Santana do Parnaíba, Pirapora do Bom Jesus, Itaquaquecetuba.

As autoras afirmam que a maioria das cidades-dormitório se relacionam à expansão de áreas pobres. Assim, Torres et al. (2003) relatam que a periferização levou os moradores mais pobres para regiões cada vez mais distantes e precárias, tanto para o entorno da capital, como para as cidades limítrofes. Bógus; Véras (2000) destacam também que parte da população das cidades-dormitório compõe uma classe-média alta e reside em condomínio de alta renda, como ocorre em Barueri.

${ }^{21}$ De acordo com dados censitários, a RMSP apresenta um elevado nível de renda por domicílios, com valor médio de $\mathrm{R} \$ 175,04$, valor acima da média nacional que é de $\mathrm{R} \$ 949,99$ (IBGE, 2010). 
A Figura 121 indica a vulnerabilidade social por UDH. Ela ratifica as análises anteriores, onde a região central da RMSP (capital) apresenta a maior mancha de baixa vulnerabilidade social (azul), enquanto nas periferias a vulnerabilidade social aumenta. Notam-se pouquíssimas UDHs classificadas como muito alta (vermelho), poucas áreas como alta (laranja) e muitas áreas como média (amarelo) vulnerabilidade social. No geral, a Figura 120 aponta áreas de baixa e média vulnerabilidade social em todo território da RMPS, ratificando o estudo de Bógus; Taschner (1999) onde as autoras afirmam que a RMSP possui uma estrutura espacial não dual.

No entanto, Taschner; Bógus, (2001b) relatam a existência de espaços fortemente segregados, principalmente com a crescente onda de condomínios fechados e o número expressivo de aglomerados subnormais na RMSP $(10,08 \%$ dos domicílios). Assim Bógus; Taschner (1999) classificam a RMSP como um "espaço que tende mais à fragmentação do que à dualização e onde a polarização social é extremamente forte" (BÓGUS; TASCHNER, 1999, p. 170).

Embora a Figura 121 não dê destaque a alta vulnerabilidade social na RMSP, é importante destacar que a pobreza e miséria estão presentes. Martins (2006) destaca na RMSP aquela vulnerabilidade social ignorada pelas estatísticas nacionais, representada pelos moradores de ruas que se instalam nas praças, pontes e viadutos e se espalham nas cidades. De acordo com informações da prefeitura paulistana, a capital possui cerca de 25 mil moradores de rua, $40 \%$ a mais do que o último levantamento realizado em 2015 (VILARDAGA, 2017). 


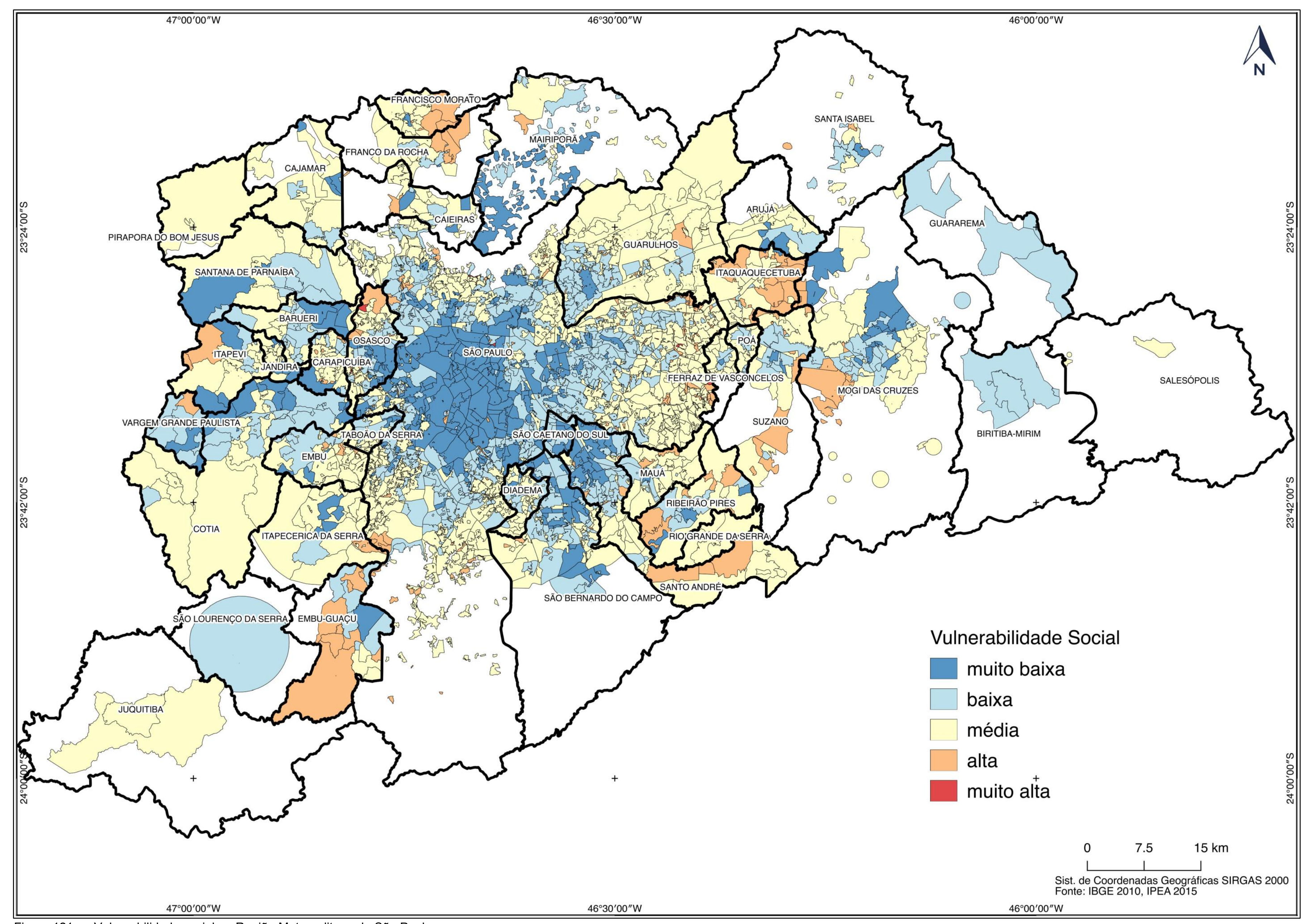

Figura 121 - Vulnerabilidade social na Região Metropolitana de São Paulo 
O resultado das grandes áreas urbanas sem planejamento resultou na má ocupação do espaço, saneamento básico e serviços básicos de saúde precários, ineficiência de transporte público, violência, etc. (TORRES et al., 2003). Saraiva; Marques (2007) relatam que, para agravar, a maioria dos aglomerados subnormais da RMSP estão localizados em áreas non edificante, geralmente em áreas de proteção ambiental e que oferecem riscos. Bógus, Véras (2000) destacam as cidades de São Bernardo do Campo e Santo André como exemplos de ocorrência de vários casos de ocupações irregulares, sobretudo em áreas de proteção de mananciais por população de baixa renda.

Outra preocupação constante, quanto à gestão da RMSP, se concentra sobre os problemas ambientais, como por exemplo: a impermeabilização do solo (causador de enchentes), as poluições atmosféricas, a falta d'água e diminuição da cobertura vegetal, principalmente das áreas de preservação permanente nas margens dos rios (JACOBI, 1993).

Para Jacobi (1993), a importância dos espaços verdes vem sido amplamente debatida como agente minimizador dos referidos problemas ambientais. Ab'Sáber (2004b) também destaca a importância dos espaços verdes para melhoria da qualidade de vida (âmbitos social e cultural), principalmente nas áreas periféricas de São Paulo.

\begin{abstract}
Elas não têm um pouco de verde. A dificuldade de se implantar o verde é enorme, apesar da qualidade geral do clima que está sobre aquele conjunto de humanidade urbana. Não existe outro elemento além de ruas e casas mal ajambradas, posto que sólidas. As pessoas saem muito cedo e voltam muito tarde. Voltam tarde e se veem na contingência de dormir o mais cedo possível, depois de uma curta sessão de TV. O benefício da televisão é o único elemento de fluxo da civilização ocidental, ao qual se reduz sua vida social e cultural (AB'SÁBER, 2004c, p. 231).
\end{abstract}

Estudo realizado por Jacobi (1999) na cidade de São Paulo mostra que áreas mais ricas possuem $73 \%$ de pessoas que moram próximas à parques e espaços verdes públicos, enquanto nas áreas pobre o número cai para $40 \%$. "Estes dados nada mais fazem senão reforçar o caráter de uma urbanização desigual, onde problemas ambientais seletivos afetam também desigualmente os moradores urbanos" (JACOBI, 1999, p. 50). Assim, a presente análise se faz necessário não apenas para validar ou refutar as referidas afirmações, mas sobretudo para 
vislumbrar alternativas à gestão urbana que concilie o aumento dos espaços verdes com desenvolvimento urbano sustentável.

\subsubsection{Espaços Verdes Urbanos na Região Metropolitana de São Paulo}

O mapeamento identificou a porção de $1.839,36 \mathrm{~km}^{2}$ de espaços verdes urbanos no recorte proposto, a maior quantidade dos EVU das amostras analisadas. Esse valor corresponde a $40 \%$ da área analisada da RMSP. A Tabela 21 mostra a proporção das áreas analisadas e dos espaços verdes urbanos.

Em uma análise visual, percebe-se que os espaços verdes da RMSP estão em maior quantidade nas áreas periféricas (bordas) (Figura 122). Esses espaços verdes das bordas compõem aquilo que se entende de cinturão verde do planalto paulistano (AB`SÁBER, 2004a), também descrito por Mello-Théry (2011):

A concentração de áreas de matas nas periferias das zonas sulsudoeste-oeste e o norte (o Parque Estadual da Cantareira, o pico do Jaraguá), enquanto nas zonas sul-sudeste, leste, nordeste e noroeste, identifica-se a reduzida presença de mata (nativa ou reconstituída), apenas na APA Capivari-Monos (zona de amortecimento do Parque Estadual da Serra do Mar), ou as nascentes das represas Billings e Guarapiranga. A mancha urbana se espalha seguindo o traçado das principais rodovias que convergem para São Paulo. Nos bairros e municípios localizados a noroeste da Região Metropolitana cortados pelas vias Anhanguera e Bandeirantes, encontram-se apenas resquícios de mata, tendo a urbanização fragmentada se espraiado sobre áreas mais íngremes ou de riscos (MELLO-THÉRY, 2011, p. 181).

As cidades que apresentaram maior cobertura vegetal foram: Cotia $(190,9$ km²), Guarulhos $\left(133,31 \mathrm{~km}^{2}\right)$ e Santana do Parnaíba $\left(120,57 \mathrm{~km}^{2}\right)$. A capital São Paulo apresentou 110,37 km², o que representa apenas 10,40\% de EVU. A RMSP foi o único caso onde a capital metropolitana não apresentou maior quantidade de EVU.

Em termos de porcentagem de EVU em relação à área analisada, as cidades de Juquitiba (81,13\%), São Lourenço da Serra (80,84\%), Embu-Guaçu $(70,47 \%)$, Rio Grande da Serra $(69,83 \%)$ e Santana do Parnaíba $(66,39 \%)$ apresentaram as maiores proporções.

A cidade que apresentou menor quantidade de espaços verdes foi São Caetano do Sul $\left(0,27 \mathrm{~km}^{2}\right)$. O que é justificável ao constatar que ela apresenta uma malha urbana bastante densa, em virtude da alta densidade populacional em um território relativamente pequeno $\left(15,47 \mathrm{~km}^{2}\right)$. 
Tabela 21 - Espaços verdes urbanos por cidade na Região Metropolitana de São Paulo

\begin{tabular}{|c|c|c|c|c|}
\hline UF & Cidades & Área $\mathrm{Km}^{2}$ & EVU km² & \% EVU/Área \\
\hline & ARUJÁ & 58,74 & 28,35 & 48,27 \\
\hline & BARUERI & 66,29 & 16,03 & 24,18 \\
\hline & BIRITIBA-MIRIM & 71,12 & 29,61 & 41,63 \\
\hline & CAIEIRAS & 43,95 & 25,96 & 59,07 \\
\hline & CAJAMAR & 149,88 & 79,34 & 52,94 \\
\hline & CARAPICUÍBA & 34,90 & 7,43 & 21,29 \\
\hline & COTIA & 326,97 & 190,90 & 58,38 \\
\hline & DIADEMA & 31,08 & 4,38 & 14,09 \\
\hline & EMBU & 71,15 & 38,42 & 54,01 \\
\hline & EMBU-GUAÇU & 133,49 & 94,07 & 70,47 \\
\hline & FERRAZ DE VASCONCELOS & 16,91 & 3,68 & 21,77 \\
\hline & FRANCISCO MORATO & 43,54 & 15,14 & 34,78 \\
\hline & FRANCO DA ROCHA & 53,96 & 22,34 & 41,40 \\
\hline & GUARAREMA & 99,34 & 32,26 & 32,48 \\
\hline & GUARULHOS & 321,62 & 133,31 & 41,45 \\
\hline & ITAPECERICA DA SERRA & 135,38 & 85,23 & 62,96 \\
\hline & ITAPEVI & 83,42 & 46,17 & 55,35 \\
\hline & ITAQUAQUECETUBA & 83,37 & 26,07 & 31,27 \\
\hline & JANDIRA & 17,61 & 6,21 & 35,26 \\
\hline \multirow[t]{21}{*}{ SP } & JUQUITIBA & 125,22 & 101,59 & 81,13 \\
\hline & MAIRIPORÃ & 99,36 & 57,22 & 57,59 \\
\hline & MAUÁ & 62,43 & 15,91 & 25,48 \\
\hline & MOGI DAS CRUZES & 224,91 & 92,11 & 40,96 \\
\hline & OSASCO & 65,69 & 7,65 & 11,64 \\
\hline & PIRAPORA DO BOM JESUS & 100,84 & 64,45 & 63,91 \\
\hline & POÁ & 15,83 & 4,35 & 27,47 \\
\hline & RIBEIRÃO PIRES & 100,02 & 64,69 & 64,68 \\
\hline & RIO GRANDE DA SERRA & 36,67 & 25,61 & 69,83 \\
\hline & SALESÓPOLIS & 7,21 & 1,20 & 16,59 \\
\hline & SANTA ISABEL & 24,46 & 6,84 & 27,95 \\
\hline & SANTANA DE PARNAÍBA & 181,59 & 120,57 & 66,39 \\
\hline & SANTO ANDRÉ & 177,39 & 99,61 & 56,15 \\
\hline & SÃO BERNARDO DO CAMPO & 149,21 & 39,58 & 26,52 \\
\hline & SÃO CAETANO DO SUL & 15,47 & 0,27 & 1,77 \\
\hline & SÃO LOURENÇO DA SERRA & 107,55 & 86,94 & 80,84 \\
\hline & SÃO PAULO & 1061,52 & 110,37 & 10,40 \\
\hline & SUZANO & 103,54 & 31,39 & 30,32 \\
\hline & TABOÃO DA SERRA & 20,57 & 3,89 & 18,93 \\
\hline & VARGEM GRANDE PAULISTA & 42,87 & 20,24 & 47,20 \\
\hline & Total & 4565,05 & 1839,36 & 40,29 \\
\hline
\end{tabular}

Fonte: Elaborada pelo autor 


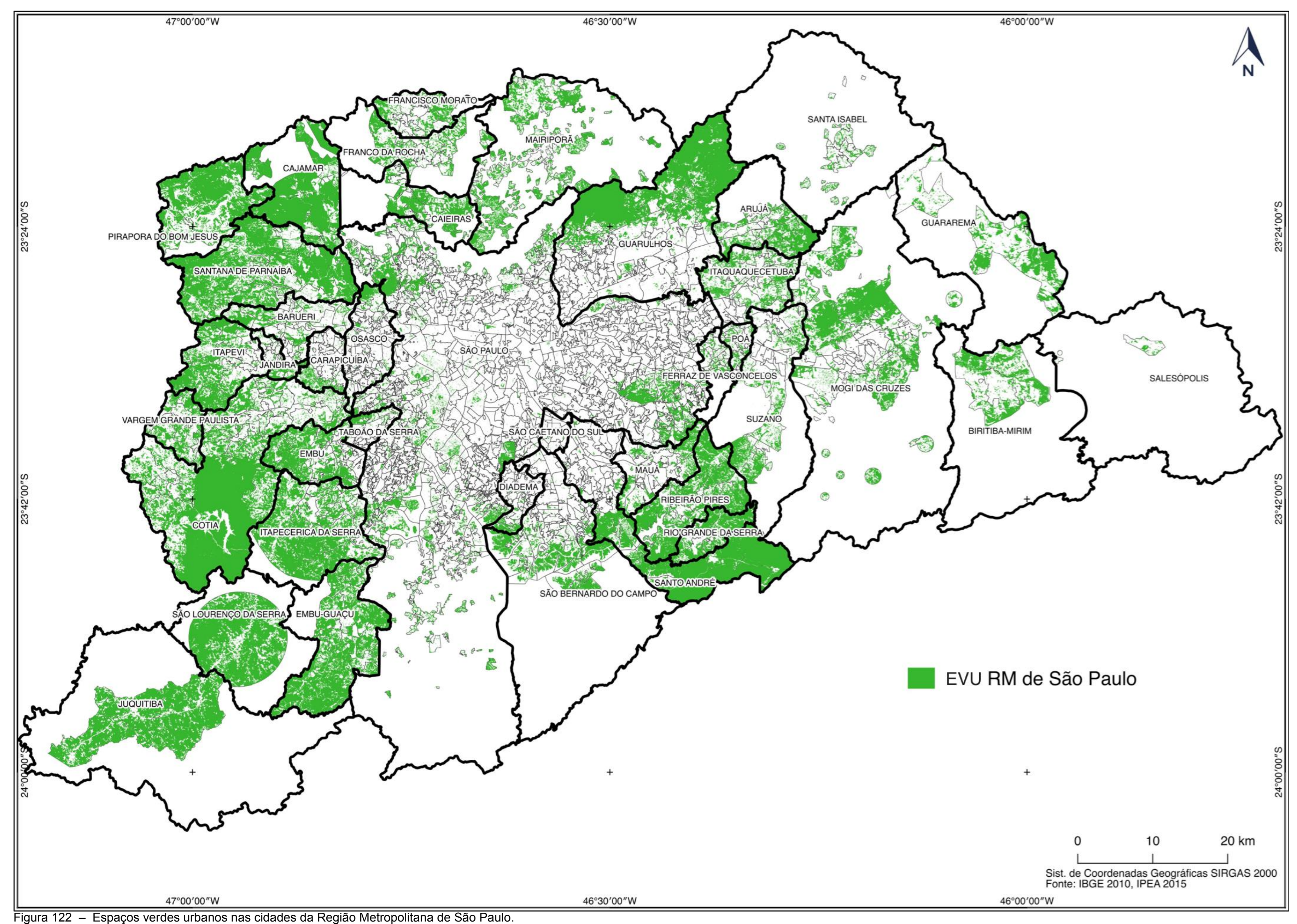




\subsubsection{Espaços Verdes Urbanos e Unidades de Conservação da Natureza}

Como já explanado, nas áreas de borda da RMSP há um cinturão verde que remetem às áreas protegidas. Ab'Sáber (2004e) afirma que na década de 1970 houve uma pressão do movimento ambientalista para que elas fossem efetivamente preservadas.

Por uma questão de consciência científica e interdisciplinária, e uma somatória de bons conhecimentos sobre a geografia do Planalto Atlântico paulista, aliados à visualização que se possuía sobre o lamentável quadro de devastação que ocorria nos planaltos interiores do estado de São Paulo, estimulou-se o movimento que culminou em uma defesa racional e inflexível da vegetação primária remanescente no entorno da colinosa bacia de São Paulo. Para obter o sucesso que causou a campanha pública de defesa integrada dos ecossistemas florestais biodiversos das serrinhas, foram usados argumentos cruzados entre si, que até hoje - 25 anos decorridos - ainda são válidos e irretocáveis (AB`SÁBER, 2004a, p. 365).

Afora a importância ecológica e a fragilidade ambiental, Ab'Sáber cita fatores preponderantes para o reconhecimento legal da proteção do cinturão verde. O primeiro diz respeito "a proteção de componentes topográficas florestadas capazes de reter a expansão incontrolável da mancha urbana" e o segundo relaciona-se com o "resguardo inflexível das águas e mananciais das serrinhas e escarpas florestadas para abastecimento de um vasto estoque de humanidade" (AB'SÁBER, 2004a, p. 366).

Assim, Ab'Sáber (2004e) narra que a primeira ação governamental para proteção do cinturão verde foi realizado em 1984. Por meio do Decreto Estadual $n^{\circ}$ 22.717 (SÃO PAULO, 1984) foi declarada e institucionalizada a nível estadual a APA da Serra do Mar.

Emerge também da década de 1980 o pedido de reconhecimento internacional, por meio da UNESCO (Organização das Nações Unidas para a Educação, Ciência e Cultura), de uma Reserva da Biosfera (RB $)^{22}$. O título de RB do Cinturão Verde da Cidade de São Paulo foi alcançado em junho de 1994, ao qual abrange área de mata atlântica que se estende em 73 municípios (INSTITUTO FLORESTAL, 2010)

\footnotetext{
22 A Reserva da Biosfera é uma figura instituída pela UNESCO para abrigar uma rede de áreas, no globo, de relevante valor ambiental para a humanidade. Representa um forte compromisso do Governo local, perante seus cidadãos e a comunidade internacional que realizará os esforços e atos de gestão necessários para preservar essas áreas e estimular o Desenvolvimento Sustentável, dentro do espírito da solidariedade universal (INSTITUTO FLORESTAL, 2010).
} 
Menarin (2013) narra que esta RB constitui no exemplo mais marcante de conflitos decorrentes do processo de urbanização e industrialização. Ademais, ela engloba a maior malha urbana do país, agregada a uma das áreas mais representativas de mata atlântica onde historicamente há produção agrícola que abastece a metrópole paulista (MENARIN, 2013).

Menarin (2013) e Mello-Théry (2011) reforçam a ideia de que a criação desta RB veio para facilitar a implantação de projetos e programas de nível internacional (principalmente ligados à Agenda XXI e ODM) e ao mesmo tempo articular gestão com base na participação da população local afim de solucionar os conflitos existentes e promover a preservação ambiental.

Dentro da área analisada, as maiores manchas dos espaços verdes urbanos fazem parte da RB do Cinturão Verde. De acordo com a base de dados do SNUC disponível no site do ICMBio (2010), dentro do recorte proposto das áreas analisadas existem trinta UCs o que representa $20 \%$ do total da área analisada (Tabela 22 e Figura 123), sendo a sua maioria (82,58\%) consideradas APAs e (14\%) parques estaduais (Tabela 23). Quanto à relação com espaços verdes urbanos verdes observa-se que as áreas protegidas apresentam uma quantidade considerável de EVU (64\%).

$O$ fato da maior parte do cinturão ser APA (permite ocupação) justifica a grande pressão do avanço da malha urbana sobre a referida RB. Menarin (2013) narra que o período de 1986 até 1999, 30\% da cobertura vegetal da RB foi desmatada. Para agravar, a maior incidência de desmatamento foram nas áreas dos mananciais Billings e Guarapiranga e na Serra da Cantareira, mais próximas à malha urbana (MENARIN, 2013). 
Tabela 22 - Espaços verdes urbanos por Unidades de Conservação da Natureza

\begin{tabular}{|c|c|c|c|}
\hline Nome da Área Protegida & Área km² & EVU km² & \% EVU/Área \\
\hline APA BACIA DO PARAÍBA DO SUL & 83,40 & 61,68 & 73,95 \\
\hline APA BORORÉ-COLÔNIA & 10,34 & 3,16 & 30,54 \\
\hline APA CABREUVA & 1,14 & 1,03 & 90,72 \\
\hline APA CAJAMAR & 97,42 & 78,97 & 81,06 \\
\hline APA ITUPARARANGA & 113,57 & 48,26 & 42,49 \\
\hline APA JUNDIAÍ & 1,76 & 1,36 & 77,44 \\
\hline APA MUNICIPAL DO CAPIVARI-MONOS & 4,80 & 1,98 & 41,16 \\
\hline APA PARQUE E FAZENDA DO CARMO & 8,61 & 6,37 & 73,97 \\
\hline APA PIRACICABA JUQUERI-MIRIM AREA II & 0,07 & 0,07 & 98,61 \\
\hline APA SERRA DO MAR & 31,15 & 24,85 & 79,76 \\
\hline APA SISTEMA CANTAREIRA & 98,07 & 56,44 & 57,55 \\
\hline APA VÁRZEA DO RIO TIETÉ & 88,19 & 27,56 & 31,25 \\
\hline ESTAÇÃO ECOLÓGICA DE ITAPETI & 0,89 & 0,89 & 100,00 \\
\hline FLORESTA ESTADUAL GUARULHOS & 0,92 & 0,86 & 93,03 \\
\hline PARQUE NATURAL MUNICIPAL BORORÉ & 0,002 & 0,001 & 49,44 \\
\hline PARQUE NATURAL MUNICIPAL ESTORIL & 0,38 & 0,27 & 69,82 \\
\hline PARQUE NATURAL MUNICIPAL FAZ. DO CARMO & 4,49 & 4,04 & 90,06 \\
\hline PARQUE NATURAL MUNICIPAL JACEGUAVA & 0,02 & 0,01 & 60,22 \\
\hline PARQUE NATURAL MUNICIPAL PARANAPIACABA & 4,26 & 4,25 & 99,74 \\
\hline PARQUE NATURAL MUNICIPAL VARGINHA & 0,04 & 0,04 & 98,65 \\
\hline PE ALBERTO LOFGREN & 0,07 & 0,01 & 8,50 \\
\hline PE DA CANTAREIRA & 27,03 & 26,36 & 97,52 \\
\hline PE DA SERRA DO MAR & 1,88 & 1,63 & 86,63 \\
\hline PE DAS FONTES DO IPIRANGA & 0,33 & 0,03 & 9,80 \\
\hline PE DE ITABERABA & 60,66 & 58,19 & 95,92 \\
\hline PE DE ITAPETINGA & 2,74 & 2,34 & 85,41 \\
\hline PE DO JARAGUÁ & 4,89 & 4,62 & 94,41 \\
\hline PE DO JUQUERY & 2,65 & 1,15 & 43,31 \\
\hline RPPN BOTUJURU-SERRA DO ITAPETY & 2,29 & 2,29 & 99,96 \\
\hline RPPN MUTINGA & 0,03 & 0,02 & 56,50 \\
\hline Total & 652,09 & 418,70 & 64,21 \\
\hline Total UDH Analisada & 4565,05 & 1839,36 & 40,29 \\
\hline \% Total Área Protegida/Total Analisado & 14,28 & 22,76 & \\
\hline
\end{tabular}

Fonte: Elaborada pelo autor

Tabela 23 - Espaços verdes urbanos por Unidade de Conservação da Natureza

\begin{tabular}{llllll}
\hline Tipo & Área $\mathrm{km}^{2}$ & EVU km & $\%$ Área & $\%$ EVU & $\%$ EVU/Área \\
\hline APA & 538,52 & 311,71 & 82,58 & 74,57 & 57,88 \\
Estação Ecológica & 0,89 & 0,89 & 0,14 & 0,21 & 100,00 \\
Floresta Estadual & 0,92 & 0,86 & 0,14 & 0,21 & 93,03 \\
PN Municipal & 9,19 & 8,60 & 1,41 & 2,06 & 93,67 \\
PE & 100,26 & 94,32 & 15,37 & 22,56 & 94,08 \\
RPPN & 2,32 & 2,30 & 0,36 & 0,55 & 99,45 \\
\hline Total & 652,09 & 418,70 & 100,00 & 100,17 & 64,21 \\
\hline \hline
\end{tabular}

Fonte: Elaborada pelo autor 


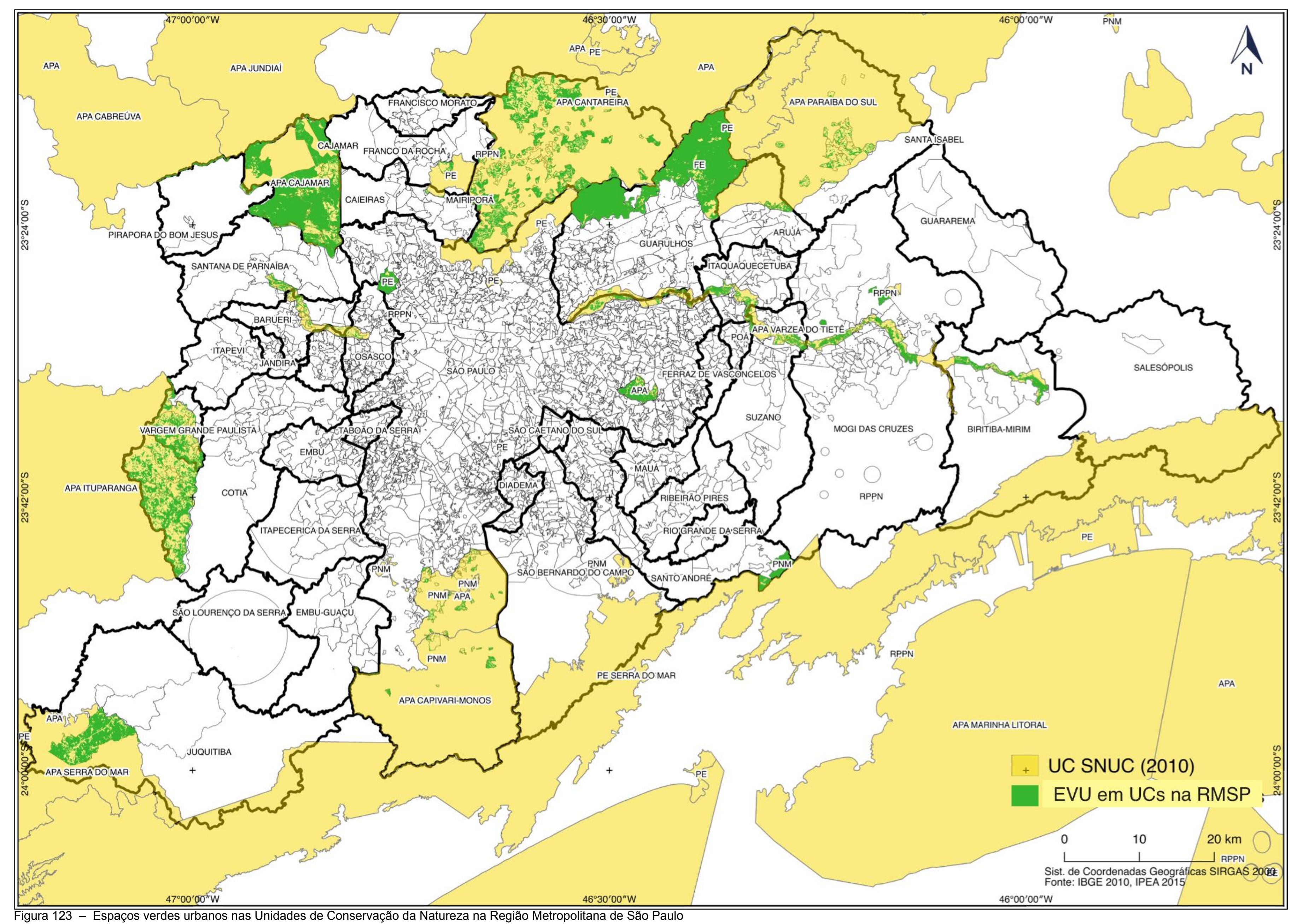


Afora as Uinidades de Conservação da Natureza, Mello-Théry (2011) cita as áreas de proteção de mananciais $\left(\mathrm{APM}^{23}\right)$ como um importante elemento na gestão metropolitana. A instituição das APMs, na década de 1970, remonta a constatação de que as áreas de mananciais já eram alvos da expansão da mancha urbana, fato agravado quando se percebeu o deslocamento das populações mais carentes para as áreas periféricas (MELLO-THÉRY, 2011).

\begin{abstract}
A ação pública mostra, assim, seu discurso antagônico à sua ação: insiste em ampliar as áreas protegidas, porém não consegue manter longe das ocupações ou mesmo de bairros regulares os mananciais fundamentais para o abastecimento da cidade (MELLO-THÉRY, 2011, p. 185).
\end{abstract}

Ainda com a existência das APMs, apenas $50 \%$ da água consumida na RMSP é "produzida" por elas, em especial dos sistemas Billings-Guarapiranga, Alto Tietê e Cantareira (Figura 124). A outra parte é importada da Bacia do Rio Piracicaba (70 km da capital). Ab'Sáber (2004e) cita a Serra da Cantareira como o exemplo maior das APMs da RMSP, a seguir a constatação do referido autor sobre a pressão antrópica nessa serra:

\begin{abstract}
A serra é um edifício geológico, um patrimônio geomorfológico, e um grande reduto de florestas tropicais de planaltos, até há pouco tempo intocado. Mas ela vem sofrendo duras pressões socialmente paradoxais: os ricos, ocupando loteamentos clandestinos a partir dos morros e patamares de morros de Mairiporã para os reveses da serra; os pobres, pressionando para invadir a base da serrania florestada, a partir de seus piemontes. Uns para chegar até aos altos da serra e escapar à poluição da Metrópole; outros tentando subir as encostas baixas da serra para obter, por invasão, um pedaço de chão pseudourbano (AB`SÁBER, 2004a, p. 369).
\end{abstract}

Dada a importância da Serra da Cantareira sobretudo pelo potencial para abastecimento hídrico da população, sendo responsável por abastecer oito milhões de pessoas (JACOBI; CIBIM; LEÃO, 2015), é importante considerar que: "tudo leva a exigir que a ênfase da proteção integrada da Serra da Cantareira seja conduzida com inteligência e espírito de gerenciamento e planos estratégicos" (AB'SÁBER, 2004a, p. 369). No entanto, a ausência desses planos estratégicos agregados às secas prolongadas e a incapacidade de comunicação e diálogo dos gestores levaram a maior crise hídrica da RMSP, no ano de 2015 (JACOBI; CIBIM; LEÃO, 2015).

23 As APMs foram instituídas pelas Leis Estaduais ( $n^{\circ} 898 / 75$ e 1171/76). A primeira lei visa a disciplina no uso do solo nas áreas de interesse hidrológico da RMSP e a segunda delimita as referidas áreas. 
Afora o sistema Cantareira (ao norte) Moroz; Canil; Ross (1994) enfatizam a grande pressão imobiliária das APMs da porção sul da RMSP que envolvem os sistemas de abastecimento: Billings-Guarapiranga e Alto Tietê. Mello-Théry (2011) também relatou essa pressão sobre a área, especificamente próxima da represa Billings, possui uma elevada densidade populacional, com novos polos industriais e de serviços. Ademais, verifica-se que as antigas chácaras transformaram-se em áreas de lazer ou em espaços de avanço de moradias periféricas (MELLO-THÉRY, 2011).

Ao cruzar os dados dos espaços verdes urbanos com as APMs de São Paulo, observa-se que elas ainda concentram grandes porções de cobertura vegetal $(63,16 \%)$, vide Tabela 24 e Figura 124. Observa-se que a APM localizada ao norte da RMSP apresenta a maior quantidade de EVU $(74,58 \%)$ em relação às do sul $(61,63 \%)$. Porém, deve-se considerar a grande área de APM ao sul dentro da área analisada $\left(1380,2 \mathrm{~km}^{2}\right)$, evidenciando mais uma vez a pressão antrópica sobre importantes áreas protegidas.

Tabela 24 - Espaços verdes urbanos na Áreas de Proteção de Mananciais

\begin{tabular}{llll}
\hline APM & Área $\mathbf{K m}^{2}$ & $\mathbf{E V U ~ k m}^{2}$ & $\%$ EVU/Área \\
\hline Norte (Cantareira) & 185,3 & 138,21 & 74,58 \\
Sul (Billings-Guarapiranga / Alto Tietê) & 1380,2 & 850,67 & 61,63 \\
\hline Total & 1565,5 & 988,88 & 63,16 \\
\hline \hline
\end{tabular}

Fonte: Elaborada pelo autor

Constata-se assim que a lei por si, não garante a proteção e preservação de áreas prioritárias. Mello-Théry (2011) e Moroz; Canil; Ross (1994) relatam a importância da articulação das políticas públicas, principalmente as de preservação ambiental e moradias. Mello-Théry (2011) e Jacobi; Cibim; Leão (2015) consideram sobretudo a importância da governança e melhoria na participação social nas tomadas de decisões, principalmente na gestão dos recursos hídricos.

As políticas públicas não podem ser fonte de conflitos; antes disso, precisam ser articuladas, estar coesas para conquistar que as populações se envolvam e passem a defender a qualidade ambiental e não as antagonizem. Além de melhorar a governança para o envolvimento das populações deve servir também para que vejam as áreas verdes como elementos importantes para a manutenção do próprio funcionamento do sistema urbano e da qualidade ambiental de seus territórios (MELLO-THÉRY, 2011, p. 186) 


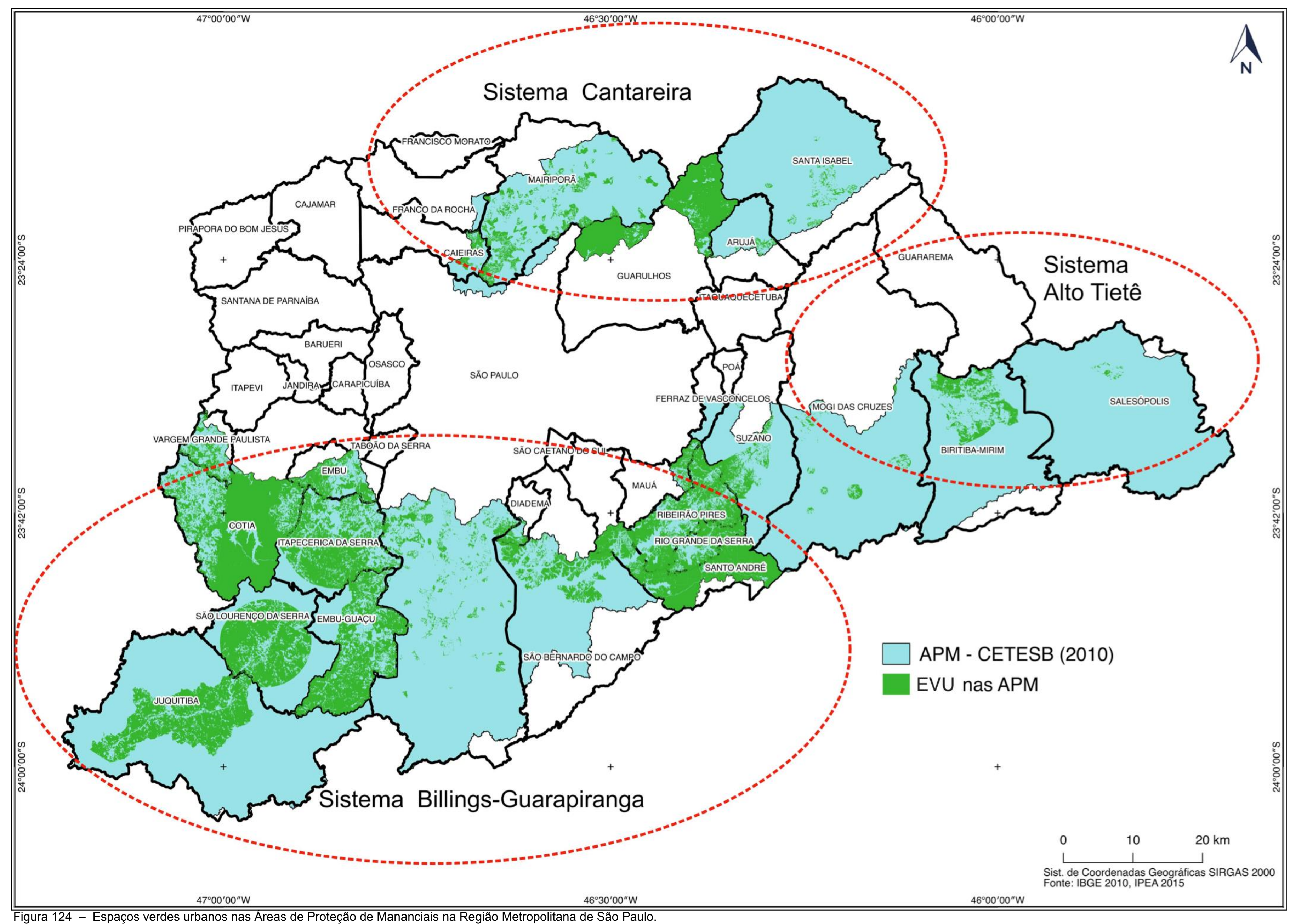


Agregam-se às citadas áreas protegidas os parques urbanos da RMSP. Mello-Théry (2011) destaca que o município de São Paulo instituiu a política municipal de Áreas Verdes (Lei Municipal no 13.430 - SÃO PAULO, 2005). A autora cita que essa legislação "trata a vegetação como elemento integrador na paisagem urbana, incorporando superfícies significativas ao Sistema de Áreas Verdes do município" (MELLO-THÉRY, 2011, p. 183).

A mesma autora remonta que os planos de espaços verdes no município de São Paulo são antigos. Ainda na década de 1960, a prefeitura desenvolveu um plano que categorizou e mapeou os espaços verdes de recreação (Figura 125). Em 1984, o Plano Diretor indicava a insuficiência de áreas para instalação de parques urbanos necessários à população. Em 2002, o plano diretor estabeleceu a política de ampliação dos espaços verdes por habitantes (MELLO-THÉRY, 2011).

$\mathrm{Na}$ prática, de 2005 até 2010 houve uma crescimento de nove $\mathrm{km}^{2}$ de espaços verdes devidamente estruturados em parques, jardins e canteiros centrais (MELLO-THÉRY, 2011). Essas áreas estão disponíveis no site da prefeitura, inclusive em formato vetorial (shapefile), onde foram espacializadas na Figura 125. 


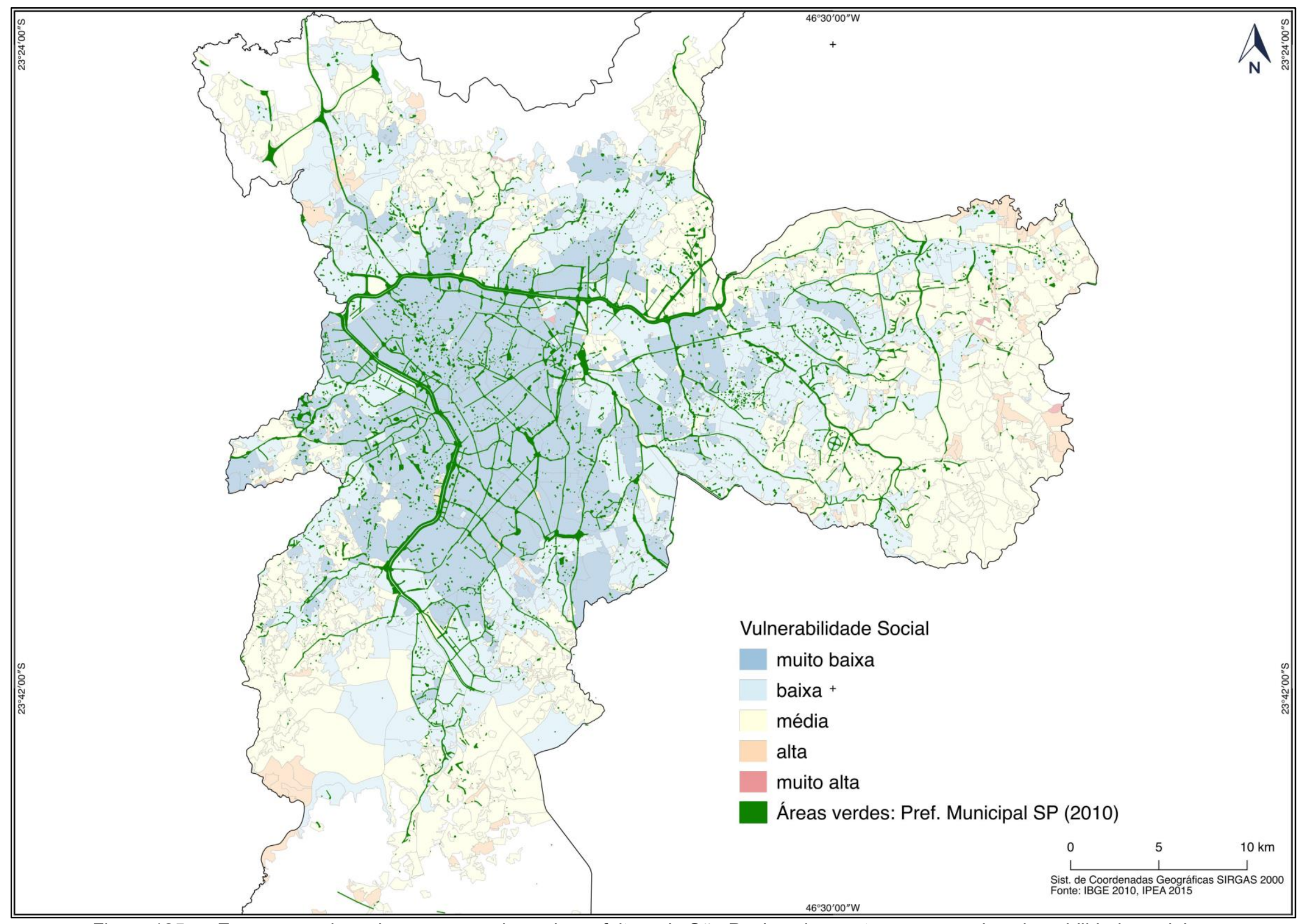

Figura 125 - Espaços verdes urbanos mapeados pela prefeitura de São Paulo sobrepostos ao mapa de vulnerabilidade social 
Nota-se que a maior parte dessas áreas estão concentradas na zona central de São Paulo, sobretudo onde a vulnerabilidade social é baixa. Usando essa mesma caracterização, Ab'Sáber (2004e) disserta da seguinte maneira sobre a quantidade dos espaços verdes na cidade de São Paulo:

O que restou de parques e jardins de bairros é muito reduzido e insuficiente para o nível de adensamento e verticalização ocorrido nos confins da Metrópole Central expandida. Merecem destaque a difusa somatória de arvoredos seletivos que margeiam os chamados bairros jardins paulistanos, incluindo-se entre eles alguns setores do Morumbi e Pacaembu, bairros que comprovadamente atenuam localmente a célula de calor que incidiu sobre São Paulo no decorrer do século XX (AB`SÁBER, 2004a, p. 168).

À medida que se distancia do cinturão intermediário, a carência de espaços públicos abertos e arborizados torna-se dramática pela sua pobreza, rusticidade e descuido. Nessas periferias carentes a disputa por pequenos espaços de lazer é uma constante. Crianças e adolescentes utilizam os pequenos campinhos de terra batida aos sábados, domingos e feriados, para o seu pequeno jogo de futebol. Os espaços utilizados para essa atividade esportiva quase única pertencem a particulares, a empresas ou ao município. Muitas vezes, porém - para frustração das crianças - os proprietários resolvem construir ou lotear as glebas que lhes pertencem, bloqueando qualquer possibilidade de uso para lazer nos aludidos terrenos (AB'SÁBER, 2004a, p. 168).

\subsubsection{Espaços Verdes Urbanos nas Unidades de Desenvolvimento Humano}

A Figura 126 indica a proporção de EVU por UDH. As menores porcentagem de EVU estão localizadas no centro da RMSP, nas áreas de maior densidade demográfica, sobretudo na cidade de São Paulo. A maior mancha da classe (0 $30 \%$ de EVU - área em marrom) corresponde a aproximadamente a $40 \%$ da área analisada, concentrando apenas $6 \%$ dos espaços verdes mapeados, abrangendo 28 cidades e $81 \%$ de toda população da área analisada.

Estudo realizado por Sepe; Takiya (2004) para o Atlas Ambiental do Município de São Paulo ratifica os dados anteriores. Ele relata que $48 \%$ da cidade de São Paulo (sobretudo área central e zona leste) é carente de cobertura vegetal, seja por maciços grandes, parque praças ou mesmo arborização de vias públicas. $O$ estudo ressalta ainda que $75 \%$ da cobertura vegetal existente se concentra na zonas sul e norte da cidade e se relacionam com áreas protegidas (SEPE; TAKIYA, 2004). 
Esta classe $(0-30 \%$ de EVU) também encontra-se nas áreas mais urbanizadas e populosas das cidades mais periféricos da RMSP, como: Salesópolis, Biritiba-Mirim, Guararema, Santa Isabel, Mairiporã, Caieiras, Francisco Morato, Franco da Rocha, Pirapora do Bom Jesus, Vargem Grande Paulista e Embu-Guaçu.

As demais classes estão concentradas nas áreas mais periféricas da RMSP, ou seja, no cinturão verde onde concentra-se a maioria das áreas protegidas da RM. Das UDHs com quantidade intermediária de EVU (30\% a 60\% - em verde claro) no interior da maior mancha (em marrom) destacam-se: Morumbi, Jardins e Cidade Universitária (USP). Sobre esses espaços verdes Ab'Sáber (2004e) narra:

Por sua vez, o Campus da Cidade da Universidade de São Paulo e o Instituto Butantã conseguiram manter uma excelente arborização ao par com pequenos tratos de biodiversidade. O que restou de parques e jardins de bairros é muito reduzido e insuficiente para o nível de adensamento e verticalização ocorrido nos confins da Metrópole Central expandida. Merecem destaque a difusa somatória de arvoredos seletivos que margeiam os chamados bairros jardins paulistanos, incluindo-se entre eles alguns setores do Morumbi e, bairros que comprovadamente atenuam localmente a célula de calor que incidiu sobre São Paulo no decorrer do século XX (AB'SÁBER, 2004a, p. 368). 


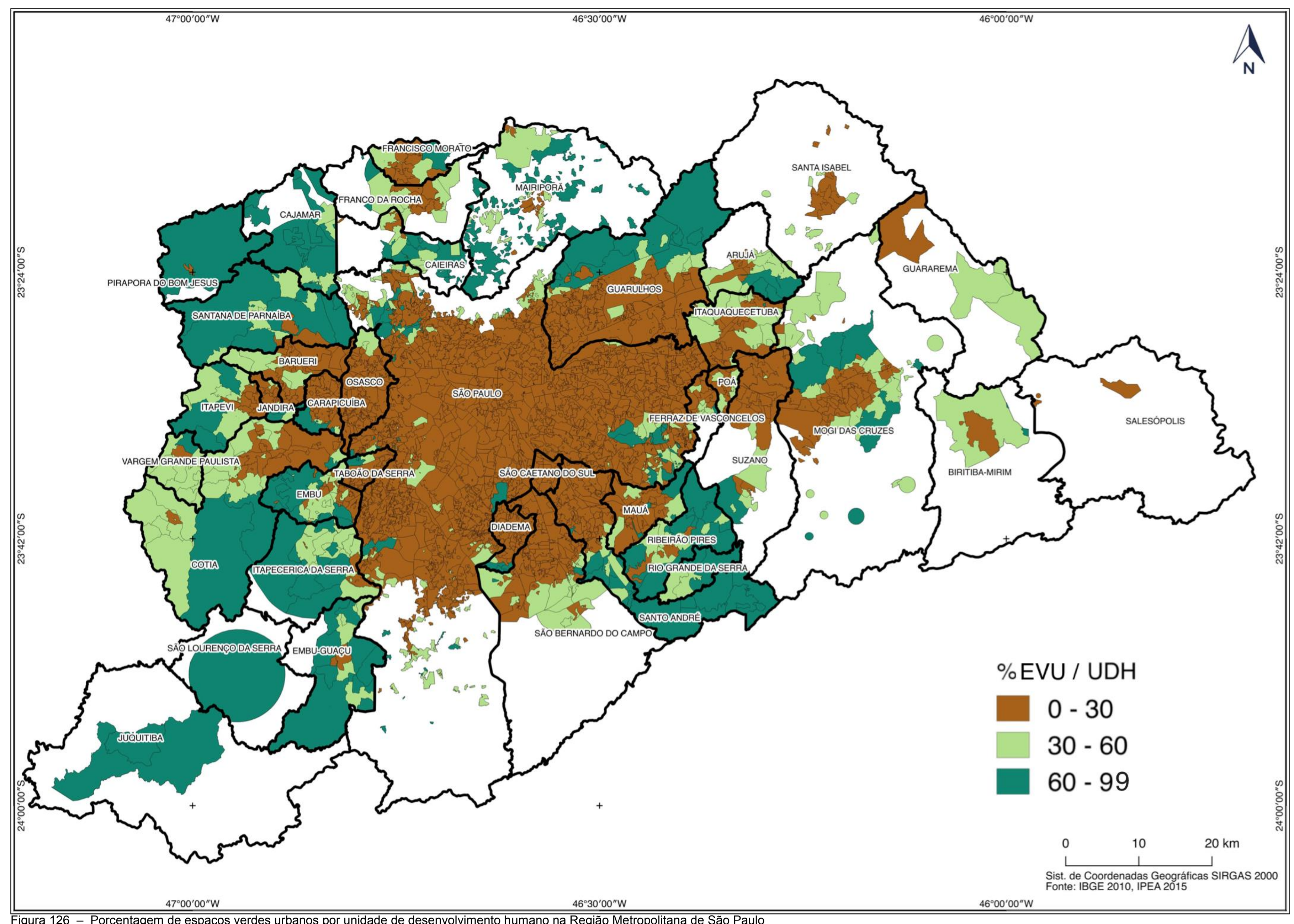


Quanto as UDHs com maior quantidade de EVU (60 - 99\% - verde escuro) em meio a mancha marrom destacam-se as localizadas no Parque do Carmo, PE Floresta do Ipiranga e Parque Estadual (PE) Floresta Guarapiranga.

Estudo de Silva; Mucci; Pelicioni (2006) relata que o Parque do Carmo (zona leste paulistana) é um dos poucos localizados na periferia da capital. Os autores descrevem como principais impactos no parque são: a pressão de invasões e a ausência de saneamento básico das comunidades vizinhas (conhecida como Gleba do Pêssego).

Reis (2002) relata que o PE Floresta do Ipiranga (também chamado como Parque do Estado) é o mais antigo do estado, fundado em 1928, nele estão situados o jardim botânico e o zoológico da capital. Ele está localizado na periferia paulistana, numa área de alta densidade demográfica, assim o referido autor correlaciona os maiores impactos desse parque: o lixo e o esgoto doméstico dos bairros vizinhos (REIS, 2002).

O PE Floresta Guarapiranga está localizado na zona sul da capital, à margem do reservatório de mesmo nome (LIEBERG, 2003). A autora destaca que este parque apresenta importantes remanescentes florestais na bacia hidrográfica a qual faz parte. O maior impacto vem da ocupação irregular nas áreas marginais da represa que despeja esgoto diretamente nos cursos d'água, comprometendo a qualidade da água que serve ao abastecimento da RMSP.

Destaca-se por fim as cidades de Juquitiba e São Lourenço da Serra (sudoeste da RMSP) as quais apresentaram toda área analisadas na classe de maior porcentagem de EVU. Essas cidades estão localizadas sobre importantes áreas de proteção de mananciais (Figura 124) essenciais para recarga hídrica do sistema de abastecimento Billings-Guarapiranga. 


\subsubsection{Análise Demográfica}

A Figura 127 indica que a RMSP apresentou maior quantidade de UDH que não possui EVU (em vermelho), ou seja espaços verdes urbanos maiores de $625 \mathrm{~m}^{2}$ em comparação com as demais regiões analisadas nesta tese. Elas estão distribuídas nas áreas de maior densidade populacional, com destaque a zona leste, norte e oeste da capital, além da área central de Santo André, Osasco, Guarulhos e Mogi das Cruzes.

As UDHs com até $15 \mathrm{~m}^{2}$ de EVU (laranja) por habitantes também estão localizadas nos centros mais populosos da RMSP o que ratifica análises anteriores quanto a densidade populacional e quantidade dos espaços verdes urbanos. Afirmase que as áreas em vermelho e laranja possuem baixa cobertura vegetal por habitantes, com quantidade menor ao valor recomentado pela Sociedade Brasileira de Arborização Urbana - SBAU (15 $\mathrm{m}^{2}$ ). Essas áreas correspondem a 30\% do total analisado, onde habitam nessas UDHs, 76,44\% da população analisada da RMSP.

As classes em amarelo, verde-claro e verde-escuro expressam de forma graduada maior quantidade dos espaços verdes por habitante. Variando de $15 \mathrm{~m}^{2}$ a $100 \mathrm{~m}^{2}$ nas áreas em amarelo, $100 \mathrm{~m}^{2}$ a $1000 \mathrm{~m}^{2}$ nas áreas em verde-claro e superior de $1000 \mathrm{~m}^{2}$ em verde-escuro. Por essa classificação observa-se visualmente que a quantidade dos espaços verdes urbanos por habitante aumenta dos centros mais urbanizados para as bordas (cinturão verde). 


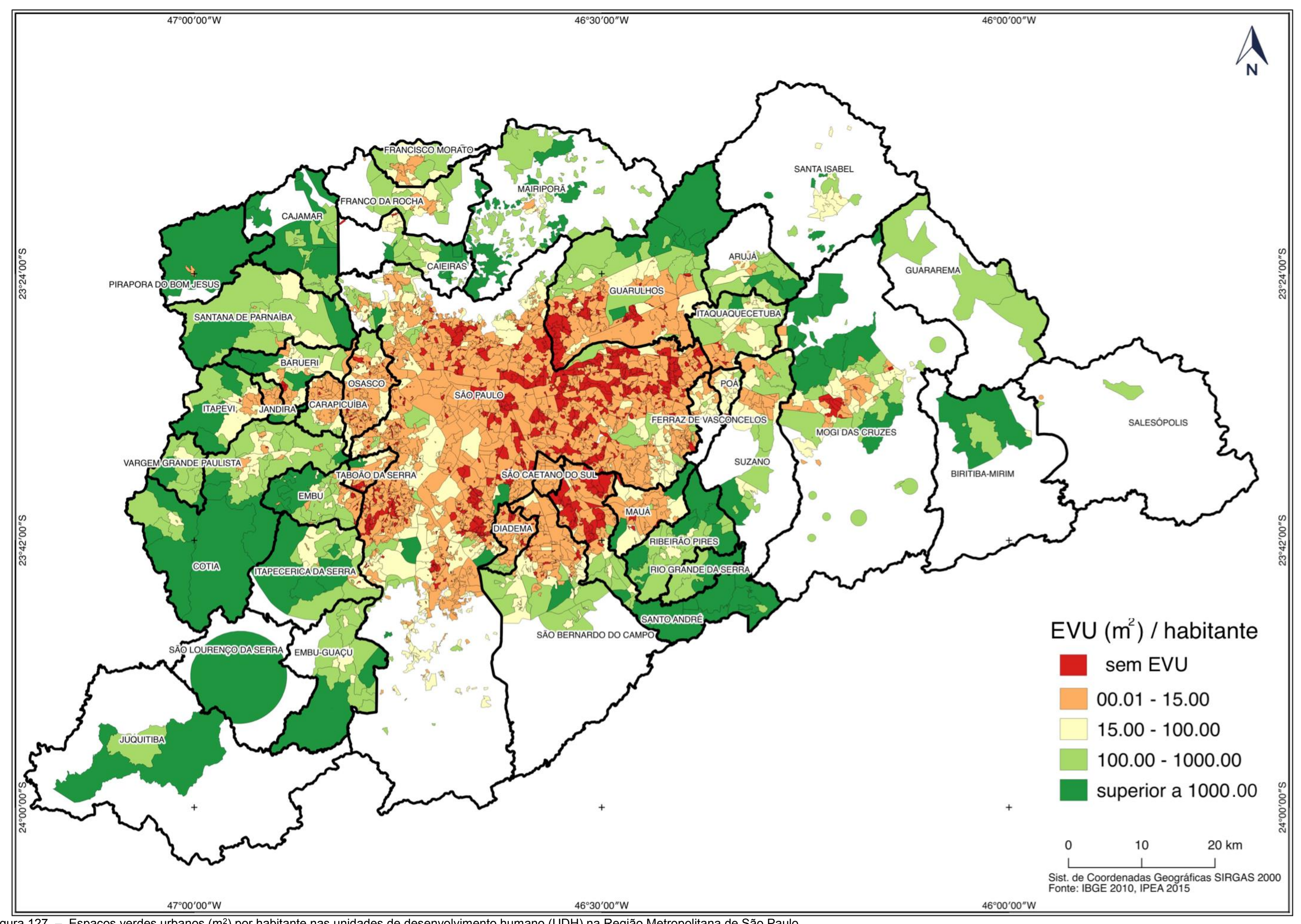

Figura 127 - Espaços verdes urbanos $\left(\mathrm{m}^{2}\right)$ por habitante nas unidades de desenvolvimento humano (UDH) na Região Metropolitana de São Paulo. 


\subsubsection{Tamanho e Distribuição dos Fragmentos dos Espaços Verdes Urbanos}

Ao categorizar o tamanho dos espaços verdes urbanos da RMSP em três classes (pequenas, intermediárias e grandes) de acordo com a curva normal de distribuição e estabelecendo o desvio padrão como limite das classes, obteve-se a seguinte categorização (Tabela 25).

Tabela 25 - Classificação dos fragmentos dos espaços verdes urbanos por tamanho

\begin{tabular}{ll}
\hline $\mathrm{EVU}\left(\mathrm{km}^{2}\right)$ & Classe de fragmentos \\
\hline $0,00-0,06$ & Pequenos \\
$0,06-127,26$ & Intermediários \\
$127,26-644,39$ & Grandes \\
\hline Fonte: Elaborada pelo autor
\end{tabular}

A Figura 128 mostra que a classe de fragmentos grandes é composta de áreas (na cor verde) localizadas na borda da RMSP. Como já discutido, formam a Reserva da Biosfera do Cinturão Verde da Cidade de São Paulo. Esses fragmentos correspondem à vegetação das áreas protegidas mostradas e discutidas anteriormente. Observa-se que na porção oeste há uma maior concentração de fragmentos dessa classe, o que Coelho (2015) afirma serem remanescentes florestais da Serra do Mar (São Lourenço da Serra, Juquitiba), Reserva Florestal (RF) Morro Grande (Cotia) e Serra da Cantareira (Cajamar).

Coelho (2015) destaca a RF Morro Grande como a principal mancha de vegetação arbórea, com pouquíssimos fragmentos de expansão antrópica. Não àtoa é considerada "área core" da RB do Cinturão Verde, coordenada pelo Instituto Florestal da Secretaria do Meio Ambiente do estado (COELHO, 2015).

O referido autor afirma que a RF do Morro Grande está intimamente ligada á proteção de mananciais, sobretudo na recarga hídrica dos reservatórios Cachoeira da Graça e Pedro Beicht, responsáveis no fornecimento de água para 500 mil habitantes. Quanto à importância ecológica (flora), Catharino et al. (2006) catalogou nessa reserva quatro espécies endêmicas, assim como espécies que não ocorriam no estado de São Paulo. 


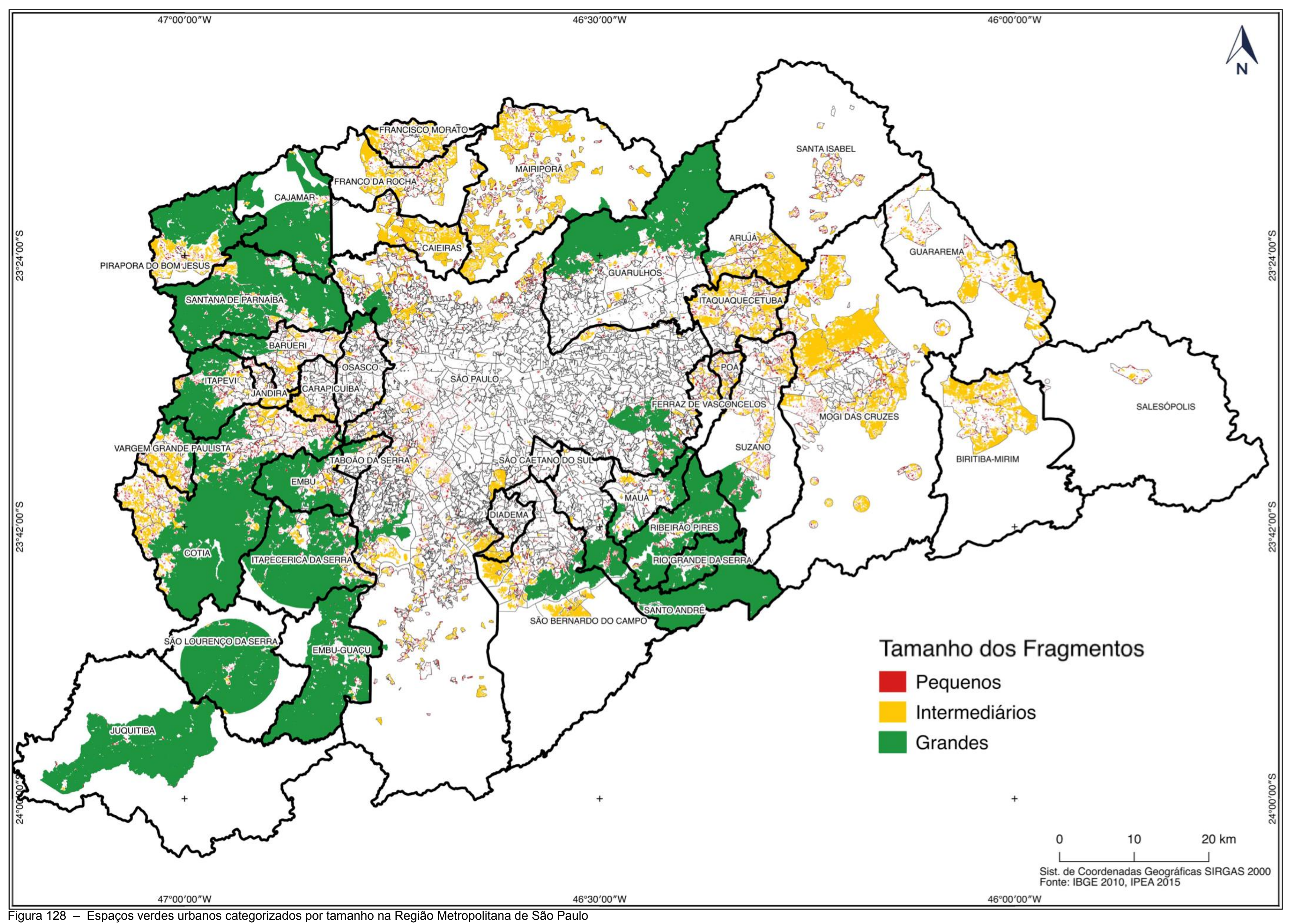


Ao analisar processo de urbanização, Coelho (2015) relata que o eixo oeste da RMSP é bastante fragmentado e disperso, o que reflete nas amplas porções de espaços verdes e núcleos urbanos espalhados. No entanto, o autor descreve uma tendência na implantação de amplos condomínios de classe-média alta (Cotia, Barueri, Santana do Parnaíba), que por sua vez prezam pelos espaços verdes como marketing imobiliário.

Infelizmente na maioria dos casos, não há articulação entre a expansão urbano com o uso dos ativos dos espaços verdes: lazer, convívio e envolvimento para conservação (COELHO, 2015). Assim, o autor relata a ocorrência da expansão de ocupações irregulares que vem causando degradação e poluição ambiental. Dado o cenário de expansão urbana sobre extensas e importantes áreas de cobertura vegetal, Coelho (2015) aponta para a necessidade de:

Conexões entre as áreas urbanas e os recursos naturais sejam estabelecidas com base tanto em critérios normativos quanto de planejamento e projeto, utilizando como referência os princípios da ecologia da paisagem. Tais ações devem ser pautadas na inversão do processo de estruturação urbana, partindo também das estruturas naturais, de modo a evitar futuras crises ambientais e permitir a conservação de recursos naturais e o convívio por parte da população (COELHO, 2015, p. 325).

Os demais fragmentos da classe grande (cor verde) estão localizados na Serra do Mar (cidades de São Bernardo, Santo André, Ribeirão Pires, Rio Grande da Serra) e na Serra da Cantareira, sobretudo ao norte de Guarulhos. Sobre os fragmentos da Serra do Mar, Moroz; Canil; Ross (1994) relataram a grande pressão do avanço da malha urbana, principalmente nas cidades que compõem a grande ABC (Santo André, São Bernardo e São Caetano).

Ressalta-se que o avanço das cidades sobre às áreas protegidas não é uma particularidade das periferias (ITIKAWA, 2008). Ao analisar a expansão urbana em dois bairros juntos à Serra do Mar (Bairro Ecológico Jardim dos Pinheiros e favela Carminha) no município de São Bernardo do Campo, a referida autora descreve ação diferenciada do estado:

Os bairros apresentam também diferenças em relação às áreas verdes e equipamentos públicos. O Jardim dos Pinheiros é dotado de uma reserva de vegetação, área de lazer às margens da represa, quadra poliesportiva; enquanto que no Carminha as áreas verdes restringem-se a sobras de terrenos e a um Parque Linear prejudicado por uma rua movimentada (ITIKAWA, 2008, p. 195). 
Quanto ao fragmento da classe grande (em verde) ao norte de Guarulhos, diz respeito à Serra da Cantareira. Couto (2011) afirma que a proximidade da área urbana favorece o desmatamento o que reflete na baixa incidência de vegetação nativa (21\%). Devido a alta declividade e a proteção legal da área, verifica-se que a cobertura vegetal é predominante, porém é composta da muitas áreas de capoeira, além de plantações de eucalipto e pinus (COUTO, 2011). Na área próxima a Guarulhos, o autor destaca como as maiores ameaças as ocupações (regulares e irregulares) e a presença de importantes rodovias: Fernão Dias, Anhanguera, além do trecho norte do Rodoanel.

A classe de fragmentos intermediários (amarelo), também apresenta significativos remanescentes florestais na área da RB Cinturão Verde. Destacam-se os fragmentos na parte leste e norte da RMSP. Os fragmentos na parte leste dizem respeito às áreas do Alto Tietê, onde estão situadas cidades com forte perfil agrícola, com destaque para as hortaliças, pomares e silviculturas (QUEIROZ, 2012). Esse perfil, aliado à expansão urbana explicam a maior fragmentação florestal na referida área refletindo na maior incidência de fragmentos da classe intermediários (amarelo).

Quanto aos fragmentos desta classe na porção norte da RB Cinturão Verde, é importante destacar que os limites analisados das cidades (Caieiras, Franco da Rocha, Francisco Morato e Mairiporã) são menores, o que reflete no tamanho dos fragmentos no interior dos seus limites serem classificados na classe intermediários. O fato é que existe um amplo espaço verde urbano ao norte da RMSP, referente a Serra da Cantareira que perpassa esses municípios. Ademais, Coelho (2015) relata na área uma expansão urbana (loteamentos, condomínio e invasões) como a principal ameaça à Serra da Cantareira.

Os demais fragmentos de classe intermediária, estão no meio da malha urbana com destaque ao Parques do Ibirapuera, Parque do Estado e ao conjunto de arborização urbana no bairro do Morumbi.

A classe de menores fragmentos é melhor analisada a partir da Figura 129, que remete ao mapa de Kernel referente às áreas de maior probabilidade de encontrá-las. Verifica-se que na capital, a maior probabilidade são nos bairros da zona oeste e norte em contraste com a zona leste (área periférica) e central. Pelo tamanho dos fragmentos e por análises em imagens de satélite, pode-se afirmar que se relacionam à arborização urbana ou pequenos parques e praças. 


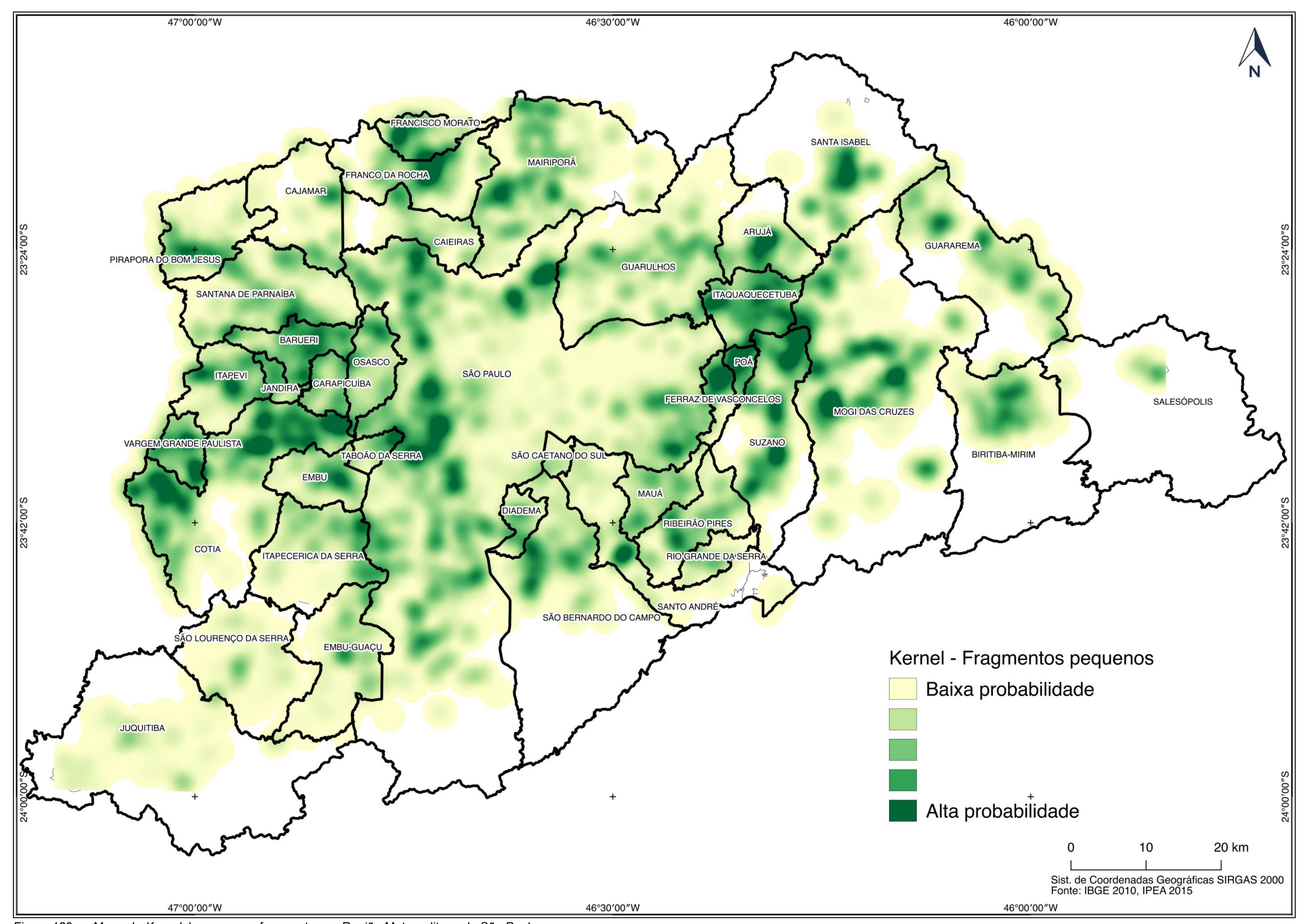

Figura 129 - Mapa de Kernel dos menores fragmentos na Região Metropolitana de São Paulo 
Afora a capital, destaca-se a grande proporção do fragmentos pequenos nas cidades a oeste e leste da capital. Poder-se-ia associar esses fragmentos à dinâmica florestal das grandes áreas protegidas da RB Cinturão Verde. Porém, ao analisar a Figura 129 sobre imagens de satélites, nota-se que eles estão majoritariamente nas áreas mais urbanizadas dessas cidades, refletindo assim, os espaços verdes de praças, parques e arborização urbana.

\subsubsection{Correlação: Espaços Verdes Urbanos e Vulnerabilidade Social}

A correlação espacial entre IVS e porcentagem de EVU na RMSP apresentou o Índice de Moran de 0,10 (Gráfico 21). O valor positivo indica que parte dessa amostra apresentou uma correlação geoestastítica que refuta a hipótese: áreas com melhores índices sociais (menor IVS) apresentam maior quantidade de EVU, e viceversa.

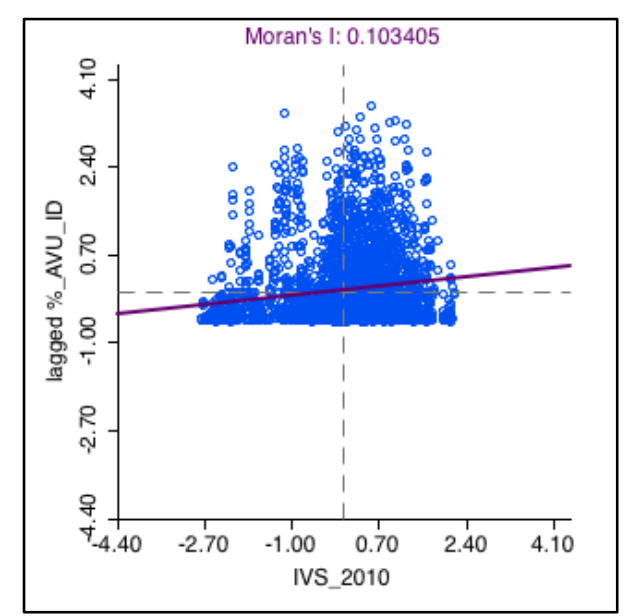

Gráfico 20 - Diagrama de Espalhamento de Moran. RMSP

Do total de 3392 UDHs da área analisada da RMSP, 42,90\% não apresentaram significância na análise proposta. O Gráfico 22 destaca as UDHs sem significância, observando que são aquelas mais próximas ao eixo da variável representada pelo IVS (horizontal). Na prática representam as UDHs onde a quantidade de EVU não variou significativamente conforme às variações de IVS. 


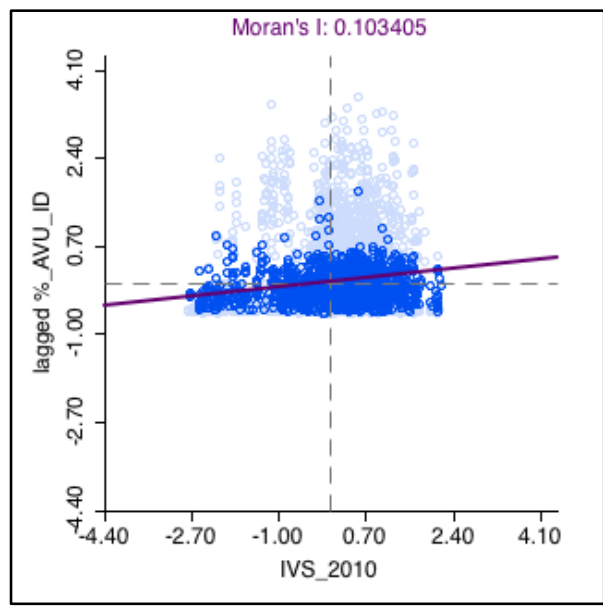

Gráfico 21 - UDHs sem significância. RMSP

O Gráfico 23 indica as 93 UDHs (2,74\%) que não apresentam significância por não apresentarem vizinhança, logo não influenciaram na análise de correlação espacial. No gráfico de correlação, essas UDHs dispostas em cima do eixo da variável dependente, representada pelo IVS.

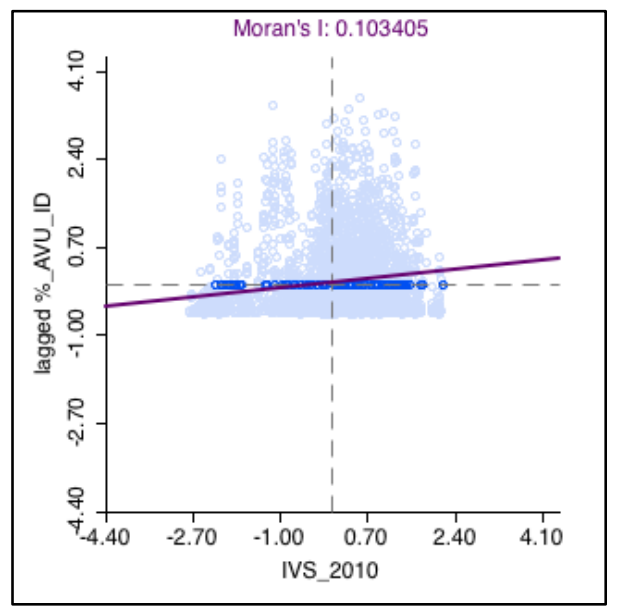

Gráfico 22 - UDHs sem vizinhança. RMSP

O Gráfico 24 mostra as 1937 UDHs que apresentaram significância na correlação proposta, o que representa $57,10 \%$ do total. O gráfico indica que são os pontos mais dispersos no gráfico. Verifica-se que o espalhamento desses pontos (representado pelas UDHs) são determinantes para a inclinação da curva de correlação, refletindo o valor positivo do Índice de Moran. 


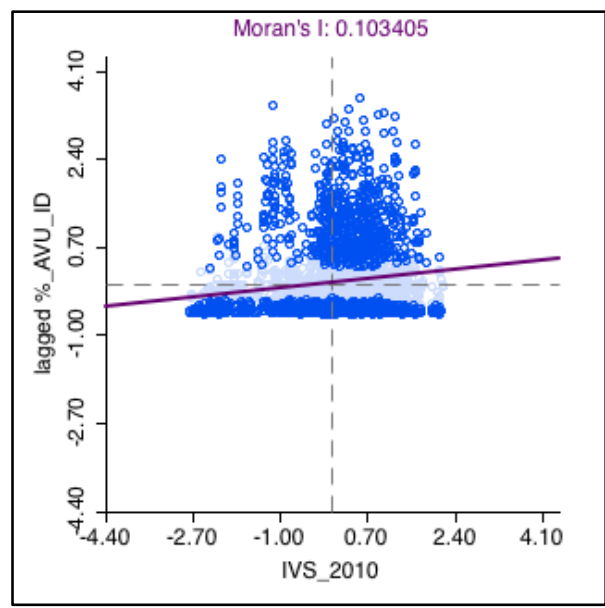

Gráfico 23 - UDHs com significância. RMSP

Ao analisar os resultados frente a hipótese, é importante destacar, novamente, os cenários esperados: a) UDH com grande porcentagem de EVU e IVS baixo e b) UDH com baixa porcentagem de EVU e IVS alto. Esses dois cenários estão representados na cor verde (cenário A) e cor vermelha (cenário B) nas Figuras 129 e 130. Esses cenários compõem 40,68\% das unidades amostrais (788 das 1937 UDHs) que apresentaram significância na correlação. É o resultado de maior proporção que corrobora a hipótese dentre todas as regiões analisadas nesta tese.

Os demais $59,32 \%$ das UDHs (1149) representam os cenários opostos à hipótese: c) UDH com grande porcentagem de EVU e IVS alto e d) UDH com baixa porcentagem de EVU e IVS baixo. Esses dois cenários estão representados na cor laranja (cenário c) e cor amarela (cenário d) nas Figuras 130 e 131.

Uma vez que a correlação é baseada na quantidade e grau de vizinhança das unidades amostrais, no caso as UDHs, as áreas que se correlacionam podem ser melhor analisadas ao inferir sobre a dimensão de área e população, conforme mostram a Figura 130 e a Tabela 26. A Figura 131 espacializa as áreas que apresentaram correlação significativa. 
Tabela 26 - Resumo da correlação espacial na Região Metropolitana de São Paulo

\begin{tabular}{|c|c|c|c|c|c|}
\hline Correlação & UDH (qtde) & IVS médio & $\% E V U / U D H$ & $\begin{array}{l}\% \\
\text { ÁREA }\end{array}$ & $\% \mathrm{POP}$ \\
\hline ALTA-ALTA (laranja) & 451 & 0,36 & 36,89 & 37,09 & 16,38 \\
\hline ALTA-BAIXA (vermelho) & 586 & 0,36 & 1,21 & 5,16 & 13,11 \\
\hline BAIXA-BAIXA (amarelo) & 698 & 0,2 & 1,58 & 12,56 & 25,12 \\
\hline BAIXA-ALTA (verde) & 202 & 0,23 & 37,24 & 17,06 & 4,73 \\
\hline SEM SIGNIFICÂNCIA & 1455 & 0,31 & 9,52 & 28,14 & 40,66 \\
\hline HIPÓTESE (vermelho + verde) & 788 & & & 22,22 & 17,84 \\
\hline OPOSTO DA HIPÓTESE (laranja + amarelo) & 1149 & & & 49,65 & 41,50 \\
\hline
\end{tabular}

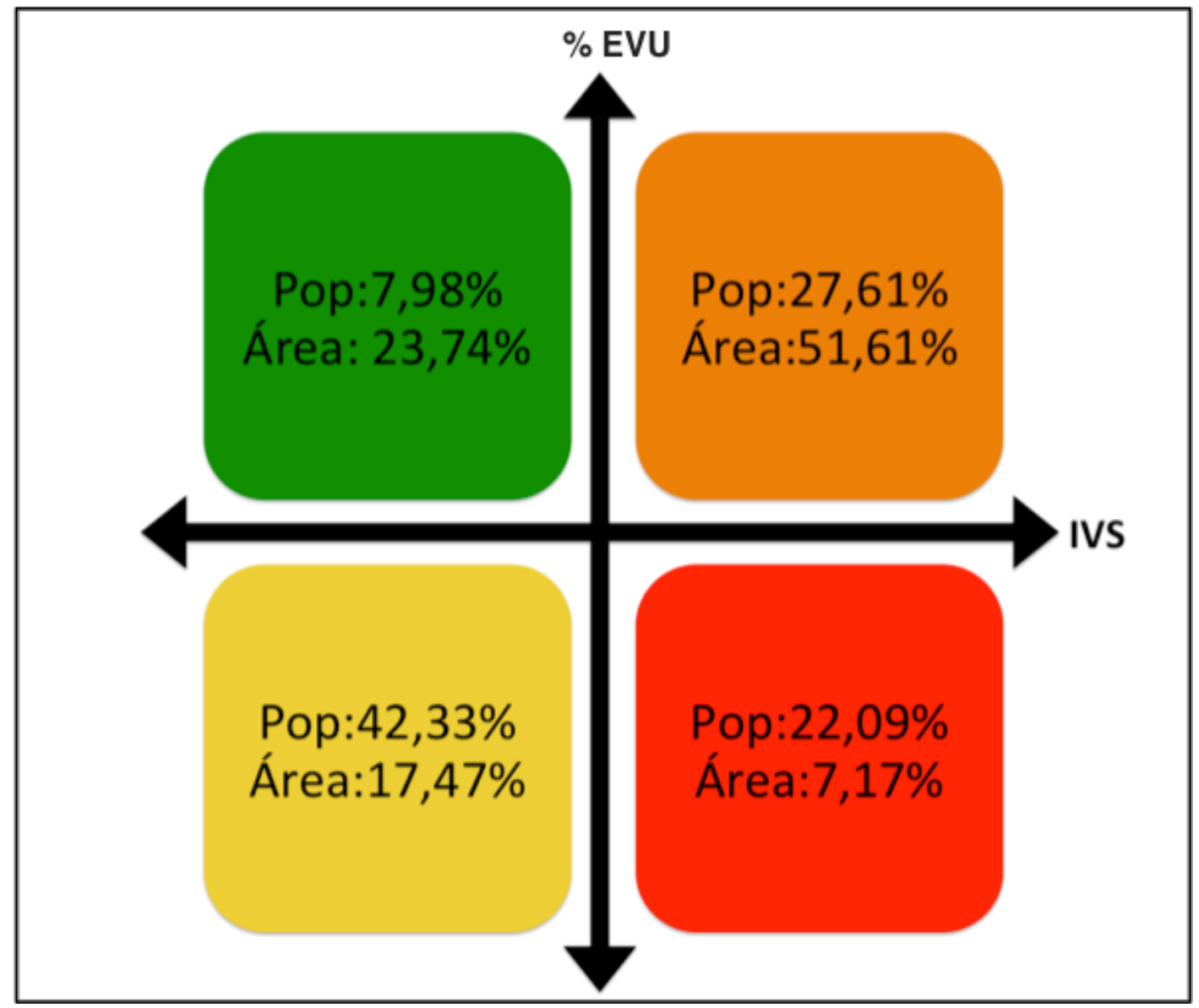

Figura 130 - Porcentual de área e população das UDHs com significância 


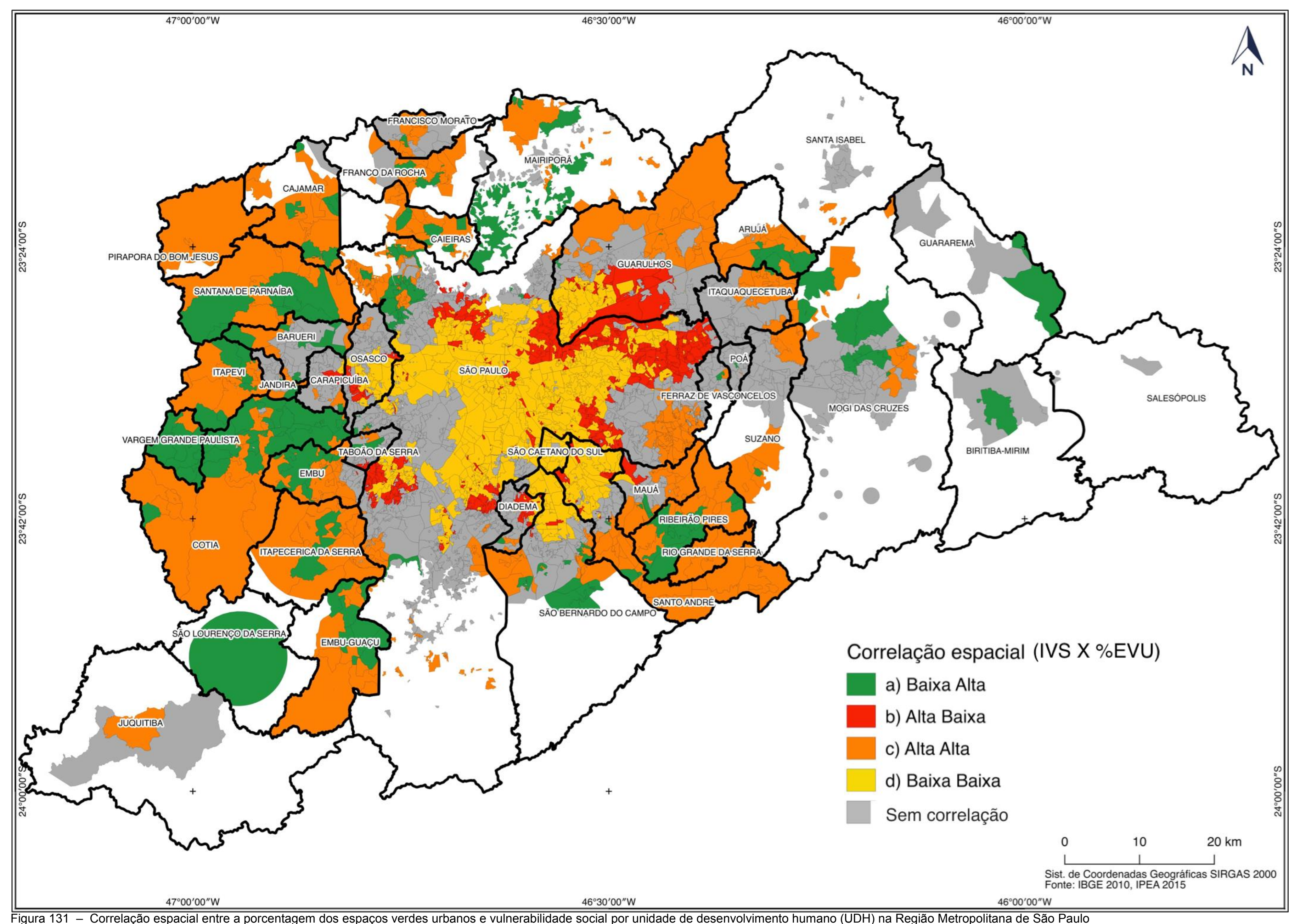


O cenário $C$, representado pela área em laranja (Figuras 130 e 131), foi o que mostrou maior magnitude em termos de área ( $51,61 \%$ das UDHs com significância e $37,09 \%$ da RMSP). Nele residem $16,38 \%$ dos habitantes da RMSP $(27,61 \%$ da população das UDHs com significância). Ele está distribuído no cinturão verde da cidade de São Paulo, onde há presença de importantes áreas protegidas, inclusive de APM. O cenário $C$ engloba 451 UDH (13,3\% do total) com IVS-médio de 0,36 e média de 36,89\% de EVU. Esses valores indicam que este cenário apresenta forte correlação entre: muitos espaços verdes urbanos e alta vulnerabilidade social.

A magnitude em termos de área deve ser observada com cuidado. Mesmo que a quantidade dos espaços verdes urbanos seja expressiva no cenário $C$ (laranja), pondera-se a importância ecológica da RB Cinturão Verde da Cidade de São Paulo em detrimento de possíveis usos dessas áreas para fins de lazer e sociabilidade. Sua função ecológica, pincipalmente como área de recarga hídrica dos mais importantes sistemas e abastecimento da RMSP precisa ser prioritário a qualquer planejamento de gestão.

Nesse cenário, a vegetação ainda é considerada a matriz no processo de ocupação urbana e fragmentação da mata atlântica. Porém, a proximidade da maior malha urbana do Brasil vem causando várias alterações antrópicas, como o caso na Serra da Cantareira que possui apenas $21 \%$ de vegetação nativa (COUTO, 2011). Portanto, os EVU nesse cenário são prioritários para se estabelecer medidas de controle ambiental, seja por legislação ou mecanismos de fiscalização e monitoramento de tal forma que elas não sejam suprimidas, garantindo sobretudo a manutenção dos serviços ambientais essenciais, como os relatado por Raimundo (2006):

Amenização das temperaturas do micro ou meso clima e melhoria da qualidade do ar, filtrando materiais particulados; produção de água em qualidade e quantidade para o abastecimento dos munícipes; e oferta de produtos naturais, como madeira, plantas ornamentais e medicinais (RAIMUNDO, 2006, p. 27).

O segundo cenário em maior magnitude quanto à área foi o cenário $D$, representado pela cor amarela (Figuras 130 e 131). Ele está concentrado no centro da RMSP, na área mais urbanizada. A Tabela 26 e a Figura 130 mostram também que existe uma população expressiva de $25,12 \%$ da RMSP, ratificando assim a alta densidade populacional nessa área. 
As $698 \mathrm{UDH}$ em amarelo (20,5\% do total) apresentaram IVS-médio de 0,2 (baixa vulnerabilidade) e apenas $1,58 \%$ dos EVU. Esses cenário indica que parte dos espaços analisados com maior densidade demográfica (central) apresenta correlação espacial entre: poucos espaços verdes urbanos e baixa vulnerabilidade social.

Inúmeros estudos destacam as consequências da pouca quantidade dos espaços verdes no centro da RMSP. Tarifa; Armani (2000) por exemplo constataram que essas áreas centrais apresentam uma variação de até $10^{\circ} \mathrm{C}$ em relação à área de borda da RMSP (Serra da Cantareira). Os autores relatam que além da formação das ilhas de calor, a falta de vegetação influi na circulação dos ventos, fazendo o ar quente e poluído do centro chegar nos remanescentes florestais da borda que "filtram" o ar poluído (TARIFA; ARMANI, 2000).

Jacobi (1999) também relata preocupação com a pouca cobertura vegetal na referida área: "A perda de cobertura vegetal tem provocado alterações microclimáticas que estão associadas aos impactos pluviais, responsáveis diretas das inundações na área urbana" (JACOBI, 1999, p. 12).

Os cenários $C$ e $D$ refletem o oposto da hipótese da tese. Eles foram os mais representativos dentre as UDHs que tiveram significância $(59,31 \%$ das UDHs), correspondendo a $49,65 \%$ da área analisada e $41,50 \%$ da população da RMR. Pode se afirmar, no caso da RMSP, que a presença de cobertura vegetal não reflete bons índices sociais.

Para o planejamento urbano é importante considerar a necessidade de implantação de cobertura vegetal no cenário D (amarelo) mesmo que IVS seja baixo, uma vez que ocupam áreas importantes da RMSP (centros de São Paulo, Osasco, Guarulhos e as cidades do ABC paulista). Como relatado, a ausência dos espaços verdes traz severos problemas urbanos (enchentes, ilhas de calor) causando prejuízos à sociedade e à cidade.

Quanto ao cenário C (laranja), destaca-se a importância de colocar os espaços verdes urbanos na articulação de politicas socioambientais promotoras de desenvolvimento urbano e social. Nesse caso, constata-se que a carência de tais políticas é tão grave quanto a carência dos próprios espaços verdes.

Quanto aos cenários referentes à hipótese, verifica-se que o cenário $B(\mathrm{em}$ vermelho) apresentou valor de IVS-médio $(0,36)$ e baixíssima porcentagem média de EVU (1,21\%), o menor valor encontrado. Ele contém uma população de $13,11 \%$ 
numa menor área que apresentou significância $(5,16 \%$ da área da RMSP). Este cenário é formado por 586 UDHs (17,27\% do total) localizadas nas áreas periféricas e bastante próximas às UDHs do cenário D (amarelo).

A maior quantidade de UDHs desse cenário está na zona leste da capital e de Guarulhos. Estudo de Amato-Lourenço et al. (2016) ratifica a carência dos espaços verdes na zona leste atrelada à vulnerabilidade social. Na análise de tais autores, utilizou-se o banco de dados dos espaços verdes da prefeitura municipal e o índice paulista de vulnerabilidade social, desenvolvido pela Fundação SEADE (Sistema Estadual de Análise de Dados). Quanto a vulnerabilidade social, Alves (2006) afirma que a zona leste paulistana concentra a maior quantidade de áreas de riscos de enchentes da capital, oriundas da ocupação nas várzeas do alto Tietê. Para agravar, na referida área há uma elevada concentração populacional de pessoas pobres com o mínimo de infraestrutura sanitária.

No cenário $A$ (verde) residem apenas $4,73 \%$ dos habitantes numa extensa área, que equivale a $17,06 \%$ do total analisado da RMSP. Este foi o cenário que apresentou maior valor médio de cobertura verde $(37,24 \%$ de EVU) e baixo IVS $(0,23)$. Nesse caso há correlação entre elevados índices sociais e alta cobertura vegetal. As maiores UDHs desse cenário estão no cinturão verde de São Paulo, sobretudo na porção oeste nas áreas de maior estrutura urbana. Chama-se atenção da proximidade dessas UDHs às do cenário C (laranja).

Os cenários hipotéticos ocupam partes menores, porém estratégicas na RMSP. Nessas áreas, é possível visualizar a desigualdade social conjugada a presença e ausência dos espaços verdes. Para a gestão urbana que vise a redução da vulnerabilidade social, é importante destacar o cenário B (vermelho) como zonas prioritárias de estabelecimento dos espaços verdes como equipamentos urbanos que garantam qualidade de vida além de melhorias na infraestrutura urbana.

A análise geoestastítica permitiu visualizar zonas prioritárias para a gestão urbana: as áreas de carência de espaços verdes urbanos (cenários B e D), assim como áreas de carência de políticas públicas para tornar os EVU em elementos promotores de desenvolvimento social e urbano (cenário $\mathrm{C}$ ).

Ademais, no caso da RMSP é importante também visualizar as áreas sem significância, as quais correspondem a 33\% das UDHs, $28 \%$ da área e $40 \%$ da população. Além disso, encontram-se num anel intermediário entre o centro com pouca árvores e as bordas com bastante. É certo que análises sequentes esse anel 
irá "afinar". A tendência histórica é que o núcleo (cenários amarelo e vermelho) se estenda. Esse fato indica atenção às áreas onde hoje a desigualdade não é vista e perceptível, mas que amanhã podem ser. As políticas pró-espaços verdes podem ganhar maior aplicabilidade e serem mais específicas no enquadramento dos cenários, porém tão importante quanto tais medidas é a percepção da sociedade da importância dos espaços verdes nas cidades.

\subsection{Síntese dos Resultados}

Dado o elevado número de informações e dados quantitativos a respeito dos espaços verdes urbanos nas RM analisadas e na RIDE-DF entorno, apresentam-se a seguir tópicos e tabelas com a compilação dos principais resultados. Além de possibitar a análise conjunta dos resultados elas facilitam comparações entre as regiões analisadas.

\subsection{1 Áreas Mapeadas: Espaços Verdes Urbanos e Vulnerabilidade Social}

A Tabela 27 mostra a dimensão do trabalho realizado, descrevendo as áreas (em $\mathrm{km}^{2}$ ), a população residente, porcentagem de EVU, além do IVS médio nas regiões analisadas.

Tabela 27 - Áreas $\left(\mathrm{km}^{2}\right)$, população, porcentagem de espaços verdes e índice de vulnerabilidade social médio nas regiões analisadas

\begin{tabular}{lllll}
\hline & Área $\left.\mathbf{( k m}^{\mathbf{2}}\right)$ & Pop. (milhões) & \% EVU & IVS médio \\
\hline RIDE-DF e Entorno & $2.104,47$ & 3,55 & 30,22 & 0,30 \\
RM de Manaus & $1.023,97$ & 1,97 & 59,41 & 0,35 \\
RM de Porto Alegre & $2.538,75$ & 4,09 & 29,34 & 0,25 \\
RM de Recife & 885,54 & 3,38 & 38,92 & 0,35 \\
RM de São Paulo & $4.565,05$ & 18,92 & 40,29 & 0,30 \\
\hline \hline
\end{tabular}

Fonte: Elaborada pelo autor

A Região Metropolitana de São Paulo, maior área analisada e com maior população residente, apresentou uma das maiores porcentagem de EVU no recorte proposto $(40,29 \%)$. Como foi discutido, a maior parte desses EVU estão concentrados nas bordas da RM, zona de áreas protegidas (APM e UCs) e expansão urbana. Quanto ao IVS médio dessa RM $(0,30)$, indica média vulnerabilidade social, porém destaca-se que nas bordas esse índice é maior, do que na região central. 
A Região Metropolitana de Manaus e Recife também apresentaram consideráveis porcentagens de EVU (59,41 e 38,92\% respectivamente). Como na RMSP, a maior parte dos EVU estão em locais específicos das RMs, locais de ampla vegetação onde não houve consolidação da malha urbana. Essas RMs apresentaram os maiores IVS médios das regiões analisadas $(0,35)$.

A RIDE-DF e Entorno e a RM de Porto Alegre apresentaram as menores porcentagem de EVU, indicando que as malhas urbanas são mais consolidadas, com menos áreas periurbanas do que as demais. Assim como a RM de São Paulo, a RIDE-DF e Entorno apresentou 0,30 de IVS o que indica média vulnerabilidade social, porém a análise intraurbana mostrou discrepância principalmente entre o centro com baixa vulnerabilidade social e as periferias com alta. A RM de Porto Alegre apresentou o menor IVS médio $(0,28)$, e até na análise intraurbana a variância foi menor do que nas demais regiões.

Estes resultados mostram que o simples ranqueamento dos EVU não obedecem a lógica posta hipótese da tese (quanto mais EVU maior o índice social). Retoma-se aqui o estudo de Haase et al. (2017) ao qual afirma que a presença dos espaços verdes urbanos não significa automaticamente que as cidades são mais sustentáveis, principalmente naquilo que tange a inclusão social. Por isso a relação entre quantidade de EVU e qualidade de vida precisa ser posta em análise, caso-acaso, sobretudo quando se busca uma compreensão nas implicações sociais.

\subsubsection{Espaços Verdes Urbanos e Áreas Protegidas nas Unidade de Desenvolvimento Humano}

\subsubsection{Espaços Verdes Urbanos nas Unidades de Conservação da Natureza}

A Tabela 28 mostra a quantidade das UCs dentro da área analisada, os EVU dessas UCs, assim como o tipo e a porcentagem das mais representativas. A categoria APA foi a mais representativa em todas as regiões analisadas. Sendo que as APAs das RM de Manaus, RM de Recife e RM e São Paulo foram as que apresentaram maior porcentagem de EVU. 
Tabela 28 - Espaços verdes urbanos nas Unidades de Conservação da Natureza nas áreas analisadas

\begin{tabular}{lllll}
\hline & $\begin{array}{l}\text { \% UC nas } \\
\text { UDHs }\end{array}$ & \% EVU UC & $\begin{array}{l}\text { mais } \\
\text { representativa }\end{array}$ & $\begin{array}{l}\text { \% mais } \\
\text { representativa }\end{array}$ \\
\hline RIDE-DF e Entorno & 68,6 & 32,02 & APA & 84,02 \\
RM de Manaus & 16,46 & 84,59 & APA & 95,12 \\
RM de Porto Alegre & 8,48 & 33,62 & APA & 70,85 \\
RM de Recife & 16,08 & 64,90 & APA & 91,25 \\
RM de São Paulo & 14,28 & 64,21 & APA & 82,58 \\
\hline \hline
\end{tabular}

Fonte: Elaborada pelo autor

A RIDE-DF e Entorno foi a que apresentou maior proporção de UCs (68\% de toda área analisada). Apesar disso, foi a que apresentou menor porcentagem de EVU $(32,02 \%)$ dentro de tais UCs. O fato da maior quantidade $(84,02 \%)$ dessas UCs ser APA justifica baixa quantidade de EVU, uma vez que esse tipo permite maior quantidade de usos se comparada às outras categorias de UCs, incluindo ocupação urbana.

Como já discutido, a RMM apresentou grande quantidade de EVU referente a extensos fragmentos de floresta amazônica que não estão no rol de áres protegidas. Contudo, a porção de $16,46 \%$ de UC da referida área tem alta quantidade de EVU $(84,59 \%)$, o que pode ser explicado pela forte presença extensa hidrografia, o que implica em grande área destinada à preservação de matas ciliares, por meio de APPs.

A RM de Recife e a RM de São Paulo apresentaram resultados semelhantes na análise de UCs nas áreas em estudo. Sendo que, cerca de $15 \%$ do seus territórios são UC (majoritariamente APA), com aproximadamente 64\% de EVU. A RM de Porto Alegre apresentou a menor porção de UC na área analisada, e estas se mostraram bastantes fragmentadas apresentando apenas 33,62\% de EVU.

Diante de tais resultados, nota-se que as UCs nas RM de Manaus, Recife e São Paulo concentram porções significativas de espaços verdes urbanos. Nestes casos, há o agravante das UCs estarem localizadas na áreas de expansão da fronteira urbana. Mello-Théry (2011) caracteriza essas áreas pelo grande afluxo de pessoas de baixa renda, surgimento de assentamentos ilegais e sem o mínimo necessário de infraestrutura urbana.

A referida autora alerta que o modelo de gestão urbana no Brasil se restrige à ação dual ante o problema de moradia ou da conservação. Momm-Schult et al. (2013) citam ainda a dificuldade de gestão da expansão urbana sobre áreas 
protegidas, sobretudo do ente municipal. Os municípios não podem propor e executar políticas públicas nas UCs, uma vez que no contexto federativo brasileiro, estas áreas protegidas são regidas por leis federais.

As políticas públicas não podem ser uma fonte de conflito; pelo contrário, elas precisam ser articuladas, serem coesas para que as populações se envolvam e defendam a qualidade ambiental ao invés de se opor a ela. Além de melhorar a governança para o envolvimento das populações, também deve servir para que as pessoas vejam as áreas verdes como elementos importantes para manter o funcionamento do sistema urbano e a qualidade ambiental de seus territórios (MELLO-THÉRY, 2011, p. 186).

Dada a importância dos EVU dentro de UCs, além da melhor governaça das áreas protegidas retoma-se aqui a importância da integração políticas urbanas e ambientais. Assim, o estabelecimento das áreas protegidas (como as Unidades de Conservação da Natureza) em áreas urbanas precisam fazer parte de um modelo de desenvolvimento local (MELLO-THÉRY, 2011).

\subsubsection{Espaços Verdes Urbanos nas Áreas de Proteção de Mananciais}

Ainda que as APM sejam categorias exclusivas do Estado de São Paulo e do Distrito Federal, cabe evidenciar que a Tabela 29 indica a porcentagem de APMs nas áreas analisadas, além da porcentagem de EVU nessas áreas protegidas.

Tabela 29 - Área de Proteção de Manaciais e espaços verdes urbanos nestas áreas

\begin{tabular}{lll}
\hline & \% APM nas UDHs & $\%$ EVU APM \\
\hline DF e Entorno & 3,27 & 33,63 \\
RM de São Paulo & 34,29 & 63,16 \\
\hline \hline
\end{tabular}

Fonte: Elaborada pelo autor

Os valores mais significativos foram na RM de São Paulo, sendo 34,29\% de APM na área analisada, contando com 63,16\% de EVU. A RIDE-DF e Entorno apresentou valores menores $(3,27 \%$ de APM) com apenas $33,63 \%$. Os dados indicam que deveria haver maior preocupação do poder público em aumentar o índice de EVU nas referidas áreas, considerando que são fundamentais para o abastecimento de água das cidades e que tanto o DF quanto a RM de São Paulo estão vivenciando crise hídrica.

Ao analisar esses resultados deve-se proceder com cautela, uma vez que eles se restrigem às áreas urbanas. $\mathrm{O}$ valor alto desses resultados, principalmente para RM de São Paulo, precisam ser relativizados uma vez que estão em áreas de expansão urbana (periurbanas), onde o próprio IBGE considera do tipo urbano. 
Quanto à RIDE-DF e Entorno constatou-se que elas estão nas bordas das áreas analisadas, implicando em baixa porcentagem de EVU.

\subsubsection{Porcentagem dos Espaços Verdes Urbanos nas Unidades de Desenvolvimento Humano}

A Tabela 30 mostra uma visão geral da categorização por porcentagem dos EVU nas regiões analisadas, sendo segregadas por porcentagem de área $e$ população. No geral a tabela indica que a maior parte da população reside em adensamentos populacionais (áreas centrais) e com pouca quantidade de EVU ( 0 a $30 \%)$.

Tabela 30 - Porcentagem de área e população das regiões analizadas por categoria dos espaços verdes urbanos

\begin{tabular}{llllllll}
\hline Categorias: \% de EVU & \multicolumn{2}{c}{$\mathbf{0}<\mathrm{EVU}<\mathbf{3 0 \%}$} & \multicolumn{2}{c}{$\mathbf{3 0}<\mathrm{EVU}<\mathbf{6 0 \%}$} & \multicolumn{2}{c}{$\mathbf{6 0}<\mathrm{EVU}<\mathbf{1 0 0 \%}$} \\
& \% Área & \% Pop. & \% Área & \% Pop. & \% Área & $\%$ Pop. \\
\hline RIDE-DF e Entorno & 58,17 & 78,29 & 33,99 & 16,64 & 7,84 & 5,07 \\
RM de Manaus & 26,03 & 80,75 & 17,03 & 12,91 & 56,94 & 6,34 \\
RM de Porto Alegre & 57,29 & 68,99 & 23,84 & 22,22 & 18,87 & 8,78 \\
RM de Recife & 36,09 & 70,77 & 41,58 & 23,05 & 22,33 & 6,19 \\
RM de São Paulo & 42,92 & 83,97 & 21,77 & 9,86 & 35,30 & 6,17 \\
\hline \hline
\end{tabular}

Fonte: Elaborada pelo autor

A categoria mais significativa em termos de área e população foi a de 0 à $30 \%$ de EVU. O único caso onde a porcentagem de área foi maior, em outra categoria, foi na RMM que apresentou $56,94 \%$ de área na categoria de $60 \%$ à $100 \%$ de EVU. Resultado este, decorrente da ampla área de floresta amazônica, ao norte da capital Manaus.

Ante o exposto, esse resultado evidencia que as áreas de maior densidade demográfica possuem menos EVU, cenário comum nos grandes centros urbanos. Este tendência foi obsevada nos estudo de Fuller; Gaston (2009) em 386 cidades européias e no de Richards; Passy; Oh, (2017) em 111 cidades do sudeste asiático.

Fuller; Gaston (2009) ao analisar a porcentagem de espaços verdes nas cidades europeias, também correlacionaram o resultado com o número de habitantes por cidade e com o tamanho da cidade. Os autores concluíram que a correlação é maior quando os EVU são correlacionados com o tamanho da cidade. 
Ou seja, a provisão de espaço na cidade influi mais na presença/tamanho dos EVU do que o aumento populacional.

Outro ponto a se destacar, mencionado no trabalho Richards; Passy; Oh, (2017), que se mostrou importante para explicar a quantidade dos EVU nas cidades foi o nível econômico. "Increases in city wealth may increase demand for green space among wealthier urban populations, which may result in better protection and creation of green spaces" (RICHARDS; PASSY; OH, 2017, p. 558). A análise das correlações estatísticas entre quantidade de EVU e níveis socioeconômicas serão melhor discutidas no item 4.6.6, mas vale destacar aqui o argumento do referido estudo de que quanto maior o nível econômico da cidade, maior é a demanda por espaços verdes mesmo que pequenos, que podem integrar a infraestrutura verde ${ }^{24}$ das cidades.

Percebe-se que o mapeamento e categorização das porcentagens de EVU no espaços das regiões analisadas apesar de apresentarem resultados congruentes do esperado, suas causas podem ser melhores debatidas e justificadas seja por motivos demográficos ou socioeconômicos. Ademais, ao citar o termo infraestrutura verde, é importante destacar que os pequenos espaços verdes (quintais, jardins, canteiros centrais, arborização urbana) estão nela incluída (HAASE et al., 2017). Ressalta-se que os mesmos não foram contabilizados na presente análise mas que precisam serem considerados em discussões mais aprofundadas, sobretudo quando se mencionar a carência dos EVU.

\subsubsection{Análise Demográfica: Espaços Verdes Urbanos $\left(\mathrm{m}^{2}\right)$ por Habitante}

A Tabela 31 destaca a quantidade de EVU por habitante e evidencia com clareza a carência de EVU para a maioria da população nas regiões analisadas, se somadas as porcentagens da população da primeira e segunda categorização (sem EVU e 0,01 à $15 \mathrm{~m}^{2}$ ).

O caso negativo mais extremo é o da RMSP, como 5,15\% da área total sem EVU, onde residem $25,78 \%$ da população total. Por outro lado, a RMM apresentou

\footnotetext{
24 Infraestrutura Verde é uma rede estrategicamente planejada e projetada de áreas naturais e semi-naturais, integradas com outras características ambientais para conservar a biodiversidade e oferecer uma ampla gama de serviços ecossistêmicos (BENEDICT; MCMAHON, 2012).
} 
69,09\% de área com mais de $1000 \mathrm{~m}^{2}$ de EVU por habitante, onde vivem apenas $3,83 \%$ da população total.

Tabela 31 - Porcentagem de área e população nas categorias de espaços verdes urbanos (m2) por habitante

\begin{tabular}{|c|c|c|c|c|c|c|c|c|c|c|}
\hline & \multicolumn{2}{|c|}{ Sem EVU } & \multicolumn{2}{|c|}{$0<\mathrm{EVU}<15 \mathrm{~m}^{2}$} & \multicolumn{2}{|c|}{$15<\mathrm{EVU}<100 \mathrm{~m}^{2}$} & \multicolumn{2}{|c|}{$100<\mathrm{EVU}<1000 \mathrm{~m}^{2}$} & \multicolumn{2}{|c|}{$\mathrm{EVU}>1000 \mathrm{~m}^{2}$} \\
\hline & \% Área & \% Pop. & \% Área & \% Pop. & \% Área & \% Pop. & \% Área & \% Pop. & \% Área & $\%$ Pop. \\
\hline RIDE-DF e Entorno & 1,90 & 11,62 & 11,33 & 43,02 & 15,92 & 26,00 & 34,62 & 16,7 & 36,22 & 2,66 \\
\hline RM de Manaus & 1,39 & 11,03 & 9,28 & 53,58 & 11,48 & 26,01 & 8,76 & 5,56 & 69,09 & 3,83 \\
\hline RM de Porto Alegre & 0,26 & 4,64 & 14,79 & 49,71 & 25,42 & 27,99 & 47,36 & 17,48 & 12,17 & 0,18 \\
\hline RM de Recife & 0,51 & 3,16 & 18,88 & 52,93 & 24,93 & 31,16 & 39,77 & 11,69 & 15,91 & 1,06 \\
\hline RM de São Paulo & 5,15 & 25,78 & 23,15 & 53,75 & 13,69 & 13,03 & 27,19 & 6,25 & 30,81 & 1,19 \\
\hline
\end{tabular}

Fonte: Elaborada pelo autor

Nesse contexto, cabe reiterar que o índice mínimo utilizado foi de $15 \mathrm{~m}^{2}$ por habitantes, conforme definido pela Sociedade Brasileira de Arborização Urbana (SBAU, 1996). Porém há de destacar que não há um consenso científico sobre esse índice.

O fato é que a pesquisa revelou que a carência de EVU por habitantes é majoritária, uma vez que mais de $50 \%$ da população nas regiões analisadas residem em UDH com índice menor de $15 \mathrm{~m}^{2}$ por habitantes, valor considerado baixo mesmo utilizando outros índices. Esse dado ratifica a constatação de Cavalheiro; Nucci (1998, p. 287) de que "a maioria das grandes cidades brasileiras encontra-se muito aquém do mínimo sugerido, indicando uma baixa qualidade de vida". Isso evidencia a importância desses resultados para o planejamento e gestão das cidades que visam a melhoria da qualidade de vida através da disponibilidade dos EVU à sociedade.

\subsubsection{Tamanho dos Fragmentos dos Espaços Verdes Urbanos}

A Tabela 32 indica a porcentagem dos EVU por tamanho (pequenos, médios e grandes) em relação a toda área dos EVU de cada região estudada. No geral, a classe de fragmentos pequenos foi minoria em todos os casos. A classe dos fragmentos intermediários foi maioria na RIDE-DF e Entorno e na RM de Porto Alegre. A classe dos fragmentos grandes foi maioria na RM de Manaus e de São Paulo. A RM de Recife teve certa equidade quanto a porcentagem dos EVU intermediários e grandes (ambos com 45\%). 
Tabela 32 - Porcentagem dos espaços verdes urbanos por tamanho nas regiões analisadas

\begin{tabular}{llll}
\hline & $\begin{array}{l}\text { \% EVU } \\
\text { Pequenos }\end{array}$ & $\begin{array}{l}\text { \% EVU } \\
\text { Intermediários }\end{array}$ & $\begin{array}{l}\text { \% EVU } \\
\text { Grandes }\end{array}$ \\
\hline RIDE-DF e Entorno & 9,72 & 67,89 & 22,39 \\
RM de Manaus & 8,95 & 34,04 & 57,01 \\
RM de Porto Alegre & 12,72 & 72,68 & 14,60 \\
RM de Recife & 8,93 & 45,72 & 45,33 \\
RM de São Paulo & 7,13 & 23,53 & 69,34 \\
\hline \hline
\end{tabular}

Fonte: Elaborada pelo autor

A análise do tamanho dos fragmentos requer outros estudos de aprofundamento, porém deve-se observar as características específicas de cada região, além de questionar os fatores positivos ou negativos da quantidade de cada classe por região. Por exemplo: o fato da RM de Porto Alegre possuir a maior proporção de fragmentos pequenos pode ser visto pelo lado positivo uma vez que seriam as áreas com maior potencial de se tornarem equipamentos urbanos (jardins, parques) com melhor distribuição espacial, promovendo maior qualidade de vida de forma mais ampla.

A ampla presença de fragmentos intermediários na RIDE-DF e Entorno evienciam que os EVU reflete em melhor qualidade da infraestrutura urbana e qualidade de vida (maior área de absorção de água, maior controle térmico, acústico e grandes áreas para lazer).

Não obstante, destaca-se que a RM de Manaus e São Paulo possuem poucos fragmentos pequenos e muitos fragmentos grandes, uma vez que a malha urbana (habitações, prédios, arruamento) é bem densa nas áreas centrais de tais RM. Destaca-se aqui o estudo de Davies et al. (2008) (análise realizada em Sheffield - Inglaterra) que atestou que grandes gradientes de densificação urbana afetam negativamente na presença e tamanho dos EVU e a topografia (declividade) afeta positivamente.

Entretanto, considerando que a categorização do tamanho dos fragmentos varia conforme a região, cabe reiterar que as breves análises apresentadas nesse item foram generalizadas e para casos específicos devem ser reavaliadas, utilizando-se de outros parâmetros de ordens físicas (topografia) e até sociais. Isso, pois, por exemplo, pode-se discutir que os fragmentos pequenos ou já funcionam como equipamentos urbanos ou não são capazes de atender as demandas sociais de esporte, lazer e cultura devido tamanho reduzido. Há, portanto, que se discutir 
cada região considerando ainda novos olhares sob a ótica da população e não apenas de indicadores.

\subsubsection{Correlação Espacial: Porcentagem dos Espaços Verdes Urbanos e Vulnerabilidade social}

A Tabela 33 indica os valores do índice de Moran e a porcentagem das UDH que apresentaram significância na correlação realizada (porcentagem de EVU e IVS nas UDHs). Em todos os casos o Índice de Moran ficou próximo a zero, indicando baixa correlação espacial. A RM de Recife apresentou a maior magnitude $(0,17)$ e a RIDE-DF e Entorno foi o único caso onde o índice apresentou valor negativo, conforme o esperado na hipótese.

\begin{tabular}{lll} 
Tabela & \multicolumn{3}{c}{ Resultados da correlação espacial aplicada às regiões analisad } & Ind. Moran & \% UDH sig. \\
\cline { 2 - 3 } RIDE-DF e Entorno & $\mathbf{- 0 , 0 1}$ & 25,17 \\
RM de Manaus & 0,13 & 24,81 \\
RM de Porto Alegre & 0,05 & 23,45 \\
RM de Recife & $\mathbf{0 , 1 7}$ & 37,50 \\
RM de São Paulo & 0,10 & $\mathbf{5 7 , 1 0}$ \\
\hline \hline
\end{tabular}

Fonte: Elaborada pelo autor

Quanto a porcentagem de UDHs com significância, a RM de São Paulo obteve o maior valor, $57 \%$, e as demais apresentaram valores inferiores a $50 \%$. Mesmo com baixa correlação, foi possível discutir as implicações da correlação de cada cenário, considerando a área de abrangência e população residente (Tabela 34). 
Tabela 33 - Porcentagem de área e população residente nos cenários obtidos na correlação espacial das regiões analisadas

\begin{tabular}{lllllllllll}
\hline Correlação IVS x \%EVU & \multicolumn{2}{c}{ Alta-Alta } & \multicolumn{2}{c}{ Alta-Baixa } & \multicolumn{2}{c}{ Baixa-Baixa } & \multicolumn{2}{c}{ Baixa-Alta } & \multicolumn{2}{c}{ Sem Correlação } \\
& \% Área & $\%$ Pop. & $\%$ Área & $\%$ Pop. & \% Área & \% Pop. & \% Área & \% Pop. & \% Área & $\%$ Pop. \\
\hline RIDE-DF e Entorno & 4,13 & 2,12 & 4,92 & 15,35 & 2,84 & 8,72 & 17,49 & 13,78 & 70,63 & 60,04 \\
RM de Manaus & 48,56 & 18,30 & 0,37 & 1,75 & 3,37 & 13,38 & 2,26 & 2,47 & 45,44 & 64,10 \\
RM de Porto Alegre & 8,61 & 9,35 & 5,23 & 11,66 & 3,90 & 13,78 & 4,48 & 7,04 & 77,79 & 58,17 \\
RM de Recife & 26,41 & 19,28 & 4,09 & 7,95 & 5,68 & 11,39 & 5,77 & 2,94 & 58,05 & 58,43 \\
RM de São Paulo & 37,09 & 16,38 & 5,16 & 13,11 & 12,56 & 25,12 & 17,06 & 4,73 & 28,14 & 40,66 \\
\hline \hline
\end{tabular}

Fonte: Elaborada pelo autor

Das UDH com significância, o cenário caracterizado por alta vulnerabilidade social e alta porcentagem de EVU (coluna laranja) foi o mais representativo nas RMs de Manaus, Recife e São Paulo. Isso, pois há presença de amplos espaços verdes em áreas periurbanas nestas RMs.

Levanta-se aqui um argumento mencionado no estudo de Haase et al. (2017), de que em se tratando do planejamento e gestão urbana, o problema maior não é a carência de espaços verdes mas também sobre proteção, gerenciamento e uso dos espaços verdes que já existem. Eles estão presentes na paisagem urbana sobretudo em zonas de maior vulnerabilidade social.

Sobre amplos espaços verdes urbanos, vale destacar aqui o comunicado técnico publicado pela Empresa Brasileira de Pesquisa Agropecuaria - Embrapa, denominado "Identificação, mapeamento e quantificação das áreas urbanas do Brasil” (FARIAS et al., 2017). O referido comunicado invalida a presença de amplos espaços verdes nas áreas periurbanas e urbanas e os desclassificam da análise, reduzindo as áreas urbanas e periurbanas no Brasil.

Destarte, o referido comunicado técnico apresentou como resultado uma nova delimitação estabelecida por meio de fotointerpretação e digitalização manual dos polígonos dos setores censitários urbanos. A delimitação excluiu as áreas consideradas não urbanizadas, sobretudo nas zonas periurbanas, devido ampla presença dos EVU.

Assim, os autores relatam que nos dados dos setores censitários do tipo urbano do IBGE "existiem áreas extensas não urbanizadas, com presença de agricultura, matas nativas, pastagens e outras formas de ocupação não coerentes com sua respectiva classificação" (FARIAS et al., 2017, p. 2).

Apesar da exclusão de áreas, optou-se por aplicar a metodologia de correlação espacial. A título de comparação de resultados foram geradas 
correlações espaciais para essa delimitação proposta por Farias et al. (2017). Os resultados detalhados dessa comparação estão no Apêndice A.

Mesmo com a diminuição dessas áreas periurbanas e urbanas, os índices de Moran e a proporção de área dos cenários mantiveram similares aos valores apresentados nos itens pretéritos (respeitando os limites do setores censitários do IBGE). Isso porque nas áreas de borda, mesmo sendo excluindo o excesso de EVU, eles se mantém em grande quantidade na paisagem uma vez que as ocupações nas áreas periurbanas (gralmente zonas de expansão urbana) são mais esparsas, sendo impossível desconsiderá-las.

Ademais, independentente da base utilizada, o que mais influência o resultado não é a presença dos espaços verdes apenas nas áreas periurbanas, mas sobretudo os EVU em toda área analisada. Destacando assim as zonas mais centrais, onde há maior quantidade de UDH.

Destaca-se por fim que:

Las zonas periurbanas tienen los índices más altos de crecimiento y reciben más migrantes de las zonas rurales, así como migrantes de la ciudad misma. Estas zonas están integradas en muchos aspectos con la ciudad, pero la mayoría de los proyectos forestales en las zonas periurbanas se conciben como proyectos rurales. Si no se integran en la planificación urbana, están condenados al fracasso (KUCHELMEISTER, 2000 p.49).

Assim, discutir a presença dos espaços verdes nas áreas periurbanas, conforme discorreu Kuchelmeister (2000), é fundamental para promoção do desenvolvimento sustentável das cidades, possibilitando não apenas a expansão ordenada, mas também planejada e sustentável sob a ótica socioambiental. 


\section{CONSIDERAÇÕES FINAIS E RECOMENDAÇÕES}

Através de análises geosestastísticas em cidades de quatro Região Metropolitana (Manaus, Porto Alegre, Recife e São Paulo) mais a RIDE-DF e Entorno onde residem $20 \%$ da população urbana brasileira, a tese investigou se "os bairros de classes média e alta têm mais espaços verdes do que os da periferia". Mesmo existindo vários casos onde áreas ricas tenham mais EVU em detrimento das mais pobres, a hipótese foi refutada. Conclui-se que os EVU não estão concentrados majoritariamente em áreas de maior nível socioeconômico.

Ainda que a hipótese da tese tenha sido refutada, é importante ressaltar a robustez da metodologia apresentada, que abarcou vários métodos da geoanálise que complementaram a verificação da hipótese. Pode-se destacar, primeiramente, a categorização da porcentagem de EVU nas UDH, dimensionando-as e relacionando-as com densidade demográfica e áreas protegidas (UCs e APMs).

Para investigar a hipótese, esta tese procurou mostrar caminhos para analisar os EVU no recorte intramunicipal, na escala das Unidades de Desenvolvimento Humano - UDH (ponderação realizada pelo IPEA dos setores censitários próximos e de características socioeconômicas semelhantes). Ao optar por essa escala buscou-se ter resultados compatíveis à realidade, uma vez que na escala municipal os valores de EVU impossibilita visualizar possíveis concentrações e analisar a distribuição dos mesmos.

Dada a importância da distribuição mais igualitária dos EVU, sobretudo visando a sustentabilidade nas cidades e a inclusão social (HAASE et. al 2016), a pesquisa buscou saber como os EVU estão distribuídos no território. Destarte, foi realizada uma análise de distribuição espacial da porcentagem de EVU correlacionada ${ }^{25}$ com índices socioeconômicos nas UDHs. Como resultado desta análise, a tese apresentou e discutiu os quatro cenários que integram as combinações entre baixa ou alta quantidade de EVU e altos ou baixos níveis de vulnerabilidade social.

A discussão dos cenários evidenciou que inserir os EVU no planejamento e ordenamento territorial das cidades é uma necessidade. É importante, assim, refletir

${ }^{25}$ O método utilizado foi a "Autocorrelação Bivariada Local de Moran", operacionada no software livre: GeoDA. 
sobre o cenário mais representativo da RIDE-DF e Entorno, pois ele expressa um exemplo de planejamento urbano que levou em consideração a presença dos EVU. Neste caso, o cenário que mostrou maior significância (em termos de população e área) foi aquele onde houve planejamento urbano, apresentando maior porcentagem de EVU e menores índices de vulnerabilidade social. No entanto, há de se destacar que o planejamento urbano da RIDE-DF e Entorno foi direcionado a partes específicas do DF, sobretudo as com melhores índices socioeconômicos. "A cidade que nasceu para ser una e igualitária a partir do Plano Piloto" (PAVIANI, 2005 , p. 193) ainda promove uma forte desigualdade social e a desigualdade de uso dos espaços públicos, como os espaços verdes urbanos.

A Região Metropolitana de São Paulo (RMSP) também apresentou resultados importantes de serem retomados. A análise geoestastítica mostrou que a RMSP teve o maior número de UDHs que apresentaram significância (64\%). Ou seja, a maior região analisada em população, área territorial e quantidade de UDHs apresentou maior correlação geoestastítica entre as variáveis analisadas. Neste caso, os cenários opostos à hipótese foram os mais representativos em número de UDH, população e área. Destacam-se a área central (baixa quantidade de EVU e baixa vulnerabilidade social) e as bordas (alta quantidade de EVU e alta vulnerabilidade social). Cenários estes descritos por Ab`Sáber (2004a) da seguinte forma:

O que restou de parques e jardins de bairros centrais é muito reduzido e insuficiente para o nível de adensamento e verticalização ocorrido nos confins da Metrópole Central expandida (AB'SÁBER, 2004a, p. 168).

A serra é um edifício geológico, um patrimônio geomorfológico, e um grande reduto de florestas tropicais de planaltos, até há pouco tempo intocado. Mas ela vem sofrendo duras pressões socialmente paradoxais ... Uns para chegar até aos altos da serra e escapar à poluição da Metrópole; outros tentando subir as encostas baixas da serra para obter, por invasão, um pedaço de chão pseudourbano (AB`SÁBER, 2004a, p. 369).

Nesse contexto, fica mais evidente que a abundância dos EVU per si, sobretudo nas áreas periurbanas, não implica necessariamente em qualidade de vida, embora até traga benefícios como: melhoria da qualidade do ar e temperatura 
mais amena. Tão importante quanto a cobertura vegetal, é implementar espaços e práticas que garantam a utilização e apropriação dos EVU pela população.

Nas quatro Regiões Metropolitanas analisadas, o cenário com maior representatividade em termos de área foi o que apresentou alta vulnerabilidade social, assim como a quantidade de EVU, característicos de áreas periurbanas. Colocando este cenário no centro do debate das políticas ambientais que tratam dos EVU, nota-se que o problema maior não é a sua carência, mas sim a ausência de política pública para implementação desses espaços, os quais são mais vulneráveis socialmente, como equipamentos urbanos. Como Maricato (1999) afirma, são áreas destinadas cada vez mais às ocupações precárias e predatórias.

A presença dos EVU precisa estar articulada com políticas de promoção social. Como relatou Kuchelmeister (2000), tais políticas, nas zonas periubanas, são fundamentais para a expansão ordenada, planejada e sustentável sob a ótica socioambiental. Para tanto, é preciso se tonar compatível a melhoria nos níveis de qualidade vida conjugada à preservação ambiental. Nesse ponto, Jacobi (2003 p.196) enfatiza a importância da educação ambiental "para criar novos estilos de vida que promovam a consciência ética e questione o modelo de desenvolvimento, marcado pelo caráter predatório e pelo reforço das desigualdades socioambientais".

Espera-se, assim, que os resultados da tese sirvam de instrumento orientador a programas e atividades educativas relacionadas a conscientização da importância dos EVU. Diante de uma realidade contraditória e geradora de desigualdades (CARLOS, 1992), a população precisa estar suprida de argumentos para lutar por mais políticas ambientais, que resultem na implantação de novos EVU ou mesmo para a presença de políticas de manutenção ou revitalização dos mesmos.

Quando bem distribuídos e estabelecidos como equipamentos urbanos, os EVU podem atenuar as penalidades históricas das populações menos favorecidas ao propiciar melhor qualidade de vida. Seus benefícios socioeconômicos podem ainda serem potencializados quando a implementação dos EVU estiver associada a outros equipamentos de uso coletivo, como centros comunitários, postos de saúde e escolas.

Ao se propor espaços verdes como equipamento urbano em comunidades carentes de infraestrutura urbana, além do espaço de convivialidade (ILLICH, 1973), inclusão e participação, a sociedade tende a apropriá-los. Com o sentimento de pertencimento por parte da população, os espaços verdes tendem ser mais 
protegidos estabelecendo sinergia entre benefícios sociais, ambientais e econômicos. No mesmo sentido, Smaniotto Costa (2008) afirma que os EVU, quando apropriados pela população, podem contribuir até na formação da identidade de uma comunidade.

Além de definir cenários, a metodologia utilizada permitiu revisitar algumas particularidades de cada Região Metropolitana e da RIDE-DF e Entorno. Assim, a discussão dos resultados não se fez necessária apenas para validar ou refutar hipótese, mas, sobretudo para vislumbrar alternativas à gestão ambiental urbana diante das especificidades locais. A abordagem das questões locais conjugada à investigação dos aspectos socioeconômicos, ambientais e históricos merecem ser mais aprofundadas e enriquecidas em novos estudos.

Sobre a dimensão dos dados trabalhados, a pesquisa mapeou 11,12 mil $\mathrm{km}^{2}$ de áreas urbanas que cobrem 114 cidades brasileiras além do DF, localizadas em todas as regiões brasileiras. Verificou-se a presença de 4,17 mil $\mathrm{km}^{2}$ de EVU (áreas maiores do $625 \mathrm{~m}^{2}$ ) o que representa $37,5 \%$ do total analisado. Embora esses valores brutos não ensejem nesse momento maiores discussões, eles se fazem necessários para destacar a representatividade dos dados analisados além das suas potencialidades para análises mais aprofundadas ou para estudos futuros. Seja sobre as potencialidades de EVU como equipamentos urbanos, seja sobre a importância das UCs para manutenção dos EVU em áreas urbanas ou ainda sobre o preocupante fato da maioria da população das regiões analisadas residirem em UDHs abaixo do índice mínimo de EVU $\left(15 \mathrm{~m}^{2}\right)$ determinado pela Sociedade Brasileira de Arborização Urbana.

O fato de mais de $50 \%$ da população analisada residir em locais com pouca quantidade de EVU por habitante merece ser destaque, visando o conhecimento dos gestores públicos e da sociedade. Esta informação precisa ser tomada com preocupação, uma vez que a carência de espaços verdes tem inúmeras correlações comprovadas com questões sociais (saúde e qualidade de vida), como aponta o levantamento realizado por Amato-Lourenço et al. (2016). E também está associada com o aumento nos gastos com a infraestrutura urbana (drenagem urbana) e na incidência de desastres ambientais (DOWAK, 2010).

Quantos às dificuldades de execução da tese, é preciso enfatizar o desafio de mapear os espaços verdes urbanos. O mapeamento de áreas urbanas é uma tarefa complexa, exige recursos técnicos (imagens e softwares), especialistas, recursos 
financeiros e tempo. Para exemplificar o desafio, a maior parte do tempo de execução da tese foi despendida para mapear os espaços verdes urbanos na escala compatível (1:25.000), mesmo com metodologia pré-definida.

Considerando a realidade técnico-financeira das administrações públicas municipais (responsáveis pela gestão dos espaços verdes nas cidades), é no mínimo inviável atribuir apenas a elas a obrigação de produzir estudos cartográficos das informações ambientais urbanas, como os espaços verdes e hidrografia. Para o levantamento de tais informações urge a necessidade de projetos contínuos nos moldes dos realizados pelo INPE, com o PRODES que mapeia o desmatamento na Amazônia, ou mesmo o INCRA, com o Cadastro Ambiental Rural (CAR). Pode-se inclusive pensar em projetos interinstitucionais e/ou colaborativos com a participação de universidades, prefeituras, centros de pesquisas, instituições governamentais e organizações do terceiro setor, de forma a viabilizar a produção contínua desses dados. Tão importante quanto a produção cartográfica é a garantia de sua periodização.

Apesar das dificuldades, pode-se afirmar que o uso da metodologia envolvendo o sensoriamento remoto e sistemas de informações geográficas permitiu uma criteriosa análise dos espaços verdes urbanos como aquele delimitados como áreas maiores do que $625 \mathrm{~m}^{2}$. Apesar da tese focar a discussão na correlação espacial dos espaços verdes urbanos com o Índice de Vulnerabilidade Social (IPEA, 2015), destacam-se também as suas múltiplas potencialidades ainda a serem exploradas. Por exemplo, para a gestão e planejamento territorial, esses dados podem ganhar maiores significados e discussões quando relacionados aos mapas de drenagem urbana, áreas de riscos, variações do microclima, potencialidades turísticas, por exemplo.

Destaca-se, por fim, que os resultados apresentados nos mapas, nos dados quantitativos e na indicação espacial de áreas prioritárias para implantação dos EVU como grandes legados desta pesquisa. Além dos resultados, a descrição detalhada da metodologia para as análises dos EVU pode ser replicada em diferentes escalas e áreas de estudos, valendo-se de softwares-livres, imagens de satélites e de dados socioeconômicos obtidos gratuitamente (bases do IBGE e IPEA). Espera-se assim, que tais contribuições sejam efetivas à ciência, às administrações públicas e principalmente para a sociedade. 


\section{Referências Bibliográficas}

AB `SÁBER, A. N. A cidade de Manaus - Primeiros Estudos. Boletim Paulista de Geografia, p. 18-45, 1953.

AB`SÁBER, A. N. As bases geoeconômicas essenciais da região de São Paulo. Revista das Faculdades Campineiras, v. 1, n. 2, p. 10-18, 1954.

AB`SÁBER, A. N. O sítio urbano de Porto Alegre. Boletim Paulista de Geografia, p. 3-30, 1965.

AB `SÁBER, A. N. A estrutura metropolitana e o novo aeroporto de São Paulo. Geografia e Planejamento, p. 1-19, 1975.

AB `SÁBER, A. N. Fundamentos da geomorfologia costeira do Brasil atlântico inter e subtropical. Revista Brasileira de Geomorfologia, v. 1, n. 1, p. 27-43, 2000.

AB`SÁBER, A. N. Tipologia dos espaços da natureza do Brasil. Scientific American Brasil, p. 98, 2003.

AB'SÁBER, A. N. As serras florestadas que envolvem as colinas paulistanas. In: São Paulo - Ensaios Entreveros. 1. ed. São Paulo - SP: EdUSP, 2004a. p. 365376.

AB`SÁBER, A. N. A "Revanche"das Águas. In: São Paulo - Ensaios Entreveros. 1. ed. São Paulo - SP: EdUSP, 2004b. p. 207-218.

AB`SÁBER, A. N. Ecologia urbana de uma metrópole na conjutura do subdesenvolvimento. In: São Paulo - Ensaios Entreveros. 1. ed. São Paulo - SP: EdUSP, 2004c. p. 225-268.

AB `SÁBER, A. N. O desenvolvimento de São Paulo e o futuro da "Bacia Urbana" regional. In: São Paulo - Ensaios Entreveros. 1. ed. São Paulo - SP: EdUSP, 2004d. p. 269-292.

AB'SÁBER, A. N. Padrões e ruas e processos de urbanização. In: São Paulo Ensaios Entreveros. 1. ed. São Paulo - SP: EdUSP, 2004e. p. 137-206.

AB`SÁBER, A. N.; MARIGO, L. C. Ecossistemas do Brasil. São Paulo: Metalivros, 2006. v. 22

ABREU, A. H.; OLIVEIRA, R. DE. Áreas verdes e municípios. Santa Catarina, p. 2, 2004.

AHERN, J. Green infrastructure for cities: the spatial dimension. In. Cities of the Future: Towards Integrated Sustainable Water and Landscape Management. IWA Publishing. Anais...Citeseer, 2007

ALBUQUERQUE, A. F. Análise morfodinâmica na Reserva Ecológica de Camaçari, Cabo de Santo Agostinho-PE. Dissertação (Mestrado em Geografia)- 
Recife - PE: Universidade Federal de Pernambuco - Centro de Filosofia e Ciências Humanas, 2007.

ALENCAR, J. O. A História do Bairro de Águas Compridas (Olinda)vozesdazonanorte.blogspot.com.br, 9 out. 2016. Disponível em: <http://vozesdazonanorte.blogspot.com.br/2016/09/o-bairro-de-aguas-compridasolinda.html>. Acesso em: 9 set. 2017

ALMANZA, E. et al. A study of community design, greenness, and physical activity in children using satellite, GPS and accelerometer data. Active Living Research, v. 18, n. 1, p. 46-54, 1 jan. 2012.

ALMEIDA, L. Q.; CARVALHO, P. F. A negação dos rios urbanos numa metrópole brasileira. Observatorio Geografico da America Latina, 2009.

ALMEIDA, L. Q.; CORREAA, A. C. B. Dimensões da negação dos rios urbanos nas metrópoles brasileiras: o caso da ocupação da rede de drenagem da planície do Recife, Brasil. Geo UERJ, v. 1, n. 23, p. 114-135, 2012.

ALMEIDA, P. F. C. A gestação das condições materiais da implantação da indústria gaúcha-1870-1930. Ensaios: Fundação de Economia e Estastística Siegfried Emanuel Heuser, p. 546-577, 1992.

ALONSO, J. A. F. Gênese e institucionalização da região metropolitana de Porto Alegre. Textos para Discussão: FEE (Fundação de Economia e Estastística Siegfried Emanuel Heuser), p. 3-19, 2008.

ALVES, M. A. DA S. Experiências internacionais em gestão metropolitana: três estudos de caso. 2009.

AMATO-LOURENÇO, L. F. et al. Metrópoles, cobertura vegetal, áreas verdes e saúde. Estudos Avançados, v. 30, p. 113-130, 2016.

AMAZONAS. Lei Estadual $\mathrm{n}^{\circ} 41$. Concessão de área de $100 \mathrm{~km} 2$ da Reserva Florestal do Governo do Amazonas ao INPA. . 16 fev. 1963.

ANDRADE, B. et al. Tipos de solos, fatores climáticos e influência dos morros no crescimento urbano de Porto Alegre. In: SETUBAL, R. B.; BOLDRINI, I. L.; ABREUFERREIRA, P. M. (Eds.). . Campos dos Morros de Porto Alegre. Porto Alegre RS: Igré - Associação Sócio - Ambientalista, 2011. p. 33-38.

ANDRADE, M. C. O. Recife, problemática de uma metrópole de região subdesenvolvida... 1. ed. Recife - PE: Editora Universitária - UFPE, 1979.

ANSELIN, L. Exploratory spatial data analysis and geographic information systems. In: New tools for spatial analysis. 1. ed. Luxembourg: Eurostat, 1994. p. 45-54.

ANSELIN, L. Local indicators of spatial association-LISA. Geographical analysis, v. 27, n. 2, p. 93-115, 1995. 
ANSELIN, L. et al. The Moran scatterplot as an ESDA tool to assess local instability in spatial association. In: Spatial Analytical Perspectives in GIS. 1. ed. Iondon UK: Taylor \& Francis, 1996. v. 4p. 121-138.

ANSELIN, L.; SYABRI, I.; KHO, Y. GeoDa: an introduction to spatial data analysis. Geographical Analysis, v. 38, n. 1, p. 5-22, 2006.

ARAÚJO, J. A. Sobre a cidade e o urbano em Henri Lefebvre. GEOUSP: Espaço e Tempo (Online), n. 31, p. 133-142, 2012.

ARAUJO, M. DE F. I. Reestruturação produtiva e transformações econômicas: Região Metropolitana de São Paulo. São Paulo em perspectiva, v. 15, n. 1, p. 20 30, 2001.

AYDIN, M. B. S.; ÇUKUR, D. Maintaining the carbon-oxygen balance in residential areas: A method proposal for land use planning. Urban forestry \& urban greening, v. 11, n. 1, p. 87-94, 2012.

AZEVEDO, A. F. Z.; PORTUGAL, M. S.; MONTEIRO, S. Estagnação econômica, descontrole dos gastos públicos e deficiência de infra-estrutura: o caso do Rio Grande do Sul. Porto Alegre: Universidade Federal do Rio Grande do Sul, Curso de Pós-Graduação em Economia, 1996.

AZEVÊDO, J. K. C. Percepção dos Proprietários sobre a Biodiversidade de suas Florestas e a Necessidade de Incentivos Econômicos para sua Conservação na APA Aldeia-Beberibe, Pernambuco. Mestrado (Gestão e políticas ambientais)—Recife -PE: Universidade Federal de Pernambuco - Centro de Filosofia e Ciências Humanas, 2015.

BACEN. Endividaemnto dos estados, 2016. Disponível em: <http://www4.bcb.gov.br/fis/dividas/lmdividas.asp>. Acesso em: 8 set. 2017

BAKOS, M. M. Marcas do positivismo no governo municipal de Porto Alegre. Estudos Avançados, v. 12, n. 33, p. 213-226, 1998.

BAKOS, M. M. Porto Alegre e seus eternos intendentes. 2. ed. Porto Alegre - RS: EDIPUCRS, 2013. v. 1

BALTAZAR, A. B. Diretrizes de um Plano Regional para o Recife. Tese (Apesentrada para o concurso para o provimento da cátedra de Urbanismo e Arquitetura Paisagística)—Recife - PE: Universidade do Recife - Escola de Belas Artes, 1951.

BANCO-MUNDIAL. Índice de GINI, 2015. Disponível em: <https://datos.bancomundial.org/indicador/SI.POV.GINI>. Acesso em: 4 jun. 2107

BARBOSA, T. DA R. Ocupações urbanas e a (re) produção das moradias populares em Manaus: estudos no bairro do Coroado e loteamento Rio Piorini. Dissertação (Mestrado em Sociedade e Cultura da Amazônia)-Manaus: Universidade Federal do Amazonas - Instituto de Ciencias Humanas e Letras, 2009. 
BARCELLOS, T. M. Região Metropolitana de Porto Alegre: expansão urbana e dinâmica imobiliária nos anos 90. Indicadores Econômicos - FEE (Fundação de Economia e Estastística Siegfried Emanuel Heuser), p. 65-90, 2004.

BARGOS, D. C.; MATIAS, L. F. Áreas verdes urbanas: um estudo de revisão e proposta conceitual. Revista da Sociedade Brasileira de Arborização Urbana, Piracicaba-SP, v. 6, n. 3, p. 172-188, 2011.

BARROS FILHO, M. N. M. Modelos da estrutura socioespacial urbana e práticas estatais de intervenção em favelas no Recife. Anais: Encontros Nacionais da ANPUR, v. 10, 2013.

BARROS, H. R.; LOMBARDO, M. A. Zoneamento climático urbano da cidade do Recife: uma contribuição ao planejamento urbano. GEOUSP: Espaço e Tempo (Online), v. 1, n. 33, p. 186-197, 2013.

BECKER, B. K. A fronteira no final do século XX: oito proposições para um debate sobre a Amazônia brasileira. Espaço \& Debates, n. 3, p. 59-73, 1984.

BECKER, B. K. Geopolítica da amazônia. Estudos avançados, v. 19, n. 53, p. 7186, 2005.

BECKER, B.; STENNER, C. Um futuro para a Amazônia. São Paulo: Oficina de Textos, 2008.

BENEDICT, M. A.; MCMAHON, E. T. Green infrastructure: linking landscapes and communities. [s.I.] Island Press, 2012.

BITOUN, J. Os embates entre as questões ambientais e sociais no urbano. Dilemas urbanos: novas abordagens sobre a cidade. São Paulo: Contexto, p. 300-301, 2003.

BITOUN, J. et al. Região Metropolitana do Recife no contexto de Pernambuco no Censo 2010. Recife, 2012. Disponível em: <http://observatoriodasmetropoles.net/download/Texto_BOLETIM_RECIFE_FINAL.p df>. Acesso em: 9 set. 2017.

BITOUN, J.; MIRANDA, L.; SOUZA, M. Â. Como anda a Região Metropolitana do RecifeObservatório Pernambuco de Políticas Públicas e Práticas Socioambientais (UFPE/FASE), 2006.2 Disponível em: <http://www.observatoriodasmetropoles.ufrj.br/como_anda/como_anda_RM_recife.p df>. Acesso em: 22 ago. 2017

BLANCO-BELLO, R.; VICTORIA-COGOLLO, K. Los espacios públicos en sectores populares de cartagena: lugares de encuentro y desencuentro. Entramado, v. 9, n. 2, p. 176-190, 2013.

BLOCH, M. A sociedade feudal. Portugal: Ediçoes 70, 1979. v. 6-Lugar da história BÓGUS, L. M. M.; TASCHNER, S. P. São Paulo, velhas desigualdades, novas configurações espaciais. Revista Brasileira de Estudos Urbanos e Regionais, n. 1, p. 153-174, 1999. 
BÓGUS, L. M. M.; VÉRAS, M. P. B. A reorganização metropolitana de São Paulo: espaços sociais no contexto da globalização. Cadernos Metrópole, n. 03, p. 81-98, 2000.

BOONE-HEINONEN, J. et al. Where can they play? Outdoor spaces and physical activity among adolescents in U.S. urbanized areas. Preventive Medicine, v. 51, n. 3, p. 295-298, 1 set. 2010.

BOVO, M. C.; AMORIM, M. C. DA C. T. Áreas Verdes Urbanas, a Imagem, o Mito e a Realidade: um estudo de caso sobre a cidade de Maringá/PR. Formação (Online), v. 1, n. 16, p. 60-69, 2011.

BRASIL. Lei Federal complementar $n^{\circ} 14$. Estabelece as regiões metropolitanas de São Paulo, Belo Horizonte, Porto Alegre, Recife, Salvador, Curitiba, Belém e Fortaleza. . 8 jul. 1973.

BRASIL. Lei Federal n 6766 . Dispõe sobre o Parcelamento do Solo Urbano e dá outras providências. . 20 dez. 1979.

BRASIL. Lei Federal nº 6.938. Política Nacional de Meio Ambiente. . 1981.

BRASIL. Constituição da República Federativa do Brasil. Constituição Federal. . 1988.

BRASIL. Lei Federal $n^{\circ}$ 9.985. SNUC - Sistema Nacional de Unidades de Conservação da Natureza. . 18 jul. 2000.

BRASIL. Lei Federal $n^{\circ}$ 10.257. Estatuto da Cidade (Atos do Poder Legislativo). . 2001.

BRASIL. Lei federal $n^{\circ}$ 6047. Política Nacional de Desenvolvimento Regional PNDR. . 22 fev. 2007.

BRASIL. Lei federal n 12.651. Novo Código Florestal. . 25 maio 2012, p. 2.166-67.

BRASIL. PL n 396. PL Senado FEDERAL: Estabelece diretrizes gerais da política urbana e dá outras providências (Estatuto da Cidade), para dispor acerca da delimitação das áreas verdes urbanas. . 2014.

BRASIL. Lei Federal n 13.465. Regularização Fundiária Rural e Urbana. . 11 jul. 2017.

BRAUDEL, F. Les débuts de la Révolution à Bar-le-Duc. Paris: Dossiers Documentaires Meusiens, 1989.

BURSZTYN, M. A.; BURSZTYN, M. Fundamentos de política e gestão ambiental: caminhos para a sustentabilidade. [s.I.] Garamond, 2012.

CAIADO, M. C. S. Estruturação intra-urbana na região do Distrito Federal e entorno: a mobilidade e a segregação socioespacial da população. Revista Brasileira de Estudos de População, v. 22, n. 1, p. 55-88, 2013. 
CâMARA, G.; CARVALHO, M. S. Análise espacial de eventos. Análise espacial de dados geográficos. Brasília: Embrapa, 2004.

CAMARGO, A. S. G.; SILVA, M. C.; OLIVEIRA PRESZNHUK, R. A. MOVIMENTOS SOCIAIS PRÓ-SUSTENTABILIDADE URBANOAMBIENTAL. Revista Educação \& Tecnologia, n. 8, 2004.

CARDOSO, A. L. Trajetórias da questão ambiental urbana: da Rio 92 às Agendas 21 locais. Revista Paranaense de Desenvolvimento-RPD, n. 102, p. 51-69, 2011.

CARLOS, A. F. A. A cidade. São Paulo - SP: Editora Livraria da Fisica, 1992.

CARLOS, A. F. A. A (re) produção do espaço urbano. São Paulo - SP: Edusp, 1994.

CARLOS, A. F. A. Espaço-tempo na metrópole: a fragmentação da vida cotidiana. São Paulo - SP: Editora Contexto, 2001.

CARLOS, A. F. A. O espaço urbano: novos escritos sobre a cidade. São Paulo SP: Editora Contexto, 2004.

CARNEIRO, A. R. S. Parque e Paisagem: um olhar sobre o Recife. 1. ed. Recife PE: EDUFPE, 2010.

CARRION, O. B. K. Mercado imobiliário e padrão periférico de moradia: Porto Alegre e sua Região Metropolitana. Ensaios: FEE (Fundação de Economia e Estastística Siegfried Emanuel Heuser), p. 225-250, 1989.

CARVALHO, A. B. P.; OZORIO, C. P. Avaliação sobre os banhados do Rio Grande do Sul, Brasil. Revista de Ciências Ambientais, v. 1, n. 2, p. 83-95, 2007.

CASSIANO, K. R. M. Análise geográfica de áreas de risco na bacia hidrográfica no Igarapé do Mindu-Manaus (AM). Dissertação (Mestrado em Geografia)Florianópolis - SC: Universidade Federal de Santa Catarina - Centro de Filosofia e Ciências Humanas, 2013.

CASTELLS, M. A questão urbana. [s.I.] Paz e terra, 1983.

CASTRO, D. G.; NOVAES, P. R. Copa do Mundo 2014 e os impactos no direito à moradia: uma análise das cidades-sede brasileiras. Os impactos da Copa do Mundo 2014 e das Olimpiadas 2016, v. 20, p. 79, 2014.

CASTRO, J. Homens e caranguejos. 3. ed. Rio de Janeiro: Civilização Brasileira Ed. Record, 2007.

CATHARINO, E. L. M. et al. Aspectos da composição e diversidade do componente arbóreo das florestas da Reserva Florestal do Morro Grande, Cotia, SP. Biota Neotropica, v. 6, n. 2, p. 1-18, 2006.

CAVALCANTE FILHO, P. P. et al. RIMA - Relatório de Impacto Ambiental: Implantação de ações estruturadoras no setor via parque da zona espacial de conservação urbana e ambiental do rio Paratibe (ZECUA) no município de 
Paulista - PEJBR engenharia, , 2013. Disponível em: <http://www.cprh.pe.gov.br/downloads/RIMAZECUADOPARATIBE.pdf>. Acesso em: 7 set. 2017

CAVALCANTE, K. V.; FRANCHI, T.; LOPES, R. H. Região metropolitana de Manaus: Características e dilemas do desenvolvimento de uma região metropolitana na Amazônia Ocidental. Chão Urbano, v. 4, n. XV, p. 1-19, 2015.

CAVALHEIRO, F.; NUCCI, J. C. Espaços livres e qualidade de vida urbana. Paisagem e ambiente, n. 11, p. 277-288, 1998.

CERQUEIRA, D. et al. Atlas da violência 2017Instituto de Pesquisa Econômica Aplicada (Ipea) / Fórum Brasileiro de Segurança Pública (FBSP), , 2017. Disponível em: <http://ipea.gov.br/atlasviolencia/>. Acesso em: 7 jul. 2017

CHIAPPETTI, A. B. Ocupação do Parque Estadual Delta do Jacuí: conflitos de uso territorial. Dissertação (Mestrado em Geografia)-Porto Alegre - RS: Universidade Federal do Rio Grande do Sul - Instituto de Geociências, 2005.

CHOAY, F. A NATUREZA URBANIZADA, A INVENÇÃO DOS" ESPAÇOS VERDES". Projeto História. Revista do Programa de Estudos Pós-Graduados de História. ISSN 2176-2767, v. 18, 1999.

CHUNG, C. K. L.; ZHANG, F.; WU, F. Negotiating Green Space with Landed Interests: The Urban Political Ecology of Greenway in the Pearl River Delta, China. Antipode, 2018.

CIDADE, L. C. F. Acumulação flexível e gestão do território no Distrito Federal. In: PAVIANI, A. (Ed.). . Brasília - gestão urbana: conflitos e cidadania. Coleção Brasília. 1. ed. Brasília DF: Universidade de Brasilia, 1999. p. 223-251.

CMMAD. Nosso futuro comum (Relatório Brundltland). 2. ed. Rio de Janeiro: FGV, 1991.

CODEPLAN, G. Pesquisa distrital por amostra de domicílios - Lago SulCompanhia de Planejamento do Distrito Federal, , 2016. Disponível em: <http://www.codeplan.df.gov.br/images/CODEPLAN/PDF/pesquisa_socioeconomica/ pdad/2016/PDAD_Lago_Sul.pdf>. Acesso em: 7 jul. 2017

COELHO, L. L. Dispersão, fragmentação e paisagem: Relações entre dinâmicas naturais e urbanas no vetor oeste da Região Metropolitana de São Paulo. Tese (Doutorado em Arquitetura e Urbanismo)—São Paulo - SP: Universidade de São Paulo- Faculdade de Arquitetura e Urbanismo, 2015.

COELHO, R. F. Ribeirinhos urbanos: modos de vida e representações sociais dos moradores do Puraquequara. Dissertação (Mestrado em Sociedade e Cultura da Amazônia)—Manaus: Universidade Federal do Amazonas - Instituto de Ciências Humanas e Letras, 2006.

COMAM. Resolução COMAM n 5 . Conselho Municipal de Meio Ambiente - Dispõe sobre o Plano Diretor de Arborização Urbana de Porto Alegre. . 29 set. 2006. 
COPQUE, A. C. DA S. M. et al. Expansão urbana e redução de áreas verdes na localidade do Cabula VI Região do miolo da cidade do Salvador, Bahia. Anais XV Simpósio Brasileiro de Sensoriamento Remoto [Em linha], Curitiba. Disponível em: http://www. dsr. inpe. br/sbsr2011/files/p0313. pdf [Consult. 10jun. 2012], 2011.

CORBUSIER, L.; GIRAUDOUX, J. A carta de Atenas. Traducao Rebeca Scherer. 1. ed. São Paulo: Hucitec - EdUSP, 1993.

CORREAA, P. B. Ilhas de calor na cidade de Manaus: aspectos observacionais e de modelagem. Dissertação (Mestrado em Clima e Ambiente)-Manaus - AM: Instituto Nacional de Pesquisa da Amazônia - INPA / Universidade do Estado da Amazônia -UEA, 2013.

COSTA, A. T. M.; SOUZA, D. B. A violência no eixo Brasília-Goiânia. Revista brasileira de segurança pública, v. 6, n. 2, p. 298-311, 2012.

COSTA, L. Brasília, cidade que inventei. 1. ed. Brasília DF: Governo do Distrito Federal - ArPDF, CODEPLAN, DEPHA, 1991.

COSTA, M. F. et al. Verticalização da Praia da Boa Viagem (Recife, Pernambuco) e suas Consequências Sócio-Ambientais. RGCI-Revista de Gestão Costeira Integrada, v. 8, n. 2, p. 233-245, 2008.

COUTO, M. S. H. Ocupação irregular e criminalidade na região da Serra da Cantareira-SP. Revista LEVS- Laboratório de Estudos da Violência da UNESP/Marília, v. 8, n. 8, p. 107-126, 2011.

DADVAND, P. et al. Risks and benefits of green spaces for children: a crosssectional study of associations with sedentary behavior, obesity, asthma, and allergy. Environmental Health Perspectives (Online), v. 122, n. 12, p. 1329, 2014.

DAVIES, R. G. et al. City-wide relationships between green spaces, urban land use and topography. Urban Ecosystems, v. 11, n. 3, p. 269, 23 abr. 2008.

DE MELLO-THÉRY, N. A. Conservação de áreas naturais em São Paulo. Estudos Avançados, v. 25, n. 71, p. 175-188, 2011.

DE TOLEDO, M. C. B. Análise das áreas verdes urbanas em diferentes escalas visando a conservação da avifauna. 2007.

DEAECTO, M. M. Fernand Braudel e o estudo das cidades: suas rotas e hierarquias nas origens do capitalismo moderno. História Revista, v. 13, n. 1, p. 4, 2008.

DISTRITO-FEDERAL. Lei complementar $n^{\circ}$ 17. Plano de Ordenamento Territorial do DF - PDOT. . 28 jan. 1997 a.

DISTRITO-FEDERAL. Decreto no 18857. Regulamentaçãp das Áreas de Proteção de Manancial - DF. . 7 ago. 1997 b.

DISTRITO-FEDERAL. Lei complementar $\mathrm{n}^{\circ}$ 827. SDUC - Sistema Distrital de Unidades de Conservação da Natureza. . 22 jul. 2010. 
DISTRITO-FEDERAL. Decreto $n^{\circ}$ 33.588. Ampliação e recategorização do Parque Ecológico e de Uso Múltiplo Olhos d'Água, situado na Região Administrativa de Brasília - RA-I. . 22 mar. 2012.

DONOVAN, G. H.; BUTRY, D. T. Trees in the city: Valuing street trees in Portland, Oregon. Landscape and Urban Planning, v. 94, n. 2, p. 77-83, 2010.

DOYLE, P. C. Comercialização de habitações populares em Brasília. In: PAVIANI, A. (Ed.). . Brasília: moradia e exclusão. Coleção Brasília. 1. ed. Brasília DF: Universidade de Brasilia, 1996. p. 115-138.

DRUMMOND, J. A. L. O jardim dentro da máquina: breve história ambiental da Floresta da Tijuca. Revista Estudos Históricos, p. 276-298, 1998.

EASTMAN, J. R. Idrisi Andes. Guide to GIS and image processing, p. 87-131, 2006.

FADURPE. Zonemento Ambeintal da APA Santa Cruz - PEFundação Apolônio Salles de Desenvolvimento Educacional - Recife - PE, , 2010. Disponível em: $<$ http://www.cprh.pe.gov.br/ARQUIVOS_ANEXO/zoneamentosantacruz;2243;20120 906.pdf>. Acesso em: 10 set. 2017

FARIAS, A. R. et al. Identificação, mapeamento e quantificação das áreas urbanas do BrasilEmbrapa - Comunicado Técnico (4), , jun. 2017. Disponível em: $<$ https://ainfo.cnptia.embrapa.br/digital/bitstream/item/163906/1/20170522-COT4.pdf>. Acesso em: 8 ago. 2017

FARRO, A. L.; DEMIRHISAR, D. G. The Gezi Park movement: a Turkish experience of the twenty-first-century collective movements. International Review of Sociology, v. 24, n. 1, p. 176-189, 9 abr. 2014.

FERREIRA, I. C. B.; PENNA, N. A. Brasília: novos rumos para a periferia. In: PAVIANI, A. (Ed.). . Brasília: moradia e exclusão. Coleção Brasília. 1. ed. Brasília DF: Universidade de Brasilia, 1996. p. 189-212.

FONSECA, A. J. S.; SILVA, H. P. B. S. Reflexões sobre a evolução do pensamento geográfico na formulação de bases legais para a proteção de florestas urbanas na Região Metropolitana do Recife-PE-Brasil. Contribuciones a las Ciencias Sociales, p. 8, 2017.

FONTOURA, L. N. J. Planejamento urbano-ambiental: o uso e ocupação do solo no Distrito Federal. Revista Especialize On-line IPOG-Goiânia-5a Edição, n. 005, 2012.

FORESTI, C.; PEREIRA, M. D. B. Utilização de indices vegetativos obtidos com dados do sistema TM-LANDSAT no estudo da qualidade ambiental urbana: cidade de São Paulo. Boletim de Geografia Teoretica. Anais... In: $4^{\circ}$ SEMINARIO LATINO-AMERICANO DE SENSORIAMENTO REMOTO. Gramado (RS): Instituto Espacial de Pesquisas Espaciais, 1986

FREITAS, R. Regiões Metropolitanas: uma abordagem conceitual. REVISTA HUM@ NAE, v. 4, n. 1, 2012. 
FULLER, R. A.; GASTON, K. J. The scaling of green space coverage in European cities. Biology Letters, 2009.

GANEM, R. S. et al. Ordenamento territorial e plano diretor: o caso do Distrito Federal. Cadernos Aslegis (Associação dos Consultores Legislativos e de Orçamento e Fiscalização Financeira da Câmara dos Deputados), p. 79-98, 2008.

GARCIA, G. Mansão Matarazzo. Disponível em: <http://www.saopauloantiga.com.br/mansao-matarazzo/>. Acesso em: 1 jul. 2017.

GENTIN, S. Outdoor recreation and ethnicity in Europe-A review. Urban Forestry \& Urban Greening, v. 10, n. 3, p. 153-161, 1 jan. 2011.

GINI, C. Variabilità e mutabilità. Reprinted in Memorie di metodologica statistica (Ed. Pizetti E, Salvemini, T). Rome: Libreria Eredi Virgilio Veschi, v. 1, 1912.

GIRÃO, O. Análise de processos erosivos em encostas na zona sudoeste da cidade do Recife-Pernambuco. Tese (Doutorado em Geologia)—Rio de Janeiro RJ: Universidade Federal do Rio de Janeiro - Instituto de Geociências, 2007.

GONTIJO, J. C. F. Uso e características dos fragmentos florestais urbanos da cidade de Manaus/AM. Dissertação de Mestrado - Programa de Pós-graduação em Ciências do Ambiente e Sustentabilidade na Amazônia-Manaus: Universidade Federal do Amaazonas - Centro de Ciências do Ambiente, 2008.

GORZ, A. Da aptidão ao tempo livre. CEPAT Informa, Curitiba, n. 51, p. 32, 1999.

GORZ, A. A Ideologia Social do Carro. In: LUDD, N. (Ed.). . Apocalipse motorizado: a tirania do automóvel em um planeta poluído. Traducao Leo Vinicius. 2. ed. São Paulo: Conrad Editora do Brasil, 2004. p. 158.

GOUVEAA, L. A. DE C. Brasília: a capital da segregação e do controle social: uma avaliação da ação governamental na área da habitação. 1. ed. São Paulo: Annablume, 1995. v. 36

GRIMAL, P. L'art des jardins. 2. ed. France: Presses Universitaires de France Vendôme, Impr. des P.U.F., 1964.

GUASSELLI, L. A.; ETCHELAR, C. B.; BELLOLI, T. F. Os impactos do cultivo de arroz irrigado sobre as áreas úmidas da Área de Proteção Ambiental do Banhado Grande do rio Gravataí-RS. Anais XVI. Anais... In: SIMPÓSIO BRASILEIRO DE SENSORIAMENTO REMOTO. Foz do Iguaçu - PR: INPE, 2013

HAASE, D. et al. Greening cities - To be socially inclusive? About the alleged paradox of society and ecology in cities. Habitat International, v. 64, p. 41-48, 1 jun. 2017.

HARDT, L. P. A. Subsídios ao planejamento de sistemas de áreas verdes baseado em princípios de ecologia urbana: aplicação a Curitiba-PR. Dissertação apresentada ao Curso de Pós-Graduação em Engenharia FlorestalCuritiba - PR: Universidade Federal do Paraná, 1994. 
HARVEY, D. A Justiça Social e a Cidade. Traducao Armando Corrêa Da Silva. São Paulo: Hucitec, 1980.

HARVEY, P. Dicionário Oxford de literatura clássica grega e latina. Tradução Mário da Gama Cury. Rio de Janeiro: Zahar, 1987.

HASENACK, H. et al. Vegetação e Ocupação de Porto Alegre. In: HASENACK, H. (Ed.). . Diagnóstico Ambiental de Porto Alegre: geologia, solos, drenagem, vegetação/ocupação e paisagem. 1. ed. Porto Alegre - RS: PMPA - Secretaria de Meio Ambiente, 2008. v. 1p. 56-69.

HECKERT, M. Access and equity in greenspace provision: A comparison of methods to assess the impacts of greening vacant land. Transactions in GIS, v. 17, n. 6 , p. 808-827, 2013.

HELM, J. Rua Gonçalo de Carvalho "a mais bonita do mundo" / Porto Alegre RShttp://www.archdaily.com.brl, $2011 . \quad$ Disponível em: $<$ http://www.archdaily.com.br/br/01-2129/rua-goncalo-de-carvalho-a-mais-bonita-domundo-porto-alegre-rs>. Acesso em: 9 set. 2017

HENKE-OLIVEIRA, C. Planejamento ambiental na cidade de São Carlos (SP) com ênfase nas áreas públicas e áreas verdes: diagnóstico e propostas. Dissertação-São Carlos: Mestrado em Ecologia e Recursos Naturais Universidade Federal de São Carlos, 1996.

HENKE-OLIVEIRA, C. Análise de padrões e processos no uso do solo, vegetação, crescimento e adensamento urbano. Estudo de caso: Município de Luiz Antônio (SP). Tese de Doutorado-São Carlos: Ecologia e Recursos Naturais Universidade Federal de São Carlos, 2001.

HENRIQUE, W. O direito à natureza na cidade. 1. ed. Salvador: Edufba, 2009.

HOFFMANN, R. Distribuição de renda: medidas de desigualdade e pobreza. São Paulo: Edusp, 1998. v. 22

HULSMEYER, A. F.; MACEDO, S. S. APPS URBANAS E AS MUDANÇAS NO CÓDIGO FLORESTAL: DIRETRIZES PARA A LEGISLAÇÃO MUNICIPALFaculdade de Arquitetura e Urbanismo - USP, , 2015. Disponível em: $<$ http://quapa.fau.usp.br/wordpress/wp-content/uploads/2015/11/APPS-urbanas-eas-mudanças-no-código-florestal-diretrizes-para-a-legislação-municipal.pdf>. Acesso em: 7 set. 2017

IBGE. Aglomerados subnormais: Informações territoriaisCenso Demográfico, , 2010a. . Acesso em: 7 set. 2016

IBGE. Censo Demográfico 2010: agregado por setores censitários dos resultados do universolnstituto Brasileiro de Geografia e Estastística, , 2010b.

IBGE. Base de informações do Censo Demográfico 2010: Resultados do Universo por setor censitárioMinistério de Planejamento, Orçamento e Gestão / Instituto Brasileiro de Geografia e Estatística - Centro de Documentação e Disseminação de Informações, , 2011. Disponível em: 
<http://www.ipea.gov.br/redeipea/images/pdfs/base_de_informacoess_por_setor_ce nsitario_universo_censo_2010.pdf>. Acesso em: 4 mar. 2017

ICMBIO. Parque Nacional da Tijuca, 2017. Disponível em: <http://www.icmbio.gov.br/parnatijuca/>. Acesso em: 4 abr. 2017

ILLICH, I. TOOLS FOR CONVIVIALITY. New York: Harper \& Row, 1973. v. 47

INSTITUTO FLORESTAL. Reserva da Biosfera do Cinturão Verde da Cidade de São Paulo, 2010. Disponível em: <http://iflorestal.sp.gov.br/o-instituto/rbcv/>. Acesso em: 10 out. 2017

IPEA. Unidades de Desenvolvimento Humano (UDH), 2012. . Acesso em: 6 ago. 2017

IPEA. Atlas da Vulnerabilidade Social nas Regiões Metropolitanas Brasileiras. Brasília DF: Instituto de Pesquisa Econômica e Aplicada, 2015.

ITIKAWA, V. K. Mananciais e urbanização: recuperação ambiental na sub-bacia Billings: os bairros ecológicos em São Bernardo do Campo, São Paulo (19972007). Dissertação (Mestrado em Arquitetura e Urbanismo)—São Paulo - SP: Universidade Presibiteriana Mackenzie, 2008.

JACOBI, P. A percepção de problemas ambientais urbanos em São Paulo. Lua Nova: Revista de Cultura e Política, v. 31, p. 47-55, 1993.

JACOBI, P. Cidade e meio ambiente: percepções e práticas em São Paulo. 1. ed. São Paulo: Annablume, 1999.

JACOBI, P. R. Educação ambiental, cidadania e sustentabilidade. Cadernos de pesquisa, n. 118, p. 189-205, 2003.

JACOBI, P. R.; CIBIM, J.; LEÃO, R. DE S. Crise hídrica na Macrometrópole Paulista e respostas da sociedade civil. Estudos Avançados, v. 29, n. 84, p. 27-42, 2015.

JACOBS, J. Morte e vida de grandes cidades. 3. ed. Brasil: Wmf Martins Fontes, 2011.

JANNUZZI, P. DE M. São Paulo, século XXI: a maior metrópole das Américas. Ciência e Cultura, v. 56, n. 2, p. 30-32, 2004.

JELLICOE, G. A. The search for a paradise garden. IFLA yearbook, v. 86, p. 6-33, 1985.

JONES, K. R. "The Lungs of the City": Green Space, Public Health and Bodily Metaphor in the Landscape of Urban Park History. Environment and History, v. 24, n. 1, p. 39-58, 1 fev. 2018.

KUCHELMEISTER, G. Árboles y silvicultura en el milenio urbano. Unasylva, v. 200, n. 51, p. 49-55, 2000. 
KUCHELMEISTER, G.; BRAATZ, S. Una nueva visión de la silvicultura urbana. Unasylva, v. 44, n. 173, p. 3-12, 1993.

LEFEBVRE, H. A linguagem e a sociedade. Traducao José António Machado. Lisboa: Ulisseia, 1966.

LEFEBVRE, H. O pensamento marxista e a cidade. Traducao Maria Idalina Furdado. Lisboa: Ulisseia, 1972.

LEFEBVRE, H. A Produção do Espaço. Traducao Sérgio Martins; Doralice Barros Pereira. 4. ed. Paris: Anthropos, 1991.

LEFEBVRE, H. A revolução urbana. Traducao Sérgio Martins; Margarida Maria De Andrade. Belo Horizonte - MG: Editora UFMG, 2004. v. 39

LEFEBVRE, H. Espaço e política. Traducao Margarida Maria Andrade; Sérgio de Souza Martins. Belo Horizonte: UFMG, tradução brasileira. 1972, Editions Anthropos, 2008a.

LEFEBVRE, H. O direito à cidade. Traducao Rubens Eduardo Ferreira Frias. 5. ed. São Paulo. Centauro São Paulo, 2008b.

LIEBERG, S. A. Análise sucessional de fragmentos florestais urbanos e delimitações de trilhas como instrumento de gestão e manejo no programa de uso público do Parque Ecológico do Guarapiranga, São Paulo. Tese (Doutorado em Ciências Biológicas)—Rio Claro - SP: Universidade Estadual Paulista "Júlio De Mesquita Filho" Instituto de Ciências Biológicas, 2003.

LIMA, A. M. L. P. et al. Problemas de utilização na conceituação de termos como espaços livres, áreas verdes e correlatos. Congresso Brasileiro de Arborização Urbana. Anais...1994

LIMA, D. F. Produção e apropriação do espaço nas bordas intraurbanas no sudoeste da cidade do Recife-PE: análise da dinâmica imobiliária nos bairros de Tejipió e Sancho. Dissertação (Mestrado em Engenharia Urbana e Ambiental) João Pessoa - PB: Universidade Federal da Paraíba - Centro de Tecnologia, 2011.

LIMA, D. F. et al. Bordas urbanas: análise da produção e apropriação dos espaços periurbanos da cidade do Recife, Pernambuco. Revista Brasileira de Gestão e Desenvolvimento Regional, v. 10, n. 4, p. 26-45, 2014.

LIMA, M. C. Quando o amanhã vem ontem: a institucionalização da Região Metropolitana de Manaus e a indução ao processo de metropolização do espaço na Amazônia Ocidental. Tese (Doutorado em Geografia)—São Paulo: Universidade de São Paulo - Faculdade de Filosofia,Letras e Ciências Humanas, 2014.

LOBODA, C. R.; DE ANGELIS, B. L. D. Áreas verdes públicas urbanas: conceitos, usos e funções. Ambiência, v. 1, n. 1, p. 125-139, 2009.

LOTITO, M. P. A cidade como espetáculo: publicidade e vida urbana na São Paulo dos anos 20. 1. ed. São Paulo - SP: Annablume, 2000. 
MACEDO, S. S. Espaços livres. Paisagem e ambiente, n. 7, p. 15-56, 1995.

MACEDO, S. S.; SAKATA, F. G. Parques urbanos no Brasil. In: Coleção Quapá. São Paulo. SP. Edusp, 2002.

MAMMARELLA, R.; BARCELLOS, T. M. Estrutura social e segmentação do espaço metropolitano. Um retrato da Região Metropolitana de Porto Alegre em 2000. Cadernos Metrópole, p. 133-168, 2005.

MARICATO, E. Metrópole na periferia do capitalismo. llegalidade, desigualdade e violência. Capital \& Class, v. 23, n. 3, p. 182-185, 1999.

MARINHO, G.; LEITÃO, L.; LACERDA, N. Transformações urbanísticas na região metropolitana do Recife: um estudo prospectivo. Cadernos Metrópole. ISSN (impresso) 1517-2422;(eletrônico) 2236-9996, n. 17, p. 193-217, 2007.

MARQUES, A. A. B. As Unidades de Conservação e os Parques - Desafios para a Conservação da Natureza no Distrito Federal. 1. ed. Brasília DF: CÂMARA LEGISLATIVA DO DISTRITO FEDERAL, 2015. v. 1

MARQUES, C. P.; ARANHA, J. Apontamentos de Detecção Remota. UTAD, Vila Real, 2000.

MARTIN, E. V.; MEIRA, J. R.; OLIVEIRA, P. L. Avaliação dos morros de Porto Alegre com base no uso do solo. In: MENEGAT, R. et al. (Eds.). . Atlas ambiental de Porto Alegre. Porto Alegre - RS: UFRGS, 1998. p. 83-100.

MARTINS, G. N.; MELO, A. O valor da preservação do Parque dos Manguezais em Recife-PE: uma utilização do método de opções reais. ANPEC - Associação Nacional dos Centros de Pós-graduação em Economia, v. 4, n. 146, p. 1-19, 2007.

MARTINS, J. D. AS REGRAS DA METRÓPOLE Campo Urbanístico e Ordem Social na Região Metropolitana de São Paulo. Tese (Doutorado em Sociologia) Brasília DF: Universidade de Brasília, Instituto de Ciências Sociais, Departamento de Sociologia, 2006.

MAZZEI, K. M.; COLESANTI, M. T. M.; DOS SANTOS, D. G. Áreas verdes urbanas, espaços livres para o lazer. Revista Sociedade \& Natureza, v. 19, n. 1, p. 33-43, 2007.

MEDEIROS, E. B. O lazer no planejamento urbano. 1. ed. Rio de Janeiro - RJ: FGV, 1975.

MELLO-THÉRY, N. A. Conservação de áreas naturais em São Paulo. Estudos Avançados, v. 25, n. 71, p. 175-188, 2011.

MENARIN, C. A. Entorno da sustentabilidade: a reserva da biosfera do Cinturão Verde da cidade de São Paulo (1971-2008). Tese (Doutorado em História)-Assis - SP: Universidade Estadual Paulista - UNESP - Faculdade de Ciências e Letras, 2013. 
MENDES, C. H. A. Implicações ambientais do desenvolvimento da infra-estrutura: saneamento urbano. Revista de Administração Pública, v. 26, n. 4, p. 32-51, 1992.

MERCADANTE, M. A vegetação urbana: diretrizes preliminares para uma proposta metodológica. Encontro Nacional de Estudos Sobre o Meio Ambiente, v. 3, p. 51-59, 1991.

MESQUITA, O. M. La belle vitrine: Manaus entre dois tempos 1890-1900. Manaus: FAPEAM, 2009.

MILLER, H. J. Potential contributions of spatial analysis to geographic information systems for transportation (GIS- T). Geographical Analysis, v. 31, n. 4, p. 373-399, 1999.

MILLER, R. W.; HAUER, R. J.; WERNER, L. P. Urban forestry: planning and managing urban greenspaces. 3. ed. Long Grove, Illinois: Waveland press, 2015.

MMA. Áreas verdes urbanas, 2012. Disponível em: <http://www.mma.gov.br/cidades-sustentaveis/areas-verdes-urbanas>. Acesso em: 15 dez. 2015

MOLINARI, D. C.; VIDAL, K. F.; MACEDO, O. P. C. Uso de geotecnologias aplicadas à delimitação de áreas de risco a voçorocamento em Manaus (AM). Caderno de Geografia, v. 25, n. 43, p. 192-205, 2015.

MOMM-SCHULT, S. I. et al. Integration of urban and environmental policies in the metropolitan area of São Paulo and in Greater London: the value of establishing and protecting green open spaces. International Journal of Urban Sustainable Development, v. 5, n. 1, p. 89-104, 2013.

MORAES, E. DE O. et al. As funções dos parques urbanos da cidade de Manaus. Anais Programa Ciência na Escola, v. 2, n. 1, p. 77-83, 2014.

MORAES, J. M. Toponômios do Município de Olinda. Revista Brasileira de Geografia, p. 441-473, 1962.

MORAN, P. A. P. Notes on continuous stochastic phenomena. Biometrika, v. 37, n. 1/2, p. 17-23, 1950.

MOREIRA, F. D. A construção de uma cidade moderna: Recife (1909-1926). Dissertação (Mestrado em Arquitetura e Urbanismo)-Recife - PE: Universidade Federal de Pernambuco -, 1994.

MORO, D. A. As áreas verdes e seu papel na ecologia urbana e no clima urbano. Revista UNIMAR, Maringá, v. 1, n. 2, 1976.

MOROZ, I. C.; CANIL, K.; ROSS, J. L. S. Problemas ambientais nas áreas de Proteção aos Mananciais da Região Metropolitana de São Paulo. Revista do Departamento de Geografia, v. 7, n. 13, p. 35-48, 1994. 
MOURA, R.; LIBARDI, D.; BARION, M. I. Institucionalização de regiões metropolitanas: qual o sentido? Revista Paranaense de Desenvolvimento-RPD, $n$. 111, p. 129-143, 2011.

MTNYC. One Million trees, 2013. Disponível em: <http://www.milliontreesnyc.org>. Acesso em: 4 abr. 2017

MUNIZ, R. et al. Plano Manejo APA Aldeia-BeberibeGoverno do Estado de Pernambuco, , maio 2012.2 Disponível em: <http://www.cprh.pe.gov.br/ARQUIVOS_ANEXO/PM\%20AB3\%20Volume\%205.pdf> . Acesso em: 20 set. 2017

NOGUEIRA, A. C. F.; SANSON, F.; PESSOA, K. A expansão urbana e demográfica da cidade de Manaus e seus impactos ambientais. XIII Simpósio Brasileiro de Sensoriamento Remoto. Anais...Florianópolis - SC: INPE, 21 abr. 2007

NOGUEIRA, A. R. B. LUGAR E CULTURA: a produção da vida no Careiro da Várzea-AM. ACTA GEOGRÁFICA, v. 1, n. 2, p. 85-95, 2010.

NOWAK, D. J. et al. Sustaining America's urban trees and forests. Mewtown Square, Pensilvânia: United States Department of Agriculture, Forest Service, Northern Research Station, 2010. v. 62

NUCCI, J. C. Qualidade ambiental e adensamento urbano: um estudo de ecologia e planejamento da paisagem aplicado ao distrito de Santa Cecília, MSP. [s.I.] Humanitas, FFLCH/USP, 2001.

NUNES, M. G. A prática da atividade orizícola pela agricultura familiar no município de Santo Antônio da Patrulha. Trabalho de Conclusão de Curso (Tecnólogo em Desenvolvimento Rural))—Santo Antônio da Patrulha: Universidade Federal do Rio Grande do Sul - Departamento de Ciências Econômicas, 2011.

OLIVEIRA, A. M. S. D. F. et al. Ocupações e usos nas ilhas do Delta do Jacuí - Rio Grande do Sul - Brasil. Observatório Gográfico da América Latina, p. 1-11, 2011.

OLIVEIRA, M. DE et al. (EDS.). A Reserva Ducke. 1. ed. Manaus: Attema, 2008. v. 1

OLIVEIRA, E. M. Variação temporal da cobertura de uso do solo dos morros de Porto Alegre (1991-2002). Trabalho de Conclusão de Curso (Bacharel em Ciências Biológicas)-Porto Alegre - RS: Universidade Federal do Rio Grande do Sul Departamento de Ecologia, 2012.

OLIVEIRA, J. A.; SCHOR, T. Manaus: transformações e permanências, do forte à metrópole regional. In: CASTRO, E. (Ed.). . Cidades na Floresta. 1. ed. São Paulo: Annablume, 2009. p. 41-98.

OLIVEIRA, M. L. A. A.; PORTO, M. L. Ecologia da paisagem do Parque Estadual do Delta do Jacuí, Rio Grande do Sul, Brasil: mapa da cobertura do solo e vegetação, a partir de imagem do LANDSAT TM5. Iheringia, Série Botânica, v. 53, p. 89-144, 1999. 
OLIVEIRA, N. A urbanização no RS: características recentes. Indicadores Econômicos FEE, v. 23, n. 4, p. 277-294, 1996.

OLIVEIRA, W. Geologia da planície do Recife: contribuição ao seu estudo. 1. ed. Recife - PE: Oficinas Gráficas do Jornal do Commercio, 1942.

ONU. Cúpula das Nações Unidas sobre o Desenvolvimento Sustentável, 2015a. Disponível em: <https://nacoesunidas.org/pos2015/cupula/>. Acesso em: 6 jul. 2017

ONU. Transformando Nosso Mundo: A Agenda 2030 para o Desenvolvimento Sustentável. Nova York: Organização das Nações Unidas, 2015b.

PADILHA, V. Desafios da crítica imanente do lazer e do consumo a partir do shopping center. Artcultura, v. 10, n. 17, 2009.

PÁEZ, A.; SCOTT, D. M. Spatial statistics for urban analysis: a review of techniques with examples. GeoJournal, v. 61, n. 1, p. 53-67, 2005.

PAULISTA - PE. Decreto municipal $n^{\circ}$ 94. Institui áreas de utilidade pública de interesse social para fins de desapropriação. . 31 dez. 1985.

PAVIANI, A. A violência do desemprego. In: PAVIANI, A.; FERREIRA, I. C. B.; BARRETO, F. F. P. (Eds.). . Brasília: dimensões da violência urbana. Coleção Brasília. 1. ed. Brasília DF: Universidade de Brasilia, 2005. p. 193-218.

PELUSO, M. L. Brasília: do mito ao plano, da cidade sonhada à cidade administrativa. Revista Espaço e Geografia, v. 6, n. 2, p. 1-29, 2003 a.

PELUSO, M. L. Reflexões sobre ambiente urbano e representações sociais. In: PAVIANI, A.; GOUVÊA, L. A. (Eds.). . Brasília: Controvérsias Ambientais. Coleção Brasília. 1. ed. Brasília DF: Universidade de Brasilia, 2003b. p. 181-196.

PENHAVEL, P. F. DO C. Urbanização por expropriação: o caso do Setor Noroeste (Brasília-DF). Dissertação (Mestrado em Sociologia).-Goiânia: Faculdade de Ciências Sociais, Universidade Federal de Goiás, 2013.

PENNA, N. A. Urbanização, cidade e meio ambiente. GEOUSP: Espaço e Tempo (Online), n. 12, p. 125-140, 2016.

PENTEADO, A. DE F. Mapeamento e análise geomorfológicos como subsídio para identificação e caracterização de terras inundáveis, estudos de caso da bacia hidrográfica do Rio dos Sinos-RS. Tese (Doutorado em Geografia)-São Paulo: Universidade de São Paulo - Faculdade de Filosofia, Letras e Ciências Humanas, 2011.

PEREIRA, D. A.; PATO, C. Valores e comportamento ecológico: dimensões para Educação Ambiental em Parques Urbanos. AMBIENTE \& EDUCAÇÃO-Revista de Educação Ambiental, v. 20, n. 2, p. 81-101, 2016.

PERNAMBUCO. Lei Estadual $n^{\circ}$ 9.860. Criação das Áreas de Proteção de Manancial do estado de Pernambuco. . 4 jul. 1986. 
PERNAMBUCO. Lei Estadual $\mathrm{n}^{\circ}$ 9.931. Criação das APA Estuarianas de Pernambuco. . 4 ago. 1989.

PERNAMBUCO. Decreto Estadual $n^{\circ}$ 32.488. Criação da APA de Santa Cruz. . 3 abr. 2008.

PERNAMBUCO. Lei Estadual $\mathrm{n}^{\circ}$ 13.787. Sistema Estadual de Unidade de Conservação da Natureza (SEUC). . 7 ago. 2009.

PERNAMBUCO. Decreto Estadual n ${ }^{\circ}$ 34.692. Criação da APA Aldeia-Beberibe. . 17 mar. 2010.

PERNAMBUCO. Lei Estadual $n^{\circ}$ 14.324. Categoriza as Reservas Ecológicas da Região Metropolitana do Recife. . 7 mar. 2011.

PIRENNE, H. As cidades da Idade Média. 3-ed. Trad. port., Lisboa: EuropaAmérica, 1973.

PLATA, J. A. R.; VILCHIS, M. DEL C. V.; VÁZQUEZ, A. I. G. Green Areas and Environmental Justice: Toward the Urban Sustainability of León, Guanajuato. In: Sustainable Development Research and Practice in Mexico and Selected Latin American Countries. [s.l.] Springer, 2018. p. 283-296.

PMC. Mato do Júlio: memória de Cachoeirinha é lembrada a partir da Casa dos Baptista (por Martins V.) - Prefeituta Municipal de Cachoeirinha - RS. público. Disponível em: <https://www.oreporter.net/herdeiros-impedem-acesso-a-casa-dosbaptista-no-mato-do-julio/>. Acesso em: 8 jul. 2017.

PONTUAL, V. Tempos do Recife: representações culturais e configurações urbanas. Revista brasileira de história, v. 21, n. 42, p. 417-434, 2001.

PORTO, M. L. et al. Unidades de Conservação Ambiental no Município de Porto Alegre. In: VOLKMER, J. A. et al. (Eds.). . Retratos de cooperação científica e cultural: 40 anos do Instituto Cultural Brasileiro-Alemão. 1. ed. Porto Alegre RS: EDIPUCRS, 1999. p. 63-77.

PRIETO, É. C. O Estatuto da Cidade e o Meio Ambiente. IV Congresso Brasileiro de Direito Urbanístico São Paulo. Anais...2006

QUEIROZ, G. C. M. DE. Fortalecimento e fragmentação do cinturão verde do Alto Tietê: perspectivas sobre a atividade agrícola da região. Dissertação (Mestrado em Administração)-São Caetano do Sul - SP: Universidade Municipal de São Caetano do Sul - USCS, 2012.

RAIMUNDO, S. A paisagem natural remanescente na região metropolitana de São Paulo. São Paulo em Perspectiva, v. 20, n. 2, p. 19-31, 2006.

RAMALHO, A. M. F.; MELLO, G. M. S.; CAVALCANTE, M. A. H. A vez do oeste metropolitano: planejamento ou oportunidade? Breve leitura sobre o planejamento oeste da Região Metropolitana do Recife. In: SOUZA, M. A. A.; BITOUN, J. (Eds.). . RECIFE: TRANSFORMAÇÕES NA ORDEM URBANA. 1. ed. Rio de Janeiro - RJ: Letra Capital, 2015. 
RECIFE. Parques e Praças- RecifeDados georreferenciados de Recife, 2016. Disponível em: <http://dados.recife.pe.gov.br/dataset/parques-e-pracas>. Acesso em: 9 set. 2017

REGALDO, F. et al. Piseagrama: Camapanhas, 2015. Disponível em: <piseagrama.org/campanha>. Acesso em: 11 nov. 2017

REIS, L. A. M. Resíduos sólidos e líquidos encontrados no PEFI. In: BICUDO, D. C.; FORTI, M. C.; BICUDO, C. E. M. (Eds.). . Parque Estadual das Fontes do Ipiranga (PEFI): unidade de conservação que resiste à urbanização de São Paulo. São Paulo: Secretaria do Meio Ambiente do Estado de São Paulo. 1. ed. São Paulo SP: Secretaria de Meio Ambiente de São Paulo, 2002. p. 259-270.

RIBEIRO, B. Doria decide criar Parque Augusta e vai oferecer terrenos a construtoras, 19 abr. 2017. Disponível em: <http://saopaulo.estadao.com.br/noticias/geral,doria-decide-criar-parque-augusta-e-vaioferecer-terrenos-a-construtoras,70001743546>. Acesso em: 5 dez. 2017

RIBEIRO, C.; PONTUAL, V. A reforma urbana nos primeiros anos da década de 1960. 10. ed. São Paulo - SP: Vitrovius, 2009.

RICHARDS, D. R.; PASSY, P.; OH, R. R. Impacts of population density and wealth on the quantity and structure of urban green space in tropical Southeast Asia. Landscape and Urban Planning, v. 157, p. 553-560, 2017.

RICHARDS, J. A. Remote sensing digital image analysis. Australia: Springer, 1986. v. 3

RIO GRANDE DO SUL. Lei estadual n 12371. Cria a Área de Proteção Ambiental Estadual Delta do Jacuí e amplia Parque Estadual Delta do Jacuí. . 11 nov. 2005.

RODRIGUES, E. M. S. et al. Epidemiology of dengue infection in Ribeirão Preto, SP, Brazil. Revista de Saúde Pública, v. 36, n. 2, p. 160-165, 2002.

RODRIGUES, R. P.; MARCELLINO, N. C. O lazer nas políticas públicas participativas de Porto Alegre: estudo das gestões municipais de 1994 a 2004. LICERE-Revista do Programa de Pós-graduação Interdisciplinar em Estudos do Lazer, v. 14, n. 3, p. 1-38, 2011.

ROLNIK, R. Zonas de Especial Interesse Social. Pólis-Ildesfes, p. 3, 1998.

ROLNIK, R. et al. O Programa Minha Casa Minha Vida nas regiões metropolitanas de São Paulo e Campinas: aspectos socioespaciais e segregação. Cadernos Metrópole., v. 17, n. 33, p. 127-154, 2015.

ROLNIK, R.; SOMEKH, N. Governar as metrópoles: dilemas da recentralização. Cadernos Metrópole., n. 08, p. 105-117, 2002.

ROMANINI, A.; MELLO, O. S. O planejamento e a gestão do uso do solo na RMPA. $4^{\circ}$ CONGRESSO LUSO-BRASILEIRO PARA O PLANEAMENTO URBANO, REGIONAL, INTEGRADO, SUSTENTÁVEL. Anais... In: PLURIS 2010: THE 
CHALLENGES OF PLANNIG IN A WEB WIDE WORD. Faro - Portugal: Universidade do Algarve, 2010

ROMERO, M. A. B. Cidades sustentáveis. Programa de Pós-Graduação da Faculdade de Arquitetura e Urbanismo - UnB, 2001.

ROMERO, M. A. B. A violência e as condições degradantes do meio urbano. In: PAVIANI, A.; FERREIRA, I. C. B.; BARRETO, F. F. P. (Eds.). . Brasília: dimensões da violência urbana. Coleção Brasília. 1. ed. Brasília DF: Universidade de Brasilia, 2005. p. 133-161.

SAITO, C. H. Contribuição metodológica para planejamento urbano de municípios de pequeno e médio porte através de SGI e banco de dados relacional. Tese (Doutorado em Geografia) - PPGG—Rio de Janeiro: UFRJ, 1996.

SALBITANO, F. et al. Guidelines on urban and peri-urban forestry: FAO Forestry Paper. Roma: FAO - Food and Agriculture Organization of the United Nations, 2016. Disponível em: <http://www.fao.org/3/a-i6210e.pdf>. Acesso em: 11 set. 2017.

SALDANHA, N. O jardim e a praça: o privado e público na vida social e histórica. rev. e atual. Revista Ciência \& Trópico, v. 11, n. 1, p. 105-121, 1983.

SALDANHA, N. O Estado moderno e a separação de poderes. 2. ed. São Paulo SP: Quartier Latin, 2010.

SANTOS, M. A urbanização brasileira. 5. ed. São Paulo: Edusp, 2005. v. 6

SÃO PAULO. Decreto Estadual n² 22.717. Declara Área de Proteção Ambiental da Serra do Mar. . 21 set. 1984.

SÃO PAULO. Lei Municipal n 13.430. Política Municipal de Áreas Verdes. . 2005.

SARAIVA, C.; MARQUES, E. A dinâmica social das favelas da região metropolitana de São Paulo. Pensamento \& Realidade, v. X, n. 21, 2007.

SBAU. SOCIEDADE BRASILEIRA DE ARBORIZAÇÃO URBANA - "Carta a Londrina e Ibiporã" - Boletim Informativo. [s.I: s.n.]. v. 3

SCHEREN, R. S. Urbanização na planície de inundação do Rio Gravataí-RS. Dissertação (Mestrado em Geografia)—Porto Alegre - RS: Universidade Federal do Rio Grande do Sul - Departamento de Geociências, 2014.

SCHERER, E.; MENDES FILHO, I. Injustiça ambiental em Manaus. [s.I.] III Conferência da Amazônia, 2004.

SCHIFFER, S. T. R. O processo de urbanização no Brasil. 1. ed. São Paulo: EdUSP, 1999.

SCOCUGLIA, J. B. C. O Parc de La Tête d'Or: patrimônio, referência espacial e lugar de sociabilidade. Arquitextos, v. 113, p. 109-110, 2009. 
SCUSSEL, M. C. B.; SATTLER, M. A. Cidades em (trans) formação: impacto da verticalização e densificação na qualidade do espaço residencial. Ambiente Construído, v. 10, n. 3, p. 137-150, 2010.

SEABRA, G. Natureza, consumo e a reciclagem das ciades. In: SEABRA, G. (Ed.). . Terra: Cidades, Natureza e Bem Estar. 1. ed. João Pessoa - PB: Editora Universitária - UFPB, 2012.

SEDUMA, G. PLANO DIRETOR DE ORDENAMENTO URBANO E TERRITORIAL PDOTSecretaria de Estado de Desenvolvimento Urbano e Meio Ambiente, Governo do Distrito Federal, 2007. Disponível em: <http://www.segeth.df.gov.br/preservacao-e-planejamento-urbano/pdot.html>. Acesso em: 5 jun. 2017

SEGAWA, H. M. Ao amor do público: jardins no Brasil. 1. ed. São Paulo: FAPESP, 1996.

SEPE, P. M.; TAKIYA, H. o verde, o território, o ser humano: diagnóstico e bases para a definição de políticas públicas para áreas verdes no Município de São Paulo. 1. ed. São Paulo - SP: Secretaria do Verde e do Meio Ambiente SVMA/PMSP Secretaria de Planejamento - SEMPLA/PMSP, 2004.

SERAFIM, A. R. M. D. B. R. O verde na cidade: análise da cobertura vegetal nos bairros do centro expandido da cidade do Recife-PE. Dissertação (Mestrado em Gestão e políticas ambientais)—Recife - PE: Universidade Federal de Pernambuco Centro de Filosofia e Ciências Humanas, 2008.

SEVCENKO, N. O front brasileiro na guerra verde: vegetais, colonialismo e cultura. Revista Usp, n. 30, p. 108-119, 1996.

SHAFTOE, H. Convivial urban spaces: Creating effective public places. London: Earthscan, 2012.

SHASHUA-BAR, L.; HOFFMAN, M. E. Vegetation as a climatic component in the design of an urban street. An empirical model for predicting the cooling effect of urban green areas with trees. Energy and Buildings, v. 31, n. 3, p. 221-235, 2000.

SILVA, A. B. A RECONFIGURAÇÃO DE UMA PERIFERIA DE AMENIDADES: À PROCURA DA NATUREZA EM ALDEIA (CAMARAGIBE/PE). Tese (Doutorado em Geografia)—Recife - PE: Universidade Federal de Pernambuco - Centro de Filosofia e Ciências Humanas, 2015.

SILVA, D. A. A influência das áreas verdes no clima da cidade de Manaus. Dissertação de mestrado (Geografia)—Manaus: Universidade Federal do Amazonas - Instituto de Ciencias Humanas e Letras, 2009.

SILVA, J. A. DA. Direito urbanístico brasileiro. 7. ed. São Paulo: Malheiros, 2012.

SILVA, J. B. DA. Estatuto da cidade versus estatuto de cidade-eis a questão. Dilemas urbanos: novas abordagens sobre a cidade. São Paulo: Contexto, p. 29-34, 2003a. 
SILVA, M. K. A expansão do Orçamento Participativo na região metropolitana de Porto Alegre: condicionantes e resultados. A inovação democrática no Brasil. São Paulo: Cortez, p. 157-185, 2003b.

SILVA, M. M.; MUCCI, J. L. N.; PELICIONI, M. C. F. A área de proteção ambiental "Fazenda e Parque do Carmo": os problemas ambientais, as dificuldades de gestão e a influência na qualidade de vida da população. [s.l: s.n.].

SILVERMAN, B. W. Density estimation for statistics and data analysis. 1. ed. Bath, UK: CRC press, 1986. v. 26

SMA. AS UNIDADES PROTEGIDAS DO RECIFE: A CIDADE DO RECIFE E SEU PATRIMÔNIO AMBIENTALSecretaria de Meio Ambiente de Recife - Diretoria de Políticas Ambientais, , 2012. Disponível em: <http://www2.recife.pe.gov.br/wpcontent/uploads/UNIDADES-DE-CONSERVAÇÃO-MUNICIPAIS.pdf>. Acesso em: 4 dez. 2016

SMAM. Áreas Verdes - Secretaria Municipal de Meio Ambiente (Porto Alegre), $2013 . \quad$ Disponível em: <http://www2.portoalegre.rs.gov.br/smam/default.php?p_secao=283>. Acesso em: 9 jul. 2017

SOARES, P. R. Região Metropolitana ou Aglomeração Urbana? O debate no Rio Grande do Sul. Revista Eletrônica de Estudos Urbanos e Regionais - e metropolis, v. 15, n. 4, p. 20-29, 2013.

SOARES, P. R. R.; FEDOZZI, L. J. Transformações na Metrópole Meridional do Brasil - 1980/2010. In: FEDOZZI, L. J.; SOARES, P. R. (Eds.). . PORTO ALEGRE: transformações na ordem urbana. estudos comparativos. Porto Alegre - RS: Letra Capital Editora LTDA, 2015. p. 345-364.

SOARES, P. R. R.; FEDOZZI, L. J. Porto Alegre e sua região metropolitana no contexto das contradições da metropolização brasileira contemporânea. Sociologias, p. 162-197, 2016.

SOBRINHO, F. F. Composição e estrutura do componente arbóreo/arbustivo da floresta ciliar do arroio da Brigadeira, no Parque Municipal Fazenda Guajuviras, Canoas/RS. Dissertação (Mestrado em Ecologia)-Porto Alegre - RS: Universidade Federal do Rio Grande do Sul - Departamento de Biociências, 2005.

SOLECKI, W. D.; WELCH, J. M. Urban parks: green spaces or green walls? Landscape and Urban Planning, v. 32, n. 2, p. 93-106, 1 jun. 1995.

SOUSA, I. DOS S. A ponte Rio Negro e a Região Metropolitana de Manaus: adequações no espaço urbano-regional à reprodução do capital. São Paulo: Universidade de São Paulo, 2013.

SOUTO, A. C. G.; FELICIANO, A. L. P.; MARQUEZIN, C. Percepção ambiental: o problema do lixo na comunidade do Tururu, entorno da Mata do Janga, Paulista/PE. In: IX JORNADA DE ENSINO, PESQUISA E EXTENSÃO. Recife - PE, 13 out. 2009. 
SOUZA NASRAUI, L. A.; LUCIO, C. F. AUGUSTA CIDADE: UM PARQUE APROPRIADO? Anais $5^{\circ}$ Seminário de Iniciação Científica da ESPM. Anais... In: $5^{\circ}$ SEMIC - SEMINÁRIO DE INICIAÇÃO CIENTÍFICA . USP. São Paulo: USP, 27 out. 2016

SOUZA, A. F. R. O PARQUE ESTADUAL SAMAUMA E A EXPANSÃO URBANA DE MANAUS. Dissertação (Mestrado profissional em Processos Construtivos e Saneamento Ambiental)—Belém - PA: Universidade Federal do Pará - Instituto de Tecnologia, 2014.

SOUZA, D. B. I. RECONSTRUINDO CAJUEIRO SECO: Arquitetura, política social e cultura popular em Pernambuco (1960-64). Dissertação (Mestrado em Arquitetura e Urbanismo)—São Paulo - SP: Universidade de São Paulo - Faculdade de Arquitetura e Urbanismo, 2008.

SOUZA, D. B. I. Reconstruindo Cajueiro Seco Arquitetura, política social e cultura popular em Pernambuco (1960-1964). Aurora. Revista de Arte, Mídia e Política., n. 8, p. 1-17, 2010.

SOUZA, D. O. Influência da ilha de calor urbana das cidades de Manaus e Belém sobre o microclima local. Doutorado (Metereologia)—São José dos Campos: Instituto de Pesquisas Espaciais - INPE, 2012.

SOUZA, G. Suape lidera movimentação de cargas entre portos do Norte/Nordeste., 29 jul. 2015.2 Disponível em: <http://www.suape.pe.gov.br/news/matLer.php?id=472>. Acesso em: 20 dez. 2015

SOUZA, N. D.; OLIVEIRA, J. A. O espaço urbano e a produção de moradia em áreas inundáveis na cidade de Manaus: o igarapé do Quarenta. In: OLIVEIRA, J. A.; ALECRIM, J. D.; GASNIER, T. R. J. (Eds.). . Cidade de Manaus: visões interdisciplinares. 1. ed. Manaus: UFAM, 2003. v. 1p. 81-116.

SOUZA, N. DE J.; SOUZA, R. B. DE L. Dinâmica estrutural-diferencial da região metropolitana de porto alegre, 1990/2000. Revista de Economia, v. 30, n. 2, 2004.

SPRICIGO, G. O rural no Vale do Rio dos Sinos (RS): situação sócioeconômica e estratégias de desenvolvimento para a região. Dissertação (Mestrado em Desenvolvimento Rural)_-Porto Alegre - RS: Universidade Federal do Rio Grande do Sul - Faculdade de Ciências Econômicas, 2007.

STEINBERGER, M. Formação do aglomerado urbano de Brasília no contexto nacional e regional. In: PAVIANI, A. (Ed.). . Brasília - gestão urbana: conflitos e cidadania. Coleção Brasília. 1. ed. Brasília DF: Universidade de Brasilia, 1999. p. 21-53.

SUERTEGARAY, D. M.; SCHÀFFER, N. O. Análise ambiental: a atuação do geógrafo para e na sociedade-Porto Alegre: a metrópole e seu delta. Terra Livre, $p$. $1-15,2015$. 
TABARELLI, M.; MELO, M. D. V. C.; LIRA, O. C. A Mata Atlântica do nordeste. In: CAMPANILI, M.; PROCHNOW (Eds.). . Mata Atlântica: uma rede pela floresta. 1. ed. São Paulo - SP: Atthalaia, 2006. p. 149-164.

TAKANO, T.; NAKAMURA, K.; WATANABE, M. Urban residential environments and senior citizens' longevity in megacity areas: the importance of walkable green spaces. Journal of epidemiology and community health, v. 56, n. 12, p. 913-918, 2002.

TARIFA, J. R.; ARMANI, G. Unidades climáticas urbanas da cidade de São Paulo. 1. ed. São Paulo - SP: Secretaria do Verde e do Meio Ambiente SVMA/PMSP Secretaria de Planejamento - SEMPLA/PMSP, 2000.

TASCHNER, S. P.; BÓGUS, L. M. São Paulo: o caleidoscópio urbano. São Paulo em perspectiva, v. 15 , n. 1, p. 31-44, 2001a.

TASCHNER, S. P.; BÓGUS, L. M. M. São Paulo, uma metrópole desigual. Eure (Santiago), v. 27, n. 80, p. 87-120, 2001b.

TAVERNIA, B. G.; REED, J. M. Spatial extent and habitat context influence the nature and strength of relationships between urbanization measures. Landscape and Urban Planning, v. 92, n. 1, p. 47-52, 15 ago. 2009.

TAYLOR, L.; HOCHULI, D. F. Defining greenspace: Multiple uses across multiple disciplines. Landscape and Urban Planning, v. 158, p. 25-38, 2017.

TEIXEIRA, A. R.; SOUZA, M. A Valorização da Ruralidade a partir do Turismo: Roteiro Turístico Caminhos Rurais, Porto Alegre, Rio Grande do Sul, Brasil. Turismo e Sociedade, v. 5, n. 1, p. 231-251, 2012.

TEIXEIRA-NETO, F. Ministério Público, meio ambiente e parcelamento do solo: Reflexões acerca do impasse entre a regularização de empreendimentos urbanos consolidados e a proteção ambiental. Revista do Ministério Público do RS, p. 189-204, 2007.

TORRES, H. DA G. et al. Pobreza e espaço: padrões de segregação em São Paulo. Estudos Avançados, v. 17, n. 47, p. 97-128, 2003.

ULLMANN, R. A. Epicuro: o filósofo da alegria. 1. ed. Rio Grande do Sul: EDIPUCRS, 1996.

VAN DEN BERG, M. et al. Visiting green space is associated with mental health and vitality: A cross-sectional study in four European cities. Health \& place, v. 38, p. 815, 2016.

VASCONCELOS, A. M. N. et al. Da utopia à realidade: uma análise dos fluxos migratórios para o Aglomerado Urbano de Brasília. XV ENEP. Anais... In: XV ENCONTRO NACIONAL DE ESTUDOS POPULACIONAIS. Caxambu - MG: ABEP Associação Brasileira de Estudos Populacionais, 2006 
VEIGA, J. E. DA. Desenvolvimento territorial do Brasil: do entulho varguista ao zoneamento ecológico-econômico. Revista Bahia Análise \& Dados. Salvador. BA SEI, v. 10, n. 4, p. 193-206, 2001.

VIANA, M. B.; GANEM, R. S. APAs Federais no Brasil. 1. ed. Brasília DF: Câmara dos Deputados - Centro de Documentação e Informação, 2005.

VILARDAGA, V. De advogado a professor, diplomados viram moradores de rua em São Paulo, 10 ago. 2017. Disponível em: <http://www1.folha.uol.com.br/cotidiano/2017/10/1925287-de-advogado-a-professordiplomados-viram-moradores-de-rua-em-sao-paulo.shtml>. Acesso em: 8 out. 2017

WEBER, M. Conceito e categorias de cidade. O fenômeno urbano, v. 2, p. 68-89, 1979 .

ZHANG, C. et al. Use of local Moran's I and GIS to identify pollution hotspots of $\mathrm{Pb}$ in urban soils of Galway, Ireland. Science of the total environment, v. 398, n. 1, p. 212-221, 2008. 


\section{APÊNDICE A}

Correlação espacial utilizando a delimitação dos setores urbanos publicada pela Embrapa (FARIAS et al., 2017).

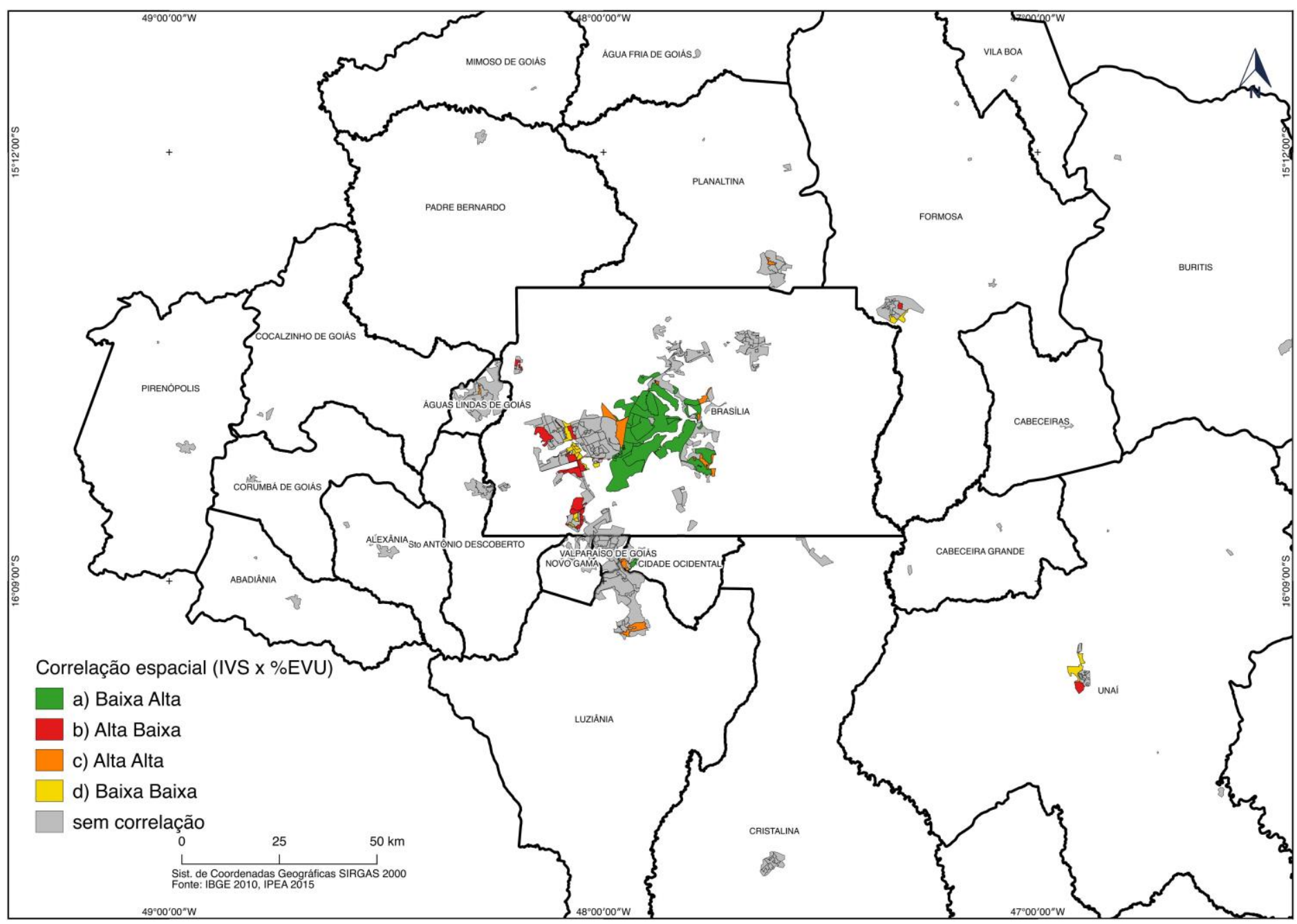

Figura 1 - Correlação espacial no recorte de áreas urbanas definidas pela Embrapa. RIDE-DF Entorno

Tabela 1 - Dados comparativos entre correlações espaciais. Setores censitários e limites definidos pela Embrapa

\begin{tabular}{lll}
\hline \multirow{2}{*}{ Correlação - RIDE DF e Entorno } & \multicolumn{1}{c}{ I Moran = -0,01 } & I Moran = -0,08 \\
\cline { 2 - 3 } & \% ÁREA IBGE & \% ÁREA EMBRAPA \\
\hline ALTA-ALTA (laranja) & 4,13 & 3,44 \\
ALTA-BAIXA (vermelho) & $\mathbf{4 , 9 2}$ & $\mathbf{3 , 8 4}$ \\
BAIXA-BAIXA (amarelo) & 2,84 & 2,61 \\
BAIXA-ALTA (verde) & $\mathbf{1 7 , 4 9}$ & $\mathbf{2 2 , 3 0}$ \\
SEM SIGNIFICÂNCIA & 70,63 & 67,81 \\
\hline HIPÓTESE (vermelho + verde) & $\mathbf{2 2 , 4 1}$ & $\mathbf{2 6 , 1 4}$ \\
OPOSTO DA HIPÓTESE (laranja + amarelo) & 6,96 & 6,05 \\
\hline \hline
\end{tabular}

Fonte: Elaborada pelo autor 


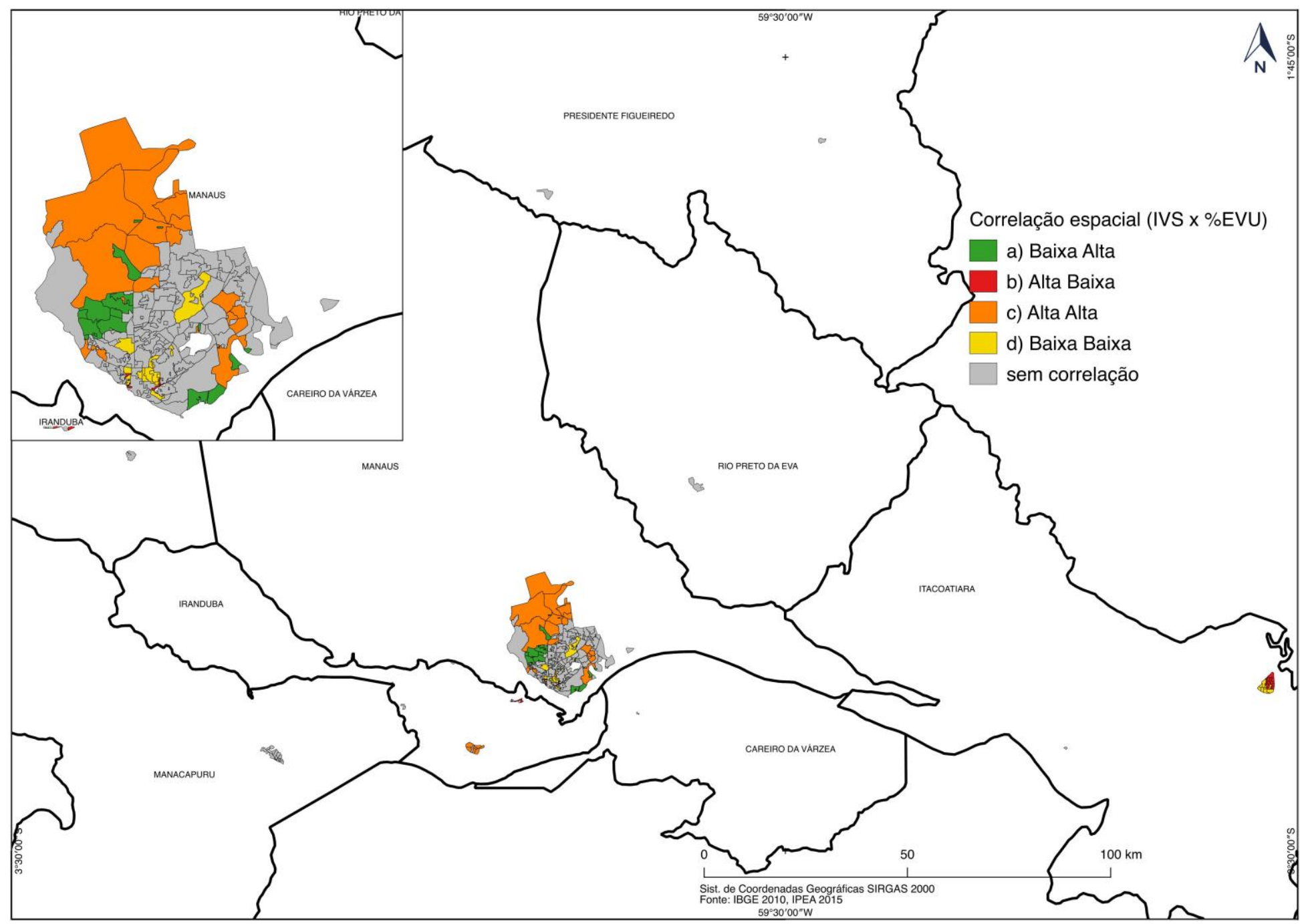

Figura 2 - Correlação espacial no recorte de áreas urbanas definidas pela Embrapa na RM de Manaus

Tabela 2 - Dados comparativos entre correlações espaciais. Setores censitários e limites definidos pela Embrapa

\begin{tabular}{lll}
\hline \multirow{2}{*}{ Correlação - RM Manaus } & I Moran = 0,13 & I Moran = 0,10 \\
\cline { 2 - 3 } & $\%$ ÁREA IBGE & \% ÁREA EMBRAPA \\
\hline ALTA-ALTA (laranja) & 48,56 & 39,12 \\
ALTA-BAIXA (vermelho) & $\mathbf{0 , 3 7}$ & $\mathbf{1 , 6 8}$ \\
BAIXA-BAIXA (amarelo) & 3,37 & 4,42 \\
BAIXA-ALTA (verde) & $\mathbf{2 , 2 6}$ & $\mathbf{5 , 9 9}$ \\
SEM SIGNIFICÂNCIA & 45,44 & 48,79 \\
\hline HIPÓTESE (vermelho + verde) & $\mathbf{2 , 6 3}$ & $\mathbf{7 , 6 7}$ \\
OPOSTO DA HIPÓTESE (laranja + amarelo) & 51,93 & 43,54 \\
\hline \hline
\end{tabular}

Fonte: Elaborada pelo autor 


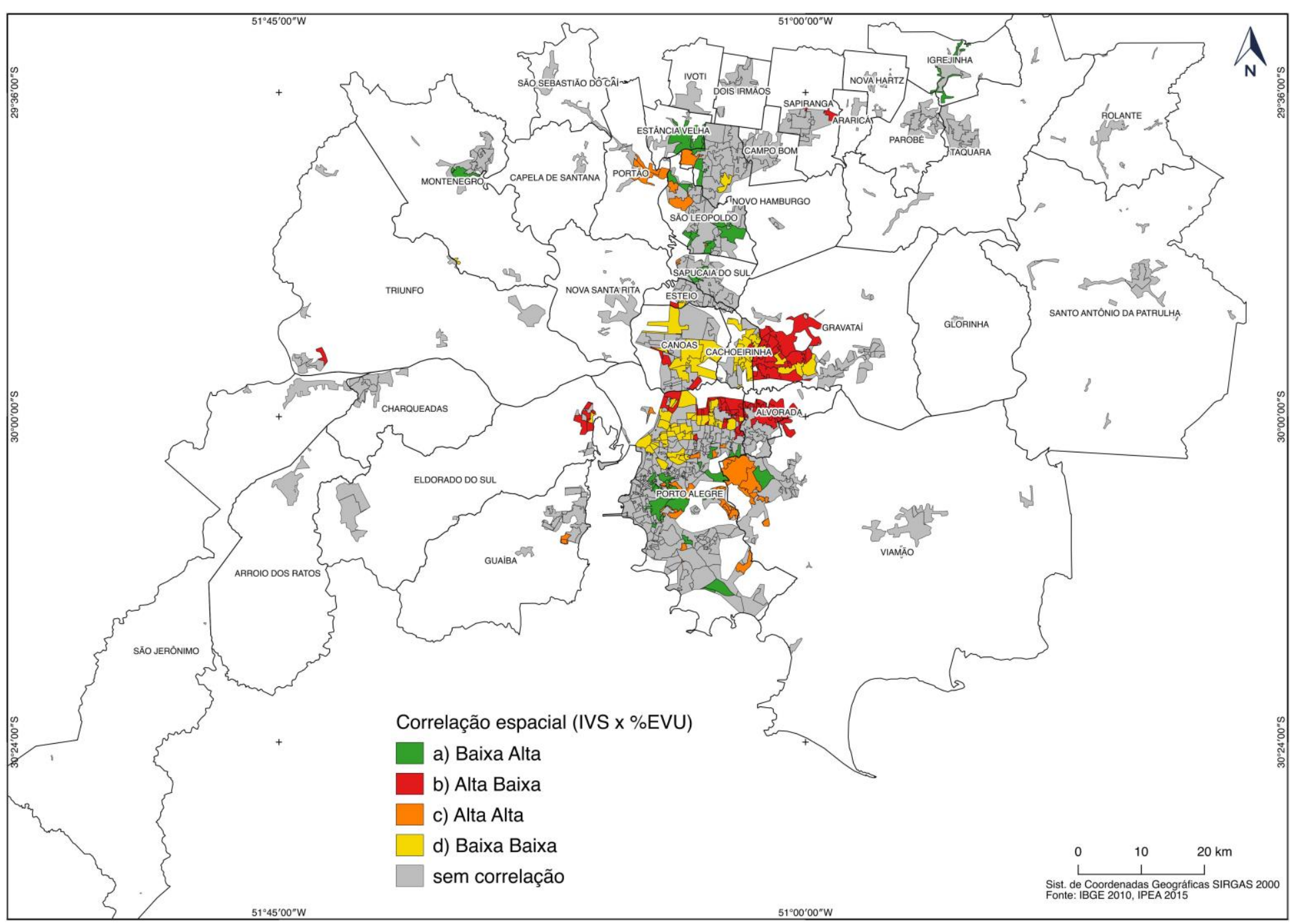

Figura 3 - Correlação espacial no recorte de áreas urbanas definidas pela Embrapa na RM de Porto Alegre

Tabela 3 - Dados comparativos entre correlações espaciais. Setores censitários e limites definidos pela Embrapa

\begin{tabular}{lll}
\hline \multirow{2}{*}{ Correlação - RM Porto Alegre } & I Moran = 0,05 & I Moran = 0,04 \\
\cline { 2 - 3 } & \% ÁREA IBGE & \% ÁREA EMBRAPA \\
\hline ALTA-ALTA (laranja) & 8,61 & 4,90 \\
ALTA-BAIXA (vermelho) & $\mathbf{5 , 2 3}$ & $\mathbf{0 , 5 0}$ \\
BAIXA-BAIXA (amarelo) & 3,9 & 8,65 \\
BAIXA-ALTA (verde) & $\mathbf{4 , 4 8}$ & $\mathbf{6 , 3 7}$ \\
SEM SIGNIFICÂNCIA & $\mathbf{7 7 , 7 9}$ & $\mathbf{7 9 , 5 7}$ \\
\hline HIPÓTESE (vermelho + verde) & $\mathbf{9 , 7 1}$ & $\mathbf{6 , 8 8}$ \\
OPOSTO DA HIPÓTESE (laranja + amarelo) & 12,51 & 13,55 \\
\hline \hline
\end{tabular}

Fonte: Elaborada pelo autor 


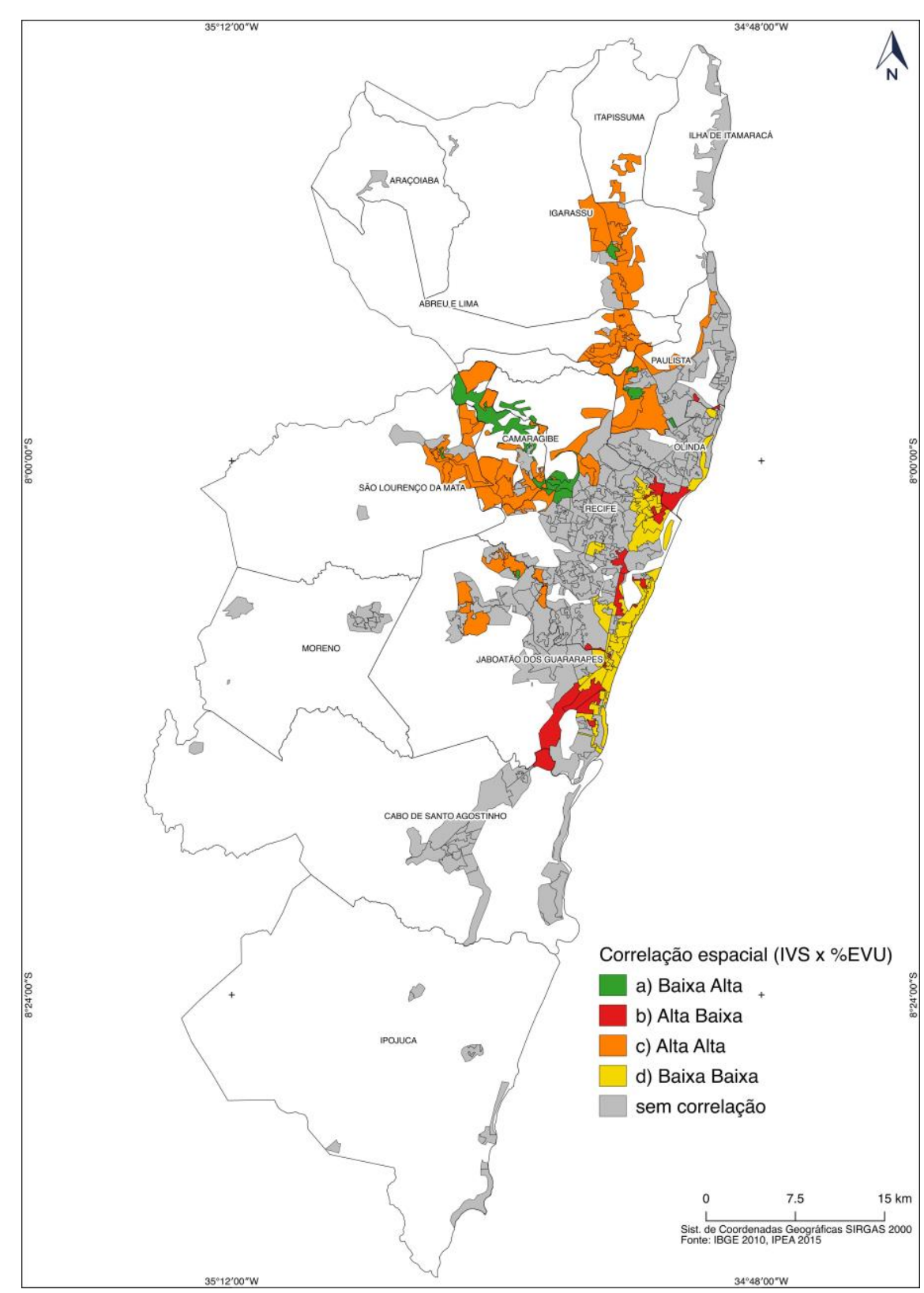

Figura 4 - Correlação espacial no recorte de áreas urbanas definidas pela Embrapa na RM de Recife

Tabela 4 - Dados comparativos entre correlações espaciais. Setores censitários e limites definidos pela Embrapa

\begin{tabular}{lll}
\multicolumn{1}{c}{ Correlação - RM Recife } & I Moran = 0,17 & I Moran = 0,19 \\
\cline { 2 - 3 } & $\%$ ÁREA IBGE & \% ÁREA EMBRAPA \\
\hline ALTA-ALTA (laranja) & 26,41 & 22,95 \\
ALTA-BAIXA (vermelho) & $\mathbf{4 , 0 9}$ & $\mathbf{4 , 2 0}$ \\
BAIXA-BAIXA (amarelo) & 5,68 & 7,33 \\
BAIXA-ALTA (verde) & $\mathbf{5 , 7 7}$ & $\mathbf{3 , 7 3}$ \\
SEM SIGNIFICÂNCIA & 58,05 & 61,79 \\
\hline HIPÓTESE (vermelho + verde) & $\mathbf{9 , 8 6}$ & $\mathbf{7 , 9 3}$ \\
OPOSTO DA HIPÓTESE (laranja + amarelo) & 32,09 & 30,28 \\
\hline \hline
\end{tabular}

Fonte: Elaborada pelo autor 


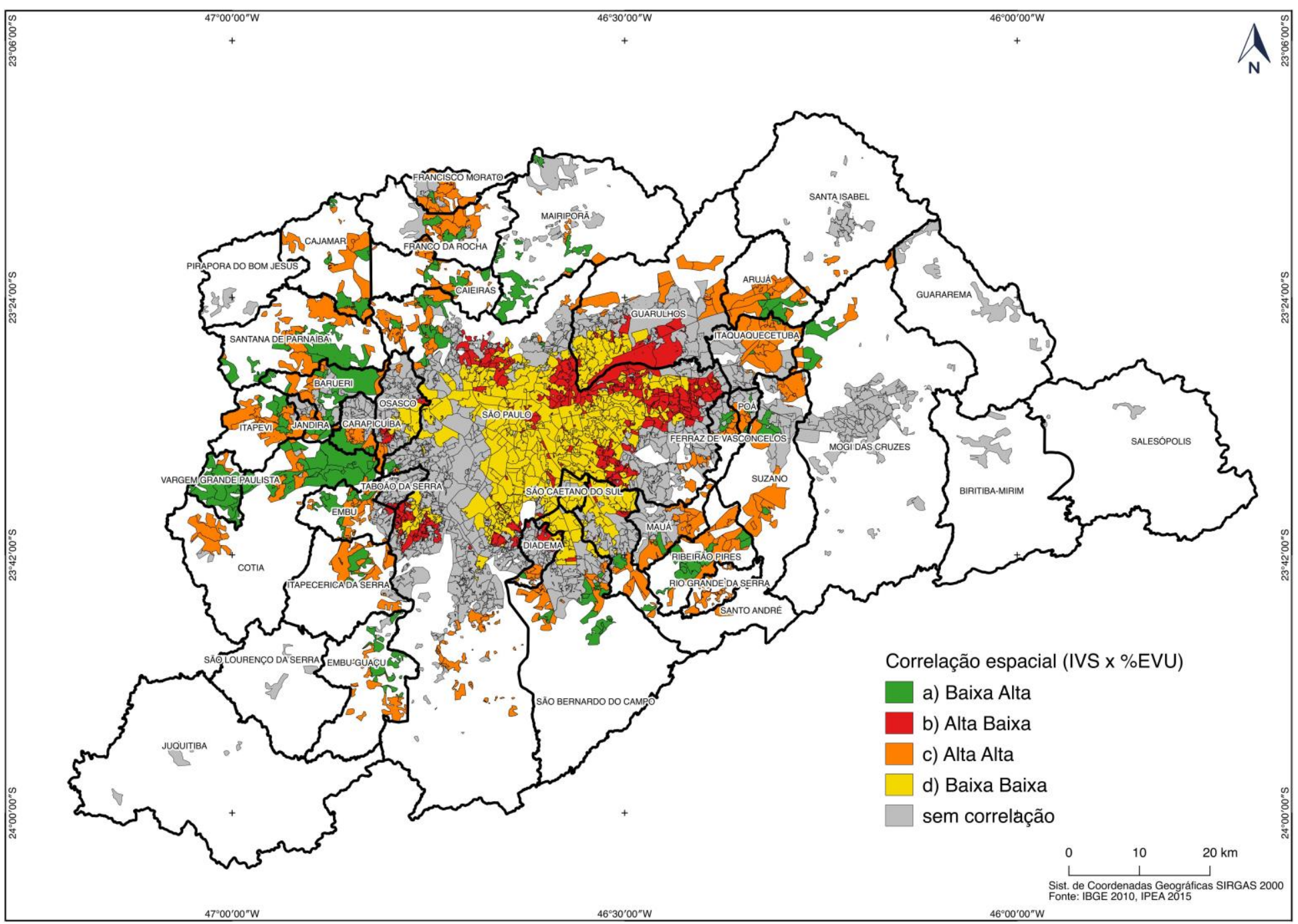

Figura 5 - Correlação espacial no recorte de áreas urbanas definidas pela Embrapa na RM de São Paulo

Tabela 5 - Dados comparativos entre correlações espaciais. Setores censitários e limites definidos pela Embrapa

\begin{tabular}{lll}
\hline \multirow{2}{*}{ Correlação - RM São Paulo } & I Moran = 0,10 & I Moran = 0,07 \\
\cline { 2 - 3 } & \% ÁREA IBGE & \% ÁREA EMBRAPA \\
\hline ALTA-ALTA (laranja) & 37,09 & 21,79 \\
ALTA-BAIXA (vermelho) & $\mathbf{5 , 1 6}$ & $\mathbf{7 , 6 5}$ \\
BAIXA-BAIXA (amarelo) & 12,56 & 18,34 \\
BAIXA-ALTA (verde) & $\mathbf{1 7 , 0 6}$ & $\mathbf{1 3 , 2 5}$ \\
SEM SIGNIFICÂNCIA & $\mathbf{2 8 , 1 4}$ & 38,97 \\
\hline HIPÓTESE (vermelho + verde) & $\mathbf{2 2 , 2 2}$ & $\mathbf{2 0 , 8 9}$ \\
OPOSTO DA HIPÓTESE (laranja + amarelo) & 49,65 & 40,13 \\
\hline
\end{tabular}

Fonte: Elaborada pelo autor 